
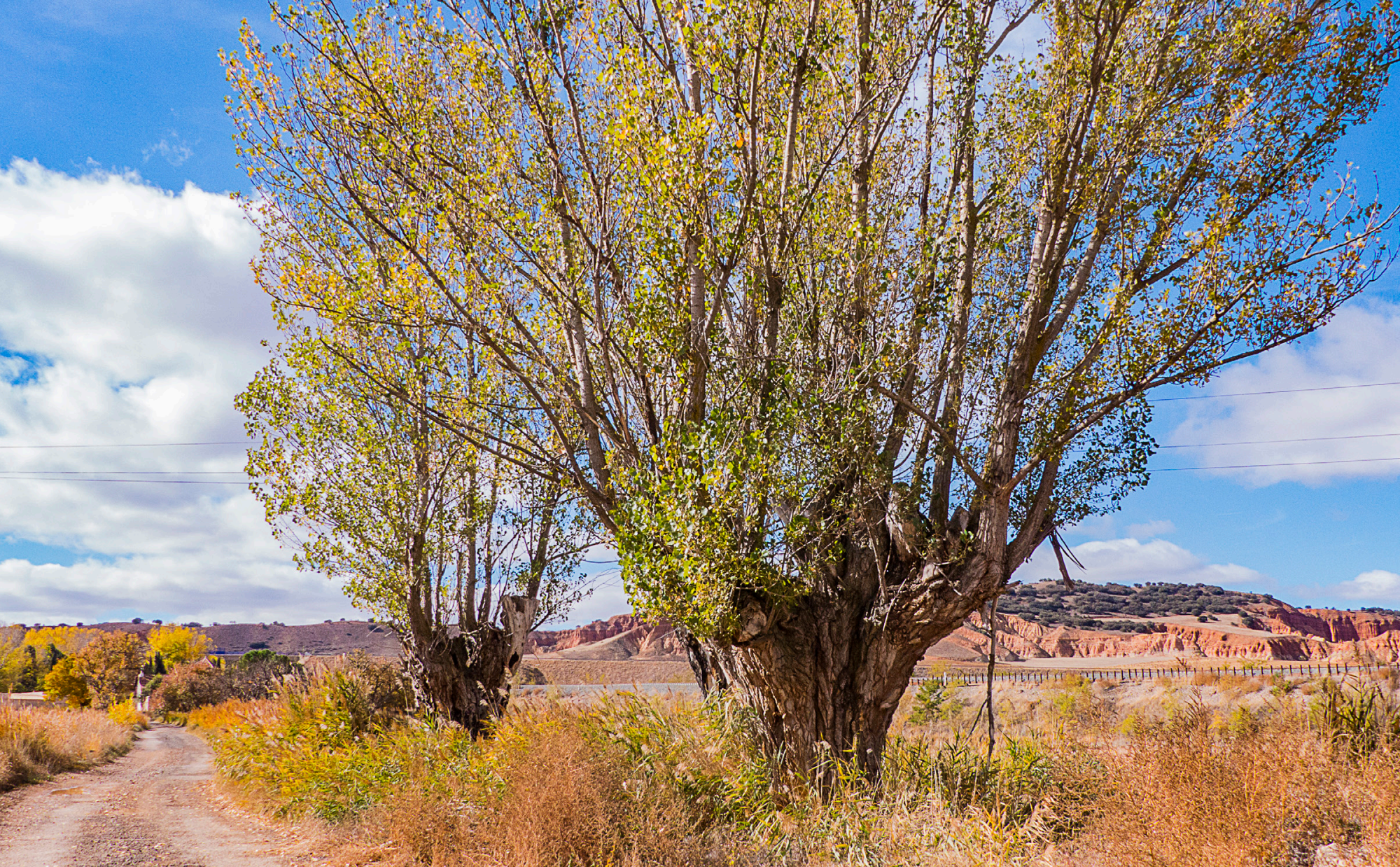

\title{
PROCESOS DE PATRIMONIALIZACIÓN DEL PAISAJE FORESTAL EN LA ESPAÑA SEPTENTRIONAL OCCIDENTAL. ESTUDIO DE CASOS
}

Autor

Alberto Merino Espeso

Directores

Dr. Juan Carlos Guerra Velasco

Dr. Alipio J. García de Celis

Universidad deValladolid
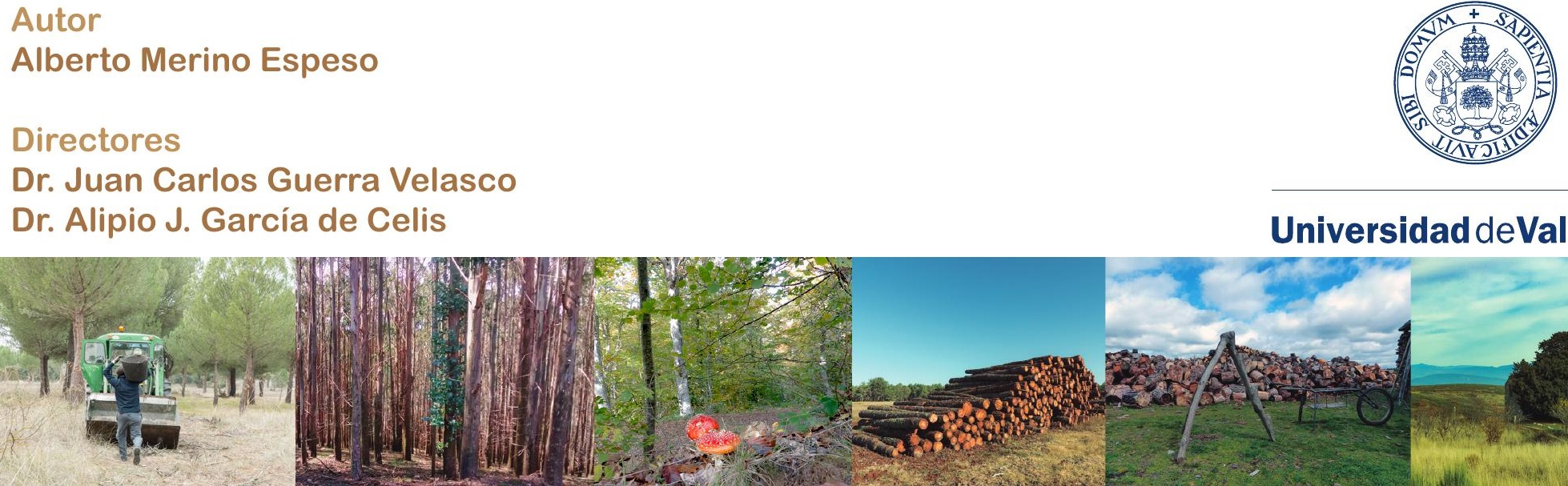
Universidad deValladolid

\author{
PROGRAMA DE DOCTORADO EN PATRIMONIO CULTURAL Y \\ NATURAL: HISTORIA, ARTE Y TERRITORIO
}

\title{
TESIS DOCTORAL:
}

\section{Procesos de patrimonialización del paisaje forestal en la España septentrional occidental. Estudio de casos.}

Presentada por Alberto Merino Espeso para optar al grado de Doctor por la Universidad de Valladolid

Dirigida por:

Juan Carlos Guerra Velasco

Alipio José García de Celis 



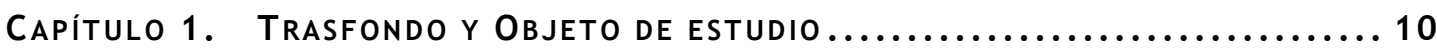

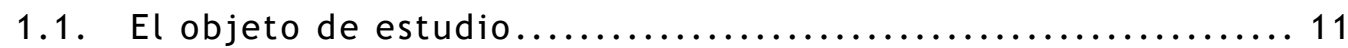

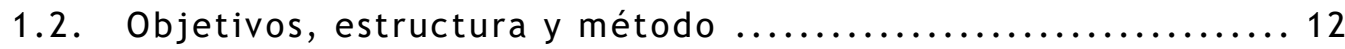

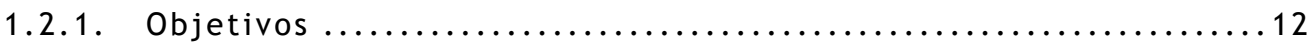

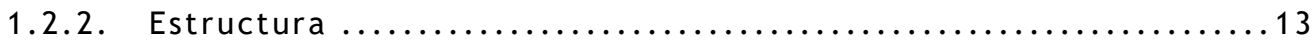

1.2.3. Método ...............................................

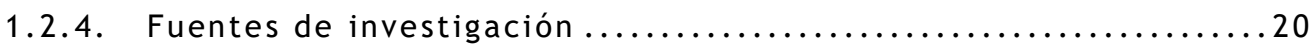

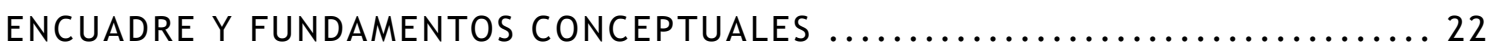

Capítulo 2. El bosque en la españa peninsular $\ldots \ldots \ldots \ldots \ldots \ldots \ldots \ldots \ldots \ldots$

2.1. La realidad forestal de la España peninsular ............... 24

2.1.1. Bosques de la España Atlántica ..........................27

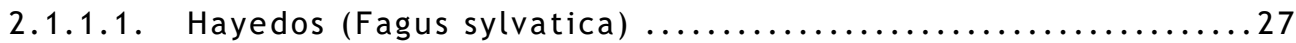

2.1.1.2. Robledales (Quercus robur y Quercus petraea) .............29

2.1.1.3. Pinares eurosibierianos (Pinus sylvestris y Pinus uncinata) ...32

2.1.1.4. Otras formaciones del bosque atlántico (Abedulares,

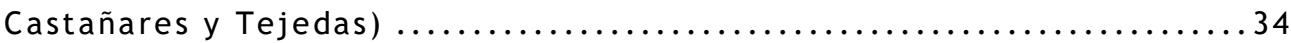

2.1.2. Bosques de la España Mediterránea ............................. 38

2.1.2.1. Encinares y alcornocales (Quercus ilex y Quercus suber) .....38

2.1.2.2. Sabinares y enebrales (Juniperus spp.)..................4 4

2.1.2.3. Pinares mediterráneos (Pinus spp.) ........................44

2.1.3. Bosques especialmente singulares ......................... 50 
2.1.3.1. Bosques marcescentes (Quercus pirenaica Willd. 1805, Quercus faginea Lamb. 1785, Quercus humilis Mill. 1768, Quercus canariensis

(Willd.) 1809) .............................................. 50

2.1.3.2. El abetal pirenaico (Abies alba) ........................5 53

2.1.3.3. Los pinsapares (Abies pinsapo) ........................54

2.1.3.4. Los bosques de producción (especies exóticas) ..............55

2.2. Las dimensiones del bosque español y su situación ......... 57

2.3. La evolución forestal española ........................ 59

2.3.1. El origen de los bosques españoles .........................59

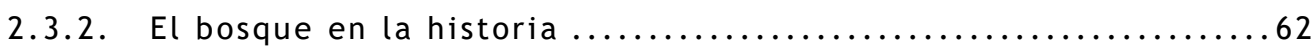

Capítulo 3. El paisaje.............................................. 83

3.1. Las dimensiones del paisaje........................ 86

3.2. La evolución del concepto paisaje ....................... 88

3.3. El Convenio Europeo del Paisaje y el Plan Nacional de Paisaje

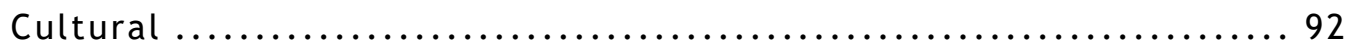

3.4. El paisaje forestal ................................. 99

3.5. Los tipos de paisaje forestal .......................... 102

3.5.1. bosques "refugio" (valores biológicos) $\ldots \ldots \ldots \ldots \ldots \ldots \ldots \ldots \ldots . \ldots \ldots$

3.5.2. Bosque productor (valores corporativos) ................. 107

3.5.3. Silvicultura intensiva (valores productivos/industriales) ...... 109

3.5.4. Bosque o arbolado de acompañamiento agropecuario (valores

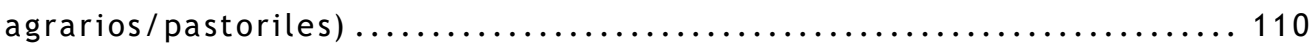

3.5.5. Árboles singulares (valores monumentales) ................ 111

Capítulo 4. El paisaje forestal como servicio ecosistémico $\ldots \ldots \ldots \ldots \ldots \ldots 115$

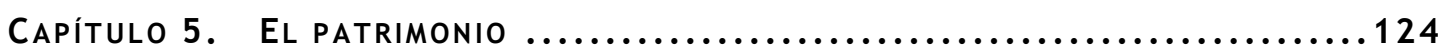

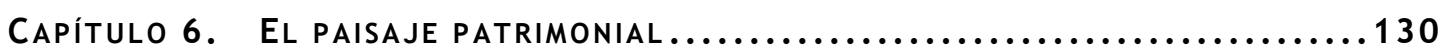

6.1. El proceso de patrimonialización ........................... 133

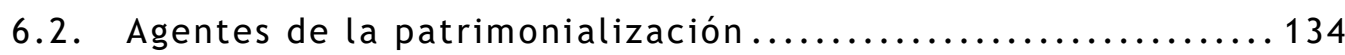


6.2.1. La percepción ........................................ 137

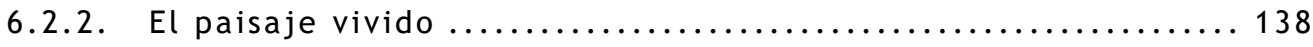

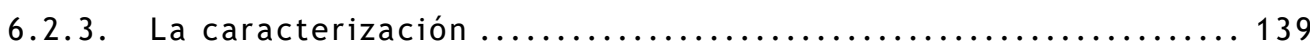

6.2.4. La transformación del espacio ......................... 140

6.3. Los indicadores de patrimonialización .................. 142

6.3.1. Indicador 1. Complejidad biológica: ..................... 143

6.3.2. Indicador 2. Figuras de protección, reconocimiento y salvaguarda presentes en el territorio: ................................. 144

6.3.3. Indicador 3. Existencia de vectores patrimoniales: .......... 145

6.3.4. Indicador 4. Identificación de la población/identidad: ........ 146

6.3.5. Indicador 5. Museística: ........................... 147

6.3.6. Indicador 6. Incorporación turística (publicidad): ........... 148

6.3.7. Indicador 7. Empleo relacionado: ....................... 149

ESTUDIO DE CASOS Y APLICACIÓN PRÁCTICA. PAISAJES FORESTALES CON VALOR

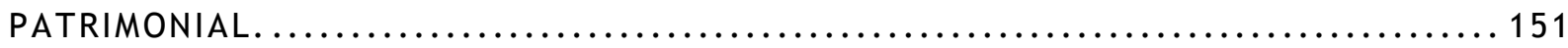

Capítulo 7. Los bosques de gran valor biológico, el bosque refugio. El

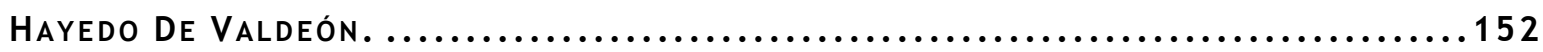

7.1. Distribución y localización del área de estudio ............. 153

7.2. Caracterización del área de estudio ..................... 157

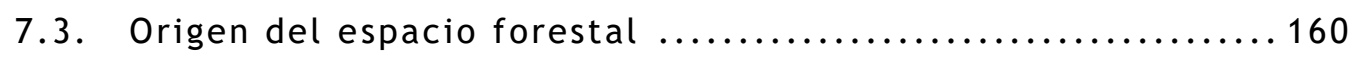

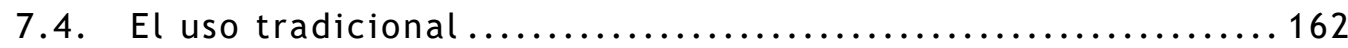

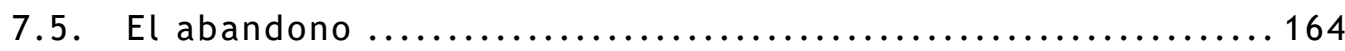

7.6. El paisaje de un espacio silvopastoril de montaña .......... 165

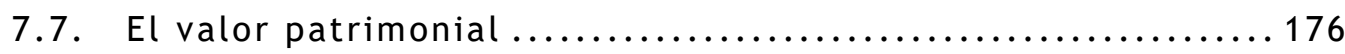

7.8. El proceso de patrimonialización a través de los indicadores.177

7.8.1. Indicador 1. Complejidad biológica $\ldots \ldots \ldots \ldots \ldots \ldots \ldots \ldots \ldots \ldots$ 
7.8.2. Indicador 2. Figuras de protección, reconocimiento y salvaguarda presentes en el territorio ................................... 181

7.8.3. Indicador 3. Existencia de vectores patrimoniales.......... 187

7.8.4. Indicador 4. Identificación y sentimiento de pertenencia...... 192

7.8.5. Indicador 5. Museística ............................ 196

7.8.6. Indicador 6. Incorporación turística..................... 201

7.8.7. Indicador 7. Empleo relacionado ..................... 205

7.8.8. Valoración final ................................... 208

Capítulo 8. Los bosques corporativos. La Tierra de Pinares de Valladolid y

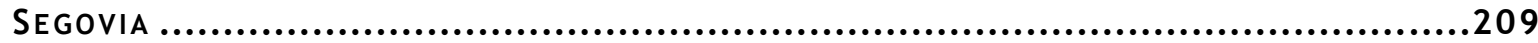

8.1. Distribución y localización del área de estudio ............2 210

8.2. Caracterización del área de estudio ......................... 216

8.3. El origen del espacio forestal ....................... 218

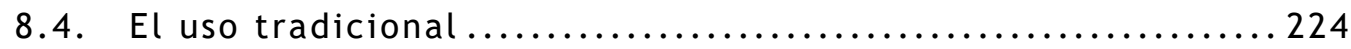

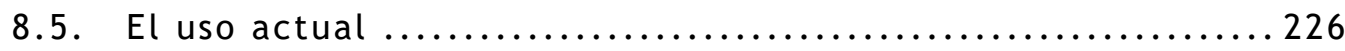

8.6. El paisaje de un espacio forestal histórico............... 230

8.7. El proceso de patrimonialización a través de los indicadores. 240

8.7.1. Indicador 1. Complejidad biológica ....................... 244

8.7.2. Indicador 2. Figuras de protección, reconocimiento y salvaguarda presentes en el territorio ................................... 249

8.7.3. Indicador 3. Existencia de vectores patrimoniales.......... 252

8.7.4. Indicador 4. Identificación y sentimiento de pertenencia..... 257

8.7.5. Indicador 5. Museística ............................. 261

8.7.6. Indicador 6. Incorporación turística...................... 263

8.7.7. Indicador 7. Empleo relacionado ..................... 265

8.7.8. Valoración final ................................... 267

Capítulo 9. Silvicultura intensiva. Los Eucaliptales de Guriezo.........268

9.1. Distribución y localización del área de estudio ............269 
9.2. Caracterización del área de estudio $\ldots \ldots \ldots \ldots \ldots \ldots \ldots \ldots \ldots 272$

9.3. El origen del espacio forestal ....................... 274

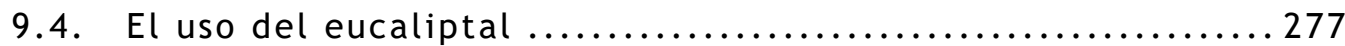

9.5. El paisaje de un espacio productivo industrial ............. 279

9.6. El proceso de patrimonialización a través de los indicadores.285

9.6.1. Indicador 1. Complejidad biológica ........................ 285

9.6.2. Indicador 2. Figuras de protección, reconocimiento y salvaguarda presentes en el territorio. .................................. 290

9.6.3. Indicador 3. Existencia de vectores patrimoniales........... 293

9.6.4. Indicador 4. Identificación y sentimiento de pertenencia..... 297

9.6.5. Indicador 5. Museística .............................. 300

9.6.6. Indicador 6. Incorporación turística.................... 302

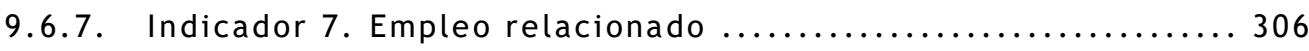

9.6.8. Valoración final ......................................... 309

Capítulo 10. arbolado de acompañamiento agropecuario. los Trasmochos del

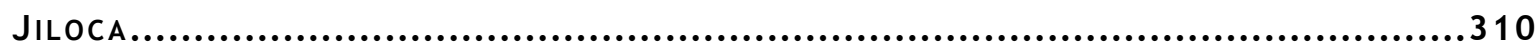

10.1. Distribución y localización del área de estudio ............. 311

10.2. Caracterización del área de estudio ..................... 316

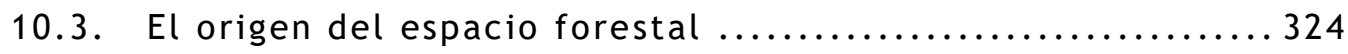

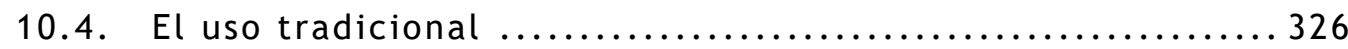

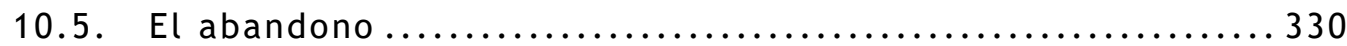

10.6. El paisaje de un espacio agrario tradicional............... 332

10.7. El valor patrimonial.................................. 341

10.8. El proceso de patrimonialización a través de los indicadores. ........................................................342

10.8.1. Indicador 1. Complejidad biológica ................... 347

10.8.2. Indicador 2. Figuras de protección, reconocimiento y salvaguarda presentes en el territorio. .................................. 352 
10.8.3. Indicador 3. Existencia de vectores patrimoniales 354

Indicador 4 . Identificación y sentimiento de pertenencia ........... 359

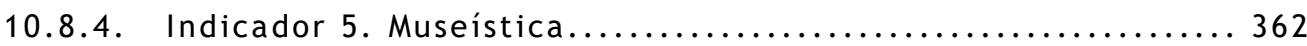

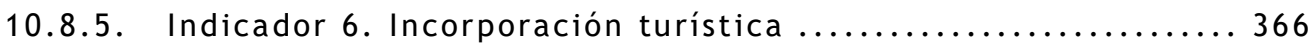

10.8.6. Indicador 7 . Empleo relacionado $\ldots \ldots \ldots \ldots \ldots \ldots \ldots \ldots \ldots \ldots$

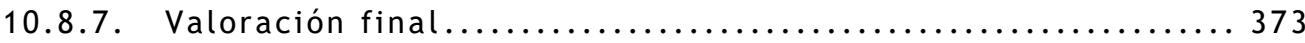

Capítulo 11. Los árboles monumentales. Los Tejos catalogados en Castilla y

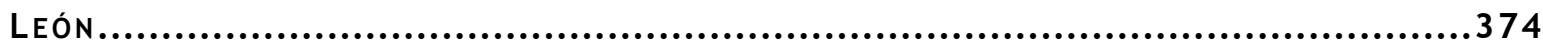

11.1. Distribución y localización del área de estudio ...........375

11.2. Caracterización del área de estudio ................. 377

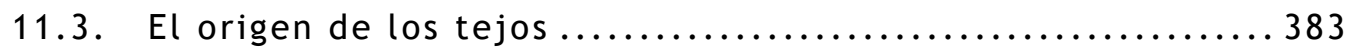

11.4. El tejo, el valor patrimonial como garante de su existencia.

11.5. El proceso de patrimonialización a través de los

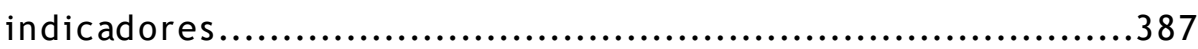

11.5.1. Indicador 1. Complejidad biológica .................. 389

11.5.2. Indicador 2. Figuras de protección, reconocimiento y salvaguarda

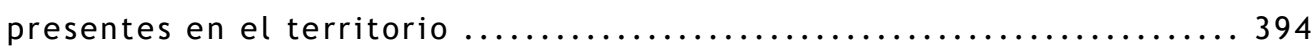

11.5.3. Indicador 3. Existencia de vectores patrimoniales ......... 399

11.5.4. Indicador 4. Identificación y sentimiento de pertenencia ....403

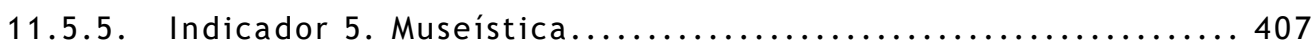

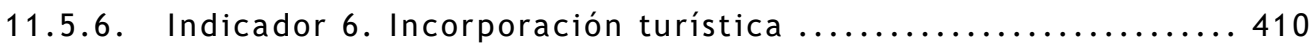

11.5.7. Indicador 7 . Empleo relacionado $\ldots \ldots \ldots \ldots \ldots \ldots \ldots \ldots \ldots \ldots 13$

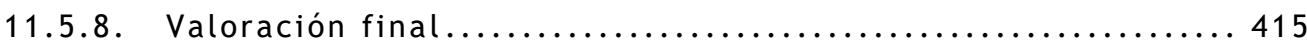

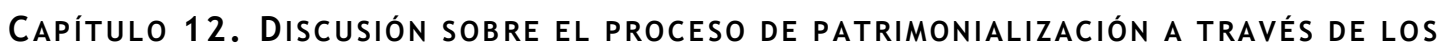
INDICADORES

12.1. Complejidad biológica ................................. 418

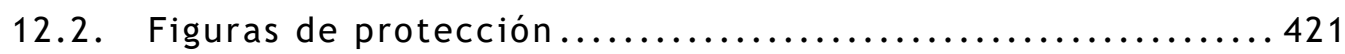


12.3. Existencia de vectores................................. 423

12.4. Identificación y sentimiento de pertenencia $\ldots \ldots \ldots \ldots \ldots . \ldots 424$

12.5. Centros de interpretación /museos .................... 426

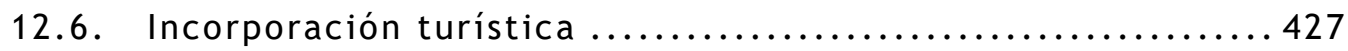

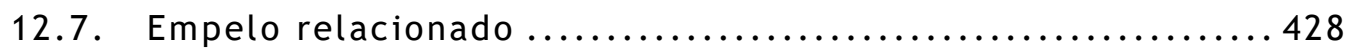

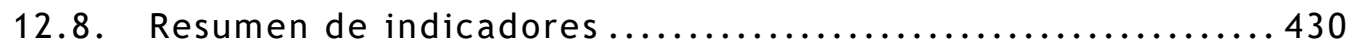

CONCLUSIONES .................................................. 434

AGRADECIMIENTOS................................................. 438

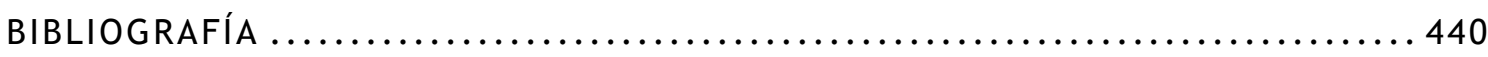

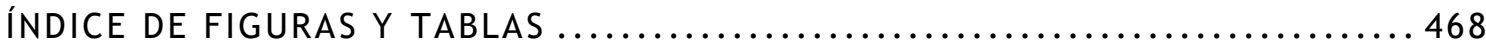

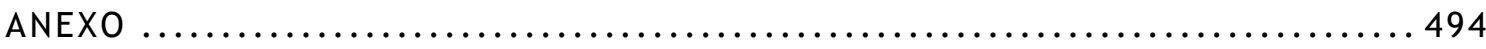




A mis padres 




\section{Resumen}

Los espacios forestales siempre han sido espacios cargados de interés, tanto los bosques como los arbolados dispersos han servido a las sociedades como elementos referenciales, fundamentos identitarios con un creciente reconocimiento social. Este estrecho vínculo viene precedido de una relación cultural de aprovechamientos. El ser humano ha basado buena parte de sus actividades en los productos obtenidos por los árboles mediante la muerte o por su aprovechamiento en vida. Estos usos y prácticas que se han ejercido sobre los árboles arrojan una realidad forestal que pudiera ser calificada como una domesticación forestal. Esta domesticación, ha generado unos paisajes de gran riqueza biológica y de importante complejidad cultural.

Para entender el valor patrimonial de lo forestal se ha realizado una aproximación diacrónica a la realidad forestal de la España peninsular explicando las formaciones, su distribución, sus características y sus requerimientos ecológicos, así como su relación antrópica. Por otro lado, este trabajo analiza los conceptos teóricos que darán sustento a la aproximación práctica, efectuando asi un repaso de los conceptos de paisaje y patrimonio. Por último y con el objetivo de obtener una comparación entre distintos tipos de paisaje forestal, se comparan cinco casos de estudio.

De acuerdo con estas premisas se ha obtenido una clasificación de tipos de paisaje forestal, bajo la cual se han delimitado los casos de estudio. Mediante el análisis de estos ejemplos se obtiene una comparación entre los distintos tipos de paisaje, identificando sus fortalezas y sus debilidades, los motivos sobre las que se asienta el reconocimiento y los valores patrimoniales que no están activados. 


\section{Abstract}

Forest areas have been spaces with special interest. Both forests and scattered woodlands have served societies as referential elements, identity foundations with an increasing social recognition. This close link is preceded by a cultural relationship of uses. Human beings have based a large part of their activities on the products obtained from trees not only through death but also during their lifetime. These uses and practices that have been performed with trees result in a forestry situation that could be described as forest domestication. This domestication has generated landscapes of high biological value and significant cultural complexity.

In order to understand the heritage value of forestry, a diachronic approach to the reality of forestry in peninsular Spain has been made. In this approach the formations, their distribution, characteristics, ecological requirements, and their anthropic relationship, are explained. On the other hand, this work analyzes the theoretical concepts that will support the practical part, by reviewing the concepts of landscape and heritage. Finally, with the purpose of obtaining a comparison between different types of forest landscape, five case studies are compared.

According to these premises, a classification of forest landscape types has been accomplished, under which the case studies have been delimited. Through the analysis of these examples, a comparison between the different types of landscape is obtained. This comparison allows to identify their strengths and weaknesses, the bases of the recognition and the inactivated heritage value. 
Introducción 
La Tesis Doctoral titulada, "Procesos de patrimonialización del paisaje forestal en la España septentrional. Estudio de casos" que aquí se presenta es el cumplimiento del requisito final para la obtención del título de Doctor y que consta de un proceso que se ha desarrollado durante 6 años en el Departamento de Geografía de la Universidad de Valladolid bajo la supervisión del CAU. D. Fernando Molinero Hernando, el Dr. D. Juan Carlos Guerra Velasco y el Dr. D. Alipio José García de Celis dentro del programa de doctorado ofrecido por la Escuela de Doctorado de la Universidad de Valladolid en Patrimonio Natural y Cultural, Historia, Arte y Territorio.

Durante el desarrollo de este proceso y como consta en los requisitos para la obtención del título se han desarrollado diferentes actividades complementarias pero necesarias para la obtención de este. Se ha participado en diversos congresos de forma activa y se han realizado diferentes artículos científicos, así como capítulos de libros que complementan esta investigación. También hay que destacar la tarea docente encomendada por el Departamento de Geografía durante los años 2014-2018 como complemento a la formación, llegándose a impartir un total de 17 créditos ECTS en el grado universitario de Geografía y Ordenación del Territorio, así como el grado universitario de Historia ambos en la Facultad de Filosofía y Letras de la Universidad de Valladolid. Durante este periodo de formación el énfasis se ha puesto en desarrollar esta investigación y empaparse de forma activa de todos aquellos aspectos que rodean al patrimonio forestal y su paisaje, lo cual supone un nicho de conocimiento de creciente interés.

Los espacios forestales siempre han sido un elemento atractivo para el ser humano desde el lugar donde desarrollar los usos tradicionales de recolección, pasando por la gestión forestal para su aprovechamiento y en este momento destacando como lugares para el ocio y el esparcimiento donde se ha optado por la protección o puesta en valor de estos espacios forestales atendiendo principalmente a sus características biológicas y naturales. El espacio forestal ha sido tradicionalmente un espacio multifuncional donde los aprovechamientos se solapaban y complementaban 
perfectamente, si bien es cierto que las sociedades tradicionales gestionaban y ordenaban sus montes en cierta medida incentivando o dando prioridad a unas especies que se adaptaban mejor a sus necesidades o que generaban unos recursos más valiosos. La llegada de la ciencia forestal a España a finales del S. XVIII y su consolidación a mediados del S. XIX va a transformar la forma de entender el bosque; se va a pasar de ese bosque multifuncional a un bosque ordenado y regular que deja de ser ese espacio de uso ciudadano y pasa a ser un espacio donde las decisiones dasonómicas de origen sajón se van a imponer sobre las decisiones vernáculas que habían gestionado el bosque tradicionalmente.

El concepto de bosque abandona su vocación natural, su perfecto caos aparente para convertirse en foresta como señalaba Agustín Pascual en su artículo “Sobre el Vocablo: Forestal” en la Revista Forestal (Pascual, 1868) asegurando que la rentabilidad debía ser la vocación del terreno arbolado y promoviendo el monte alto y ordenado por encima del ampliamente desarrollado monte bajo mediterráneo y el pastizal. De este modo y de forma generalizada el bosque pasa a ser un espacio que disminuye sus aprovechamientos, su tradición polifuncional se abandona y se impone el monte alto arbolado y ordenado bajo los nuevos criterios de la ciencia forestal de origen alemán que llega a España. Pero ¿por qué el paisaje forestal y no el paisaje en su conjunto u otro enfoque que haya sido más trabajado como el paisaje del viñedo o el paisaje de la huerta en el levante español? El paisaje forestal, en muchos casos, está siendo olvidado a la hora de estudiarlo y analizarlo. La tradición de ordenación de los espacios forestales por parte de los ingenieros de montes que lo orientaban principalmente a la producción hizo que los estudios paisajísticos no se involucrasen demasiado en estudiar el paisaje forestal por lo que es un campo abierto a la entrada de otras disciplinas aparte de la ingeniería de montes preponderante desde mediados del S. XIX y donde la geografía puede jugar un papel fundamental en esta oportunidad que se abre. Los espacios forestales están dejando de ser cada vez más esos lugares destinados a la producción que habían imaginado los ingenieros forestales 
y están pasando a ser refugio de bienestar y calidad ambiental. Los bosques, en definitiva, se están convirtiendo en una fuente de placer y la función social se impone a la función económica (Gordi, 2009).

La actividad humana por tanto es un elemento fundamental para entender el valor patrimonial del paisaje forestal, los ingenieros de montes se van a erigir como los gestores de este nuevo paisaje arbolado; sin ir más lejos los primeros Parques Naturales y Monumentos Naturales declarados a raíz de la Ley de Parques Nacionales de 1916 (Ministerio de Fomento, 1916) son propuestos por ingenieros de montes instados por el Gobierno de España a llevar a cabo este trabajo.

En este sentido, este trabajo se propone el análisis de cinco casos de estudio donde se analizarán los procesos de patrimonialización de su paisaje forestal, es decir, se pretende encontrar y describir cuál ha sido el proceso de activación patrimonial que han sufrido estos paisajes e identificar los elementos irradiadores de patrimonialización. Para esto, se ponen en contacto dos conceptos ampliamente desarrollados por diferentes autores, especialmente en los últimos años: el paisaje y el patrimonio. Estos dos conceptos tratados tradicionalmente de forma aislada están tomando contacto en nuestra legislación con la ratificación del Convenio Europeo del Paisaje por parte del Gobierno español el 26 de noviembre de 2007 y que pretende poner el paisaje en el centro de la ordenación territorial española.

Los cinco casos de estudio son paisajes forestales de gran valor atendiendo a diferentes aspectos; encontramos paisajes que se encuentran plenamente funcionales y otros que son vestigios de usos ya olvidados, pero todos ellos comparten un claro poso patrimonial en el sentido de haber sido trasmitidos por las generaciones pasadas y están íntimamente relacionados con la población de su entorno.

Lo que se pretende con esta investigación es aportar nuevos criterios para la activación patrimonial del paisaje forestal desde un punto de vista cultural y con un enfoque patrimonial, poniendo en el centro de esta 
patrimonialización los aspectos culturales, planteando un modo diferente de observar un espacio forestal que tradicionalmente ha sido observado, gestionado y protegido atendiendo principalmente a sus valores biológicos o de herencia natural y que las legislaciones de protección y salvaguarda han ido destinadas a preservar olvidando su origen antrópico directamente relacionado con los usos tradicionales de las sociedades locales.

Uno de los conceptos principales sobre los que gira la investigación es el paisaje, el cual ha tenido multitud de enfoques y perspectivas como se verá más adelante por lo que es necesario fijar desde el inicio del trabajo a qué nos estamos refiriendo cuando hablamos de paisaje. Esta investigación se enmarca en la geografía por lo que la perspectiva desde la cual se mira al paisaje no puede ser otra que ese elemento de acumulación, ese archivo de procesos donde unos elementos se van superponiendo sobre otros y cómo la visión del geógrafo es capaz de integrar todos ellos y dar respuesta a la complejidad que implica su observación y análisis científico. La vocación geográfica holística e interdisciplinar se ajusta perfectamente al propósito de la investigación. Otro de los conceptos controvertidos que se tratan en esta investigación es el de patrimonio; en la tradición latina el patrimonio siempre tiene una componente económica ya que se refiere en buena medida a los bienes heredados de un antecesor. En este caso, a lo largo de la investigación cuando se trate el patrimonio se hará referencia a su valor heredado desprendido de su valor económico. Pese a esta premisa, el enfoque que se hace del patrimonio no implica que solo vaya a tratarse como algo sin valor, sino que el objetivo de la investigación no va a ser su activación turística o incorporación al mercado pese a que posteriormente pudiera llevarse a cabo, pero no es el objetivo de este trabajo.

Esta tesis se propone dilucidar cuál ha sido el proceso que ha seguido cada uno de los ejemplos escogidos en su incorporación como paisaje patrimonial partiendo de cinco casos de estudio, los cuales, se fundamentan en cinco diferentes argumentos. Se espera dar respuesta a la pregunta de si existe un único camino a la patrimonialización del paisaje 
forestal o cada uno de estos casos han seguido caminos diferentes. Por otro lado, se hace un recorrido por la historia forestal de la España peninsular y como se ha llegado al paisaje actual.

En cuanto al objetivo principal de la investigación, conocer el proceso de patrimonialización de cada uno de los casos estudiados y sus elementos condensadores de patrimonialización, es necesario llevar a cabo una aproximación conceptual tanto al paisaje como al patrimonio. Se hará un recorrido temporal y se determinará con precisión bajo qué perspectiva se va a tratar este tema. Pero no se puede olvidar que el objeto del estudio son paisajes patrimoniales, sería un error aproximarse a cada uno de estos conceptos por separado por lo que uno de los apartados está dedicado a explicar dónde toman contacto estos dos conceptos para que puedan ser tratados como un concepto, como paisaje patrimonial y no como paisaje y patrimonio, como planteaba Josefina Gómez Mendoza en su famoso artículo “Del patrimoni paisatge als paisatges patrimoni" (Gómez, 2012) ese viaje conceptual que se debe hacer para entender el paisaje como un patrimonio en sí mismo.

Así, la hipótesis de partida de la investigación sería que un determinado paisaje forestal es un paisaje patrimonial que fundamenta su existencia en la intervención humana a lo largo del tiempo. Se trata pues de un paisaje heredado que va a merecer el calificativo de paisaje patrimonial que permita la incorporación, en último término, a las políticas de ordenación territorial y salvaguarda.

El punto de partida del que nace este trabajo, como se ha señalado, es la necesidad de incorporar al centro de las políticas de ordenación el paisaje como exige la ratificación española del Convenio Europeo del Paisaje y se plasma posteriormente en el Plan Nacional de Paisaje Cultural de 2015 elaborado por la Subdirección General del Instituto del Patrimonio Cultural de España enmarcado en el Ministerio de Educación, Cultura y Deporte. De este modo, la tesis que se presenta queda totalmente justificada ante la necesidad de incorporar este enfoque sobre el territorio 
que exige la legislación que se está poniendo en marcha y que deberá ser una constante en el futuro. La investigación no solo aporta una forma de entender el paisaje y su incorporación o activación patrimonial, sino que justifica su existencia en la medida en que plantea propuestas metodológicas y herramientas que podrán ser utilizadas para futuras investigaciones.

Respecto al marco teórico y metodológico, pese a que posteriormente se desarrollará más en profundidad, es necesario decir que existen multitud de enfoques y escuelas que van a trabajar el paisaje y van a proponer diferentes métodos para su estudio sin que exista un claro consenso sobre una sistematización reconocida para estudiar, identificar, caracterizar y evaluar los paisajes (Scazzosi, 2006) por lo que se va a proponer un planteamiento basado en un recorrido diacrónico.

Este trabajo tiene una clara vocación geográfica por lo que es irremediable su plasmación cartográfica; los casos de estudio han sido trabajados de forma minuciosa gracias a la potencialidad que aporta el gran avance técnico que han sufrido los sistemas de información geográfica (en adelante SIG) como gestores de gran cantidad de datos y elaboración de figuras realmente atractivas y que simplifican la representación de la información de forma sencilla y clara.

En resumen, la tradición geográfica del Departamento de Geografía en el estudio del paisaje y el análisis geográfico regional han empujado a llevar a cabo esta investigación observando la necesidad de incorporar nuevos criterios destinados a la planificación y ordenamiento territorial basados en los estudios paisajísticos y más concretamente en el enfoque patrimonial, que indudablemente tiene un sentido cultural, como van a exigir las futuras leyes de ordenación a diferentes escalas administrativas. 


\section{Capítulo 1. Trasfondo y Objeto de estudio}




\subsection{El objeto de estudio}

El paisaje forestal va a ser el hilo conductor de este trabajo, como se ha esbozado, este paisaje derivado de la intervención mediante usos y prácticas tradicionales de origen cultural van a delimitar el objeto del que se va a ocupar este documento.

Los paisajes que se han escogido como casos de estudio para desarrollar el trabajo son resultado y resultante de la cultura de la sociedad en que se han desarrollado y este va a ser el pivote sobre el que gire la investigación. De esta manera se procurará no perder esta esencia a la hora de analizar de forma separada cada uno de los conceptos que se tratan. El paisaje en general y el paisaje forestal en particular van a mantener el hilo conductor que permita dotar de coherencia a este trabajo, siempre acudiendo a los aspectos culturales como modeladores de este paisaje, pero sin olvidar que se está trabajando con elementos vivos como es la vegetación que va a conformar este paisaje.

El paisaje que se sitúa como eje central del trabajo, es un paisaje entendido como lienzo sobre el que esas prácticas culturales van dejando su impronta. Es, por tanto, una visión cultural del paisaje o más bien una visión patrimonial entendiendo lo patrimonial como esa herencia que ha tallado la manera de hacer de nuestros antepasados.

Con estas premisas se presenta un objeto de estudio de carácter holístico, que plantea la necesidad de un enfoque general y diacrónico pero que es a su vez concreto en tanto que se ciñe al paisaje forestal. No se pretende por tanto hacer un repaso de la realidad paisajística general, sino una aproximación a la realidad paisajística que se relaciona con los árboles en su individualidad y con la foresta en su generalidad.

En ocasiones será necesario no perder de vista el contexto paisajístico general, ya que lo forestal suele estar relacionado, en nuestra cultura, con un sinfín de prácticas tradicionales de aprovechamiento que no se entenderían de forma aislada. Es decir, lo forestal suele estar directamente 
vinculado con lo agropecuario, incluso con lo industrial en ocasiones. Es necesario tener siempre presente ese contexto general, donde todo se relaciona, pero sin perder de vista que el objeto de estudio va a ser concreto y acotado.

\subsection{Objetivos, estructura y método}

\subsubsection{Objetivos}

La geografía tradicionalmente se ha ocupado del estudio del paisaje, su carácter holístico ha convertido a nuestra disciplina en la ciencia paisajística por excelencia gracias a su capacidad de sintetizar la suma de las partes que encontramos en el territorio. Especialmente en los últimos años el paisaje se ha convertido en la expresión de la cultura territorial, por lo que comprendiendo el paisaje se alcanzará una perfecta comprensión de las dinámicas territoriales y especialmente se apreciará su dimensión cultural la cual será el pilar fundamental de su consideración patrimonial. Por otro lado, el paisaje forestal es el gran olvidado de los estudios de paisaje por lo que este trabajo permitirá poner el paisaje en el centro de aquellos territorios cuya dominancia o al menos relevancia esté representada por el paisaje forestal.

Los paisajes forestales son especialmente peculiares y se ven rodeados de una mística cultural especial, la cual irradia identidad y sentimiento de pertenencia a la población local. Esta singularidad tiene su fundamento en el valor patrimonial de estos paisajes en el sentido de construcción social y legado generacional, el cual ha generado que estos paisajes contengan una serie de valores que exceden lo propiamente natural para asentarse sobre lo cultural.

De acuerdo con estas premisas, en este trabajo se plantean tres objetivos básicos:

1. El recorrido por los distintos paisajes forestales de la España peninsular a través de las especies más relevantes, sus formaciones, su distribución espacial y sus prácticas culturales tradicionales. 
2. La aproximación conceptual al paisaje y el patrimonio, su contexto social y jurídico, así como la síntesis de estos conceptos en uno: el paisaje patrimonial.

3. Conocer los procesos de incorporación patrimonial de cinco casos de estudio y analizar su situación mediante la creación de una serie de indicadores de referencia.

\subsubsection{Estructura}

Para llevar a cabo este cometido se plantea una estructura dividida en tres partes.

El primer apartado de la tesis está destinado a describir el trasfondo y el objeto del estudio, el capítulo 1 está destinado a delimitar el objeto de estudio, la estructura y la metodología empleada.

En el segundo capítulo se desarrolla la descripción de la historia forestal de nuestro país para poder entender como se ha llegado hasta el paisaje forestal actual desde sus orígenes naturales, las primeras intervenciones humanas, la convivencia durante siglos hasta la ordenación decimonónica y la realidad forestal actual y así justificar el claro origen antrópico del bosque contemporáneo. Este primer apartado alberga también la descripción de objetivos que tiene este trabajo, la estructura y la metodología que se va a utilizar en su conjunto y en cada uno de los apartados.

Por otro lado, el segundo apartado del documento está destinado a un encuadre conceptual donde se desarrollan las nociones de paisaje, patrimonio y paisaje patrimonial permitiendo fijar los pilares sobre los que girará el tercer y último apartado del trabajo.

El capítulo tres está destinado, en su integridad, al concepto de paisaje, revisando las diferentes aproximaciones que ha tenido este concepto a lo largo de la historia centrándonos en su dimensión territorial e identitaria sin olvidar otras dimensiones que se han acercado al concepto de paisaje a lo largo de la historia, pero con una clara vocación geográfica 
que nos permite observarlo como un todo más allá de verlo como la suma de sus partes.

El capítulo cuatro se va a centrar en realizar un repaso teórico por los servicios ecosistémicos planteando este enfoque como un posible nicho de futuras investigaciones que permitan conocer de forma cuantitativa el valor de los paisajes forestales estudiados.

El capítulo cinco se centra en el concepto de patrimonio en el sentido de que la aproximación que se hace al paisaje es una aproximación cultural que inevitablemente lleva a tratar el paisaje como un elemento heredado donde encontramos vestigios de la intervención de nuestros antepasados, es decir como asegura la UNESCO estamos tratando más un paisaje cultural que un paisaje simplemente, aunque surja la contradicción de si existen los paisajes que no son culturales.

Como aglutinante de los conceptos anteriores se desarrolla el capítulo seis, que pretende poner en contacto estos dos conceptos: patrimonio y paisaje para poder enfocar el estudio desde la perspectiva del paisaje patrimonial como un nuevo concepto que aglutine esos paisajes que son resultado inequívoco de la intervención humana y que poseen elementos condensadores de patrimonialización. Este nuevo concepto está íntimamente ligado con el carácter rural del paisaje y pretende poner en el foco esa personalidad agrosilvopastoril del paisaje que debe ser clave en la gestión y ordenación territorial, más aún en el momento actual que tanta preocupación está generando el problema de la despoblación del medio rural y el abandono de las actividades tradicionales, provocado por el llamado "cambio global" que está surgiendo como una línea de investigación creciente donde la geografía debe estar presente como ciencia de síntesis. Aquí se encuentra el desarrollo conceptual del proceso de patrimonialización que posteriormente se aplicará a los cinco casos de estudio.

Este apartado contará con un epígrafe destinado a presentar como se identificarán aquellos elementos que van a ser catalizadores de 
patrimonialización y que pretenden ser catalogados y analizados en cada uno de los cinco casos de estudio. Estos elementos son fundamentales para llevar a cabo la asociación patrimonial a un paisaje ya que son la clave sobre la que gira el aspecto cultural e identitario que convierten al paisaje en un patrimonio. Igualmente, el capítulo 7 va a contener un apartado reservado a definir los indicadores y la valoración que se utilizarán para el análisis del proceso de patrimonialización de los distintos casos de estudio y que permitan la comparación entre ellos.

La tercera y última parte de la tesis está destinada al desarrollo de cinco casos de estudio desarrollados en cinco capítulos. Estos están referidos a cinco paisajes relacionados directamente con los árboles o su conjunto. Pese a que estos cinco territorios pudieran enfocarse desde muchas perspectivas, en este caso el enfoque es hacia su paisaje forestal, donde se centra el estudio. En este último apartado se pretende, desde el enfoque planteado, analizar sus características, su paisaje e identificar los elementos heredados que le dan el valor patrimonial al conjunto paisajístico. Los casos de estudio son cinco paisajes forestales que se diferencian por estar fundamentados en cinco criterios diferentes que van a ser la clave de los elementos condensadores de patrimonialización, pero todos los casos comparten el carácter rural.

- El primer caso de estudio es un hayedo situado en una ladera norte de la Cordillera Cantábrica dentro del Parque Natural de los Picos de Europa en el municipio de Posada de Valdeón (León) por lo que se encuentra bajo una figura de protección medioambiental de carácter nacional lo que va a condicionar sus características. Se trata de un hayedo de grandes dimensiones que forma un bosque compacto prácticamente monoespecífico de hayas (Fagus sylvatica L 1753) el cual tiene un origen indudablemente natural pero una dimensión claramente antrópica. Este bosque destaca por su destacable valor biológico que será la clave de su valor patrimonial. 
- El segundo caso de estudio hace referencia a un pinar (Pinus pinaster Ait.1789 y Pinus pinea L. 1753) de grandes dimensiones cuyo origen es natural pero su espectacular dimensión y su importancia económico/social derivan del incentivo que han tenido estos ejemplares por parte de las poblaciones locales durante siglos. El territorio se caracteriza por ser una gran llanura arenosa salpicada por pequeños relieves tabulares en forma de páramos o cerros testigo. El área delimitada corresponde a la agrupación de los municipios que comparten este gran bosque.

- El tercer caso de estudio está relacionado con la existencia de un eucaliptal (Eucalyptus sp.) prácticamente monoespecífico que domina el municipio de Guriezo en Cantabria y que está íntimamente relacionado con la dimensión económica siendo este bosque una plantación destinada a la obtención de celulosa que tiene un origen indudablemente humano que hinca sus raíces en las primeras plantaciones de estos árboles en la península lo que ha generado una dependencia económica importante para el municipio que se traduce en una vinculación social muy relevante. El eucaliptal se desarrolla en las laderas de la Cordillera Cantábrica con diferente orientación y tienen una ordenación claramente productivista.

- El cuarto caso de estudio es el paisaje forestal vinculado a los chopos trasmochos del valle del río Jiloca en las provincias de Zaragoza y Teruel, donde destaca el núcleo de Calamocha en el centro de la cuenca. Ese paisaje se caracteriza por un arbolado disperso que tiene su origen en la deforestación agropastoril que sufrió la cuenca para proporcionar pastos a la amplia cabaña ganadera de ovino de la Corona de Aragón (O’flanagan et al., 2011). Los trasmochos de chopo (Populus nigra L. 1753) son denominados “chopos cabeceros" en esta comarca y son el resultado de la plantación para la obtención de diferentes productos lo que implica un indudable carácter patrimonial. Estos chopos aparecen de forma dispersa salpicando la cuenca del río Jiloca. 
- El quinto caso de estudio responde a la existencia de tejos (Taxus baccata L. 1753) catalogados por la Junta de Castilla y León bajo el "Catalogo de Especímenes Vegetales de Singular Relevancia de Castilla y León" que tienen una excepcionalidad basada en su monumentalidad lo que resulta paradójico al ser protegidos mediante una ley puramente ambiental bajo la Consejería de Medio Ambiente. Estos árboles se encuentran repartidos por la Comunidad Autónoma de Castilla y León concretamente en la orla montañosa que rodea la cuenca del Duero. Los tejos tienen un especial sentido espiritual y han estado asociados tradicionalmente a diferentes culturas y creencias lo que les otorga una singularidad patrimonial indudable.

Por último, el capítulo doce va a ocuparse de una discusión acerca del análisis de los distintos procesos de patrimonialización analizados. Este capítulo divagará y comparará los diferentes procesos, el momento patrimonial en que se encuentran, sus diferencias, similitudes, así como sus causas y consecuencias. De esta forma se pretende culminar el análisis que ponga de manifiesto el por qué unos paisajes forestales se encuentran mucho más activados patrimonialmente que otros. De esta manera, conociendo las razones que permiten a un paisaje forestal adquirir un reconocimiento patrimonial, se va a poder determinar cuáles serían aquellos pasos efectivos para su reconocimiento y posterior salvaguarda en caso de ser necesario.

\subsubsection{Método}

Pese a la dificultad para establecer los criterios que delimiten lo que significa el paisaje patrimonial y la recopilación de evidencias en el proceso de patrimonialización de dichos paisajes no debe ser un impedimento para fijar un conjunto de principios metodológicos que establezcan una coherencia que articule este trabajo a lo largo del análisis geográfico propuesto. De esta forma, la investigación se apoya en cuatro pilares metodológicos que se intentan seguir a lo largo del documento. 
En primer lugar, el trabajo se enfoca a través de la aplicación de un método deductivo partiendo de la base de una hipótesis de trabajo que, consiste en que un determinado paisaje forestal es un paisaje patrimonial que fundamenta su existencia en la intervención humana a lo largo del tiempo intentando descifrar los diferentes procesos de incorporación o activación patrimonial. Esta activación se apoya en la presencia de diferentes valores que pueden ser asignados a elementos catalizadores de patrimonialización, lo que permite hablar un territorio que alberga un fuerte poso cultural, reflejado en su paisaje forestal y que debe ser un elemento central en las políticas de ordenación del territorio. La recogida de datos y la elaboración de la tesis está centrada en permitir la comparación y descubrir los criterios que van a pesar más en la incorporación patrimonial del paisaje forestal. Esta forma de trabajar es evidente que puede pasar por alto información relevante para el estudio del paisaje, del patrimonio o incluso puede obviar aspectos relevantes de la ordenación territorial que podrían ser interesantes para el conocimiento de estos temas tan relevantes en este momento; pero el trabajo obtiene coherencia a partir de las premisas y las conclusiones más que en el aporte puramente conceptual.

En segundo lugar, es necesario señalar que, como complemento a la premisa anterior, el trabajo tiene una perspectiva diacrónica. Es indudable que los paisajes actuales no son más que el resultado por acumulación de la intervención de nuestros antepasados sobre el medio. Las intervenciones de las generaciones pasadas, en especial aquellas relacionadas con los usos tradicionales vinculada a la tradición agrosilvopastoril propia del mundo rural español han quedado reflejadas en el paisaje en general y concretamente en el paisaje forestal como no podía ser de otra manera, lo que llamamos el carácter (marca) del paisaje tiene su origen en otro espacio temporal por lo que el estudio necesariamente debe acudir al pasado para comprender los procesos actuales.

En tercer lugar, el análisis empírico se fundamenta en los cinco estudios de carácter exploratorio y descriptivo basado en el método del 
estudio de caso. Un abordaje basado fundamentalmente en la implementación de una metodología de investigación cualitativa y su traducción cuantitativa. Se ha realizado un minucioso trabajo de campo en los casos de estudio que permitiera conocer de primera mano cada uno de los paisajes y se ha ejecutado una minuciosa recopilación de datos mediante distintas técnicas que permitan la comparación propuesta.

En cuarto lugar, con el fin de comparar el proceso de patrimonialización en que se encuentran cada uno de los casos de estudio se realiza un acercamiento a los diferentes indicadores que se van a considerar como testigos de patrimonialización. Este método se encuentra desarrollado en su apartado correspondiente donde se describe de forma detallada el procedimiento seguido para la identificación de los indicadores.

Una vez presentadas las premisas metodológicas señaladas es necesario destacar el uso de herramientas informáticas para los análisis estadísticos, la sistematización de datos y, como no puede ser de otra manera en un trabajo geográfico, la representación cartográfica mediante el uso intensivo de sistemas de información geográfica (en adelante SIG) manejando una geodatabase compuesta por más de 25 bases espaciales diferentes. De esta forma, con el fin de simplificar la información y complementar el texto se presentan multitud de tablas, gráficos, mapas, planos y fotografías. Como inventario, hay que señalar que se han representado 96 tablas y 226 figuras lo que da cuenta de la importancia que tiene el apoyo gráfico y que permite hacer más fácilmente interpretable el trabajo.

Como resumen, este trabajo de investigación se fundamenta en criterios metodológicos básicos que pretenden dar coherencia a los resultados. 


\subsubsection{Fuentes de investigación}

El tema que aborda este trabajo se desarrolla a escala municipal, una escala tan de detalle hace necesario el trabajo de campo que será la fuente principal. Se trata de un trabajo que pretende obtener evidencias sobre elementos que, en la mayoría de las ocasiones, ni tan siquiera están catalogados, sino que forman parte de ese "saber hacer" de los usos tradicionales o esa relación que se puede definir como intangible de la colectividad con su entorno. Los procesos de patrimonialización están directamente relacionados con aspectos que son difícilmente cuantificables como el sentimiento de pertenencia, de identificación, celebraciones, memorias, etc.

Respecto a la actividad económica hay que destacar la información obtenida de las Cuentas de Cotización de la Seguridad Social, proporcionadas por la Tesorería General de la Seguridad Social y que permiten tener una información fiable acerca de la realidad laboral por ramas de actividad de los casos de estudio, con la ventaja añadida de la homogeneidad estatal ya comentada. Esta información resulta muy relevante a la hora de obtener una vinculación socioeconómica de algunos de los casos de estudio con su realidad forestal.

En cuanto al análisis de paisaje, la información cartográfica manejada que hace referencia a multitud de aspectos relevantes en el paisaje y las posteriores jornadas de trabajo de campo para corroborar y afinar el análisis obtenido ha permitido la elaboración de la correspondiente cartografía. Las principales fuentes cartográficas han sido:

- El Instituto Geográfico Nacional (IGN)

- El Instituto Geológico y Minero de España (IGME)

- El Banco de Datos de la Naturaleza

- Las Infraestructura de datos espaciales de las Junta de Castilla y León, el Gobierno de Cantabria y el Gobierno de Aragón.

Por otro lado, en cada uno de los casos de estudio se realizan aproximaciones presenciales a la población local en aquellos núcleos de 
población que resultan especialmente relevantes para entender la relación de la realidad forestal con la sociedad. De este modo se pretende conocer el grado de vinculación que existe entre el paisaje estudiado y la población que vive en su entorno inmediato.

Por lo tanto, el trabajo de investigación realizado ha conllevado una tarea de recopilación de información de fuentes a través de instituciones públicas fundamentalmente, realizándose una extensa exploración de los aspectos definidos como indicadores de patrimonialización. Resumiendo, la investigación supone un acercamiento directo a la realidad sociocultural, así como al propio paisaje forestal. 


$$
\begin{array}{r}
\text { Encuadre y } \\
\text { fundamentos } \\
\text { conceptuales }
\end{array}
$$




\section{Capítulo 2. El bosque en la España peninsular}




\subsection{La realidad forestal de la España peninsular}

Para entender el paisaje forestal español es necesario conocer la evolución del bosque, su propiedad y la evolución que han tenido desde una perspectiva diacrónica. De este modo se plantea un paseo por la historia del bosque español siempre centrando el foco en los árboles como caracterizadores del paisaje. La flora perteneciente a la parte continental de España es la más rica de Europa (Blanco et al., 2005) al encontrarse en una zona de transición bioclimática donde aparece desde el bosque templado húmedo propio del norte de Europa hasta vegetación adaptada a la aridez muy característica de zonas desérticas como el norte de África. Esto no solo genera una gran abundancia de especies, sino que, junto con el aislamiento que le otorga su carácter peninsular, ha favorecido la existencia de endemismos ibéricos.

El bosque en el territorio peninsular de España se distingue fundamentalmente por esa dicotomía de origen climático, existiendo un bosque de la España atlántica caracterizado por los géneros Quercus y Fagus fundamentalmente, así como Castanea y Corylus en menor medida, apareciendo en la alta montaña los Betula y Sorbus.

Este bosque templado húmedo parece haber albergado importantes bosques de Pinus en épocas pretéritas según señalan diferentes estudios polínicos (López, 1978; Watts, 1986; Carrión et al., 2000; Rubiales et al., 2008) (Figura 1). Pero de forma generalizada, en el norte peninsular, el Pinus cedió terreno en favor de otros taxones apoyado en prácticas antrópicas. A partir de los años 40 del siglo XX las repoblaciones de pino se han hecho comunes en todo el territorio peninsular, por lo que en cierta medida el pino vuelve a ser común en el bosque templado húmedo español. 


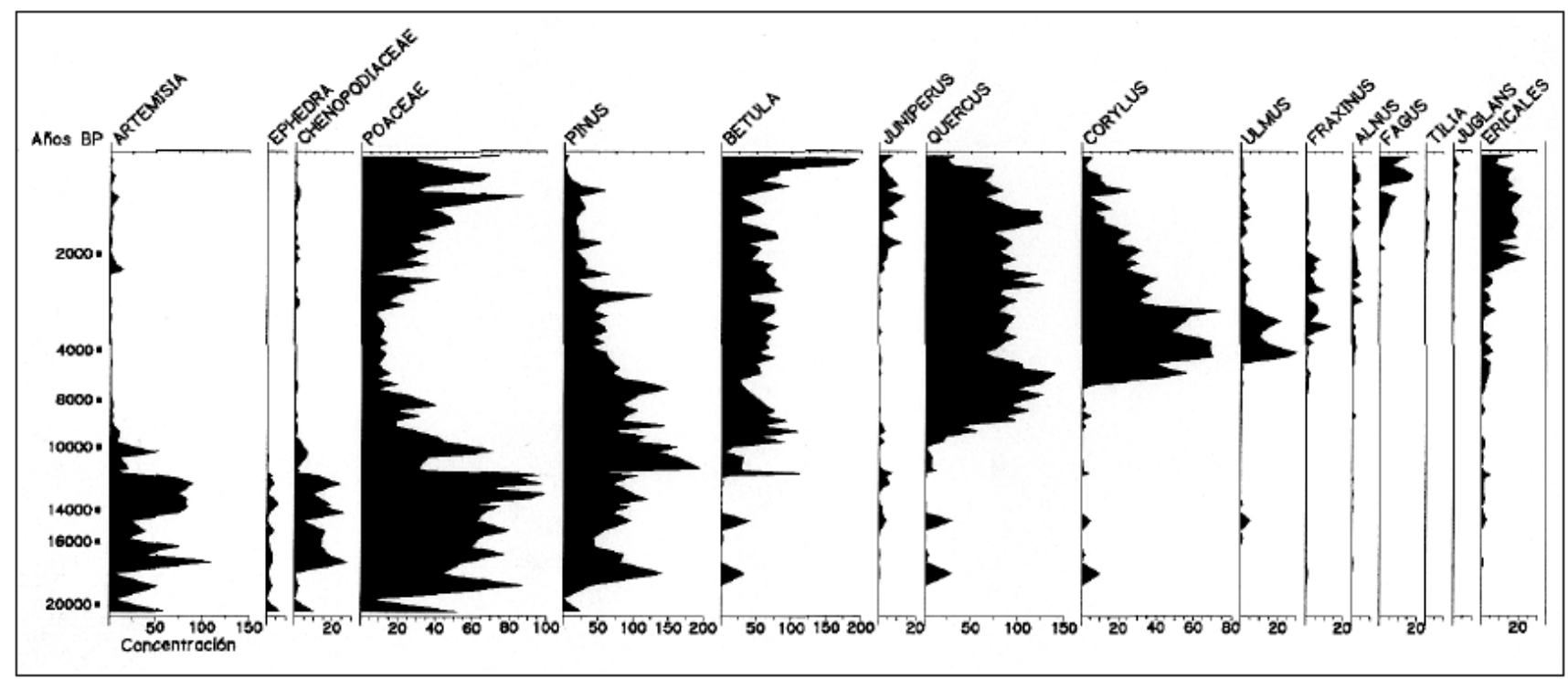

Figura 1. Secuencia polínica del Lago de Ajo en la Cordillera Cantábrica, León. Fuente. (Watts, 1986) recuperado de (Carrión García et al., 2000). Se puede apreciar el progresivo descenso del género Pinus en beneficio de otros géneros.

El bosque mediterráneo caracterizado popularmente por la encina (Quercus ilex L. 1753 ssp ballota) y el alcornoque (Quercus suber L. 1753) especialmente y de otras especies de Quercus no muy exigentes en agua. Pero no se pueden olvidar los pinos que ocupan gran extensión en el dominio mediterráneo, especialmente el Pinus pinaster y el Pinus pinea sin olvidar el Pinus halepensis Mill. 1786, el Pinus nigra J.F. Arnold 1785 y el Pinus sylvestris L. 1753 propio de la montaña mediterránea ocupando las laderas entre los 1200 y los 2000 m.s.n.m. a partir de los cuales domina el Pinus uncinata Ramond ex A. DC. 1805. Por otro lado, en los suelos pobres tan característicos del dominio mediterráneo, aparecen con frecuencia bosques o bosquetes de enebros (Juniperus communis L. 1753 y Juniperus oxycedrus L. 1753) y sabinas (Juniperus thurifera L. 1753 y Juniperus phoenicea L. 1753) que son unos de los bosques más singulares de la España peninsular.

Es necesario destacar la singularidad que introduce el pinsapo (Abies pinsapo Boiss. 1838) siendo la única masa de esta especie de abeto existente, se trata pues de un endemismo ibérico cuyo origen presenta 
cierta controversia al tratarse de una especie que ha llegado a nuestros días como una reliquia pretérita. Actualmente se encuentra restringida en las sierras de la provincia de Málaga (Sierra de las Nieves, Sierra Bermeja) y de Cádiz (Sierra de Grazalema). Así como los abetales tan característicos de la montaña pirenaica (Abies alba Mill. 1768).

En cuanto a los bosques exóticos muchas han sido las especies introducidas en nuestro país y se han instalado formando masas más o menos extensas como el Pinus radiata D. Don 1836 o el abeto de Douglas (Pseudotsuga menziessii (Mirb.) Franco 1950), destacando un género que es determinante para el bosque español en las últimas décadas es el Eucalyptus con la plantación de grandes extensiones de Eucalyptus globulus Labill 1800 en toda la fachada cantábrica y atlántica con la excepción de la provincia de Cádiz y el Eucalyptus camaldulensis Dehnh. 1832 en Huelva y Extremadura principalmente.

Partiendo de estas premisas los bosques que van a caracterizar el paisaje forestal español van a ser los siguientes.

Bosque de la España Atlántica:

- Hayedos

- Robledales

- Pinares Eurosiberianos

- Otras formaciones del bosque atlántico

Bosque de la España Mediterránea:

- Encinares y alcornocales

- Sabinares y enebrales

- Pinares mediterráneos

Por último, hay que destacar diferentes bosques especialmente singulares: 
- Los formados por las especies marcescentes que se adaptan a condiciones de humedad, así como a condiciones típicas del dominio mediterráneo reflejando un carácter transicional.

- Los abetales pirenaicos

- Los pinsapares

- Los bosques de especies exóticas

Siguiendo esta clasificación propuesta se realiza una pequeña síntesis de cada uno de ellos, así como su origen y evolución, lo que hará más sencillo comprender el momento actual del bosque de la España peninsular.

\subsubsection{Bosques de la España Atlántica}

\subsubsection{Hayedos (Fagus sylvatica)}

Se trata, probablemente, del bosque más característico de la montaña húmeda española, desarrollándose principalmente en el piso montano. Forma masas casi monoespecíficas, densas, umbrosas y con un sotobosque muy poco desarrollado; si acaso pueden convivir ciertas especies umbrófilas y que soporten bien la humedad ambiental. El haya aparece prácticamente en todos los suelos que estén desarrollados y tiende a desplazar al resto de especies a medida que desarrolla un dosel destinado a generar sus condiciones óptimas de umbría y humedad.

En cuanto a su localización hay que señalar la importancia que estos bosques toman en Navarra (Figura 2), donde aparecen algunos de los más extensos de la península, de igual modo la Cordillera Cantábrica aparece continuamente salpicada por estas formaciones que se encuentran en expansión, así como el Pirineo especialmente en sus extremos (Figura 3). Excepcionalmente aparece un importante bosque de hayas en la Cordillera Central en la frontera entre las provincias de Segovia y Madrid (Figura 4). 


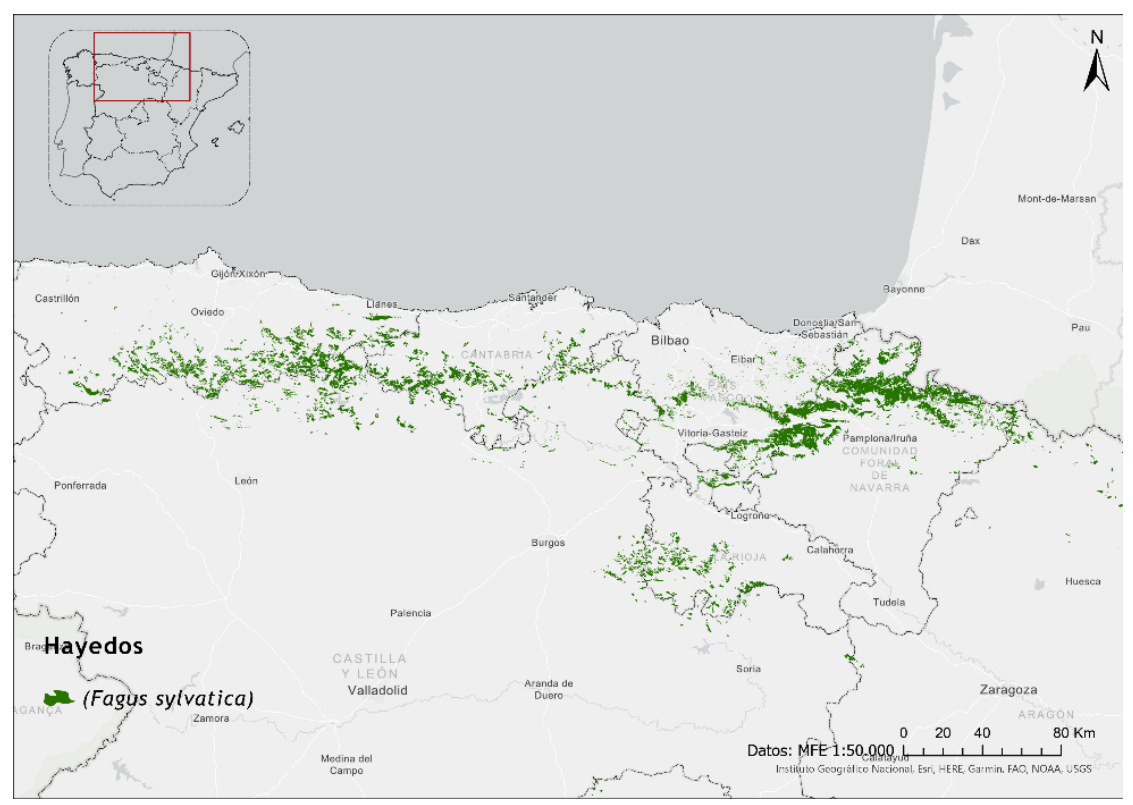

Figura 2. Distribución de los bosques de hayas en la Cordillera Cantábrica. Elaboración propia a partir de Mapa Forestal de España 1:50.000.

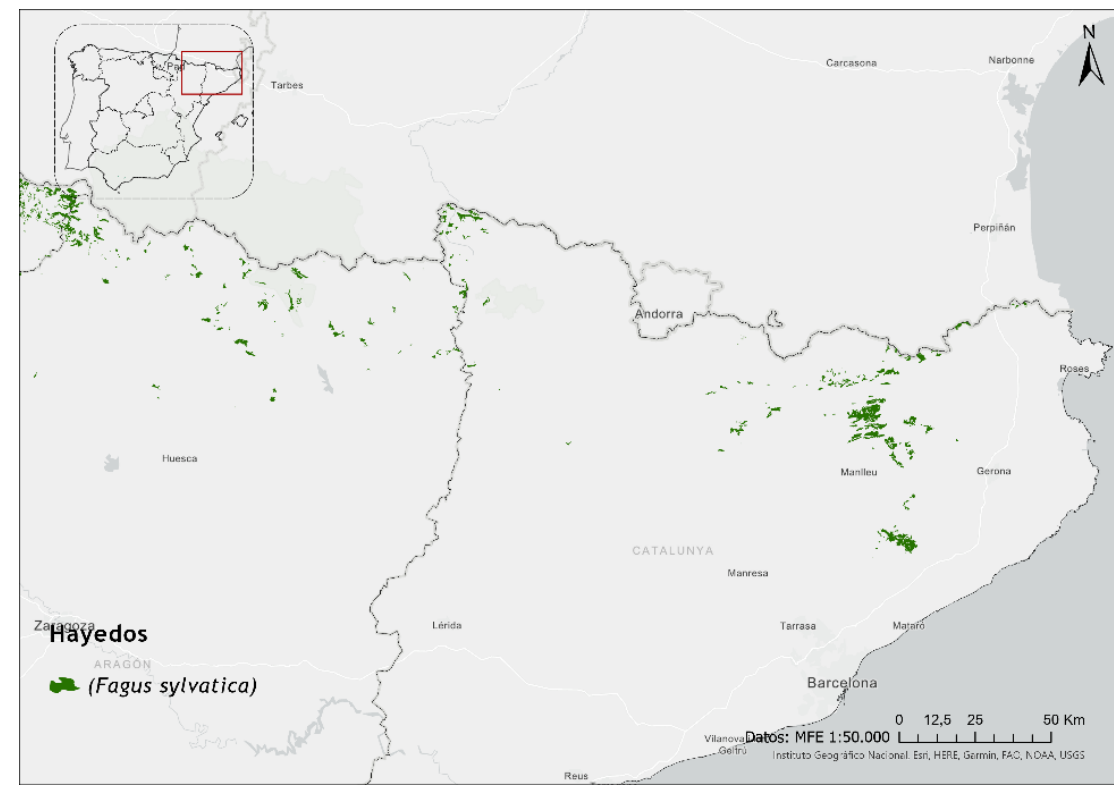

Figura 3. Distribución de los bosques de hayas pirenaicas y prepirenaicas. Elaboración propia a partir de Mapa Forestal de España 1:50.000. 


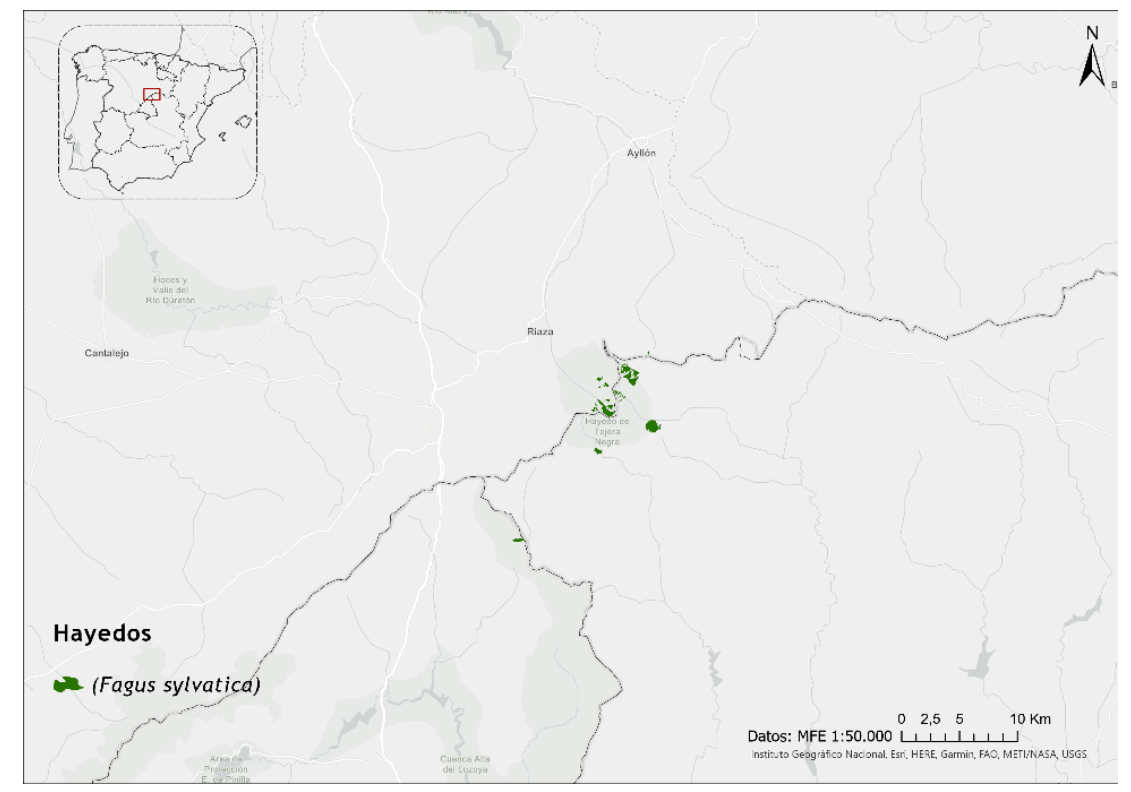

Figura 4. Los hayedos en la Cordillera Central. Elaboración propia a partir de Mapa Forestal de España 1:50.000.

El hayedo es un bosque reciente, resultado de la expansión hacia el oeste a partir del Último Máximo Glacial desde refugios internos de la península, datándose la existencia de hayas en al menos 20.000 años BP (Gómez et al., 2007) y 50.000 años BP (Ruiz et al., 2002) lo que aseguraría el origen autóctono de esta especie y no migrado desde refugios balcánicos como se creía inicialmente (Huntley y Birks, 1983; Peñalba, 1989, 1994). De este modo se produciría una expansión natural apoyada en cuestiones climáticas durante el holoceno inicial y medio, para desarrollarse la gran expansión a finales del holoceno apoyada en razones antrópicas (Ramil et al., 2000; López et al., 2008; Muñoz et al., 2008) incentivándose este bosque para la producción de madera.

\subsubsection{Robledales (Quercus robur y Quercus petraea)}

Los robledales ya sean monoespecíficos o mixtos, son el bosque más característico del piso montano y colino de la España húmeda. Generalmente forma masas mixtas con varias especies donde dominan los robles (Quercus robur L. 1753 y Quercus petraea (Matt.), Liebl. 1784) 
apareciendo comúnmente ejemplares híbridos entre las dos especies (Blanco et al., 2005). Estas masas actuales son umbrosas y densas, con un sotobosque poco desarrollado similar al del hayedo debido a la dificultad para sobrevivir con poca luz. Uno de los taxones más característico de estas formaciones boscosas es el helecho subtropical (Woodwurdia radicans) que toma un protagonismo indiscutible en los mejores robledales. Este bosque mixto dominado por las dos especies de roble señaladas supone el paradigma del bosque templado húmedo para el piso colino, pero esto ha supuesto que se haya visto sometido a una importante alteración al ser el ambiente más propicio para el desarrollo de las actividades agropecuarias.

En cuando a la distribución del robledal peninsular hay que destacar la Cordillera Cantábrica (Figura 5) y el este de los pirineos (Figura 6), pero especialmente destacan los robledales gallegos que salpican el interior de esta Comunidad Autónoma.

Los bosques mixtos de planifolios dominados por las dos especies de robles señaladas son propios de todo el centro europeo, así como del norte peninsular. Parece ser que durante los periodos más fríos estos bosques se refugiaban en las zonas costeras y volvían a expandirse durante los interglaciares de forma rápida llegando así a sustituir los bosques de coníferas (Pinus y Abies) y abedules (Betula) (Blanco et al., 2005). Pero la existencia de este bosque de Quercus caducifolios y especies propias de este bosque mixto aparecen en secuencias polínicas muy antiguas lo que asegura sin género de dudas su carácter autóctono (Desprat et al., 2009) pudiéndose apreciar una colonización de estas especies tras el último máximo glaciar que cesa rápidamente a finales del holoceno; como se ha dicho anteriormente, al ser estas formaciones propias del piso colino fueron sustituidas para la producción agropecuaria aumentando los registros de cereales, leguminosas y ericáceas a medida que se reducían los Quercus caducifolios (Peñalba, 1989; Muñoz et al., 2005; Miras et al., 2007; López, 2009; López, Martínez, et al., 2010). Actualmente se puede apreciar una recuperación de este bosque asociada al abandono rural. 


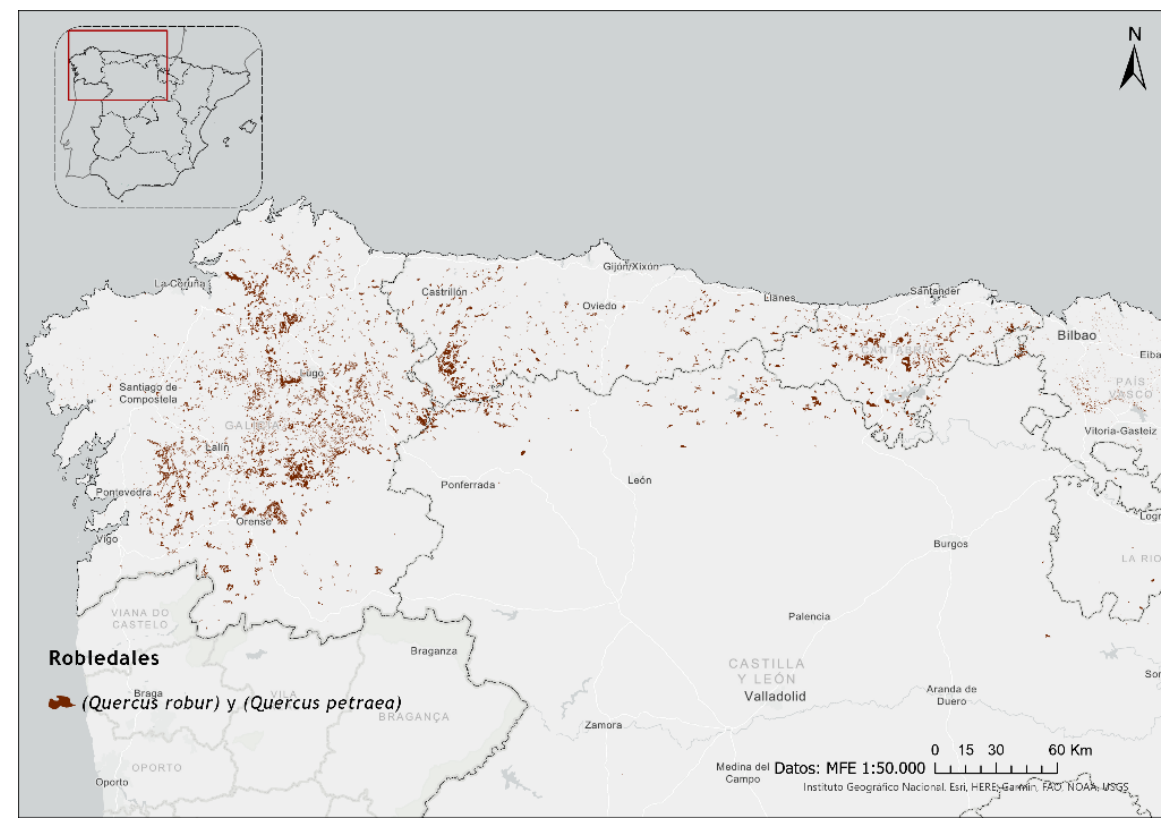

Figura 5. Distribución de los bosques de robles en el noroeste español. Elaboración propia a partir de Mapa Forestal de España 1:50.000.

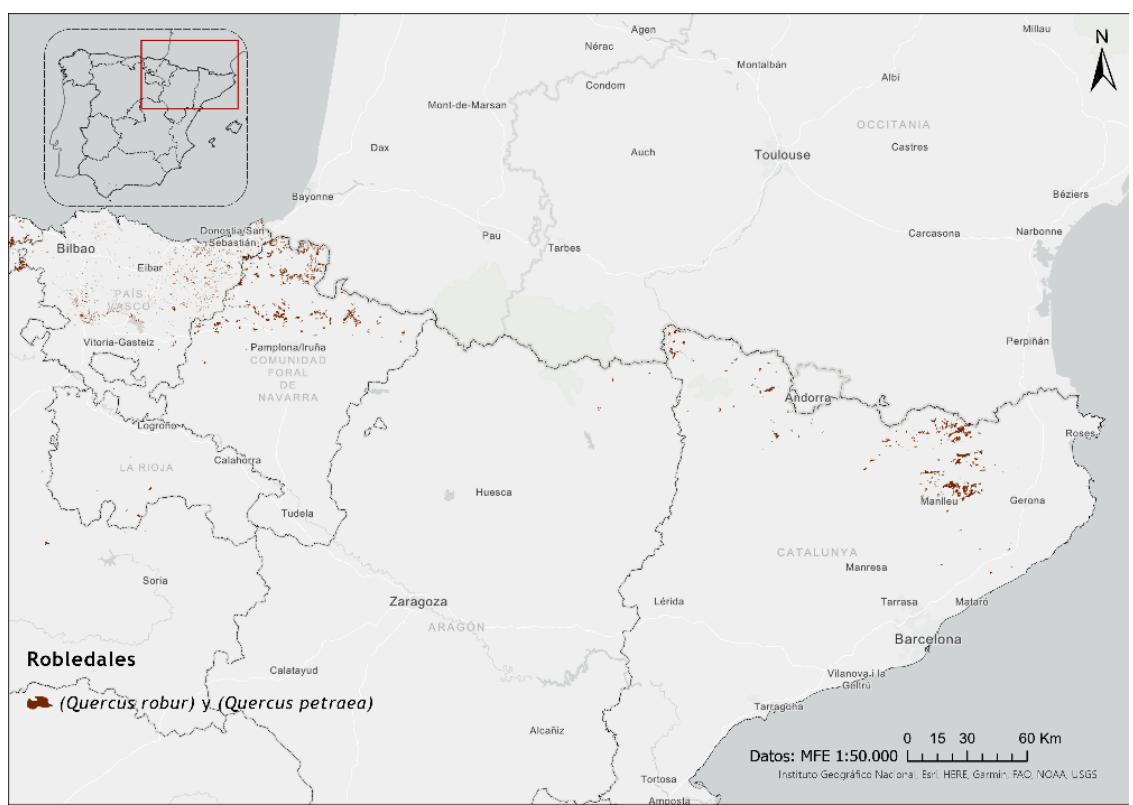

Figura 6. Distribución de los bosques de robles en los Pirineos. Elaboración propia a partir de Mapa Forestal de España 1:50.000. 


\subsubsection{Pinares eurosibierianos (Pinus sylvestris y Pinus uncinata)}

Los pinares eurosiberianos son el bosque propio de las altitudes más elevadas de la España húmeda estando caracterizados por el Pinus sylvestris y el Pinus uncinata. Se trata del refugio altitudinal de estos bosques que en momentos pretéritos más fríos dominarían altitudes más bajas pero que se han visto recluidos a la alta montaña debido al avance de los bosques de Fagáceas en los pisos inferiores. De esta manera este bosque de coníferas mejor adaptado a la rigurosidad climática y edáfica de la alta montaña se convierte en la nota predominante a medida que se asciende altitudinalmente en las montañas, a esto ayuda el carácter robusto de esta especie; se trata de un árbol ubicuista, muy frugal y que soporta muy bien el frío invernal. Dentro de esta clasificación de pinar eurosiberiano existen diferencias entre el Pinus sylvestris y el Pinus uncinata. Mientras que el primero suele rondar un techo de 1700-1800 m.s.n.m., el segundo es el árbol de la alta montaña por excelencia llegando a un techo de 2700 m.s.n.m. en el Estany de San Maurici, en los Pirineos catalanes.

En lo que se refiere a la distribución de estos pinares (Figura 7), hay señalar que los Pinus sylvestris salpican buena parte de las montañas de la mitad norte peninsular donde otras especies no se desarrollan adecuadamente. Las mejores masas aparecen en la vertiente norte de la Cordillera Central, la Serranía de Cuenca, la Sierra de Javalambre, Los Picos de Urbión en la Cordillera Ibérica, algunas partes altas de las Béticas y los Pirineos. El Pinus uncinata por su parte, se recluye casi exclusivamente en los pisos más elevados de la Cordillera Pirenaica. 


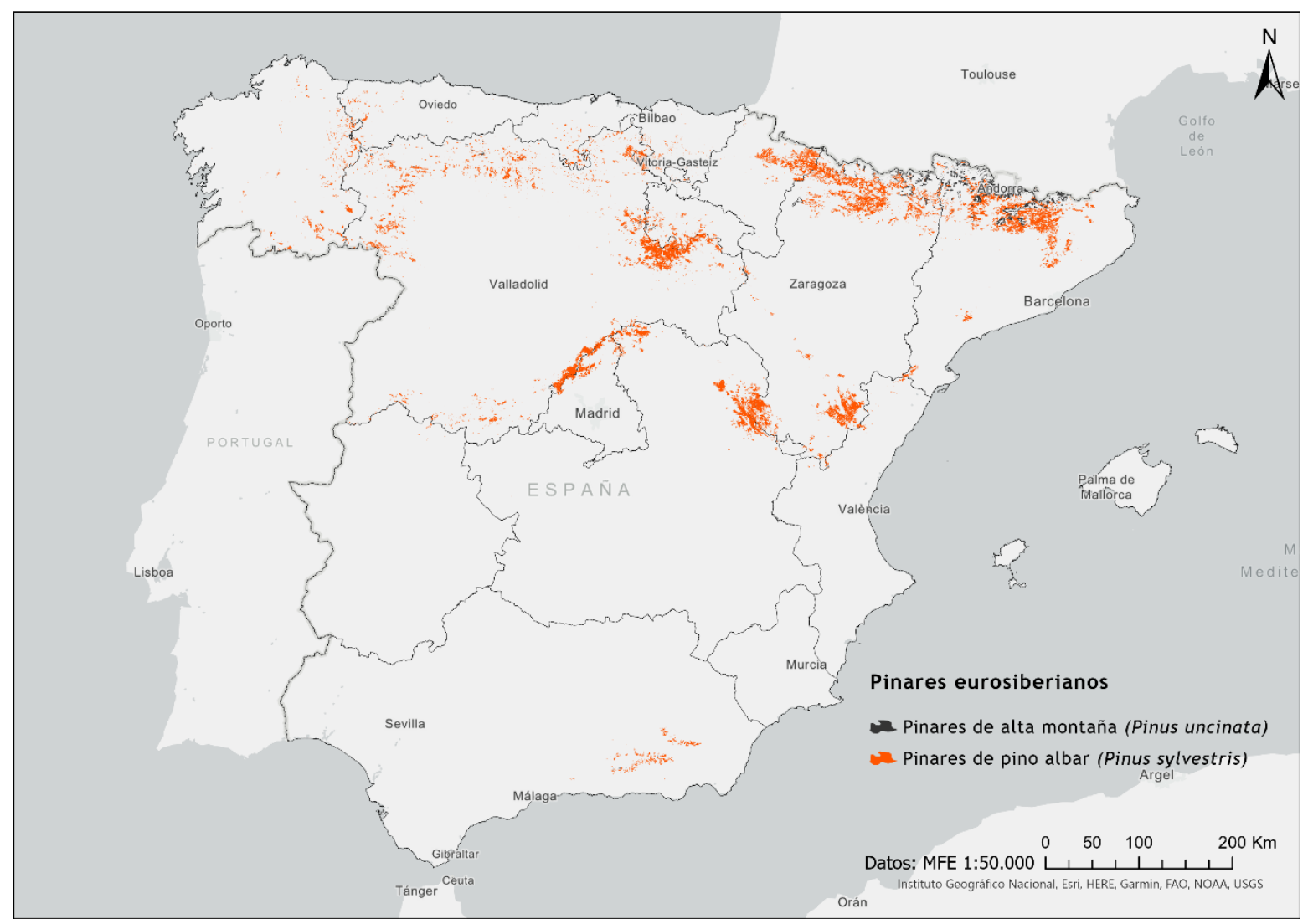

Figura 7. Distribución de los pinares eurosiberianos en la España peninsular. Elaboración propia a partir de Mapa Forestal de España 1:50.000.

En cuanto al origen de estos pinos abundantes en las montañas húmedas de la península existen evidencias basadas en restos polínicos con dataciones de hasta 44.000 años BP (Gómez et al., 2001) en el yacimiento de Moucide en Lugo, lo que hace indudable su existencia previa a la intervención humana en el norte peninsular. Estos pinares parece que se expandirían durante los pulsos fríos aprovechando su adaptación xerofílica así como al frio y su regresión durante los pulsos cálidos donde se verían desplazados por las planifolias llegando a desaparecer casi por completo en la Cordillera Cantábrica donde en algún momento fueron dominantes (Rubiales et al., 2008) empujados por el último cambio en las condiciones ambientales pero con la inestimable ayuda de la intervención humana a partir del neolítico (Allen et al., 1996; García et al., 1997; Muñoz et al., 
1997, 2007). En las montañas pirenaicas, la Cordillera lbérica, las Béticas y algunos puntos de la Cordillera Central han quedado recluidos a zonas menos aptas para el resto de especies vegetales, o han sido incentivados para la producción de madera llegando a ocupar pisos relativamente bajos que de forma natural estarían ocupados por otras especies.

\subsubsection{Otras formaciones del bosque atlántico (Abedulares, Castañares y Tejedas)}

En esta clasificación estarían otro tipo de formaciones representativas del bosque templado húmedo peninsular pero que no ocupan grandes extensiones como las formaciones anteriores, así encontramos principalmente abedulares (Betula spp), castañares (Castanea sativa Miller 1768) y tejedas (Taxus baccata) (Figura 8, Figura 9, Figura 10, Figura 11).

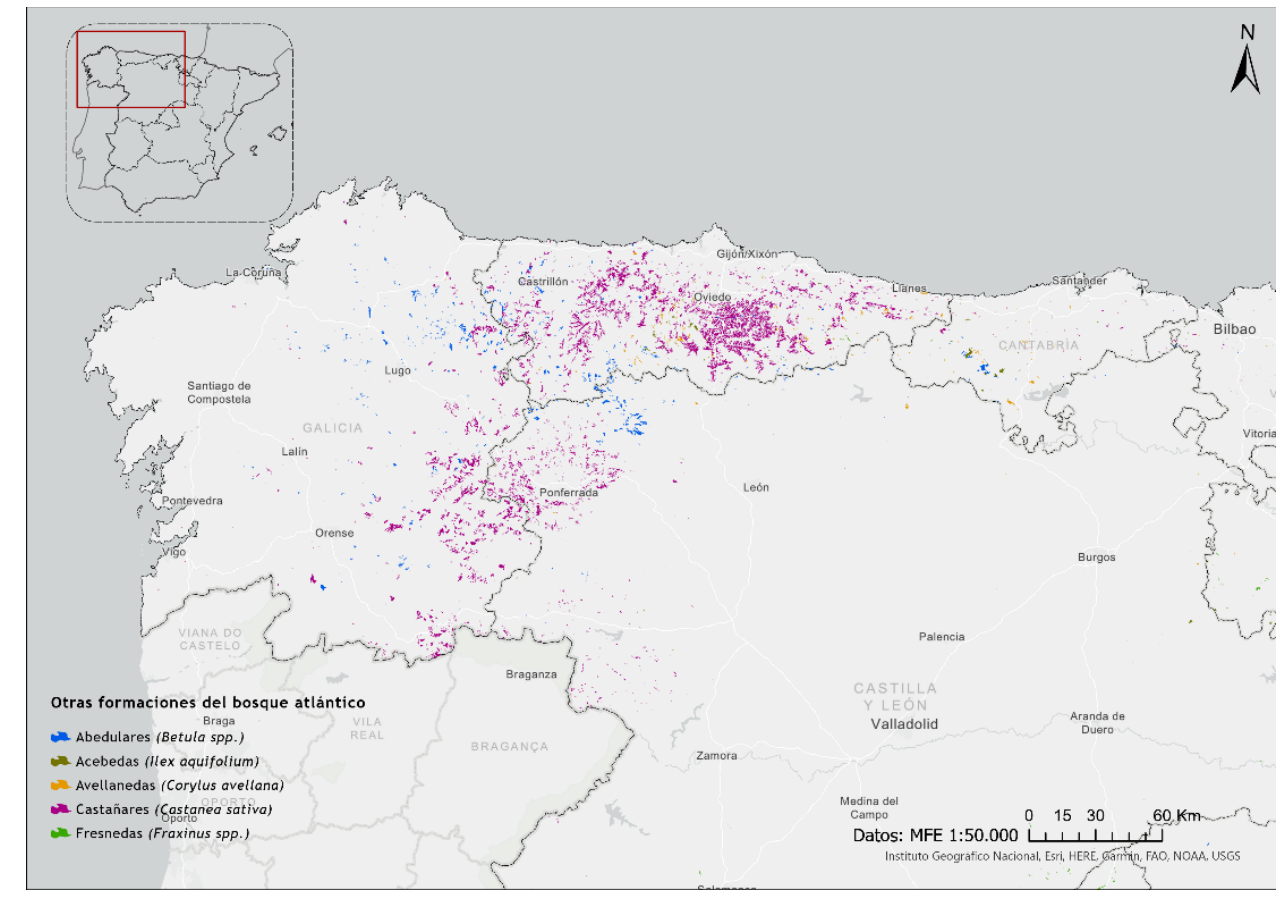

Figura 8. Distribución de las formaciones menores del bosque atlántico en el noroeste peninsular. Elaboración propia a partir de Mapa Forestal de España 1:50.000. 


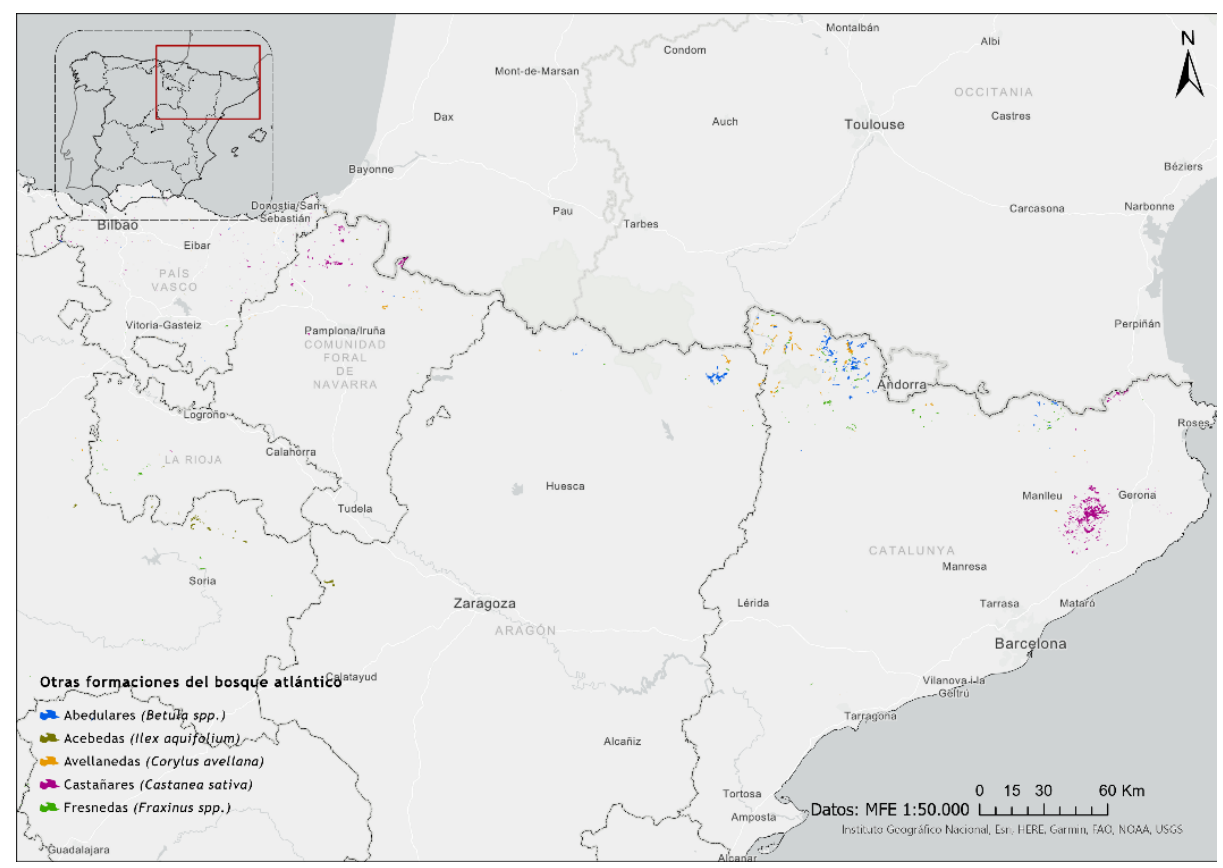

Figura 9. Distribución de las formaciones menores del bosque atlántico en el noreste peninsular. Elaboración propia a partir de Mapa Forestal de España 1:50.000.

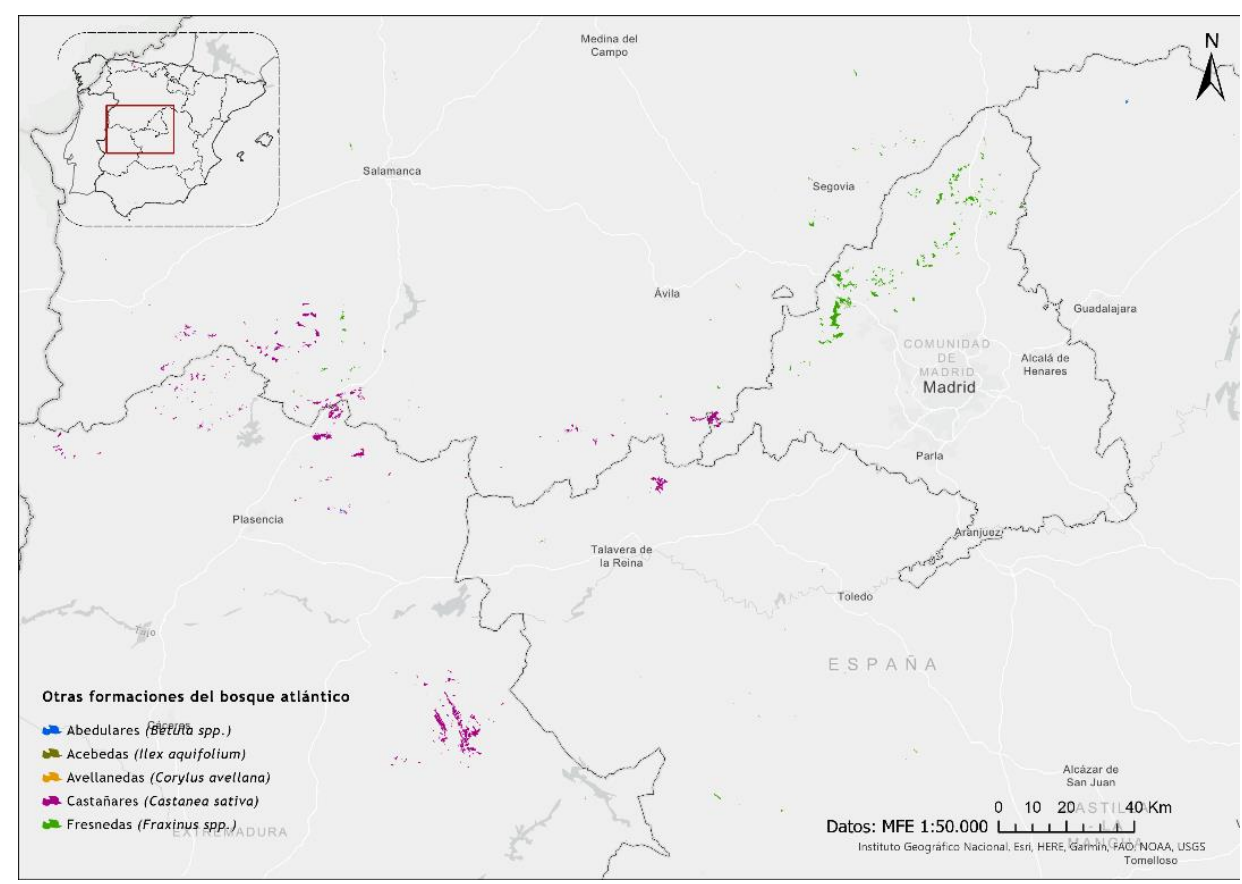

Figura 10. Distribución de las formaciones menores del bosque atlántico en el noreste peninsular. Elaboración propia a partir de Mapa Forestal de España 1:50.000. 


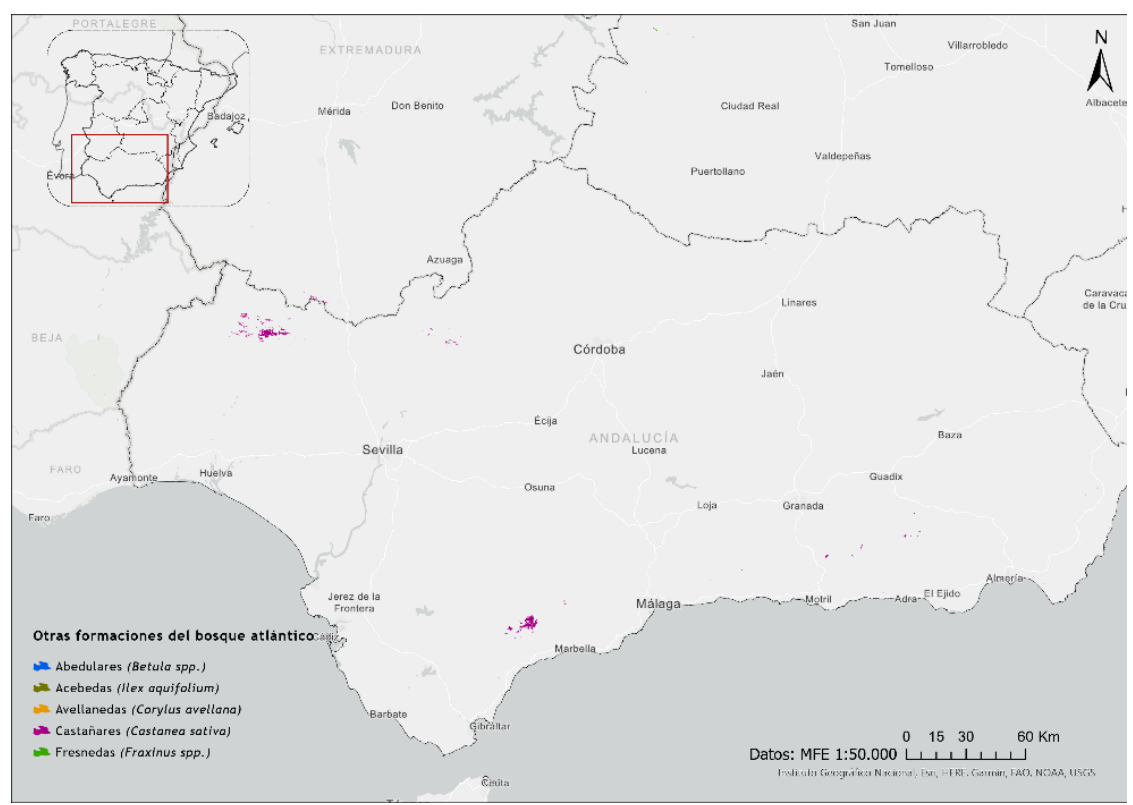

Figura 11. Distribución de las formaciones menores del bosque atlántico en el sur peninsular. Elaboración propia a partir de Mapa Forestal de España 1:50.000.

\section{$\underline{\text { Abedulares }}$}

Generalmente forma masas mixtas con otras especies y en ocasiones aparecen formando rodales monoespecíficos. Posee una gran ventaja competitiva al adaptarse a condiciones de frio incluso frio extremo lo que le permite superar los 2.000 m.s.n.m. aunque es exigente en requerimientos hídricos lo que le restringe a la montaña húmeda española. Pese a estos requerimientos se trata de una especie pionera que suele avanzar rápidamente ocupando el espacio cuando otras retroceden, en buena medida gracias a su excepcional producción de fruto y su capacidad anemócora. Debido a esta capacidad pionera, los abedulares han sido bosques muy oscilantes en cuanto a su dimensión, dispersando rápidamente a medida que los ciclos fríos cesaban y contrayéndose a medida que otras especies más lentas avanzaban y competían por el mismo espacio (el abedul requiere importante insolación por lo que en ambientes umbrosos se retira dejando paso a otro tipo de bosques). Así, parece que durante el pleistoceno el bosque de abedul presentaría a una extensión muy 
destacable en la Península Ibérica (Carrión, 2005; Gómez et al., 2007), reduciéndose en el holoceno como respuesta a esas variaciones termopluviométricas. En este sentido hay que señalar que el cese en las actividades agropecuarias conllevará una rápida expansión del abedul como puede apreciarse en diferentes evidencias polínicas (Muñoz et al., 1997, 2007; Mighall et al., 2006).

\section{Castañares}

Se trata de uno de los bosques propios del domino atlántico más cultivados para la obtención de fruto. El castaño (Castanea sativa) es un árbol que actualmente forma bosques o bosquetes (en muchas ocasiones mezclado con robles caducifolios) de pequeñas dimensiones, los importantes requerimientos del castaño son la razón fundamental de estas pequeñas dimensiones. Se trata de un árbol que no soporta las heladas, es silicícola, aunque puede desarrollarse en suelos carbonatados bien lavados por las precipitaciones, pero lo que va a determinar sin duda su distribución son sus exigencias hídricas ya que necesita al menos $800 \mathrm{~mm}$ anuales y que no exista aridez estival o sea muy moderada. Estas exigencias lo restringen en buena medida al piso colino y la parte inferior del montano por lo que existe una gran competencia con otras especies leñosas, así como con las actividades agropecuarias.

El castaño es un árbol autóctono de la península ibérica como lo atestiguan dataciones previas a la actividad humana (Llana et al., 1996; Ramil et al., 1996) aunque es cierto que se encuentra íntimamente relacionado con los cultivos antrópicos y su distribución actual puede estar en buena medida distorsionada por ello; así, parece haber sido incentivado de forma determinante en contraposición a otras especies como demuestran algunos trabajos (Allen et al., 1996; López, 2009).

\section{Tejedas}

Los tejos (Taxus baccata) suponene un bosque excepcional en tanto que representan un vestigio vivo de la vegetación pretérita que, probablemente cubrió la península al menos desde el jurásico (Blanco et 
al., 2005), actualmente no forma bosques o la hace de forma muy excepcional. Suele presentarse formando pequeños rodales o de forma aislada acompañando a construcciones míticas y religiosas.

Este retroceso que ha sufrido el tejo se debe a dos razones fundamentales, por un lado, la competencia con vegetación mucho más moderna capaz de competir en mejores condiciones por el espacio y a la acción humana deforestadora (Ros, 1988; López, Martínez, et al., 2010).

\subsubsection{Bosques de la España Mediterránea}

\subsubsection{Encinares y alcornocales (Quercus ilex y Quercus suber)}

Tanto la encina (Quercus ilex) como el alcornoque (Quercus suber) son los árboles por excelencia de la España mediterránea (Figura 12), o al menos son las especies que aparecen en la memoria colectiva cuando se habla de la vegetación mediterránea. Estas formaciones suponen un ejemplo singular de bosques de planifolios de hoja perenne y se han agrupado ya que se entiende que se trata de formaciones similares. 


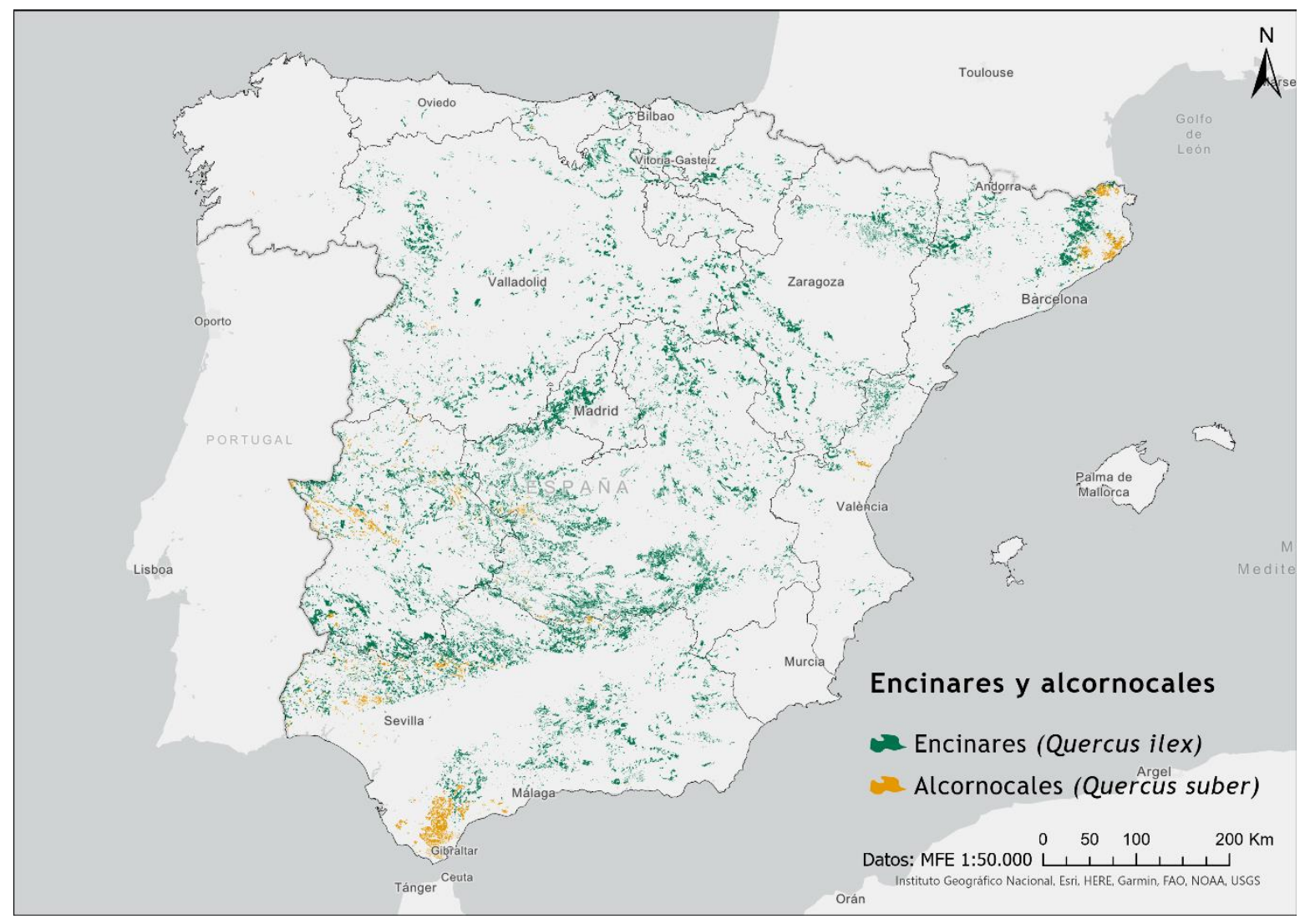

Figura 12. Distribución de los encinares y alcornocales en la España peninsular. Elaboración propia a partir de Mapa Forestal de España 1:50.000.

Esta singularidad que presentan ambas especies se fundamenta en la adaptación para superar la rigurosidad del clima mediterráneo caracterizado por los inviernos fríos y los veranos muy calurosos y secos, así estas especies han desarrollado hojas con cutículas gruesas para evitar las pérdidas de humedad y relativamente opacas para evitar la insolación durante el verano; de igual manera, son eficaces contra el frío y las heladas tardías. Su estrategia de hoja perennifolia se atribuye a la necesidad de mantener la actividad vegetativa durante todo el año y aprovechar los momentos óptimos sea cual sea el periodo estacional en que estos se produzcan.

En cuanto a las formaciones de bosque esclerófilo mediterráneo que desarrollan estas especies hay que destacar su excepcional riqueza 
florística y fitosociológica, se trata de formaciones complejas donde se relacionan multitud de especies, pero siempre bajo el dominio o preponderancia de las encinas o los alcornoques. Por otro lado, desde el punto de vista humano, hay que señalar la espectacular intervención a la que se han visto sometidas estas formaciones durante siglos, tratándose de dos de las especies más destacadas en cuanto al aprovechamiento tradicional para la obtención de recursos (fruto en forma de bellotas, leña o corteza, por ejemplo) en el mundo mediterráneo, de esta forma es difícil encontrar formaciones de encinas o alcornoques que no presenten rasgos más o menos acusados de adehesamiento. Para entender mejor cada una de las formaciones y cuál ha sido su evolución se va a proceder a tratarlas por separado.

En lo que respecta a las encinas hay que señalar la existencia de dos subespecies dominantes en la península ibérica, por un lado, la subespecie ilex caracterizada por sus hojas más laureadas y dominante en zonas litorales y sublitorales y la subespecie ballota, que se caracteriza por hojas más pequeñas, en ocasiones lobuladas o ligeramente pinchudas, esta subespecie sería la dominante en el interior peninsular y zonas de montaña. Esta diferencia parece ser una adaptación esclerófila derivada de la evolución desde la subespecie llex, que se considera más antigua y estable hacia la subespecie ballota (Blanco et al., 2005). Esta adaptación le ha permitido convertirse en una especie de baja exigencia lo que garantiza su ubicuidad.

El alcornoque por su parte aparece asociado a un clima más suave ya que soporta mal las heladas y requiere de precipitaciones por encima de los $600 \mathrm{~mm}$ anuales lo que le restringe fundamentalmente al cuadrante sur occidental peninsular, al extremo nororiental y a enclaves con climas locales o microclimas.

En cuanto al origen y evolución espacial de estos bosques esclerófilos mediterráneos hay que señalar que encontramos dataciones pleistocenas que aseguran la existencia de estas especies en la península, apareciendo 
incluso referencias de lugares que actuaron como refugios de encinas durante los periodos fríos, momentos en los cuales se retiraron del resto de Europa hacia el sur (Gómez et al., 2007; Uzquiano et al., 2008). En cuanto a las dimensiones del bosque de Quercus perennifolios se puede señalar que parece haber sido más extenso en tiempos pasados como asegura (Uzquiano, 1992a; b; c) donde plantea un bosque dominado por la encina en el neolítico para la cordillera cantábrica, apareciendo incluso el Quercus suber, en zonas costeras de Asturias. Por otro lado parece que se puede afirmar que en otros lugares del norte peninsular como el valle del Ebro, para el mismo periodo, aparecería un bosque dominado por la encina (Quercus ilex spp.ballota) con la presencia de Juniperus oxycedrus y Juniperus phoenicea (Peña et al., 2005). En otras ocasiones se puede apreciar como la intervención humana aclarando el bosque ha favorecido el desarrollo de los Quercus perennifolios en detrimento del bosque cerrado de tejo o Quercus caducifolios (Allué et al., 2009) es decir, el aumento de la cabaña ganadera se va a antojar determinante para el incremento de estas especies de acompañamiento pecuario (González, 1998; Uzquiano, 2002; Gil et al., 2008).

\subsubsection{Sabinares y enebrales (Juniperus spp.)}

Se trata de una formación forestal muy especial ya que forma bosques abiertos o ahuecados en buena medida aprovechando lugares donde no se desarrollan otro tipo de formaciones arbóreas por diferentes motivos. En muchas ocasiones se hace referencia a estas formaciones de cupresáceas como una singularidad de la península ibérica siendo uno de los pocos lugares donde encontrar este tipo de bosques. Se pueden distinguir sabinares albares (Juniperus thurifera), sabinares negrales (Juniperus phoenicea) y diferentes tipos de enebrales formados por Juniperus oxycedrus principalmente, pero en muchas ocasiones conviviendo con otras especies de Juniperus como el enebro común (Juniperus comunis) o la anteriormente nombrada sabina albar e incluso acompañado de diferentes especies del género Pinus. 
Merecen mención especial los bosques de sabina albar debido a su dimensión y su extensión en la península ibérica. Esta especie suele presentar un porte cónico en sus primeras etapas y hojas pinchudas que se irán volviendo imbricadas a medida que se hace adulta, del mismo modo su porte cambia hasta presentar diferentes aspectos donde se diferencian bien el tronco y la copa (muchas veces intervenida por la acción humana), perdiendo así su aspecto cónico.

En cuanto a sus exigencias son pocas por lo que se convierte en un árbol todoterreno, si bien es cierto que prefiere suelos básicos, en ocasiones aparece en suelo ácidos; soporta el frío invernal, el calor estival e incluso la escasez de agua. Se adapta a suelos poco profundos, raquíticos, incluso pedregosos, en ocasiones. Por todas estas razones se encuentran bosques de sabina en aquellos lugares donde pareciera que no podría haber otra formación arbórea. Se trata pues, de formaciones directamente relacionadas con la continentalidad que introduce, en el clima mediterráneo, el alejamiento de la influencia marina. Principalmente aparecen estos bosques en el interior peninsular (Figura 13), abundando en la Cordillera Ibérica, pero apareciendo desde la Cordillera Cantábrica (Barrios de Luna) hasta las Cordilleras Béticas en la provincia de Granada. 


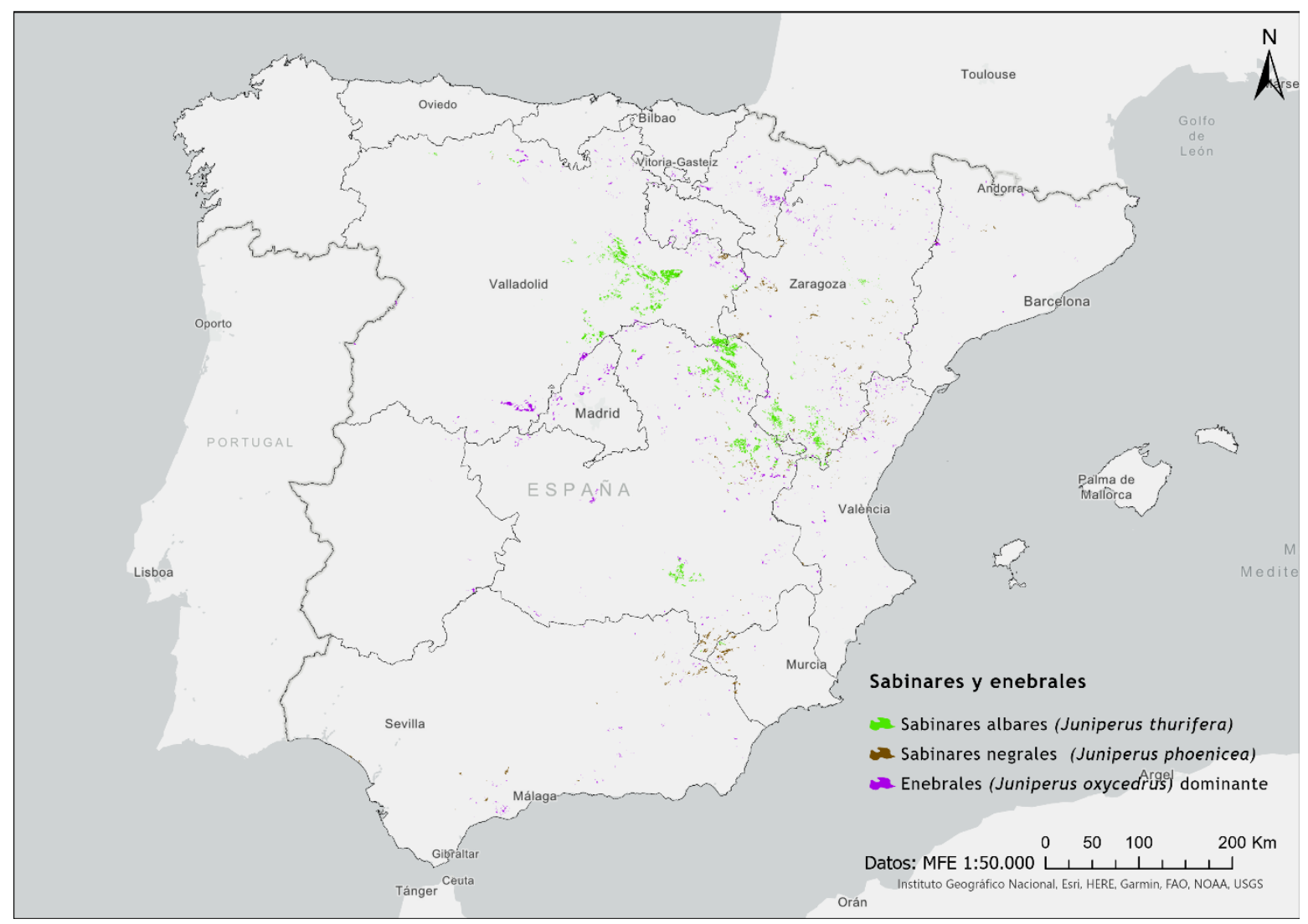

Figura 13. Distribución de los sabinares y enebrales en la España peninsular. Elaboración propia a partir de Mapa Forestal de España 1:50.000.

En lo que respecta al origen del bosque de sabinas y enebros parece que se remontan a periodo geológicos muy antiguos donde parece que pudieron ser dominantes en momentos más fríos y secos que el actual. Aparecen evidencias polínicas con dataciones cretácicas donde dominarían estos taxones incluso en el centro y noroeste de Europa (Blanco et al., 2005). Por otro lado, su evolución parece sujeta a los pulsos húmedos y secos asociados a las glaciaciones; se tiene certeza de que estos taxones avanzaban formando bosques más amplios en momentos secos y fríos mientras que el incremento de las precipitaciones los hacían retroceder (Müller, 2000; Ruiz et al., 2000, 2002) por lo que el bosque actual de Juniperus sería el resto de un bosque mucho más extenso, se puede decir que se trata del bosque relicto más característico del interior peninsular 
(Peña et al., 2005; González, Leroy, et al., 2010). Por otro lado en el momento actual se produce un hecho significativo en lo que respecta al bosque de Juniperus, por un lado parece que existe una regresión asociada al clima templado-húmedo actual que favorecería a otras especies, especialmente de Quercus, más modernas y favorables a la expansión por competencia y por otro lado el cese de ciertas prácticas agrosilvopastoriles está favoreciendo la expansión de estos taxones en las parameras del interior peninsular donde la ventaja competitiva del Juniperus es determinante colonizando espacios abandonados.

\subsubsection{Pinares mediterráneos (Pinus spp.)}

Los bosques de pinos suponen unas de las formaciones más importantes en extensión de la España mediterránea. Formados por Pinus nigra, Pinus sylvestris y Pinus uncinata (ver 2.1.1.3), en las zonas montañosas y Pinus halepensis, Pinus pinaster y Pinus pinea para las llanuras y las laderas bajas, estas formaciones han sido tradicionalmente muy modificadas mediante la acción humana por lo que su distribución, extensión o desarrollo no suelen ser significativos de un bosque cercano al clímax vegetal. Los pinos se han convertido en dominantes en buena medida gracias a la ventaja competitiva que presentan gracias a su ubicuidad y la resistencia que presentan ante condiciones desfavorables, resisten bien el calor estival, así como las heladas invernales, pero también son resistentes a los suelos pobres y a las precipitaciones escasas. Pero estas generalidades no son tal, sino que cada una de las cinco especies citadas presenta singularidades que merecen ser tratadas por separado. 


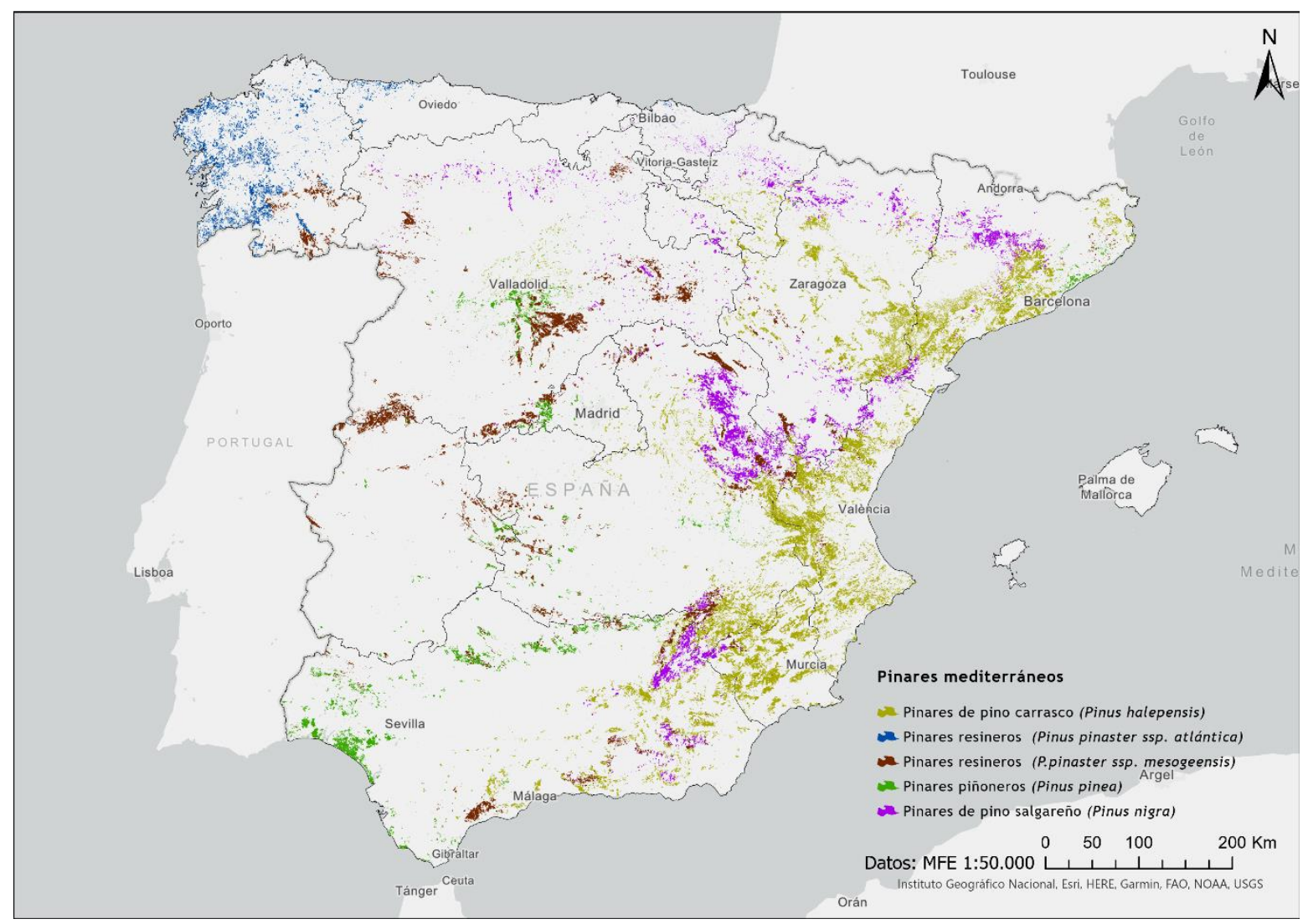

Figura 14. Distribución de los pinares mediterráneos en la España Peninsular. Elaboración propia a partir de Mapa Forestal de España 1:50.000.

\section{Pino carrasco (Pinus halepensis)}

Se trata de una especie pionera que coloniza fácilmente espacios abandonados o que presentan dificultades para otras especies; un claro ejemplo es la gran tolerancia a los sustratos básicos compactos de margas y yesos, así como la gran tolerancia a la sequía llegando a desarrollarse incluso con precipitaciones inferiores a los $200 \mathrm{~mm}$ anuales.

La distribución de estas formaciones se extiende principalmente por la mitad oriental de la península (Figura 14) llegando a formar masas singularmente extensas en las laderas de la Cordillera Ibérica, las Cordilleras Catalanas o las montañas valencianas del interior, siempre por debajo de los 800 m.s.n.m. Los condicionantes que parecen delimitar la extensión de esta especie todoterreno son las heladas que condicionan su 
desarrollo, tomando su relevo otras especies cuando las temperaturas mínimas son frecuentemente bajas y las condiciones del sustrato se vuelven más adecuadas. En cualquier caso, las bajas temperaturas no van a ser sinónimo de desaparición del pino carrasco, sino que favorecen la competencia y condicionan la vigorosidad del Pinus halepensis.

\section{Pino piñonero (Pinus pinea)}

Este árbol presenta una característica que lo hace especialmente singular y no es más que su porte aparasolado. En su etapa adulta las ramas bajas crecen hasta alcanzar la guía principal formando una copa redondeada o en forma de paraguas que lo hace inconfundible. En cuanto a los requerimientos del pino piñonero hay que destacar su preferencia por los suelos sueltos como arenas o pedregales, así como la mala tolerancia hacia los suelos compactos o arcillosos. En cuanto a los requerimientos hídricos no parece muy exigente, pero soporta mal la sequía extrema. En lo que respecta a las temperaturas aguanta bien el frío siempre que no exista humedad ambiental. Se sitúa siempre por debajo de los 800-1000 m.s.n.m. límite por encima del cual otras especies desplazan al piñonero.

De este modo y pese a las dificultades para defender la distribución natural de esta especie en tanto que ha sido cultivada e incentivada durante siglos, el pino piñonero aparecería principalmente en los suelos sueltos costeros o en las laderas bajas de las cordilleras catalanas, en los rellenos arenosos del valle del Guadalquivir y en diferentes espacios de sustrato suelto del interior peninsular como los arenales de la cuenca del Duero o algunas zonas de La Mancha (Figura 14).

\section{Pino resinero (Pinus pinaster)}

Es un árbol pionero capaz de colonizar suelos pedregosos y muy pobres, se caracteriza principalmente por su corteza oscura casi negra con tonos rojizos en sus grietas, esta característica genera un paisaje muy singular. Esta especie está adaptada a condiciones muy variables por lo que es capaz de colonizar casi cualquier tipo de ambientes en la península ibérica, encontrándolo desde el extremo suroriental hasta las costas gallegas de 
clima oceánico. Pese a esta ubicuidad el pino resinero tiene preferencia por los suelos arenosos y pedregosos, del mismo modo que el piñonero sufre en lugares con excesiva sequedad estival prefiriendo una aridez veraniega poco acusada, soporta bien el frío y las heladas que no suelen condicionar excesivamente su desarrollo.

Al igual que la distribución del pino piñonero, la distribución del resinero se ve determinada por su cultivo para aprovechamiento mediante la extracción de resina fundamentalmente y madera, en menor medida. Por esta razón, y si a ello le sumamos la preferencia repobladora de los años 40 del siglo XX, por esta especie, parece difícil asegurar que su distribución responda a la que tendría de forma natural pese a ello la distribución responde perfectamente a su potencial ecológico gracias a su excelente adaptación. De este modo destacan algunas masas que se pasan a detallar, los pinares sobre rodenales (de donde toma uno de sus famosos nombres comunes, pino rodeno) que forman las areniscas rojas mesozoicas en la cordillera ibérica en las inmediaciones de la Sierra de Albarracín o los pinares sobre arenas litorales, pero hay que destacar los pinares que se asientan sobre las dunas interiores de la cuenca del Duero en la provincia de Segovia. De igual modo los pinares gallegos de repoblación forman masas que merecen ser destacadas. En este punto es necesario señalar la diferencia que se hace en dos subespecies para el Pinus pinaster en la península ibérica, por un lado, parece estar aceptada la existencia de una especie mejor adaptada a las condiciones mediterráneas (Pinus pinaster ssp. Mesogeenesis) y una subespecie propia de las condiciones húmedas del clima atlántico (Pinus pinaster ssp. Atlántica) (Figura 14).

\section{Pino salgareño o pino laricio (Pinus nigra)}

Se trata de un árbol de la familia de las pináceas de color oscuro en su follaje y plateado en su fuste, lo que le hace inconfundible. Estos pinos son propios de un clima submediterráneo frío con rasgos de continentalización por lo que este pino soporta bien el frío invernal llegando a situar su techo altitudinal en los 2200 m.s.n.m. en las Cordilleras 
Béticas. También es tolerante a la aridez estival mediterránea, en cierta medida por lo que es capaz de colonizar lugares donde otras especies se desarrollan con dificultad. Edáficamente hablando prefiere suelos básicos calcáreos o suelos básicos compactos como los margosos; en ocasiones aparece en suelos ácidos, aunque con menor frecuencia. Lo que resulta evidente es su gran capacidad para colonizar espacios que varían desde el piso mesomediterráneo hasta alcanzar el límite inferior del oromediterráneo lo que lo otorga una gran ventaja competitiva.

Según diferentes estudios las dimensiones del bosque que formaría el Pinus nigra en la Península Ibérica durante los periodos fríos del tardiglaciar fue mucho más importante, encontrándose testigos de esta dimensión como poblaciones relictas en Gredos, Guadarrama o la ribera del Cega en la provincia de Segovia, así como restos fósiles en la provincia de Palencia (Blanco et al., 2005). Con estos precedentes y pese a la constatación de que en ocasiones estamos ante masas incentivadas por el ser humano, se puede hacer un repaso por la distribución de estos pinares en la península ibérica. Como aspecto general destaca su reclusión en la mitad oriental de la península en buena medida desplazado por la eficacia de otras especies vegetales más competitivas en condiciones edáficas y pluviométricas más favorables. Así, algunos de los pinares de pino laricio más extensos de la Península se sitúan en la montaña media calcárea del oriente peninsular entre los 1600 y los 1900 m.s.n.m. donde el Pinus sylvestris desaparece al soportar peor los suelos básicos y la escasez pluviométrica. De igual modo, entre los 900 y los 1600 metros se desarrollan extensos bosques de Pinus nigra en los valles o laderas de la montaña puramente mediterránea que presentan un clima frío y con importante aridez estival. Por último, los valles de las parameras ibéricas son otro de los lugares donde aparecen amplios bosques de pino laricio en relación con la continentalidad que introduce el aislamiento oceánico de estas parameras, así la ventaja de soportar la escasez de precipitaciones determina la existencia de estos pinos por debajo de los 900 m.s.n.m. 
Dentro del pinar mediterráneo, como ya se ha comentado aparece la excepcionalidad de encontrar Pinus sylvestris siempre por encima de los 1500 m.s.n.m. en aquellos lugares donde las condiciones de humedad lo permiten, así se puede decir que es el árbol característico de la montaña mediterránea que presenta poca aridez estival.

El pino supone un ejemplo de la vegetación mediterránea adaptada a las condiciones de dificultad que este clima ofrece para la vida vegetal, así estos árboles aparecen como algunas de las especies con mejores adaptaciones lo que ha favorecido su desarrollo y expansión. Pese a la mala fama que han tenido tradicionalmente los pinos, especialmente el Pinus pinaster, en buena medida derivado del abuso repoblador durante los años 40-50-60 del siglo $X X$, es necesario señalar que se trata de especies indudablemente autóctonas como atestiguan importantes trabajos paleobotánicos situando el $P$.pinaster con una antigüedad hasta de 33.000 años BP en Portugal (Figueiral, 1995; Figueiral y Terral, 2002) y diferentes evidencias repartidas por el territorio español como la desembocadura del Tajo con más de 7.000 años de antigüedad (García et al., 2007), carbones de la Edad del Hierro que sitúan pinos resineros en Badajoz (Rubiales et al., 2009), pólenes en la Sierra de Gredos que demuestra la existencia de un denso pinar durante unos 2700 años (López, López, et al., 2010), en la cuenca del Duero y el oeste peninsular aparecen importantes evidencias que sitúan estos pinos en el Holoceno medio y superior (Rodríguez, 2000; Franco et al., 2001, 2005; Alcalde et al., 2004; Rubiales et al., 2005, 2007; Morla et al., 2009) así como en las Cordilleras Béticas (Carrión, Andrade, et al., 2001; Carrión, Munuera, et al., 2001; Carrión et al., 2003, 2006). De igual modo aparecen evidencias de la existencia de Pinus pinea en (García, Franco, et al., 2011; Rubiales et al., 2011) con al menos una antigüedad de 2640-2470 años BP. Otras evidencias del origen autóctono del pinar mediterráneo aparecen en el valle del Ebro donde los carbones de Pinus halepensis son muy abundantes en dataciones de hasta 6000 años BC (Allué et al., 2000; Badal, 2009). En lo que respecta al Pinus nigra y como se ha señalado, parece que su extensión y dominancia fue mucho 
mayor que la actual encontrando evidencias de hasta 300.000 años BP (García, Rubiales, et al., 2011).

\subsubsection{Bosques especialmente singulares}

Dentro de esta categoría se sitúan excepciones a la clasificación anterior que van a generar un paisaje forestal muy singular.

\subsubsection{Bosques marcescentes (Quercus pirenaica Willd. 1805,} Quercus faginea Lamb. 1785, Quercus humilis Mill. 1768, Quercus canariensis (Willd.) 1809)

Estos bosques, además de destacar de forma excepcional en lo referente al paisaje forestal debido a la peculiaridad de mantener su follaje semiseco en la estación desfavorable otorgándole un característico color anaranjado o cobrizo, son muy singulares en tanto que se trata de especies íntimamente relacionadas con la transición que tiene lugar en la Península pasando de unas condiciones propias de un bosque templado húmedo a unas condiciones de bosque mediterráneo esclerófilo. De esta forma los robles marcescentes o también llamado semicaducifolios van a formar unas masas que merecen ser analizadas de forma especial.

Estos Quercus propios de la transición climática son la adaptación de especies propiamente atlánticas a las condiciones de aridez mediterránea, por lo que, van a ser propias de aquellos lugares donde existan condiciones intermedias, es decir, aquellos lugares que bajo un clima mediterráneo se mitigue de alguna manera el estrés hídrico estival. Se diferenciarán, por tanto, cuatro localizaciones atendiendo a los bosques que forman cada una de las cuatro especies citadas (Figura 15).

\section{El roble pubescente (Quercus humilis)}

Se localiza fundamentalmente en el pirineo y el prepirineo en el entorno de los 400 a 1.500 m.s.n.m. donde existen unas precipitaciones de al menos $600 \mathrm{~mm}$ anuales y bien repartidas. Soporta bien las heladas, así como el calor estival demostrando así su vocación transicional. 


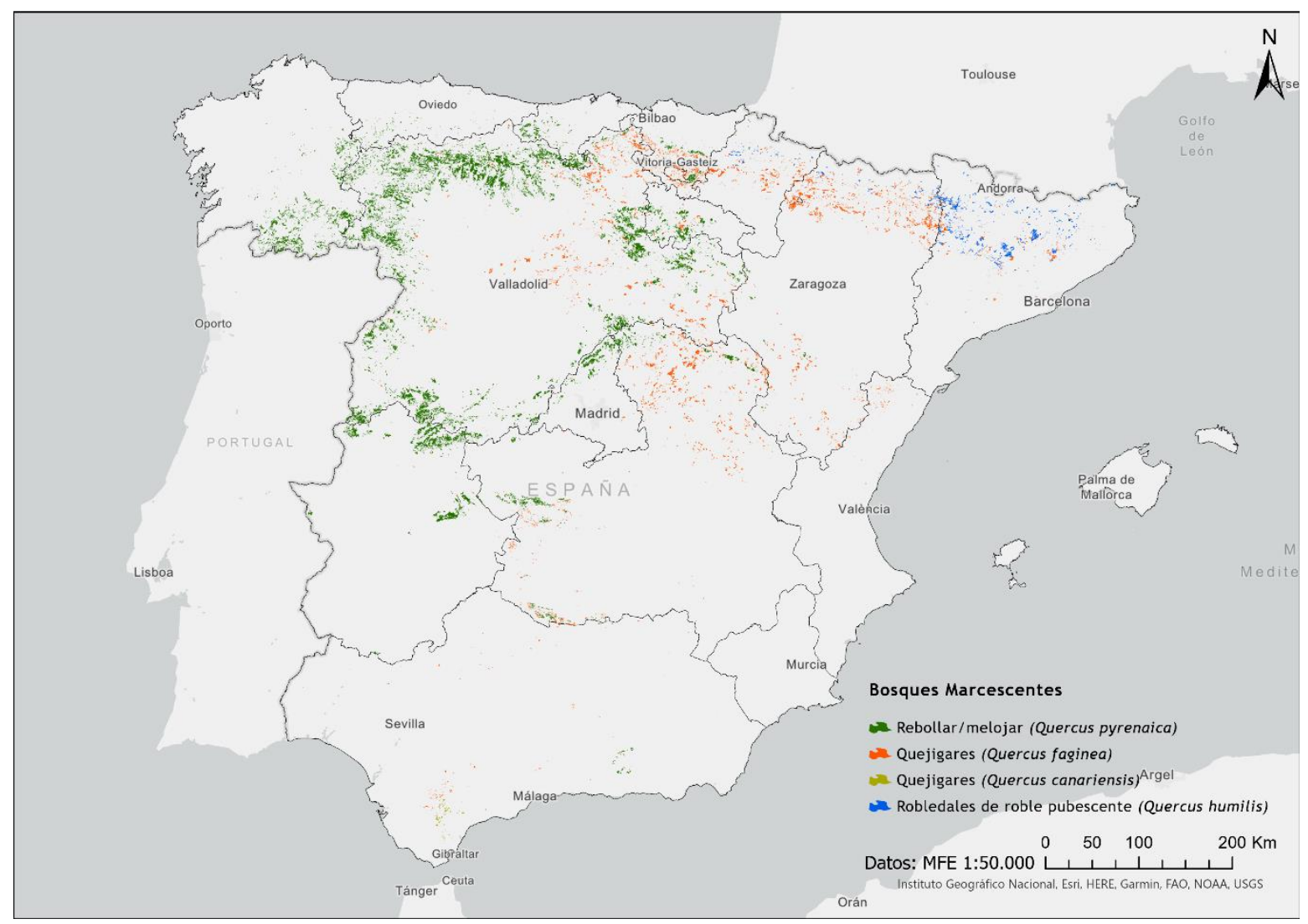

Figura 15. Distribución de los bosques marcescentes en la España peninsular. Elaboración propia a partir de Mapa Forestal de España 1:50.000.

\section{El roble rebollo, melojo, tozo, etc (Quercus pyrenaica)}

Se localiza principalmente en la orla montañosa que circunda la cuenca del Duero, asociado sin duda a ese carácter intermedio entre la aridez mediterránea del centro de la Cuenca y la dulcificación de las condiciones de sequedad que introducen las montañas. En ocasiones aparece en los Montes de Toledo formando buenas masas, como se aprecia, aparece siempre asociado al sector occidental de la península donde sus requerimientos hídricos (650 $\mathrm{mm}$ anuales) y edáficos (es silicícola, aunque puede desarrollarse en suelo lavados de bases) quedan satisfechos. Soporta bien las heladas y cierto calor veraniego. Una de las singularidades del Quercus pyrenaica es su capacidad para brotar de cepa, lo que genera bosques muy densos y cerrados. 


\section{El quejigo (Quercus faginea)}

Es un Quercus marcescente indicador, como los demás de una transición climática. Su distribución es muy dispar apareciendo por casi toda la Península, aunque más dominante siempre en el cuadrante nororiental y desapareciendo en aquellos lugares del este peninsular donde las precipitaciones son muy escasas durante los meses de verano. Se trata de un árbol que se puede calificar de todoterreno, coloniza todo tipo de suelos generando incluso sus condiciones óptimas, soporta precipitaciones abundantes, así como lugares secos con aridez moderada, llegando incluso a sobrevivir con precipitaciones inferiores a los $250 \mathrm{~mm}$ anuales, soporta el frío invernal, así como el calor estival gracias a sus hojas más coriáceas que el resto de Quercus caducifolios. Su limitada extensión y densidad actual (suele aparecer como pies aislados o pequeños rodales) parece estar asociada en un primer momento a razones antrópicas relacionadas con la deforestación al entrar en conflicto con los espacios destinados a las labores agropecuarias (Blanco et al., 2005) y a su actual competencia con la encina (Quercus ilex) a la hora de reconquistar los suelos hoy abandonados y que un día fueron suyos.

\section{El quejigo andaluz o roble moro (Quercus canariensis)}

Es el árbol marcescente de menor extensión, se restringe principalmente al suroeste peninsular y el extremo nororiental, formando pequeños rodales. Esta especie es muy exigente, de ahí su reducida extensión, no soporta el frío invernal, exige suelos ácidos o neutros y requiere de abundantes precipitaciones, al menos $600 \mathrm{~mm}$ anuales y sin aridez estival acusada. Todo esto lo restringe a fachadas occidentales y lugares con climas locales.

En cuanto al origen de estos robles marcescentes en la Península y su distribución pretérita hay que señalar en primer lugar que parecen ser el resultado de una adaptación por parte de especies anteriores de Quercus a las condiciones climáticas actuales (Postigo et al., 2007). Por otro lado, parece evidente que la influencia humana ha perjudicado notablemente a 
estas especies que habitarían las zonas más adecuadas para el cultivo, así como el aprovechamiento tan intenso al que se han visto sometidas para la obtención de madera, leña y carbón (Morales y Martínez, 2003; Rubiales et al., 2011) así como el aclareo para el pastoreo (Uzquiano, 2002).

\subsubsection{El abetal pirenaico (Abies alba)}

Los abetales en la península lbérica aparecen restringidos al piso montano pirenaico donde forman masas monoespecíficas o casi monoespecíficas mezcladas con Fagus sylvatica (Figura 16). Las razones de esta comunidad vegetal tan típica del pirineo se fundamentan, en primer lugar, en la similitud en sus requerimientos y en segundo lugar en la necesidad de sombra de las primeras etapas del abeto, la cual encuentra dentro de los umbrosos hayedos, sin embargo a medida que se asciende altitudinalmente y se llega al contacto con el piso subalpino el haya pierde su capacidad de adaptación y comienza a dominar el abeto blanco entre los 1.200 y los 1.600 m.s.n.m., llegando en ocasiones a aparecer mezclado con el Pinus uncinata en el techo altitudinal del abeto. Esta localización en la montaña pirenaica viene determinada por los requerimientos de los abetos que necesitan unas condiciones de humedad y umbrosidad elevadas para desarrollarse. Del mismo modo el abeto blanco posee una excelente capacidad de soportar el frio extremo lo que le otorga una importante ventaja competitiva sobre otras especies.

Sin duda, los abetales que hoy aparecen en el pirineo fueron más extensos durante los periodos fríos (Burjachs, 1994; Pèlachs et al., 2007) pero fueron perdiendo protagonismo debido a diferentes factores como son la intervención humana (Pèlachs, 2004; López et al., 2008) y el descenso de la precipitación estival hace unos 2.800 años BP (Jalut et al., 2000) pero lo que determina la gran dimensión del abetal en la Península son las evidencias polínicas en la Cordillera Cantábrica en varias dataciones pleistocenas (Boyer-Klein, 1980, 1985) e incluso en zonas costeras de Alicante con dataciones en torno a 15.000 años BP (Cacho et al., 1995). 


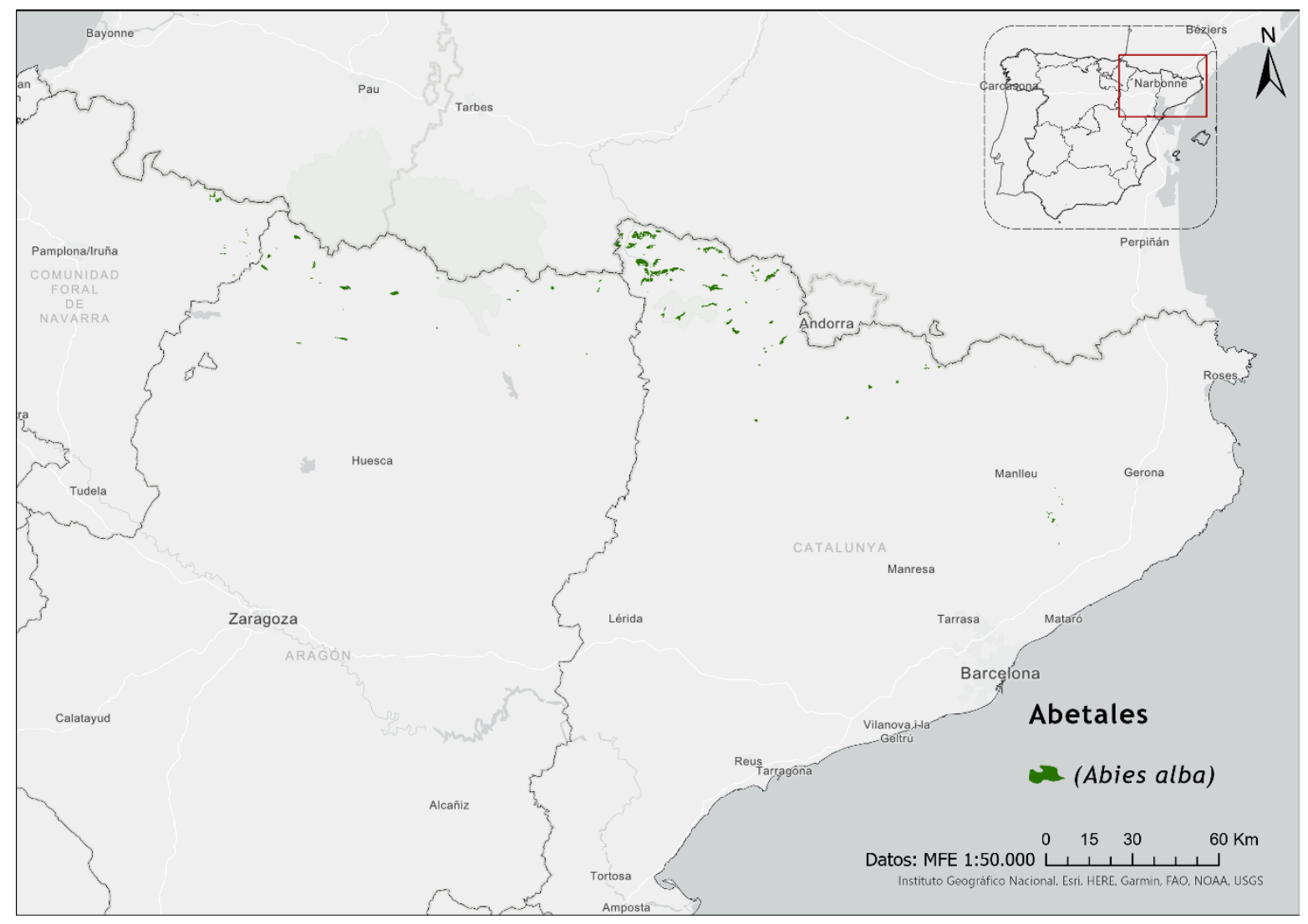

Figura 16. Distribución de los abetales de Abies alba en la España peninsular. Elaboración propia a partir de Mapa Forestal de España 1:50.000.

\subsubsection{Los pinsapares (Abies pinsapo)}

Estas formaciones constituyen uno de los paisajes forestales más singulares de la península lbérica en tanto que se trata de un endemismo localizado en un lugar muy alejado de su potencial ecológico. Los pinsapos son una especie del género Abies enmarcada en un clima mediterráneo lluvioso. Se trata de un abeto relicto que habita en las sierras de Las Nieves, Sierra Bermeja y Grazalema siempre por encima de los 1.000 m.s.n.m. y llegando hasta los 1.700 (Figura 17). Esta localización actual parece que responde a un refugio de los abetos en las laderas occidentales de abrigos locales en momentos de aridificación del clima (Tzedakis et al., 2002; Carrión et al., 2003; Willis y Niklas, 2004). Actualmente estos bosques relictos que rondan las 2.000 hectáreas están protegidos desde el 
punto de vista ambiental/biológico por algunas de las más estrictas leyes españolas (Parque Nacional) y europeas (Directiva Hábitat).

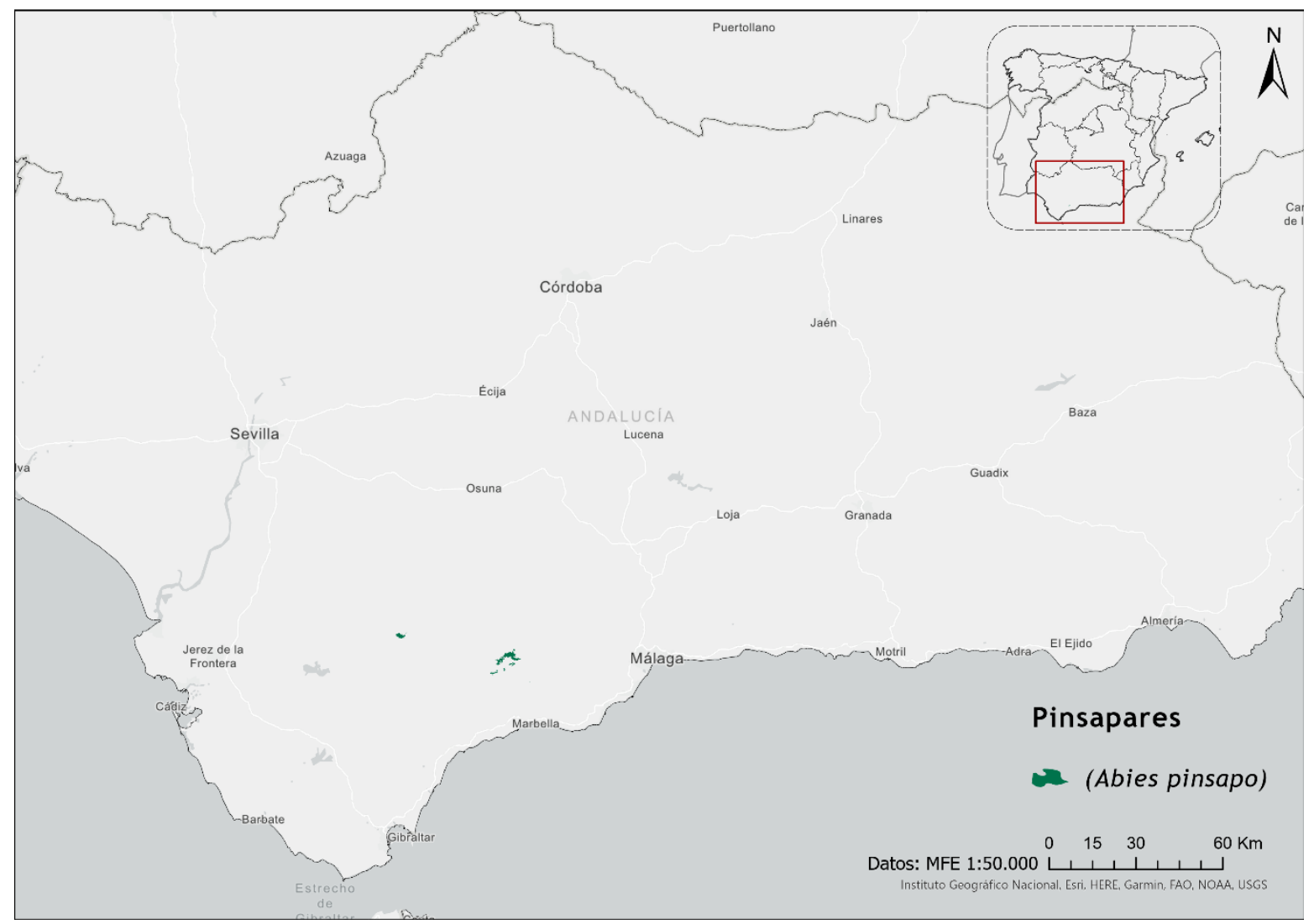

Figura 17. Distribución de los pinsapares en la España peninsular. Elaboración propia a partir de Mapa Forestal de España 1:50.000.

\subsubsection{Los bosques de producción (especies exóticas)}

Las plantas de origen exótico en España suponen buena parte de las especies vegetales que componen nuestra flora, se calcula que alrededor del $12 \%$ del total de los taxones presentes en nuestro país son de origen exótico, de los cuales el $29 \%$ serían fanerófitos asociados al gran empleo de árboles en jardinería ornamental lo que desmiente a la silvicultura como un riesgo para la entrada de especies invasoras ya que tan solo el $3 \%$ de las especies exóticas están relacionadas con esta práctica productiva (Sanz et al., 2004). De este modo, la silvicultura de plantas exóticas en nuestro país 
se sustenta en un reducido número de especies como el abeto de Douglas (Pseudotsuga menziessii), los híbridos de chopo canadiense (Populus $x$ canadensis), destacando el Pinus radiata, el género Eucalyptus con las dos especies presentes en España Eucalytups globulus y Eucalyptus camaldulensis (Figura 18).

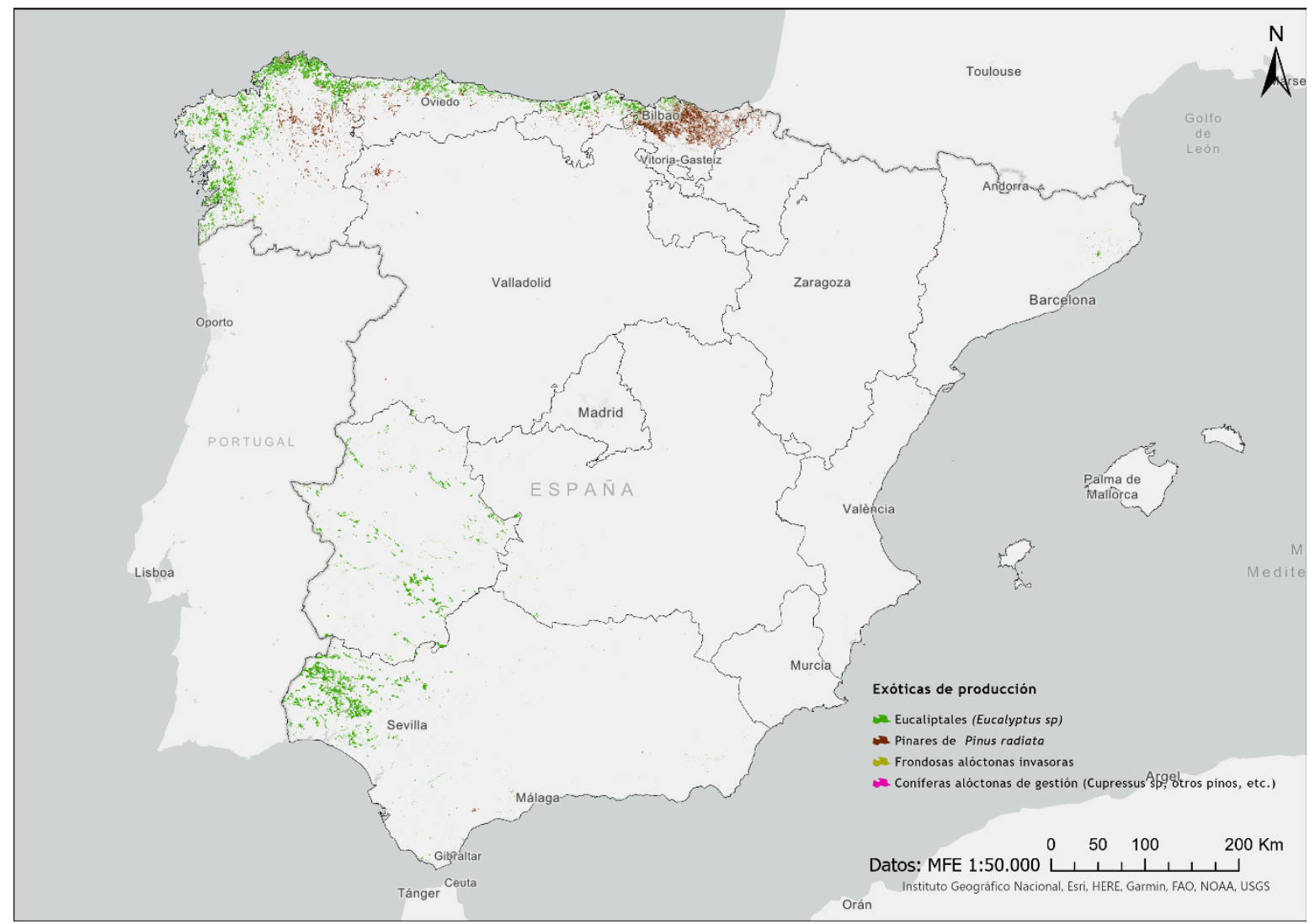

Figura 18. Distribución de los bosques de producción de especies exóticas en la España peninsular. Elaboración propia a partir de Mapa Forestal de España 1:50.000.

En lo que respecta al Pinus radiata parece llegar a España en 1857 aproximadamente, al menos es la primera referencia que aparece en (Cavanilles, 1858) utilizada en un jardín de Lekeitio (Bizkaia). Posteriormente (Secall, 1896) propone esta especie como apropiada para la silvicultura en España. Esta especie silvícola tiene un peso muy importante en el País Vasco donde representa en torno al 42\% de la superficie arbolada (Michel, 2003), especialmente en las provincias de Bizkaia y Gipuzkoa. 
En cuanto al género Eucalyptus parece que fue traído a España durante el siglo XIX desde Australia según defienden algunos autores por el misionero gallego Rosendo Salvado en 1886 (Bauer y Laso, 1964; Bauer, 1991) de acuerdo con una carta autobiográfica donde indica que ha enviado una caja de semillas a Galicia, pero parece ser más correcto señalar a Marcelino Sanz de Sautuola (descubridor de la cueva de Altamira) como el introductor de este árbol en Cantabria en el año 1863 como corrobora el informe presentado por este "Apuntes sobre la aclimatación del E.globulus en la provincia de Santander" en 1865 (Herrera, 2000). Así, gracias a Sautuola y a posteriores trabajos como la plantación en el Reformatorio de Menores de Viérnoles que demostró su adaptación, frugalidad y capacidad para rebrotar de cepa animó a ciertos propietarios a emprender estas plantaciones (Ezquerra y Gil, 2004). Pero el hecho determinante se va a producir en 1940 al crearse una legislación ad hoc para la SNIACE (empresa dedicada a la producción de celulosa situada en Torrelavega, Cantabria) que era la gran consumidora de eucalipto. Esta legislación a la medida de la SNIACE le permitía a esta consorciar la plantación directamente con los propietarios de los terrenos, posteriormente el decreto de 1944 permitió a los ayuntamientos repoblar forestalmente sus terrenos dedicados a pastos y los MUP que no estuviesen arbolados. Estas dos medidas van a ser determinantes para la transformación del paisaje forestal de la costa Cantábrica (Guerra, 2013), Galicia y las provincias del suroeste peninsular.

\subsection{Las dimensiones del bosque español y su situación}

Actualmente en España, existen unos 30 millones de hectáreas forestales de las cuales arboladas están alrededor de 20 millones, lo que supone que más de 10 millones de hectáreas se encuentran con un arbolado disperso o colonizadas por matorral. Resumiendo, aproximadamente el $40 \%$ del territorio español está ocupado por bosque (Montero y Serrada, 2013). Pero estas dimensiones no siempre fueron así y aunque hoy parezcan destacables, el bosque español sufrió un gran retroceso que se ha 
recuperado en los últimos años (Figura 19). Durante diferentes etapas de nuestra historia se ha ejercido una importante presión sobre los recursos forestales, comenzando con la puesta en cultivo de amplias superficies y acentuado por las necesidades de pasto de la espectacular cabaña ganadera medieval, contribuyeron a recluir el bosque a las zonas inservibles para pastos o agricultura. De este modo, y siempre bajo los datos que aportan Montero y Serrada en el "Informe de situación de los bosques y el sector forestal en España” es importante señalar las dimensiones del bosque español en algunos momentos clave:

- $1860 \rightarrow$ Solo existen 12 millones de hectáreas arboladas de las cuales, 6 millones de hectáreas albergan monte alto, lo que supone el $12 \%$ del territorio español.

- Entre 1860 y $1930 \rightarrow$ Se pierden 5 millones de hectáreas forestales por la desamortización y las acciones de colonización interior.

- $1940 \rightarrow$ España solamente cuenta con 5 millones de hectáreas de monte alto (el mínimo histórico) lo que supone menos del $10 \%$ del territorio.

Pero las dimensiones del bosque español se han recuperado en cierta medida y parece que esta tendencia se mantiene. Esta recuperación forestal se debe fundamentalmente a 3 factores:

1. El éxodo rural: El paso de una agricultura de subsistencia a una agricultura industrial ha permitido la incorporación de amplios espacios para la reconstrucción forestal al abandonarse buena parte de las tierras menos fértiles o más inaccesibles y restringirse así las labores agrícolas a las zonas más fértiles y accesibles.

2. Las repoblaciones dirigidas: Por las administraciones, especialmente las relacionadas con la Dictadura Franquista a partir de los años 40 y que llegaron hasta los comienzos del sistema democrático actual. 
3. Las repoblaciones de particulares: Asociadas especialmente a la entrada de España en la Unión Europea y la llegada de fondos de la Política Agrícola Común (PAC) destinados a la reforestación que van a incentivar a los particulares a la repoblación de sus parcelas de suelo forestal y que tienen su momento más relevante entre los años 1995 y 2005.

Esta recuperación forestal que se ha producido en España es muy destacable si lo comparamos con otros territorios, más aún si se tienen en cuenta los condicionantes (Figura 19).

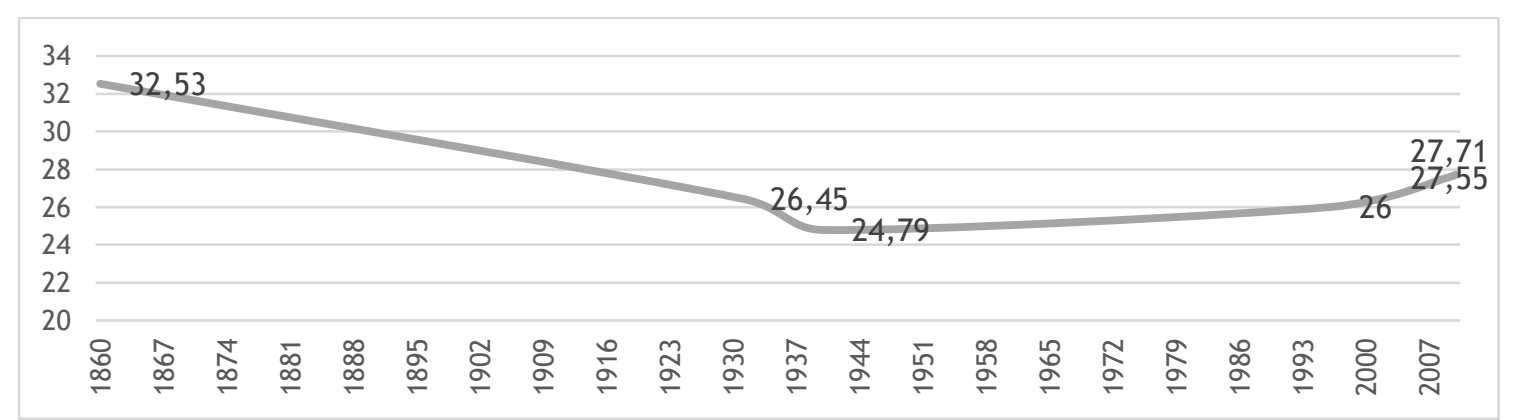

Figura 19. Evolución de la superficie forestal española (millones de hectáreas). Elaboración propia a partir de (Montero y Serrada, 2013)

\subsection{La evolución forestal española}

Para llegar a esta situación de avance del bosque en España la superficie forestal ha pasado por diferentes etapas cuya tendencia general ha sido a la deforestación, pero como se ha señalado las últimas décadas parecen enfocadas a recuperar la riqueza forestal que un día tuvo la península. A continuación, se hará una descripción diacrónica de cuales han sido estas etapas.

\subsubsection{El origen de los bosques españoles}

Durante la convivencia de baja presión sobre el medio de los primeros humanos, en las primeras etapas del holoceno, los análisis polínicos nos indican que estaríamos ante la expansión del bosque gracias al aumento de 
las temperaturas tras la retirada de la última era glaciar (Dryas reciente), las formaciones herbáceas retroceden y son sustituidos por bosque cerrado en un primer momento de dominancia generalizada del género Pinus (Figura 1) que va a comenzar a retroceder en el dominio atlántico mediado el holoceno hacia el 5000 a.C. hasta su regresión e incluso llegando a desaparecer en muchos lugares de la Cordillera Cantábrica donde habían sido dominantes (Rubiales et al., 2008). Con esta desaparición del género Pinus en el norte peninsular empiezan a generarse dos realidades forestales que hoy prevalecen, mientras que el norte estaría dominado por las frondosas caducifolias, especialmente el género Quercus, el dominio mediterráneo estaría caracterizado por el Pinus que sería el dominante hasta mediado el holoceno donde parece que los Quercus perennifolios comienzan a sustituir a los pinos, pero sin desplazar a estos definitivamente (Carrión et al., 2000).

Mediado el holoceno ocurre un acontecimiento fundamental para el bosque en nuestro país, el hombre comienza a transformar su modo de vida pasando de unas actividades basadas en la recolección y la caza hacia asentamientos basados en las labores agropecuarias y pastoriles (Neolítico). Para la puesta en marcha de este nuevo modelo es necesario eliminar algunos espacios forestales mediante roturaciones y quemas permitiendo así la apertura de campos y bosques adehesados donde llevar a cabo estas nuevas actividades. De este modo, en los análisis polínicos se puede apreciar perfectamente la aparición de pólenes de cereales, así como la matorralización (Muñoz et al., 2001; Carrión et al., 2006, 2010; Mighall et al., 2006; López, 2009; López, Martínez, et al., 2010). (Figura 20). 


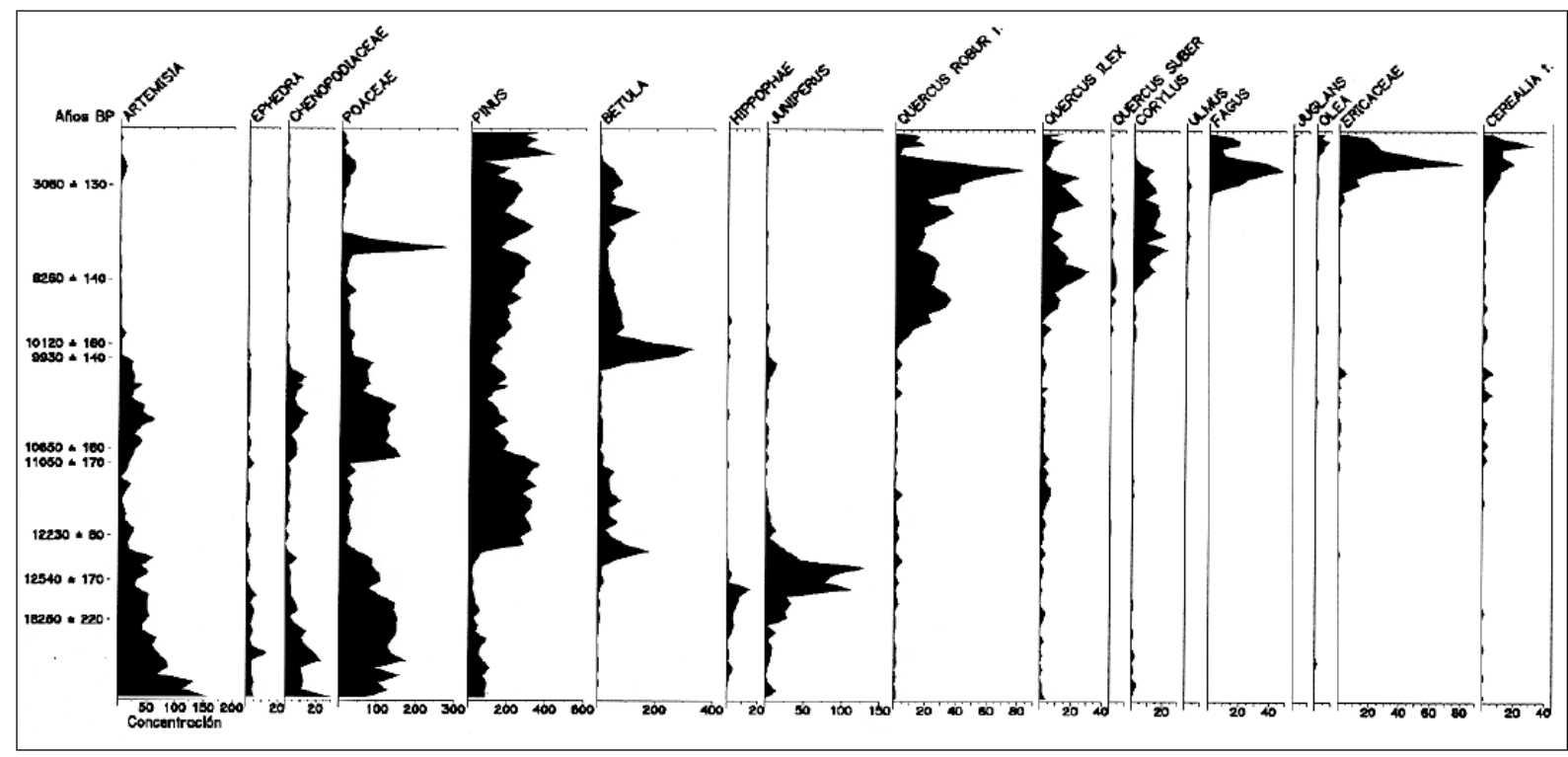

Figura 20. Secuencia polínica de Quintanar de la Sierra, Burgos. Fuente: (Peñalba, 1994) recuperado de (Carrión et al., 2000). Se aprecia la aparición de los cereales y la matorralización sincrónicamente con la reducción de los Quercus Robur, Betula sp. Y Corylus sp. y la expansión del Fagus sylvatica.

La aparición de los metales en la península ibérica en torno al 3000 a.C. es otro momento clave para el bosque ibérico. La llegada de la metalurgia requiere de una gran cantidad de combustible para su elaboración que se va a extraer de los bosques en forma de leña y especialmente de carbón vegetal lo que lleva a incrementar la presión sobre los bosques especialmente de Quercus muy valorados por su poder calorífico. La expansión del haya (Fagus sylvatica) (Figura 20) se produce también en este momento, el cual puede considerarse como el punto en que la flora actual se instala definitivamente (López, 1978).

Si bien es cierto que la expansión o regresión de las especies que conformarán la flora, así como la degradación asociada a la intervención humana que va a deforestar la península no se producen de igual forma en todo el territorio, sino que aparecen diferencias regionales. En lo que se refiere a la intervención humana, pese a la evidencia de agricultura a lo largo de toda la península, la deforestación parece avanzar de sur a norte apareciendo evidencias en el 2000 a.C. en la hoy Andalucía y Valencia y 
llegando a Guadarrama alrededor del siglo I (Carrión et al., 2000). Se produciría una reducción de las especies arbóreas y se aprecia un incremento de pólenes relacionados con la expansión del matorral de ericáceas y garrigas, así como in continuado incremento de leguminosas.

\subsubsection{El bosque en la historia}

Tras la llegada de los romanos a la península se comienzan a tener evidencias escritas sobre el bosque que poblaría lo que hoy es la España peninsular. Algunas de estas evidencias pertenecen conocidos cronistas de la época como Plinio el Viejo, que ocupó el cargo de procurador de Citerior y Estrabón que pese a no visitar la península realiza una gran descripción en su tercer libro sobre la península ibérica. Ambos autores hacen referencia a los bosques que albergaría la península y a sus características por lo que nos sirven como fuente para construir una visión que nos permita conocer cómo era la realidad forestal de la hoy España peninsular.

Plinio el Viejo en su obra "Historia Natural" hace varias referencias a los bosques españoles a continuación, se relatan algunas de ellas:

"los montes de Hispania, áridos y estériles en los que ninguna cosa crece, no tienen más remedio que dedicarse al oro" (Pérez y Matías, 2008)

“Montes de Boj cubrían los pirineos” (Blázquez, 1971)

"Bosques de juníperos muy altos cubrían el territorio de los vacceos" (Blázquez, 1971)

Pero si hay que destacar las referencias que nos van a dar una panorámica de la realidad forestal española estas son las que aporta Estrabón, el geógrafo griego, como se ha comentado, a través de diferentes fuentes hace referencia a diferentes aspectos relacionados con el bosque, algunas de ellas se pasan a citar:

"Iberia en su mayor parte es poco habitable, pues casi toda se halla cubierta de montes, bosques y llanuras de suelo pobre y desigualmente regado" (Blázquez, 1971) 
"La vertiente ibérica de los pirineos tiene hermosos bosques de árboles de todas las especies, singularmente de hoja perenne" (Blázquez, 1971)

"Partiendo de Calpe, cruza la Bastetania y la Oretania una cordillera cubierta de densos bosques de corpulentos árboles que separa la zona costera de la interior" (Estrabón et al., 1998)

Estrabón hace referencia continua hacia el comercio de madera y barcos de forma muy insistente en lo que hoy sería la actual Andalucía lo que hace pensar en grandes bosques que estarían siendo deforestados (Estrabón et al., 1998).

Otra de las referencias del geógrafo griego es a las encinas de las cuales dice, se obtienen "bellotas para el consumo humano en el norte de la península", Estrabón hace referencia también a encinas rastreras (Cortijo, 2007) lo que podría indicar degradación del bosque.

El norte, según el Geógrafo sería más forestal que el sur, en repetidas ocasiones hace referencia al bosque como el "lugar donde viven los bárbaros" (Estrabón et al., 1998).

"La cordillera llamada Orospeda, se extiende desde la mitad de la costa mediterránea, se desvía hacia el sur y la costa que empieza en las columnas; atraviesa el campo espartario y luego enlaza con el bosque sito en el interior, entre Nueva Carquedón y la zona cercana a Málaca" (Estrabón et al., 1998).

En otras ocasiones algunas referencias son fundamentales para tener la certeza de la capacidad de los habitantes de la península de intervenir el bosque, Estrabón tiene especial predilección por los espacios intervenidos y dedicados a la labranza, en este sentido vamos a encontrar referencias como:

"Las riberas del Betis están cultivadas con gran esmero, y ofrecen a la vista extensiones cuidadosamente explotadas con bosques y todo tipo de plantaciones" (Estrabón et al., 1998). 
"Tierras aledañas al Betis, en su margen derecha se extiende una llanura extensa, elevada y fértil con grandes árboles y pastos" (Estrabón et al., 1998).

"En un estero del tajo hay una islita con hermosos bosques y viñedos" (Estrabón et al., 1998)

Acudiendo a otras fuentes más cercanas en el tiempo que corroboren estas descripciones de los clásicos, la gran obra de Schulten "Numantia" describe la zona de los Iberos donde presenta la Cordillera Ibérica poblada de bosques en amplias extensiones donde los Quercus y los enebros (Juniperus sp.) serían los dominantes (Hopfner, 1954) lo que encaja perfectamente en esa descripción que Plinio el Viejo daría para el interior de la península.

Por norma general, y como explica María Luisa Cortijo en su artículo “Los árboles silvestres en la iberia de Estrabón” el Geógrafo pasa por alto, con un simple vocablo que hace referencia al bosque no alterado (Tabla 1), todo lo referente al bosque silvestre del norte peninsular donde, según este, se refugian los bárbaros. Por tanto, se puede asegurar que para la descripción de Estrabón lo civilizado es el bosque intervenido y del cual se extraen recursos de forma ordenada mientras que el bosque silvestre apenas es tenido en cuenta salvo como refugio de poblaciones menos avanzadas e "incivilizadas" como Estrabón dice. Esto hace pensar en una clara dicotomía entre el norte peninsular con un bosque nativo mixto y el sur donde existe una intervención en él cual se ahueca el monte e incluso se rotura para la creación de campos de cultivo. 


\begin{tabular}{|c|c|c|c|}
\hline Refer. & Vocablo & Localización & Observaciones \\
\hline III, 1,2 & $\delta \rho \cup \mu о \varpi\}$ & Iberia & $\begin{array}{l}\text { Aplicable a norte, centro, montaña. } \\
\text { Alusión casual. }\end{array}$ \\
\hline III, 2, 3 & $\begin{array}{l}\alpha\} \lambda \sigma o\} \\
\mu \varepsilon \gamma \alpha \lambda \mathrm{o} \varpi \delta \varepsilon v \delta \rho o v \\
\mu о v o \varpi \xi \nu \lambda \mathrm{o}\} \\
\phi \cup \tau \circ \cup \rho \gamma 1 \varpi \alpha\end{array}$ & $\begin{array}{l}\text { Turdetania. Riberas y } \\
\text { llanura del Betis }\end{array}$ & $\begin{array}{l}\text { Paisaje domesticado, genérico y } \\
\text { bucólico. Adjetivado (grande). } \\
\text { Navegación }(I I, 3,4) \text {. Ver III, } 3,1 \text {. } \\
\text { Barcas de un solo tronco: Ver III, } 3,7 \text {. }\end{array}$ \\
\hline III, 2,6 & 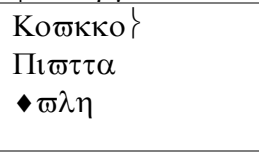 & $\begin{array}{l}\text { Turdetania } \\
\text { (especilmente interior) }\end{array}$ & $\begin{array}{l}\text { Relación indirecta con pino y encina. } \\
\text { Astilleros con madera local. Uso } \\
\text { "civilizado" de productos y madera. } \\
\text { Paisaje domesticado. }\end{array}$ \\
\hline III, 2,7 & $\begin{array}{l}\delta \rho \diamond \phi \lambda\} \\
\beta \alpha\} \lambda \alpha \vee 0\}\end{array}$ & Turdetania (litoral) & $\begin{array}{l}\text { Encina marina y terrestre. Se concreta } \\
\text { el nombre y se describe el árbol. }\end{array}$ \\
\hline III, 2,9 & $\delta \rho \cup \mu о \varpi\}$ & $\begin{array}{l}\text { Turdetania (valor } \\
\text { genérico) }\end{array}$ & $\begin{array}{l}\text { Mito: bosques que arden y funden } \\
\text { metales. Referencia al paisaje } \\
\text { anecdótica en una descripción } \\
\text { claramente minera. }\end{array}$ \\
\hline $\mathrm{III}, 3,1$ & $\varepsilon \diamond \varpi \alpha \lambda \delta \varepsilon\}$ & $\begin{array}{l}\text { Lusitania (isla del } \\
\text { Tajo) }\end{array}$ & $\begin{array}{l}\text { Vegetación adjetivada (frondosa). } \\
\text { Paisaje domesticado y bucólico. } \\
\text { Semeja a III, } 2,3 \text { (Betis). Describe el } \\
\text { río, no el paisaje. }\end{array}$ \\
\hline $\mathrm{III}, 3,7$ & 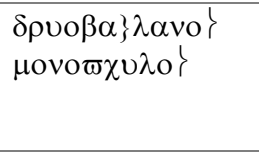 & $\begin{array}{l}\text { Lusitania (y pueblos } \\
\text { montañeses) }\end{array}$ & $\begin{array}{l}\text { Alusión directa a encina y bellota. Uso } \\
\text { "salvaje" del producto. Barcas de un } \\
\text { solo tronco: actividad naval, pero no } \\
\text { potente. Ver } 111,2,3 \text {. }\end{array}$ \\
\hline III, 4, 2 & $\begin{array}{l}\bullet \varpi \lambda \eta \\
\mu \varepsilon \gamma \alpha \lambda \mathrm{o} \varpi \delta \varepsilon v \delta \rho o v\end{array}$ & $\begin{array}{l}\text { Turdetania (Basetania } \\
\text { y Oretania) }\end{array}$ & $\begin{array}{l}\text { Paisaje de bosque adjetivado } \\
\text { (frondoso, grande). Ver III, } 4,10 \text { - } \\
\text { Descrpción básicamente orográfica: } \\
\text { límite interior-litoral. }\end{array}$ \\
\hline III, 4,6 & $\mathrm{O} \lambda \times \varpi \alpha \sigma \tau \rho \circ \nu$ & $\begin{array}{l}\text { Costa } \\
\text { levantinocatalana }\end{array}$ & $\begin{array}{l}\text { Referencia toponímica latina que no } \\
\text { implica necesariamente un paisaje. } \\
\text { Oleaster=acebuche }\end{array}$ \\
\hline $\mathrm{III}, 4,10$ & $\delta \rho u \mu о \varpi\}$ & $\begin{array}{l}\text { Entre Nueva Carquedón } \\
\text { y Málaca }\end{array}$ & $\begin{array}{l}\text { Alusión genérica a bosques, dentro de } \\
\text { una descripción orográfica de la } \\
\text { Oróspeda. Ver } 111,4,2 \text {. }\end{array}$ \\
\hline $\mathrm{III}, 4,11$ & $\begin{array}{l}\varepsilon \diamond \varpi \delta \varepsilon v \delta \rho o v \\
\diamond \varpi \lambda \eta\end{array}$ & $\begin{array}{l}\text { Costado ibérico del } \\
\text { Pirineo. } \\
\text { Carretanos }\end{array}$ & $\begin{array}{l}\text { Árboles adjetivados (de toda especie y } \\
\text { hoja perenne), pero sin concretar } \\
\text { especies. Zona bastante civilizada. }\end{array}$ \\
\hline $\mathrm{III}, 4,13$ & $\bullet \varpi \lambda \eta$ & Celtiberia & $\begin{array}{l}\text { Contraste civilización-barbarie, } \\
\text { ciudad-aldea, agricultura-bosque. }\end{array}$ \\
\hline $\mathrm{III}, 5,1$ & $\Pi \imath \tau \cup o \diamond \phi \lambda \sigma \sigma \alpha \imath$ & Baleares & $\begin{array}{l}\text { Paisaje de pinos, no necesariamente } \\
\text { contemporáneo, pero quizás real en el } \\
\text { pasado (Plin. III, } 10,76) \text {. Ver III,5,2. }\end{array}$ \\
\hline $\mathrm{III}, 5,2$ & $\delta \times \varpi v \delta \rho \circ v$ & Baleares & $\begin{array}{l}\text { Ejemplares concretos, de nombre no } \\
\text { especificado. Integrado en un paisaje } \\
\text { agrario: casa-árbol. Acción } \\
\text { civilizatoria romana. }\end{array}$ \\
\hline $\mathrm{III}, 5,10$ & $\delta \times \varpi v \delta \rho o v$ & $\begin{array}{l}\text { Entre Gádira y Nueva } \\
\text { Carquedón }\end{array}$ & $\begin{array}{l}\text { Ejemplares concretos descritos, pero } \\
\text { no identificados. Relación con Egipto } \\
\text { y Capadocia. Gádira: reminiscencias } \\
\text { míticas. }\end{array}$ \\
\hline
\end{tabular}

Tabla 1. Los árboles silvestres en la Iberia de Estrabón. Fuente: recuperado de (Cortijo, 2007) 
En definitiva, la romanización de la península y la consiguiente tendencia a la generalización de la agricultura como base de la economía hacen pensar que los bosques van a sufrir un continuo retroceso hasta situarse en el $50 \%$ de su extensión original (Bauer, 1991).

El tiempo de los visigodos en la península fue un momento de desahogo para el bosque, pese a ser constante el aprovechamiento de leña y carbón como combustible o la madera para construcción, la Ley Visigoda (Lex Visigothorum) reservaba un apartado para los bosques donde se prohibía explícitamente el pastoreo del ganado en estos, quedando severamente sancionados los desafueros contra los árboles (Hopfner, 1954).

Con el comienzo de la civilización musulmana de la península comienza un periodo convulso conocido vulgarmente como la "Reconquista" que se caracteriza por un continuo conflicto militar de escaramuzas. El bosque en este contexto va a sufrir de forma muy significativa, en muchas ocasiones se va a eliminar mediante la quema para evitar el refugio de militares contrarios y emboscadas (Fernández, 1990) parece que practicado fundamentalmente por los cristianos. Pero no solo los gobiernos islámicos parecían más protectores del bosque a la hora de utilizarlo para la guerra, sino que, la base económica y productiva de la civilización islámica frente a la cristiana coetánea, va a determinar la realidad forestal a cada lado de las fronteras. Los cristianos centraban su producción en los cereales, lo que implicaba la roturación de amplias superficies de bosque y el pastoreo extensivo con el fuego recurrente como herramienta para la liberación de pastos. Mientras, los musulmanes practicaban preferentemente el regadío o la producción frutal en mosaico, siendo menos consumidores de espacio, lo que implicaba, si se comparan los grandes bosques a uno y otro lado de la frontera; los del norte, de los cristianos, ocupan mucha menos extensión que los de al-Ándalus. La deforestación del norte está mucho más avanzada en el siglo IX (Martínez, 1999). Pero si este periodo de conquista cristiana hacia el sur es destacable por algo en lo relacionado al bosque, va a estar relacionado con la singularidad que va a introducir en cuanto a la propiedad de estos en los territorios ganados. Por norma estos bosques arrebatados 
del dominio musulmán serán de propiedad Real, siendo el monarca el que va a distribuir estos recursos mediante la propiedad de "realengo", perteneciente al Rey, propiedad de "señorío", otorgada a algún título nobiliario y propiedad de "abadengo", entregada por el poder Real a alguna congregación religiosa. Estos nuevos territorios se poblaron con gentes provenientes de territorios antiguos, a los cuales se les permitía el uso y disfrute de los recursos que ofrecía el bosque mediante gestión comunal (Figura 21).

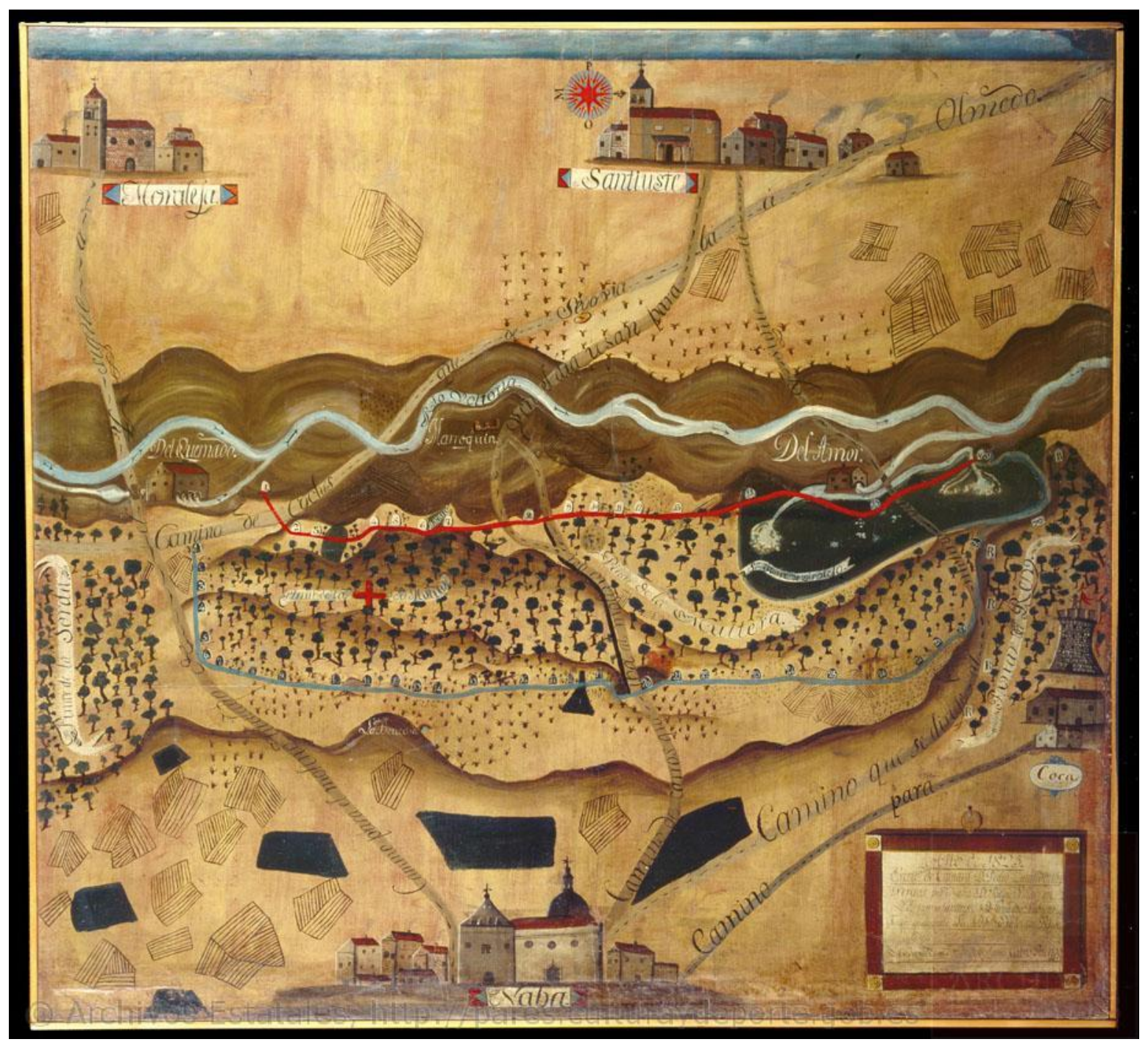

Figura 21. Carta topográfica de un sector de pinares delimitado por líneas de mojones, situado entre Nava de la Asunción y el río Voltoya (Segovia). Archivo de la Real Chancillería de Valladolid (Anón, 1825) 
Pero si hay que destacar un hecho que explique la realidad forestal española este es la creación del Honrado Concejo de la Mesta (Martínez, 1993; Costa y Aguilella, 1997; Luís et al., 2001; Gil, 2011; Zavala et al., 2011) en el año 1273 por Alfonso $X$, esta asociación de pastores que guiará los designios de la producción de la famosa lana castellana durante los próximos siglos se verá beneficiada mediante importantes poderes sobre la política forestal que va a determinar la suerte de los bosques futuros. El Concejo de la Mesta y la protección de la ganadería trashumante por encima de todo en la Corona de Castilla derivó en un importante deterioro de los bosques en beneficio de los pastos (Figura 22), se pueden señalar cinco hechos que afectaron al espacio arbolado tras la creación del Concejo.

1. La eliminación del sotobosque y por tanto de la regeneración natural al ser arrasado por el paso de ganado ovino.

2. La continua corta de ramaje por parte de los pastores para alimentar al ganado y para la construcción de refugios en su trashumancia.

3. El permanente ramoneo del ganado a su paso por los espacios forestales que deterioró los árboles en muchas ocasiones hasta la muerte.

4. La quema de bosques para cubrir las necesidades crecientes de pastos.

5. La erosión de suelos al quedar estos desprovistos de su cubierta vegetal por sobrepastoreo, lo que provocó la desertificación de determinados lugares anteriormente ricos en cubierta forestal impidiendo así su recuperación. Uno de los ejemplos paradigmáticos de este proceso son las Bardenas Reales en Navarra. 


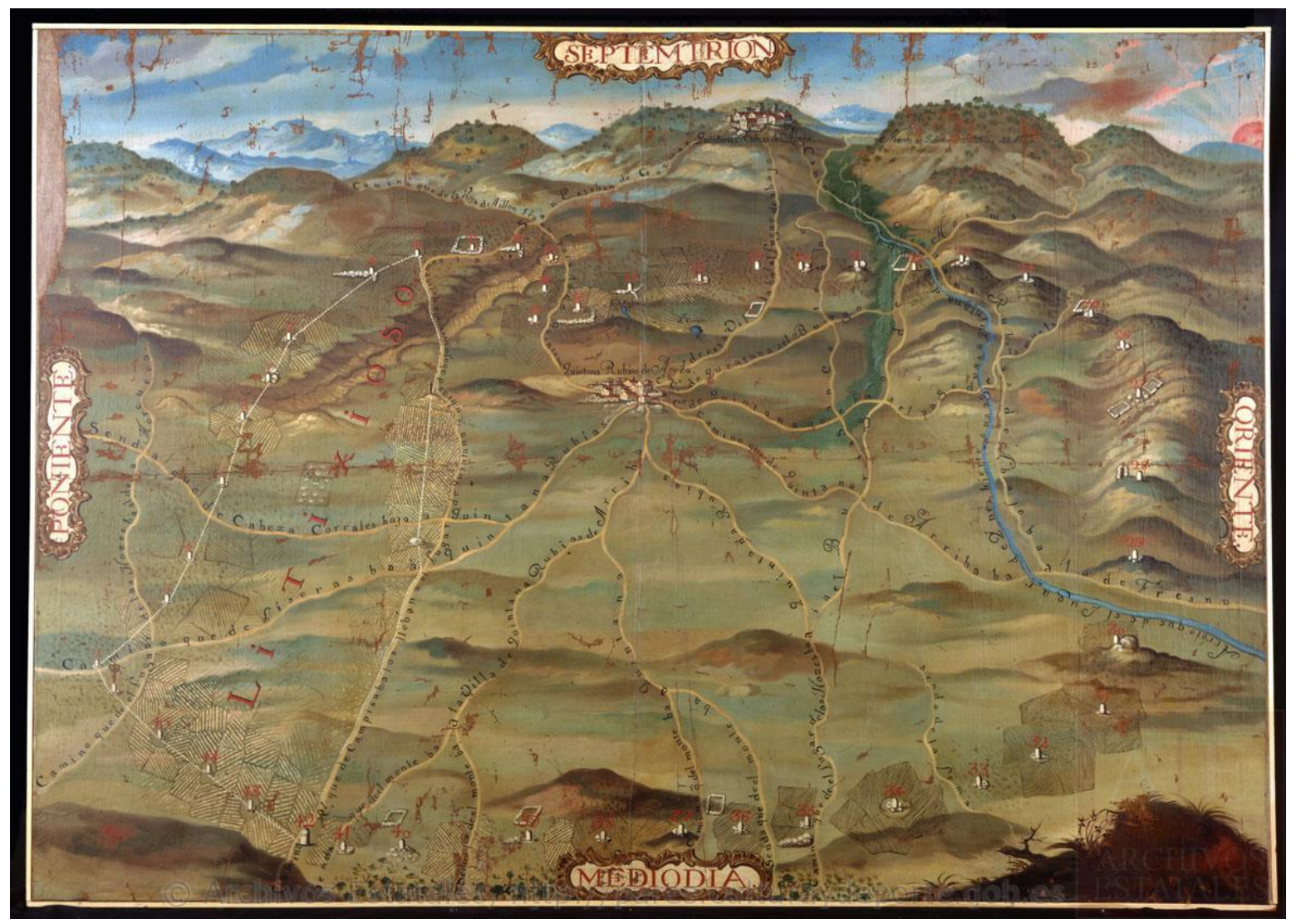

Figura 22. Carta topográfica de un terreno litigioso entre Quintanas Rubias de Arriba y Quintanas Rubias de Abajo (Soria) (Anón, 1766). Se puede apreciar la reclusión hacia las cumbres de los espacios arbolados.

Otro de los grandes deforestadores de España fue la Marina y su creciente necesidad de madera para la construcción de barcos. Como relata Lope de Vega en sus "Rimas de 1602" en "A la jornada de Inglaterra a bordo del “San Juan"” cuando servía al ejército español camino de las Islas Británicas a bordo de la llamada Armada Invencible: 


\begin{abstract}
“Famosa Armada de estandartes llena
Partidos de la roja estola

Árboles de la fe, donde tremola

Tanta flámula blanca en cada entena;
\end{abstract}

Selva de mar, a nuestra vista amena, que del cristiano Ulises la fe sola

te saca de la margen española contra la falsedad de una sirena, $[\ldots .$.$] "$

Donde refleja la espectacular suma de madera empleada para la construcción de barcos llamando a la Armada Invencible "selva de mar". La cantidad de madera de esta flota llegaría a ser de 300.000 toneladas de madera en el año 1573 (Bauer, 1991).

La caída de la Armada Invencible y la famosa "Instrucción de Toribio Pérez Bustamante" en 1656 -que será la base para las leyes de montes posteriores hasta la llegada de la ciencia forestal a España - bajo el reinado de Felipe IV que va a ser consciente de la necesidad de mantener el bosque, van a suponer un alivio para el monte español que apenas durará un siglo. En esta instrucción se aprecia una preocupación no solo del interés puntual de cubrir las necesidades de madera destinadas a la construcción de galeones, sino que en ocasiones se hace referencia a la necesidad de reforestar los montes para el beneficio de las generaciones futuras. 
Inicio de la Instrucción de Toribio Pérez Bustamante (1656):

"Hay tres suertes de montes; los primeros de vecinos particulares; los segundos de los Concejos y los terceros de su Majestad: en los que particulares los dueños cuidarán de su aumento y conservación como mejor les pareciere"

(Ibarra, 1777)

Cita de la Instrucción donde se aprecia la necesidad de reforestar para el disfrute de las generaciones futuras, hasta entonces algo desconocido:

"[...] y también porque los montes concejiles son Realengos y así deben advertir a todos lo mucho que les importa conservarlos, porque no puede haber lugar bueno sin montes: y si los pasados no los hubieran conservado, no los gozarán los presentes, y si los presentes no los conservan, no los tendrán los venideros."

(Ibarra, 1777)

La llegada de los Borbones y su nueva política naval que volverá a exigir grandes cantidades de madera pondrá otra vez al bosque en un momento crítico. Pero hay que señalar, en este sentido, que se observa cierta preocupación por parte de la nueva administración borbónica respecto del bosque con la promulgación de ciertas leyes destinadas a frenar la deforestación: 
- "Pragmática de Aranjuez del 3 de mayo de 1716" Donde Felipe $\checkmark$ ordena que:

"se planten pinos carrascos, álamos y otros árboles en los montes baldíos, concejiles y de particulares a costa de los dueños por los concejos, pena de privación de oficio y ejecutarlo a su costa, y que los corregidores visiten todos los años los montes, siendo esto causa de residencia"

(De la Cruz, 1855)

- “Ordenanza para la conservación y aumento de los montes de Marina" 1748. En esta ordenanza se crea la figura del intendente de Marina que estará al cargo de los bosques próximos a la mar o a los ríos navegables aquellos que se encuentren a menos de 25 leguas $(138 \mathrm{~km})$ (Martínez, 2014). Esto va a suponer la entrada de la administración central en la gestión forestal hasta entonces cedida a los poderes locales.

- "Ley forestal 7 de diciembre de 1748 Real Orden para el aumento y conservación de montes y plantíos" en la cual se insta a los vecinos a plantar árboles, sembrar bellotas o piñones $\mathrm{e}$ incentivar los plantíos aunque no tuvo muy buena acogida (Madrazo, 2010).

Pese a esta preocupación por el lamentable estado del bosque español mostrada por del Estado y directamente desde el poder Real no se conseguía frenar su deterioro, esto se fundamenta en cinco aspectos:

1. El aumento de la población y con ello las necesidades de madera, leña y carbón.

2. Se incrementa la necesidad de carbón vegetal para las herrerías ante la creciente demanda de productos metálicos y la inexistencia de carbón mineral.

3. La política naval de los Borbones necesitó grandes cantidades de madera para la construcción de galeones. 
4. El Estado reclama la plantación y el fomento de los plantíos, pero no desarrolla financiación para ellos.

5. La ciencia forestal aún no ha llegado a España, lo que genera la existencia de múltiples actores en la toma de decisiones en ocasiones contradictorias. En este contexto se enmarca la Desamortización.

Tanta es la deforestación en la España peninsular que William Bowles en su "Introducción a la Historia Natural y a la Geografía Física de España" se refiere a la Península de este modo:

"No se puede considerar sin lástima la escasez de árboles que hay en España y lo árido que se presenta su terreno en la mayor parte de sus provincias interiores. Muchos atribuyen esta falta a la sequedad y buscan razones o pretextos con que explicar el mal, sin querer buscar sus causas. En Castilla la vieja llega el desvario hasta decir que son perjudiciales los árboles, porque abrigan los pájaros. Disparate que mueve a cólera y no merece respuesta. Las causas verdaderas de esta miseria son la desidia y la ignorancia. Reparando solamente lo que pasa en Madrid, se hallará lo mucho que se ha destruido de lo que se plantó en tiempo de Felipe II y lo poco que se ha repuesto. Su dehesa, que fue antiguamente "buen monte de puerco y de oso" es ahora la imagen de la aridez, pudiendo ser un bello bosque de encinas, para las cuales es muy apropósito su terreno de arcilla mezclada con arena."

(Bowles, 1789)

Todos estos hechos son relevantes para asegurar que la realidad forestal española era muy preocupante (Figura 23), pero a finales del siglo XVIII va a suceder uno de los acontecimientos que determinarán los montes españoles. Las ideas liberales llegan a España, en lo que al bosque 
concierne, de la mano de Jovellanos y Campomanes principalmente (Informe sobre la ley Agraria 1749, Tratado de la Regalía de Amortización 1765 , etc.) y van a suponer un desastre para el patrimonio forestal español bajo la idea de que el liberalismo sería la llave mágica para solucionar los problemas de España. Pero esto choca con la realidad patrimonial del bosque, el cual necesita propiedad común o estrictas leyes que frenen su deterioro. Así, la Desamortización, comenzada a principios del XIX con las leyes liberales de Argüelles en 1813 y especialmente con las famosas Desamortizaciones de Mendizabal de 1836 y Madoz de 1855 van a suponer un auténtico desastre para el bosque español con la pérdida de cinco millones de hectáreas de espacio arbolado pertenecientes fundamentalmente a instituciones religiosas y entidades municipales. Estos bosques fueron vendidos a particulares con el propósito de activarlos económicamente al considerarse espacios improductivos los que rápidamente los hicieron dinero mediante la roturación y venta de la madera. Como consecuencia se produjo la destrucción forestal más grave en toda la historia de España (Bauer, 1991). Este proceso privatizador se llevó a cabo en todo el conjunto del territorio español, pero es necesario señalar que fue mucho más relevante en la mitad sur de España (Gallego et al., 1994). 


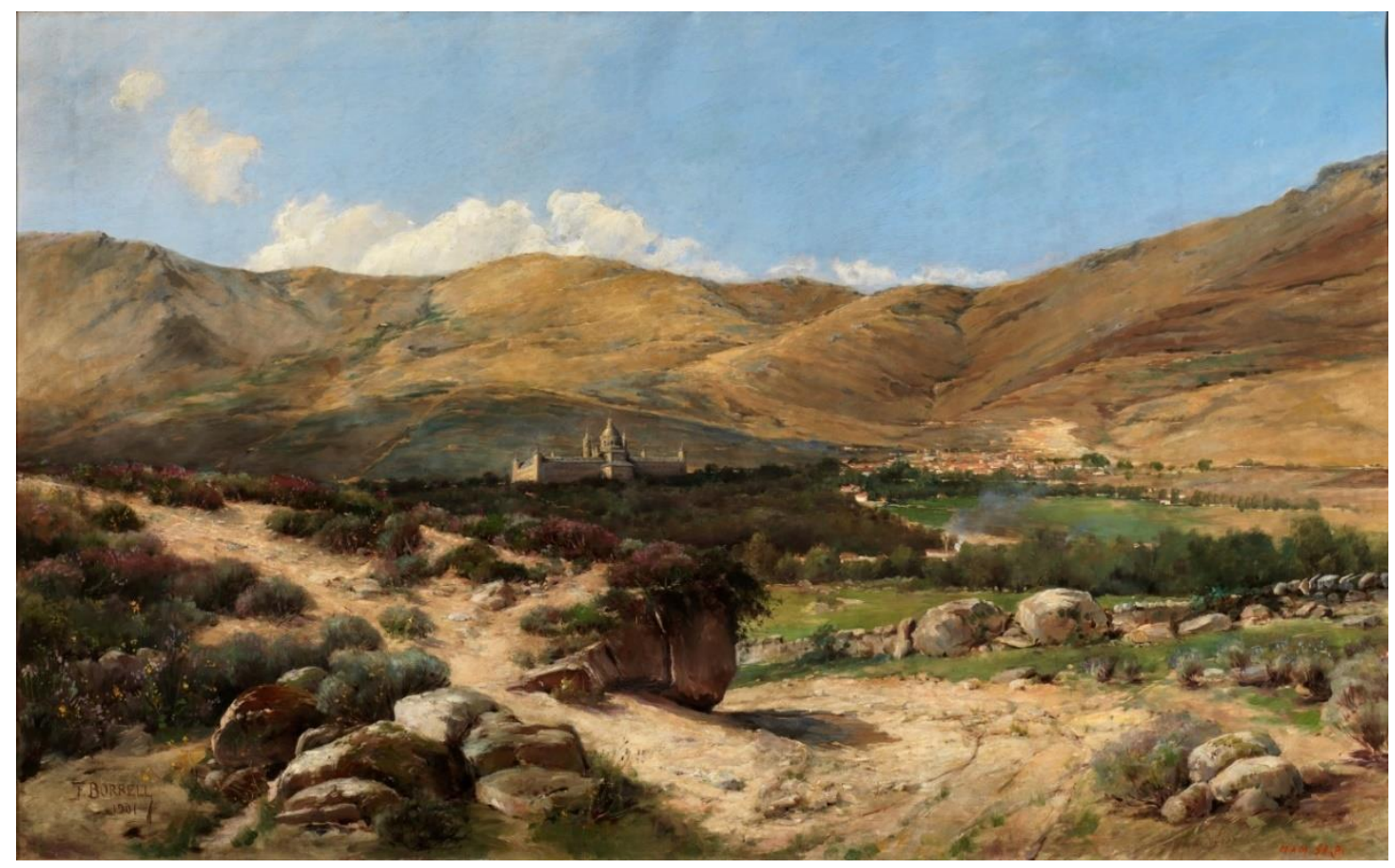

Figura 23. Paisaje de El Escorial (Borrell, 1901). Se puede observar la Sierra de Guadarrama al fondo, completamente deforestada.

Pero el siglo XIX va a ser testigo de un momento contradictorio en lo que al bosque se refiere, van a entrar en conflicto dos visiones contrapuestas. Por un lado, estas ideas desamortizadoras comenzadas en el siglo XVIII que favorecen la destrucción forestal basándose en la rentabilidad económica y por otro lado la lucha de diferentes colectivos, intelectuales, periodistas (Bauer y Laso, 1964) pero especialmente los ingenieros de montes centrados en evitar la venta de los montes públicos que culminó con la aprobación del “Catálogo de Montes Públicos y Demás Terrenos Forestales Exceptuados de la Desamortización por Razones de Utilidad Pública” en 1862 y su rectificación de 1877-1896. Este Catálogo consiguió salvar más de 8 millones de hectáreas de su venta (ICONA, 1993; Calvo, 2003), lo que a la postre hubiera supuesto su completa desaparición (ICONA, 1993; Calvo, 2003).

Por tanto, el siglo XIX se va a convertir en el testigo de uno de los acontecimientos más relevantes para los bosques españoles. Este Catálogo 
va a ser el resultado final de las nuevas corrientes de gestión del bosque que aparecerán con la llegada de la ciencia forestal a España de la mano de Agustín Pascual ${ }^{1}$. De este modo se va a generar una corriente de opinión propensa a la protección del bosque y a defender el mantenimiento de este en manos públicas para que pueda ser gestionado de acuerdo al interés general, de lo contrario decía, "se verá reducido a monte bajo" (Gómez, 1992). La desaparición o degradación del bosque generó importantes problemas como avenidas, inundaciones, pérdida de suelos como se pudo ver en las inundaciones posteriores a la desamortización siendo las más destacadas las de 1869 y 1878 del Júcar y el Guadalentín respectivamente (Potenciano, 2004). Basándose en esta necesidad de mantener la propiedad pública de los montes se va a redactar el ya citado Catálogo de Montes Públicos y demás Terrenos Forestales Exceptuados de la Desamortización por Razones de Utilidad Pública mediante un proceso evolutivo basado en diferentes ideas, que estarán apoyadas por el Ministerio de Fomento, quien encargó una consulta al Cuerpo de Ingenieros de Montes donde se concluyó la necesidad de exceptuar de la desamortización aquellos montes que cumpliesen determinadas condiciones. Estas ideas, como se ha señalado fueron evolucionando con el tiempo.

En un primer momento el criterio fundamental para reclamar la necesidad de propiedad pública de los montes españoles será la especie arbórea, se van a incluir en el Catálogo aquellos montes que contengan determinadas especies que aparecen recogidas en este y que se

\footnotetext{
1 Así en 1847 se va a crear en Villaviciosa de Odón la Escuela de Ingenieros de Montes heredera de esa ciencia forestal alemana aprendida por Agustín durante su formación en ese país, considerando a este el padre de la ciencia forestal española (Bauer, 1991; Gómez, 1992). La Escuela, que será el germen del Cuerpo de Ingenieros que guiará el destino del bosque español a partir de este momento, fue puesta en marcha por el ya nombrado Agustín pascual y por Bernardo de la Torre Rojas ocupando, este último la dirección llevando así la parte administrativa y de gestión. Estos primeros ingenieros formados en la Escuela de Villaviciosa de Odón son instruidos mediante una corriente de pensamiento global lejos de doctrinas sectoriales y con un fuerte conocimiento geográfico basado en la caracterización del territorio mediante una formación teórica pero fundamentalmente práctica cuyo origen hay que enmarcarlo en la doctrina de Giner de los Ríos y la Institución Libre de Enseñanza (Gómez, 1992).
} 
consideraban estratégicas para el interés general como los pinares y robledales generalmente restringidos a las zonas montañosas.

En un segundo momento se va a incluir el criterio de uso público, se promueve dejar el bosque en aquellas zonas que se considere necesario por razones de interés general independientemente de las especies que formen ese monte, de esta forma se va a incluir encinares y prados boyales que en un primer momento no habían sido considerados, así como masas especialmente densas.

Por último, se incluirán en la excepción desamortizadora los Montes de Utilidad Pública a partir del Real Decreto de 20 de septiembre de 1896 donde aparecerá por primera vez esta figura de propiedad y que salvará de ser vendidos a buena parte de montes cuyo principal uso es el aprovechamiento comunal. Pese a ser este Catálogo un punto de inflexión en la tendencia deforestadora española y siendo muy relevante para la realidad forestal y su conservación, en ningún caso se incluyeron criterios de construcción territorial o identitarios para exceptuar un monte de la venta (Gómez, 1992).

Así se refleja la creación de los Montes de Utilidad Pública (MUP) en el R.D. de 20 de septiembre de 1896 publicado en La Gaceta de Madrid:

"[...]se entenderá que son montes de utilidad pública las masas de arbolado y terrenos forestales que por sus condiciones de situación de suelo y de área sea necesario mantener poblado o repoblar de vegetación arbórea forestal para garantir, por su influencia física en el país o en las comarcas naturales donde tenga su asiento, la salubridad pública, el mejor régimen de las aguas, la seguridad de los terrenos o la fertilidad de las tierras destinadas a la agricultura, revisándose con sujeción a este criterio el actual Catálogo de los montes exceptuados por su especie y cabida."

(Gaceta de Madrid, 1896) 
Una vez aprobado de forma definitiva el Catálogo y creada la base teórica sobre la que se desarrollará la ciencia forestal, el siglo XX va a ser el momento de la repoblación y ordenación. La necesidad de esta gestión de los bosques españoles se fundamenta en la dificultad agronómica del territorio español, condicionado fundamentalmente por la mala distribución de los recursos hídricos, por lo que la ciencia forestal estará íntimamente ligada a la ciencia geográfica. Las soluciones van a tener un importante poso territorial, esto se va a apreciar por primera vez en la regulación de 1930 se plantea la ordenación de los montes atendiendo a sus beneficios indirectos (Gómez, 1992). Pero lo que de verdad va a caracterizar la primera mitad del siglo XX va a ser la necesidad de cubrir buena parte del territorio por vegetación leñosa y esto se verá reflejado en las primeras inclusiones de reforestación en los presupuestos públicos a través de las disposiciones de 1908 que pondrá la base territorial mediante las divisiones hidrográfico-forestales y las secciones forestales de las confederaciones hidrográficas, la ley republicana de 1935 que creó el Patrimonio Forestal enfocado a la productividad, el Plan General de Repoblación Forestal concluido en 1939 y del Patrimonio Forestal del Estado del régimen franquista de 1940 (Gómez y Mata, 1992). Así la administración entra a ser un actor realmente activo en la política forestal estando enfocado, fundamentalmente, al productivismo, se va a comenzar a plantar especies de crecimiento rápido abandonando la vocación conservadora que había sido la tendencia hasta entonces (Gómez, 2001). Se puede decir que en pocos años la ciencia forestal avanza rápidamente hasta convertirse, ya en tiempos de la segunda república, en una de las escuelas más activas y relevantes del mundo debido a la dificultad que presenta la península para el desarrollo de esta.

Para la segunda mitad del S.XX la ciencia forestal española estará condicionada por la política que va a desarrollar el régimen dictatorial, durante el final de la II República existen evidencias de que se pretendía incluir criterios paisajísticos en la gestión forestal pero la irrupción de la Dictadura Franquista y el régimen autárquico van a poner el foco en los 
valores cinegéticos y piscícolas (Gómez, 1992). El último gobierno republicano había considerado por primera vez en la historia la delimitación de reservas integrales vegetales asociadas a la ordenación de montes, pero los nuevos criterios políticos de corte más conservador, con fuerte sentimiento patrimonial van a chocar con la gestión y ordenación que se venía practicando.

Con la llegada al poder del régimen dictatorial de Franco se va a producir en España lo que se ha llamado la "industrialización del bosque" (Tabla 2). Esta va a comenzar con la aprobación del Plan General de Repoblación Forestal de España de 1939 que tiene una clara finalidad industrial productivista asociada a la necesidad autárquica de madera (Jiménez, 2002) centrándose, principalmente, en especies autóctonas de turno corto (Uriarte, 2010) pero en ocasiones repoblando con otras especies de turno más largo. Esta repoblación puesta en marcha, en ocasiones no solo estaría pensada para la producción de madera, sino que tenía un segundo objetivo destinado a frenar la erosión de suelos que impidiese el colmatado de los embalses coetáneos y futuros. En cualquier, caso parece evidente que existieron dos realidades diferenciadas a la hora de enfocar las repoblaciones, por un lado, la clara vocación productivista de turno corto se aprecia en Galicia, la fachada atlántica y el suroeste peninsular y por otro lado, el interior peninsular más centrado en las especies de turno largo (Gómez y Mata, 1992).

Durante esta etapa, se va a producir un acontecimiento que va a ser fundamental para el futuro del bosque español, a partir de la década de 1950 comienza el llamado "éxodo rural” español por el cual la población rural, en claro crecimiento, se encuentra frente a un campo en modernización que no absorbe la mano de obra existente y a su vez, las nuevas industrias situadas en las ciudades van a atraer a esa mano de obra excedentaria del mundo rural, con el consiguiente descenso de la presión sobre el medio en general y sobre los recursos energéticos y constructivos que ofrecía el bosque en particular. Así, en el mundo rural, la sustitución de la madera como material de construcción por nuevos materiales 
metálicos y de derivados áridos, así como la sustitución de los combustibles que ofrecía el bosque por combustibles derivados del petróleo, especialmente los gasificados, contribuyeron al abandono de los aprovechamientos comunales del monte (Fernández, 1990).

En definitiva, mientras este descenso de la presión sobre el bosque se producía, la política foresta de la dictadura y los primeros años del sistema democrático actual iban a centrarse en repoblar buena parte de los montes deforestados, así entre 1940 y 1982 se repoblaron en España casi tres millones de hectáreas (Fernández, 1990) de los cuales parece que realmente fueron 2.400 .000 hectáreas al estar hinchadas las cifras por parte de la administración (Rico, 1995) modificando, en algunos casos, no en todos como ha sido la creencia dominante, la composición vegetal original. Uno de los aspectos que va a determinar la composición florística de los bosques españoles a partir de este momento va a ser ese cambio de usos al que se hacía referencia, con la decadencia del bosque como abastecedor de carbón y de leña se inicia un paulatino descenso de la multifuncionalidad de los montes (Gómez et al., 2014) tendentes al bosque monoespecífico. 


\begin{tabular}{l|l|l|} 
Especie & Superficie (ha) & $\%$ \\
\hline Pinus pinaster & 352.490 & 30,03 \\
Pinus halepensis & 297.474 & 25,34 \\
\cline { 2 - 3 } $\begin{array}{l}\text { Pinus sylvestris } \\
\text { Pinus pinea }\end{array}$ & 215.360 & 18,35 \\
\cline { 2 - 3 } $\begin{array}{l}\text { Pinus nigra } \\
\text { Pinus radiata }\end{array}$ & 91.400 & 7,78 \\
\cline { 2 - 3 } $\begin{array}{l}\text { Pinus canariensis } \\
\text { Pinus uncinata }\end{array}$ & 78.250 & 6,66 \\
\cline { 2 - 3 } $\begin{array}{l}\text { Eucaliptus ssp. } \\
\text { Populus ssp. }\end{array}$ & 40.480 & 3,44 \\
\hline $\begin{array}{l}\text { Otras } \\
\text { Total }\end{array}$ & 12.600 & 1,07 \\
\cline { 2 - 3 } & 1.520 & 0,12 \\
\hline
\end{tabular}

Tabla 2. Superficies repobladas en España por el Patrimonio Forestal del Estado en 1940 1960, por especies. Fuente: (Pita, 1963) recuperado de (Uriarte, 2010)

Por último, hay que destacar como otro de los acontecimientos que van a determinar el bosque español la entrada de España en la Unión Europea en el año 1986 y la asimilación por tanto de la Política Agrícola Común (PAC) que va a convertirse en un hito no solo para la transformación agropecuaria española y el cambio de paradigma en el medio rural, sino que resulta muy relevante para la realidad forestal en nuestro país. Las “Políticas de Forestación de Tierras Agrarias" incluidas en la PAC a partir del año 1994 y que han sido fundamentales en cuanto al incremento de masa forestal española (especialmente hasta 2010) (Fernández et al., 2016) que, junto con la regeneración natural que se produce tras el abandono rural reduciendo la presión sobre el medio (Lasanta et al., 2014) y la puesta en marcha de un marco estratégico por parte del Estado como es el Plan Forestal Español aprobado el 5 de Julio de 2002 por el Consejo de Ministros del Gobierno de España con el fin de garantizar los objetivos generales y las directrices básicas que garanticen el cumplimiento de los compromisos internacionales asumidos por el Estado español en todo su territorio 
(Consejo de Ministros, 2002), permiten pensar en un futuro de expansión forestal.

\begin{tabular}{|c|c|c|}
\hline Acontecimiento & Fecha & Consecuencias \\
\hline Neolítico & 6000 a.C. & $\begin{array}{l}\text { Comienza la intervención antrópica para } \\
\text { agricultura y pastos. }\end{array}$ \\
\hline Calcolítico & 3000 a.C. & $\begin{array}{l}\text { Comienza intervención para abastecer } \\
\text { ferrerías. }\end{array}$ \\
\hline "Reconquista" & S.VIII-XV & $\begin{array}{l}\text { Deforestación estratégica militar } \\
\text { Propiedad de realengo, señorío y } \\
\text { abadengo. Uso comunal. }\end{array}$ \\
\hline El Consejo de la Mesta & 1273 & $\begin{array}{l}\text { Privilegio de planteamientos favorables } \\
\text { para obtener pastos. }\end{array}$ \\
\hline La administración Borbónica & 1700 & $\begin{array}{l}\text { Preocupación forestal destinada a } \\
\text { abastecer a la Marina. } \\
\text { Legislación forestal. }\end{array}$ \\
\hline La Desamortización & $1813-1855$ & $\begin{array}{l}\text { Venta cinco millones de hectáreas } \\
\text { arboladas. }\end{array}$ \\
\hline El Catálogo de MUP & $1862-1896$ & $\begin{array}{l}\text { Salvación de más de } 8 \text { millones de } \\
\text { hectáreas de su venta a particulares. } \\
\text { Aparece la figura de MUP }\end{array}$ \\
\hline Las repoblaciones dirigidas & $1940-1982$ & $\begin{array}{l}\text { Repoblación más de } 3 \text { millones de } \\
\text { hectáreas con pinos. }\end{array}$ \\
\hline El éxodo rural & $1950 \ldots$ & $\begin{array}{l}\text { Reducción presión sobre el bosque. } \\
\text { Regeneración natural } \\
\text { Incorporación de terrenos agrícolas a uso } \\
\text { forestal. }\end{array}$ \\
\hline Políticas de Forestación (PAC) & $1994 \ldots$ & $\begin{array}{l}\text { Subvenciones europeas destinadas a la } \\
\text { forestación de terrenos agrícolas para } \\
\text { particulares. }\end{array}$ \\
\hline
\end{tabular}

Tabla 3. Resumen de los acontecimientos más relevantes en la historia forestal española. Elaboración propia. 


\section{Capítulo 3. El paisaje}


Según el DLE (R.A. Española y A.D.A. Española, 2014) define paisaje como "parte de un territorio que puede ser observada desde un determinado lugar" en su primera acepción, su segunda y tercera acepción hacen referencia directamente a su aspecto estético y más concretamente a su excepcionalidad estética cuando lo definen como "espacio natural admirable por su aspecto artístico" y como "pintura o dibujo que representa un paisaje (refiriéndose a la acepción segunda)" pero lo más relevante de la palabra paisaje es su etimología derivada del francés pays que hace referencia al "territorio rural", de este modo se puede relacionar el paisaje directamente con el modo de vida rural, con los usos tradicionales propios de una comunidad.

En cuanto a su origen, paisaje aparecerá en las lenguas romances durante el Renacimiento con la pintura italiana, la representación de elementos religiosos ficticios como un santo o una virgen acompañados o dispuestos sobre un fondo que representa un lugar real va a ir avanzando hasta abandonar la representación religiosa y centrarse puramente en el lugar real, así nacerá en Italia la pittura que representa el paese, es decir la pintura que representa un país que acabará derivando en el paesaggio del S XVI (Fernández, 2014) y en España en paisaje en 1708 (Coromines y Pascual, 1991).

El paisaje es entendido, en nuestro caso como una construcción social, es el resultado de la intervención humana sobre el medio. Es por tanto un sistema, un todo que forma el espacio donde el ser humano desarrolla su actividad (Bolòs, 1983). Este sistema necesita pues un análisis integrador, no se pueden analizar sus partes de forma aislada o inconexa, sino que se necesita de una visión integradora y de conjunto propia del pensamiento geográfico. Como ya se ha señalado una construcción social, se trata de un elemento que carece de sentido sin la presencia humana, es por tanto percibido, vivido, caracterizado y transformado (Gómez, 2012). Esta manera de entender el paisaje es propia de la ciencia geográfica, que relaciona, indudablemente, el espacio con la intervención humana. Se puede decir que el espacio no es ni más ni menos que un paisaje donde se 
relacionan las diferentes partes del sistema. Según esto, se entiende que el paisaje por definición es cultural, la visión geográfica debe entender el paisaje como un espacio donde los elementos se relacionan siempre bajo el control de la actividad humana.

La tradición nos indica que el paisaje es una imagen, probablemente heredado del concepto paisaje como la representación de un instante que hinca sus raíces en la pintura. Pretende definir el paisaje, por tanto, como una construcción social, ya que sin la mirada del autor este no existe, pero reduce el paisaje a un elemento estético. Si bien es cierto que no se puede separar el paisaje de su tradición estética, no debe reducirse solo a esto porque estaríamos olvidando el intangible, el valor cultural que se vuelca sobre el territorio (Besse, 2010). La estética es, por tanto, uno de los valores innegables del paisaje, pero no se puede olvidar que el observador no tiene por qué ser un pintor o un poeta, el observador tiene su propia valoración estética, la cual, generalmente está modelada al gusto del momento.

Pero la clave sobre la que va a girar el concepto de paisaje en este trabajo es esa relación paisaje-sociedad, lo que establecerá en último término su valor patrimonial. Se entenderá que uno de los aspectos fundamentales para la gestión de un paisaje es el mantenimiento de su funcionalidad que será reflejo de su cultura. Entendiendo esta como la capacidad de mantener los significados originales e identitarios de un bien, en tanto que la integridad informa sobre la parte del bien que condensa los valores patrimoniales y cómo se inserta esa parte en el conjunto. Se va a asimilar entonces que la autenticidad de un paisaje va a ser lo contrario a la tematización, así la autenticidad hace referencia a la veracidad de los paisajes y preservación de sus funciones y sus significados (Silva y Fernández, 2017). Y todo esto está íntimamente ligado con que esa relación paisaje-sociedad se mantenga activa.

Resumiendo, si se pudiera asimilar el estudio del cuerpo humano con el estudio territorial, el análisis del paisaje desde la geografía sería la 
fisiología, la ciencia médica destinada a estudiar el funcionamiento del cuerpo humano, alejándose así de la tradición que equipararía el análisis del paisaje con la anatomía, que se limitaría a describir la estructura humana. El geógrafo será, ante un paisaje, un fisiólogo.

\subsection{Las dimensiones del paisaje}

Tradicionalmente el paisaje era entendido como la representación, concepto que cambió tras ese traslado de foco del objeto al sujeto, pero en ocasiones seguía aproximándose al paisaje desde la dimensión puramente estética pero como se ha visto la realidad del paisaje abarca muchos más aspectos que deben tenerse en cuenta, los cuales serán la base sobre la que se fundamente su valor patrimonial. De este modo es necesario realizar una breve clasificación de cuales van a ser las dimensiones que van a componer el paisaje según se entiende en este trabajo y que llevan a pasar someramente sobre los aspectos estéticos para enfocar el paisaje como recurso (Ortega, 1998; Sanz, 2000; Sabaté, 2004; Zoido, 2004; Mata, 2008a).

- Dimensión estética

Basada, como se viene repitiendo, en el enfoque artístico fundamentalmente y asociada a la representación de un momento determinado y de algún elemento excepcional por ajustarse al gusto del momento histórico en el que se enmarca la obra o el movimiento artístico. Esta dimensión del paisaje es una de las más conocidas y uno de los pilares fundamentales ya que incluso durante el esfuerzo que se ha hecho en los últimos tiempos en desmarcarse de ella los organismos que legislan y orientan el camino que ha de seguir el paisaje, ponen el foco en sus valores estéticos, incluso la dimensión científica del paisaje en ningún momento deja de perseguir esta singularidad armónica y de apariencia agradable pese a intentar huir de ella para poder realzar el resto de dimensiones.

- Dimensión cultural 
Aquella que se relaciona con el poso tradicional del paisaje, para la geografía es una de las dimensiones fundamentales y sobre la que se basa, principalmente, la corriente científica dominante en el momento actual. En este sentido, el "carácter" que proponen los métodos de análisis del paisaje tendrían en esta dimensión su pilar fundamental al entender que la cultura será en último término el fundamento de los usos tradicionales que dejan la "marca" sobre el medio físico lo que dará como resultante el paisaje geográfico.

\section{- Dimensión simbólica}

Se trata de los aspectos intangibles que se asocian al paisaje, aquellos elementos que aparecen relacionados a la expresión territorial pero que no van a dejar una "marca" observable a través de los sentidos. La dimensión simbólica se asocia principalmente con creencias, celebraciones, acontecimientos, etc. en definitiva hechos relevantes que tienen una estrecha relación territorial pero que solo acudiendo a la población local se pueden desentrañar, de este modo podrán encontrarse realidades intangibles que pueden ser tan o incluso más importantes que otras objetivas (Olivera, 2011).

- Dimensión histórica

Cuando se alude a la dimensión histórica de un paisaje se hace referencia a su profundidad temporal, cómo el resultado de lo que hoy percibimos y documentamos se ha desarrollado de forma diacrónica y por tanto en función de los avances técnicos que poseían las sociedades que vivían en un territorio determinado. Este hecho temporal, que es determinante para entender lo que hoy existe, tiene una estrecha vinculación con la dimensión cultural ya que las prácticas desarrolladas por las sociedades a través del tiempo están directamente relacionadas con el momento histórico, estas prácticas van a ir dejando un poso sobre el medio que servirá como fuente para la investigación histórica, en tanto en cuanto, el paisaje se trata de un proceso acumulativo, un archivo de procesos donde se puede acudir para entender cómo desarrollaban su actividad vital los 
habitantes de ese lugar. Siempre que se trata la dimensión histórica es necesario hablar de las permanencias, esos elementos que se superponen unos a otros sin eliminar los anteriores que nos permiten entender la evolución del paisaje y que sería imposible de desentrañar sin atender a la secuencia en su totalidad (Garrabou y Naredo, 2008).

- Dimensión ambiental

Está íntimamente ligada con el medio físico y sería la relación que existe entre el resto de las dimensiones y el potencial ecológico del territorio en cuestión. Concretamente en la capacidad de adaptación que la intervención humana ha tenido para con su medio físico. De esta manera vamos a encontrar paisajes donde la dimensión ambiental o medioambiental va a resultar dominante, mientras que en otros paisajes queda difuminada o supeditada a otras dimensiones que resultan más relevantes o al menos preponderantes. Pese a esta dominancia ambiental donde los elementos biológicos, su riqueza, abundancia o singularidad sobresalgan por encima de los elementos culturales o de base antrópica es necesario señalar que el paisaje siempre será resultante de las decisiones humanas en su sentido cultural.

Pese a esta disgregación de las diferentes dimensiones que van a componer el paisaje se hace necesario recordar el carácter holístico que necesita de un enfoque que evite analizar la suma de sus partes para profundizar en el significado del conjunto, lo que en definitiva es el concepto paisaje para la ciencia geográfica o como lo definió Carl Sauer en la primera mitad del siglo XX la suma de aspectos naturales y socioculturales que desembocaría en la dimensión cultural de la naturaleza (Sauer, 1925; Bertrand et al., 2007).

\subsection{La evolución del concepto paisaje}

El paisaje no puede ser entendido como un elemento externo al hombre, sino como un elemento con el que interactúa, el paisaje es el resultado de la intervención humana, es innegable, pero el hombre a su vez 
es el resultado de su paisaje. Cuando observamos una determinada escena algunos elementos nos parecen extraños o poco familiares, o no logramos hacerlos encajar dentro de nuestra lógica marcada por la tradición, pero existen elementos que guían nuestra mirada, que nos hacen reconocer un paisaje y estructurarlo independientemente de lo exótico que este pueda ser: las cercas, los cultivos o las casas son elementos comunes que surgen como estructurantes derivados de la necesidad de cualquier sociedad de satisfacer sus necesidades fundamentales (Jackson, 1986).

En alguna ocasión puede parecer que existen espacios donde la actividad humana es muy pequeña o casi nula, espacios de marcado carácter natural como grandes cumbres o bosques y selvas prácticamente inexploradas o inalteradas por la intervención humana; sin embargo, no podemos olvidar que el paisaje no existe por sí mismo, sino que es el resultado de un observador, es decir, el paisaje no es si no existe alguien que lo interpreta.

El paisaje es un espacio y es un territorio, de igual forma que un territorio es un espacio y tiene un paisaje propio y un espacio pertenece a un territorio con un paisaje característico. Desde la visión geográfica, en ocasiones puede parecer que estas fronteras se diluyen, en ocasiones se habla indistintamente de espacio, territorio y paisaje. Es necesario, por tanto, si el objeto de estudio es el paisaje, delimitar y describir a qué nos estamos refiriendo exactamente. Es el elemento geográfico que responde a la observación y la interpretación, mientras que el espacio es en sí mismo y el territorio es el resultado de la organización humana. “[...] para la práctica del geógrafo un territorio ha venido siendo un espacio terrestre estructurado y localizado. Y un paisaje, un territorio formalizado e interpretado." (Martínez, 2010).

En las lenguas de origen germánico encontramos una separación mucho más apropiada para definir lo que entendemos como paisaje geográfico y desligarlo así de la tradición estética. Landscape (en inglés) o landschaft (en alemán) se refieren a la porción de tierra (land) donde se desarrolla la 
actividad humana (Higueras, 2003) dejando para el paisaje estético tradicional al que se refiere la pintura, por ejemplo, la palabra scene, de hecho, parece ser que hasta el siglo XV ladnschaft ya se utilizaba como término administrativo (Fernández, 2014).

Se entiende por tanto el paisaje como un sistema, un todo, donde se desarrollan las actividades humanas que lo modifican, el cual es observado por alguien que lo percibe y lo interpreta. Es el resultado de la modificación del hombre sobre el espacio donde desarrolla su actividad, lo que Humboldt denominaba el "paisaje natural".

No podemos entender el paisaje actual, sin entender las lógicas económicas que en él se desarrollan, nos encontramos en un momento donde la economía global es un gigante que avanza sin piedad sobre los usos tradicionales, la economía de mercado, en pos de la globalidad, absorbe todo elemento propio de un territorio y lo desvirtúa. La economía de mercado, como es sabido, tiene crisis sistémicas producidas por la excesiva acumulación, las cuales se resuelven, desde el punto de vista geográfico, incorporando nuevos espacios a la lógica capitalista. La incorporación de estos nuevos espacios, hasta ahora de usos tradicionales, se realiza mediante la creación de nuevas infraestructuras que conviertan en rentable lo que antes no lo era. Generando así un nuevo paisaje que será destruido y sustituido cuando deje de ser rentable. "Las contradicciones internas del capitalismo se expresan mediante la configuración y desconfiguración incesantes de los paisajes geográficos". (Harvey, 2007). Se debe entender el paisaje como el lugar donde se desarrollan las actividades humanas, el cual es transformado tanto por la acción del hombre a pequeña escala mediante usos tradicionales como por la intervención administrativa, supeditada en la mayoría de los casos a optimizar la rentabilidad de un espacio.

SI atendemos a la naturaleza normativa que rodea el concepto de paisaje, se puede asegurar que se ha viajado del valor simbólico al valor vital (Figura 24). En los últimos años, los estudios de paisaje se suceden 
como trabajos en sí mismos o como elemento inspirador para otros proyectos científicos. Pero el concepto de paisaje y la forma de enfrentar su estudio ha sido cambiante. Los primeros instrumentos legales de índole paisajística están relacionados con la protección del valor simbólico en muchas ocasiones asociados a cuestiones patrióticas que se desarrollan en Europa durante la primera mitad del S. XX (Cáncer, 1995) de hecho, podría fijarse el inicio del concepto “paisaje” en este sentido, actuando como una religión laica que sirva para sacralizar reliquias destinadas a la reafirmación cultural y su externalización (Prats, 2006).

Se debe esperar hasta los años 60 para volver a cuestionar el concepto de paisaje y su inclusión en los textos legales, en esta ocasión, comienza la inquietud por incluir aspectos de ordenación y gestión del territorio centrados en la preservación de objetos histórico-artísticos (Luginbühl, 2002). Los años 80 y comienzos de los 90 van a ser el inicio de la preocupación ambiental, por lo que el paisaje y su estudio se vinculan de forma inseparable a criterios de protección ecológica fundamentándose en las corrientes de estudio del paisaje desde una visión ecogeográfica o de ecología del paisaje propuesta por Tricart y Killian en 1982 (Cáncer, 1994).

Por último, se puede ver cómo la política asociada al estudio del paisaje y su protección avanza desde la protección hacia un modelo centrado en tres aspectos fundamentales que se reflejan en el Convenio Europeo del Paisaje: la protección, la gestión y la ordenación, que van a orientar el concepto de paisaje y el estudio de este (Busquets y Cortina, 2009).
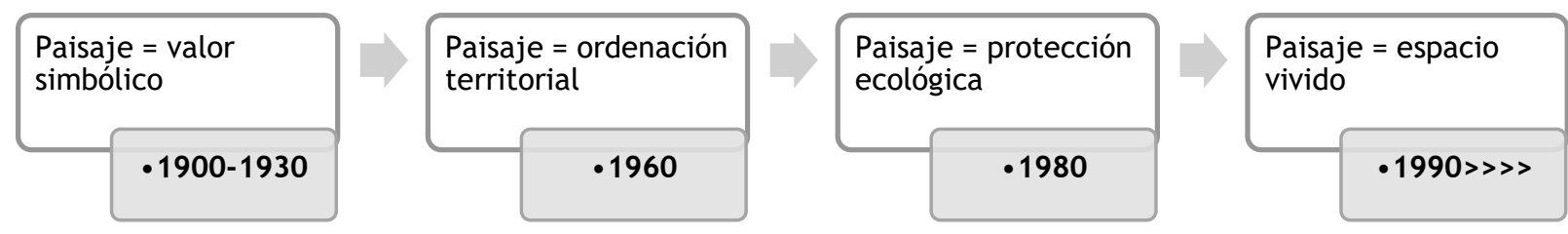

Figura 24. Resumen de la orientación en los estudios de paisaje. Elaboración propia. 
La atención pública, hasta la mitad del siglo XX, centrada en los paisajes destacables va siendo reemplazada paulatinamente hacia una visión totalizadora donde el paisaje abandona lo singular para ser un todo (Wascher, 2005). Se avanza de una referencia estética subjetiva (Morgan 1978) a una referencia vital (Gómez, 2012), de esta manera el paisaje pasa a ser considerado el espacio donde vivir abandonando el concepto del espacio para visitar, cambiando el foco del "objeto" al sujeto" (Gómez y Mata, 2006; Silva y Fernández, 2017). En este sentido, el paisaje será entendido como el derecho de los que lo viven de gestionarlo y protegerlo sobre el derecho del que lo visita, transitando desde la legislación destinada a "museizar" el paisaje mediante la prohibición, totalmente contrarias a la esencia de construcción social del paisaje (Frolova, 2009) a legislaciones que promueven la convivencia de los usos tradicionales, al fin los creadores últimos del paisaje.

La aparición del método británico LCA (Landscape Character Assessment) transforma la forma de delimitar el paisaje, pasando de la tradición visual que ha acompañado al concepto de paisaje desde tiempos inmemoriales hasta el momento actual donde el paisaje es un aglutinador sensorial que no solo afectan a la vista, sino que abarca elementos tan dispares como los olores o los recuerdos (Cano, 2007; Ross, 2014).

\subsection{El Convenio Europeo del Paisaje y el Plan Nacional de Paisaje Cultural}

"Por paisaje se entenderá cualquier parte del territorio tal como la percibe la población, cuyo carácter sea el resultado de la acción y la interacción de factores naturales y/o humanos". Así define el Convenio Europeo del Paisaje (en adelante CEP) el paisaje (Consejo De Europa, 2000). Esta definición propuesta por el Consejo de Europa en el año 2000 en Florencia viene a reafirmar la visión de elemento construido que la ciencia geográfica ha planteado en el estudio del paisaje desde el mítico "paisaje natural" de Humboldt pasando por "Geosistema Territorio Paisaje" de los 
Bertrand y llegando a la ingente cantidad de artículos científicos, libros, documentos o comunicaciones en congresos que han florecido al calor de este reconocimiento europeo.

El CEP ha sido el punto de partida del cambio de foco que se señalaba anteriormente, la visión integradora que ha aportado al estudio del paisaje viene acompañada de un cambio en el concepto, un cambio que articula el modo de enfocar el paisaje a través de tres ejes fundamentales: el territorio, la percepción y el carácter (Mata, 2014).

Por un lado, la aproximación al paisaje como territorio implica que todos los paisajes van a ser de interés para la legislación que se desarrolle bajo el paraguas del Convenio. Los paisajes excepcionales van a ser tan importantes como los paisajes cotidianos, los paisajes de singulares condiciones naturales van a ser tan valiosos como los paisajes donde domine la intervención humana como refleja el artículo 2 del CEP "abarcará las áreas naturales, rurales, urbanas y periurbanas". El paisaje, por tanto, pasa a ser el territorio en sí mismo.

En segundo lugar, el CEP pone el acento en la relación que existe entre la fisionomía del paisaje y su percepción a través de los sentidos, principalmente el visual pero no solo como se puede apreciar en la creciente aportación que diferentes disciplinas están haciendo en los últimos años al estudio sensorial del paisaje (Cano, 2007; Ross, 2014). De este modo, el observador es fundamental para el CEP en el sentido de tener en cuenta a los actores que, en último término son los generadores del paisaje.

Por último, el pilar que va a sustentar el acercamiento al paisaje que propone el CEP es el carácter de este. Si entendemos carácter como nos propone el diccionario de la Real Academia de la Lengua Española en su sexta acepción "...cualidades o circunstancias propias de una cosa, de una persona o de una colectividad, que las distingue...de las demás" o según el diccionario de Oxford para la lengua inglesa (ya que es el gobierno británico el gran impulsor del "character" en los estudios de paisaje con su método 
"Landscape Character Assessment") donde se define "character" como "The mental and moral qualities distinctive to an individual" (las cualidades mentales y morales distintivas de un individuo), el CEP pretende enfocar el paisaje centrándose en aquello que singulariza un paisaje de otro. Por otro lado, como apunta Rafael Mata lo que va a convertir el carácter del paisaje en el centro de atención, en el eje sobre el que gire su estudio es la vertiente patrimonial. Si se atiende a la primera acepción que aporta el Diccionario de la RAE de la palabra carácter, "Señal o marca que se imprime, pinta o esculpe sobre algo" directamente vinculada con su origen etimológico del griego charáttein "hacer una incisión, marcar", el carácter del paisaje será esa señal o marca que se ha dejado sobre la base o infraestructura que es el medio físico. Es decir, la marca que ha dejado el paso de la intervención humana sobre el medio físico será lo que da carácter a un paisaje, será la marca que las generaciones pasadas dejaron, así el paisaje después del CEP va a estar directamente relacionado con el patrimonio (Mata, 2014). El paisaje será el archivo de esos procesos que lo convirtieron en lo que hoy percibimos a través de los sentidos. De este modo se va a justificar la vertiente temporal o histórica en los estudios de paisaje que en muchas ocasiones lleva a difuminar las líneas entre un estudio geográfico, etnográfico, antropológico... pero que realmente es el resultado de una aproximación interdisciplinar.

En lo que se refiere a la protección de los paisajes el CEP busca en el concepto de patrimonio -entendido siempre desde la acepción de elemento heredado- el apoyo necesario para justificar la necesidad de preservación "por protección de los paisajes se entenderán las acciones encaminadas a conservar y mantener los aspectos significativos o característicos de un paisaje, justificados por su valor patrimonial derivado de su configuración natural y/o la acción del hombre" respecto a la gestión "se entenderán las acciones encaminadas, desde una perspectiva de desarrollo sostenible, a garantizar el mantenimiento regular de un paisaje, con el fin de guiar y armonizar las transformaciones inducidas por los procesos sociales, económicos y medioambientales" lo que pone de manifiesto la preocupación 
del Consejo de Europa por la banalización paisajística que sufre el territorio europeo en ese proceso de formación y reformación de paisajes que Harvey justificaba en la incorporación a la rentabilidad (Harvey, 2007).

Pero lo que ha venido a revolucionar el CEP ha sido la apertura del concepto paisaje al conjunto del territorio europeo ya sean paisajes urbanos, rurales, periurbanos, naturales, humanizados, con figura de protección o sin ella, estéticamente agradables o no y centrar a la gente, es decir trasladar el foco del objeto al sujeto en todos los aspectos que forman el paisaje (Gómez y Mata, 2006). Esta revolución donde el territorio es el paisaje ha venido a solucionar muchos problemas de gestión y protección tradicionales derivados de la dicotomía entre leyes destinadas al patrimonio natural y leyes destinadas al patrimonio cultural lo que impedía desarrollar leyes que impidiesen la “museización” del paisaje que sin duda es absolutamente contrario a su esencia de construcción social (Frolova, 2009). La tradición prohibitiva de la legislación patrimonial o natural se ha demostrado ineficiente a la hora de dar respuesta al paisaje que necesita de una legislación planificadora que permita la convivencia de los usos tradicionales que son, a la postre, creadores del paisaje.

Así el CEP va a reconocer que todos los paisajes son susceptibles de ser atendidos, gestionados y ordenados lo que ha hecho que, especialmente tras su ratificación por el Gobierno de España el 26 de noviembre de 2007 se haya comenzado la elaboración de diferentes catálogos autonómicos, nacionales, municipales, etc. Como colofón, la ratificación del CEP ha puesto en marcha el Plan Nacional de Paisaje Cultural (en adelante PNPC) que pretende ser el marco bajo el que se desarrolle la estrategia paisajística española y que tendrá vigencia en todo el territorio del estado.

El PNPC define el paisaje como paisaje cultural lo que en sí mismo y atendiendo al CEP es una clara redundancia en el sentido de que si el paisaje es el resultado de las acciones humanas siempre será por necesidad cultural. De este modo el paisaje cultural es, para el PNPC (Carrión, 2015) "el resultado de la interacción en el tiempo de las personas y el medio 
natural, cuya expresión es un territorio percibido y valorado por sus cualidades culturales, producto de un proceso y soporte de la identidad de una comunidad" poniendo al ser humano en el primer lugar y haciendo hincapié en que "el interés cultural de estos paisajes no es producto de su belleza sino del valor intrínseco que poseen desde el punto de vista cultural".

En cuanto a los pilares normativos que van a regular el PNPC se encuentran:

- El Convenio del Patrimonio Mundial de la UNESCO. Paris, 1972. Ratificado por España el 1 de Julio de 1982 y que va a vincular la normativa española a la nueva categoría “Paisaje Cultural" que definió la UNESCO en la "Operational Guidelines for the implementation of the World Heritage Convention" aprobada en la $16^{a}$ sesión del Comité del Patrimonio Mundial celebrado en Santa Fe en 1992 y que se renueva periódicamente (UNESCO World Heritage Committe, 2008). Esta nueva guía operacional creó esta nueva categoría paisajística donde la intervención humana destaca por encima del resto de elementos naturales y va a definir el paisaje cultural como "obras de labor combinada del hombre y la naturaleza" estableciendo tres categorías para esta nueva definición de paisaje cultural (Tabla 4):

- Paisaje claramente definido, creado y diseñado intencionalmente por el ser humano. Se trata de paisajes ajardinados y parques, construidos por razones estéticas que generalmente, aunque no siempre, se encuentra asociados a edificios religiosos o monumentos de otra índole.

- Paisaje evolucionado orgánicamente, debido a un imperativo inicial de carácter social, económico, administrativo y/o religioso, y que ha evolucionado hasta su forma actual como respuesta a la adecuación a su entorno natural. Este proceso 
se refleja de formas diferentes, por lo que se establecen subtipos:

- Paisaje vestigio (o fósil) es aquel que su proceso evolutivo concluyó en algún momento del pasado, pero sus rasgos característicos son todavía visibles materialmente.

- Paisaje vivo es el que conserva un papel social activo en la sociedad contemporánea asociado con el modo de vida tradicional y cuyo proceso de evolución sigue activo.

- Paisajes culturales asociativos son aquellos en los que existen poderosas asociaciones, religiosas, artísticas 0 culturales con el medio natural, en lugar de pruebas culturales materiales, que pueden ser inexistentes o poco significativas.

- El CEP del consejo de Europa del que ya se ha señalado anteriormente su importancia e influencia.

\begin{tabular}{|c|c|c|c|}
\hline \multirow[t]{2}{*}{$\begin{array}{l}\text { Tipo de } \\
\text { paisaje }\end{array}$} & \multirow[t]{2}{*}{$\begin{array}{l}\text { Paisaje claramente } \\
\text { definido }\end{array}$} & $\begin{array}{c}\text { Paisaje evolucionado } \\
\text { orgánicamente }\end{array}$ & \multirow{2}{*}{$\begin{array}{l}\text { Paisajes } \\
\text { culturales } \\
\text { asociativos }\end{array}$} \\
\hline & & $\begin{array}{ll}\text { Paisaje } & \text { Paisaje } \\
\text { vestigio } & \text { vivo }\end{array}$ & \\
\hline \multirow[t]{2}{*}{ Formación } & Parques y jardines & $\begin{array}{l}\text { Proceso social } \\
\text { tradicional }\end{array}$ & Inmaterial \\
\hline & & $\begin{array}{cc}\text { Proceso } & \text { Proceso } \\
\text { finalizado } & \text { activo }\end{array}$ & \\
\hline Asociación & Asociación Monumental & $\begin{array}{c}\text { Usos tradicionales } \\
\text { /productiva }\end{array}$ & $\begin{array}{c}\text { Asociación } \\
\text { mental con el } \\
\text { medio }\end{array}$ \\
\hline Dominancia & Artística/monumental & Territorial & Etnográfica \\
\hline
\end{tabular}


De acuerdo con estos pilares normativos e inspiradores, el PNPC fundamenta su existencia en el objetivo de:

Salvaguarda de los paisajes de interés cultural, entendiendo por salvaguarda las medidas encaminadas a garantizar la viabilidad del paisaje cultural, comprendidas las acciones de identificación y caracterización, documentación, investigación, protección, mejora, revitalización, cubriendo los aspectos necesarios de definición, delimitación, análisis de componentes y gestión; todo ello desde una perspectiva de desarrollo sostenible

Para lo que va a plantear diferentes objetivos encaminados a subsanar los problemas legales que tiene la salvaguarda del paisaje desde el momento en que lo equiparamos con el territorio. Todo se convierte en paisaje lo que hace necesaria una sistematización que el PNPC fundamenta en los siguientes objetivos:

- Identificación, caracterización y salvaguarda.

- Establecer unas bases consensuadas para la identificación y caracterización de los paisajes de especial interés cultural.

- Elaborar una propuesta de paisajes de especial interés cultural, que incluya, además de su identificación y caracterización, su valoración.

- Establecer objetivos, directrices y líneas de actuación específicas para la salvaguarda de los paisajes de especial interés cultural, que potencien su carácter y calores, compatible con su evolución y desarrollo, y favorezcan su interpretación y disfrute público.

- Sensibilización social y reconocimiento político.

- Promover e impulsar el reconocimiento social y la sensibilización de las administraciones públicas y de la ciudadanía sobre la dimensión y los valores culturales del paisaje. 
- Contribuir a la incorporación de criterios de salvaguarda de los valores culturales del paisaje en políticas, planes y actuaciones sectoriales con incidencia en el territorio.

- Cooperación internacional, nacional y autonómica.

- Impulsar la cooperación con políticas y redes de paisaje culturales a escala europea, específicamente en materia de estudio y salvaguarda de paisajes de carácter transfronterizo, conforme a lo que establece el Convenio Europeo del Paisaje.

- Promover la cooperación entre distintos Departamentos ministeriales que tienen competencias al respecto.

- Promover igualmente la cooperación entre Comunidades Autónomas, y entre estas y la Administración General del Estado en materia de criterios y objetivos de actuación, sobre todo en paisajes culturales compartidos por más de una Comunidad Autónoma.

- Generar bases de documentación, conocimiento y valoración para la inclusión de Paisajes Culturales de la Lista del Patrimonio Mundial de la UNESCO.

De este modo se ponen las bases para una catalogación y sistematización que permita implementar políticas de salvaguarda del paisaje que el PNPC ha definido como cultural, pero que en último término será del total del territorio nacional al entender paisaje como lo plantea el CEP, lo que implica poner el paisaje en el centro de la planificación y ordenación territorial.

\subsection{El paisaje forestal}

El concepto de paisaje, como se ha visto anteriormente es un todo que lejos de simplificar hace compleja la visión del territorio y su análisis. Podría parecer que en este caso paisaje y forestal no son compatibles al ser lo forestal una simplificación, una simple parte del conjunto que forma 
el paisaje, pero los casos de estudio que se plantean no pueden en ninguna ocasión verse separados de su aprovechamiento forestal (Madrazo, 2010). Se puede decir que lo forestal refleja la personalidad del paisaje en estos cinco casos de estudio o como dice Josep Gordi i Serrat en su aportación sobre los paisajes forestales en el famoso manual destinado a la gestión del paisaje de Busquets y Cortina "no es conveniente considerar el bosque fuera de su contexto territorial" (Gordi, 2009) asegurando que es el momento de incorporar lo forestal al estudio del paisaje.

El paisaje forestal, pese a parecer un elemento natural, hay que interpretarlo como un paisaje humanizado y transformado. Decía Don Jesús García Fernández en sus reflexiones sobre la humanización del paisaje vegetal que "[...]las masas de vegetación [...] tienen tanto de naturales, como de antropogénicas. Lo primero lo son en cuanto se dejan a su desarrollo espontáneo; y lo segundo en todo lo demás" (García, 2002) y como, partiendo de esta premisa, el bosque actual no responde a su desarrollo espontáneo, se puede asegurar que la flora en su forma y distribución ha sido influida significativamente por la acción humana (Bauer, 1991; Guerra, 2001; García, 2002) se trata de un paisaje construido por el hacha guiada por la búsqueda de recursos (García, 1996, 2001, 2002; Lozano et al., 2002; Guerra, 2012). Tiene dos vertientes que marcan su evolución, por un lado, la planificación y dirección que marca la ley o las instituciones y por otro lado el desarrollo que se identifica con los hábitos y las prácticas culturales, así distinguiremos entre paisajes políticos y paisajes vernáculos (Jackson, 1986) siendo el paisaje forestal, prácticamente en su mayor parte un paisaje político en la medida que se trata de un espacio ordenado por la ingeniería forestal. En este sentido, el paisaje forestal está en buena medida definido por esos hábitos y prácticas locales, es sin duda un paisaje de carga cultural que se enmarca dentro del paisaje agrario, si entendemos lo agrario lo relacionado con el medio rural (Capel, 2013). Así, los cuidados culturales asociados a los usos tradicionales van a ser determinantes para el mantenimiento del bosque tal como lo conocemos (Molinero et al., 2008). Este paisaje forestal va a tener dos 
momentos de construcción claramente diferenciados, por un lado, el uso tradicional hasta mediados del S. XVIII donde va a llegar la ciencia forestal de origen sajón y convertirá el paisaje vernáculo en paisaje político.

En el momento actual y atendiendo a esa superposición de decisiones y prácticas que supone un paisaje, la realidad forestal está compuesta por esa acumulación que en un principio partía de la base de las prácticas tradicionales, sería lo que aportaría la dimensión vernácula en el paisaje, y la dimensión política resultado de las decisiones administrativas que van a definir la realidad del paisaje forestal que hoy observamos (dimensión política). En ese palimpsesto que supone el paisaje, será imprescindible descifrar a que responden las marcas que hoy caracterizan la realidad paisajística a la qué nos enfrentamos.

Pero cuando se observa un paisaje de dominancia forestal ¿qué elementos son los que definen el paisaje? Al igual que en un paisaje de dominancia agrícola las especies vegetales, los campos de cultivo o su expresión cultural son los rasgos que van a imprimir carácter, o por otro lado, en un paisaje urbano los edificios, sus tipologías o sus espacios públicos son los rasgos que definen sus valores; el paisaje forestal, lo van a definir, por un lado, su dimensión natural o potencial ecológico (especies forestales, tallas, tamaños, portes, colores, formas, etc.) y por otro lado su dimensión cultural (las formas de aprovechamiento, las formas creadas mediante podas, artefactos derivados del uso tradicional, los usos del suelo, etc.), en definitiva las decisiones tomadas por la sociedad. Es indudable por tanto que los caracteres que van a proporcionar materialidad a los paisajes del bosque tienen, por tanto, origen en su aprovechamiento, bien a través de los paradigmas de la ciencia forestal o bien debido a técnicas silvícolas de carácter tradicional y basadas en la experiencia (Guerra et al., 2010; Guerra, 2012).

Pero donde realmente reside la potencia del paisaje forestal no está tanto en su espacio arbolado, sino que lo desborda para inundar su ámbito inmediato, pese a no ser el centro de la economía en el momento actual, 
el bosque permanece y proporciona carácter al paisaje (Guerra, 2012) dándole personalidad. Esto se puede ver en la aparición constante de referencias al espacio arbolado mediante iconografías tanto de la administración en eventos, eslóganes, como de particulares en sus empresas.

\subsection{Los tipos de paisaje forestal}

Los bosques son fundamentales para entender el paisaje siendo estos resultante y resultado de la relación tradicional de las sociedades con su entorno, pero en lo que respecta a su valor patrimonial es necesario destacar la preocupación creciente de proteger estas áreas, actualmente de los 900 espacios calificados como Patrimonio de la Humanidad por la UNESCO, un centenar son bosques que ocupan 75 millones de hectáreas y en su declaración han primado fundamentalmente aspectos de excepcionalidad (Capel, 2013).

Los espacios forestales, tradicionalmente han sido un lugar para el aprovechamiento humano. Históricamente el uso del bosque, en nuestra sociedad, viene caracterizado por la multifuncionalidad o el aprovechamiento de todos los elementos que nos ofrece un espacio forestal. Ha sido utilizado como espacio de recreo al ser un lugar especial por sus valores naturales, como un espacio productivo ya sea mediante el aprovechamiento de los recursos en vida de los árboles (resinas, podas...) como la tala de individuos para la obtención de madera, el bosque a su vez ofrecía un espacio adecuado para la explotación cinegética o para la explotación ganadera aprovechando sus pastos o la producción de ramón. Pero estos usos tradicionales y compatibles del bosque han sido sustituidos por usos mucho más concretos, se ha pasado del uso compatible al uso exclusivo abandonando su multifuncionalidad que se consolida durante el siglo XX (Gómez et al., 2014).

De este modo, los bosques han pasado a ser reconocibles por la actividad que en ellos se desarrolla, así encontramos espacios cuyo principal objetivo es la conservación atendiendo a su alto valor biológico, 
otros espacios forestales cuya principal razón de ser es la tradición histórica de una explotación ancestral de carácter corporativo, en otros espacios forestales es la producción destinada al uso industrial su principal activo, mientras que otros espacios forestales no son ni más ni menos que museos vivos, ya que es el valor monumental lo que permite su conservación, por último, el uso agrario y de aprovechamiento tradicional de otros espacios forestales es la clave para entender su existencia. Se ha pasado por tanto de un uso multifuncional del espacio forestal a un uso específico de este, lo que ha generado paisajes muy diferenciados con una tendencia hacia los bosques monoespecíficos. Se trata más que de un bosque de una foresta como proponía Agustín Pascual en su artículo "Sobre el vocablo: forestal" citado en (Gómez y Mata, 2006). Habiendo heredado bosques (naturales) legaremos forestas (donde se hace referencia a la vocación productiva del espacio forestal).

Es indudable, en el momento histórico que nos encontramos, la creciente preocupación por los espacios forestales entendidos como un refugio de naturaleza, frente a la realidad urbana que crece de forma desmesurada, el rural, lo agrario y lo forestal se está convirtiendo en un valor creciente. Ya en el origen de la protección ambiental con las leyes de Parques Nacionales en la primera década de 1910 lo forestal se contemplaba como algo a preservar, en este primer momento de legislación ambiental las normas se inclinaban hacia la protección por criterios biogeográficos y con menor atención a la agricultura (Capel, 2013) pero hoy han virado hacia una preocupación por lo agrosilvopastoril.

Como se ha planteado, para convertir un paisaje en paisaje patrimonial es necesario identificar aquellos elementos catalizadores de patrimonialización, en este caso, en el paisaje forestal estos catalizadores de patrimonialización son los valores que los van a singularizar y que se van a presentar en forma de diferentes elementos tangibles o intangibles, pero que son identificables (Naranjo, 2010; Mata et al., 2012). 
Atendiendo a la clasificación basada en el metabolismo forestal que plantea Juan Carlos Guerra en diferentes trabajos (Guerra et al., 2010; Guerra, 2012) y con la inclusión de una nueva tipología forestal no contemplada, se puede resumir el paisaje forestal en: paisaje "refugio" o bosque natural, el paisaje del bosque productor, el paisaje del monte bajo tradicional, el paisaje de la silvicultura y el paisaje forestal monumental (Tabla 5).

\begin{tabular}{|c|c|c|c|c|c|}
\hline & $\begin{array}{l}\text { Bosque } \\
\text { "refugio" }\end{array}$ & $\begin{array}{l}\text { Bosque } \\
\text { productor }\end{array}$ & $\begin{array}{l}\text { Monte bajo } \\
\text { tradicional }\end{array}$ & $\begin{array}{l}\text { Silvicultura } \\
\text { intensiva }\end{array}$ & $\begin{array}{c}\text { Forestal } \\
\text { monumental }\end{array}$ \\
\hline $\begin{array}{l}\text { Orientación } \\
\text { productiva }\end{array}$ & $\begin{array}{c}\text { Maderas, } \\
\text { leña, pasto }\end{array}$ & $\begin{array}{l}\text { Madera, } \\
\text { resina y } \\
\text { piñón }\end{array}$ & $\begin{array}{l}\text { Leña, } \\
\text { pasto, } \\
\text { Madera y } \\
\text { carbón }\end{array}$ & $\begin{array}{l}\text { Madera de } \\
\text { calidad, } \\
\text { celulosa y } \\
\text { viruta }\end{array}$ & No tiene \\
\hline $\begin{array}{c}\text { Intensidad del } \\
\text { aprovechamiento }\end{array}$ & Bajo & Medio & Bajo & Alto & \\
\hline $\begin{array}{c}\text { Forma } \\
\text { fundamental de } \\
\text { la masa }\end{array}$ & Monte alto & Monte alto & $\begin{array}{c}\text { Monte } \\
\text { bajo/ } \\
\text { medio o } \\
\text { pies } \\
\text { sueltos }\end{array}$ & Monte alto & $\begin{array}{l}\text { Monte alto o } \\
\text { pies sueltos }\end{array}$ \\
\hline $\begin{array}{l}\text { Tipo de } \\
\text { silvicultura }\end{array}$ & Conservación & $\begin{array}{l}\text { Producción y } \\
\text { conservación }\end{array}$ & Tradicional & Intensiva & Conservación \\
\hline Perdurabilidad & Alta & Alta & Media/baja & Media/baja & Alta \\
\hline Geometrías & Ausentes & Presentes & Ausentes & Presentes & Ausentes \\
\hline Cromatismo & Alto & Bajo & medio & Bajo/medio & Alto \\
\hline $\begin{array}{c}\text { Existencia de } \\
\text { artefactos }\end{array}$ & Baja & Alta & Media/alta & Alta & Alta \\
\hline
\end{tabular}

\subsection{1. bosques "refugio" (valores biológicos)}

Parece evidente que existe un consenso sobre la capacidad de intervención del ser humano en el medio, en este sentido se pueden plantear la aportación del químico Paul Crutzen, ganador del Premio Nobel de Química en 1995 cuando afirmó que el Holoceno había terminado para dar paso al Antropoceno apoyándose en la evidencia de que el mundo había cambiado tanto que el hombre había sobrepasado los límites naturales para ser el agente principal de cambio como así lo recoge el economista y profesor de Desarrollo Sostenible del Instituto de la Tierra de la Universidad de Columbia, Jeffrey Sachs cuando afirma que asistimos a una 
era en que “la Tierra está dominada por el ser humano, porque el volumen de las actividades humanas es ahora tan grande que ha desbaratado todos los sistemas fundamentales para el sostenimiento de la vida" (Sachs, 2011). O como dijo Georges Bertrand en la conferencia inaugural del Coloquio de Geohistoria celebrado en Toulouse durante el mes de octubre de 2016 "el no retorno del medio ambiente a la geografía" señalando que el hombre dirige el destino del planeta por lo que el enfoque debe ser geográfico más que medioambiental (Valette y Carozza, 2019).

En este sentido la aproximación patrimonial que se hace a un bosque de singular valor "natural" se centrará en los valores que hacen que un espacio forestal tenga consideración patrimonial atendiendo a las características biológicas, es decir supone un elemento singular que merece especial consideración por ser un espacio de especial biodiversidad, singularidad biológica o un ecosistema especialmente destacable. Es necesario partir de la base, como se ha dicho, de que no existe un bosque natural entendiendo este como un espacio que se ha desarrollado por si solo sin la intervención humana. El clímax vegetal no se alcanza en ninguna ocasión ya que las actividades antrópicas modifican en mayor o menor medida esta evolución natural, más aún si nos encontramos ante un bosque ordenado resultado de la ciencia forestal de origen decimonónico y destinado a la producción. Como decía Ortega, “La Naturaleza (...) apenas tiene hoy representación objetiva, en la medida en que se encuentra por completo alterada o sometida a los efectos perturbadores de la presencia humana" (Ortega, 1998). En este caso, se va a entender “natural" como aquel espacio que es especialmente destacable por sus valores biológicos, independientemente de si se trata de un espacio vegetal intervenido o no por la acción humana. Pese a lo que pudiera pensarse y sabiendo que las ordenaciones, al menos hasta tiempos recientes, no tenían en cuenta la biodiversidad pero parece que tampoco la impiden como aseguran algunos estudios en bosques fuertemente intervenidos mediante una ordenación de más de 40 años (Cabeza de Hierro de Rascafría) afirmando que el ecosistema 
no habría perdido diversidad ni funcionalidad biológica (Rojo et al., 2001; Gómez y Mata, 2006).

Una vez que está claro que la naturaleza como clímax vegetal independiente de la acción humana está lejos de ser algo generalizado, sino que más bien, como decía Agustín Pascual estaríamos ante una foresta en tanto en cuanto los bosques que conocemos son resultado de la ordenación de la ciencia forestal a partir del siglo XIX y anteriormente influidos, de forma más o menos importante, por la ordenación popular vinculada a los usos tradicionales. De este modo se puede asegurar que cuando una masa forestal es destacable por sus características "naturales" se estaría haciendo más referencia a su valor ecosistémico o biológico que a sus características de origen y evolución independiente que sería el significado etimológico. En este sentido, un bosque reconocible por sus características naturales, entendidas de este modo, va a albergar algunos vectores que son identificables y que serán los encargados de trasladar al bosque de un conjunto de especies vegetales al patrimonio. Estos vectores, aunque parezcan resultados del libre albedrío natural no son ni más ni menos que el resultado de la convivencia entre el bosque y el ser humano, por tanto, aquellos elementos que se identifiquen por muy naturales que pudieran parecer tienen un poso que debe identificarlos como elementos patrimoniales. Los aspectos de herencia serán la clave, por tanto.

En este sentido los bosques de esta categoría suelen ser más montanos que de llanura y albergan ciertos aspectos metafísicos asociados al misticismo del bosque y representarían ese ideal de bosque frondoso y nemoroso propio de la literatura o cinematografía asociada a lo forestal. En este bosque, resultante de esa intensa relación de trasformación humana encontramos ciertos elementos que actuarían como vectores paisajísticos que lo relacionarán con lo patrimonial como pueden ser: grandes árboles, que en ocasiones pudieran ser considerados monumentales, antiguas carboneras o espacios vacíos donde estas se asentaban, intervenciones humanas en los ejemplares para su mejor aprovechamiento mediante podas, etc. En definitiva, vestigios de esa secular intervención humana. 
En los últimos años la presión sobre estos bosques se ha reducido lo que ha derivado en su naturalización y densificación, principalmente asociada a la regeneración del sotobosque que se desarrolla rápidamente al no verse frenada por la actividad ganadera o por actividades tradicionales de control del matorral.

\subsubsection{Bosque productor (valores corporativos)}

Son valores que provienen de una tradición muy prolongada en el tiempo generando paisajes forestales muy intervenidos destinados a algún tipo de aprovechamiento en un primer momento tradicional y en un segundo momento derivado de la ordenación. Estos paisajes suelen arrojar una marcada identidad sobre la población local en tanto en cuanto son proveedores de rentas derivadas de su explotación. Se trata de espacios forestales altamente intervenidos, en principio mediante usos tradicionales y que desde el siglo XIX han sido objeto de una ordenación destinada a la producción que ha creado el paisaje actual.

En este caso, la clave del paisaje forestal es el resultado de la combinación dialéctica de dos factores, por un lado, los condicionantes del potencial ecológico y por otro lado el impacto ininterrumpido de la intervención humana (Manero, 1983). Esto genera como resultado un espacio forestal perfectamente adaptado a sus características ecológicas, pero claramente resultante de una intervención humana que ha incentivado el bosque atendiendo a su rentabilidad económica productiva. Se puede decir que el hecho diferencial de los bosques donde dominan los valores corporativos es el hecho cultural, pese a que todos los bosques tienen ese poso cultural en este caso resulta mucho más relevante.

Pero ¿qué diferencia a este bosque destinado a la productividad de una plantación silvícola? Por un lado, su carácter corporativo entendido corporación como un conjunto de personas que gobiernan el bosque, para lo que va a ser especialmente destacable la propiedad pública de este. Estos bosques históricamente se han modelado conforme a las necesidades y los intereses de agrupaciones de individuos a través de diversas formas 
jurídicas y administrativas (Guerra, 2012). Por otro lado, su génesis histórica, es decir su desarrollo a través del tiempo destinado a satisfacer las necesidades de una colectividad.

De este modo los vectores de patrimonialización que identificarán los valores corporativos van a estar directamente relacionados con la gestión comunitaria del bosque, serán aquellos elementos que reflejen las prácticas tradicionales vinculadas con una explotación o unos beneficios comunales, así como toda aquella iconografía o reflejo del bosque en el paisaje que no es propiamente arbolado. Uno de los aspectos más relevantes de los valores corporativos es el sentimiento de pertenencia que produce el vínculo bosque-sociedad, por lo que los bosques que destacan por estos valores cuentan con una vinculación territorial asociada al sentimiento de pertenencia que se genera en ese nexo basado en la relación que determinadas comunidades establecen con sus montes colectivos. Este bosque productivo de fuerte arraigo social derivado de esa gestión que se ha llamado corporativa se caracteriza por tratarse de una reconstrucción a partir de masas más o menos densas durante la segunda mitad del S.XIX. Se trata pues, de un monte monoespecífico de fustes altos y rectos (generalmente), ordenado mediante cuarteles y separados por calles destinadas a cortafuegos o pistas. Para la mirada inexperta posee cierto aspecto de naturalidad y suele ser valorado para el recreo por parte de las sociedades locales. Los vectores propios de este paisaje forestal que van a focalizar la mirada patrimonial están directamente relacionados con esa vocación productivista (aunque algunos elementos han sido sustituidos por medios técnicos más avanzados), así encontramos potes para la recogida de la resina anclados a la corteza de los árboles (anteriormente de barro hoy de plástico), barricas metálicas diseminadas para la recogida y almacenaje de la resina dispersas por los montes, pinos con caras de resinación cortadas para su sangrado (en un primer momento a muerte, después mediante el método "Huges" -monda de los pinos- a vida y hoy mediante estimulación química), pegueras diseminadas por los pinares para la obtención de pez (hoy casi desaparecidas o reconstruidas), pies separados 
en ocasiones monumentales y ausencia de sotobosque en los pinares del piñón, carros y aperos para el transporte y la bajada de las piñas (hoy camiones y maquinaria para la vibración del pino). Pero los bosques productivos, como se ha señalado, van a generar otro paisaje que se imbrica en la cotidianidad de sus poblaciones con la presencia de industrias transformadoras (ayer hermosas resineras con sus esbeltas chimeneas o amplias eras para el secado de las piñas, hoy naves y maquinaria industriales para facilitar el trabajo). En definitiva, una expresión material verdaderamente destacable.

\subsubsection{Silvicultura intensiva (valores productivos/industriales)}

En este caso, estamos ante el paisaje forestal de vinculación industrial por excelencia. Se trata de paisajes recientes, resultado del diseño de un monte arbolado alto, generalmente monoespecífico, destinado a cubrir las necesidades de madera o celulosa de la industria. El bosque está diseñado mediante un mosaico más o menos regular donde se distinguen parcelas de árboles coetáneos de turno corto y que es aprovechado mediante cortas masivas, es decir, no se realizan entresacas como pudieran ser los montes ordenados corporativos de producción de leña. Estos bosques tienen una estética directamente relacionada con el bosque centroeuropeo de coníferas, ordenado, perfecto y productor (Gómez, 2002, 2006; Gómez y Mata, 2006; Guerra, 2012). Sería el resultado de la plantación directa, generalmente de clones, por lo que podría resumirse en la adaptación de estos al potencial ecológico. Por norma general estas plantaciones son utilizadas para la obtención de celulosa para la elaboración de papel o derivados, la producción de madera de desenrolle para embalajes o la producción de virutas ya sea para mobiliario de baja calidad o para combustible en forma de biomasa.

En este caso los vectores de patrimonialización van a estar directamente relacionados con la vocación industrial de este bosque. En concreto deben relacionarse directamente con la producción, es decir, el valor patrimonial de este bosque está directamente vinculado con su valor 
económico ya sea en un bosque de particulares, donde el beneficio será privado como en un Monte de Utilidad Pública donde el beneficio estará supeditado a su propiedad pública. En el caso de los paisajes forestales puramente productivos o de plantación, la simbología y esencia del bosque y el paisaje forestal inunda el resto de los paisajes. Se puede encontrar simbología, actividades o reflejos del bosque trascendiendo el propio espacio arbolado.

Los vectores de patrimonialización que va a arrojar el paisaje propio del bosque de producción intensiva están asociados directamente a la explotación, así vamos a encontrar pequeñas parcelas que reflejan los turnos de corta, moderna maquinaria forestal salpicando el bosque y continuos elementos fuera del propio espacio forestal que van a recordar la vinculación tan estrecha entre la sociedad y el espacio forestal silvícola. Una de las características que sin duda identifican a este paisaje es la falta de cuidados culturales asociados a unas prácticas tradicionales que nunca existieron lo que en ocasiones genera un paisaje "sucio" en lo cercano (Guerra, 2012). Son paisajes forestales que pueden ser reprochados por algunos atendiendo a sus características estéticas o biológicas alejadas, en ocasiones, de los estereotipos actuales pero que para las poblaciones locales suponen un elemento fundamental. Son paisajes que tienen un claro valor económico, se podría decir que es la razón de ser de este tipo de paisaje.

\subsubsection{Bosque o arbolado de acompañamiento agropecuario} (valores agrarios/pastoriles)

Estos paisajes suelen ser de masas frondosas poco densas o aisladas que están asociadas a espacios agrarios tradicionales, suponen un complemento para la actividad agrícola y suelen aparecer vinculados a las tierras de cultivo. Se trata del bosque campesino por excelencia siendo la perfecta manifestación de la intervención humana sobre lo forestal. Por norma general esta realidad forestal ha perdido su valor de uso y se encuentra asociado a ese proceso de abandono de las prácticas 
tradicionales que un día caracterizaron el mundo agrario pero que hoy están en desuso principalmente por la aparición de sustitutos de los productos que estos bosques ofrecían como leña y carbón, madera para mobiliario o construcción, ramón para el ganado, etc.

El paisaje del monte bajo se relaciona con lo agrícola, pero sería más correcto relacionarlo con lo agrosilvopastoril ya que en muchas ocasiones este paisaje está directamente vinculado con la forma de obtención de productos del árbol y el ganado. De este modo la relación patrimonial estará inevitablemente ligada con los usos tradicionales asociados a las practicas agropecuarias por lo que los vectores de patrimonialización que servirá para fijar la mirada de este paisaje serán círculos de antiguas carboneras, chozos, abrevaderos, corrales, rediles, etc.

\subsection{5. Árboles singulares (valores monumentales)}

En este caso, no se trata de espacios forestales propiamente dichos, sino de elementos aislados que destacan por su monumentalidad, son los árboles singulares. El carácter patrimonial de estos elementos viene determinado por sus características físicas individuales, suelen ser ejemplares perfectamente formados o que destaquen por su belleza. En este caso los valores biológicos quedan a un lado para destacar la estética por encima de todo. Suponen un elemento vivo que es tratado como un elemento monumental.

Los ejemplares que forman esta realidad forestal suelen ser antiguas "atalayas" forestales, especímenes que quedaron aislados de una masa anterior y que hoy perduran destacando sobre manera sobre su contexto paisajístico, pueden ser árboles asociados a creencias, ritos o valores metafísicos que se perpetúan gracias a ello, etc. En definitiva, son árboles que por un motivo u otro destacan en el paisaje y son un vector patrimonial en sí mismo. Pese a esto es importante destacar que en algunas ocasiones los encontramos asociados a diferentes artefactos o construcciones de singular valor como pueden ser castillos, ermitas, cementerios, etc. Estos ejemplares suelen generar un vínculo identitario muy fuerte sobre la 
población local que en muchas ocasiones es el motivo de su conservación asociado a la nostalgia de otro momento, donde se le reconoce a ese determinado espécimen como símbolo de un tiempo pasado (Corvol, 2010).

En cuanto a su valor de uso, puede decirse que actualmente se encuentran en su mejor momento, ya sean ejemplares derivados de la dinámica natural como ejemplares que han llegado hasta hoy derivados de las prácticas tradicionales los árboles monumentales están siendo catalogados, protegidos y valorados bajo el nuevo paradigma de la clorofilia (Roger y Maderuelo, 2007; Le Goff, 2008; Nogué, 2009; Guerra, 2012). 


\begin{tabular}{|c|c|c|}
\hline Paisaje & Tipo & Vectores patrimoniales \\
\hline \multirow[t]{3}{*}{ Bosque "refugio" } & $\begin{array}{l}\text { Relacionados con el medio } \\
\text { natural }\end{array}$ & $\begin{array}{l}\text { Grandes árboles } \\
\text { Grandes mamíferos } \\
\text { Diversidad biológica }\end{array}$ \\
\hline & $\begin{array}{l}\text { Derivados de la } \\
\text { ordenación/aprovechamiento }\end{array}$ & Intervenciones/podas \\
\hline & $\begin{array}{l}\text { Resultados de la cultura } \\
\text { material }\end{array}$ & Antiguas carboneras \\
\hline \multirow[t]{3}{*}{ Bosque productivo } & $\begin{array}{l}\text { Relacionados con el medio } \\
\text { natural }\end{array}$ & $\begin{array}{l}\text { Ejemplares } \\
\text { monumentales }\end{array}$ \\
\hline & $\begin{array}{l}\text { Derivados de la } \\
\text { ordenación / aprovechamiento }\end{array}$ & $\begin{array}{l}\text { Cuarteles } \\
\text { Calles/cortafuegos }\end{array}$ \\
\hline & $\begin{array}{l}\text { Resultados de la cultura } \\
\text { material }\end{array}$ & $\begin{array}{l}\text { Aperos } \\
\text { Resineras/chimeneas } \\
\text { Pegueras } \\
\text { Potes } \\
\text { Barricas metálicas }\end{array}$ \\
\hline \multirow[t]{3}{*}{$\begin{array}{l}\text { Silvicultura } \\
\text { intensiva }\end{array}$} & $\begin{array}{l}\text { Relacionados con el medio } \\
\text { natural }\end{array}$ & \\
\hline & $\begin{array}{l}\text { Derivados de la } \\
\text { ordenación / aprovechamiento }\end{array}$ & $\begin{array}{l}\text { Parcelas de turno } \\
\text { Beneficios económicos } \\
\text { directos } \\
\text { Puestos de trabajo } \\
\text { directos/indirectos } \\
\text { Incremento } \\
\text { presupuestario de las } \\
\text { administraciones } \\
\text { locales } \\
\text { lconografía }\end{array}$ \\
\hline & $\begin{array}{l}\text { Resultados de la cultura } \\
\text { material }\end{array}$ & $\begin{array}{l}\text { Maquinaria industrial } \\
\text { Fábricas }\end{array}$ \\
\hline \multirow{3}{*}{$\begin{array}{l}\text { Bosque de } \\
\text { acompañamiento } \\
\text { agropecuario }\end{array}$} & $\begin{array}{l}\text { Relacionados con el medio } \\
\text { natural }\end{array}$ & $\begin{array}{l}\text { Ejemplares modificados } \\
\text { para aprovechamiento }\end{array}$ \\
\hline & $\begin{array}{l}\text { Derivados de la } \\
\text { ordenación/aprovechamiento }\end{array}$ & Acequias y canales \\
\hline & $\begin{array}{l}\text { Resultados de la cultura } \\
\text { material }\end{array}$ & $\begin{array}{l}\text { Círculos de carboneras } \\
\text { Chozos } \\
\text { Abrevaderos } \\
\text { Corrales } \\
\text { Rediles }\end{array}$ \\
\hline \multirow[t]{3}{*}{ Árboles singulares } & $\begin{array}{l}\text { Relacionados con el medio } \\
\text { natural }\end{array}$ & Ejemplares singulares \\
\hline & $\begin{array}{l}\text { Derivados de la } \\
\text { ordenación/aprovechamiento }\end{array}$ & \\
\hline & $\begin{array}{l}\text { Resultados de la cultura } \\
\text { material }\end{array}$ & $\begin{array}{l}\text { Construcciones } \\
\text { monumentales } \\
\text { Cementerios } \\
\text { Ermitas }\end{array}$ \\
\hline
\end{tabular}




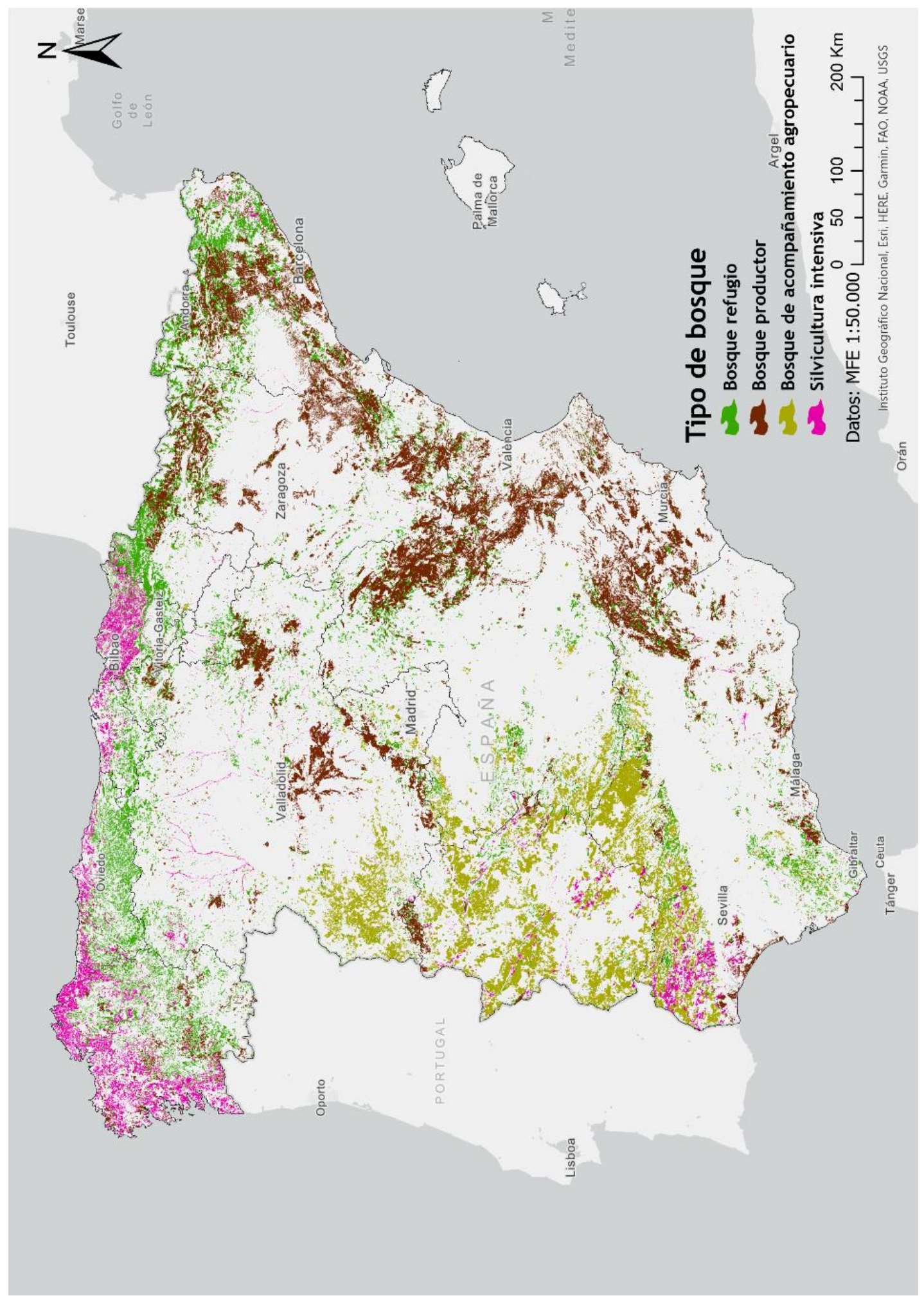

Figura 25. Distribución de los tipos de bosque según esta clasificación en la España peninsular. Elaboración propia a partir de Mapa Forestal de España 1:50.000. 


\section{Capítulo 4. El paisaje forestal como servicio ecosistémico}


El paisaje forestal, creado mediante ese método dialéctico entre el medio físico y la acción humana se erige como un refugio de valores que no solo pertenecen a la comunidad inmediatamente responsable de él, sino que trasciende la proximidad física para ser un patrimonio de la sociedad en su conjunto. Para ello, a partir de los años 70 y directamente relacionado con la creciente preocupación medioambiental, surgió una corriente que pretendía describir, delimitar y contabilizar estos valores para lo que se promovió el nombre de "servicios ecosistémicos".

Según la FAO (Organización de las Naciones Unidas para la Alimentación y la Agricultura) los servicios ecosistémicos son la "multitud de beneficios que la naturaleza aporta a la sociedad" y en cierta medida se ha pretendido contabilizar estos beneficios incluso llegando a calcular el valor económico que suponen en el conjunto del planeta (125 billones USD para 2014) (FAO, s. f.). Pero el análisis de los servicios ecosistémicos y como el paisaje forestal puede ser enfocado como uno de ellos, requiere la explicación de su origen, desarrollo y actual paradigma, lo que a la postre servirá para desarrollar un método de valoración que en último término justificará la necesidad de salvaguarda de estos paisajes patrimoniales del bosque.

Desde los años 70 se ha producido un crecimiento exponencial de las publicaciones relacionadas con los servicios ecosistémicos (SSEE en adelante) (Fisher et al., 2009), hasta el momento actual que parece haberse encontrado un consenso a la hora de afrontar el estudio de estos, en buena medida gracias a la plataforma Intergovernmental science-policy Platform on Biodiversity and Ecosystem Services, en adelante IPBES encargada de generar un consenso científico-político en torno a los SSEE.

Las primeras aproximaciones a este concepto se deben a (Westman, 1977; Ehrlich y Ehrlich, 1982) que van a afrontar por primera vez la necesidad de contabilizar cuánto valen los servicios que aporta la naturaleza, entendiendo esta como los ecosistemas sometidos a las leyes naturales. De este modo se va a generar una corriente científica y de 
opinión que pretende defender la necesidad de mantener y cuidar el medio natural centrándose en los beneficios que este aporta a la sociedad. Pero pese a parecer un concepto simple se ha producido una continua reflexión del marco teórico y conceptual, especialmente durante los años 90 (Perrings et al., 1992; Daily et al., 1997; Daly, 1999) siendo un referente esencial la publicación (Costanza et al., 1997) donde se fijarán las bases para la monetización de los SSEE.

En los últimos años y pese a que sigue existiendo una abultada reflexión conceptual en torno a los SSEE (Haines-Young y Potschin, 2012; Nahlik et al., 2012; von Haaren et al., 2014) las Naciones Unidas han pretendido fijar un marco conceptual que permita un enfoque común y un sistema clasificatorio homogéneo mediante la puesta en marcha de la iniciativa “Evaluación de los Ecosistemas del Milenio" en el año 2000 concluyendo con la publicación de una documentación que sirva de referente (MEA, 2003). Este documento clasifica los SSEE en cuatro grupos: provisión, regulación, cultural y soporte (Tabla 7).

\begin{tabular}{|c|c|c|}
\hline Servicios de provisión & Servicios de regulación & Servicios culturales \\
\hline Productos obtenidos & Regulación de procesos & Beneficios inmateriales \\
\hline $\begin{array}{ll}\text { - } & \text { Comida } \\
\text {. } & \text { Leña } \\
\text {. } & \text { Fibras } \\
\text {. } & \text { Bioquímicos } \\
\text { Recursos genéticos }\end{array}$ & $\begin{array}{ll}\cdot & \text { Regulación climática } \\
\text { - } & \text { Regulación sanitaria } \\
\text {. } & \text { Regulación hídrica } \\
\text { - } & \text { Purificación hídrica } \\
& \text { polinización }\end{array}$ & $\begin{array}{ll}\cdot & \text { Espirituales y } \\
\text { religiosos } \\
\text { Recreación y } \\
\text { ecoturismo } \\
\text {. } & \text { Estética } \\
\text {. } & \text { Inspirador } \\
\text {. } & \text { Educativa } \\
\text {. } & \text { Identidad territorial } \\
\text { Patrimonio cultural }\end{array}$ \\
\hline
\end{tabular}

\section{Servicios de soporte}

Necesarios para el resto de los servicios

Formación de suelos

Ciclos nutrientes

Producción primaria

Tabla 7. Clasificación de los SSEE según "Ecosystems and human well-being: a framework for assessment” (MEA, 2003). Elaboración propia 
Pese a esta clasificación planteada por las Naciones Unidas y aun habiendo sido aceptada de forma generalizada, actualmente suelen tratarse los tres primeros tipos de SSEE entendiendo que contabilizar el cuarto grupo es redundar, lo que genera una duplicidad (Potschin y HainesYoung, 2011). De igual modo, esta clasificación se plantea tratarla como una cascada o sucesión donde unos elementos van a depender de otros de forma jerárquica, lo cual presenta un amplio consenso científico (de Groot et al., 2010; Haines-Young y Potschin, 2012; van Oudenhoven et al., 2012; Spangenberg et al., 2014; Böck et al., 2015; La Notte et al., 2017). Esta visión de cascada tradicional, inicialmente propuesta por (Haines-Young y Potschin, 2010) se basaba en la descomposición de las diferentes dimensiones de un servicio ecosistémico, así se disgregaría este en: su estructura, su función, el beneficio y por último el valor que tiene para la sociedad (Figura 26), esta cascada ha sido interpretada y reinterpretada para llegar a enfocar el análisis de los SSEE a través de una cascada multiflujo que se adapta mejor a la realidad del medio físico y su relación humana (Figura 27).

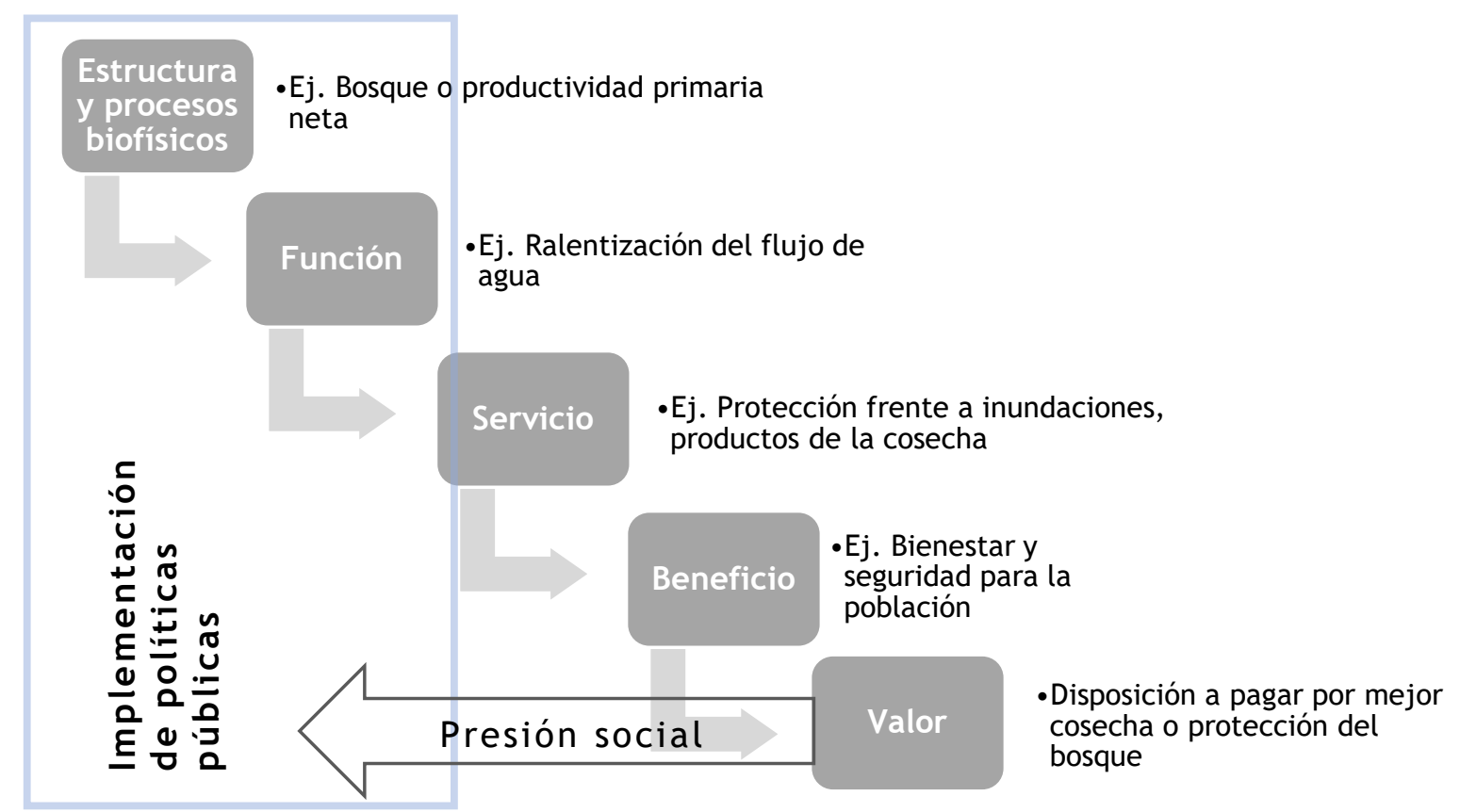

Figura 26. Elaboración propia a partir de la cascada de los SSEE de (Haines-Young y Potschin, 2010). 


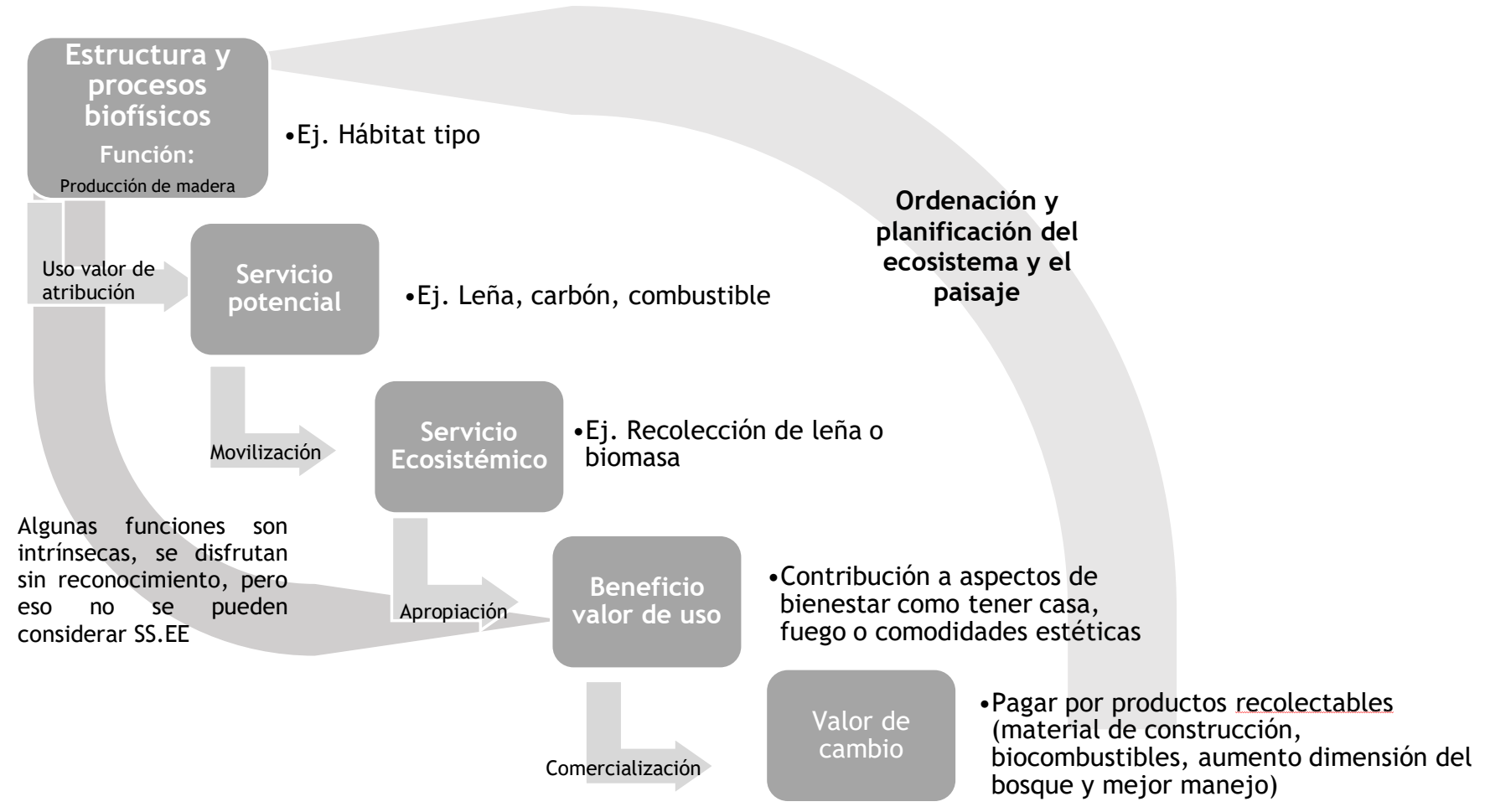

Figura 27. Elaboración propia a partir de la cascada de los SSEE de (Spangenberg et al., 2014). 
Pero esta forma de abordar los SSEE ha evolucionado en los últimos años hasta diferenciar los aportes de un servicio ecosistémico según sea material o inmaterial (Small et al., 2017; Díaz et al., 2018) siendo la tendencia generalizada y defendida por IPBES (Figura 28). Este cambio de enfoque que se ha producido en el estudio de los SSEE, donde inicialmente se planteaba que el objetivo de la cascada era contabilizar el valor de cambio del recurso natural hacia un enfoque basado en la contribución a la sociedad, se ha fundamentado en las corrientes críticas que durante años defendían el excesivo enfoque mercantilista de todos los aspectos del medio natural (Schröter et al., 2014, 2017; Spangenberg et al., 2014; Casalderrey, 2017; Small et al., 2017).

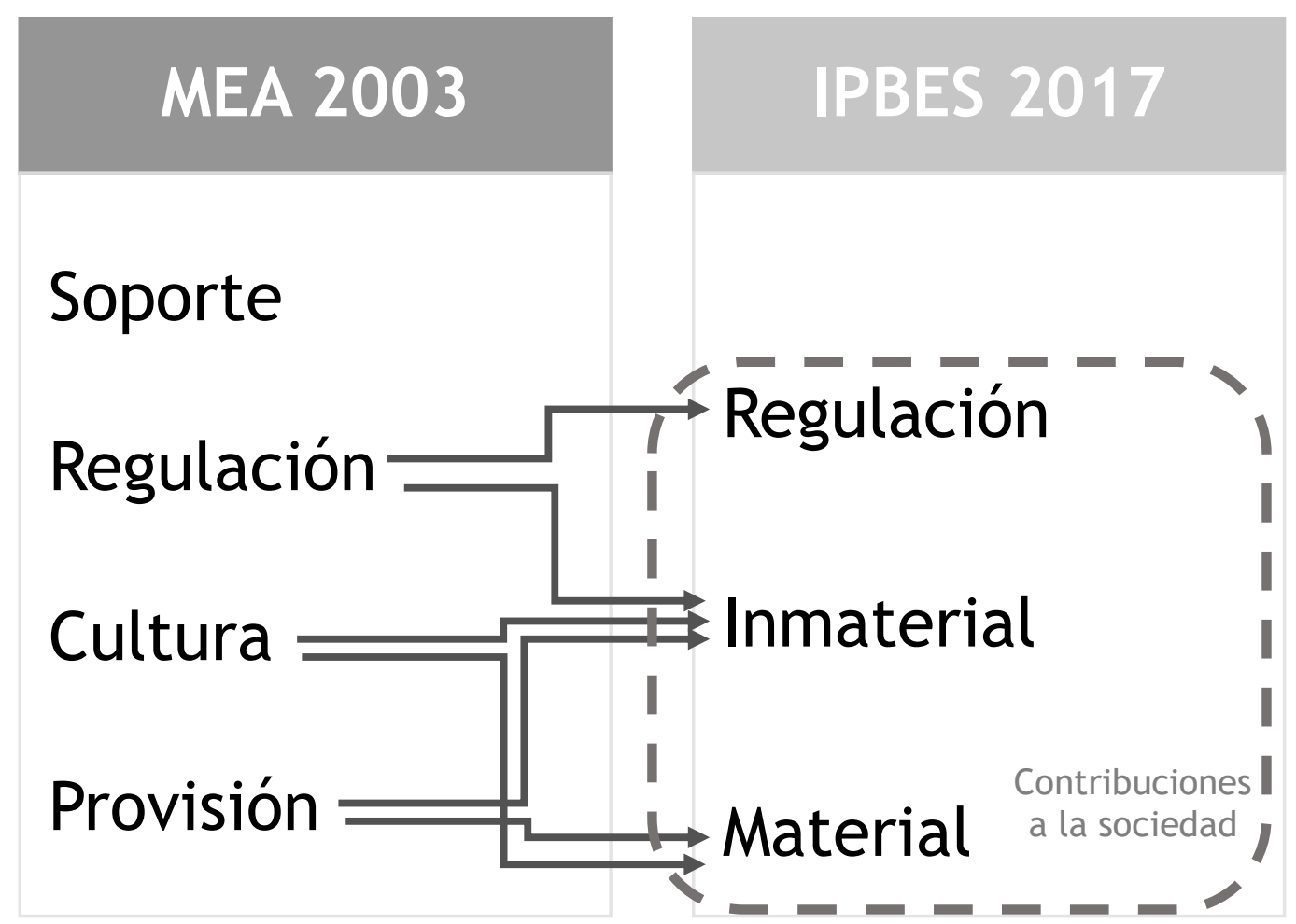

Figura 28. Cambio en la valoración de los SSEE desde el planteamiento de los Ecosistemas del Milenio hacia el actual paradigma de contribuciones naturales a la sociedad. Elaboración propia a partir de (Díaz et al., 2018).

En este sentido, IPBES ha propuesto la creación de 18 categorías que ha llamado NCP (Nature's Contributions to People) Contribuciones 
Naturales para la Sociedad, con el fin de homogeneizar el estudio internacional de los SSEE (Tabla 8). Esta clasificación puede servir como aproximación de futuras investigaciones en profundidad que permitieran la contabilización y cuantificación del valor ecosistémico en los distintos casos de estudio planteados. Como referencia para trazar un trabajo de este tipo se plantean trabajos contrastados que han llevado a cabo esta tarea de valoración de estudios de caso como (Getzner, 2010; Voces et al., 2010; Hein, 2011; Rodríguez et al., 2016). 


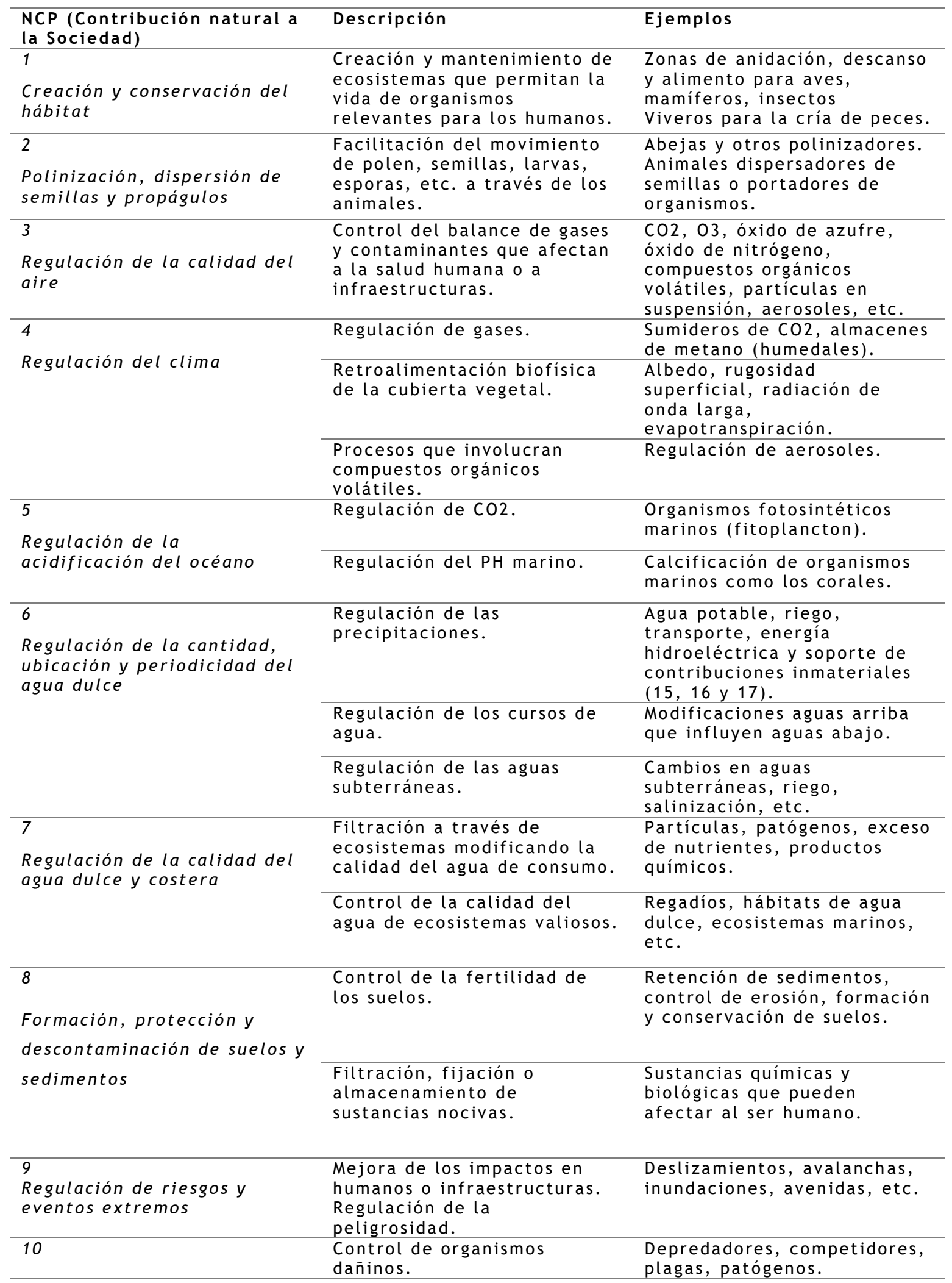




\begin{tabular}{|c|c|c|}
\hline \multirow[t]{3}{*}{$\begin{array}{l}\text { Regulación de organismos } \\
\text { perjudiciales para los } \\
\text { humanos }\end{array}$} & $\begin{array}{l}\text { Regulación por depredadores } \\
\text { o parásitos de } \\
\text { sobrepoblaciones. }\end{array}$ & Conejos, roedores, etc. \\
\hline & $\begin{array}{l}\text { Eliminación de cadáveres por } \\
\text { carroñeros. }\end{array}$ & $\begin{array}{l}\text { Ganado muerto, animales } \\
\text { silvestres muertos, etc. }\end{array}$ \\
\hline & $\begin{array}{l}\text { Control del daño biológico y } \\
\text { de degradación de } \\
\text { infraestructuras. }\end{array}$ & Palomas, murciélagos, etc. \\
\hline $\begin{array}{l}11 \\
\text { Energía }\end{array}$ & $\begin{array}{l}\text { Producción de energía de } \\
\text { forma directa. }\end{array}$ & $\begin{array}{l}\text { Biomasa, pellets, residuos } \\
\text { agrícolas y ganaderos, leña, } \\
\text { etc. }\end{array}$ \\
\hline \multirow{2}{*}{$\begin{array}{l}12 \\
\text { Comida y alimento para } \\
\text { animales }\end{array}$} & $\begin{array}{l}\text { Recolección de alimentos } \\
\text { humanos. }\end{array}$ & $\begin{array}{l}\text { Caza, pesca, recolección de } \\
\text { frutos, etc. }\end{array}$ \\
\hline & $\begin{array}{l}\text { Producción de alimento para } \\
\text { animales domésticos. }\end{array}$ & Producción forrajera. \\
\hline \multirow[t]{2}{*}{$\begin{array}{l}13 \\
\text { Materiales y asistencia }\end{array}$} & $\begin{array}{l}\text { Producción de materiales a } \\
\text { través de cultivos o } \\
\text { ecosistemas más o menos } \\
\text { naturales. }\end{array}$ & $\begin{array}{l}\text { Madera, fibras, resinas, } \\
\text { papel, perlas, conchas, etc. }\end{array}$ \\
\hline & $\begin{array}{l}\text { Uso de organismos vivos para } \\
\text { decoración y } \\
\text { aprovisionamiento. }\end{array}$ & $\begin{array}{l}\text { Plantas ornamentales, } \\
\text { mascotas, animales de } \\
\text { transporte o trabajo. }\end{array}$ \\
\hline \multirow[t]{2}{*}{$\begin{array}{l}14 \\
\text { Médico, bioquímico y } \\
\text { recursos genéticos }\end{array}$} & $\begin{array}{l}\text { Producción de materiales } \\
\text { utilizados con fines } \\
\text { medicinales derivados de } \\
\text { organismos vivos. }\end{array}$ & $\begin{array}{l}\text { Plantas medicinales como el } \\
\text { sauce... }\end{array}$ \\
\hline & $\begin{array}{l}\text { Producción genética de } \\
\text { animales o plantas con fines } \\
\text { biotecnológicos. }\end{array}$ & $\begin{array}{l}\text { Experimentación, híbridos, } \\
\text { clones, etc. }\end{array}$ \\
\hline $\begin{array}{l}15 \\
\text { Aprendizaje e inspiración }\end{array}$ & $\begin{array}{l}\text { Aprovisionamiento de } \\
\text { recursos para el desarrollo } \\
\text { de capacidades educativas, } \\
\text { científicas o de inspiración } \\
\text { artística y tecnológica. }\end{array}$ & $\begin{array}{l}\text { Recursos docentes y } \\
\text { científicos. } \\
\text { Ejemplos de adaptación como } \\
\text { referentes tecnológicos } \\
\text { (biomimetismo de } \\
\text { organismos). }\end{array}$ \\
\hline $\begin{array}{l}16 \\
\text { Experiencias físicas y } \\
\text { psicológicas }\end{array}$ & $\begin{array}{l}\text { Disposición de recursos para } \\
\text { desarrollar actividades de } \\
\text { beneficio espiritual y físico. }\end{array}$ & $\begin{array}{l}\text { Relajación, recreo, ocio, } \\
\text { turismo, disfrute estético, } \\
\text { mejora de la salud, etc. }\end{array}$ \\
\hline \multirow[t]{4}{*}{$\begin{array}{l}17 \\
\text { Soporte de la identidad }\end{array}$} & $\begin{array}{l}\text { Paisajes, hábitats u } \\
\text { organismos como base } \\
\text { religiosa o metafísica. }\end{array}$ & $\begin{array}{l}\text { Ermitas, celebraciones, } \\
\text { cultos, ritos... }\end{array}$ \\
\hline & $\begin{array}{l}\text { Aportes para formar el } \\
\text { sentimiento de pertenencia } \\
\text { territorial. }\end{array}$ & $\begin{array}{l}\text { Conexión con paisajes o } \\
\text { experiencias de base } \\
\text { territorial. }\end{array}$ \\
\hline & $\begin{array}{l}\text { Base para las narraciones o } \\
\text { mitos. }\end{array}$ & $\begin{array}{l}\text { Identificación de lugares, } \\
\text { paisajes, hábitats u } \\
\text { organismos. }\end{array}$ \\
\hline & $\begin{array}{l}\text { Satisfacción de reconocer un } \\
\text { paisaje propio como valioso }\end{array}$ & Orgullo de paisaje legado. \\
\hline $\begin{array}{l}18 \\
\text { Conservación de opciones } \\
\text { (sostenibilidad) }\end{array}$ & $\begin{array}{l}\text { Capacidad de mantener } \\
\text { ecosistemas, hábitats, } \\
\text { paisajes o especies para las } \\
\text { generaciones futuras. }\end{array}$ & $\begin{array}{l}\text { Diversidad biológica. } \\
\text { Capacidad de nuevos } \\
\text { descubrimientos. } \\
\text { Capacidad de adaptación y } \\
\text { evolución genética. }\end{array}$ \\
\hline
\end{tabular}

Traducción y elaboración propias. 


\section{Capítulo 5. El patrimonio}


En la cultura latina, hemos denominado patrimonio a aquellos elementos que nos venían dados por nuestros antecesores, siempre y cuando tuvieran algún tipo de valor significativo susceptible de ser protegido o conservado. Pero si atendemos a la definición exacta de patrimonio, en algunos de los idiomas de origen latino encontramos un hecho singular que no se repite en la cultura anglosajona donde lo denominan heritage (herencia). Este hecho singular es el valor económico, mientras que heritage o herencia suponen un elemento de transmisión generacional simplemente por el hecho de serlo, patrimonio connota un determinado valor económico.

(Diccionario de La Lengua Española n.d.)

Patrimonio: (Del lat. Patrimonîum)

1. m. Hacienda que alguien ha heredado de sus ascendientes.

2. m. Conjunto de los bienes y derechos propios adquiridos por cualquier título.

3. m. Patrimonialidad

4. m. Der. Conjunto de bienes pertenecientes a una persona natural o jurídica, o afectos a un fin, susceptibles de estimación económica.

Herencia: (Del lat. haerentia, n. pl. del part. act. de haerēre, estar adherido, infl. en su significado por heredar).

1. f. Derecho de heredar.

2. f. Conjunto de bienes, derechos y obligaciones que, al morir alguien, son transmisibles a sus herederos o a sus legatarios.

3. f. Rasgo o rasgos morales, científicos, ideológicos, etc., que, habiendo caracterizado a alguien, continúan advirtiéndose en sus descendientes o continuadores. 
4. f. Rasgos o circunstancias de índole cultural, social, económica, etc., que influyen en un momento histórico procedentes de otros momentos anteriores.

5. f. Biol. Conjunto de caracteres que los seres vivos reciben de sus progenitores.

Pero la clave que da sentido a este estudio patrimonial, no se centra en un elemento construido o en un recurso natural aislado, sino que pone el foco en los recursos territoriales. Este entendimiento de lo territorial como patrimonio es una preocupación reciente (Eversley, 1974) que tiene como objetivo vincular la conciencia social con elementos culturales que permitan mantener la memoria de un pasado común (Ross, 2004). Estos procesos de patrimonialización de lo territorial son especialmente relevantes en momentos de crisis social como la actual ya que, permiten una identificación de valores que reafirman como grupo y generan un sentimiento de seguridad frente a lo desconocido en los miembros de una comunidad.

El paisaje, entendido desde la geografía, es una construcción social, por lo que en sí mismo contiene valores y percepciones positivas, pero también pueden ser negativas, razón por la cual no deja de ser un paisaje. Mientras, desde otras disciplinas, como las artes, se ha entendido este como un elemento positivo en sí mismo, olvidando aquellos espacios que estéticamente no resultan atractivos de acuerdo con los cánones actuales de belleza.

Con el patrimonio, en muchas ocasiones ha ocurrido algo parecido, aquellos elementos transmitidos por nuestros ancestros que, atendiendo a los cánones de belleza contemporáneos, nos han resultado desagradables o simplemente no han sido relevantes para el canon de belleza establecido, han sido rechazados. Mientras, los elementos que, de acuerdo con el gusto del momento, han resultado aceptados socialmente, se les ha dotado de un valor económico utilizándose la definición de patrimonio como un adjetivo que los convertía en mercancía. "A veces la patrimonialización se utiliza 
como un mecanismo de mercadotecnia para vender lugares al turismo" (Capel, 2014)

En este sentido no se puede hablar del patrimonio como un elemento destinado a la explotación económica, cabría hablar, si fuese posible de herencia mejor que de patrimonio, como hace la cultura anglosajona que reserva la palabra patrimony (patrimonio) para aquellos elementos que tienen una valoración económica y, como se ha señalado anteriormente, utiliza la palabra heritage (herencia) para aquellos elementos que se valorarán por el hecho de haber sido recibidos de nuestros antepasados. “[...] solo aparentemente los términos de origen latino que designan al patrimonio se pueden equiparar con los anglosajones: heritage se refiere más a la herencia y al que hereda (heir), mientras que patrimonio significa más los bienes transmitidos en herencia por los ascendientes." (Gómez, 2012 ).

En nuestra sociedad se ha hecho habitual la utilización de los bienes patrimoniales, ya sean materiales o inmateriales, para su uso comercial, fundamentalmente se tratan de explotar desde el punto de vista turístico. Las administraciones pugnan por obtener declaraciones patrimoniales oficiales, cuanto más alta sea la instancia que declare un bien patrimonio, más satisfacción obtiene la administración de turno. ¿Pero esa declaración patrimonial es entendida como un valor en sí mismo o trata de utilizarse para obtener un beneficio económico? Generalmente la respuesta suele ser la segunda, las administraciones utilizan de forma política las figuras patrimoniales, apoyándose en ellas para lanzar estrategias turísticas o marcas singulares que garanticen una buena fuente de ingresos.

El patrimonio ha de ser entendido como una herencia, un aspecto singular que sea resultado de una construcción social que caracterice un paisaje y que debe ser entendida en sí misma, desmarcada de su valor mercantil. Se utilizará la palabra patrimonio para definir los elementos transmitidos por nuestros antepasados, no sin remarcar antes que no se están entendiendo como una mercancía sino como un elemento que hemos 
heredado y que puede tener otros valores que carezcan de un valor económico a simple vista. "Hoy muchos piensan en el patrimonio por su dimensión económica turística. Debería pensarse por sí mismo, como memoria para los residentes y para la Humanidad." (Capel, 2014). En este sentido, el patrimonio debe ser entendido no tanto como el elemento en sí como el valor que se le atribuye (Silva y Fernández, 2017), se trataría más bien de una creación humana en el sentido de construcción intelectual que el valor que pudiera tener el elemento por sí solo.

Otro de los objetivos que ha tenido el patrimonio o la patrimonialización de determinados elementos ha sido el enfoque identitario, de hecho, se puede fijar el origen de este concepto tal cual lo conocemos hoy como reafirmador de identidad actuando el patrimonio como una religión laica que sirve para sacralizar un discurso en torno a reliquias que sirvan como apoyo de una reafirmación cultural y su externalización (Prats, 2006).

Por otro lado, se puede orientar el patrimonio desde su vertiente administrativa, para Rocío Silva la noción de patrimonio tiene un origen eminentemente institucional y una plasmación normativa que se superpone y que es descifrado o interpretado por cada una de las disciplinas que se ocupan del patrimonio con diferentes resultados (Silva, 2016). De este modo el patrimonio ha seguido un camino de lo particular a lo general promovido desde la antropología (Prats, 1998) pasando de centrar el foco desde el objeto al sujeto, es decir centrando la visión patrimonial tanto en el productor como en el que observa y disfruta del elemento patrimonial y desplazando de algún modo el propio elemento u objeto patrimonial. Hasta la segunda mitad del siglo XX el patrimonio se restringía a los elementos de relevancia histórico-artística que ha ido evolucionando hasta llegar a las últimas décadas cuando se produce ese cambio de enfoque. En lo que respecta al patrimonio natural era reconocido por normativas destinadas a proteger aquellos elementos que destacan por su valor ecológico o biológico como podría ser la flora o la fauna y ha ido evolucionando mediante diferentes normativas hasta fusionarse con el patrimonio cultural a partir 
de la Convención sobre la protección del patrimonio mundial, cultural y natural de la UNESCO 1972.

Siguiendo esta evolución del concepto y lo que ello conlleva al trasladar el foco del objeto al sujeto, hoy el patrimonio es más un proceso que un momento, es decir, parece acertado defender que es la patrimonialización, ese discurso que va a cargar de valores a los objetos y que a la postre será definitivo para entender la necesidad de reconocimiento y protección. Los objetos en sí mismos podrán carecer de un valor histórico-artístico e incluso económico, pero serán un refugio de valores. Pero no se puede olvidar que el bien patrimonial se encuentra situado en un espacio determinado, en un territorio concreto que es donante y receptor al mismo tiempo de valores, se debe caminar hacia una gestión que evite el problema del autismo patrimonial (Silva y Fernández, 2017).

Frecuentemente estos valores, contrastes o excepcionalidades que van a caracterizar el patrimonio de una sociedad se aprecian mejor cuando son viajeros lo que se sienten atraídos por las peculiaridades territoriales de una comarca. Suele ser frecuente que el acercamiento diario a un elemento patrimonial se haga desde una visión utilitaria que desprecia los valores heredados centrándose únicamente en esa inmediatez de rentabilidad. En muchas ocasiones, la valoración patrimonial se descubre a partir de la percepción de los visitantes o los científicos que se aproximan desde una visión totalmente diferente a local y que puede hacer tomar conciencia y activar patrimonialmente elementos que pasarían desapercibidos (Capel, 2013).

En definitiva, es necesario plantear que, atendiendo a los nuevos paradigmas (Zoido, 2006; Mata, 2014; Fernández y Silva, 2015; Silva, 2016; Silva y Fernández, 2017), el patrimonio va a ser siempre inmaterial en tanto en cuanto se trata de un valor creado por el hombre a raíz del significado que se le ha dado a un elemento concreto, más que el elemento en sí mismo. 


\section{Capítulo 6. El paisaje patrimonial}


Entendiendo el paisaje como una construcción social resultado de las interacciones entre el medio natural como infraestructura donde se van a desarrollar las actividades humanas, que serán las que finalmente doten de carácter el resultado estético y entendiendo el patrimonio como las características singulares de un elemento transmitidas por nuestros antepasados y que serán reconocidas y en último término preservadas, se plantea el momento de conectar los dos elementos que van a fundamentar el trabajo. El paisaje y el patrimonio dan un giro para formar el concepto de paisaje patrimonial que como asegura Josefina Gómez Mendoza se trata de un concepto que se retroalimenta constantemente (Gómez, 2012). El patrimonio indudablemente implica esa necesidad de ser heredado y el paisaje no es ni más ni menos que la continua transformación del medio por parte de una sociedad a lo largo del tiempo. Podría incluso afirmarse en algún caso que paisaje patrimonial es una redundancia en sí mismo. Pese a esto, la idea de que los paisajes cambian y se adaptan más rápido hoy que ayer y que los actuales son menos ricos y más banales que los legados por la historia parece una idea extendida (Capel, 2013).

En este sentido se presenta la dificultad de discernir cuales serían los paisajes que van a merecer el calificativo de patrimonial, cuáles de todo el conjunto necesitan de un reconocimiento y protección especial. El planteamiento anterior que asegura una continua retroalimentación hace necesario plantear un criterio mínimo que otorgue a un paisaje el calificativo de patrimonial, de este modo solo aquellos paisajes que por sus altos valores merezcan ser objeto de reconocimiento y salvaguardia especial que garantice la conservación de esos valores obtendrán ese calificativo de patrimoniales (Mata et al., 2012).

Bajo la visión histórico-artística tradicional, la identificación de altos valores que mereciesen el reconocimiento y la protección especial que les otorgaría el calificativo de patrimonio era sencilla, se limitaba a su antigüedad, rareza o calidad artística entre otros criterios, pero todos ellos fácilmente cuantificables. Tras el cambio de concepto de patrimonio en ese viaje que ha puesto el foco más en el sujeto que en el objeto se hace 
más difícil cuantificar o identificar esos valores susceptibles de ser reconocidos y protegidos, pero con el apoyo de los criterios aportados por el Convenio Europeo del Paisaje o el Plan Nacional de Paisaje Cultural, así como diferentes aportaciones como las de (Mata, 2008b, 2014; Molinero y Tort, 2018). La transformación de un paisaje en paisaje patrimonial tendría como fundamento la existencia de procesos de apropiación social y asignación de valores más relacionados con la carga sentimental o identitaria que con aspectos objetivamente apreciables. Este proceso puede darse en un doble sentido, de “abajo arriba" cuando la sociedad local toma conciencia de su patrimonio y lo eleva para su reconocimiento y preservación o de “arriba abajo" siendo este último el más habitual cuando son las administraciones públicas las que, mediante diferentes normativas y aproximaciones científico-académicas, activan patrimonialmente un paisaje.

Cómo se escogen estos vectores y cómo se le da sentido al relato que los relaciona con el territorio es un problema metodológico que está aún sin resolver debido a la continua superposición de elementos y a la necesidad de un método ad hoc para cada territorio en función de su carga de elementos con valores patrimoniales. Existen algunas propuestas como el modelo que plantean Silva y Jover que acuden a un catálogo de elementos patrimoniales, concretamente al elaborado por Florencio Zoido para la Junta de Andalucía (Silva y Jover, 2017), pero esto parece más apropiado para territorios donde la carga monumental sea destacable, aspecto que no sucede con frecuencia en el paisaje forestal, al tratarse más de un paisaje cotidiano que de un paisaje excepcional en tanto que deriva de usos y prácticas destinados a la obtención de recursos, sería lo que Jackson llamaba el paisaje vernáculo (Jackson, 1986). De este modo y como se ha señalado, los vectores vendrán definidos en un método ad hoc, que puede servir para fijar un método para futuras investigaciones sobre el paisaje forestal (Tabla 6). 


\subsection{El proceso de patrimonialización}

El proceso de patrimonialización podría definirse como el reconocimiento de un valor social y la voluntad de conservarlo y transmitirlo (Dérioz, 2010), este valor responde a la interacción que el individuo tiene con su entorno por lo que se trata de un elemento dinámico que cambia constantemente. En ocasiones elementos que suponían un mero instrumento de trabajo o una construcción destinada a satisfacer las necesidades de la población han abandonado su significado para pasar a ser tratados como elementos patrimoniales. Así las representaciones que la sociedad vincula a un elemento van desapareciendo para pasar a tomar otros significados que van a ser el motor del proceso de patrimonialización. La aceptación de ese proceso basado en el relato será lo que convierte un paisaje en patrimonial (Silva y Fernández, 2015)

Este proceso se basa en un recorrido de ida y vuelta, siempre con el retorno, que le permita mantener esa doble dirección, siendo en ocasiones tan permeable que hace difícil identificar realmente su origen, más teniendo en cuenta que todos los paisajes de las zonas habitadas del planeta son patrimoniales, en tanto que forman parte de la identidad de sus habitantes (Silva y Fernández, 2017). El territorio es una manifestación de la sociedad que lo construye y proporciona una imagen de esa sociedad, a través del paisaje como resultado de las soluciones a determinados problemas de uso y ordenación de los recursos (Ortega, 1998). Esto va a desembocar en que todos los paisajes son patrimoniales si entendemos patrimonial como ese legado de nuestros antepasados. Pero el calificativo de paisajes patrimoniales va a estar restringido a aquellos que sean especialmente relevantes o singulares (Mata et al., 2012; Fernández y Silva, 2015; Silva y Jover, 2017).

De acuerdo con esto, unos paisajes se van a encontrar en un momento de este "relato" mientras que otros paisajes se encontrarán en otro instante, esta diferencia se va a fundamentar principalmente en la sociedad local y su capacidad de apropiación patrimonial. 


\subsection{Agentes de la patrimonialización}

Cualquier elemento que hoy reconocemos como patrimonial ha seguido ese proceso que deriva, fundamentalmente en figuras de salvaguarda y promoción turística. Pero es fundamental reconocer cuál ha sido el detonante, las chispa que enciende el proceso. Ese detonante está representado por una persona física, un conjunto de personas que se aglutinan en torno al bien patrimonial o una administración preocupada por la salvaguarda del patrimonio así vamos a distinguir dos procesos de patrimonialización en función del protagonista de esa detonación (Figura 29).

Uno de los condensadores fundamentales de patrimonialización, son los movimientos sociales y en especial las asociaciones que pretenden poner en valor los aspectos derivados de aquellos elementos con los que ellos se sienten identificados. Estos elementos que son utilizados por las sociedades como reafirmadores de su identidad hunden sus raíces en elementos diferenciadores y singularidades lo que permite poner el foco sobre aspectos que serán la base para ese proceso de patrimonialización. Por otro lado, se van a identificar procesos que surgen desde arriba, siendo la administración o los estudios científico-académicos los que va a activar patrimonialmente el paisaje que posteriormente será interiorizado por la población local. 

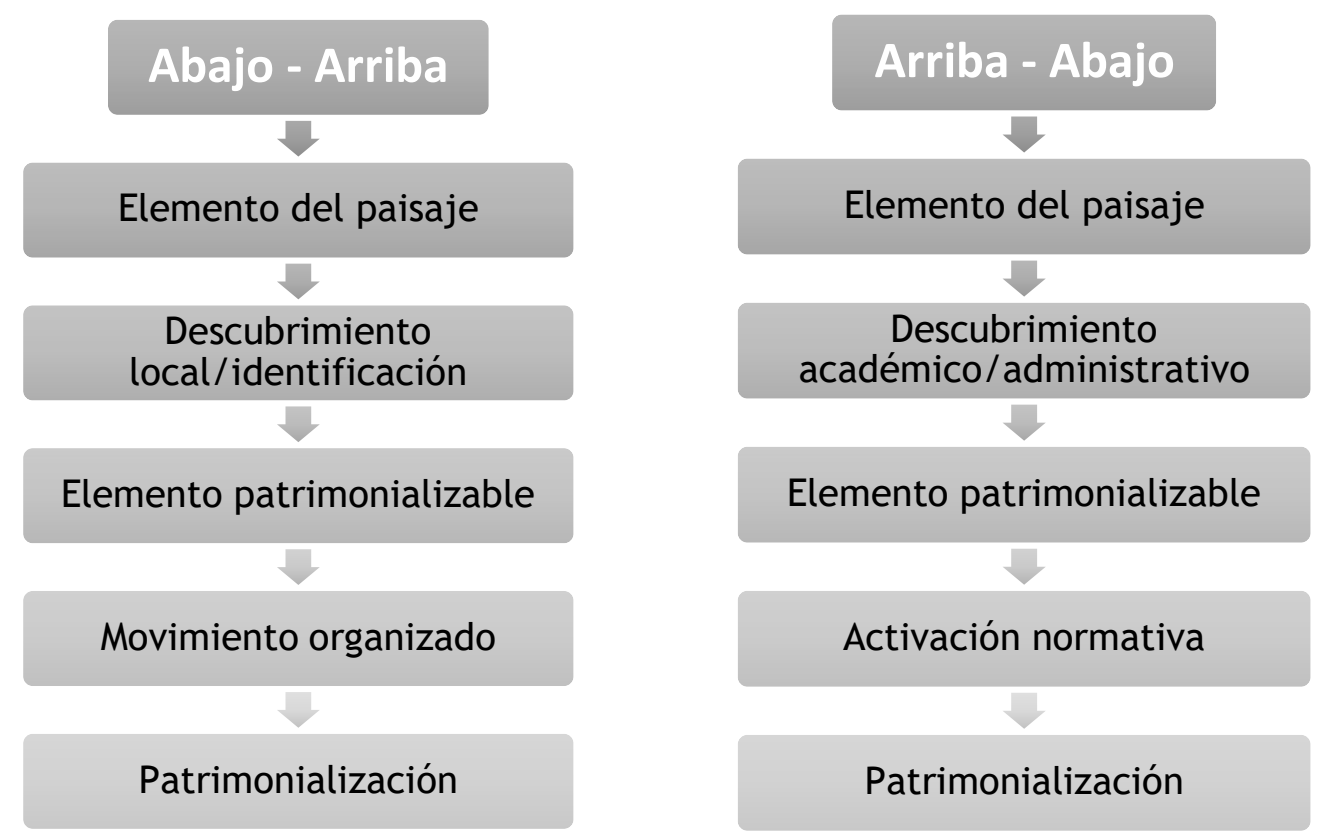

Figura 29. secuencia de patrimonialización en sus dos vertientes. Elaboración propia

El proceso "abajo arriba" se cimenta a través de un colectivo de la sociedad civil organizada que toma conciencia de su patrimonio e incita al académico a estudiarlo con el fin de que la administración acabe reconociendo la necesidad de preservarlo (Stobbelaar y Pedroli, 2011). Este proceso gravita en buena medida en el valor identitario del patrimonio que va a ser utilizado como reafirmación social. Mientras, el proceso de patrimonialización dirigido “arriba abajo” (Arnesen, 2011), ya sea por académicos o directamente desde el ámbito institucional va a descubrir nuevos aspectos desconocidos para la sociedad que convive con el nuevo patrimonio y derivará, en la mayoría de los casos, en una apreciación y valoración por parte de la población local.

Este proceso que es la patrimonialización y que, bajo el paradigma actual, va a ser el que va a conceder el adjetivo de patrimonial a un paisaje, se va a fundamentar en lo que José Naranjo llama "vectores" (Naranjo, 2010) y que la UNESCO va a definir como “atributos" (UNESCO World Heritage Committe, 2008), esos elementos que van a destacar por 
encima del conjunto. Para un proceso de “abajo arriba” el vector fundamental será la identidad, esos paisajes que definen un sentimiento colectivo de pertenencia van a ser los que merezcan el calificativo de patrimoniales. Mientras, en los procesos que tengan una dirección "arriba abajo" los vectores van a ser mucho más variados, la academia pondrá el foco en elementos de excepcional valor o singularidad científica; la administración pondrá el foco en elementos históricos, artísticos, simbólicos, naturales, etc. Los vectores van a ser esos condensadores de patrimonialización, esos elementos que van a convertir a ese paisaje en único. Algunos de estos vectores podrán ser una construcción histórica, un elemento artístico, un acontecimiento etnográfico que cargue de simbolismo el paisaje, un método tradicional, un sistema agrosilvopastoril excepcional, en definitiva, aquellos elementos que conviertan un paisaje en excepcional.

Pese a lo que pueda parecer, los vectores no van a ser aislados de su contenedor, ya que al estudiar el paisaje y calificarlo como patrimonial o no, los vectores van a interesar en la medida que generan un discurso que caracteriza el conjunto paisajístico. El paisaje patrimonial va a ser aquel paisaje que sepa generar un nuevo relato que englobe los elementos singulares y todo aquello que podría considerarse un paisaje cotidiano. En este caso los vectores que se identifiquen darán coherencia a conjuntos paisajísticos que comparten una personalidad forestal. En esta investigación se analizarán cinco casos de estudio que, atendiendo a diferentes valores catalizadores han sufrido este proceso patrimonializador, todos ellos con un importante poso cultural, se puede decir que todos comparten un origen donde las decisiones humanas han destacado por encima de los condicionantes o potencialidades naturales, se trata, pues de cinco espacios forestales de indudable génesis antrópica y de dominancia cultural.

Este proceso que va a seguir un paisaje para ser considerado como patrimonial se apoya en su estrecha vinculación cultural, esa génesis antrópica a la que antes se hacía referencia y que se verá reflejada en 
cuatro características que planteaba Josefina Gómez Mendoza en ese viaje “Del patrimonio paisaje a los paisajes patrimonio" (Figura 30) donde asegura que los paisajes que se convierten en patrimonio es porque son percibidos, vividos, caracterizados y transformados por las poblaciones (Gómez, 2012). En este sentido cabe preguntarse cuáles son las características que un paisaje debe tener para cumplir estos cuatro criterios por lo que se plantea una breve reflexión acerca de cada uno de estos aspectos.

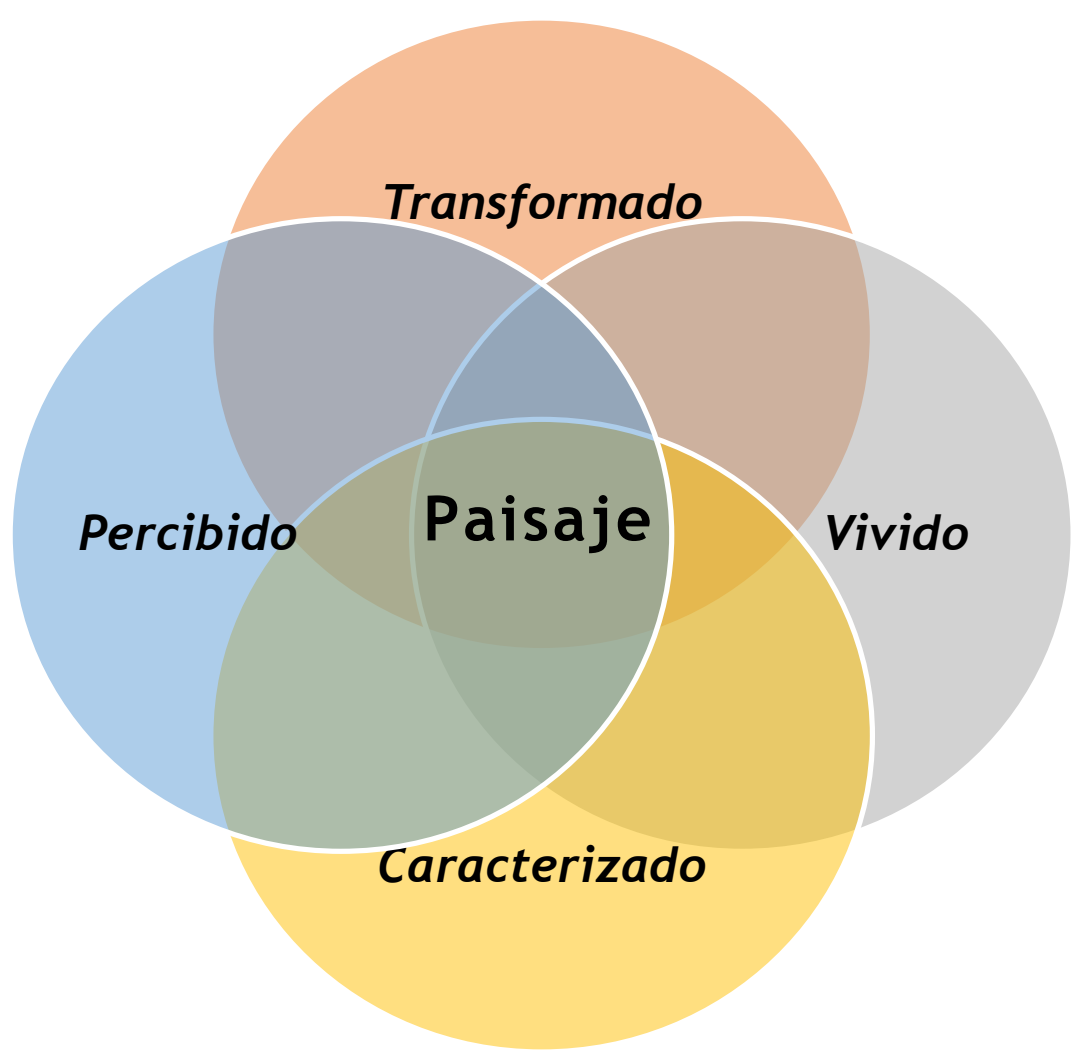

Figura 30. Características del paisaje patrimonial. Elaboración propia a partir de (Gómez, 2012).

\subsubsection{La percepción}

La percepción es la asimilación de algo a través de los sentidos siendo, en el paisaje, la vista el sentido de asimilación principal pero no se puede prescindir del resto de sentidos a la hora de asimilar el paisaje. Como se 
ha señalado anteriormente, el paisaje también tiene la dimensión relacionada con otros sentidos como el oído (existen paisajes que están directamente relacionados con determinados sonidos y que, mediante un proceso de condicionamiento escucharlos nos retrotraen a estos como puede ser el paisaje urbano del metro de las grandes ciudades repleto de músicos callejeros), el olfato (algunos paisajes van a tener uno de sus puntos fuertes en la percepción olfativa, siendo los olores una de las características fundamentales como podría serlo el olor a azahar en la primavera de Sevilla), incluso se podría incluir el gusto (la vinculación de ciertos productos agropecuarios con los atributos aportados por las condiciones del medio físico están en claro auge, no tenemos más que acudir a una cata vinícola para entender la relación que se establece entre las características edáficas o pluviométricas con los matices que destacan en un vino). Así la percepción del paisaje, que en un momento se estableció únicamente con su percepción visual está dando paso a una experiencia mucho más compleja donde los sentidos se mezclan para dar paso a paisajes mucho más complejos.

En este sentido el estudio de paisaje que se plantea incluye estos aspectos relacionados con las diferentes percepciones del sujeto por lo que se reflejan algunos de estos aspectos en cada uno de los casos de estudio.

\subsubsection{El paisaje vivido}

El carácter hereditario del paisaje lo convierte en un espacio vivido, la tradición es un aspecto fundamental para entender el paisaje forestal como un elemento propio con un valor patrimonial muy importante. Así entra en juego la subjetividad que cada uno de los individuos van a proyectar sobre el paisaje en relación con sus vivencias o experiencias. Estaríamos ante el espacio social que incorpora los actos sociales y sus representaciones (Lefebvre, 2013). Pero es necesario superar la trampa que ofrece analizar el espacio vivido, este no puede ser una mera colección de lugares destacables o reseñados por las poblaciones locales, es necesario acudir a las representaciones del espacio lo que debe aportar la 
información suficiente para entender los valores que la población local identifica en su paisaje pero que la visión foránea es incapaz de percibir. Como plantea Ortega en "Los horizontes de la geografía" el espacio vivido son "las representaciones espaciales vinculadas con nuestra experiencia práctica y mental, con el espacio como dimensión social [...]" (Ortega, 2000). Este pilar del paisaje patrimonial se fundamenta en el cambio de foco que se ha producido durante los últimos años en el tratamiento del paisaje del "objeto" al "sujeto" (Gómez y Mata, 2006) y que se ha explicado en su apartado correspondiente (ver 3.2).

La existencia de acontecimientos son uno de los condensadores de patrimonialización o vectores. La acumulación de experiencias va a determinar la empatía de la población hacia un determinado paisaje lo que va a ser fundamental para entender la apropiación paisajística por parte de la población local. En definitiva, el paisaje patrimonial va a tener una dimensión directamente relacionada con la experiencia y la representación, lo que supone el vínculo de relación más estrecho entre el "objeto" (el paisaje) y el "sujeto". Así, en los casos de estudio se analizarán algunos de estos aspectos como representaciones y acontecimientos que vinculen el paisaje con el colectivo.

\subsubsection{La caracterización}

Las sociedades caracterizan el espacio donde se viven mediante la relación cultural que se establece en función de los usos tradicionales, que en los últimos tiempos han dejado paso a usos de corte productivista en esa búsqueda de beneficios.

Ese carácter o marca (ver 3.1) que las sociedades locales dejan sobre los espacios forestales son clave para atribuir a estos un valor patrimonial. Las poblaciones que han sido a la postre generadoras de ese paisaje van a tener una mirada sobre él que puede distar mucho de la mirada que pudiera tener un experto, en muchas ocasiones los lugareños se sienten desapegados a su paisaje tradicional agrario en el sentido de observarlo como un vestigio improductivo o que puede frenar sus potencialidades 
productivas. No es extraño acudir a tratar con personas propias del mundo rural que reniegan de su paisaje tradicional por verlo como el paisaje del atraso técnico en el que crecieron, árboles que estorban, lindes improductivas, cercados inoportunos para la mecanización, edificios tradicionales dispuestos en contra de la lógica del "progreso", etc. son algo recurrente cuando la ciencia pretende aproximarse a la percepción del paisaje tradicional. Las poblaciones locales en ocasiones reniegan de esas “marcas" que dejaron los usos tradicionales.

Por otro lado, se acude al proceso contrario cuando lo patrimonial se encuentra imbricado con la economía local o aparece aislado o no "estorba" como suelen señalar los habitantes del medio rural. En muchas ocasiones lo patrimonial se ha convertido en un reclamo turístico que aporta un plus a la economía local por lo que la percepción de la población local es totalmente la opuesta. Se ve el paisaje patrimonial como una oportunidad. En muchas ocasiones esta activación turística se produce tras el descubrimiento y reconocimiento de expertos, científicos o simplemente población foránea y acaba con un proceso de reconocimiento patrimonial de activación "arriba-abajo" como ya se ha explicado en el apartado correspondiente.

En este sentido, en los casos de estudio va a ser imprescindible evaluar la percepción de la población local por medio de encuestas y entrevistas con expertos para poder tener una visión de este pilar que sostiene el valor patrimonial del paisaje. Se buscará en cada uno de los espacios estudiados elementos (marcas) que hayan sido conservados. Se buscarán, por tanto, evidencias concretas de esta caracterización, lo que a la postre actuará como los llamados "vectores".

\subsubsection{La transformación del espacio}

En geografía, es indudable entender cualquier paisaje como una transformación humana, el espacio forestal por tanto no puede ser de otra manera. De este modo, el paisaje forestal es transformado a lo largo del tiempo para adaptarlo mediante la cultura a lo que la sociedad conviene 
en entender que es mejor para su desarrollo, como Dice Juan Carlos Guerra, el bosque es el paisaje del hacha (Guerra, 2012). Por tanto, cada sociedad genera un paisaje propio en función de sus intereses. Hay que entender siempre el paisaje como un elemento en continua transformación pero que se ha transformado atendiendo a dos velocidades por un lado empujado por la cultura tradicional, asociada a la búsqueda de aprovechamientos, donde unos elementos se superponían sobre otros y en los últimos años empujado por la lógica del mercado exigente en rendimientos, cuyo motor de cambio es altamente destructor de permanencias (Harvey, 2007) (Figura 31).

Pero el paisaje patrimonial lo que exige es la búsqueda de esos elementos que responden a la práctica tradicional, a la transformación sostenible que no pretendía comprometer las necesidades futuras (aunque en algún momento lo hiciera, véase El Concejo de la Mesta). En cualquier caso, lo patrimonial girará en torno a esa transformación heredada de base cultural.

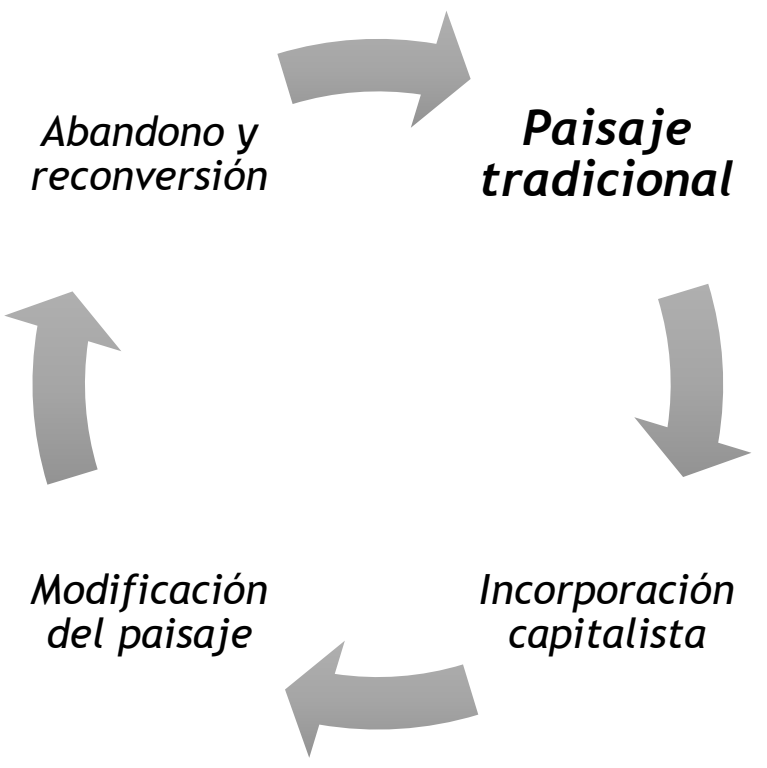

Figura 31. Proceso de evolución y formación del paisaje geográfico (asimilación en busca de beneficio económico que va a destruir las permanencias). Elaboración propia a partir de (Harvey, 2007). 
En este sentido los casos de estudio se ocuparán de reflejar cuáles han sido las prácticas de base cultural que han dado origen a estos paisajes y también pondrán de manifiesto el actual proceso de trasformación cuya base es la rentabilidad, por lo que será imprescindible identificar cuáles son los elementos que son o pueden ser borrados en ese proceso de reformación actual.

\subsection{Los indicadores de patrimonialización}

Con el objetivo de comparar el estado de patrimonialización de cada uno de los casos de estudio se realiza a continuación una disgregación de diferentes indicadores. Se considera que estos sirven como testigos del estado de patrimonialización permitiendo cuantificar o traducir a una escala numérica (mucho más amable para realizar comparaciones) la realidad patrimonial de cada caso de estudio.

El trabajo con indicadores presenta un problema de subjetividad que han discutido diferentes autores tratando de establecer qué son los indicadores y cómo se trabaja con ellos, véase (Heink y Kowarik, 2010). Así se establece que, lo que se llama indicador a partir de este momento es una información objetiva y cuantificable que se recopila mediante una serie de instrucciones específicas y bien conocidas (Hueso, 2017). De esta manera el indicador va a permitir las comparaciones en tanto que siempre ha sido recogido en unas condiciones similares.

Los indicadores que se proponen tienen como objetivo ser lo suficientemente representativos de la realidad patrimonial de los casos de estudio, ser sencillos de interpretar y partir de fuentes consistentes. Gracias a esto se puede, de un vistazo, comprender el momento y la realidad patrimonial del caso de estudio, así como establecer comparaciones, tanto espaciales como temporales, fiables de realidades muy diferentes y que a priori pareciesen imposibles de comparar. 
Se proponen, por tanto, un total de 7 indicadores que serán valorados sobre 10 puntos cada uno. De este modo se permitirá la comparación entre los diferentes procesos de patrimonialización propuestos en el trabajo.

\subsubsection{Indicador 1. Complejidad biológica:}

En el contexto actual de gusto por lo verde (Roger y Maderuelo, 2007; Le Goff, 2008; Nogué, 2009; Guerra, 2012), por lo “natural” entendido como la idealización de un espacio donde las leyes de la naturaleza hacen su trabajo alejadas de la supervisión humana, la importancia biológica de lo forestal determina su momento patrimonial. Por este motivo parece indudable incluir un indicador que haga referencia a esta riqueza biológica o madurez del ecosistema en que se encuentra adscrito el recurso forestal. Resulta evidente que las declaraciones patrimoniales y los reconocimientos administrativos se apoyan, sin lugar a duda, en estos valores ambientales, biológicos o aparentemente naturales para sus declaraciones. Pese a entender que existirían otros criterios de carácter cultural merecedores de, al menos, los mismos reconocimientos, resulta obligado dedicar un indicador a estos aspectos biológicos que determinan la actuación administrativa.

De esta manera se valorará este indicador sobre un máximo de 10 puntos fijando la valoración en los criterios que se detallan a continuación (Tabla 9):

- Existen evidencias bibliográficas fiables que demuestran una naturalidad y complejidad ecosistémica significativa ( 3 puntos).

- El ecosistema relacionado con la realidad forestal se encuentra recogido en la Directiva Hábitat 92/43/CEE como "Hábitat de Interés Comunitario" (4 puntos).

- De acuerdo con imagen de satélite y mediante trabajo de teledetección, se obtiene el índice NDVI para cada estación meteorológica. El espacio forestal objeto de estudio posee una salud superior al resto de cubiertas vegetales del municipio. ( 3 puntos). El índice NDVI es un testigo fiable que permite 
reconocer la salud de la vegetación, su vigorosidad y admite las comparaciones temporales (Pettorelli et al., 2005; Alcaraz et al., 2008; Kim et al., 2017), por lo que se realizará el tratamiento adecuado para analizar la vigorosidad y comparar estacional y espacialmente en cada caso de estudio (Castro, 2013). Una vez realizado el tratamiento se puede determinar la vigorosidad de la vegetación mediante la observación del resultado cromático, dónde los valores más cercanos a 1 (blanco) serán las cubiertas más vigorosas.

\begin{tabular}{|l|c|}
\hline Criterio & Puntuación \\
\hline Evidencias bibliográficas de naturalidad & 3 \\
\hline Hábitat de Interés Comunitario & 4 \\
\hline Salud vegetal NDVI & 3 \\
\hline
\end{tabular}

Tabla 9. Resumen criterio valoración indicador Complejidad Biológica.

\subsubsection{Indicador 2. Figuras de protección, reconocimiento y salvaguarda presentes en el territorio:}

Una de las claves que hacen entender el momento en que se encuentra un elemento patrimonial, en tanto que refleja la preocupación administrativa por el reconocimiento y preservación, son las figuras destinadas a ensalzar y conservar los valores presentes en los elementos patrimoniales. Debido a esto se plantea valorar con un máximo de 10 puntos aquel paisaje que se considere repleto de figuras de protección de esos valores.

La valoración de este indicador se hace atendiendo al cumplimiento de los siguientes criterios (Tabla 10) estableciéndose un máximo de 10 puntos si se supera este umbral:

- En el territorio se encuentra alguna figura de protección otorgada por UNESCO (4 puntos). 
- En el territorio se encuentra la figura de protección de Parque Nacional (3 puntos).

- En el territorio se encuentra la figura de Parque Natural o inferior categoría otorgada por la administración autonómica ( 2 puntos).

- En el territorio se encuentra al menos un LIC o ZEPA (1 punto).

- En el territorio aparecen otras figuras de protección (0,5 puntos)

\begin{tabular}{|l|c|}
\hline Criterio & Puntuación \\
\hline Figura otorgada por UNESCO & 4 \\
\hline Parque Nacional & 3 \\
\hline Parque Natural o inferior (CCAA) & 2 \\
\hline LIC o ZEPA & 1 \\
\hline Otras figuras & 0,5 \\
\hline
\end{tabular}

Tabla 10. Resumen criterio valoración indicador Figuras de protección.

\subsubsection{Indicador 3. Existencia de vectores patrimoniales:}

Los vectores patrimoniales son fundamentales ya que se trata de aquellos elementos que van a fijar el valor patrimonial al territorio (ver 3.5). Será la existencia de vectores relacionados con el paisaje forestal, su estado de conservación y su tratamiento patrimonial lo que determine el valor de este indicador. Estos vectores patrimoniales que se han identificado, localizado y clasificado para cada uno de los paisajes son la base para la valoración. De esta manera y de acuerdo con los tipos establecidos (Ver Tabla 6) se valorará a través de los siguientes criterios (Tabla 11):

- Se encuentran todos los vectores planteados para este paisaje forestal (4 puntos)

- Al menos la mitad de los vectores se encuentran tratados patrimonialmente ( 3 puntos) 
- Existen vectores de todos los tipos (3 puntos)

\begin{tabular}{|l|c|}
\hline Criterio & Puntuación \\
\hline Todos los vectores & 4 \\
\hline Al menos 50\% tratados patrimonialmente & 3 \\
\hline Identificados vectores de todos los tipos & 3 \\
\hline
\end{tabular}

Tabla 11. Resumen criterios valoración indicador Vectores Patrimoniales.

\subsubsection{Indicador 4. Identificación de la población/identidad:}

Una de las claves del patrimonio es el sentimiento de pertenencia que generan los valores intrínsecos del elemento patrimonial. Dicho de otra manera, el patrimonio en general y el patrimonio territorial en particular, cuyo ejemplo más destacado lo va a representar el paisaje, son un foco de identidad y pertenencia grupal (ver 6.2.2). Esto hace que se utilice esto como indicador valorándolo con un máximo de 10 puntos.

La evaluación de este indicador se hace atendiendo al cumplimiento de criterios, los cuales se basan en la recurrencia a símbolos, valores o iconografía del paisaje forestal en cuestión por parte de la población local, así como el uso de las administraciones locales de simbología relacionada con este paisaje. De acuerdo con todo esto se fijan los criterios de valoración que sirven para la valoración (Tabla 12):

- Se encuentra toponimia relacionada con el paisaje forestal en cuestión ( 2 puntos).

- Se encuentran referencias al paisaje forestal en la heráldica (2 puntos).

- La administración utiliza referencias iconográficas relacionadas con el paisaje forestal para identificar eventos o actividades ( 2 puntos).

- Los particulares utilizan referencias iconográficas relacionadas con el paisaje forestal para identificar sus negocios ( 2 puntos). 
- Asociaciones o colectivos de la sociedad civil utilizan referencias al paisaje forestal para identificarse ( 2 puntos).

\begin{tabular}{|l|c|}
\hline Criterio & Puntuación \\
\hline Toponimia & 2 \\
\hline Heráldica & 2 \\
\hline Iconografía administración & 2 \\
\hline Iconografía de particulares & 2 \\
\hline Referencias de asociaciones & 2 \\
\hline
\end{tabular}

Tabla 12. Resumen criterios valoración indicador Identificación de la población.

\subsubsection{Indicador 5. Museística:}

La exposición de elementos relacionados con la cultura material, con el objetivo de salvaguardar sus valores, es un buen indicador de la salud patrimonial de cualquier elemento. Esto se va a llevar a cabo a través de tres cauces fundamentales que, a la postre, serán los criterios de valoración de este indicador. Por un lado, los museos o centros de interpretación, por otro lado, las jornadas donde se exhiben elementos o técnicas tradicionales y, por último, la elaboración de mobiliario urbano destinado a representar esas prácticas directamente relacionadas con la cultura material. En este sentido se propone valorar la existencia de estos espacios sobre un máximo de 10 puntos. Para hacer cuantificable la realidad museística se proponen una serie de criterios con un valor de referencia (Tabla 13):

- Se encuentran centros de interpretación/museos oficiales relacionados con el paisaje forestal (4 puntos).

- Existen museos o similares, relacionados con el paisaje forestal en cuestión, gestionados por particulares (2 puntos).

- Existen jornadas o eventos de exaltación relacionadas con la cultura material derivada de la realidad forestal ( 2 puntos) 
- Existe mobiliario urbano dedicado a exhibir o exaltar la cultura material relacionada con el paisaje forestal ( 2 puntos)

\begin{tabular}{|l|c|}
\hline Criterio & Puntuación \\
\hline Centros de interpretación/museos oficiales & 4 \\
\hline Museos de particulares & 2 \\
\hline Jornadas de exaltación & 2 \\
\hline Mobiliario de exhibición o exaltación & 2 \\
\hline
\end{tabular}

Tabla 13. Resumen criterios valoración indicador Museística.

\subsubsection{Indicador 6. Incorporación turística (publicidad):}

La existencia y recurrencia de publicidad orientada a ensalzar las cualidades turísticas relacionadas con el paisaje forestal se plantea como uno de los indicadores que van a permitir la comparación entre los casos de estudio. Se valorará con un máximo de 10 puntos la existencia de reclamos turísticos relacionados con el paisaje forestal de acuerdo con los siguientes criterios (Tabla 14):

- Se encuentran reclamos turísticos por parte de administraciones supramunicipales (4 puntos).

- Se encuentran reclamos turísticos de primer orden por parte de la administración local ( 2 puntos).

- Se encuentran reclamos turísticos por parte de particulares (2 puntos).

- La reivindicación turística relacionada con el paisaje forestal, en cualquiera de los criterios anteriores, se encuentra, al menos, al mismo nivel publicitario que otras reivindicaciones patrimoniales (2 puntos). 


\begin{tabular}{|c|c|}
\hline Criterio & Puntuación \\
\hline Reivindicación turística supramunicipal & 4 \\
\hline Reivindicación turística municipal & 2 \\
\hline Reivindicación turística de particulares & 2 \\
\hline Reivindicación turística igual que otros elementos & 2 \\
\hline
\end{tabular}

Tabla 14. Resumen criterios valoración indicador Incorporación Turística.

\subsubsection{Indicador 7. Empleo relacionado:}

Los puestos de trabajo que relacionados con el uso del elemento que se está definiendo como patrimonial, en este caso el paisaje forestal de cada uno de los casos de estudio se entiende que son un indicador fundamental del momento en que se encuentra el proceso. La patrimonialización como se ha visto, se encuentra directamente relacionada con la sociedad local y solo será exitosa si afecta positivamente a esta, por lo que el trabajo que sea capaz de generar es clave para esa asimilación social. Así, la cantidad de trabajo relacionado se va a valorar con un máximo de 10 puntos atendiendo a los siguientes criterios de valoración (Tabla 15):

- Al menos el 0,5\% de los trabajadores ocupados se encuentran empleados en silvicultura o explotación forestal (3 puntos).

- Al menos el $5 \%$ de los trabajadores ocupados se encuentran empleados en sectores relacionados con la realidad forestal (Industria de la madera, Industria del papel y Fabricación de muebles) (3 puntos).

- Los trabajadores relacionados con la silvicultura se han incrementado desde 2007 (2 puntos).

- Los trabajadores relacionados con las actividades de la madera y el papel se han incrementado desde 2007 ( 2 puntos). 


\begin{tabular}{|l|c|}
\hline Criterio & Puntuación \\
\hline Al menos 0,5\% ocupados en Silvicultura & 3 \\
\hline Al menos 5\% de ocupados en sectores relacionados & 3 \\
\hline Trabajadores silvicultura se incrementan & 2 \\
\hline Trabajadores relacionados se incrementan & 2 \\
\hline
\end{tabular}

Tabla 15. Resumen criterios valoración indicador Empleo relacionado. 


\section{Estudio de casos y}

aplicación

práctica. Paisajes

forestales con

valor patrimonial. 


\section{Capítulo 7. Los bosques de gran valor biológico, el bosque refugio. El Hayedo De Valdeón.}


Se trata de un paisaje forestal donde la estructura de la masa que lo compone evoca una fuerte sensación de naturalidad al tratarse de un bosque que, por haber perdido buena parte de la presión en forma de aprovechamiento tradicional y al estar sometido a una figura de protección natural que limita sus usos, proyecta la imagen de un monte arbolado “natural” (Guerra et al., 2010).

\subsection{Distribución y localización del área de estudio}

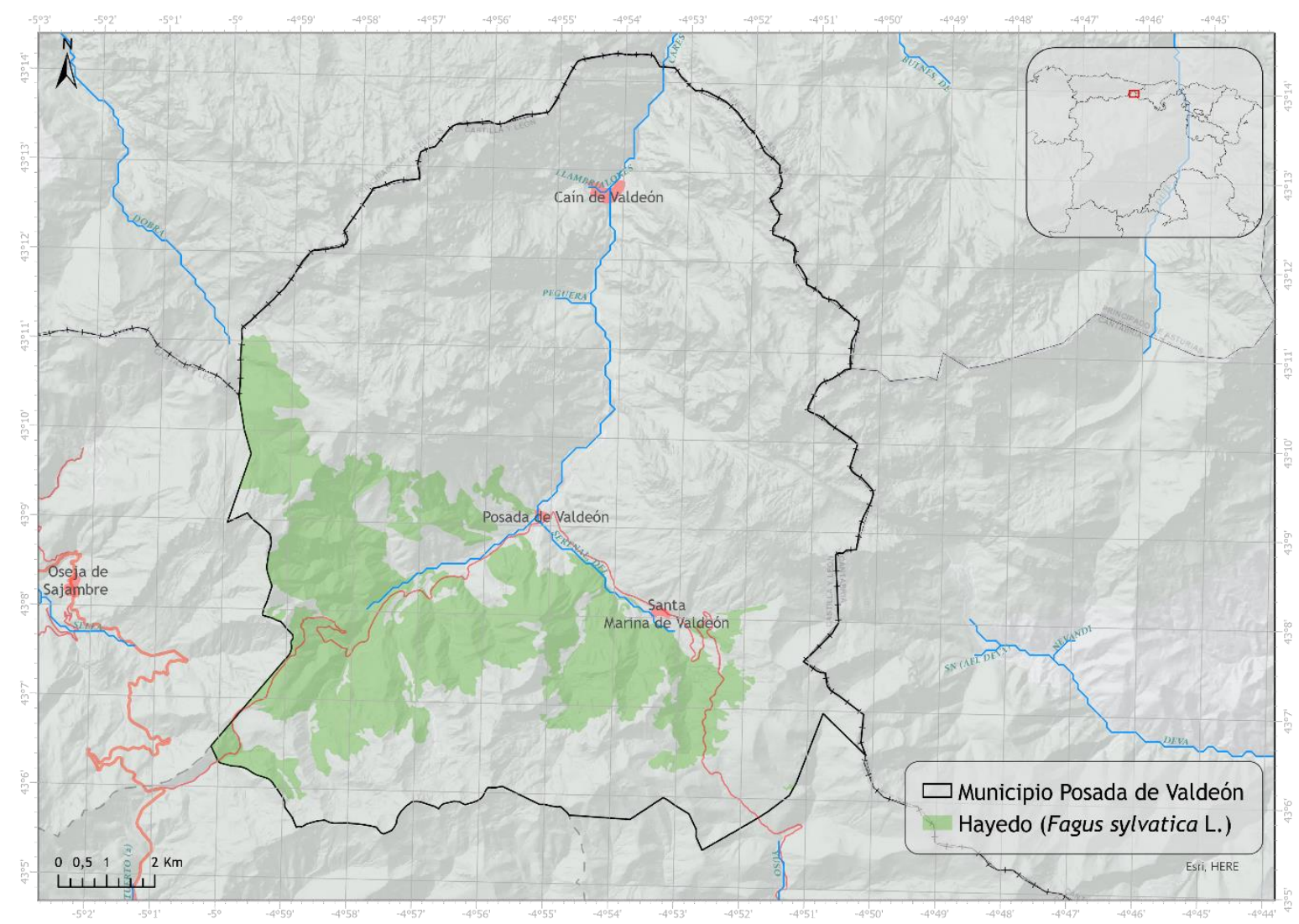

Figura 32. Mapa de localización del área de estudio, municipio Posada de Valdeón. Elaboración propia a partir de Mapa Forestal de España 1:50.000. 
El límite escogido para delimitar el ámbito de estudio es el municipio de Posada de Valdeón (Figura 32). Este se sitúa en el extremo norte de la provincia de León en su frontera con las Comunidades de Cantabria y el Principado de Asturias, en el centro de la Cordillera Cantábrica y se sitúa dentro de los límites del Parque Nacional de los Picos de Europa. Este límite del municipio de Posada de Valdeón responde a un valle en forma de "y griega", por donde circulan los ríos Cares (aprovechando el sinclinorio de Valdeón) y Del Serenal (circulando sobre la falla de la Liebana) que vierten al Cantábrico, rodeado por enérgicas montañas lo que le otorga cierto grado de aislamiento. Las altitudes oscilan entre los 350 y los 2648 m.s.n.m del valle del Cares en Caín y Torre Cerredo (el techo de los Picos de Europa) respectivamente (Figura 33 ).

El término municipal de Posada de Valdeón se encuentra situado en el contacto entre el extremo noroccidental de la Unidad Pisuerga-Carrión (Rodríguez y Heredia, 1988) dominado por los mantos del carbonífero superior compuestos por areniscas, lutitas, pequeñas capas de carbón y conglomerados silíceos (Heredia et al., 1990) y el extremo más meridional de la Unidad Picos de Europa formado por las Calizas de Montaña y las Calizas de Picos westfalienses (Julivert y Navarro, 1984). Esta dicotomía que introducen las características geológicas se ve reflejada de forma muy significativa, en la mitad sur del municipio encontramos valles amplios, pendientes moderadas y collados relativamente bajos; mientras que la mitad norte aparece reservada para la alta montaña con grandes desniveles, enérgicas pendientes, valles estrechos y elevadas cumbres. De este modo el río Cares que en su nacimiento circulaba por un valle amplio se encaja en las calizas formando una estrecha garganta (Figura 34). 
Estudio de casos y aplicación práctica. Paisajes forestales con valor patrimonial.

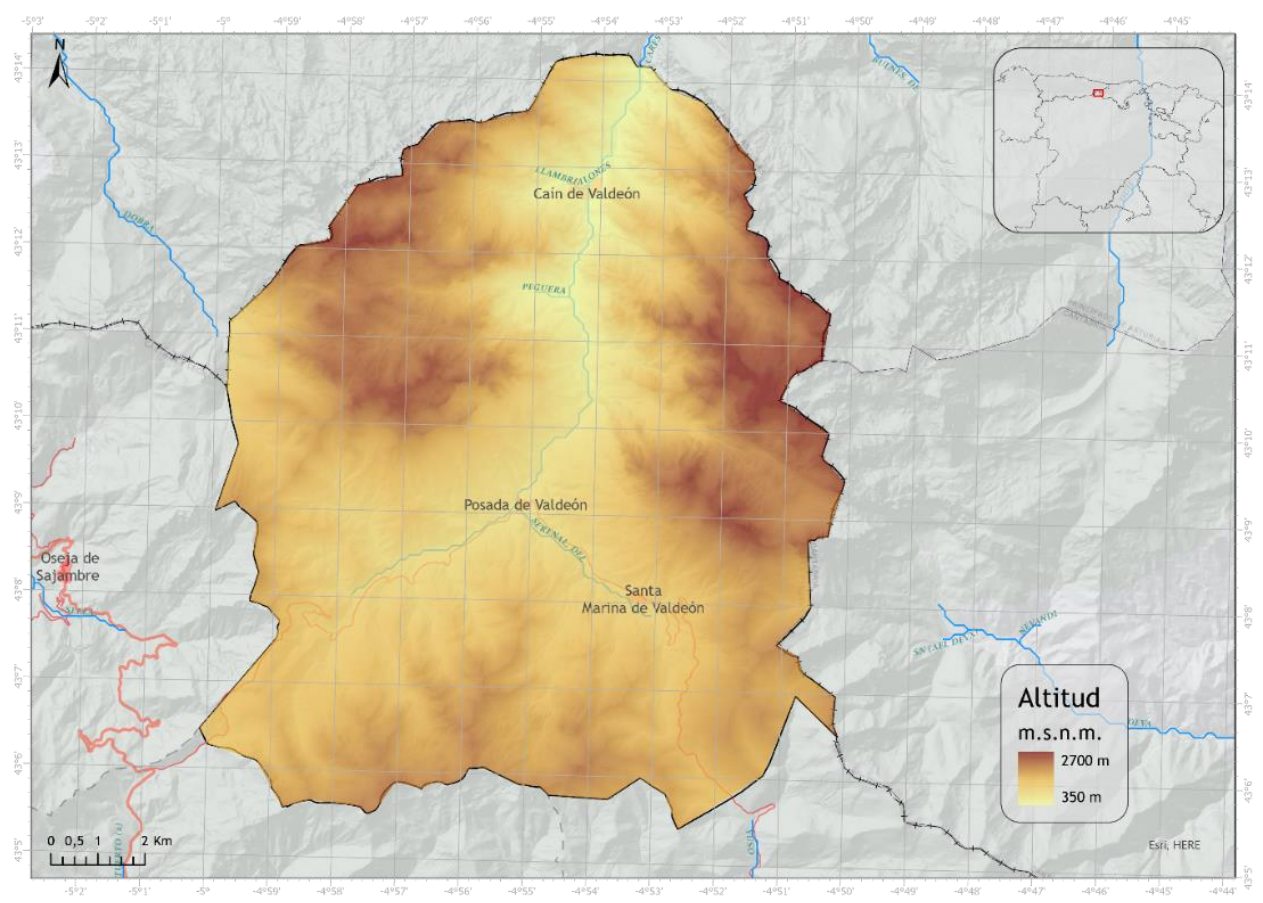

Figura 33. Mapa de altitud en el municipio de Posada de Valdeón. Elaboración propia a partir de Modelo Digital del Terreno Instituto Geográfico Nacional.

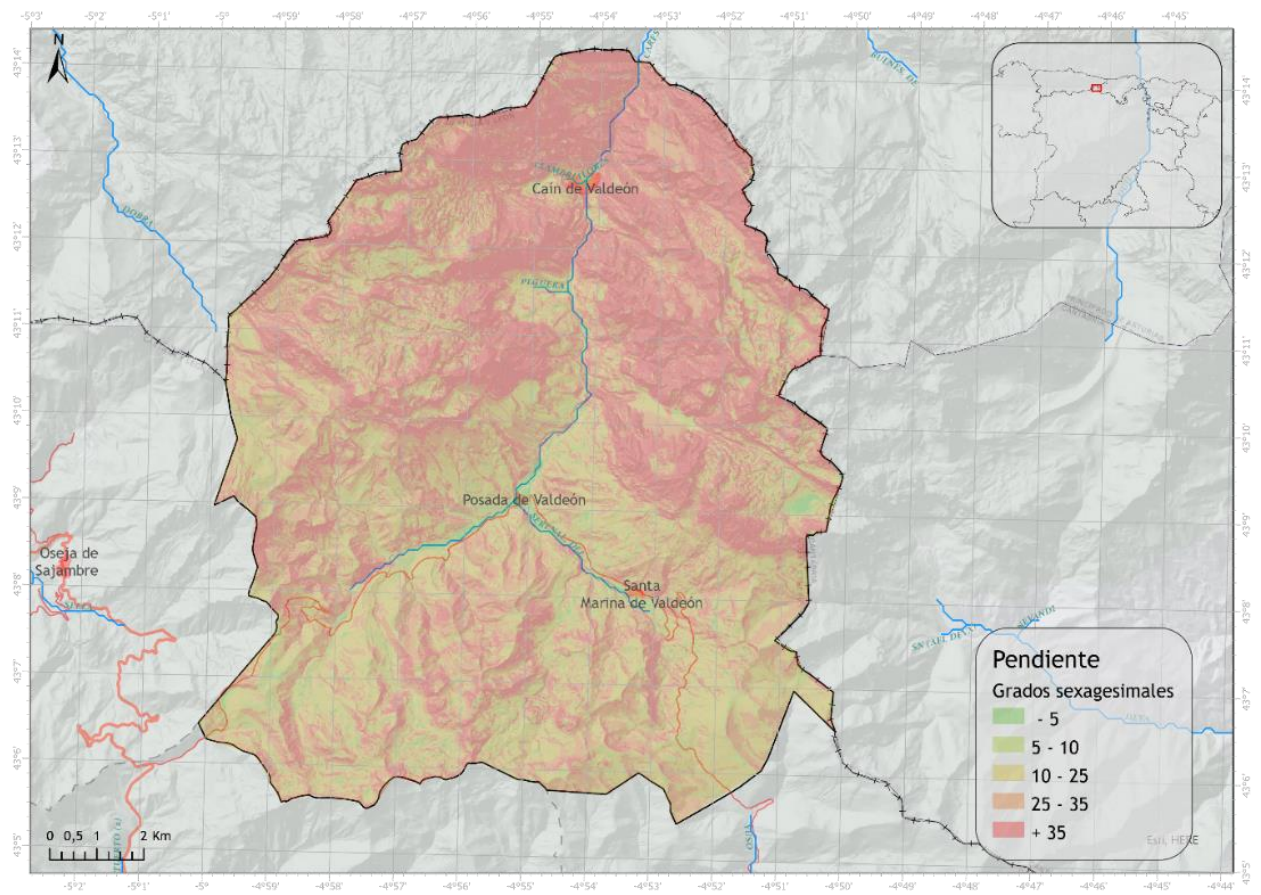

Figura 34. Mapa de pendientes en el municipio de Posada de Valdeón. Elaboración propia Modelo Digital del Terreno Instituto Geográfico Nacional. 
Derivado también de sus características geológicas y geomorfológicas aparece una diferencia destacable entre la mitad septentrional y meridional del municipio y que a la postre va a ser determinante para el paisaje forestal del que se ocupa este trabajo; se trata de la orientación de las laderas, mientras que los mantos de la Unidad Pisuerga-Carrión aparecen orientados al norte, el gran obstáculo que introduce la Unidad Picos de Europa determina la orientación sur de las laderas en el término municipal (Figura 35). Así, la orientación de umbría a la que responde la mitad sur del municipio determina una menor insolación y una mayor humedad, condicionantes ecológicos para albergar el gran bosque de hayas.

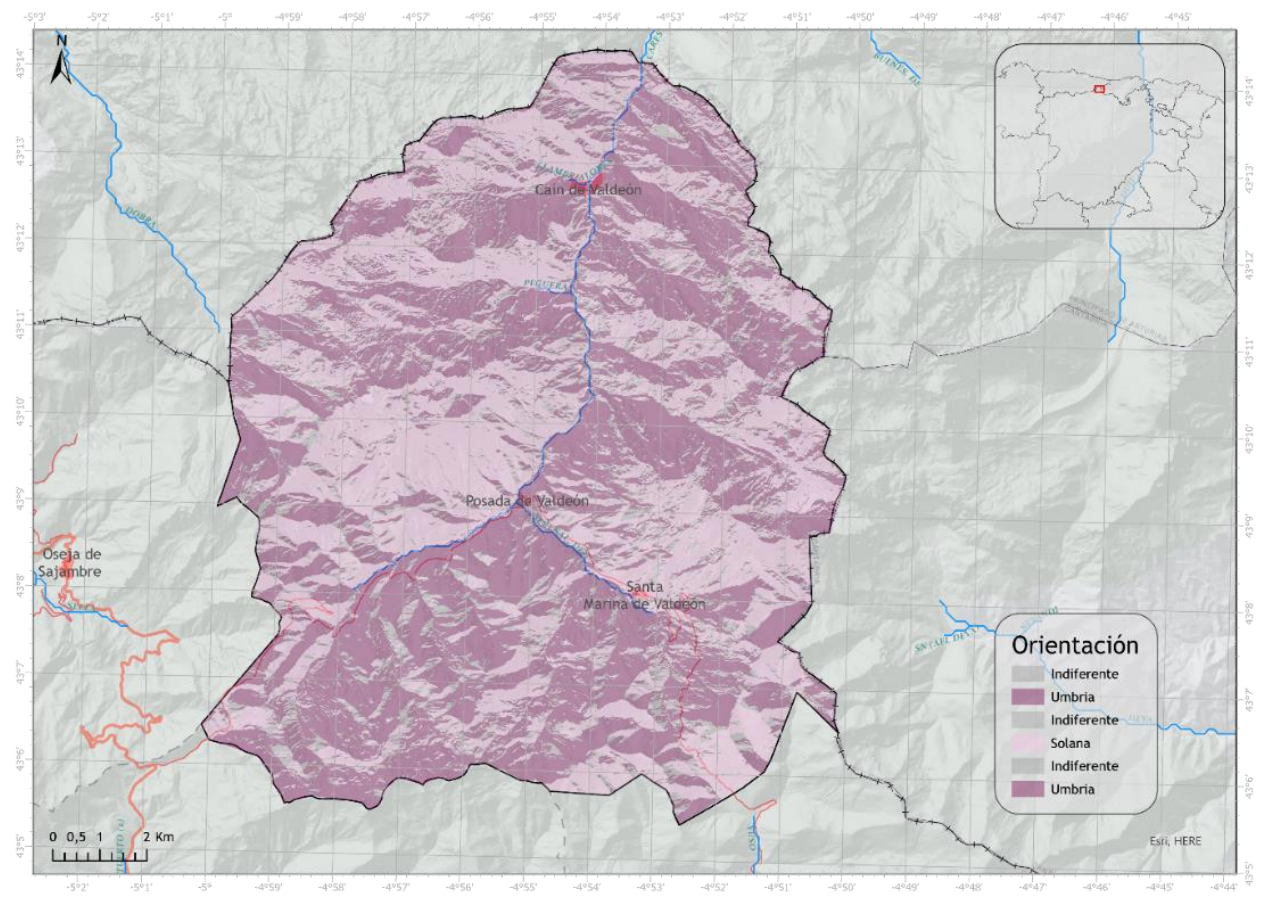

Figura 35. Mapa de orientaciones en el municipio de Posada de Valdeón. Elaboración propia Modelo Digital del Terreno Instituto Geográfico Nacional. 


\subsection{Caracterización del área de estudio}

Respondiendo al enclave que otorgan los sedimentos cuaternarios de relleno aluvial en el fondo del valle aparecen pequeños campos de siega fundamentalmente para la obtención de forraje, así como pequeñas huertas donde se cultivan hortalizas o maíz, este mosaico agrario aparece delimitado en muchas ocasiones por muretes, setos o cambios topográficos de origen antrópico para la creación de bancales. De este modo los usos agrícolas aparecen restringidos al fondo de los valles desapareciendo a medida que el Cares se encaja en la Unidad Picos de Europa. Por otro lado, en las partes bajas de las laderas, aparece un mosaico de pastizal y espacios colonizados por el matorral que en un tiempo respondían a pastizal de la ganadería extensiva propia de estas áreas de montaña. A medida que se asciende en las laderas vuelve a aparecer una dicotomía fundamentada en las diferencias geológicas y geomorfológicas; por un lado, dentro de la Unidad Picos de Europa aparecen grandes espacios donde domina la roca desnuda resultado de los impresionantes desniveles y la ausencia de suelo (Figura 36); por otro lado, en la Unidad Pisuerga-Carrión aparece un bosque de frondosas fundamentalmente de hayas (Fagus sylvatica) pero en laderas de solana aparece un bosque mixto de frondosas donde se intercalan diferentes especies del género Quercus. Para el piso subalpino y alpino (aproximadamente por encima de $\operatorname{los} 1500 \mathrm{~m}$ de altitud) se reservan pastizales de altura destinados en un momento a la cabaña ganadera de ovino de la Corona de Castilla, hoy en degradación siendo ocupados por matorral y el avance del bosque (Figura 37 ). 


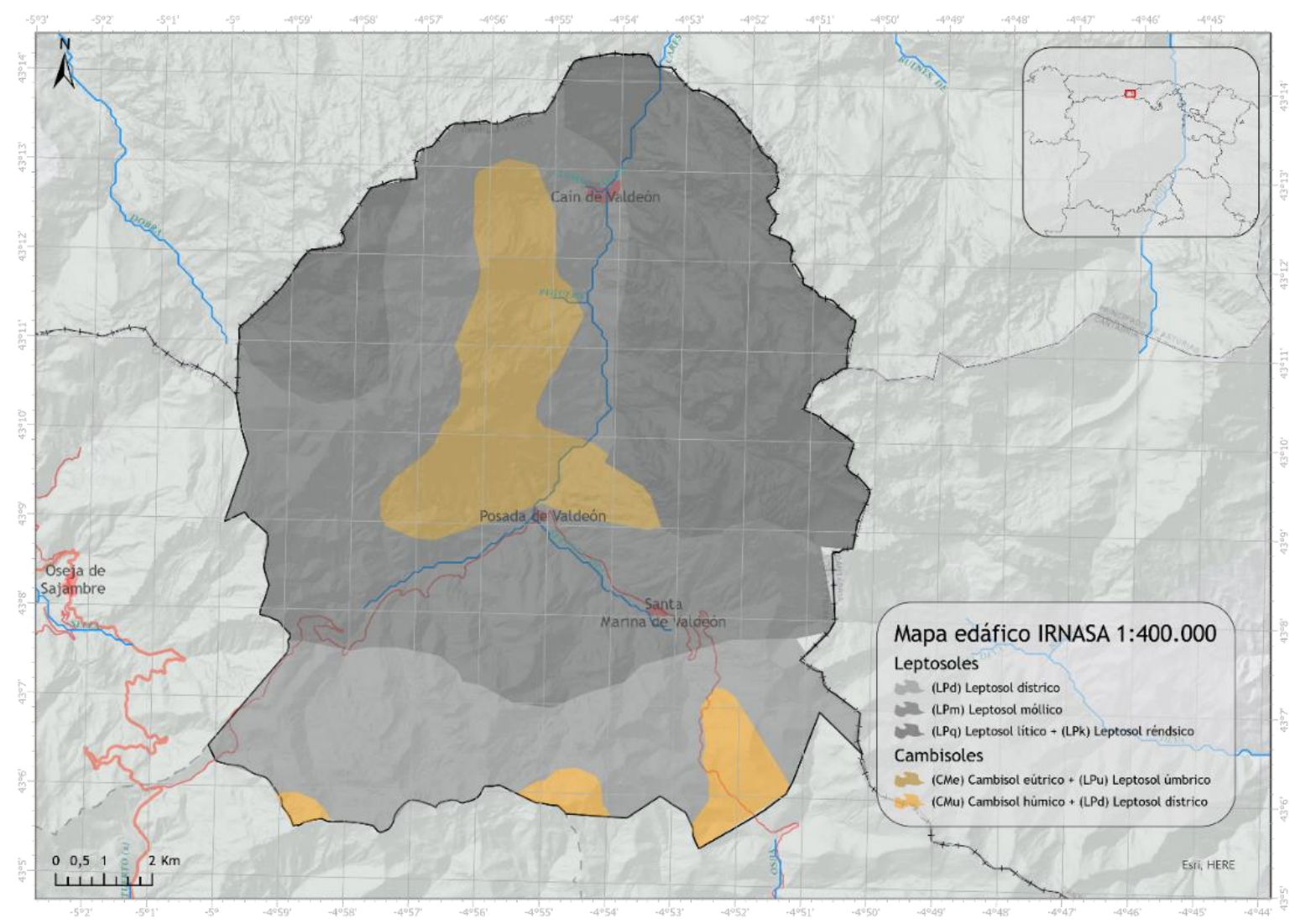

Figura 36. Mapa edáfico del municipio de Posada de Valdeón. Elaboración propia a partir de IRNASA 1:400.000. 


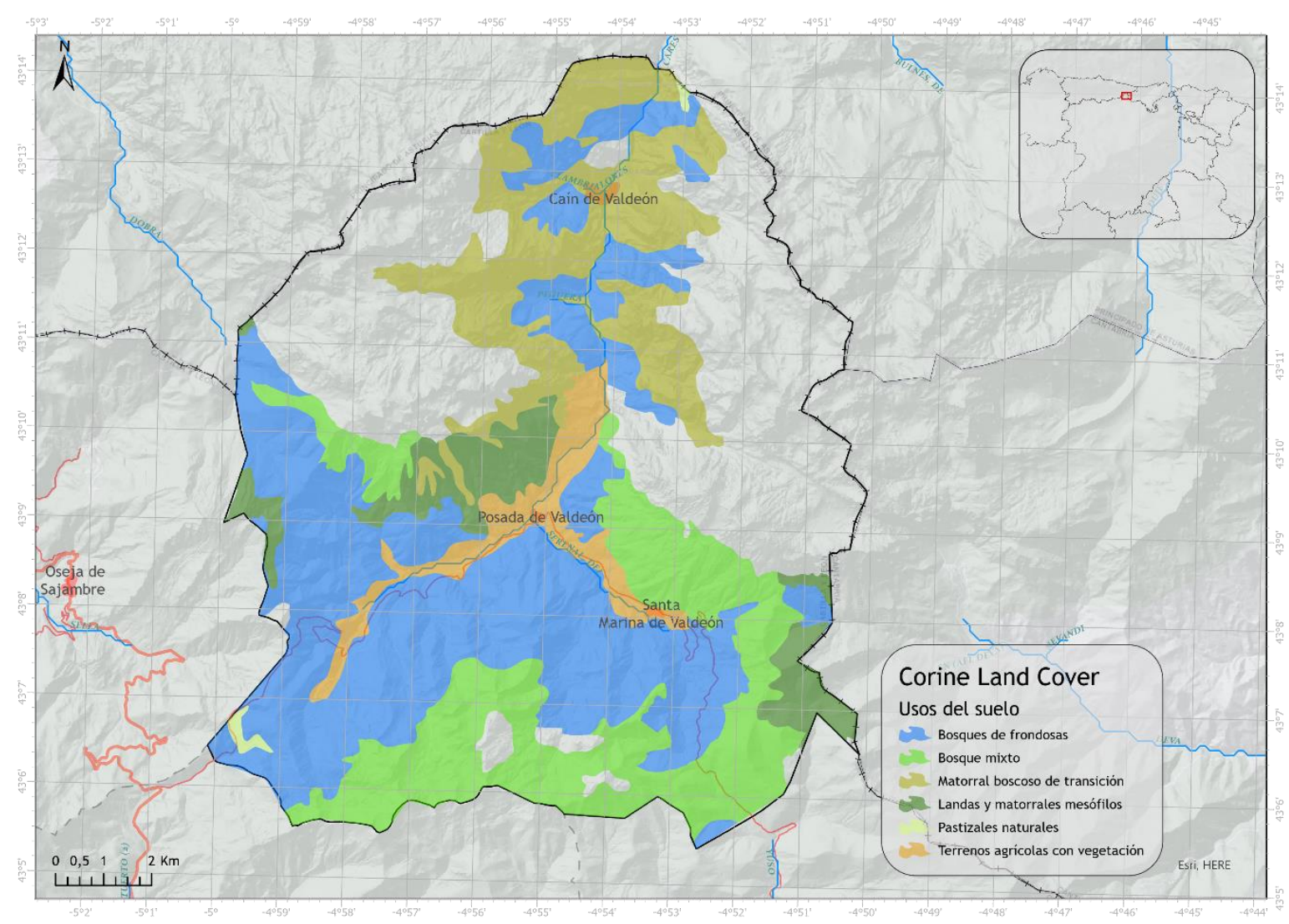

Figura 37. Usos del suelo en el municipio de Posada de Valdeón. A partir de Corine Land Cover, elaboración propia.

El valle de Valdeón posee cierto grado de aislamiento al encontrarse rodeado por todos sus flancos por cadenas montañosas, para acceder a él por su flanco sur se debe hacer o bien por el puerto de Panderruedas que da acceso a través del puerto del Pontón desde Riaño o bien a través del Puerto de Pandetrave desde Portilla de la Reina o bien por el norte a través de la famosa ruta del Cares que conecta por un acceso no transitable por vehículos Caín con el Puente de Poncebos donde se vuelve a tener acceso por carretera dentro del Principado de Asturias. Este aislamiento le ha permitido, en buena medida, permanecer estable y evitar ciertos procesos de transformación derivados de las lógicas de mercado y la incorporación a procesos productivos de gran impacto. Se aprecia el aislamiento del Valle, por ejemplo, en la inexistencia de una carretera que llegase hasta Posada 
de Valdeón hasta bien pasada la segunda mitad del siglo XX o la reciente construcción en 2016 de la carretera que conecta Santa Marina (acceso sureste) con Posada de Valdeón; así como la inexistencia de conexión por carretera o ferrocarril del Valle con Asturias. Este aislamiento al que se hace referencia, que es en buena medida una de las principales señas de identidad de este territorio, se refleja en su etimología (Valle de Eón) derivado del euskera donde Eón significaría “estar quieto” (Quiroga, 1962), siendo esta estaticidad una de las principales razones que explican las características naturales del municipio y concretamente el bosque "refugio" de hayas que albergan sus laderas de umbría.

\subsection{Origen del espacio forestal}

Cuando se hace referencia a las hayas (Fagus sylvatica) es necesario acudir a los estudios palinológicos para comprender que se trata de una especie reciente en la realidad forestal de la península y concretamente de la Cordillera Cantábrica. El haya llegó a la península ibérica, tras la retirada de los últimos hielos, a través de los Pirineos procedente del este de Europa hace unos 4000 años BP y se produjo una expansión hacia el oeste llegando a aparecer en diferentes diagramas polínicos de la Cordillera Cantábrica en torno a 3000 BP, frenándose su avance hacia el Oeste hace unos 1500 BP (López, 1978; Peñalba, 1994; Carrión et al., 2000) lo que indica que se trata de unas masas que tienen su desarrollo durante el calcolítico y su consolidación durante el óptimo climático romano.

El enclave que ocupa el hayedo de Valdeón reúne las condiciones ecológicas perfectas para el desarrollo de esta especie, por un lado su orientación norte le otorga las condiciones de humedad necesarias para soportar los momentos de aridez y la existencia de los dos paredones calcáreos que introducen los Picos de Europa convierten al enclave en un espacio especialmente sombrío teniendo el haya una ventaja competitiva sobre otras especies vegetales al poseer la capacidad para soportar ambientes con poca luz (Blanco et al., 2005). Respecto de sus requerimientos hídricos, el haya necesita en España condiciones 
pluviométricas superiores a los $900 \mathrm{~mm}$ para desarrollarse de forma desahogada (Oria y Díez, 2003). En cuanto al sustrato no parece muy exigente al encontrar hayedos en todo tipo de suelos (Ruiz, 2006; Oliet et al., 2014) aunque sí destaca por exigir suelos desarrollados. Otra de las singularidades del haya con respecto a otras especies vegetales es su preferencia por formar masas monoespecíficas (Blanco et al., 2005) mediante el desarrollo de un amplio dosel de copas que impide la entrada de luz en el interior de la masa.

Pero para comprender este espacio forestal es indispensable señalar su propiedad pública, siendo en Posada de Valdeón prácticamente todo su territorio -95,2\% (Rodríguez y Maya, 2008)- MUP (Monte de Utilidad Pública) incluidos en el Catálogo de Montes que permitió su excepción de la desamortización (Figura 38). Esta propiedad pública, gestionada desde tiempos inmemoriales por las Juntas de Vecinos del Real Concejo de Valdeón, del Real Concejo de Caín y del Real Concejo de Santa Marina de Valdeón permitió mantener el bosque de hayas ajeno a cualquier peligro deforestador al ser gestionado mediante la lógica comunal lo que favorece una identificación vecinal con el bosque obteniendo todos los vecinos recursos de éste. Así, la propiedad pública será indispensable para entender el carácter patrimonial del hayedo. 


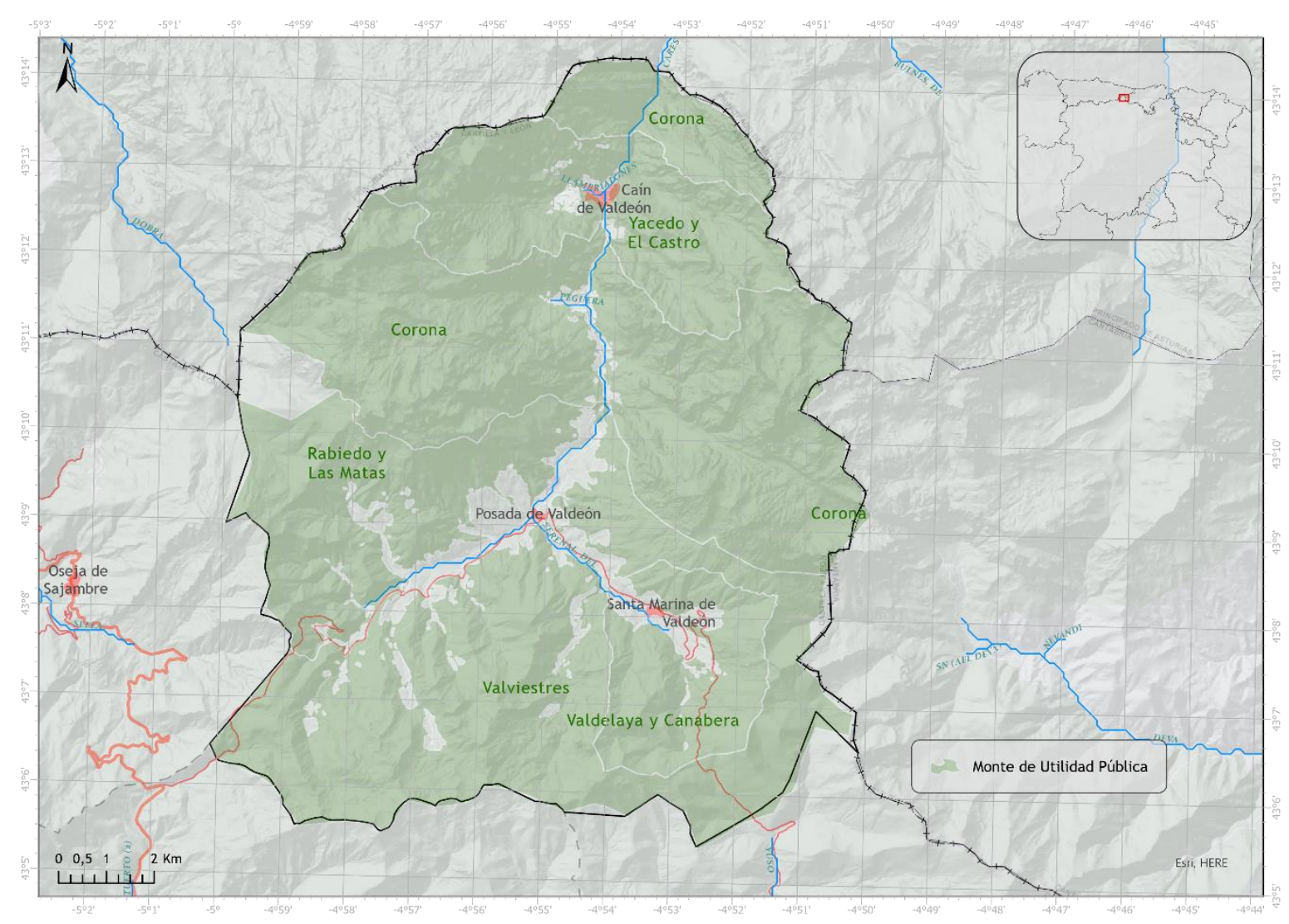

Figura 38. Montes de Utilidad Pública en el municipio de Posada de Valdeón. Elaboración propia a partir de MUP CyL

\subsection{El uso tradicional}

La existencia del espacio forestal del que se está tratando compuesto por una extensa masa fundamentalmente de hayas que se asientan en las laderas de umbría de la Cordillera Cantábrica responde a una convivencia secular entre el hombre y la vegetación relacionada con diferentes usos tradicionales vinculados con una economía de base rural. Es importante señalar que en los hayedos que se asientan en el conjunto de la Cordillera Cantábrica el uso maderero y silvopastoril ha predominado frente a la leña (Agúndez et al., 1995); sabiendo esto, los usos predominantes que se han dado a este hayedo han sido: 
Un refugio perfecto para albergar al ganado de tiro y la cría de cerdos usándolo como prado boyal, los animales no solo se alimentarían de los pastos que crecían acompañando a las hayas en ese microclima húmedo y fresco que supone el interior de un hayedo, sino que se aprovechaban las hojas en forma de alimento, así como los hayucos (el fruto del haya) muy ricos en aceites.

Otro de los aprovechamientos tradicionales y que dan sentido al bosque es el uso maderero ejecutado mediante huroneo de los mejores pies destinados a la elaboración de todo tipo de aperos de labranza, carros, madera para construcción, etc. este aprovechamiento maderero no solo estaría destinado al consumo interno del valle sino que parece que existía un importante intercambio comercial de los productos Valdeoneses en las ciudades de León, Valladolid y principalmente la Tierra de Campos, donde la escasez de árboles hacía muy apreciados los productos de madera de haya elaborados en Valdeón y Sajambre los cuales se intercambiarían por vino y trigo además de suponer un importante ingreso para la economía tradicional de montaña (de la Iglesia, 2006; Rodríguez y Maya, 2008). La elaboración de las famosas madreñas o almadreñas (calzado de madera en forma de zueco propio de diferentes territorios cantábricos) también está directamente relacionado con la madera del hayedo. Pese a esta predominancia maderera, no se puede olvidar la obtención de leña y carbón para combustible de uso cotidiano. De este modo el aprovisionamiento que facilitaba el bosque a los habitantes de Valdeón es fundamental para comprender su existencia.

La existencia del bosque de hayas en el valle de Valdeón está, en definitiva, directamente relacionado con los aprovechamientos tradicionales vinculados a una economía de montaña. Todo esto, junto con la existencia de abundantes pastos en las canales que dan acceso a las peñas y en los puertos que dan acceso a los valles, así como la propiedad pública del monte, hicieron que el gran hayedo se perpetuase en el tiempo ayudado siempre por la preferencia de las hayas por las laderas de umbría reservando este espacio forestal para la producción de maderas y carbones. 


\subsection{El abandono}

El hayedo del valle de Valdeón se ha mantenido en el tiempo pese a la presión ganadera y gracias al aporte que sus recursos tenían en la economía local. Como la mayor parte de los usos tradicionales vinculados a economías de montaña silvopastoriles, los aprovechamientos del hayedo se han abandonado prácticamente en su totalidad. El refugio y pasto que ofrecía para el ganado porcino y de labor ya no resulta necesario al haberse sustituido éste por maquinaria agropecuaria mucho más eficiente lo que ha derivado en una densificación del bosque y el desarrollo de especies herbáceas antes casi inexistentes. Por otro lado, esta mecanización generalizada del campo frenó la demanda de aperos de madera en los espacios agrícolas como la Tierra de Campos, lo que supuso un freno para la producción de éstos en los valles de montaña de León en general y en Valdeón en particular. La sustitución, en buena medida, de la leña y el carbón vegetal por recursos energéticos derivados de hidrocarburos a partir de mediados de los años 50 ha hecho que la explotación del bosque sea abandonada prácticamente en su totalidad (existe alguna explotación de leñas testimonial). A todo esto, hay que sumar que el hayedo de Valdeón tiene una peculiaridad con respecto a otros espacios forestales estudiados $y$ es que se encuentra incluido en la delimitación del Parque Nacional de los Picos de Europa lo que conlleva, como ocurre en la mayoría de las protecciones ambientales, una limitación y prohibición de multitud de prácticas tradicionales vinculadas con los recursos que ofrece el bosque como la caza, la recolección o la obtención de leñas.

Pese a este abandono de usos tradicionales, que un día fueron razón de la existencia del hayedo, y gracias, fundamentalmente a tres factores, el hayedo de Valdeón goza de una salud excepcional y se encuentra en un proceso de consolidación incluso expansión en algunos casos. En primer lugar, el atractivo turístico que despiertan para las actividades de ocio los espacios forestales densos y nemorosos, lo que diferentes autores han dado en llamar la "clorofilia" (Roger y Maderuelo, 2007; Le Goff, 2008; Nogué, 
2009; Guerra, 2012). Por otro lado, el descenso de la presión que se ejerce sobre el bosque en las economías europeas actualmente favorece su densificación y expansión. Por último, la propiedad pública, que nunca se ha perdido, ejercida a través de las Juntas Vecinales aíslan al bosque de la lógica comercial lo que favorece su conservación.

Así, el hayedo de Valdeón se abre a una nueva perspectiva de uso, fundamentalmente basada en ese cambio de relato destinado al ocio y el turismo, que ha creado un nuevo escenario donde el hayedo se encuentra en uno de sus mejores momentos como bosque refugio y parece que esta tendencia se mantendría e incluso intensificaría. Aun así, cabe el riesgo de que una legislación demasiado proteccionista derive en una excesiva maduración del bosque incurriendo en una degradación por falta de renovación (Gil et al., 2007) que conllevaría la pérdida de biodiversidad.

\subsection{El paisaje de un espacio silvopastoril de montaña}

En general, los espacios de montaña, debido a la dificultad para el desarrollo de las actividades tradicionales, son lugares especialmente ricos en elementos propios del ingenio del hombre para adaptarse al potencial ecológico donde vive $y$, este caso, es un claro ejemplo de este tipo de paisaje. Cuando se analiza el paisaje del municipio de Posada de Valdeón se pone de manifiesto que estamos ante un espacio de montaña donde se van a dar grandes contrastes entre la realidad de los valles y las características propias de las cumbres.

La personalidad del paisaje está directamente relacionada con la vocación silvopastoril de su economía tradicional de montaña. Se trata pues, de un paisaje caracterizado por tres elementos fundamentales. Los pastos derivados de la vocación trashumante y hoy aprovechados fundamentalmente para el ganado vacuno (aunque también aparece ganado caprino y caballar); estos pastos pueden separarse entre los de fondo de valle, que aparecen intercalados con los prados de siega, y los pastos de 
altura de los puertos y las canales que dan acceso a las peñas. Por otro lado, el espacio forestal caracterizado fundamentalmente por el hayedo formando una masa monoespecífica y situado en las laderas orientadas a la umbría (aunque también aparecen pequeños bosquetes o ejemplares aislados de otras especies fundamentalmente Quercus). Por último, la anomalía que introducen las peñas calcáreas de la Unidad Picos de Europa y que hacen de la mezcla del paisaje de dominante natural y el paisaje de dominante tradicional un auténtico referente a nivel internacional. De este modo, se trata de un paisaje donde la naturaleza parece dominante a simple vista, pero si se analiza cuidadosamente la realidad está cargada de artefactos, delimitaciones, elementos construidos y decisiones humanas que ordenan la fuerza de la naturaleza. Algunos de estas evidencias son el camino de Panderruedas a Posada, el camino de Pandetrave a Santa Marina, círculos de carboneras dentro del bosque, majadas para el ganado, bancales, etc.

Mediante un proceso de observación y análisis se determina articular la siguiente clasificación de unidades de paisaje y elementos que actúan como catalizadores de patrimonialización y que le otorgan carácter al paisaje de Valdeón:

- Cultivos

- Prados de siega (cultivos de herbáceas que se sitúan en el fondo del valle destinados al alimento del ganado mediante la siega) (Figura 39).

- Bancales (Cultivos de herbáceas que se sitúan en las terracillas construidas para dulcificar la pendiente de las laderas, generalmente orientadas a la solana) (Figura 40).

- Huertas (situadas generalmente en las cercanías de los núcleos de población y destinadas al autoconsumo) (Figura 39).

- La alta montaña (peñas y roquedo desnudo) (Figura 41).

- Forestal

- Gran hayedo situado en las laderas de umbría (Figura 41). 
- Otros espacios arbolados (diferentes bosquetes generalmente de Quercus que aparecen salpicando el municipio) (Figura 42).

- Matorral de degradación (Figura 40).

- Urbano (la característica principal acerca del paisaje urbano en Valdeón es la dispersión de su poblamiento que aparece salpicando todo el valle en forma de pequeñas aldeas). (Figura 41). 


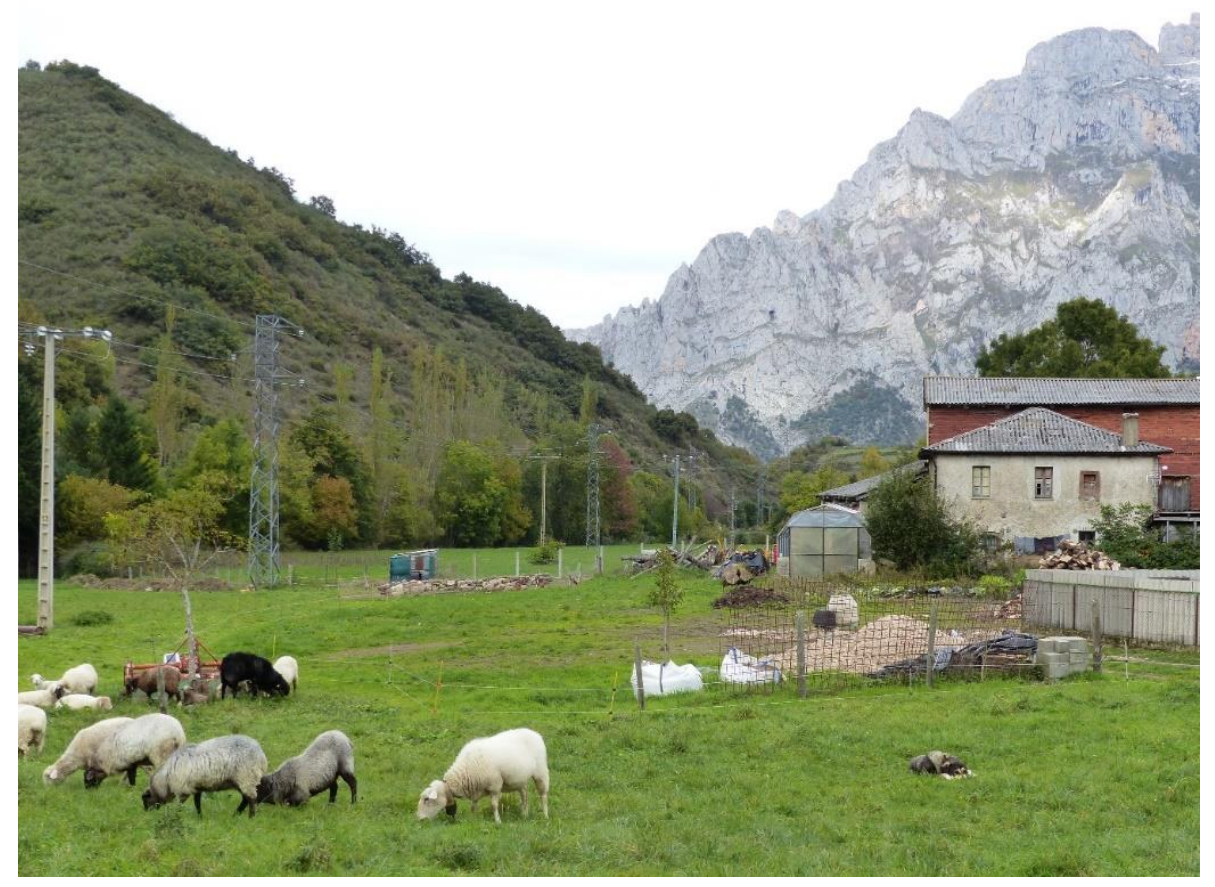

Figura 39. Prados de diente, siega y huertos en el fondo del Valle junto a Posada de Valdeón. Imagen propia.

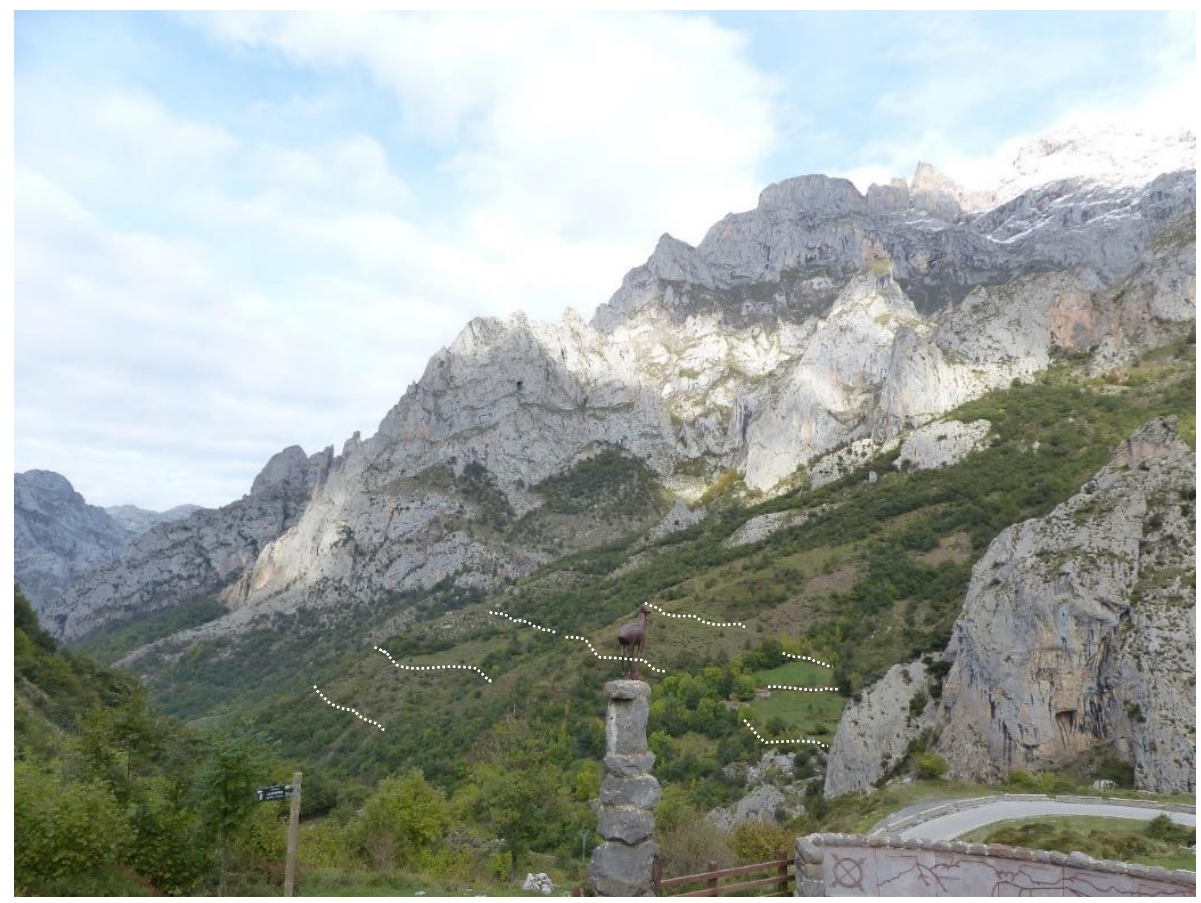

Figura 40. Bancales abandonados (marcados con línea discontinua) con matorral en avance. Imagen propia. 
Estudio de casos y aplicación práctica. Paisajes forestales con valor patrimonial.

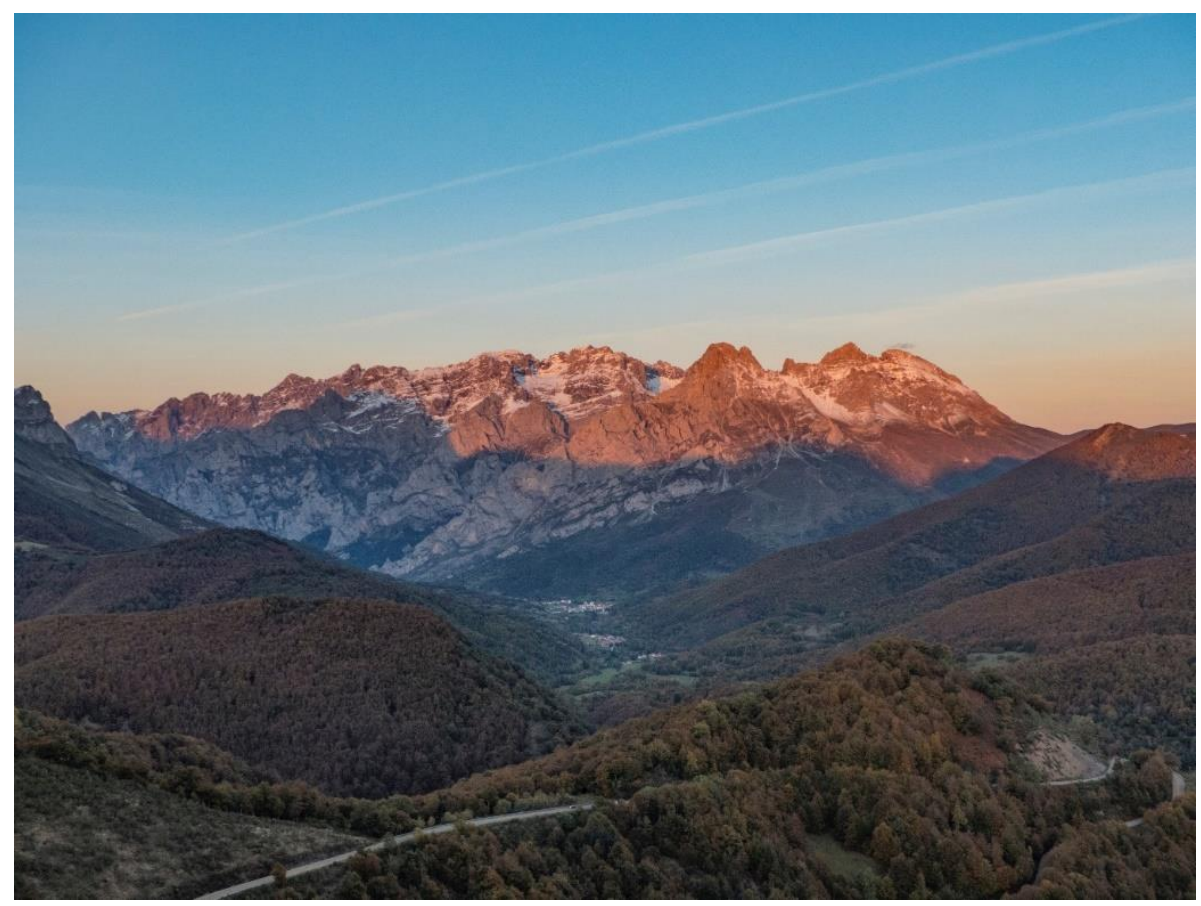

Figura 41. Hayedo en las laderas de umbría, Caldevilla de Valdeón, Soto de Valdeón, Posada de Valdeón y el Macizo Central de los Picos de Europa al fondo. Imagen propia.

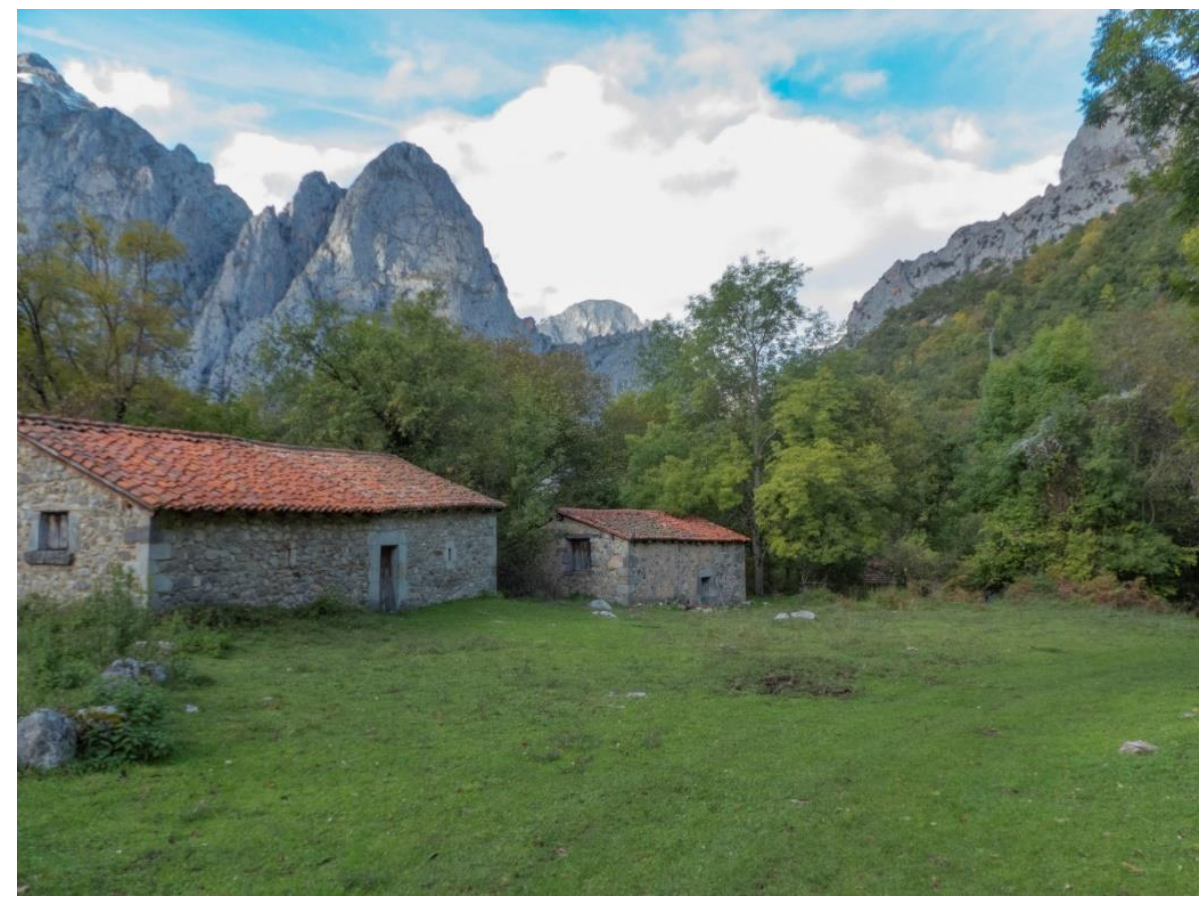

Figura 42. Praderas y robledales en el Monte Corona. Imagen propia. 
Dentro de este paisaje tradicional de montaña el objeto de estudio es el paisaje del hayedo que supone una singularidad al tratarse de un bosque extraordinariamente extenso, desarrollado y bien conservado, pero también existen elementos realmente singulares en este paisaje que actúan como catalizadores como son las majadas que salpican los puertos y que se relacionan directamente con la ganadería trashumante que en otros momentos inundó estos prados.

Como se ha señalado, estamos ante un espacio protegido mediante la figura de Parque Nacional por lo que existe una normativa ambiental y de reconocimiento patrimonial, pero ésta no va a destacar por el enfoque cultural del paisaje, sino que pone el foco en los aspectos ecológicos, biológicos y geomorfológicos fundamentalmente.

Pese a este reconocimiento patrimonial de conjunto, el paisaje del hayedo es el centro alrededor del que gira este trabajo, por lo que es necesario centrarse en este espacio concreto aun incurriendo en obviar parte del paisaje de este valle, especialmente sus características geomorfológicas ampliamente estudiadas y reconocidas. Así, el hayedo de Valdeón, un bosque prácticamente monoespecífico compuesto por Fagus sylvatica, especímenes de gran tamaño y amplias copas que genera un bosque cerrado con un importante dosel que impide el desarrollo de otras especies más heliófilas al tratarse de un espacio sombrío; en ocasiones, el haya comparte espacio o forma comunidad vegetal con tejos (Taxus baccata) y acebos (Ilex aquifolium), así como diferentes herbáceas de floración temprana como estrategia de supervivencia a la penumbra propia del hayedo como pueden ser Anemone nemorosa, Scilla lilio-hyacinthus, Helleborus viridis, Hepática triloba, Corydalis cava, Euphorbia hyberna, Oxalis acetosella, etc. (Gil et al., 2007). Este hayedo se restringe al límite superior del piso montano, el bosque aparece restringido, en su parte superior a los 1500 metros de altitud o aparece de forma testimonial por encima de este límite. 
Este paisaje responde, como se ha señalado, por una parte, al condicionante ecológico (fundamentalmente a la orientación norte de las laderas de la Unidad Pisuerga-Carrión) y por otro lado a la decisión humana de mantener el bosque mediante un aprovechamiento de entresaca arrojando un paisaje de fuerte carácter patrimonial. Así, el haya es el elemento catalizador, y la singularidad que supone un bosque de tan extraordinaria dimensión, concretamente 4934 hectáreas según el Mapa Forestal 1:50000 elaborado entre 1997-2006 (MAPAMA, 1997) (Figura 43, Figura 44, Figura 45) lo que supone el $14 \%$ del término municipal de Posada de Valdeón hacen relevante considerar este espacio forestal que ha sido eclipsado por la extraordinaria relevancia de los Picos de Europa. 


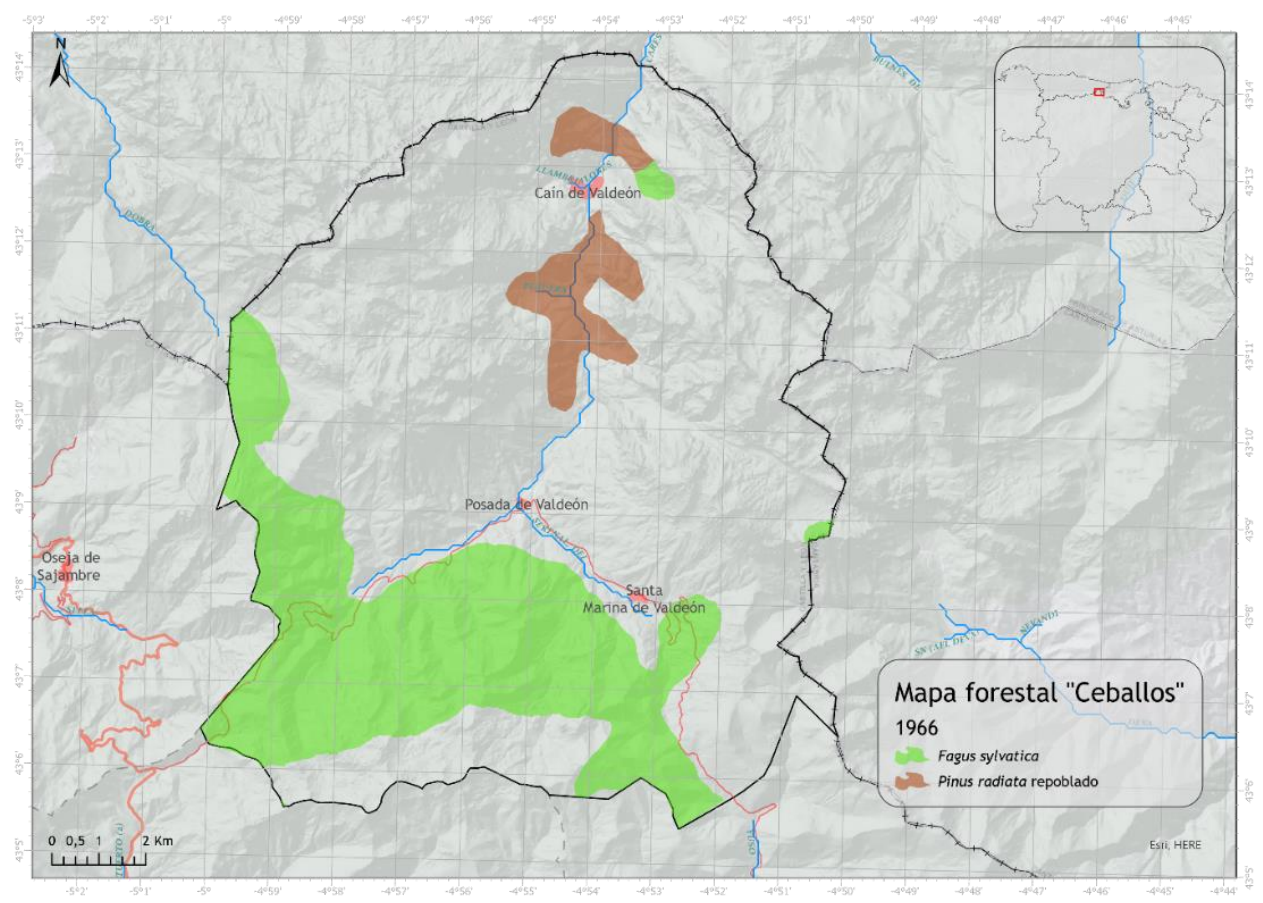

Figura 43. Mapa Forestal de España 1966, conocido como “mapa Ceballos", en Posada de Valdeón. Elaboración propia.

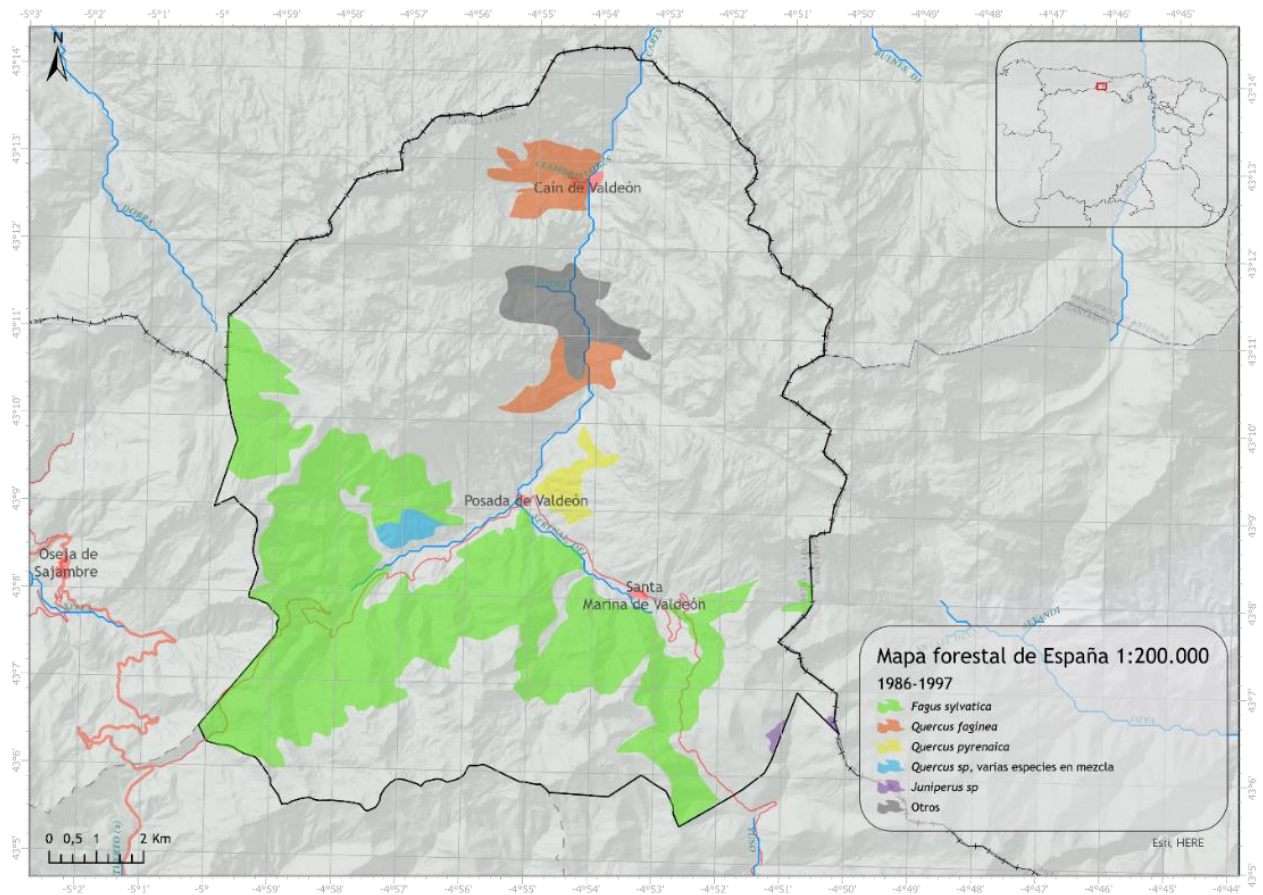

Figura 44. Mapa Forestal de España (1986-1997) en Posada de Valdeón. Elaboración propia. 


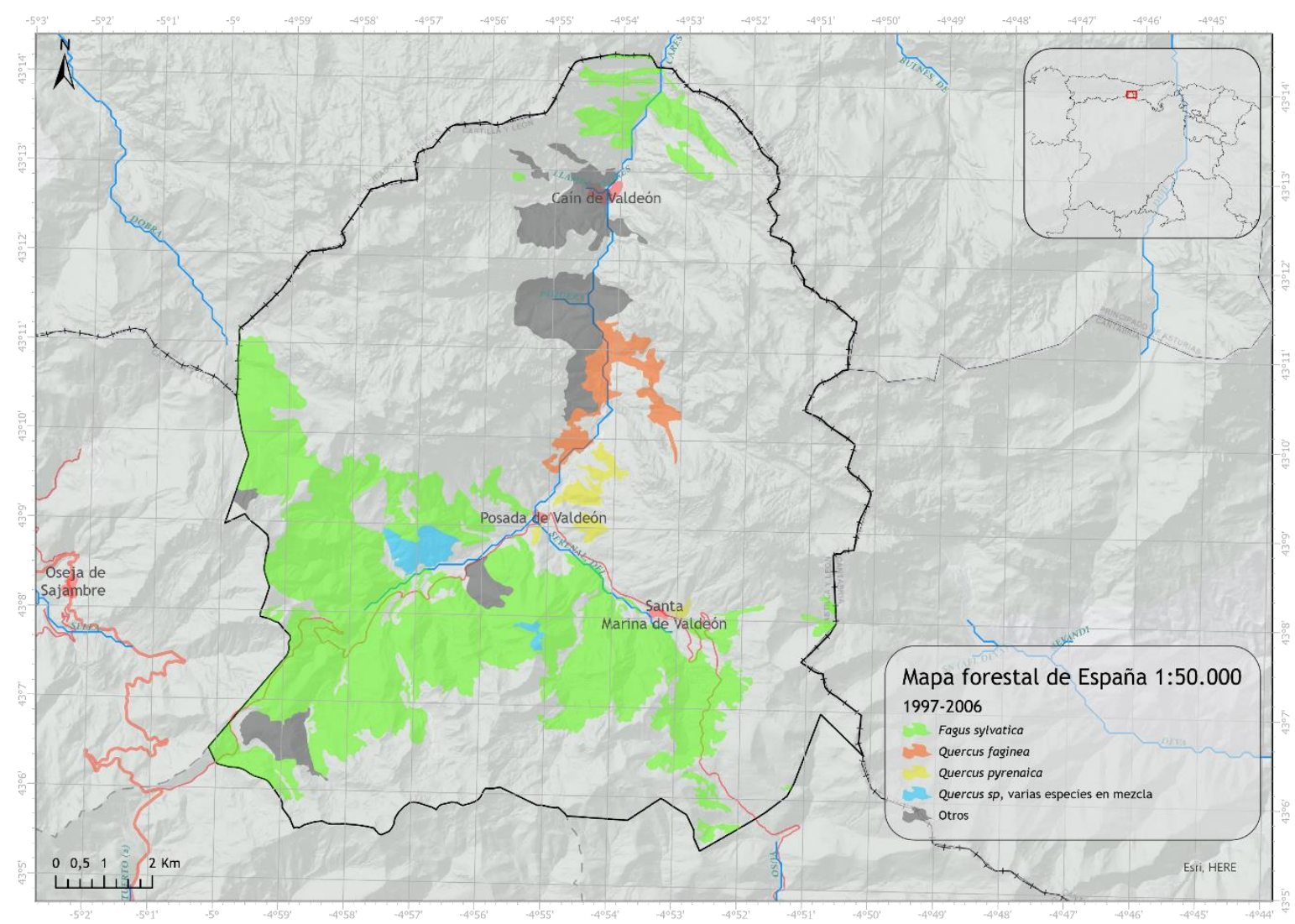

Figura 45. Mapa Forestal de España (1997-2006) en Posada de Valdeón. Elaboración propia.

Este bosque se caracteriza por unas condiciones de naturalidad muy reseñables lo que genera una sensación de escasa intervención antrópica cuando nos aproximamos a él; se trata de un ejemplo perfecto de lo que se ha llamado bosque refugio aludiendo a esa sensación de inmovilismo que trasmite (Guerra, 2012). Pero pese a esta sensación de dominancia natural donde los elementos biológicos se relacionan en un ordenado caos que recuerda a los bosques idealizados, no se puede olvidar la íntima relación que este bosque ha tenido con los habitantes de este territorio durante siglos y que se pone de manifiesto de forma muy destacable en las "juntas vecinales" que han gestionado y gestionan este espacio forestal y gracias a las cuales hoy en día este bosque ha llegado hasta hoy. Así se pueden encontrar diferentes referencias en la montaña leonesa que ponen de 
manifiesto esta estrecha relación entre los usos tradicionales y el mantenimiento del bosque como las Ordenanzas de la Merindad de Valdeburón de 1662 donde se limita la corta de madera con el fin de conservar los montes; limitando que cada vecino al año podrá "hacer dos carros con sus ruedas y un par de ruedas sin carro y un eje de carro y no otras ningunas maderas para vender, de las que dañan y talan los montes" Igualmente en 1800 la ordenanza del vecino Concejo de Sajambre regula el descote y la corta de varas (Rodríguez y Maya, 2008). El 26 de mayo de 1757 “Don Juan de Martino, merino mayor de Valdeburón, urge a los jueces ordinarios de los concejos de la merindad que velen por el cumplimiento de las Ordenanzas de la tasa de maderas aprobadas por Felipe II (1593) y Felipe IV (1622)" recogido en el Archivo del Ayuntamiento de Valdeón (Martino, 1980). Esta vinculación de la población local del valle de Valdeón con el bosque de hayas, su mantenimiento y cuidado han conseguido que exista este extraordinario bosque de gran valor biológico y paisajístico que se encuentra en expansión. 
Estudio de casos y aplicación práctica. Paisajes forestales con valor patrimonial.

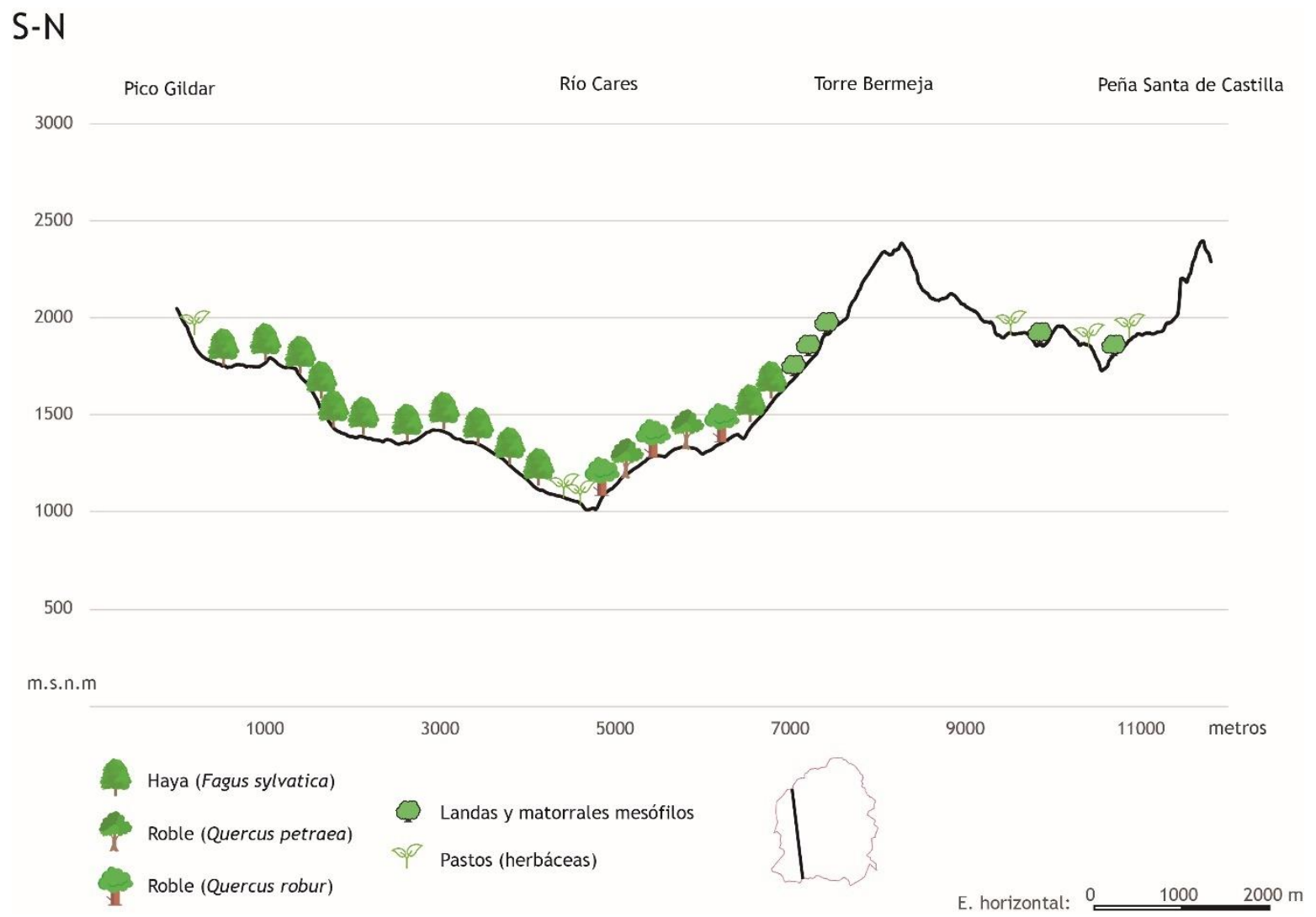

Figura 46. Perfil vegetal del municipio de Posada de Valdeón, sector oriental. Elaboración propia a partir de trabajo de campo. 


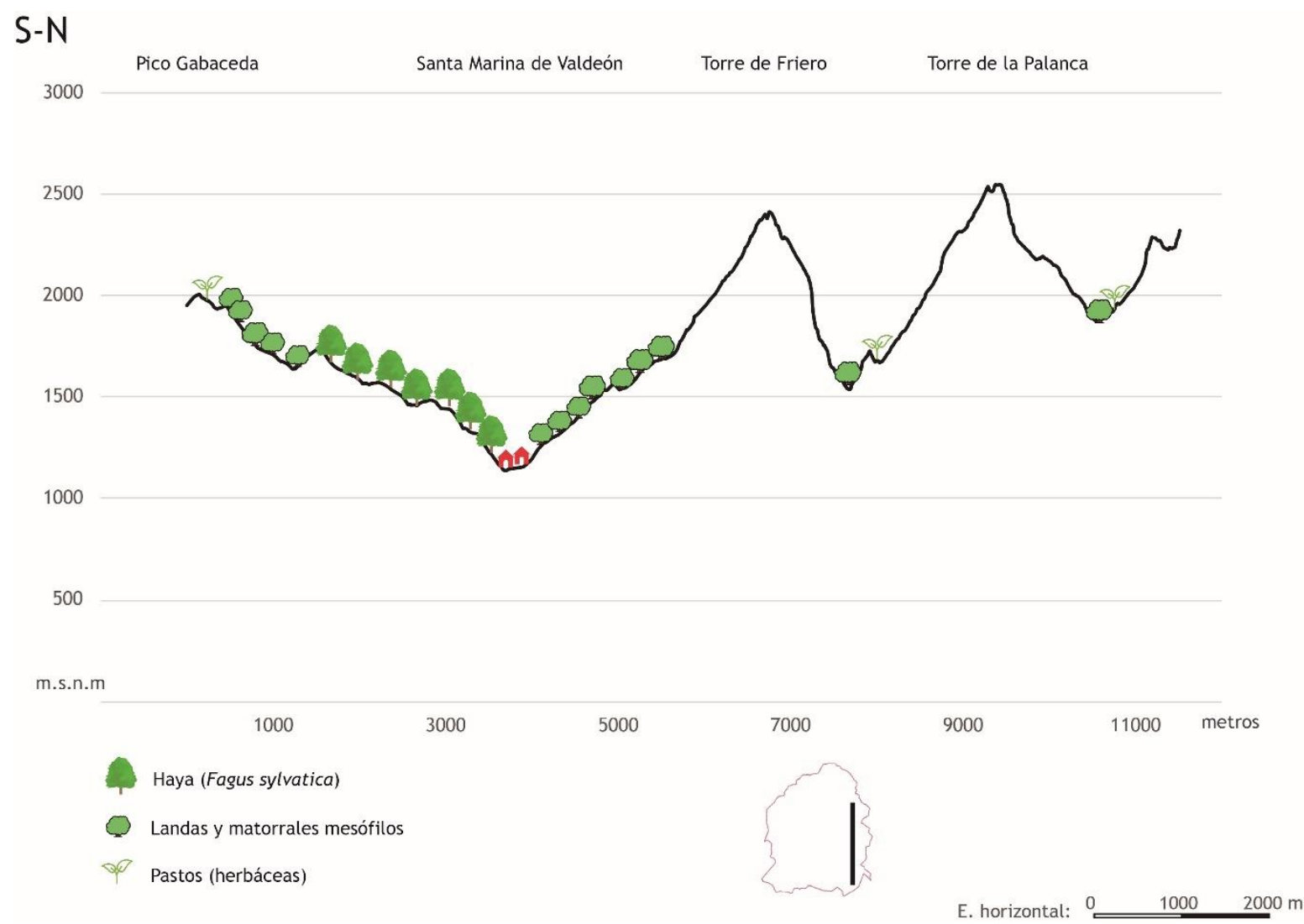

Figura 47. Perfil vegetal del municipio de Posada de Valdeón, sector occidental. Elaboración propia a partir de trabajo de campo.

\subsection{El valor patrimonial}

El hayedo de Posada de Valdeón, como ha quedado demostrado, tiene un indudable valor patrimonial que se asienta de forma muy relevante en sus circunstancias biológicas. El hecho más relevante que lleva a esta reflexión es la existencia de dos pequeñas masas pertenecientes a este gran conjunto forestal que han sido reconocidas por UNESCO como excepcionales atendiendo a su origen natural. Así, los hayedos de la Cuesta Fría y Asotín han sido declarados en Julio de 2017 como patrimonio de la humanidad, presentación conjunta con Albania, Alemania, Austria, Bélgica, Bulgaria, Croacia, Eslovaquia, Eslovenia, España, Italia, Rumania, Ucrania, dentro de la categoría "Ancient and Primaveral Beech Forests of the Carpathians and 
Other Regions of Europe". La declaración se ha basado en el criterio IX del patrimonio UNESCO "Ser ejemplos sobresalientes que representan importantes procesos ecológicos y biológicos en curso en la evolución y el desarrollo de ecosistemas terrestres, de agua dulce, costeros y marinos y comunidades de plantas y animales".

Por otro lado, se han reflejado los aspectos culturales que han perpetuado esta masa forestal hasta nuestros días, esa relación del bosque con la sociedad local como proveedor de recursos y cómo esta producción se ha realizado de una forma sostenible capaz de garantizar la viabilidad de este extraordinario hayedo.

Por estas razones, no cabe duda en señalar que el valor patrimonial del hayedo de Posada de Valdeón se va a sostener en dos pilares que, pese a no haber sido reconocido por las administraciones de forma equitativa, ambas suponen aspectos fundamentales para la existencia y el mantenimiento de este bosque caducifolio. La declaración UNESCO garantiza su origen natural de forma indudable mientras que las prácticas tradicionales han asegurado su expansión y persistencia en el tiempo.

\subsection{El proceso de patrimonialización a través de los indicadores.}

Al marcar como objetivo la comparación de diferentes procesos de patrimonialización del paisaje forestal se hizo necesario el establecimiento de una serie de indicadores de patrimonialización que quedaron definidos en el apartado correspondiente (ver 6.3). En este sentido se pasan a valorar los indicadores propuestos para el caso que ocupa este capítulo, siendo el paisaje forestal del hayedo enmarcado en el municipio de Posada de Valdeón. 


\subsubsection{Indicador 1. Complejidad biológica}

\begin{tabular}{|l|c|}
\hline Criterio & Puntuación \\
\hline Evidencias bibliográficas de naturalidad & 3 \\
\hline Hábitat de Interés Comunitario & 4 \\
\hline Salud vegetal NDVI & 3 \\
\hline
\end{tabular}

Tabla 16. Resumen criterios valoración indicador Complejidad Biológica.

Mediante la recopilación de información y observación realizadas en el trabajo de campo, el apoyo aportado por fuentes bibliográficas fiables (García y Goldsmith, 1988; García, 1992; Gómez et al., 2008; Riutort y Alvarez, 2017), el análisis de las formaciones recogidas en la Directiva Hábitat (Comisión Europea, 1992) así como el análisis NDVI de las cubiertas vegetales presentes en el municipio, se fija el valor de este indicador para el paisaje forestal.

Este bosque, gracias a su inaccesibilidad desde el norte alberga una gran riqueza tanto en flora como en fauna y posee rasgos de naturalidad superiores a sus vecinos de Liébana y Sajambre, al haber sido sometidos estos, a frecuentes cortas (García y Goldsmith, 1988). De igual modo, resulta evidente que los manejos tradicionales de estos ecosistemas son fundamentales para su riqueza biológica (García, 1992). Por otro lado, se ha confirmado este hayedo como uno de los espacios forestales con mayor diversidad en organismos presentes en el suelo (Riutort y Alvarez, 2017), un claro indicador de madurez del ecosistema. Todo esto, acompañado de la reciente declaración de dos masas pertenecientes a este hayedo como bosques ejemplo de “Hayedos primigenios de los Cárpatos y otras regiones de Europa" (UNESCO, 2017), hace indudable asegurar el cumplimiento de este criterio, otorgando los 3 puntos correspondientes. 
En lo que se refiere a la existencia de formaciones recogidas en la Directiva Hábitat, el municipio de posada de Valdeón se encuentra completamente cubierto por este tipo de figuras de protección ambiental albergando 38 formaciones entre las que destacan por extensión y valor biogeográfico (Figura 48):

- Blechno spicant-Fagetum sylvaticae (Hayedo basófilo)

- Festucetum burnatii (Prados de diente)

El dominio de esta figura de protección natural en el municipio y su relación directa con el hayedo determinan el cumplimiento de este criterio y su correspondiente puntuación.

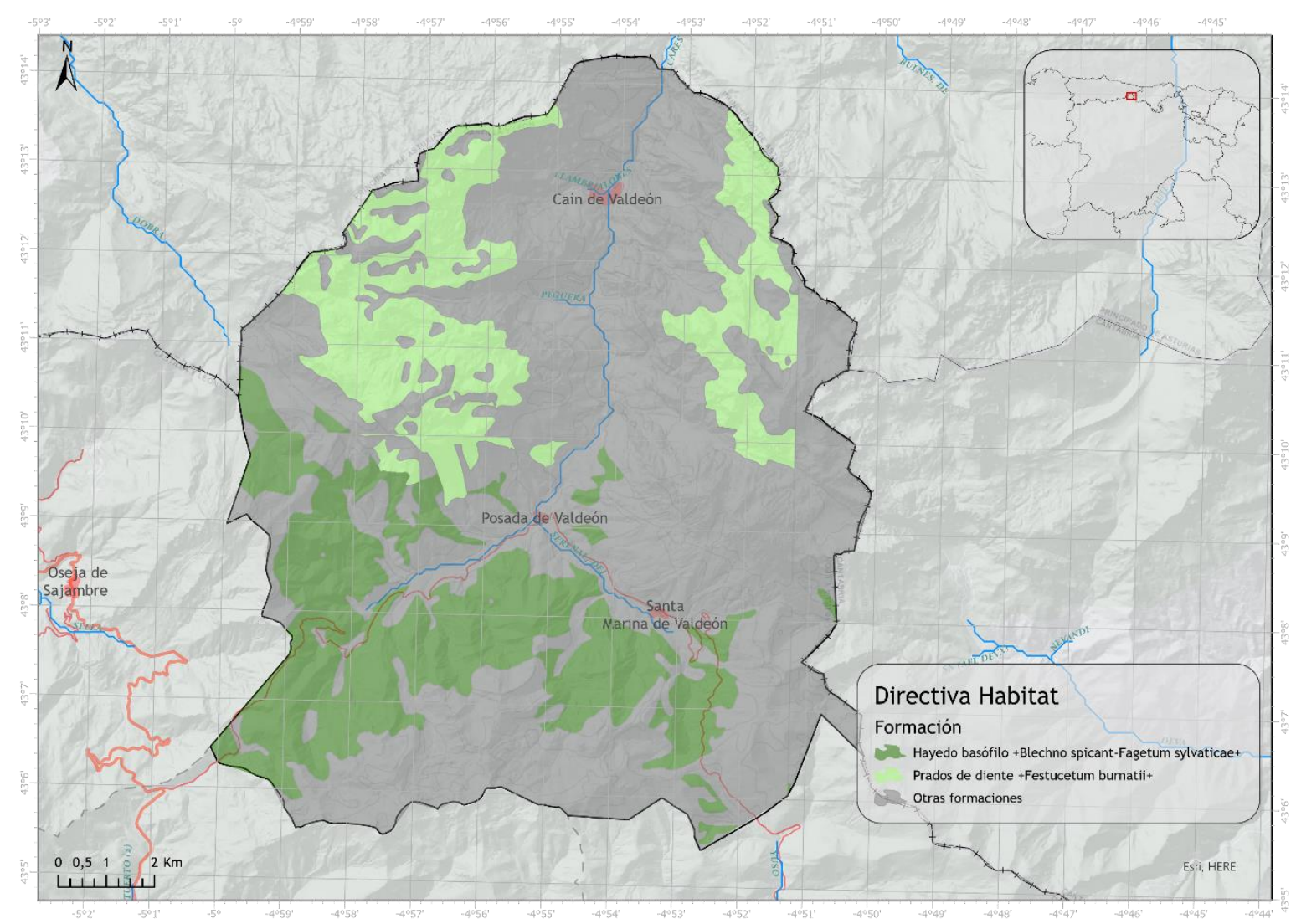

Figura 48. Mapa formaciones recogidas en la Directiva Hábitat en Posada de Valdeón. Elaboración propia a partir de Directiva Hábitat Banco de Datos de la Naturaleza. 
En cuanto al índice NDVI (ver 6.3.1), el hayedo destaca de forma indiscutible en vigorosidad con respecto al resto de cubiertas (Figura 49), destacando como un reservorio vegetal a lo largo del año (Tabla 17). Esto indica que debe obtener la valoración máxima de 3 puntos.

\begin{tabular}{|c|c|c|c|}
\hline & Hayedo & Cultivos & Otra veg. (robledal) \\
\hline Invierno & $-0,01$ & 0,2 & 0,18 \\
\hline Primavera & 0,47 & 0,54 & 0,47 \\
\hline Verano & 0,39 & 0,33 & 0,53 \\
\hline Otoño & 0,16 & 0,3 & 0,42 \\
\hline
\end{tabular}

Tabla 17. Valor NDVI de distintas cubiertas a lo largo del periodo vegetativo. Elaboración propia.
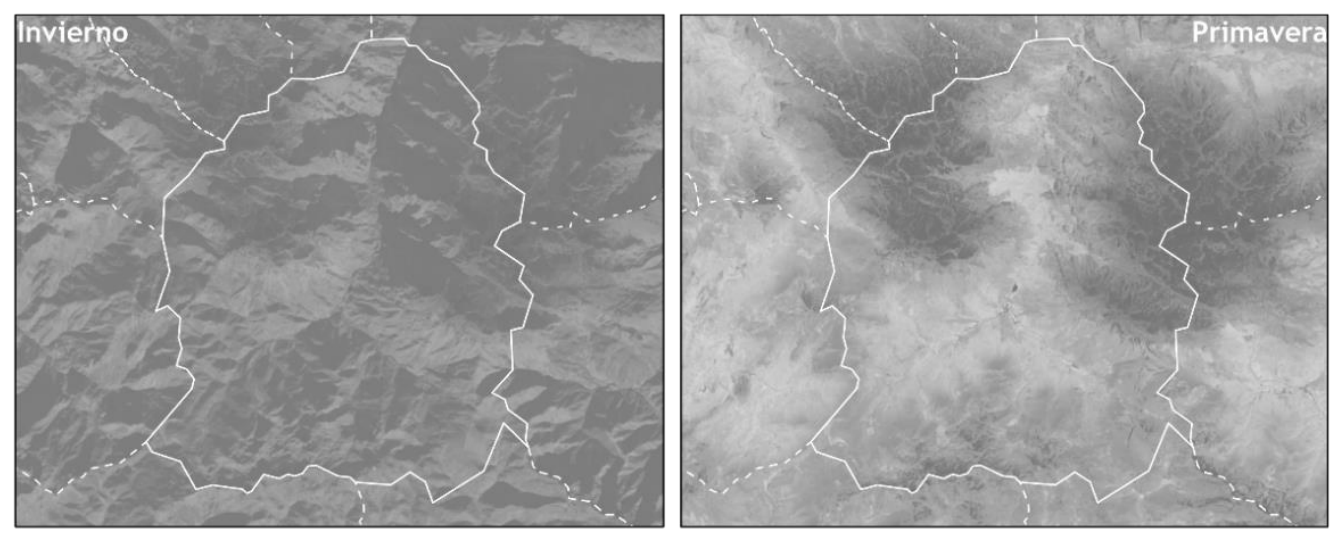

Municipio de
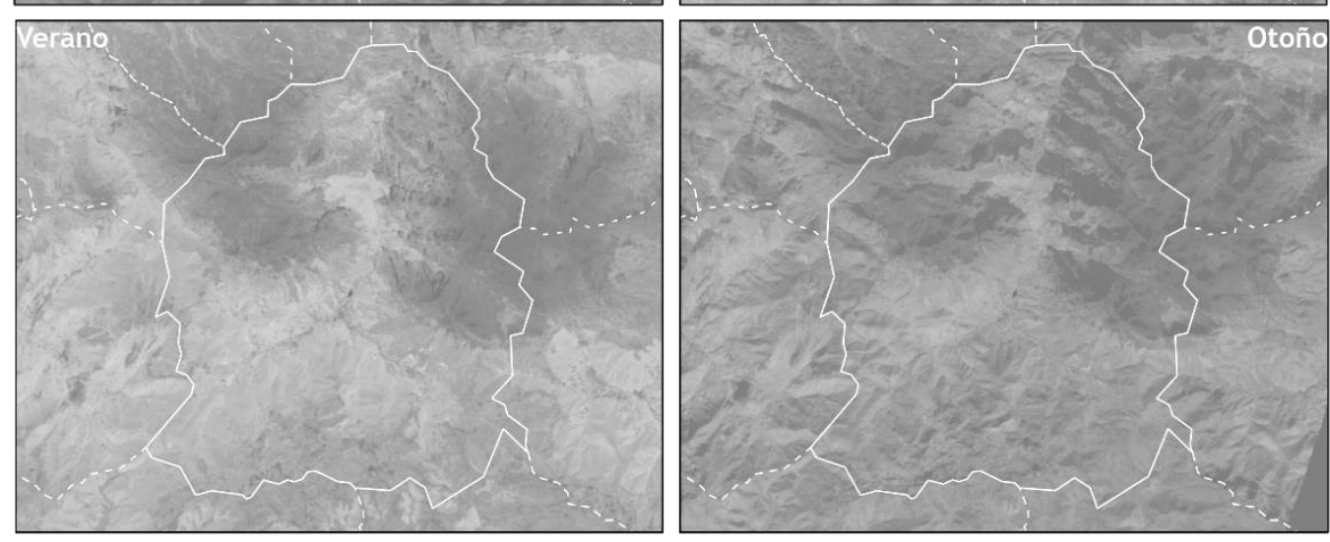

Posada de

Valdeón

índice

NDVI

Figura 49. Representación del índice de vegetación de diferencia normalizada para los meses de enero, mayo, agosto y octubre respectivamente. Imágenes Landsat 8 . Elaboración propia. 
De esta manera, el indicador relacionado con la complejidad biológica tiene la calificación máxima de 10 puntos sobre 10 al haber cumplido todos los criterios propuestos (Tabla 18).

\begin{tabular}{|c|c|c|}
\hline Criterio & Puntuación & Cumplimiento \\
\hline $\begin{array}{lll}\text { Evidencias } & \text { bibliográficas } & \text { de } \\
\text { naturalidad } & & \end{array}$ & 3 & $\begin{array}{c}\text { No hay duda de su } \\
\text { naturalidad } \\
\text { atendiendo a la } \\
\text { bibliografía } \\
\text { existente }\end{array}$ \\
\hline Hábitat de Interés Comunitario & 4 & $\begin{array}{l}\text { La formación } \\
\text { vegetal que } \\
\text { sustenta el paisaje } \\
\text { del hayedo es } \\
\text { dominante }\end{array}$ \\
\hline Salud vegetal NDVI & 3 & $\begin{array}{l}\text { El hayedo supone } \\
\text { un reservorio } \\
\text { vegetal con } \\
\text { respecto a su } \\
\text { entorno inmediato }\end{array}$ \\
\hline
\end{tabular}

Tabla 18. Resumen criterios cumplidos valoración indicador Complejidad Biológica.

\subsubsection{Indicador 2. Figuras de protección, reconocimiento y} salvaguarda presentes en el territorio

\begin{tabular}{|l|c|}
\hline Criterio & Puntuación \\
\hline Figura otorgada por UNESCO & 4 \\
\hline Parque Nacional & 3 \\
\hline Parque Natural o inferior (CCAA) & 2 \\
\hline LIC o ZEPA & 0,5 \\
\hline Otras figuras & \\
\hline
\end{tabular}

Tabla 19. Resumen criterios valoración indicador Figuras de protección 
Para fijar el valor de este indicador se realiza una recopilación de información sobre las figuras administrativas que aparecen en el municipio de Posada de Valdeón y que están relacionadas con el paisaje forestal. Pese a que algunas de ellas pudieran parecer más preocupadas de ensalzar otros valores como el patrimonio geomorfológico o biológico, el recurso forestal es clave para la existencia de estas figuras, siendo la foresta un elemento clave en las declaraciones. De esta manera y de acuerdo con las figuras presentes, las cuales se superponen unas a otras creando un territorio especialmente denso en lo referente a figuras administrativas de especial protección.

Figuras presentes en el territorio:

- Parque Nacional Picos de Europa (Figura 50)

- Reserva de la Biosfera Picos de Europa (Figura 51)

- LIC Picos de Europa (Figura 52)

- ZEPA Picos de Europa (Figura 53)

- Bosques Patrimonio de la Humanidad de Asotín y Cuesta Fría. (Figura 54) 
Estudio de casos y aplicación práctica. Paisajes forestales con valor patrimonial.

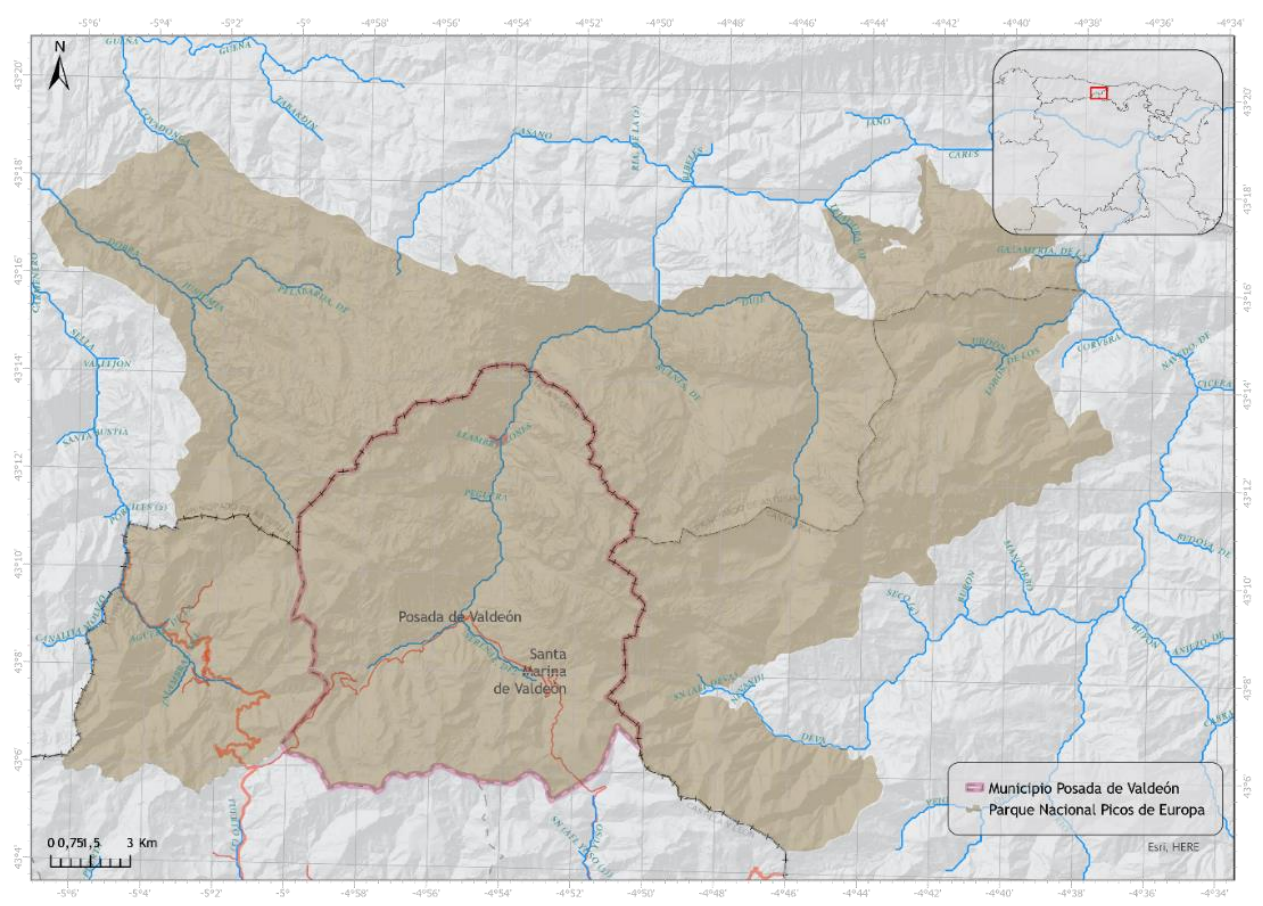

Figura 50. Parque Nacional Picos de Europa. Elaboración propia.

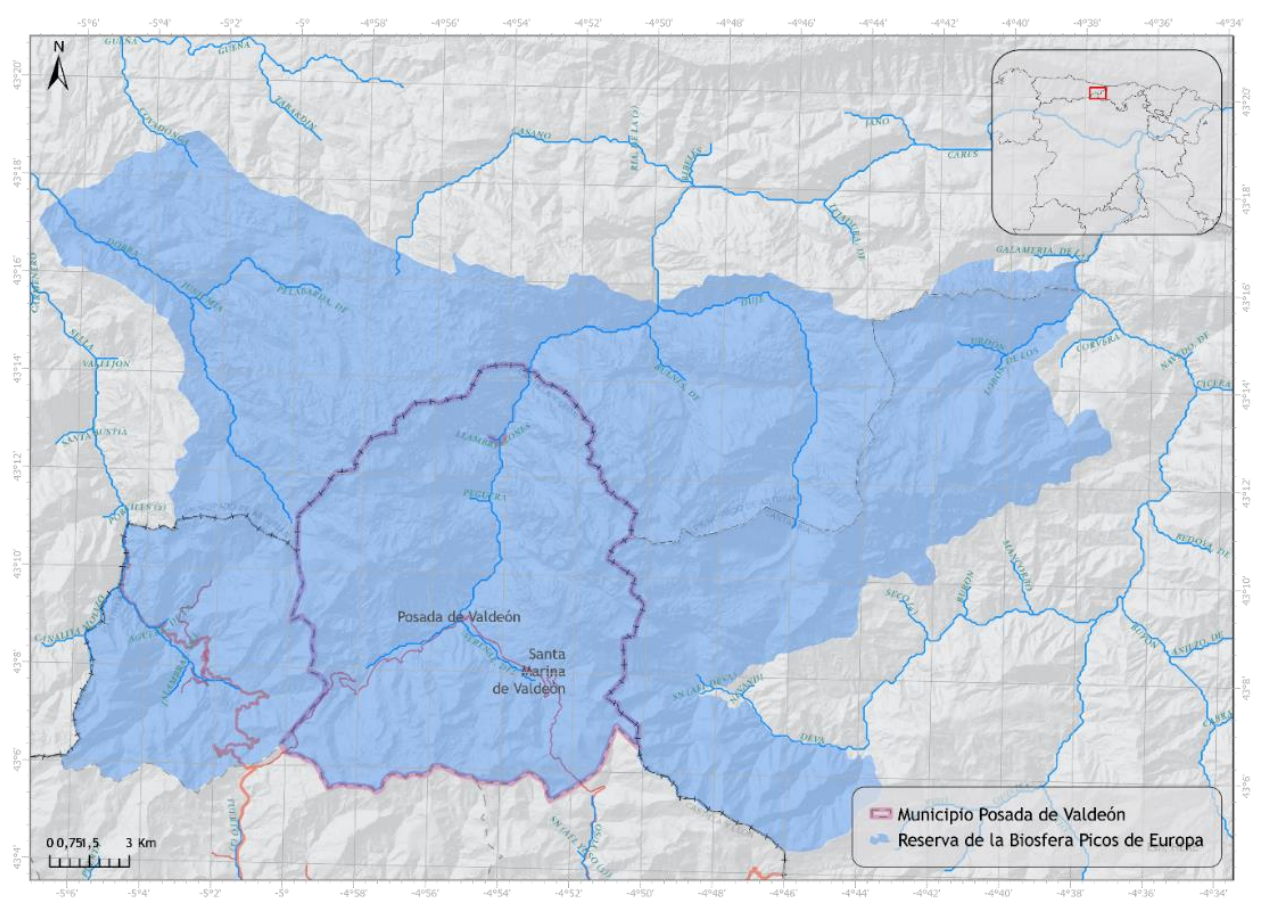

Figura 51. Reserva de la Biosfera Picos de Europa. Elaboración propia. 


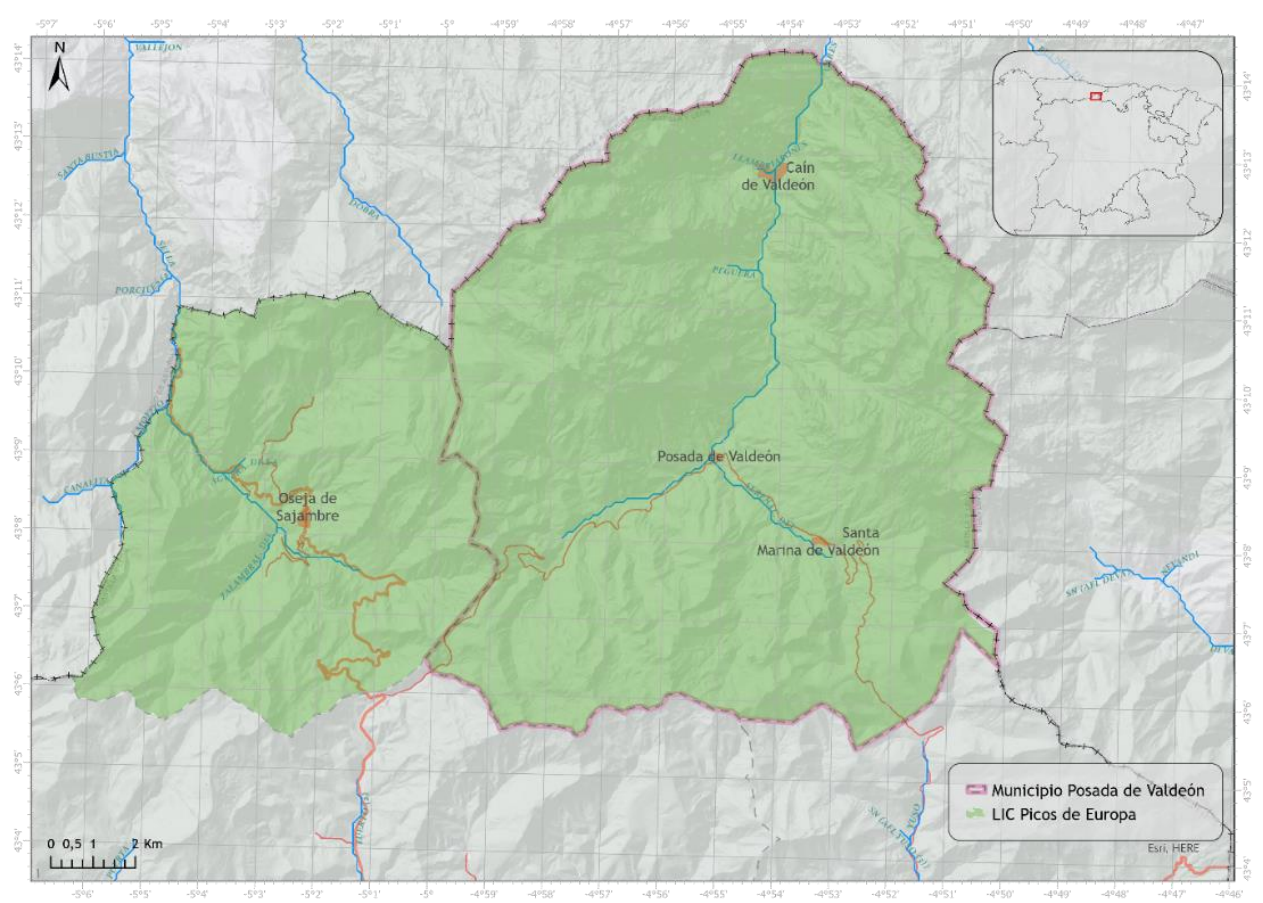

Figura 52. Lugar de Interés Comunitario Picos de Europa. Elaboración propia.

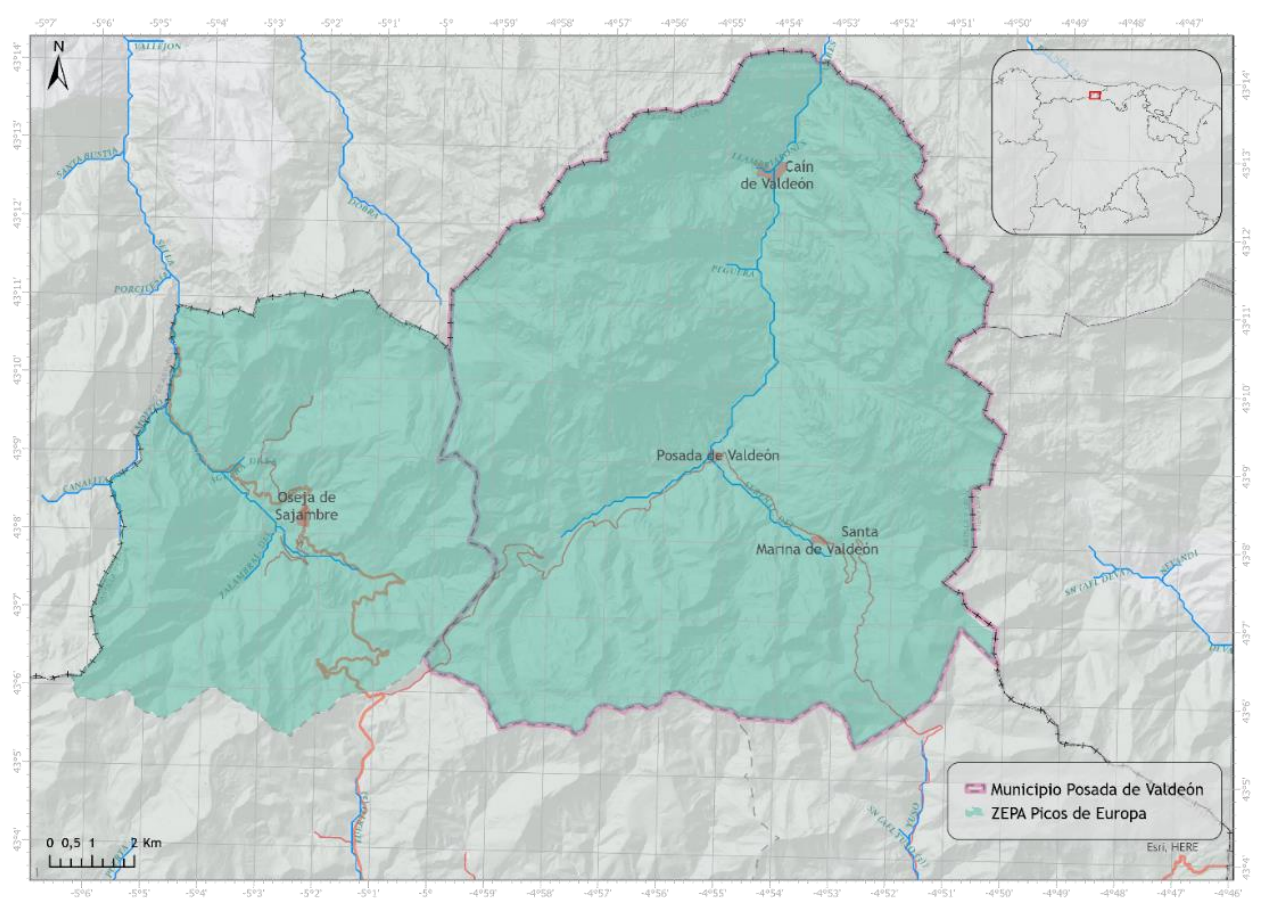

Figura 53. Zona de Especial Protección para las Aves Picos de Europa. Elaboración propia. 


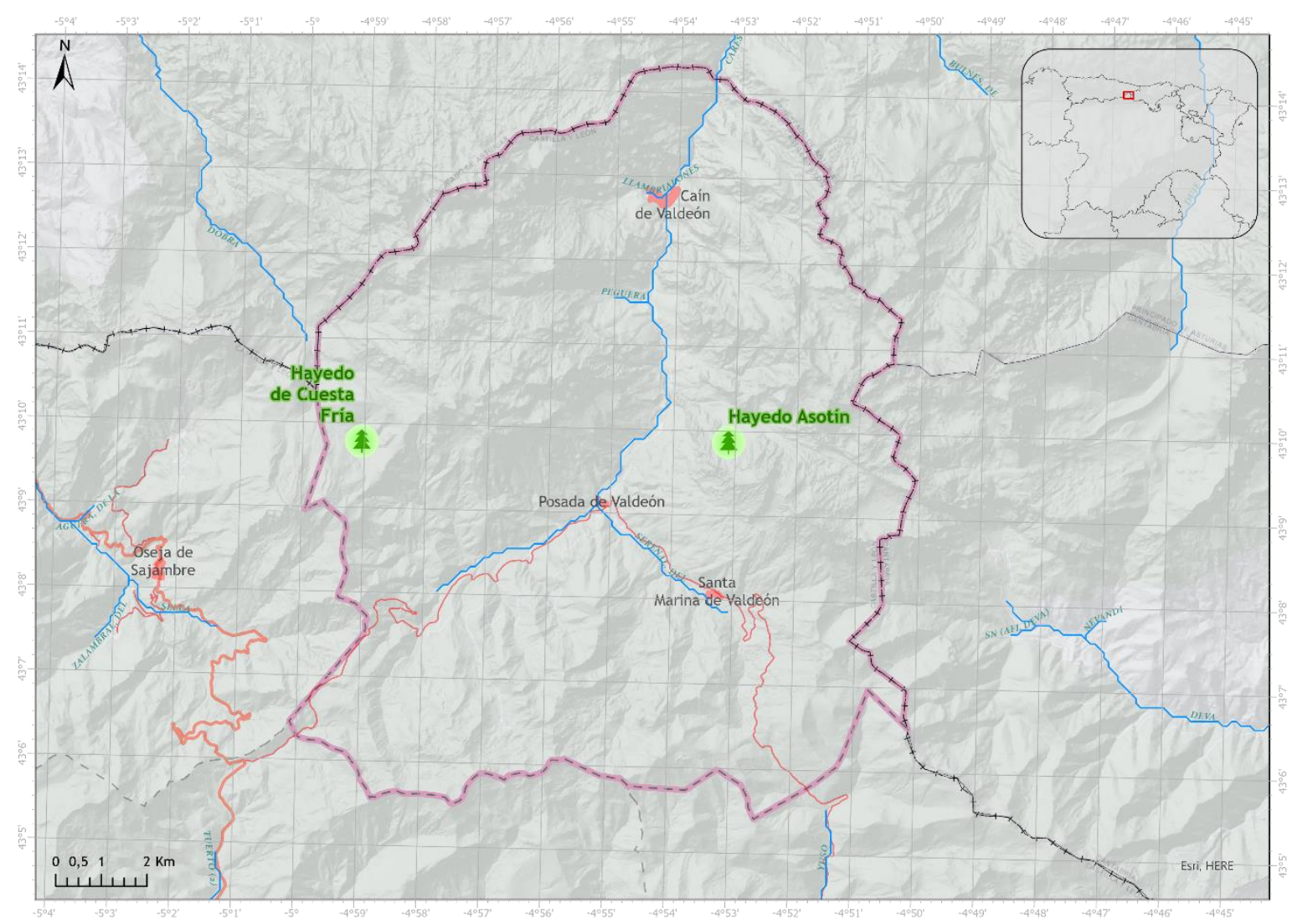

Figura 54. Localización de los hayedos catalogados como Patrimonio de la Humanidad por UNESCO. Elaboración propia.

Además de todas estas figuras que preservan los valores naturales y culturales, el hayedo de posada de Valdeón que ocupa a este capítulo se encuentra enmarcado en la figura de Monte de Utilidad Pública bajo la propiedad de juntas vecinales, lo que va a garantizar el uso forestal de este espacio (Figura 55). 
Estudio de casos y aplicación práctica. Paisajes forestales con valor patrimonial.

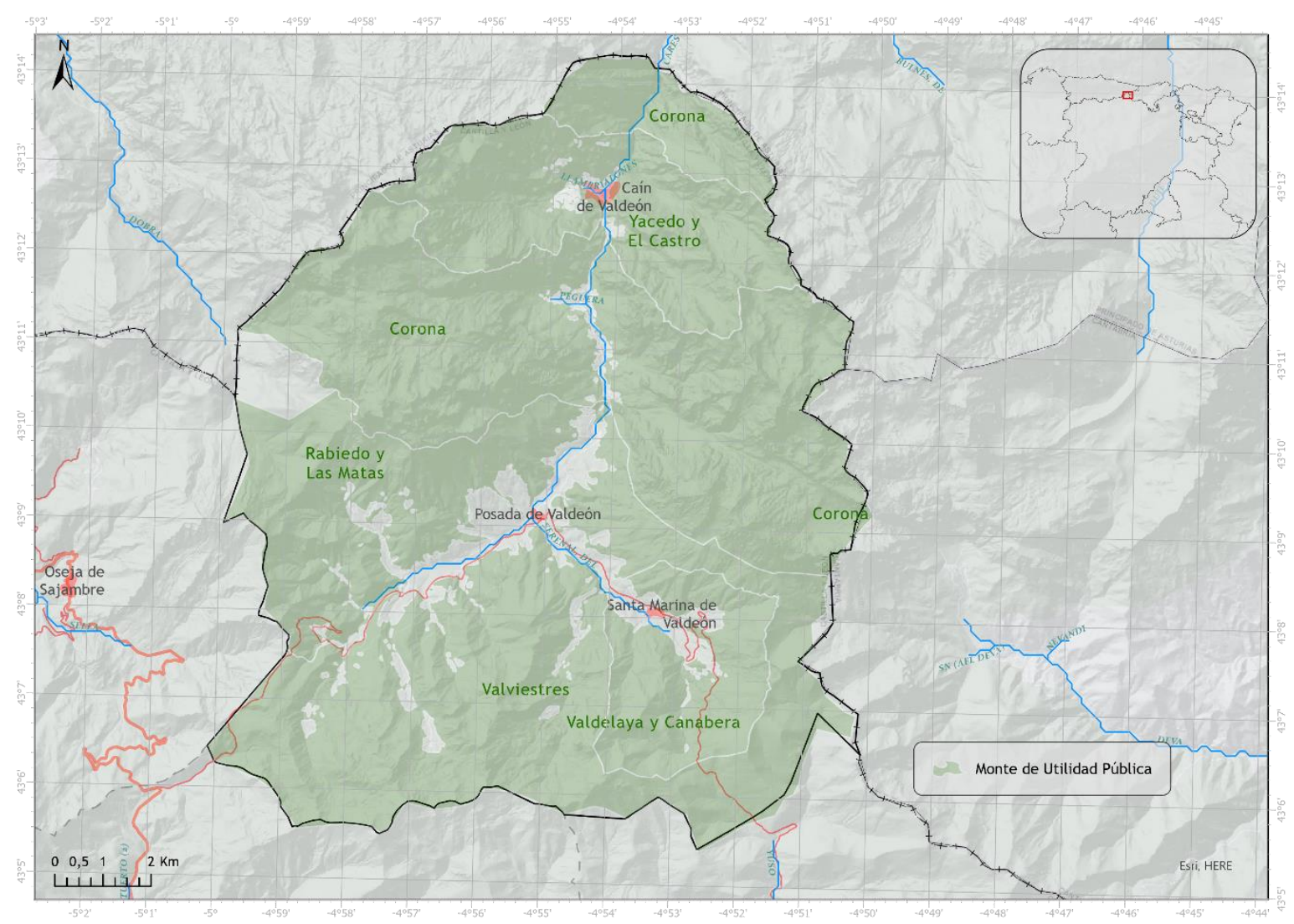

Figura 55. Mapa de los Montes de Utilidad Pública en Posada de Valdeón. Elaboración Propia a partir de Montes de Utilidad Pública Junta de Castilla y León. 
De acuerdo con esto, este indicador suma un total de 10 puntos al presentar todas las figuras propuestas como criterio (Tabla 20).

\begin{tabular}{|c|c|c|}
\hline Criterio & Puntuación & Cumplimiento \\
\hline Figura otorgada por UNESCO & 4 & $\begin{array}{c}\text { Hayedos } \\
\text { primigenios de los } \\
\text { Cárpatos y otras } \\
\text { regiones de Europa } \\
\text { Reserva de la } \\
\text { Biosfera }\end{array}$ \\
\hline Parque Nacional & 3 & $\begin{array}{l}\text { Parque Nacional de } \\
\text { los Picos de Europa }\end{array}$ \\
\hline Parque Natural o inferior (CCAA) & 2 & $\begin{array}{l}\text { Parque Regional de } \\
\text { los Picos de Europa }\end{array}$ \\
\hline LIC O ZEPA & 0,5 & $\begin{array}{c}\text { Lic y Zepa Picos de } \\
\text { Europa }\end{array}$ \\
\hline Otras figuras & 0,5 & MUP \\
\hline
\end{tabular}

Tabla 20. Resumen criterios cumplidos valoración indicador Figuras de protección.

\subsubsection{Indicador 3. Existencia de vectores patrimoniales}

\begin{tabular}{|l|c|}
\hline Criterio & Puntuación \\
\hline Todos los vectores & 4 \\
\hline Al menos 50\% tratados patrimonialmente & 3 \\
\hline Identificados vectores de todos los tipos & 3 \\
\hline
\end{tabular}

Tabla 21. Resumen criterios valoración indicador Vectores Patrimoniales

Los vectores patrimoniales van a ser esos elementos de referencia presentes en el territorio que fijan el valor patrimonial. Es por esta razón que se consideran importantes para definir el momento patrimonial de los paisajes. Así, van a ser determinantes para entender en qué momento del proceso se encuentra el paisaje forestal del hayedo perteneciente al 
municipio de Posada de Valdeón. Se identifican los vectores relativos al paisaje forestal que se han delimitado en el capítulo 4 y se interpreta su estado de conservación y tratamiento con el fin de valorar numéricamente este indicador.

En el caso que ocupa a este capítulo se han identificado ejemplos de los vectores propuestos (Tabla 6) para el paisaje del bosque "refugio" y se constatan los siguientes ejemplos:

Grandes árboles: Se encuentran varios ejemplares que responden a este vector, bien conservados y con intervenciones destinadas a su preservación (Figura 56).

Antiguas carboneras: Se ha encontrado algún ejemplo de sus emplazamientos, pero no existen evidencias de carboneras que pudieran ser funcionales o al menos representativas de lo que un día fueron estos elementos tradicionales (Figura 57).

Intervenciones/podas: Se aprecia alguna intervención en ejemplares significativos, de igual modo se observa cierto abandono en el aclarado tradicional y limpieza del bosque (Figura 58). 


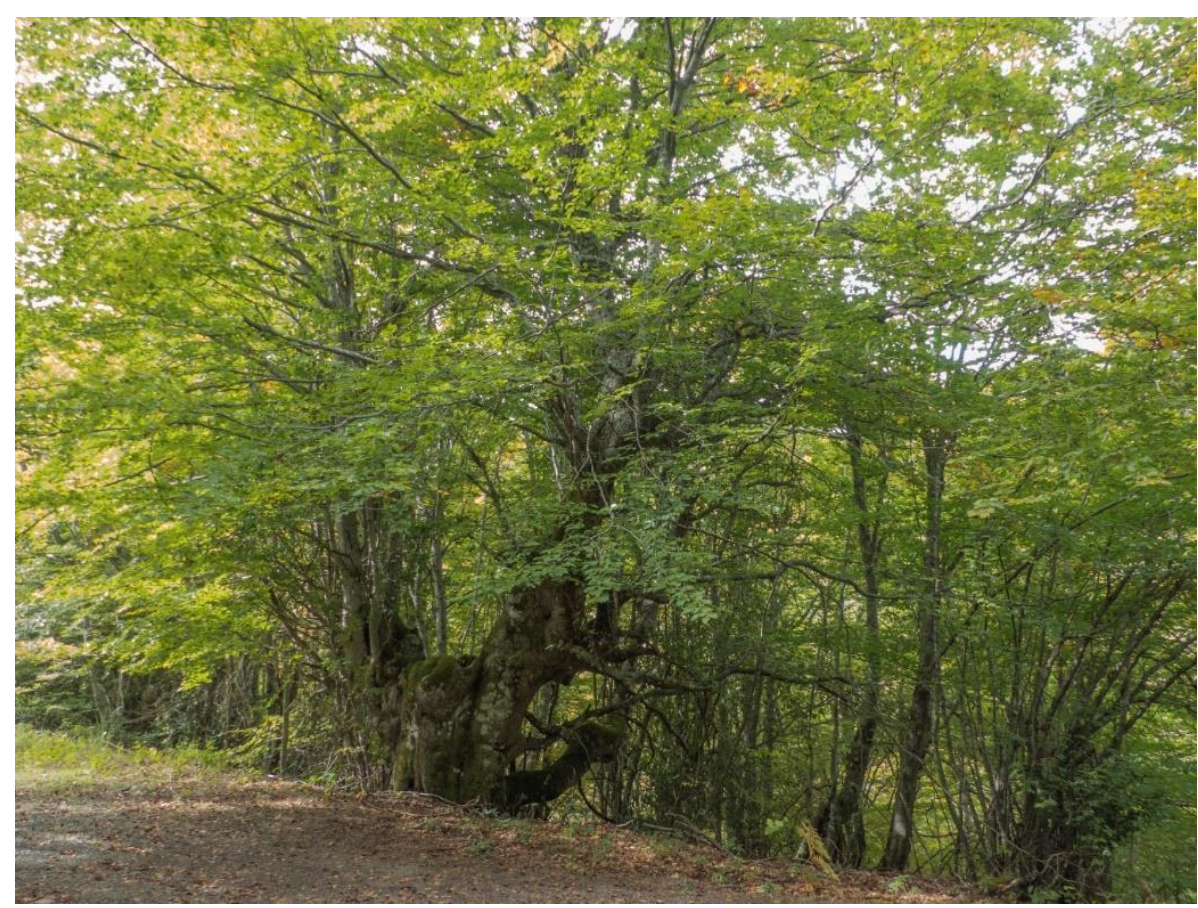

Figura 56. Haya (Fagus sylvatica) sujeta a distintos aprovechamientos en repetidas ocasiones, hayedo de Posada de Valdeón. Imagen propia.

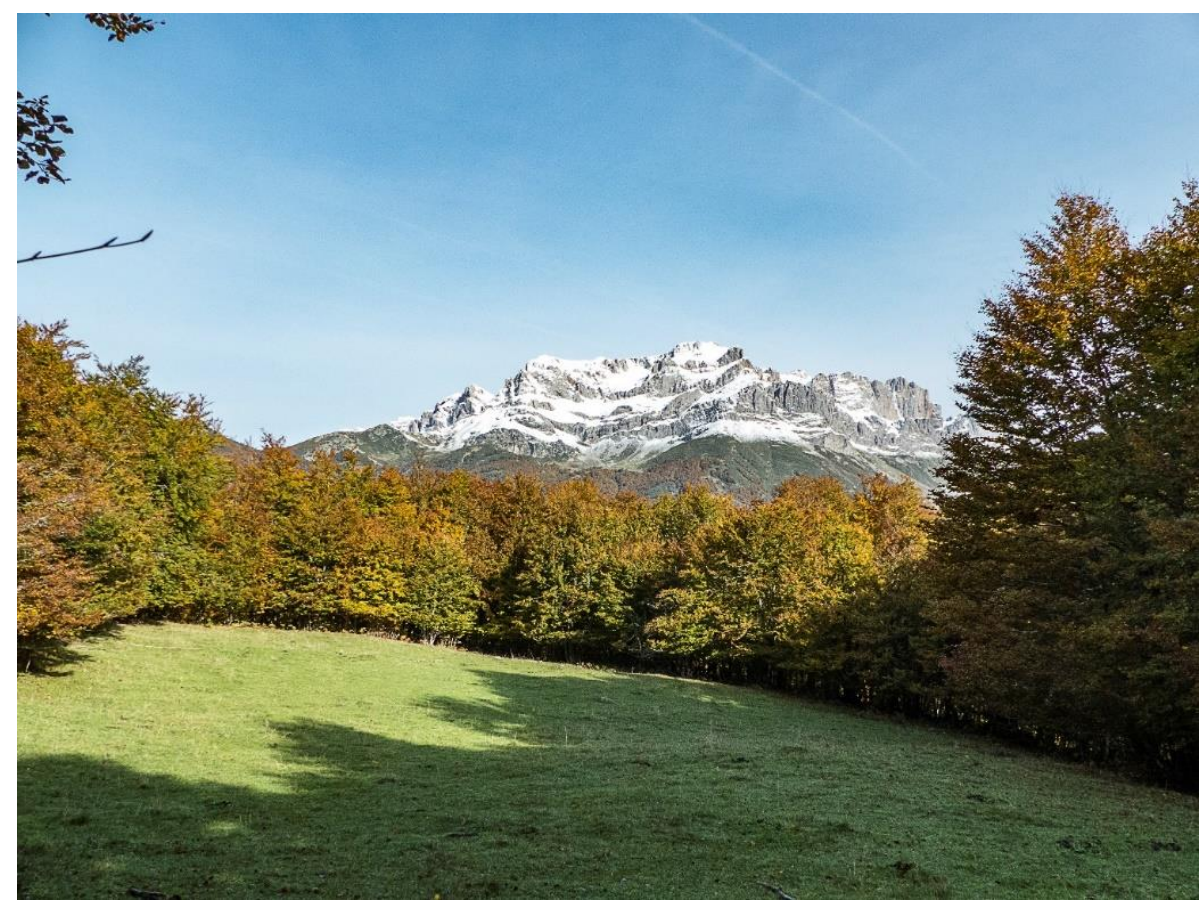

Figura 57. Espacio circular, diáfano, destinado a la elaboración de carbón en el hayedo de Posada de Valdeón. Imagen propia. 


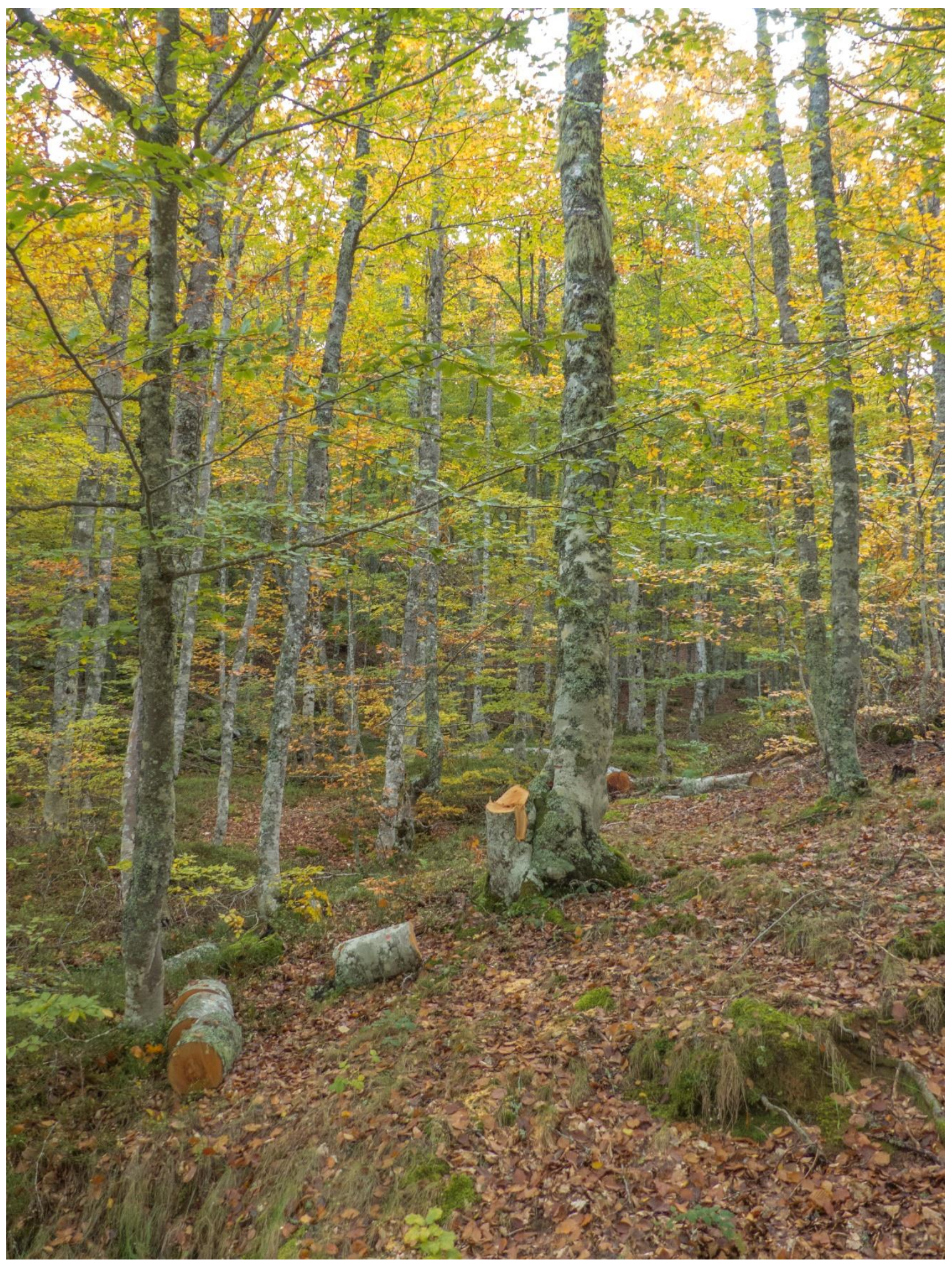

Figura 58. Haya intervenida con el objetivo de eliminar individuos dominados. Imagen propia. 
Grandes mamíferos: Se han observado diferentes especies de cérvidos, difícilmente identificables por la distancia. Aunque si existen especies emblemáticas que pueden determinar este indicador son el oso pardo cantábrico (Ursus arctos arctos) y el Lobo ibérico (Canis lupus signatus). En este caso, ante la excesiva dificultad de observar a estos grandes mamíferos se acude a referencias externas fiables. Así se constata la existencia de poblaciones de lobo ibérico en avance (García et al., 2014) y una población constante de oso pardo en el hayedo de Valdeón (Ezquerra et al., 2009; Luque, 2014).

Diversidad biológica: Como se ha puesto de manifiesto en el indicador correspondiente (ver 0 ) el bosque de Valdeón tiene una alta complejidad biológica por lo que este vector está constatado.

De acuerdo con esto, la valoración es de 7 puntos al haber cumplido dos de estos criterios planteados inicialmente. Todos los vectores asociados al bosque refugio aparecen en el caso de este hayedo ( 4 puntos), por lo que cumple tambien el criterio de poseer vectores de todos los tipos (3 puntos). Por otro lado, están tratados patrimonialmente dos de los 5 vectores (grandes mamíferos bajo protección ambiental de Parque Nacional y la diversidad biológica mediante distintas figuras como por ejemplo Hábitat de Interés Comunitario) Los vectores asociados a la ordenación y las prácticas culturales no están tratados patrimonialmente por lo que no cumple este criterio (Tabla 22). 


\begin{tabular}{|c|c|c|}
\hline Criterio & Puntuación & Cumplimiento \\
\hline Todos los vectores & 4 & $\begin{array}{c}\text { Todos los vectores } \\
\text { se han identificado }\end{array}$ \\
\hline Al tratados & 3 & $\begin{array}{c}\text { Solo dos de los } 5 \\
\text { han sido tratados }\end{array}$ \\
tipos & 3 & $\begin{array}{c}\text { Todos los tipos de } \\
\text { vectores se han } \\
\text { identificado }\end{array}$ \\
\hline
\end{tabular}

Tabla 22. Resumen criterios cumplidos valoración indicador Vectores Patrimoniales

\subsubsection{Indicador 4. Identificación y sentimiento de pertenencia}

\begin{tabular}{|l|c|}
\hline Criterio & Puntuación \\
\hline Toponimia & 2 \\
\hline Heráldica & 2 \\
\hline Iconografía administración & 2 \\
\hline Iconografía de particulares & 2 \\
\hline Referencias de asociaciones & 2 \\
\hline
\end{tabular}

Tabla 23. Resumen criterios valoración indicador Identificación de la población

La valoración de este indicador se fundamenta en las evidencias que existen de apropiación cultural para fundamentar el sentimiento de pertenencia de la población local. Para fijar objetivamente esta apropiación se propusieron una serie de referencias que relacionan el paisaje forestal con la iconografía o simbología utilizada por las administraciones o los particulares a la hora de plasmar su identidad (ver 6.3.4).

En este sentido se han encontrado escasas referencias que permitan asociar la iconografía local con su paisaje forestal. La existencia del Parque Nacional fundamentado, en buena medida, en las características geológicas 
y geomorfológicas, absorbe las referencias iconográficas, lo que se traduce en una identificación local más centrada en las grandes crestas calcáreas o los profundos y angostos valles kársticos. Igualmente se ve reflejada la secular relación con los prados de altura, la ganadería extensiva pero no parece relevante la toponimia relacionada con la economía tradicional de producción de aperos de madera de haya o roble.

En lo que se refiere a la toponimia, revisada a partir del Nomenclátor geográfico básico de máxima actualidad editado por el Instituto Geográfico Nacional, se han identificado algunas referencias asociadas al monte (Monte Redondo, Monte Valdestrés o Robledo), pero en ningún caso se han encontrado referencias concretas al hayedo. De igual manera se han identificado topónimos referidos al uso ganadero tradicional (Sestil Ruedina, Pradolargo, Cabreriza, Majada Pasterez, etc) y multitud de referencias geomorfológicas (Peña Las Cabras, Gargantera, Loma Sellado, Collado Colgandoiro, Pico del Cuerno, etc.). Con todo esto se resuelve que no puede cumplir el criterio.

En cuanto a la heráldica del municipio no aparece ninguna referencia forestal. Se resuelve mediante referencias a una posada y al río Cares que articula el valle. Por este motivo no cumple el criterio propuesto (Figura 59).

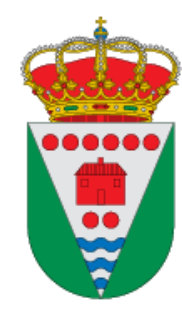

\section{Ayuntamiento \\ Posada de Valdeón \\ LEÓN | CASTILLA Y LEÓN}

Figura 59. Escudo del municipio de Posada de Valdeón. Recuperado de www.valdeon.org.

En cuanto a la iconografía utilizada por la administración como referencia corporativa, el ayuntamiento va a acudir a referencias relacionadas con aspectos geomorfológicos (Figura 60), en ningún caso se 
han encontrado referencias al paisaje forestal del hayedo, por lo que no cumple este criterio de valoración.

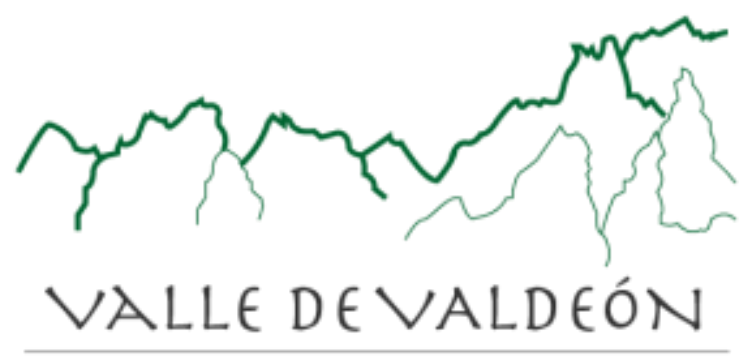

PARQUE NACIONAL DE LOS PICOS DE EUROPA I LEÓN I CASTILLA Y LEÓN

Figura 60. Imagen corporativa del Ayuntamiento de Posada de Valdeón. Recuperado de www.valdeon.org

En lo que se refiere a la simbología utilizada por particulares para identificar sus negocios, en ningún caso se han encontrado referencias al hayedo, al igual que sucede con la simbología corporativa del ayuntamiento, los aspectos geomorfológicos van a dominar (Figura 61). Por todo esto, no cumple el criterio propuesto.
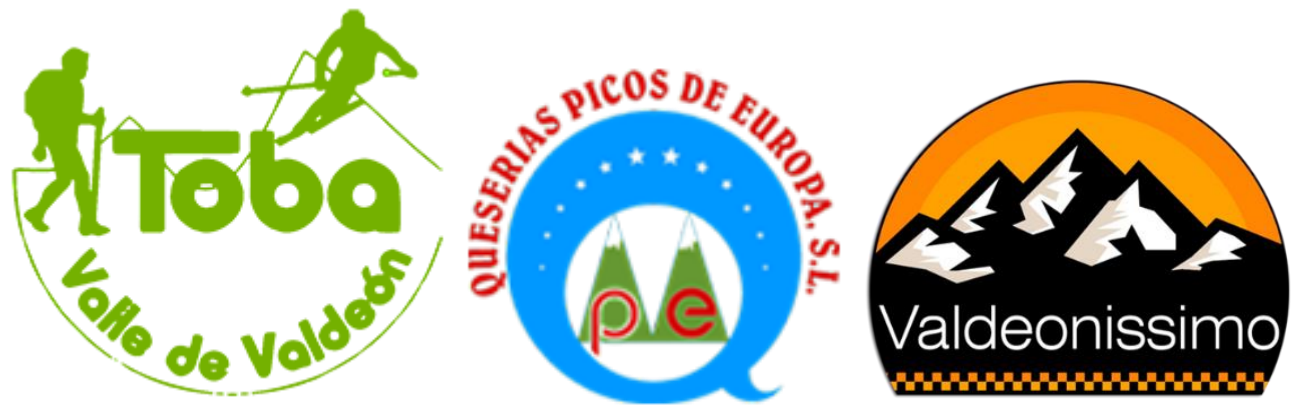

Figura 61. Imágenes de distintos negocios en Posada de Valdeón. De izquierda a derecha: Toba aventura (www.tobaraventura.com), Queserías Picos de Europa S.L. (www.quesospicosdeeuropa.com), Taxis Valdeonissimo (www.valdeonissimo.com).

Al igual que en los casos anteriores no se han encontrado referencias iconográficas que asocien el paisaje forestal en cuestión con la identificación de la sociedad civil organizada, en la única asociación que se ha encontrado con iconografía se acude al urogallo cantábrico, especie 
animal de singular relevancia en la montaña cantábrica (Figura 62), la otra asociación presente en el municipio, sin iconografía como tal, acude para tomar nombre a una especie vegetal muy relevante, así, la Asociación de Mujeres El Acebo" no hace referencia al hayedo. De este modo, se conviene que no cumple el criterio planteado.

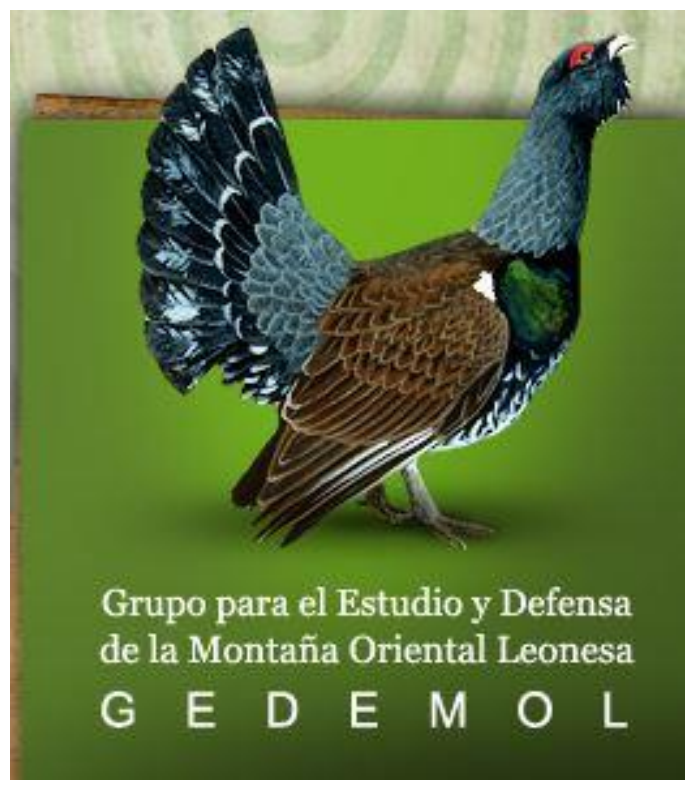

Figura 62. Logotipo utilizado por el Grupo para el Estudio y Defensa de la Montaña Oriental Leonesa sito en Santa Marina de Valdeón. Recuperado de www.gedemol.org

En este caso, el paisaje forestal asociado al hayedo de Posada de Valdeón no cumple ninguno de los criterios propuestos (Tabla 24) por lo que su valoración para este indicador es de 0 puntos. 


\begin{tabular}{|c|c|c|}
\hline Criterio & Puntuación & \begin{tabular}{c} 
Cumplimiento \\
\hline Toponimia
\end{tabular} \\
\hline Heráldica & 2 & $\begin{array}{c}\text { No se encuentran } \\
\text { topónimos }\end{array}$ \\
\hline Iconografía administración & 2 & $\begin{array}{c}\text { No aparecen } \\
\text { referencias al } \\
\text { hayedo }\end{array}$ \\
\hline Iconografía de particulares & 2 & $\begin{array}{c}\text { La administración } \\
\text { no usa referencias } \\
\text { al hayedo }\end{array}$ \\
\hline Referencias de asociaciones & 2 & $\begin{array}{c}\text { Los particulares no } \\
\text { usan referencias al } \\
\text { hayedo }\end{array}$ \\
\hline $\begin{array}{l}\text { Tabla 24. Resumen criterios cumplidos valoración indicador } \\
\text { población }\end{array}$ & & $\begin{array}{c}\text { Identificación de la } \\
\text { usan referencias } \\
\text { vinculadas con el } \\
\text { hayedo }\end{array}$ \\
\hline
\end{tabular}

\subsubsection{Indicador 5. Museística}

\begin{tabular}{|l|c|}
\hline Criterio & Puntuación \\
\hline Centros de interpretación / museos oficiales & 4 \\
\hline Museos de particulares & 2 \\
\hline Jornadas de exaltación & 2 \\
\hline Mobiliario de exhibición o exaltación & 2 \\
\hline
\end{tabular}

Tabla 25. Resumen criterios valoración indicador Museística.

Este indicador, que se basa en la existencia de espacios destinados a conservar y ensalzar los valores propios de prácticas tradicionales. Suponen un testigo fiable para identificar la salud patrimonial de cualquier elemento, por este motivo se afirma que la existencia y recurrencia de 
estos espacios es fundamental para valorar el instante patrimonial de un paisaje.

En consecuencia, hay que señalar que, asociado al Parque Nacional se está construyendo un espacio de próxima inauguración para la recepción de visitantes (Figura 63) (sin fecha prevista por parte de ninguna administración consultada). Este espacio, sin duda, ensalzará los valores del hayedo recogiendo, en cierta medida, su valor patrimonial. Pero esto se ve diluido entre la complejidad y riqueza del Parque, por lo que la preponderancia del valor patrimonial del hayedo se supedita a otros aspectos naturales, biológicos o sociales. En cualquier caso, Posada de Valdeón cuenta con un espacio oficial destinado al Parque, por lo que cumple el criterio propuesto, obteniendo 4 puntos.

- leonoticias.com/comarcas/posada-valdeon-albergara-20200806132829-nthtml

In Comarcas | Posada de Valdeón albergará un centro de información del Parque Nac Comarcas León San Andrés Villaquilambre Valverde Astorga La Bañeza Sur c

\section{Posada de Valdeón albergará un centro de información del Parque Nacional de los Picos de Europa}

Solo en julio, han visitado el Centro de Oseja de Sajambre 1.150 personas, que han participado en el programa de actividades diseñado para este verano

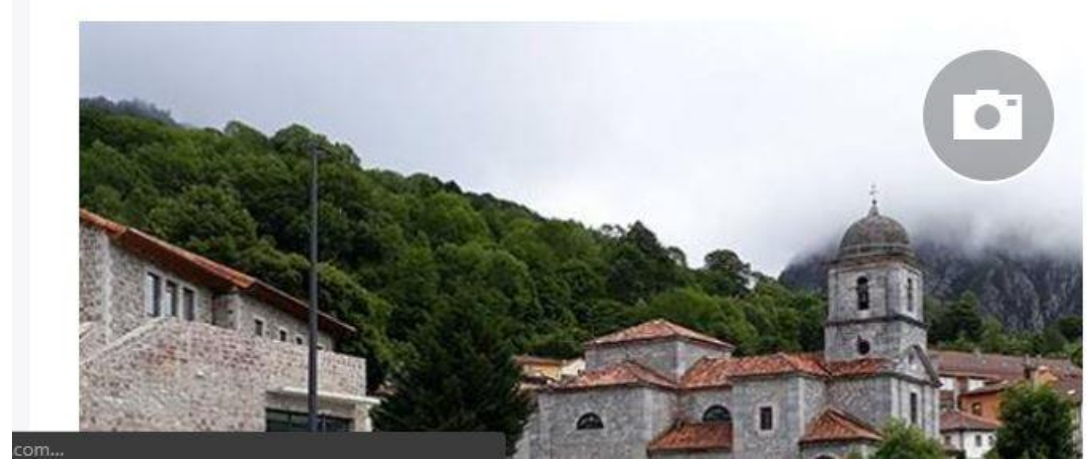

Figura 63. Una de las noticias relacionadas con la instalación destinada a la recepción de visitantes en Posada de Valdeón. Recuperado de https: / / www.leonoticias.com/comarcas/posada-valdeon-albergara-20200806132829nt.html 
En cuanto a los museos de particulares que pudieran recoger y ensalzar los valores del paisaje forestal que nos ocupa, no se ha encontrado ninguna referencia por lo que no puede cumplir este criterio.

Los eventos o jornadas destinados a poner en valor las prácticas tradicionales asociadas al hayedo no parecen tener lugar en este municipio al no encontrar ninguna referencia a este tipo de eventos. Se han encontrado otros eventos asociados con el folclore, usos y prácticas tradicionales y gastronomía (Figura 64). En este caso el criterio planteado no se cumple.
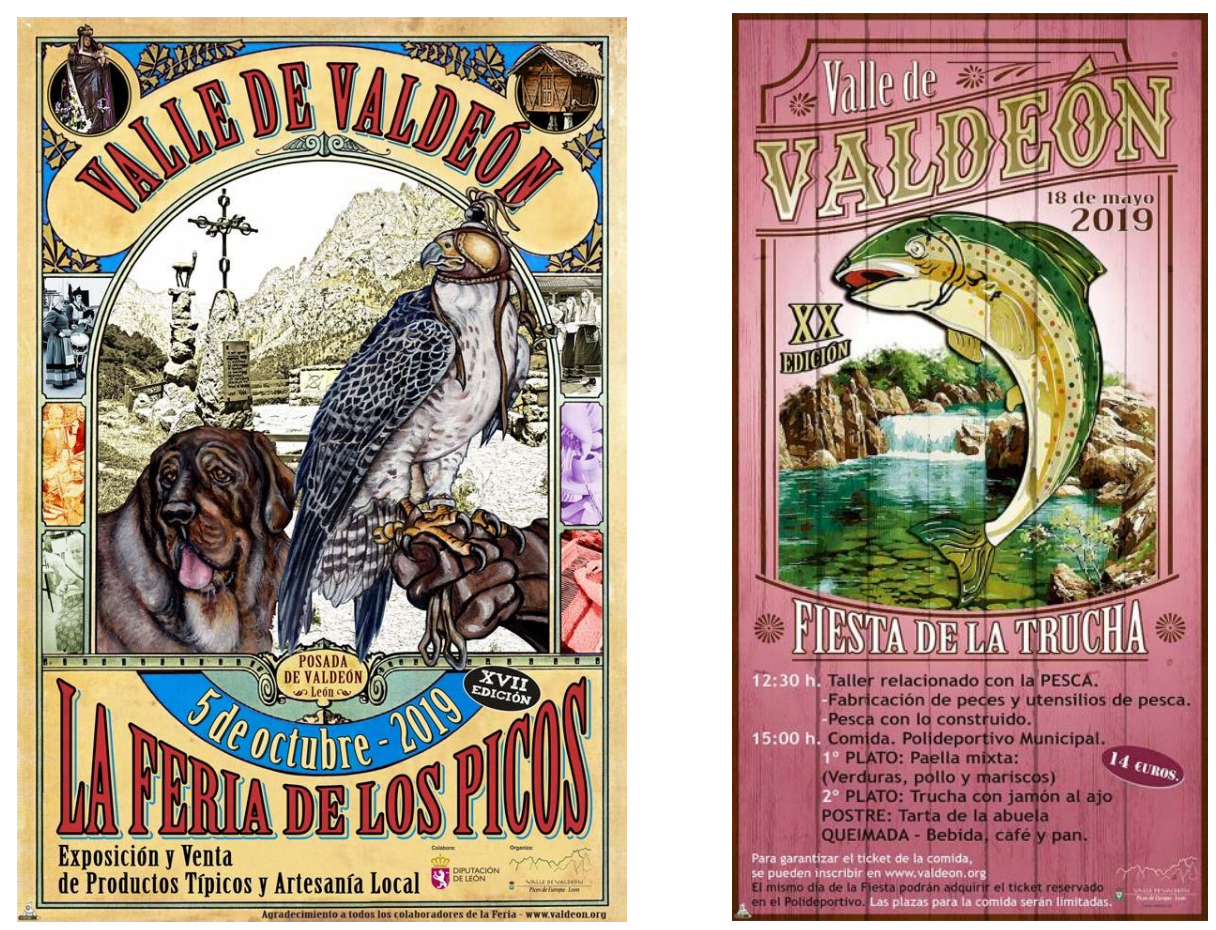

Figura 64. Carteles de dos de los eventos tradicionales más relevantes en Posada de Valdeón. Recuperados de https://valdeon.org/actualidad/fiestas-y-celebraciones/

No se han encontrado elementos de mobiliario público destinado a ensalzar los valores de las prácticas culturales asociadas al paisaje forestal del hayedo. En cambio, existen elementos inscritos a la tradición ganadera como el famoso “Chorco de los Lobos” (Figura 65), el excepcional cuidado de la Ermita de Corona (Figura 66), la restauración de los Hórreos 
tradicionales (Figura 67) o la representación de una cabra en el Mirador del Tombo (Figura 40), que presentan un importante tratamiento patrimonial. Por tanto, se demuestra que existe una preocupación patrimonial que no está centrada en el paisaje del hayedo y sus prácticas tradicionales. Con estas premisas se puede asegurar que no cumple el criterio propuesto.

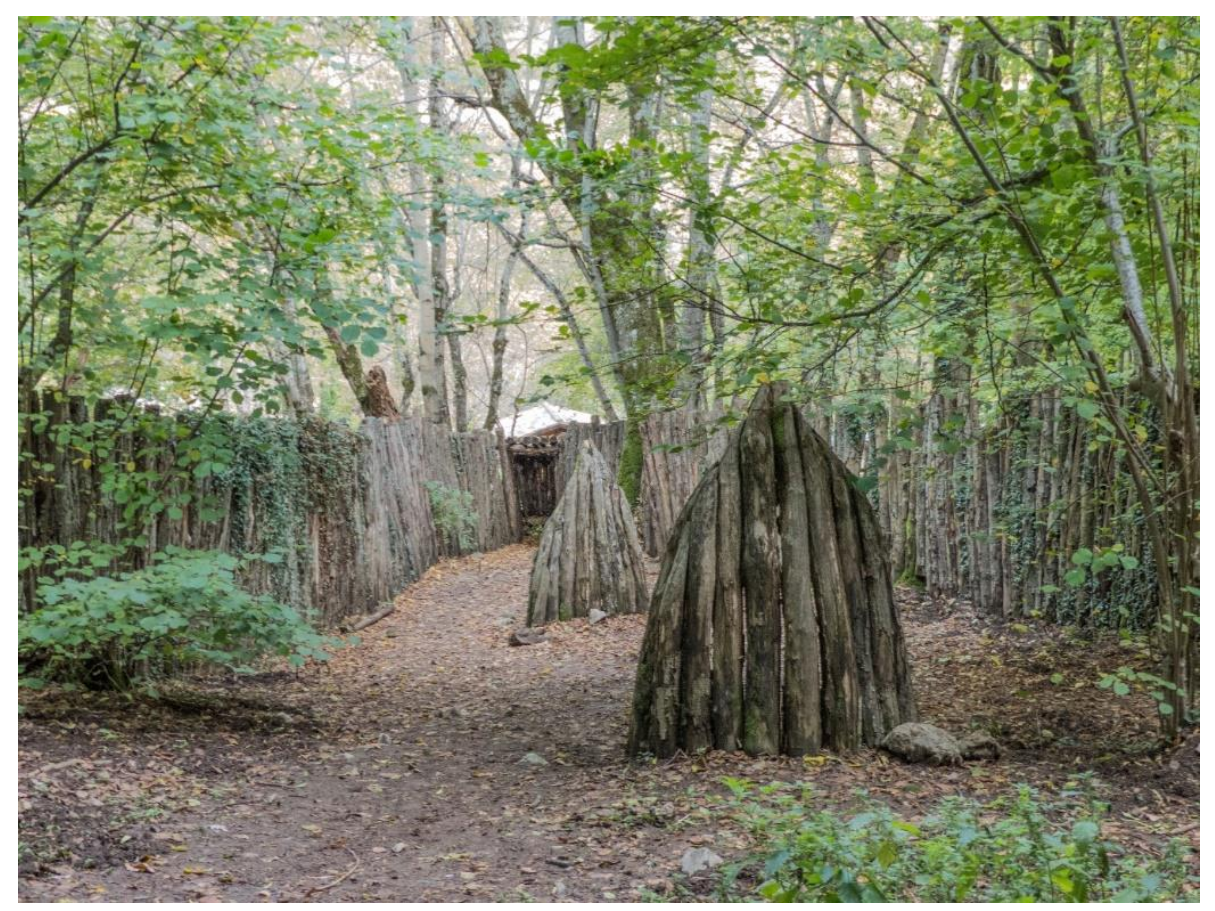

Figura 65. El "Chorco de los Lobos", construcción tradicional para el control poblacional de lobos ibéricos en Posada de Valdeón. Imagen propia. 


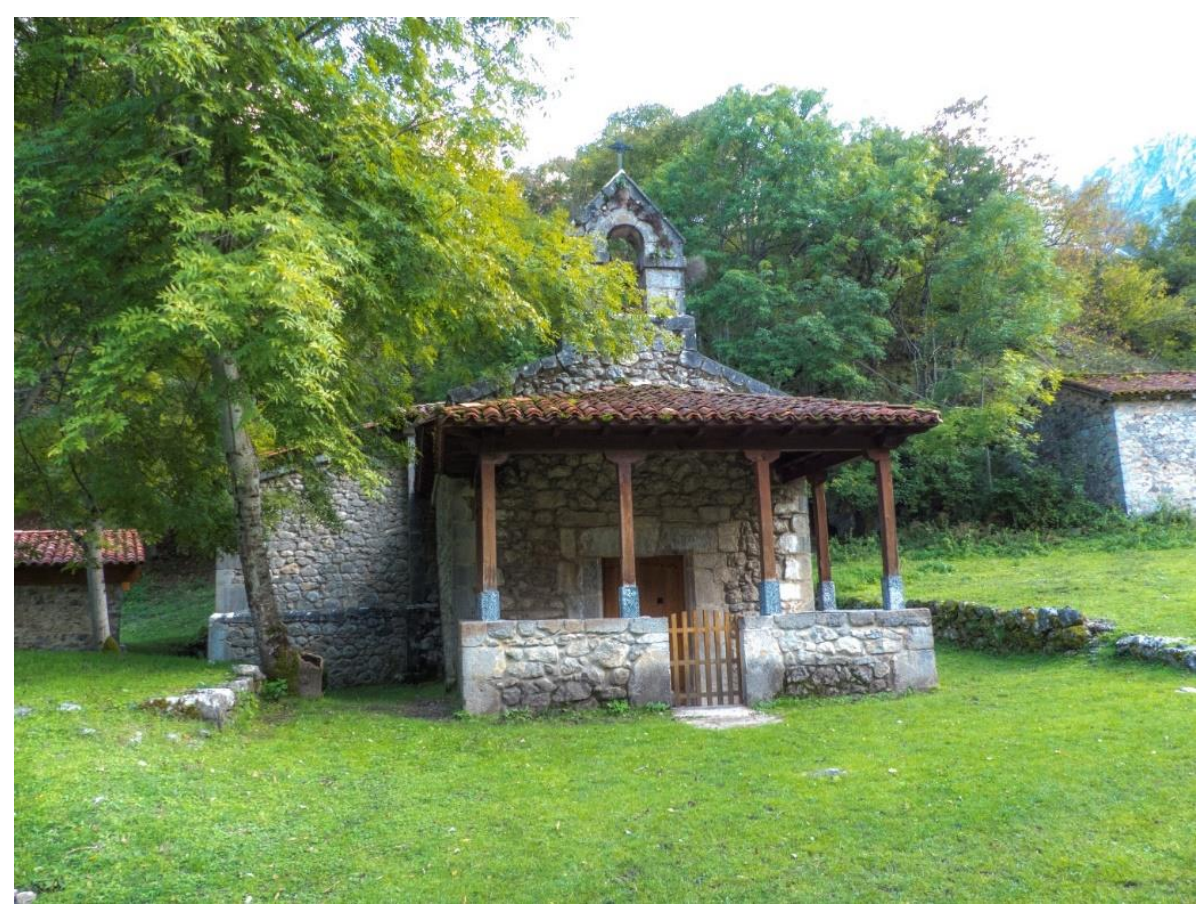

Figura 66. Ermita Corona en Posada de Valdeón. Imagen propia.

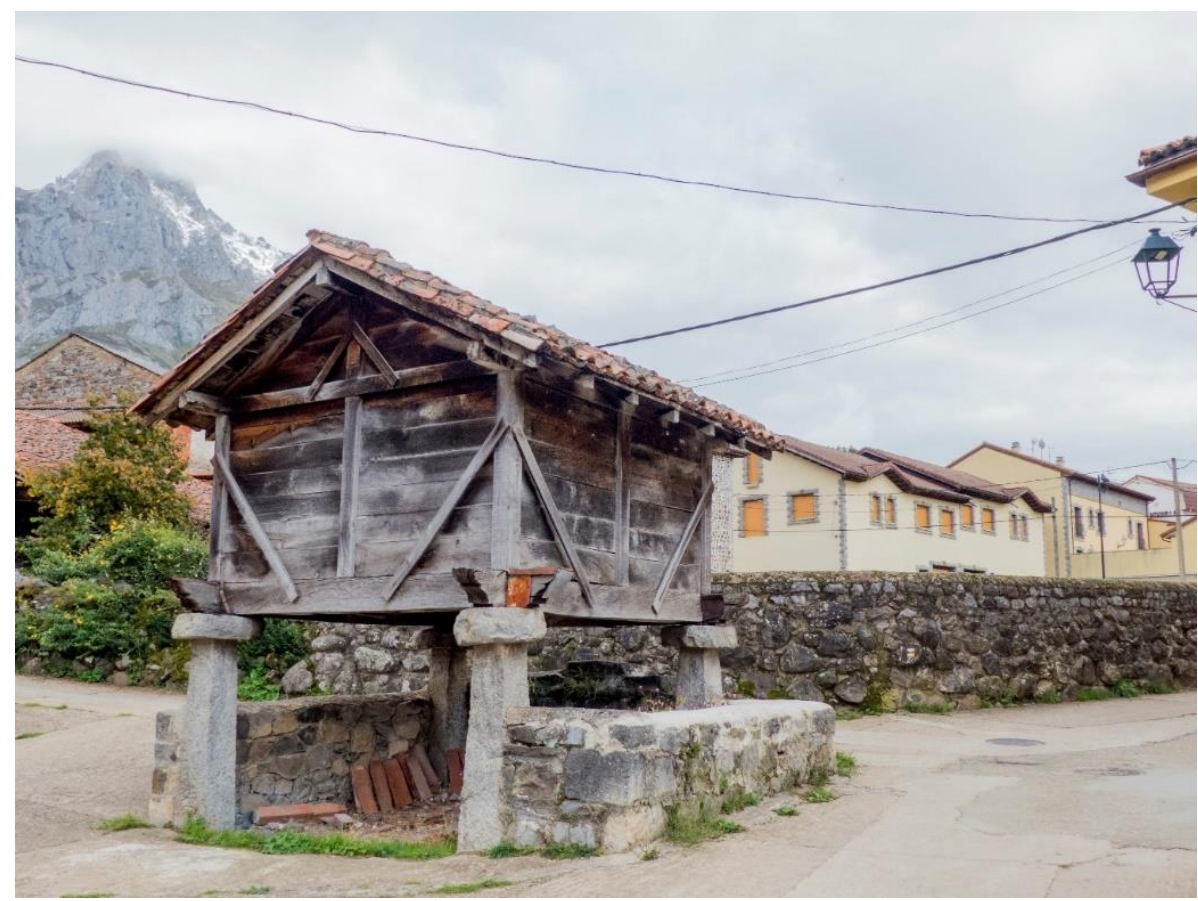

Figura 67. Hórreo tradicional en el núcleo de Posada de Valdeón. Imagen propia. 
De acuerdo con la matriz planteada, el indicador destinado a valorar la musealización del paisaje forestal del hayedo de Valdeón tiene una puntuación de 4 puntos sobre 10 (Tabla 26).

\begin{tabular}{|c|c|c|}
\hline Criterio & Puntuación & Cumplimiento \\
\hline oficiales & 4 & $\begin{array}{c}\text { Centro de } \\
\text { recepción de } \\
\text { visitantes del } \\
\text { Parque Nacional }\end{array}$ \\
\hline Museos de particulares & 2 & $\begin{array}{c}\text { No se han } \\
\text { encontrado }\end{array}$ \\
\hline Jornadas de exaltación & 2 & $\begin{array}{c}\text { No se han } \\
\text { encontrado }\end{array}$ \\
\hline Mobiliario de exhibición o exaltación & 2 & $\begin{array}{c}\text { No se ha } \\
\text { encontrado }\end{array}$ \\
\hline
\end{tabular}

Tabla 26. Resumen criterios cumplidos valoración indicador Museística.

\subsubsection{Indicador 6. Incorporación turística}

\begin{tabular}{|l|c|}
\hline Criterio & Puntuación \\
\hline Reivindicación turística supramunicipal & 4 \\
\hline Reivindicación turística municipal & 2 \\
\hline Reivindicación turística de particulares & 2 \\
\hline Reivindicación turística igual que otros elementos & 2 \\
\hline
\end{tabular}

Tabla 27. Resumen criterios valoración indicador Incorporación Turística.

En el contexto actual el patrimonio es utilizado de manera recurrente como reclamo turístico. De esta forma y de acuerdo con lo planteado en el apartado correspondiente, donde se especifica la valoración de este 
indicador (ver 6.3.6) la reiteración del uso del patrimonio forestal va a ser uno de los indicadores más fiables para reconocer el momento patrimonial en que se encuentra un paisaje forestal.

En lo que se refiere a administraciones supramunicipales que utilicen el hayedo como reclamo turístico no se han encontrado referencias. Los reclamos turísticos de administraciones como la Diputación de León o la Junta de Castilla y León que se ocupan del municipio de Posada de Valdeón se centran en la espectacular ubicación del valle entre dos crestas calcáreas y aluden, de forma generalizada a la ruta del Cares como gran reclamo (Figura 68). Por estos motivos no cumple el criterio propuesto.

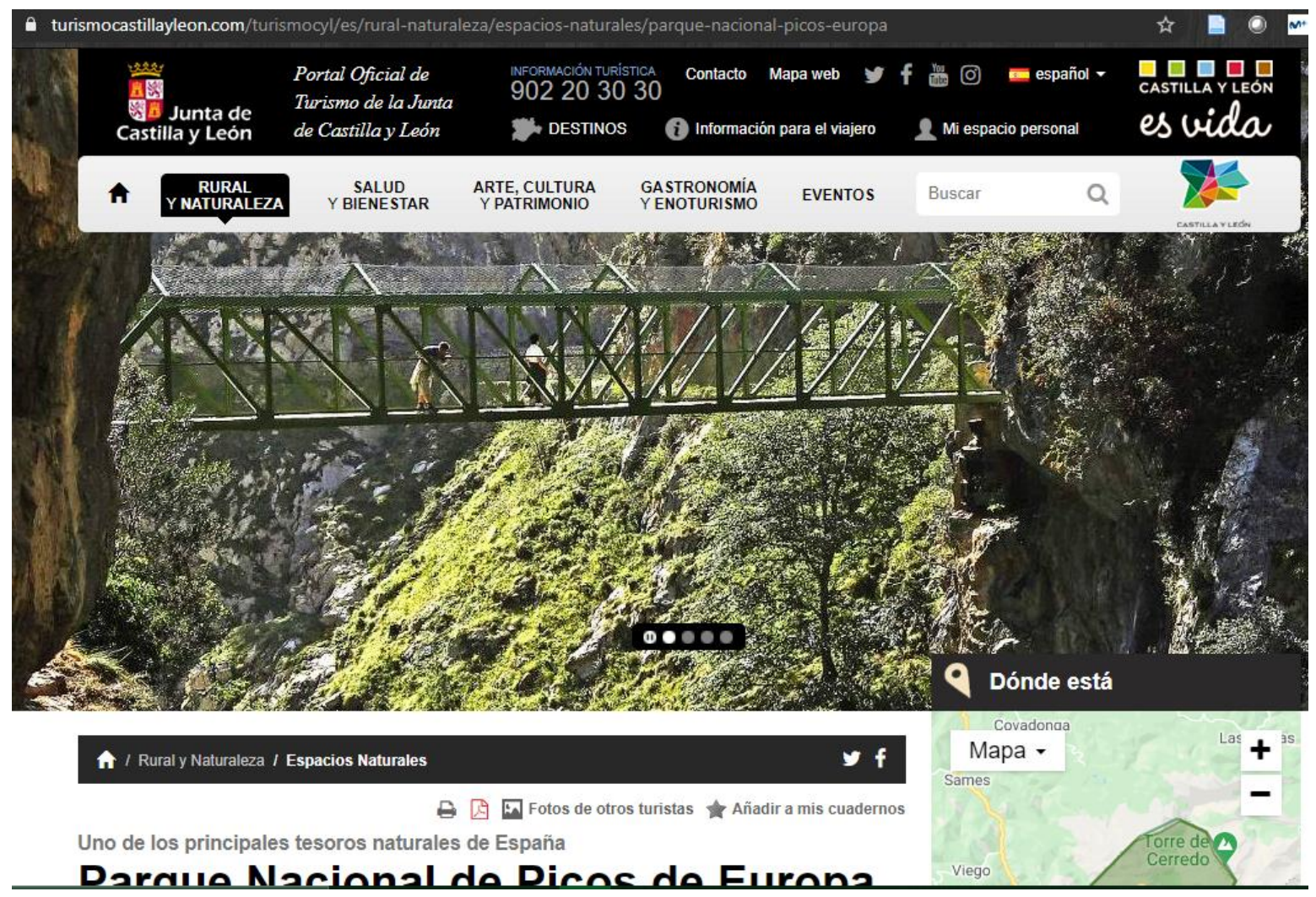

Figura 68. La ruta del Cares como principal reclamo en el portal de turismo de la Junta de Castilla l León. Recuperado de https: / / www.turismocastillayleon.com/turismocyl/es/rural-naturaleza/espaciosnaturales/parque-nacional-picos-europa. 
En el caso que ocupa a este capítulo, se ha encontrado alguna referencia a la nueva declaración UNESCO de los hayedos primigenios (Figura 69). En este caso el criterio planteado de reclamo turístico de nivel municipal se cumple, por lo que se valora con 2 puntos.

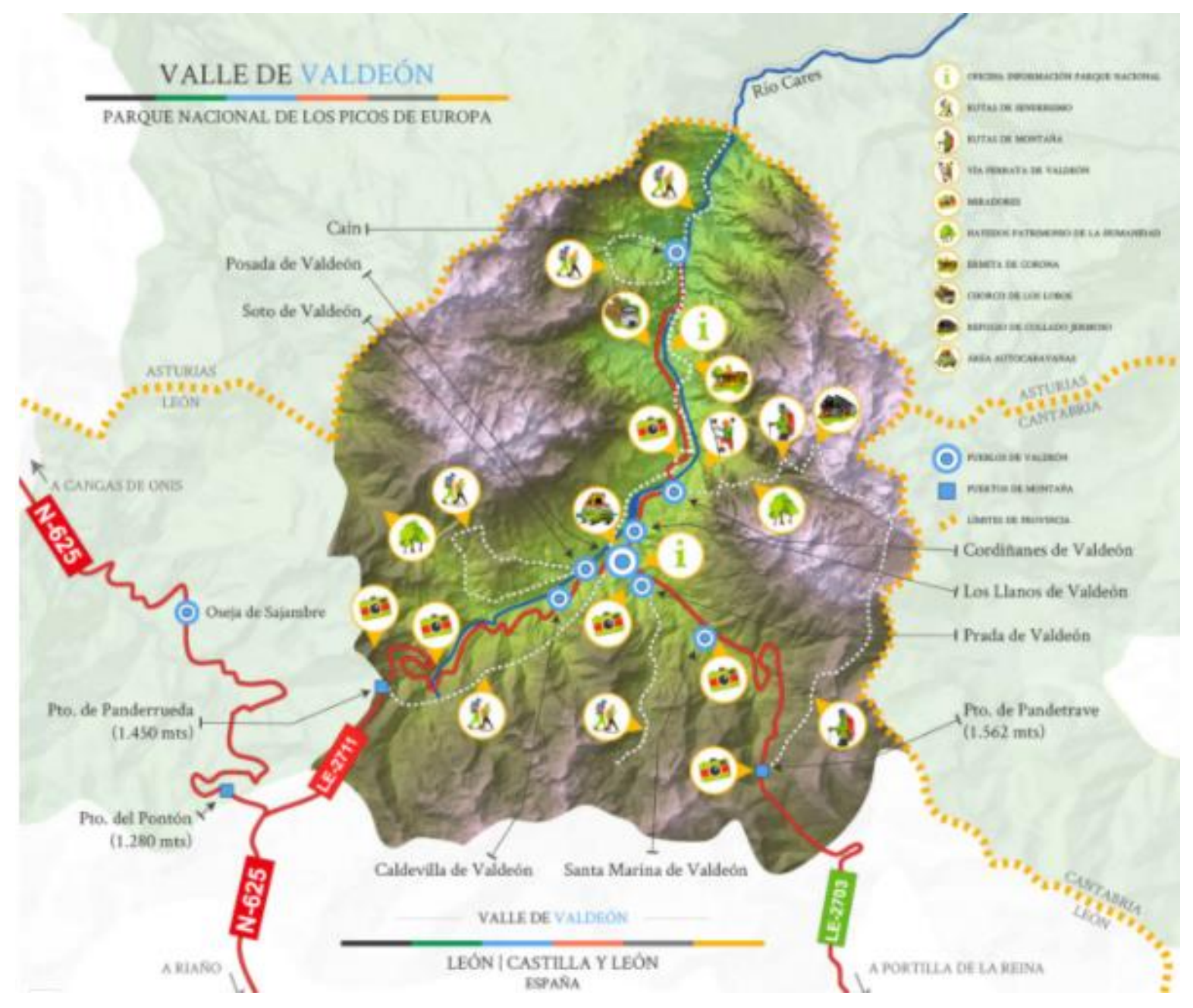

Figura 69. Mapa turístico interactivo del Municipio de Posada de Valdeón, en el se puede apreciar la importancia que tienen los hayedos Patrimonio de la Humanidad. Recuperado de: https://valledevaldeon.es/descubre-valdeon/mapa-interactivo/

Los particulares que ostentan negocios relacionados con el turismo, fundamentalmente la hostelería, no van a utilizar el hayedo como reclamo para sus negocios. Fundamentalmente centran su imagen en aspectos geomorfológicos (Figura 70) y otros elementos patrimoniales como los 
hórreos (Figura 71). El criterio que se ocupa de esta relación entre el paisaje forestal y la identificación turística de actividades privadas no se cumple.

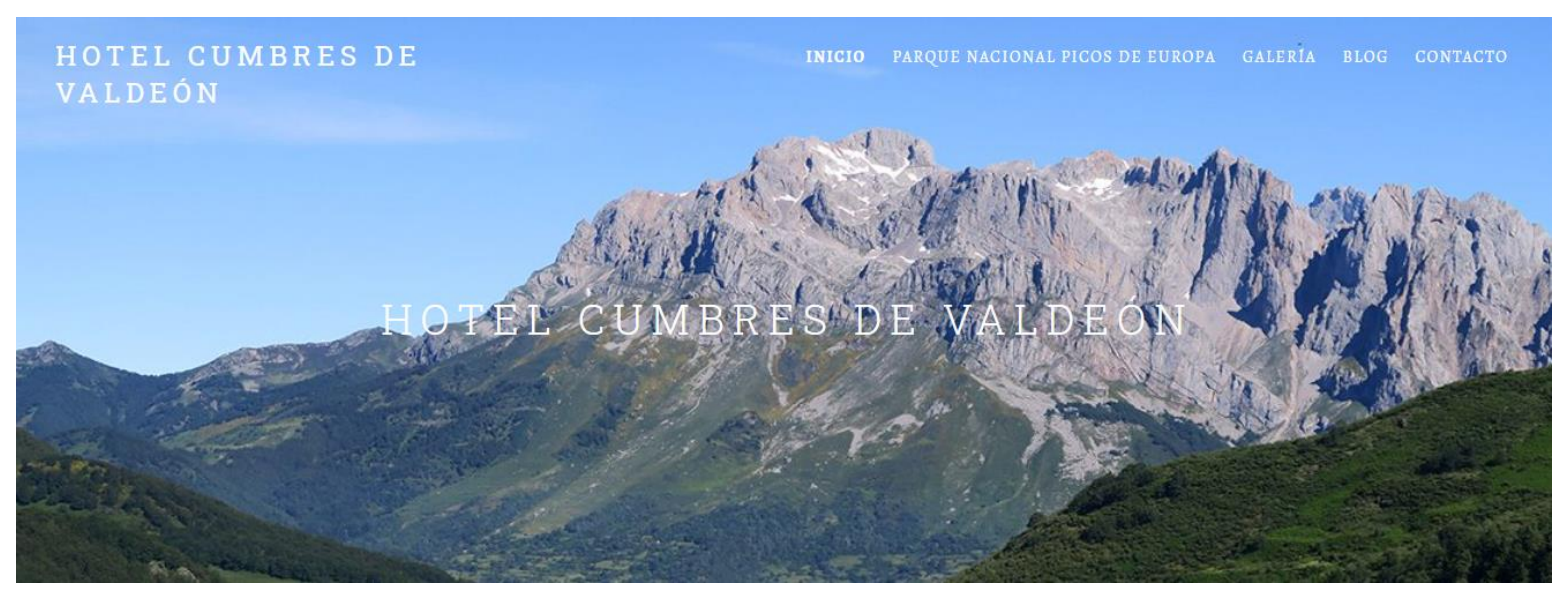

Figura 70. Infografía Hotel Cumbres de Valdeón, uno de los alojamientos más importantes del municipio. Recuperado de: https://hotelcumbresvaldeon.com
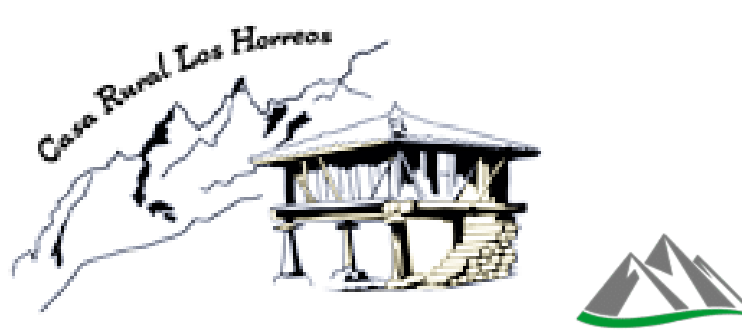

CASA RURAL EL TOMBO LA RISA

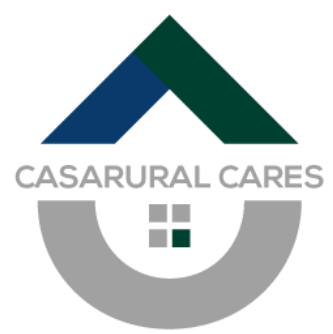

Figura 71. Infografías de algunas de las casas rurales más relevantes del Municipio de Posada de Valdeón. Recuperado de: https://casaruralposadadevaldeon.com; https: //www.eltombolarisa.com /; https: / / casaruralcares.com/; respectivamente.

Como se ha visto, los reclamos turísticos se centran especialmente en las características geomorfológicas del valle, especialmente se alude a las crestas calcáreas y a la conocida ruta del río Cares. De este modo no cabe más que señalar que este criterio planteado no se cumple. 


\begin{tabular}{|c|c|c|}
\hline Criterio & Puntuación & Cumplimiento \\
\hline $\begin{array}{ll}\text { Reivindicación } & \text { turística } \\
\text { supramunicipal } & \end{array}$ & 4 & $\begin{array}{c}\text { No se han } \\
\text { encontrado } \\
\text { referencias al } \\
\text { hayedo }\end{array}$ \\
\hline Reivindicación turística municipal & 2 & $\begin{array}{c}\text { El hayedo aparece } \\
\text { en reclamos } \\
\text { municipales }\end{array}$ \\
\hline $\begin{array}{lll}\text { Reivindicación } & \text { turística } & \text { de } \\
\text { particulares } & \end{array}$ & 2 & $\begin{array}{c}\text { No se han } \\
\text { encontrado } \\
\text { referencias al } \\
\text { hayedo }\end{array}$ \\
\hline $\begin{array}{l}\text { Reivindicación turística igual que } \\
\text { otros elementos patrimoniales }\end{array}$ & 2 & $\begin{array}{l}\text { El hayedo queda en } \\
\text { un segundo plano }\end{array}$ \\
\hline
\end{tabular}

Tabla 28.: Resumen criterios cumplidos valoración indicador Incorporación Turística

\subsubsection{Indicador 7. Empleo relacionado}

\begin{tabular}{|l|c|}
\hline Criterio & Puntuación \\
\hline Al menos 0,5\% ocupados en Silvicultura & 3 \\
\hline Al menos 5\% de ocupados en sectores relacionados & 3 \\
\hline Trabajadores silvicultura se incrementan & 2 \\
\hline Trabajadores relacionados se incrementan & 2 \\
\hline
\end{tabular}

Tabla 29. Resumen criterios valoración indicador Empleo relacionado.

El indicador que se basa en el empleo asociado con el paisaje forestal trata de poner de manifiesto la estrecha relación entre el valor de uso y el valor patrimonial. De acuerdo con esta relación, que en buena medida reactiva la preocupación social por el elemento patrimonial, se valora la vinculación patrimonio-sociedad. 
En cuanto a la información que ofrece Posada de Valdeón sobre los trabajadores, según los datos ofrecidos por la Seguridad Social, demuestra la escasa relación que tiene la actividad laboral con el bosque de hayas que caracteriza el paisaje forestal en cuestión. Para el año 2015 encontramos un trabajador ocupado en tareas referidas al epígrafe 02 (Silvicultura y explotación forestal) de la CNAE (Clasificación Nacional de Actividades Económicas). Este trabajador, en datos relativos sobre el total de trabajadores en este municipio para este mismo año (121), representa el $0,83 \%$ de los empleados, por lo que cumple el primer criterio de valoración.

En lo que se refiere al empleo relacionado, los epígrafes CNAE 16 (Industria de la madera y el corcho), 17 (Industria del papel) y 31 (Fabricación de muebles) para el año 2015, Posada de Valdeón no presenta ningún trabajador. De este modo la valoración de este epígrafe no cumple el criterio planteado.

En cuanto a la evolución de los trabajadores ocupados en la silvicultura, para los años previos a 2015 no está reflejado que hubiese ninguno ocupado en estas tareas, por lo que en este caso se cumple el criterio planteado.

Por otro lado, en las actividades relacionadas, o trabajos indirectos no se cumple, ya que solamente encontramos un trabajador ocupado en la fabricación de muebles para el año 2013, el resto de las actividades y año no reflejan trabajadores para ninguno de los años, por lo que estos empleos no se han incrementado. El empleo en Posada de Valdeón descansa fundamentalmente en las actividades de hostelería destinadas a satisfacer las necesidades de los turistas cada vez más numerosos (Figura 72). Se da por no cumplido este criterio. 
Estudio de casos y aplicación práctica. Paisajes forestales con valor patrimonial.

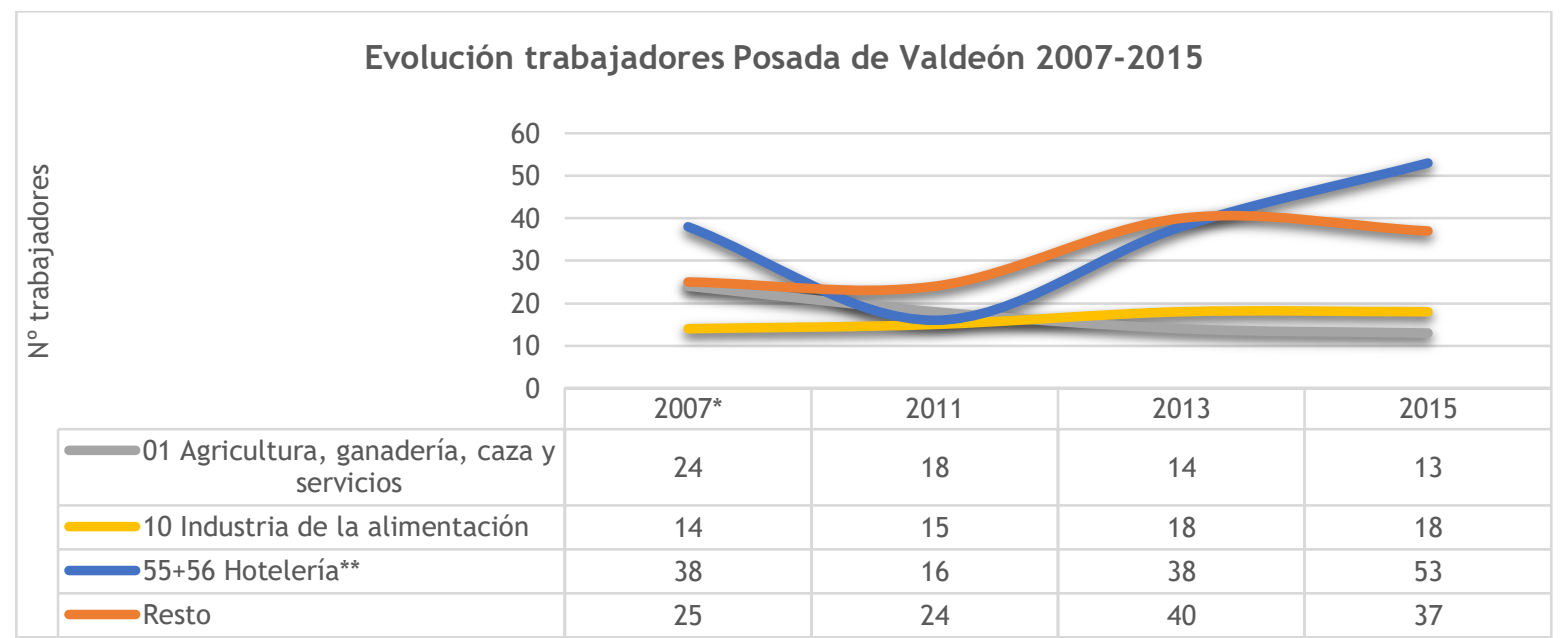

Figura 72. CNAE09 dos dígitos desagregado municipal. *transformación códigos CNAE93/CANE09. **CNAE 93 código 55. Elaboración propia.

\begin{tabular}{|c|c|c|}
\hline Criterio & Puntuación & Cumplimiento \\
\hline $\begin{array}{c}\text { Al menos 0,5\% ocupados en } \\
\text { Silvicultura }\end{array}$ & 3 & $\begin{array}{c}\text { Para 2015 el 0,83\% de } \\
\text { los trabajadores. } \\
\text { sectores relacionados }\end{array}$ \\
\hline $\begin{array}{c}\text { Trabajadores silvicultura se } \\
\text { incrementan }\end{array}$ & 2 & $\begin{array}{c}\text { No existen } \\
\text { trabajadores ocupados. } \\
\text { registrado supone un } \\
\text { incremento. }\end{array}$ \\
\hline $\begin{array}{c}\text { Trabajadores relacionados se } \\
\text { incrementan }\end{array}$ & 2 & No se incrementan. \\
\hline
\end{tabular}

Tabla 30. Resumen criterios cumplidos valoración indicador Empleo relacionado 


\subsubsection{Valoración final}

\begin{tabular}{|l|l|}
\hline Indicador & Valoración \\
\hline I1. Complejidad biológica & 10 \\
\hline 12. Figuras de protección & 10 \\
\hline 13. Existencia de vectores & 7 \\
\hline 14. Identificación y sentimiento de pertenencia & 0 \\
\hline 15. Centros de interpretación/museos & 4 \\
\hline 16. Incorporación turística & 2 \\
\hline 17. Empleo relacionado & 5 \\
\hline & Valoración final \\
\hline
\end{tabular}

Tabla 31. Valor obtenido por cada uno de los indicadores propuestos para el paisaje referente al municipio de Posada de Valdeón.

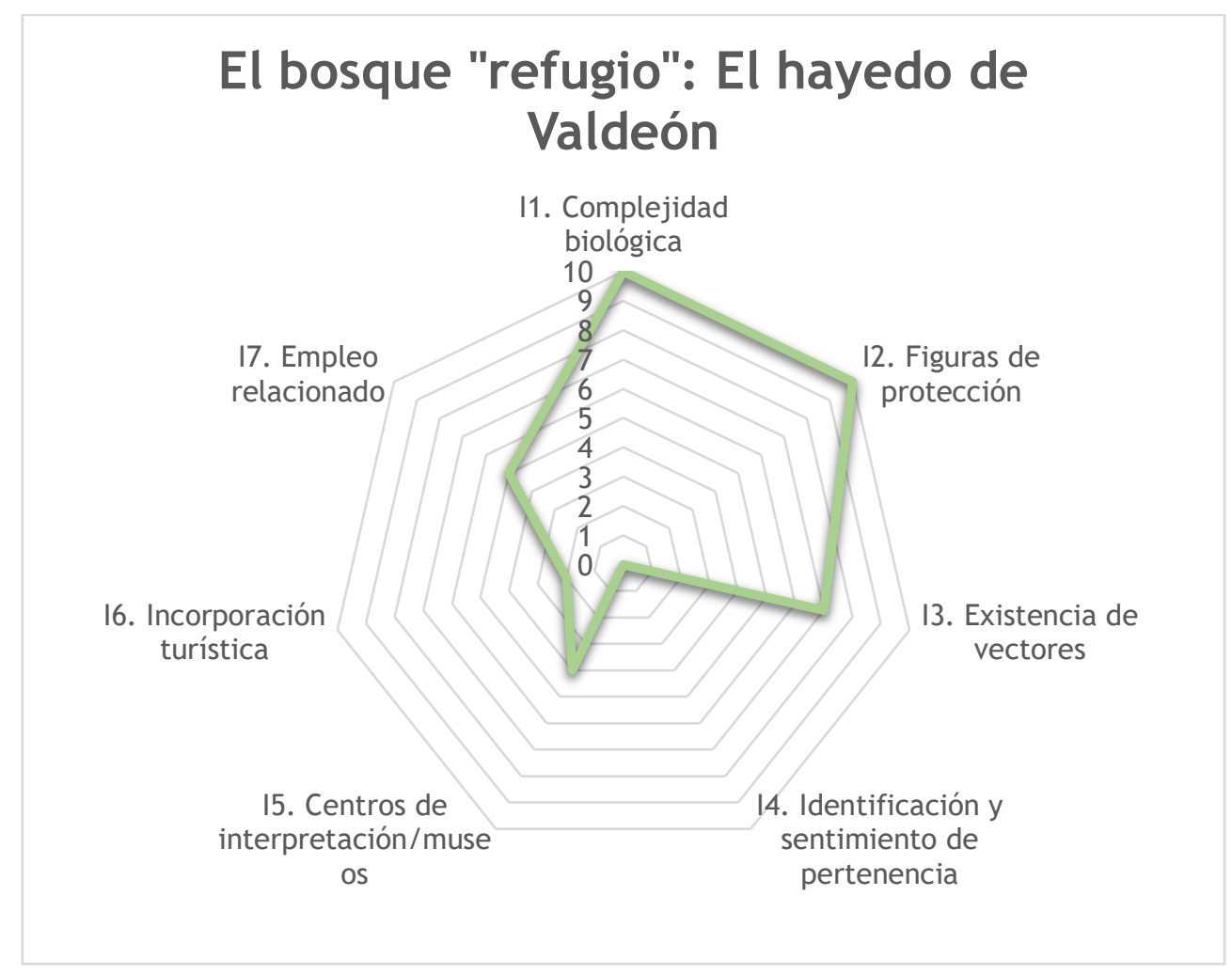

Figura 73. Representación de la situación patrimonial del hayedo de Posada de Valdeón según los indicadores analizados. Elaboración propia 


\section{Capítulo 8. Los bosques corporativos. La Tierra de Pinares de Valladolid y Segovia}


La Tierra de Pinares es una comarca con una marcada identidad propia, es el pinar el que, a lo largo de la historia, ha determinado ésta. Así podemos entender este paisaje como un paisaje patrimonial caracterizado por su contexto histórico, la vegetación autóctona de pinos y su consiguiente ordenación y explotación a lo largo de los siglos, es la clave para entender este espacio forestal, que hunde sus raíces en los valores históricos-corporativos, entendiendo su predominancia a una situación de aprovechamiento cultural.

\subsection{Distribución y localización del área de estudio}

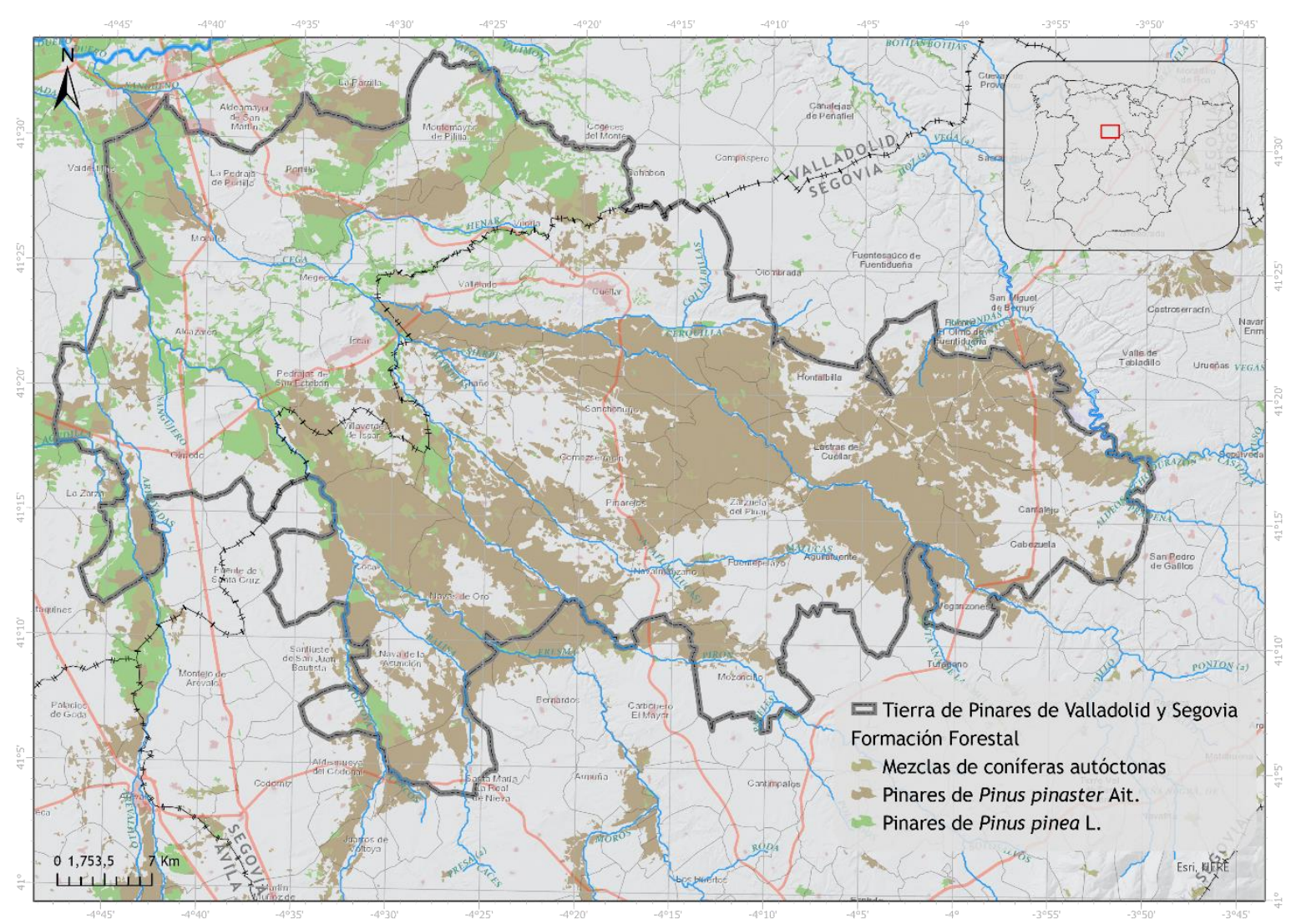

Figura 74. Mapa de localización del área de estudio escogida para la Tierra de Pinares de Valladolid y Segovia. Elaboración propia a partir de Mapa Forestal de España 1:50.000. 
El ámbito del estudio se sitúa en el centro de la cuenca del Duero exactamente repartido casi a partes iguales entre las provincias de Valladolid (mitad norte) y Segovia (mitad sur) (Figura 74). El límite escogido responde a los municipios donde el pinar representa una dominante de su paisaje y aparecen vinculados a diferentes estudios geográficos realizados sobre este territorio (Manero, 1983; Calonge, 1987; García, 2004).

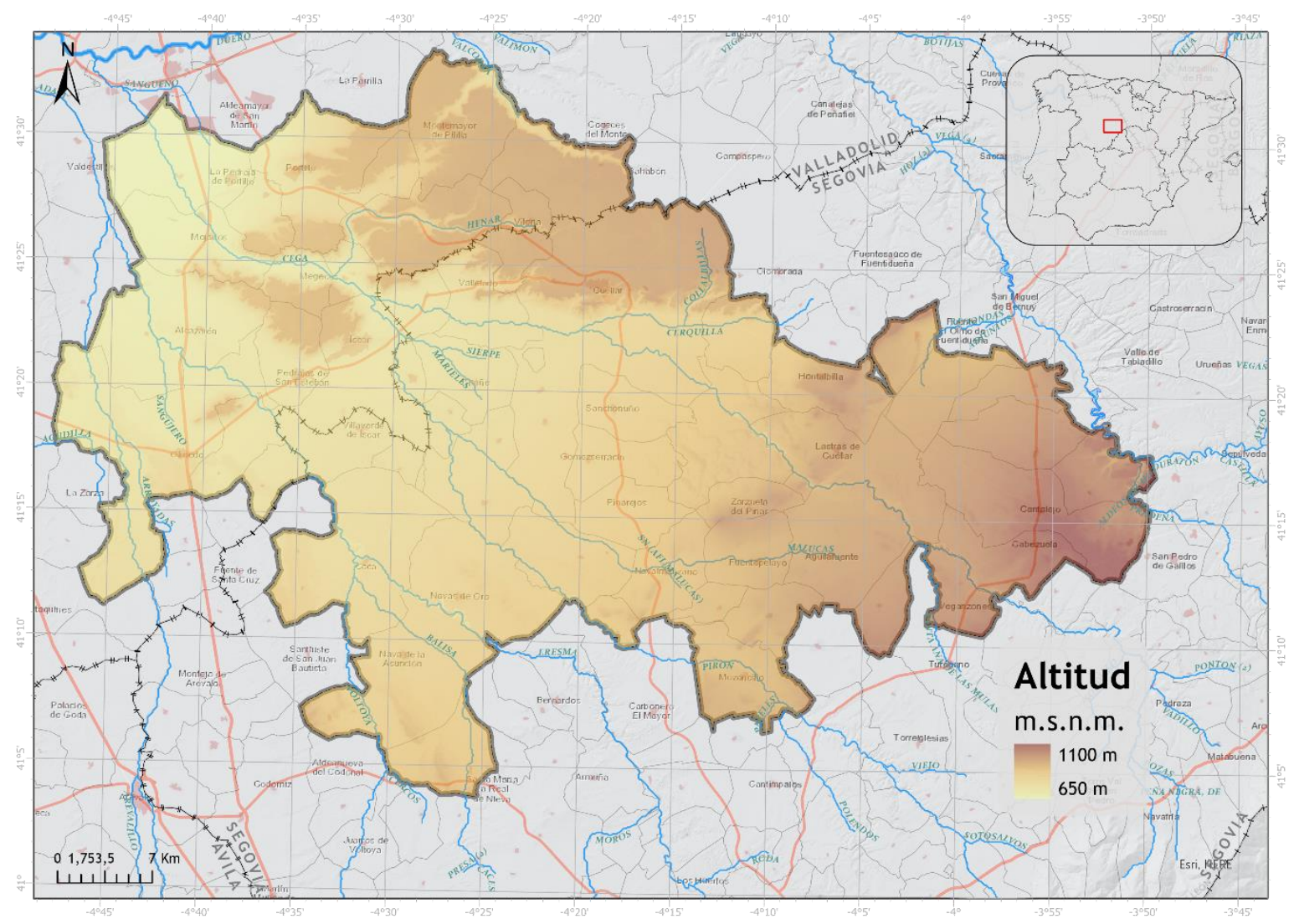

Figura 75. Mapa de altitud de la zona de estudio planteada, Tierra de Pinares de Valladolid y Segovia. Elaboración propia Modelo Digital del Terreno Instituto Geográfico Nacional. 


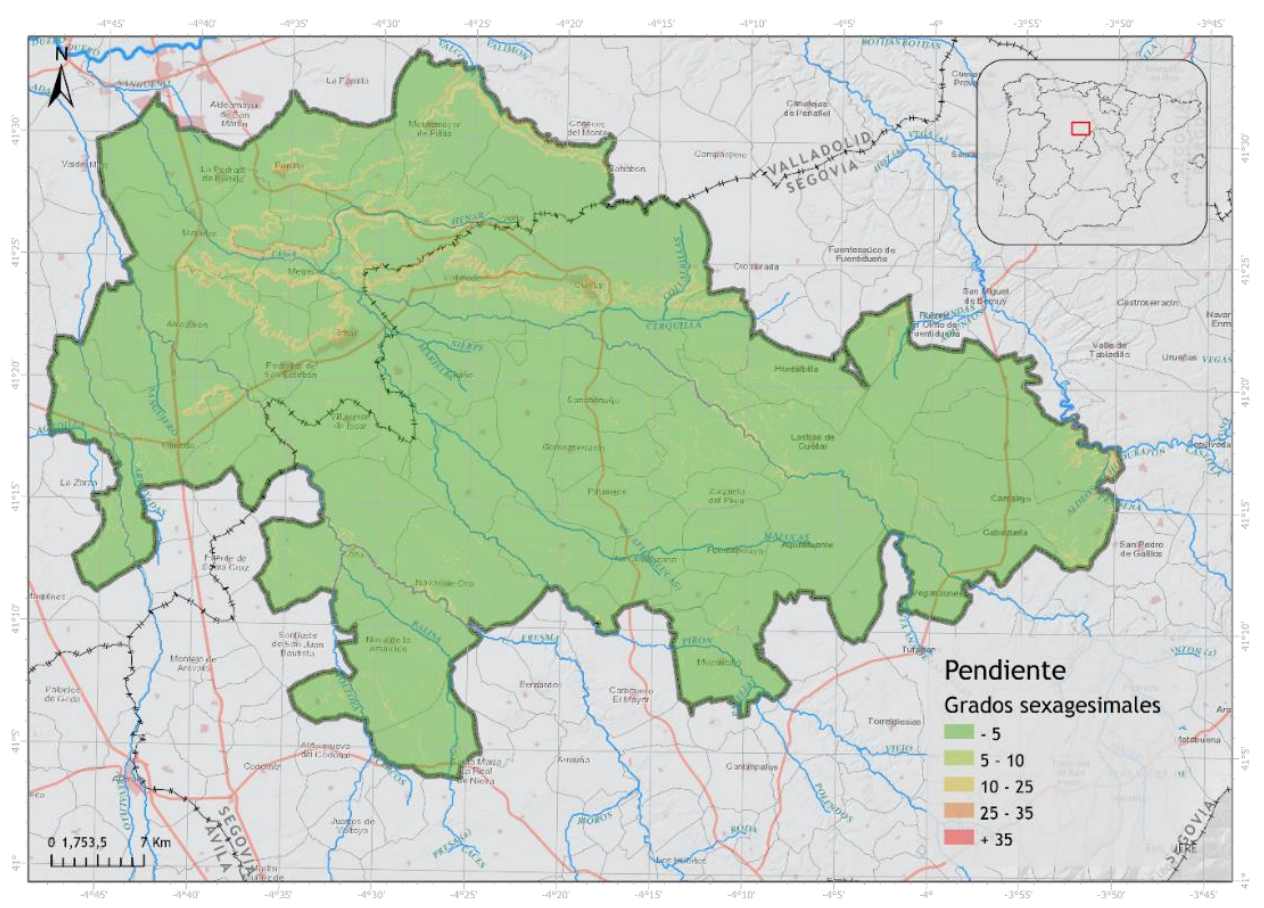

Figura 76. Mapa de pendientes de la Tierra de Pinares de Valladolid y Segovia. Elaboración propia Modelo Digital del Terreno Instituto Geográfico Nacional.

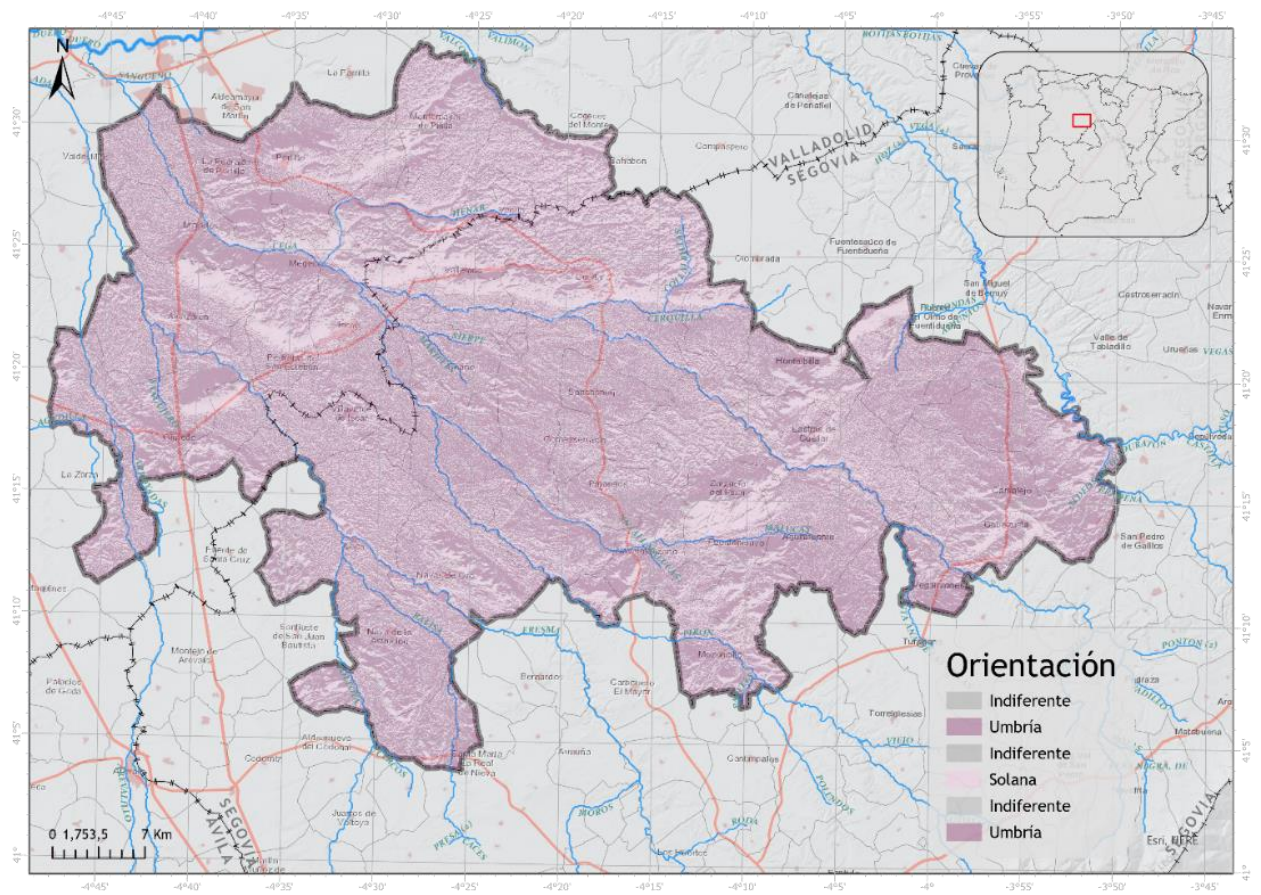

Figura 77. Mapa de orientaciones de la Tierra de Pinares de Valladolid y Segovia. Elaboración propia Modelo Digital del Terreno Instituto Geográfico Nacional. 
La gran llanura donde se asienta el espacio forestal que se trata, se encuentra situada en el centro de la cuenca sedimentaria del Duero, concretamente en su margen izquierda y delimita por el norte con el gran río que articula la cuenca. Se trata de un espacio llano (Figura 76 y Figura 77) con una altitud que oscila entre los 650 y los 1100 m.s.n.m (Figura 75), salpicado (en su mitad norte) de pequeños cerros que resaltan unos 100 150 metros resultado de la erosión diferencial tras el desmantelamiento por parte de la red hídrica de los materiales carbonatados miocenos. La llanura a la que se hace referencia presenta una ligera inclinación con dirección sur-norte derivada de ese carácter de cuenca donde los extremos aparecen levantados y el interior hundido (hasta el punto más bajo que representa el Duero), por lo que a medida que se avanza en dirección sur hacia la Cordillera Central se va ascendiendo ligeramente. Esta gran llanura ha sido el lugar idóneo para acoger el manto arenoso que la tapiza y que se convierte en el condicionante principal de esta formación forestal (Manero, 1983). Este manto tiene su origen a finales del pleistoceno cuando la red hídrica que circula con dirección Sur-Norte proveniente de la cordillera central deposita la gran cantidad de alteritas graníticas que transportaba durante los periodos de deshielo, sufriendo un importante retroceso en los periodos fríos. De este modo encontramos un manto arenoso compuesto principalmente por cuarzo y feldespato con una potencia que oscila entre los 10 y los 80 metros y que tendría un espesor medio de unos 20 metros (García, 2004). La distribución tan amplia del manto responde a la acción eólica que en los periodos fríos dispersó las arenas por los interfluvios generando los campos de dunas que hoy aparecen fosilizados por el pinar. Es necesario señalar la dicotomía que existe entre la Tierra de Pinares vallisoletana, donde el manto de arenas es menor, lo que ha permitido el desempeño de una agricultura más desarrollada y la Tierra de Pinares segoviana, donde el espesor arenoso, mucho mayor, ha condicionado sin ninguna duda las características edafológicas desarrollándose manchas forestales mucho más extensas y continuas. Se puede afirmar que el manto arenoso es el condicionante ecológico que ha 
permitido el desarrollo de este espacio forestal, observando cómo la delimitación del pinar coincide casi a la perfección con los suelos de matriz arenosa (Figura 78), que eran descartados para el cultivo.

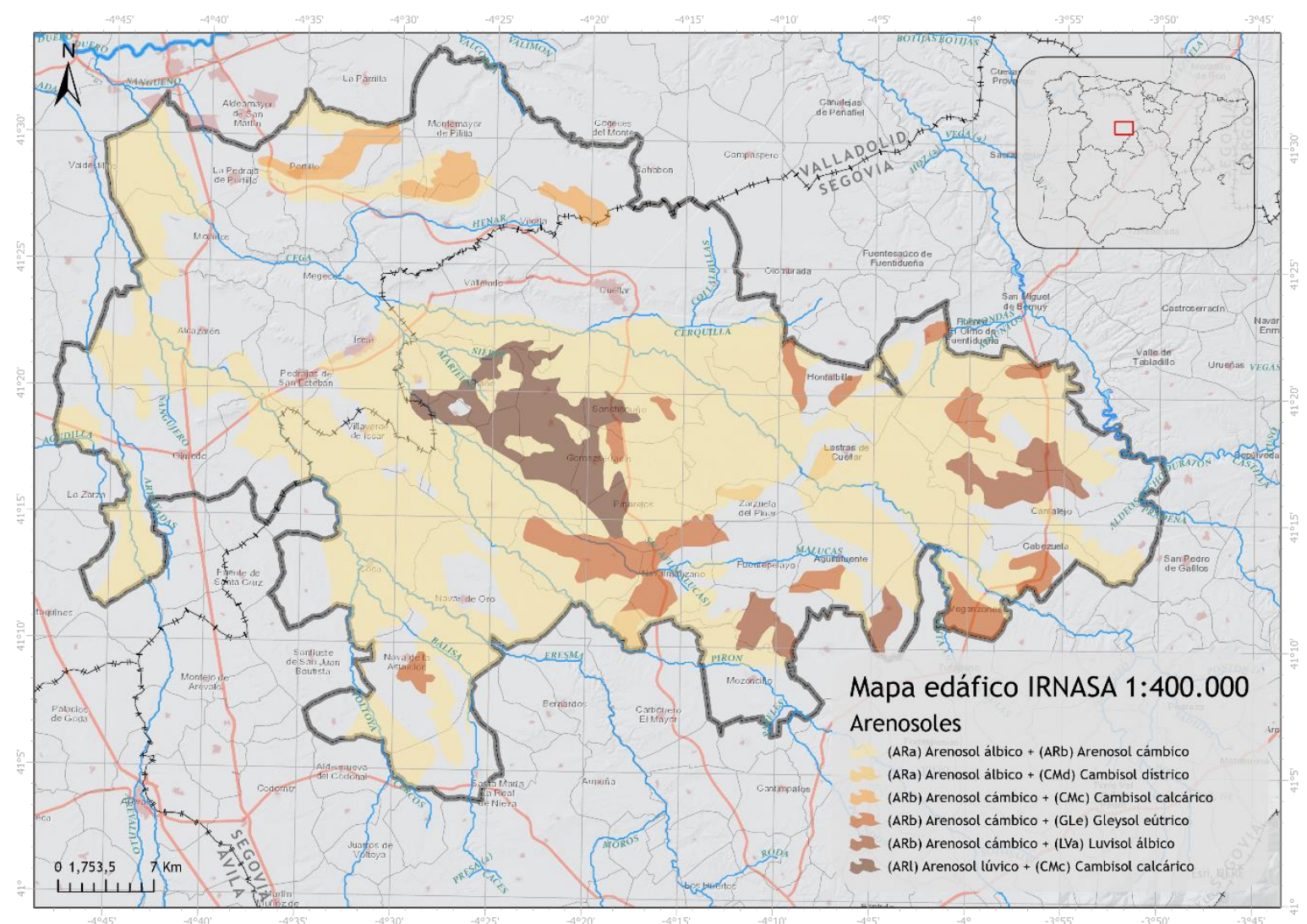

Figura 78. Clasificación de los arenosoles. Elaboración propia a partir de mapa IRNASA $1: 400.000$.

A la hora de escoger la delimitación para el estudio que aquí se desarrolla se planteó el problema de la existencia de diferentes municipios situados en el norte de la Tierra de Pinares, que se encuentran muy próximos a la ciudad de Valladolid lo que introduce una distorsión de su identidad pinariega, sus dinámicas económicas y por tanto de su carácter paisajístico íntimamente relacionado con el pinar en algún momento pero hoy desvirtuado en favor de la influencia urbana, por este motivo se excluyen de la delimitación que se propone. En cuanto al límite sur este viene perfectamente marcado por la dicotomía geológica, el manto arenoso 
deja paso a materiales sedimentarios del terciario a medida que se avanza hacia el sur se hacen más presentes derivados del levantamiento que introduce la Cordillera Central (Rodríguez, Díaz de Neira, et al., 2007). El límite oriental queda perfectamente delimitado, en primer lugar por los páramos calcáreos miocenos para la mitad norte (en ocasiones las arenas han llegado a coronar los páramos y aparecen extensas manchas de pinos) mientras que en la mitad meridional el límite lo van a constituir los materiales cretácicos pertenecientes al Macizo de Sepúlveda, donde se labran la famosas Hoces del Duratón; ambos relieves quedan destacados de la llanura por lo que suponen un límite claro e indiscutible, así mismo los suelos van a ser completamente diferentes atendiendo a su matriz por lo que en ellos no se ha optado por el desarrollo de extensas masas de pino como es propio del ámbito de estudio. Por otro lado, el límite occidental parece difuso y en ocasiones contradictorio, en él se alternan depósitos arenosos de mayor o menor extensión junto con terrazas fluviales que darán acomodo a extensos viñedos perdiéndose el carácter paisajístico motivo del trabajo; en este sentido se ha escogido el límite que marcan las terrazas del Voltoya, el Adaja y el Zapardiel, pese a obviar espacios dominados por el pino en lo que se ha llamado la Tierra de Pinares de Ávila que supone un relleno arenoso que se alterna con depósitos de gravas para dar paso finalmente hacia el oeste a diferentes formaciones arcósicas miocenas (Rodríguez, Martín-Serrano, et al., 2007) (Figura 79). 


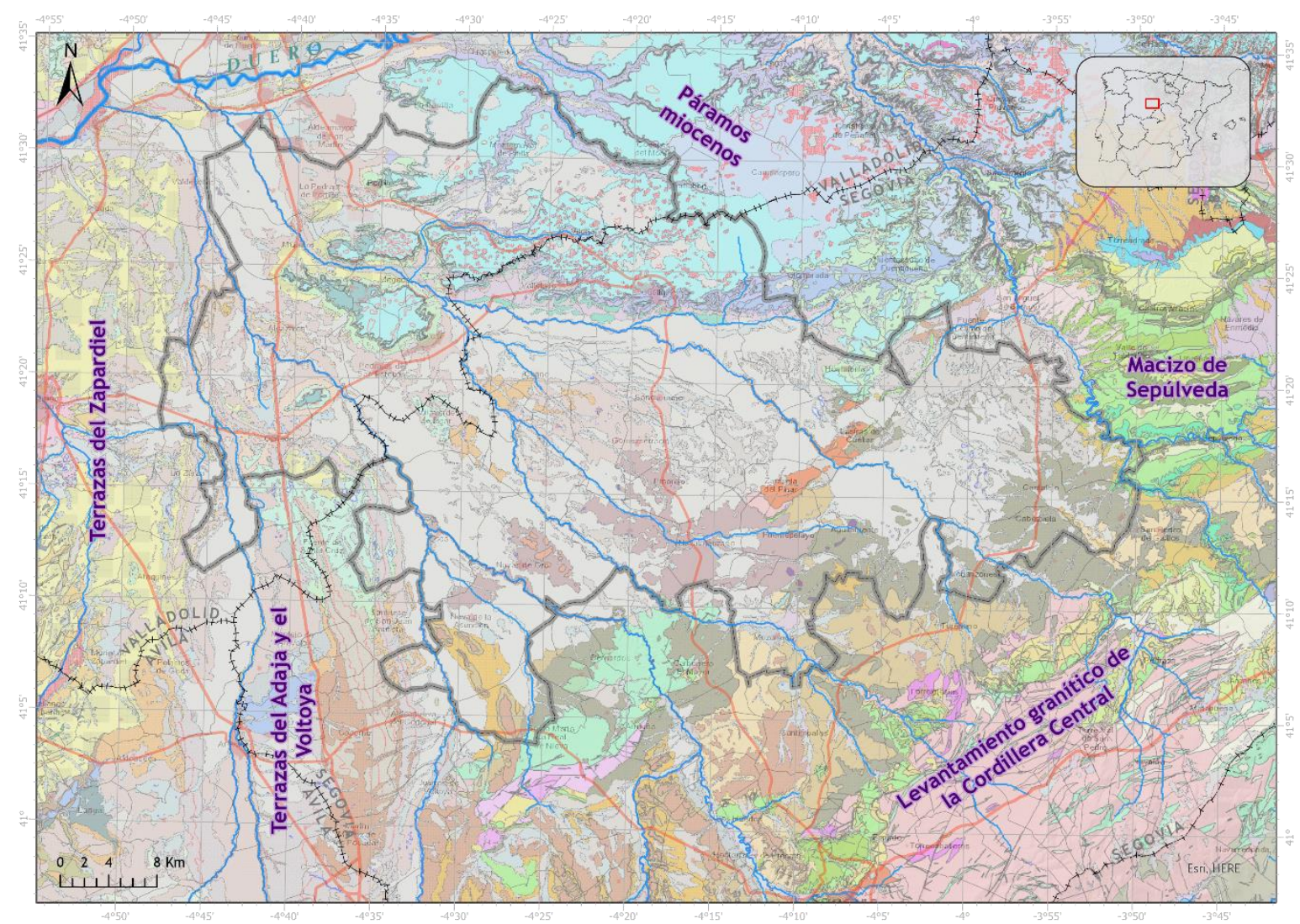

Figura 79. Esquema geológico de los límites de la Tierra de Pinares de Valladolid y Segovia. Elaboración propia a partir de Geode 50 (IGME).

\subsection{Caracterización del área de estudio}

La gran llanura arenosa que determina el ámbito de estudio supone una gran extensión donde la dominancia del paisaje del pinar es una constante, de las poco más de 460.000 hectáreas que tiene el área delimitada para realizar el estudio, los pinares ocupan unas 124.000 hectáreas lo que supone el $27 \%$ del espacio (MAPAMA, 1997). Esta proporción refleja perfectamente la estrecha vinculación que existe entre el pinar y el paisaje de este territorio, pero la Tierra de Pinares y su paisaje no puede entenderse sin la singularidad que introduce en su corazón el desarrollo de una agricultura de regadío asociada a la cercanía del nivel freático y a la existencia de un gran acuífero que aporta los recursos 
hídricos necesarios. Así, la conocida como comarca del Carracillo (Figura 80) situada en el centro de la Tierra de Pinares y delimitada por los ríos Cega y Pirón al norte y sur respectivamente, se erige como un territorio excepcionalmente fértil donde se producen hortalizas y frutas como las fresas que necesitan de suelos sueltos y gran cantidad de agua. Una de las peculiaridades de esta tradición hortícola es la explotación de los recursos hídricos a través de pozos artesianos que permitían un fácil acceso al agua hoy en día sustituidos, en ocasiones, por perforaciones más profundas necesarias para acceder al agua tras la sobreexplotación del acuífero. De cualquier modo, la peculiaridad paisajística que introducen estas explotaciones agrícolas que salpican la Tierra de Pinares en claros y navas, otorga al paisaje una excepcional singularidad e incrementa su riqueza estética y etnográfica.

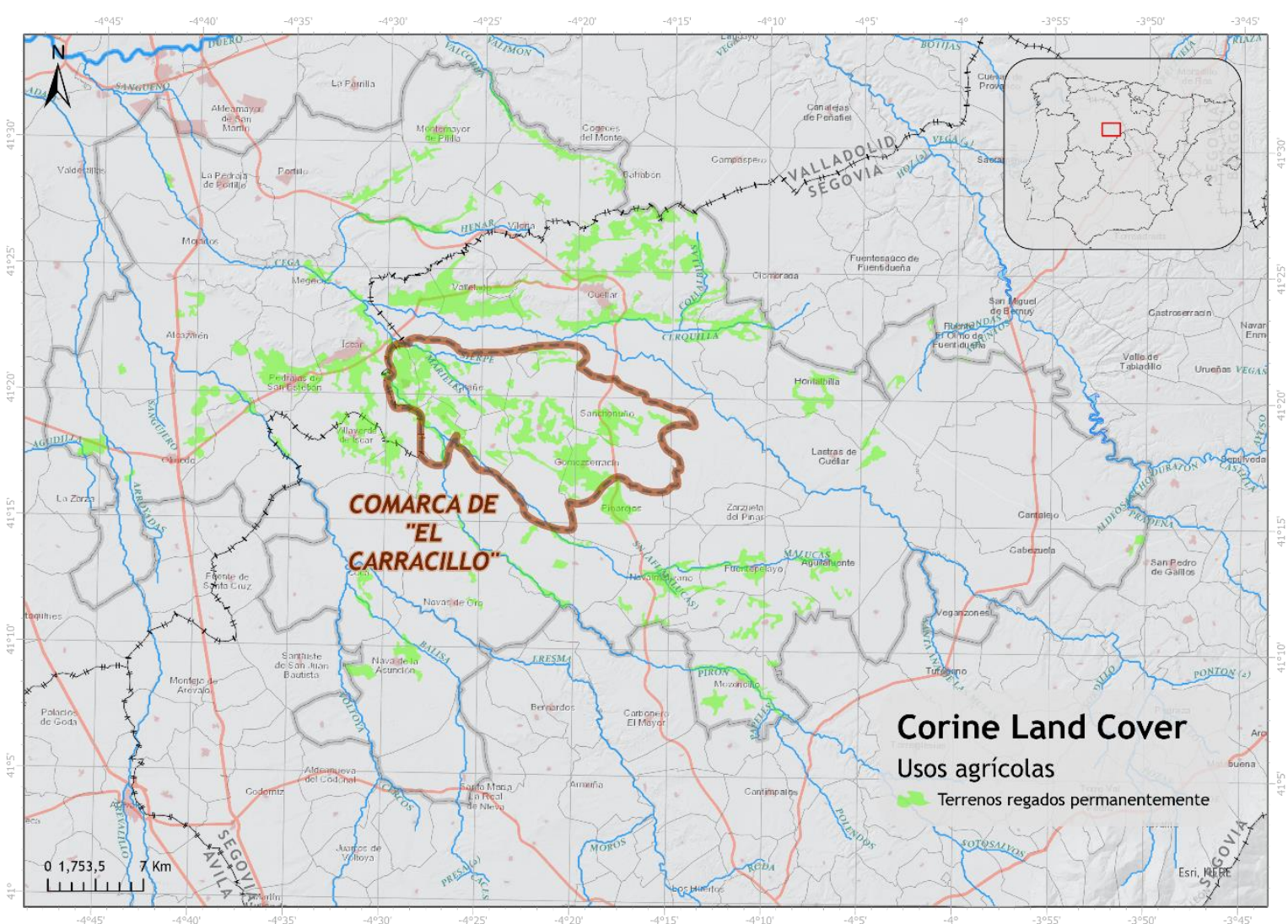

Figura 80. Mapa con la delimitación de la comarca de “El Carracillo" según la Comunidad de Regantes del Carracillo. Elaboración propia. 
El espacio delimitado para realizar el estudio, como se ha señalado, aparece salpicado en su mitad norte por cerros y páramos calcáreos de origen mioceno que responden al relleno de materiales carbonatados provenientes de las cordilleras Cantábrica e Ibérica. Estos cerros en muchas ocasiones albergan una cubierta arenosa derivada de la movilización y removilización eólica cuaternaria que ha permitido el desarrollo de extensos pinares en su parte superior pero que aparecen alternados con extensos campos de cultivos de secano más característicos de los páramos del norte del Duero.

\subsection{El origen del espacio forestal}

El paisaje pinariego que hoy se contempla en sus características y dimensiones tiene un origen indudablemente humano, no porque las especies de pinos protagonistas no sean totalmente naturales y autóctonas (Alcalde et al., 2004), sino porque es el resultado de una influencia humana en la organización del espacio y la reducción de la comunidad vegetal de Quercetum que sería la dominante de este paisaje vegetal (Calonge, 1987). Estas especies de pináceas (Pinus pinaster Ait. y Pinus pinea L.) son el reflejo de una perfecta adaptación al potencial edáfico de la llanura arenosa (Merino, 2018) y han sido incentivados debido a los productos que ofrecían a la población local.

La vegetación potencial sería un bosque mediterráneo mixto formado por quercíneas, fundamentalmente por encinas arbustivas (Quercus ilex ssp.ballota) y quejigos (Quercus faginea Lam.). Actualmente esta formación se mantiene en las cuestas de los páramos, en pequeños rodales en las culminaciones y de forma testimonial salpicando los pinares. Parece que esta formación se habría mantenido como un bosque denso en las culminaciones de los páramos hasta las roturaciones del S.XIX, habiéndose destinado a reserva de caza para la realeza y como aprovechamiento para la obtención de leña, carbón vegetal o bellota por parte de los vecinos de las comunidades de Villa y Tierra (Arranz et al., 1995). 
Las características y extensión del pinar actual van a venir asociadas, en primer lugar, a la excelente tolerancia de estas dos especies de pino a los suelos de arenas silíceas que sustentan el espacio forestal (Figura 78) y que condicionan unos suelos sueltos y lavados. Así las sociedades que se asentaron bajo las declaraciones de Villa y Tierra durante los siglos XII y XIII optaron por el desarrollo de estos bosques con el objetivo de favorecer el asentamiento de nuevos pobladores. Se han encontrado evidencias de esta preocupación desde el siglo XIII (Terán et al., 1988) con importantes evidencias del impulso que tuvieron durante el reinado de los Reyes Católicos o Carlos I (Hopfner, 1954).

Existen importantes evidencias que se han encontrado como referencias para demostrar el origen de este bosque de pinos de llanura. Así, 1546 en la Ordenanzas de la Villa y Tierra de Cuellar se incluyen normas para la correcta conservación de sus pinares acerca de su repoblación, acotados de ganado, prohibiciones de cortas fraudulentas, lucha contra incendios forestales, etc. por ejemplo la Ordenanza respecto a los incendios imponía penas gravísimas "caiga y incurra en las penas corporales de muerte establecidas en derecho y leyes contra los incendios" (Oria y Díez, 2003).

En la Ordenanzas del Concejo de Cantalejo de 1550 distintos capítulos tratan de la protección y conservación de los montes, concretamente el capítulo quinto señala que:

"que cualquiera persona que por pesquisa o en otra qualquier manera fuere fallado que cortó o hizo cortar qualquier pie de pino sin la dicha liçençia cayga $e$ incurra en pena de seysçientos maravedís y el pino para el conçejo; e, si deçentare pino para rrasinero, el que le començo u otro alguno proçediere cayga en pena de doçientos maravedís e, si se cayere el pino, seiscientos maravedís y el pino para el concejo, e, si se cortare rayzes de pino, por cada rayz de pino un rreal; y el que 
cortare una rama verde, un rreal de cada una, y de cada rrama deseca, de cada pino, de cinquenta maravedís [...] y el que hiziere hoya para carbón que cayga en pena de çíncuenta maravedís..." (Fuentenebro, 1986)

El capítulo séptimo hace referencia a las plantaciones de pinos:

“...porque las dichas dehesas están muy despobladas e no ay pinos pequeños ni los dexan creçer los ganados y, si en esto no se proveyere, en pocos años se asolarían las dichas dehesas e no quedaría montes ni pinos en todas ellas, como por uista de ojos paresçe, y auido nuestro acuerdo con personas de espirinçia e de buen zelo, hallamos que el rremedio seria rromper la tierra para que se devolviese e aocase e la yerba se matase e las çespederas dse ablandase y el parto se defendiese y que desta manera los piñones nascerian y los árboles creçerian y, quando fuesen en algún crecimiento tal que quedasen seguros para que los ganados no los paçiesen, se pondrían adereçar los pinos que saliesen derechos, se podrían guardar y se podría tornar a pastar, y que desta manera se podría en otra temporada hacer otra parte del monte y que çesarian los daños e ynconbinientes susodichos. Por ende hordenamos e mandamos que el pinarejo susodicho se are e guarde en esta manera: que lo primero se amojone la mitad por la parte que paresçiere al conçejo e alcalde e regidores e diputados en su nonbre hazia la parte de la talaya, porque hazia aquella parte se a de sembrar al año que viene la hoja y estará más guardado; y por conçejo se are y se sienbre de piónes albares y se acote y quede acotado hasta tanto que los pinos estén tanto nasçidos e tan creçidos que se pueda desacotar sin perjuyzio del monte $\mathrm{y}$, allende de lo que se oviere 
de arar, se le dé coto como paresiere a los dichos ofííales del conéjo, e que durante el dicho coto se lleve de pena a qualquier rex mayor dos marauedis de dia $e$ quatro de noche e, si fuere dos vezes en la semana, la pena doblada $y$, si tres a merced del conçejo..." (Fuentenebro, 1986)

Otra de las referencias escritas que van a demostrar la dominancia de este paisaje forestal es el libro que William Bowles dedica a la geografía de España, mediante el procedimiento descriptivo a lo largo de un viaje describe lo que va encontrando a su paso. De esta manera, en el viaje que realiza de Madrid a Bayona por Valladolid, Burgos y Vitoria, Bowles hace especial referencia a la importante extensión que tiene el pinar en la llanura arenosa que se va a encontrar en su camino a Valladolid tras abandonar lo que parecería la campiña segoviana, dadas sus referencias a las albercas y manantiales.

“Pasado el referido llano, quatro leguas más allá, se entra en otro más pequeño, arenoso, fértil: y con poca interrupción, se llega á otra llanura arenosa en que hay á una parte viñas, y á otra un bosque de pinos: y desde allí á Valladolid ya no se encuentra mas que arena, quijo, pedregales y pinares, hasta un paco antes de la Ciudad [...]"

(Bowles, 1789) 


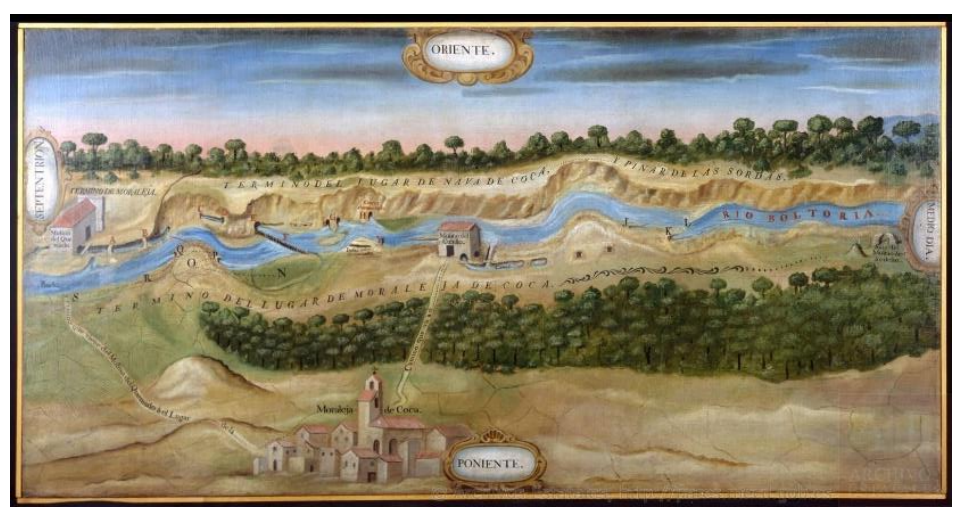

Figura 81. Vista cartográfica de un tramo del río Voltoya entre Moraleja de Coca y Nava de la Asunción (Segovia). Donde se puede apreciar las importantes dimensiones del pinar. Archivo de la Real Chancillería de Valladolid. (Anón, XVII-XVIII)

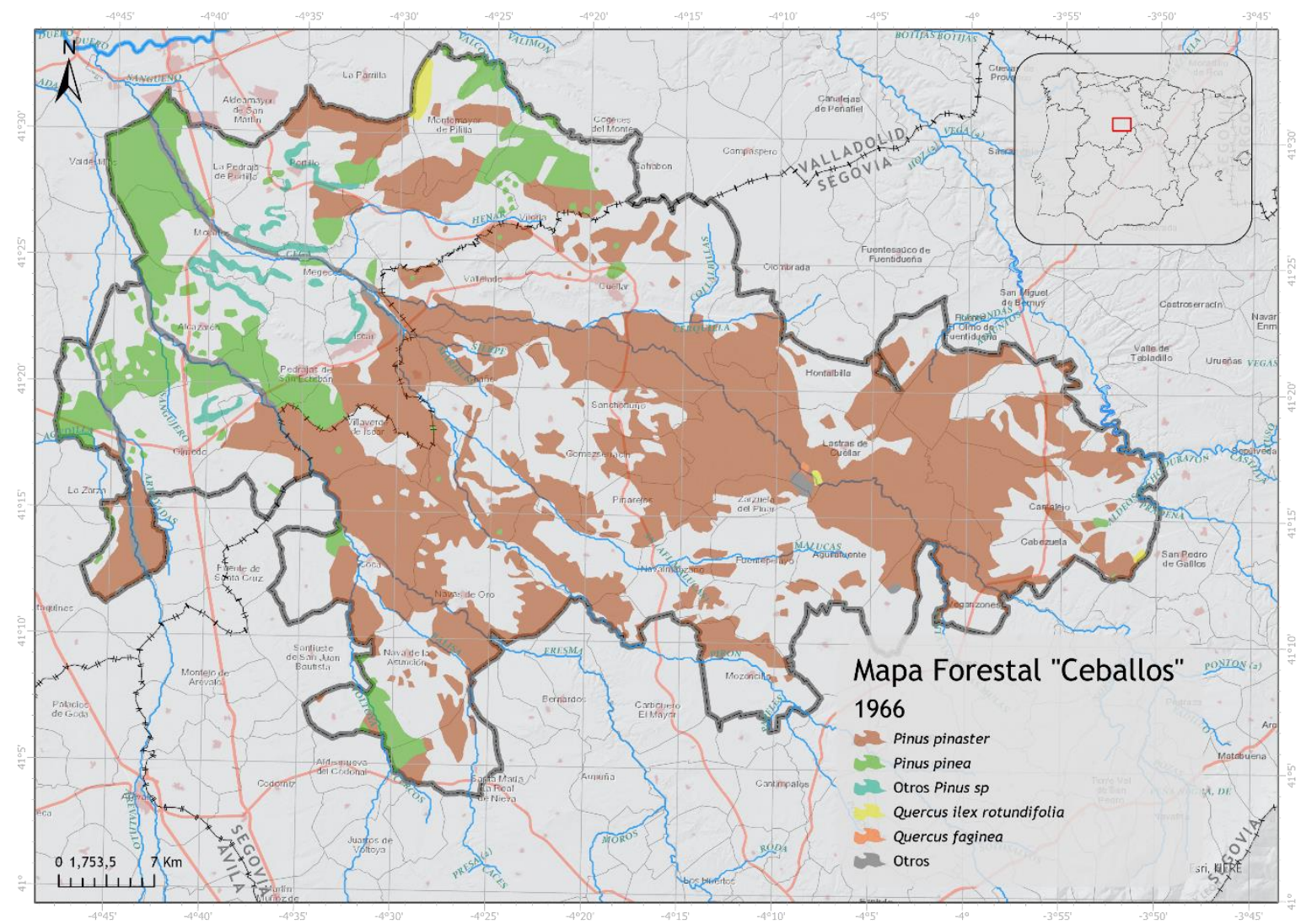

Figura 82. Mapa forestal de España (1966) conocido como “mapa Ceballos” para la Tierra de pinares de Valladolid y Segovia. Elaboración propia. 


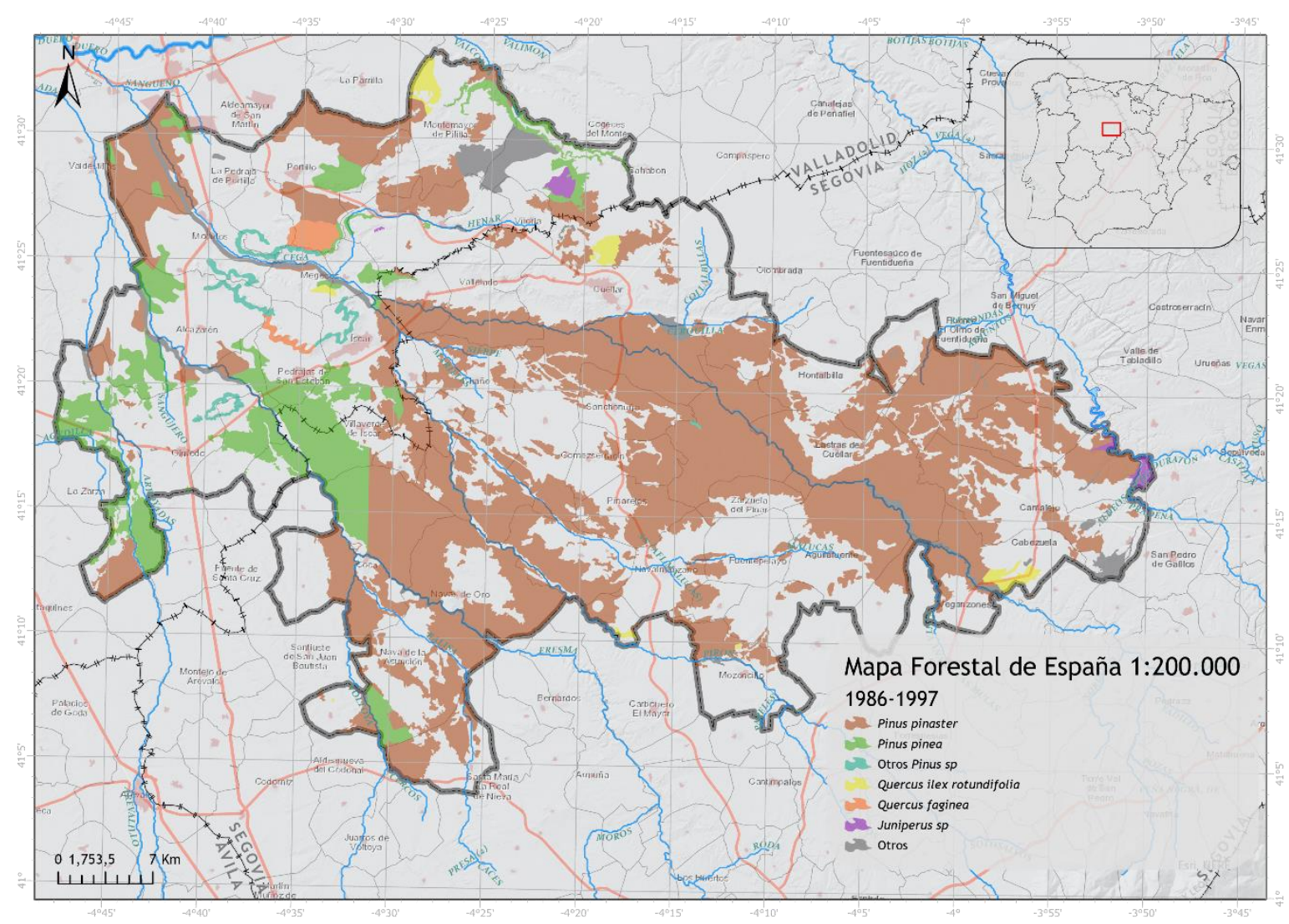

Figura 83. Mapa Forestal de España 1:200.000 para la Tierra de Pinares de Valladolid y Segovia. Elaboración propia. 


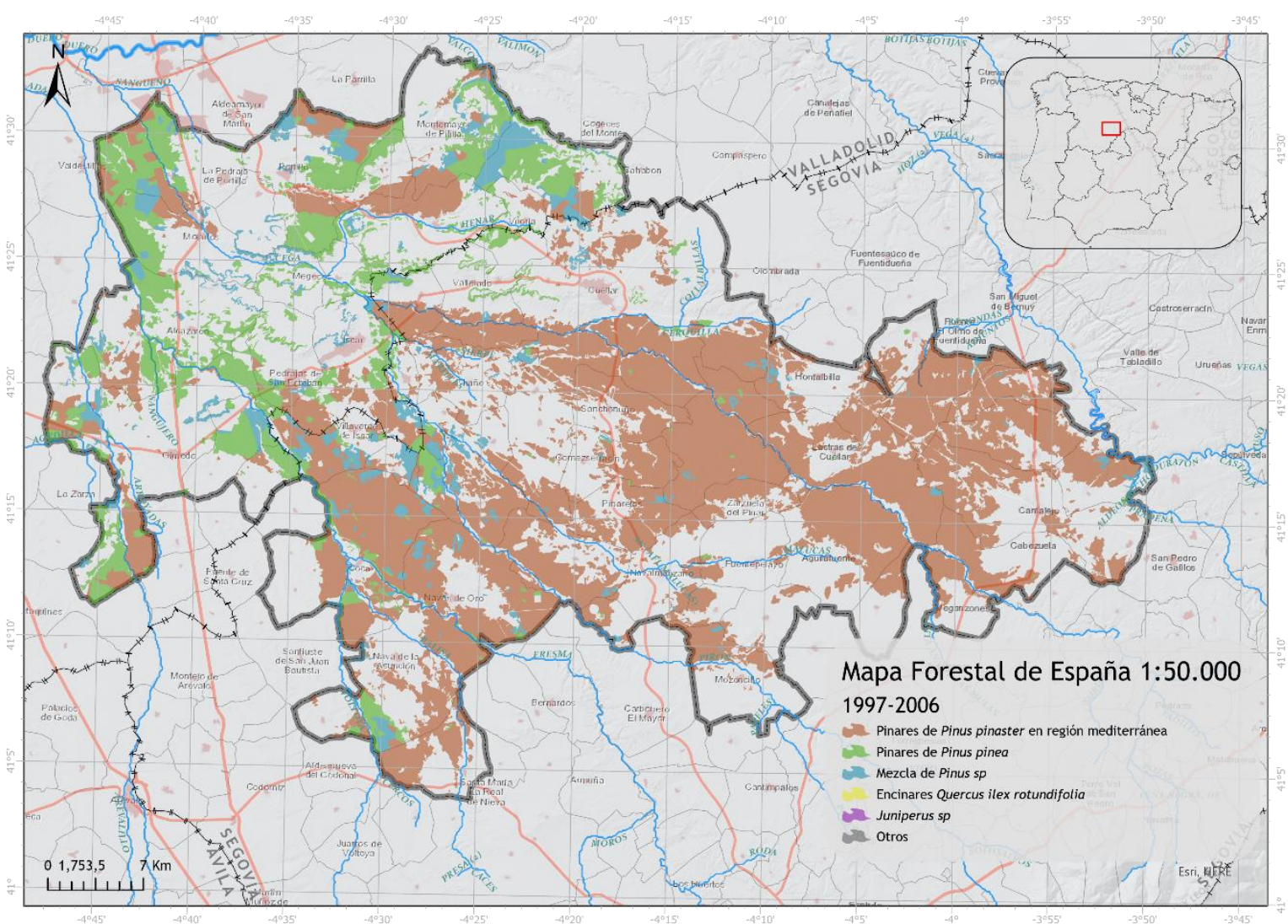

Figura 84. Mapa Forestal de España 1:50.000 para la Tierra de Pinares de Valladolid y Segovia. Elaboración propia.

\subsection{El uso tradicional}

Una de las claves que se consideran fundamentales para comprender la relación de la población local con este paisaje forestal y que explican, en buena medida, la persistencia hasta nuestros días es la propiedad pública. Existen abundantes evidencias que van a reflejar esta explotación pinariega de forma comunal, para la obtención de distintos productos desde mediados del siglo XIV (Diago, 2012). Pero si nos ha llegado un testimonio excepcional de lo que el pinar ofrecía a los habitantes de esta llanura arenosa, es el testimonio que el boticario de Cuéllar, Don Pedro Ucero y que remitía a la Real Sociedad Económica de los Amigos del País de la provincia de Segovia, publicada en 1786: 
"No se halla parte en esta noble planta, que tenga su sér en vano: desde su profunda raíz, hasta su elevada cumbre, toda es proficua. No es como el sabroso manzano, que despojado del fruto es inútil: no como el dulce almendro, que mirado sin su fruta, no sirve al hombre de provecho alguno. En el pino, aun después de muerto, tenemos mucho que apreciar: aun después de seco, nos llena de beneficios..."

(Real Sociedad Económica de los Amigos del País de la Provincia de Segovia, 1785)

En este documento, Ucero va a reflejar el aprovechamiento que tenían los pinos, llegando incluso a presumir de su existencia, lo que da buena cuenta del aprecio que la sociedad local tenía a estos árboles. El boticario de Cuéllar hace referencia al uso de las resinas, el combustible en forma de madera y piñas secas, como material de construcción para vigas o aislante, incluso da cuenta de los beneficios medicinales que tendría el consumo en verde de piñas a modo de frutas ricas en vitamina $C$ o ungüentos e infusiones.

Estos aprovechamientos de los cuales existen referencias escritas antiquísimas se han desarrollado en un espacio forestal de aprovechamiento comunal lo que se va a reflejar en la futura gestión de este espacio arbolado en el predominio de la gestión pública a través de la figura de Monte de Utilidad Pública, lo cual ha garantizado, en buena medida, la llegada de estos bosques hasta nuestros días (Figura 85). 


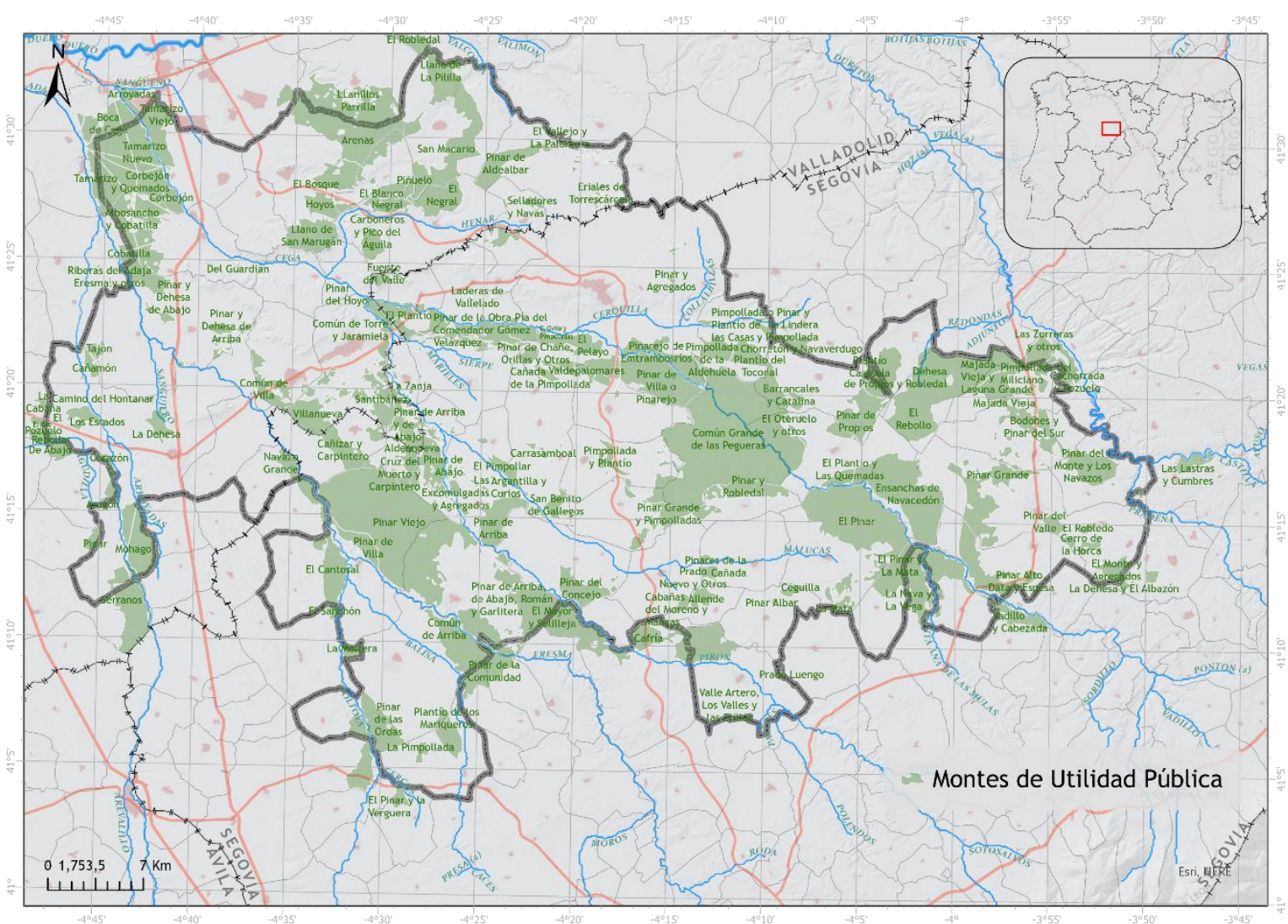

Figura 85. Mapa con los Montes de Utilidad Pública en la Tierra de Pinares de Valladolid y Segovia. Elaboración propia a partir de Montes de Utilidad Pública Junta de Castilla y León.

\subsection{El uso actual}

Con el gran salto técnico a mediados del siglo XX que va a sufrir España en general y la Tierra de Pinares en particular, todos estos usos tradicionales van a quedar reducidos. Las necesidades constructivas se van a resolver, de forma general, con otros materiales, fundamentalmente de origen mineral como el cemento y el hormigón. Las necesidades de iluminación van a quedar cubiertas por la generalización del alumbrado eléctrico. Las necesidades energéticas van a solucionarse con la difusión de los combustibles fósiles y la química moderna va a sustituir los aprovechamientos medicinales. De este modo el bosque de pinos de la llanura arenosa va a dejar paulatinamente de ser un proveedor de productos 
diversos para dar paso a un proveedor de productos valiosos y concretos. El pinar dejará de ser el suministrador de las sociedades locales para pasar a ser un suministrador de materias primas de carácter industrial.

Las primeras evidencias de este cambio tradicional hacia una producción industrial se van a producir en 1888 con la creación de la Unión Resinera Española (Uriarte, 2000) y que va a suponer un hito en esta transformación. Los bosques de pinos, en este caso, mediante la lógica planteada por la ciencia dasonómica de origen decimonónico (2.3.2). Asi, estos pinares de gestión comunal van a dar paso a espacios forestales de producción, con dos vertientes fundamentales, por un lado, los bosques de pinos resineros (Pinus pinaster Ait.) van a ser bosques destinados a la obtención de resinas bajo esa Unión Resinera Española y que va a convertir a los pinares segovianos en el principal centro de difusión del cambio técnico en la transformación industrial de la resina (Guerra, 2012). Por otro lado, los bosques de pinos piñoneros (Pinus pinea L.), conocidos como pinos albares en la comarca, van a convertirse en productores de piñas destinadas a la obtención de piñón blanco, pero siempre bajo una gestión forestal alejada de masas injertadas destinadas a la producción (Montero y Cañellas, 2000). Igualmente, estos bosques aportan, bajo una supervisión dasonómica, madera en forma de fustes.

Este aprovechamiento se ha visto acompañado de un incremento muy notable en los últimos años de la extracción de biomasa para la elaboración de "pellets". Este hecho ha quedado constatado con la instalación de la empresa Naturpellet (Figura 86) en el municipio de Sanchonuño en 2015 con una producción anual de unas 40.000 toneladas al año y con previsión de ampliación hasta las 60.000 toneladas. Estas cifras quedan amparadas bajo la previsión de incremento anual de 297.000 t/año en la producción de “pellets" para Castilla y León (Díez et al., 2011).

Resumiendo, el bosque de origen comunal destinado a satisfacer las necesidades cotidianas de la población local ha dado paso a un bosque de producción industrial (Figura 87) para obtener resinas, piñas, biomasa para 
combustible y maderas (Figura 88), siendo un aprovechamiento plenamente vigente (Figura 89).

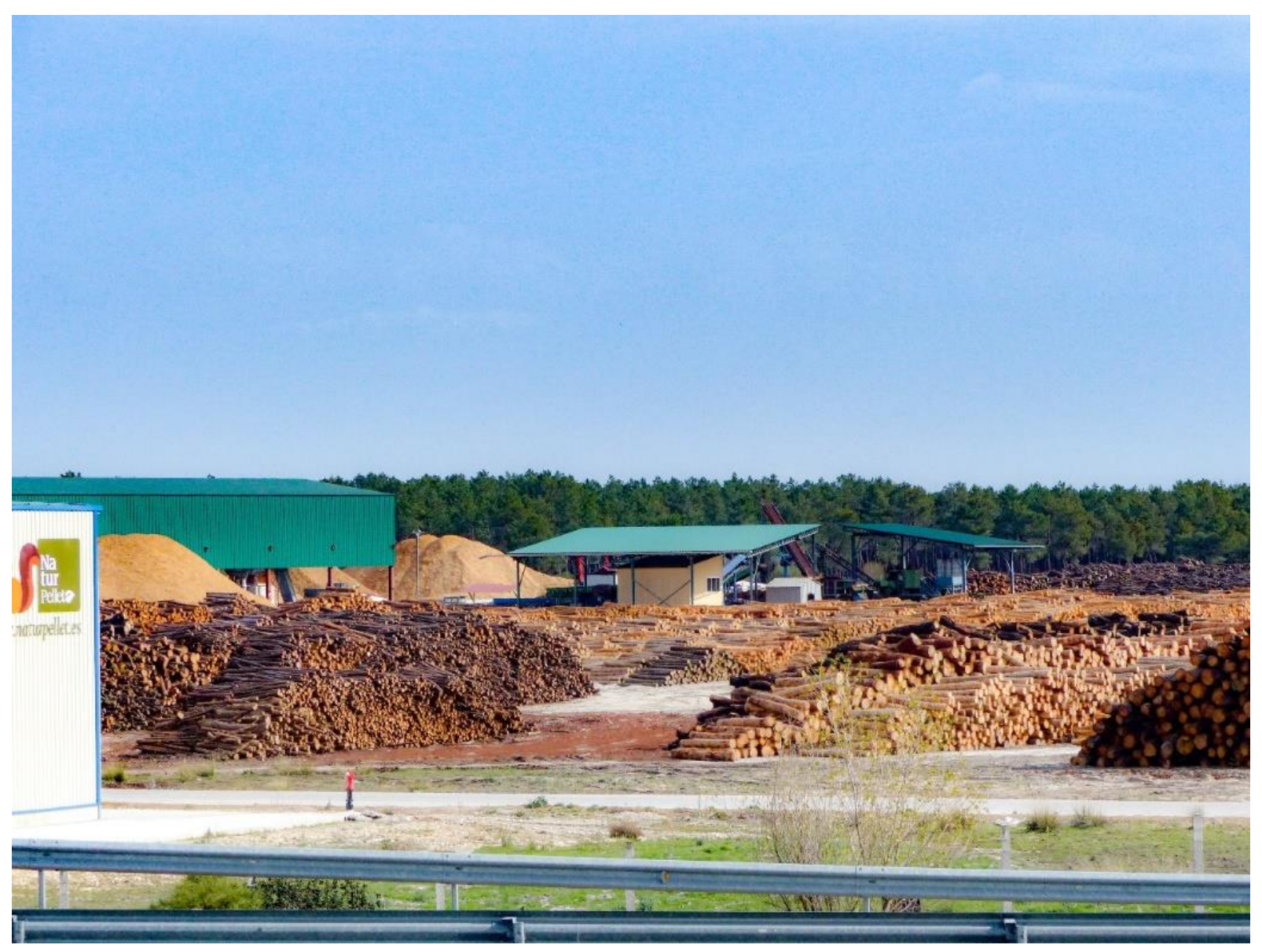

Figura 86. Empresa Naturpellet en Gomezserracín. Imagen propia. 


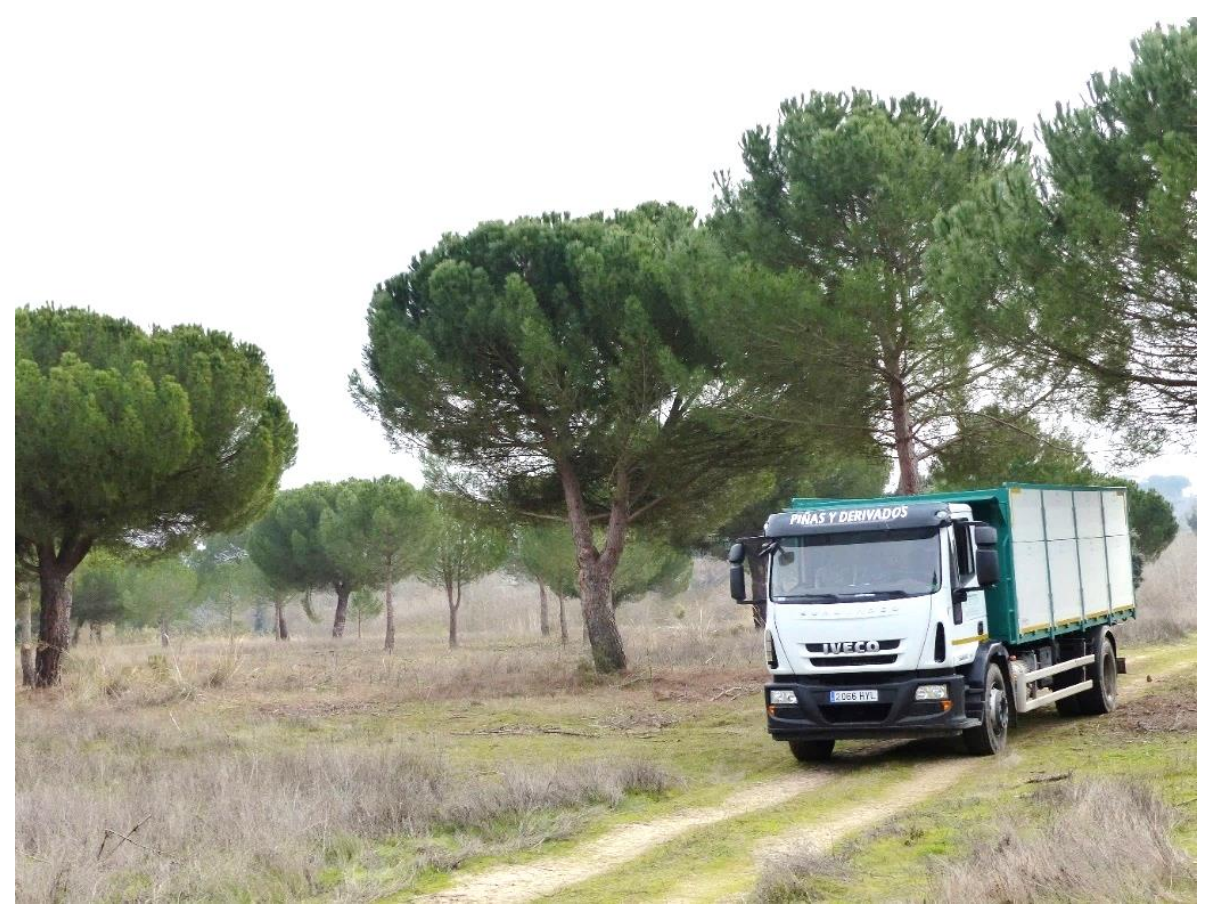

Figura 87. Camión para la recogida de piñas en el interior de un pinar de La Pedraja de Portillo. Imagen propia.

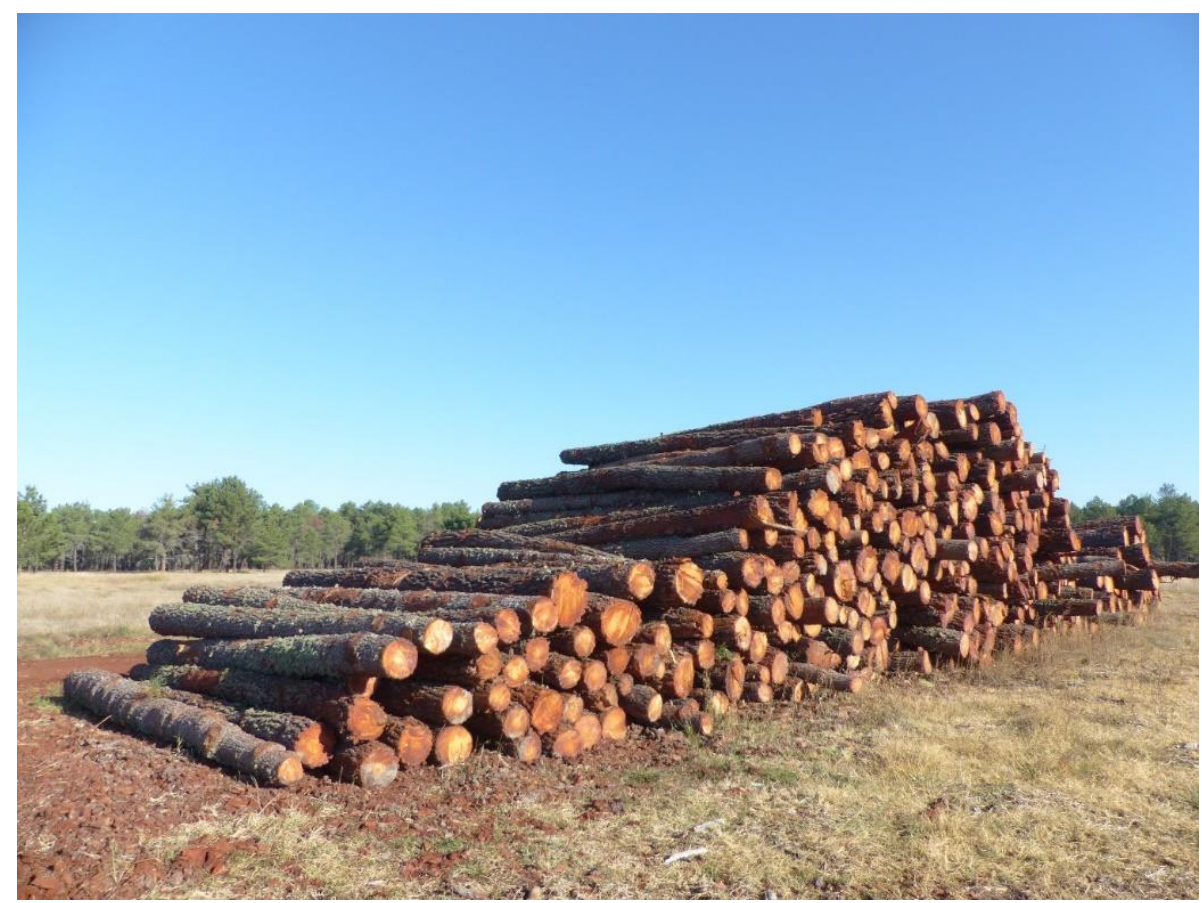

Figura 88. Troncos amontonados en las proximidades de Cantalejo. Imagen propia. 


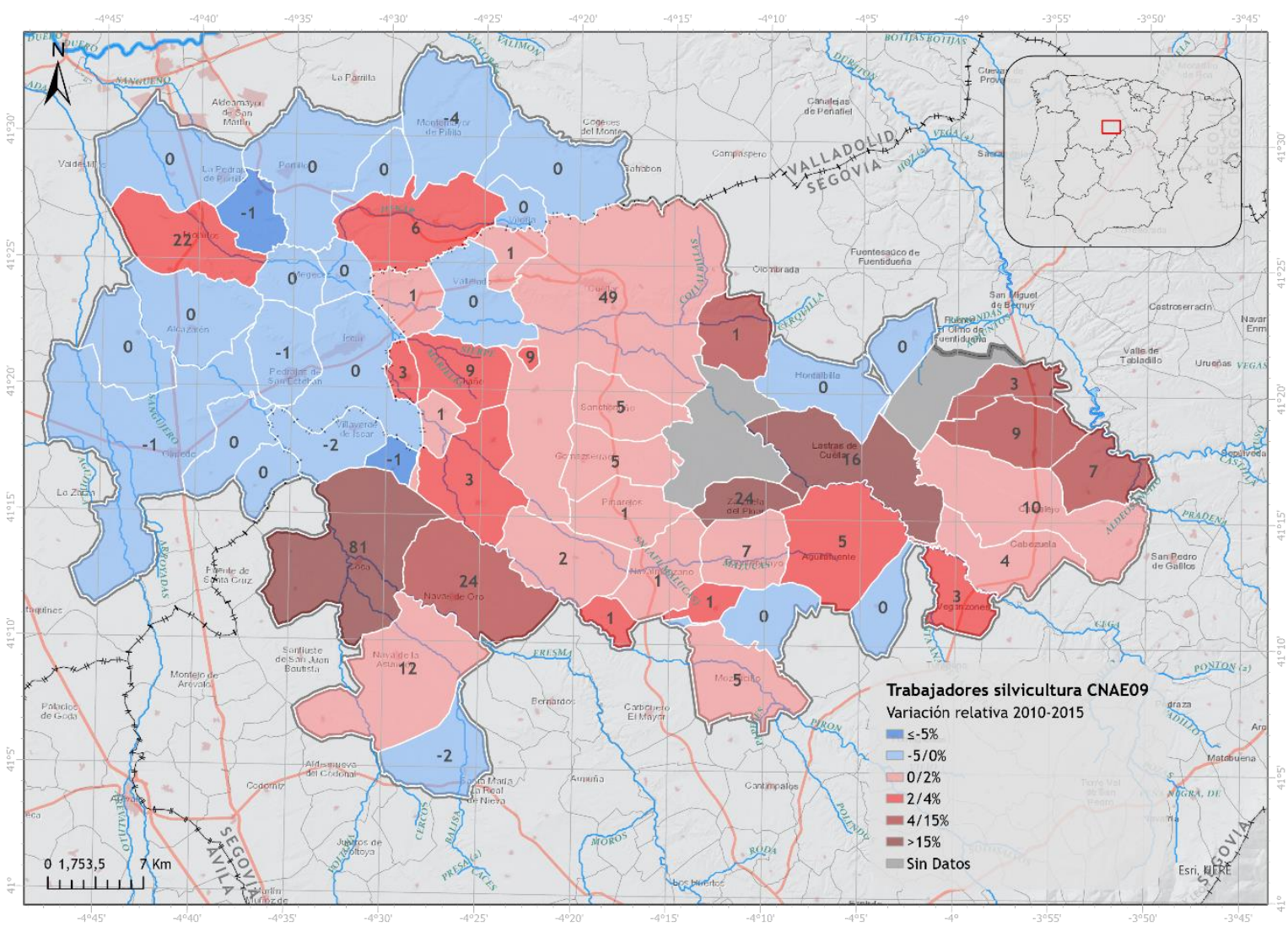

Figura 89. Mapa con la variación de trabajadores ocupados en tareas relacionadas directamente con la silvicultura en la Tierra de Pinares de Valladolid y Segovia entre 2007-2015. Elaboración propia a partir de Datos Seguridad Social CNAE.

\subsection{El paisaje de un espacio forestal histórico}

El pinar en la Tierra de Pinares de Valladolid y Segovia viene determinado, como se ha visto, por la adaptación de estas especies vegetales al complejo físico, así el sustrato arenoso y las condiciones climáticas han determinado su existencia. Por otro lado, sus extraordinarias dimensiones para un bosque de llanura están definidas por el incentivo por parte de las comunidades locales a lo largo de los siglos para la obtención de recursos mediante aprovechamientos tradicionales $y$, posteriormente, para la obtención de materias primas de manera industrial. En cualquier caso, la existencia de este paisaje forestal y sus dimensiones actuales tienen un indudable poso cultural, es decir, se trata de un espacio 
forestal, una formación vegetal, un ecosistema complejo que hunde sus raíces en las actividades humanas.

Pero este paisaje forestal no se va a circunscribir únicamente al espacio arbolado, este se va a extender por los núcleos de población apareciendo en actividades, instalaciones, equipamientos. Aunque compartan protagonismo con nuevas actividades tan dominantes como las forestales pero el bosque permanece y proporciona carácter al paisaje (Guerra, 2012).

A través de un proceso de análisis de gabinete y con el apoyo del trabajo de campo se ha determinado una clasificación de unidades de paisaje y los elementos que actúan como catalizadores de patrimonialización que explican el carácter del paisaje de la Tierra de Pinares de Valladolid y Segovia:

- Cultivos

- Regadío (espacios hortícolas permanentemente regados gracias a los tradicionales pozos artesianos) (Figura 90).

- Cultivos cerealistas de secano (Cultivos de cebada y trigo fundamentalmente y que aparecen en las culminaciones de los páramos e intercalados con algunos regadíos) (Figura 91).

- Forestal

- El pinar resinero (dominado por el Pinus pinaster Ait. y caracterizado por las intervenciones destinadas a obtener resinas) (Figura 92).

- El pinar piñonero (dominado por el Pinus pinea L.) (Figura 93).

- Las cuestas de los páramos (caracterizado por espacios forestales diversos y matorrales esclerófilos) (Figura 94).

- Urbano (Dominado por un poblamiento compacto en núcleos de población de importantes dimensiones) (Figura 95). 


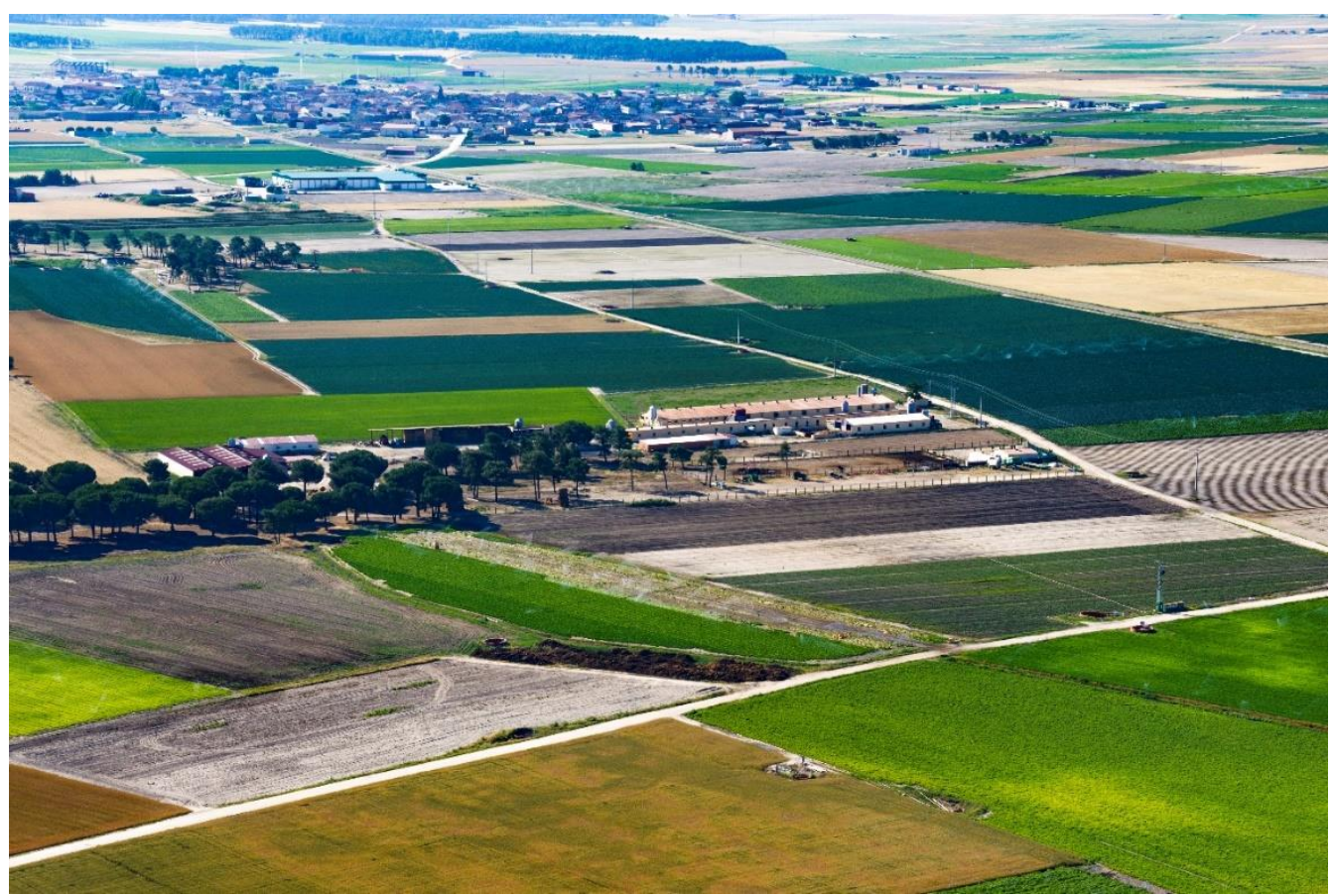

Figura 90. Imagen aérea de los regadíos de "El Carracillo". Eugenio Baraja Rodríguez

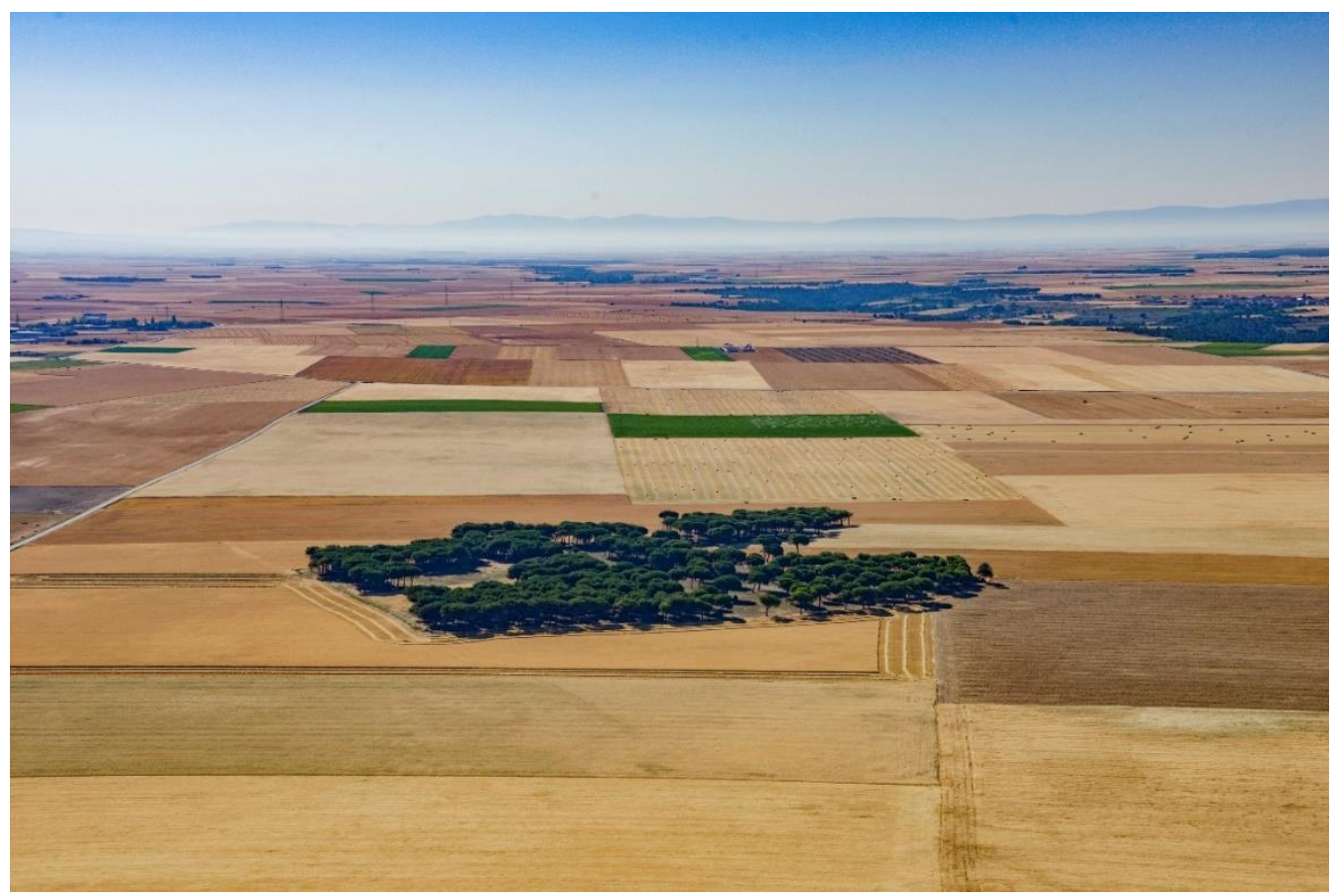

Figura 91. Cultivos de secano sobre los que se intercalan pequeños rodales de pinar. Eugenio Baraja Rodríguez. 


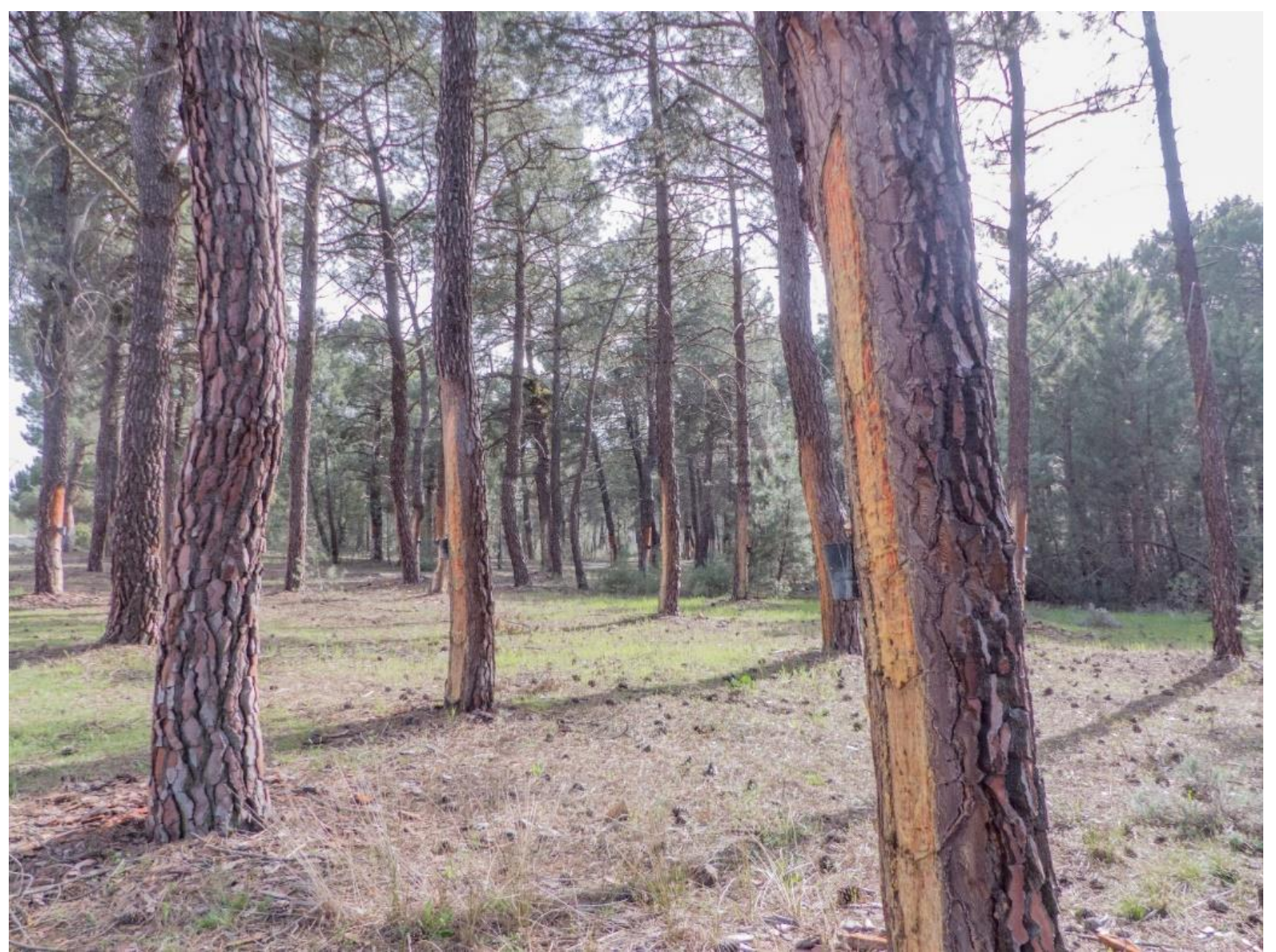

Figura 92. Pinar resinado junto a Gomezserracín. Imagen propia. 
Estudio de casos y aplicación práctica. Paisajes forestales con valor patrimonial.

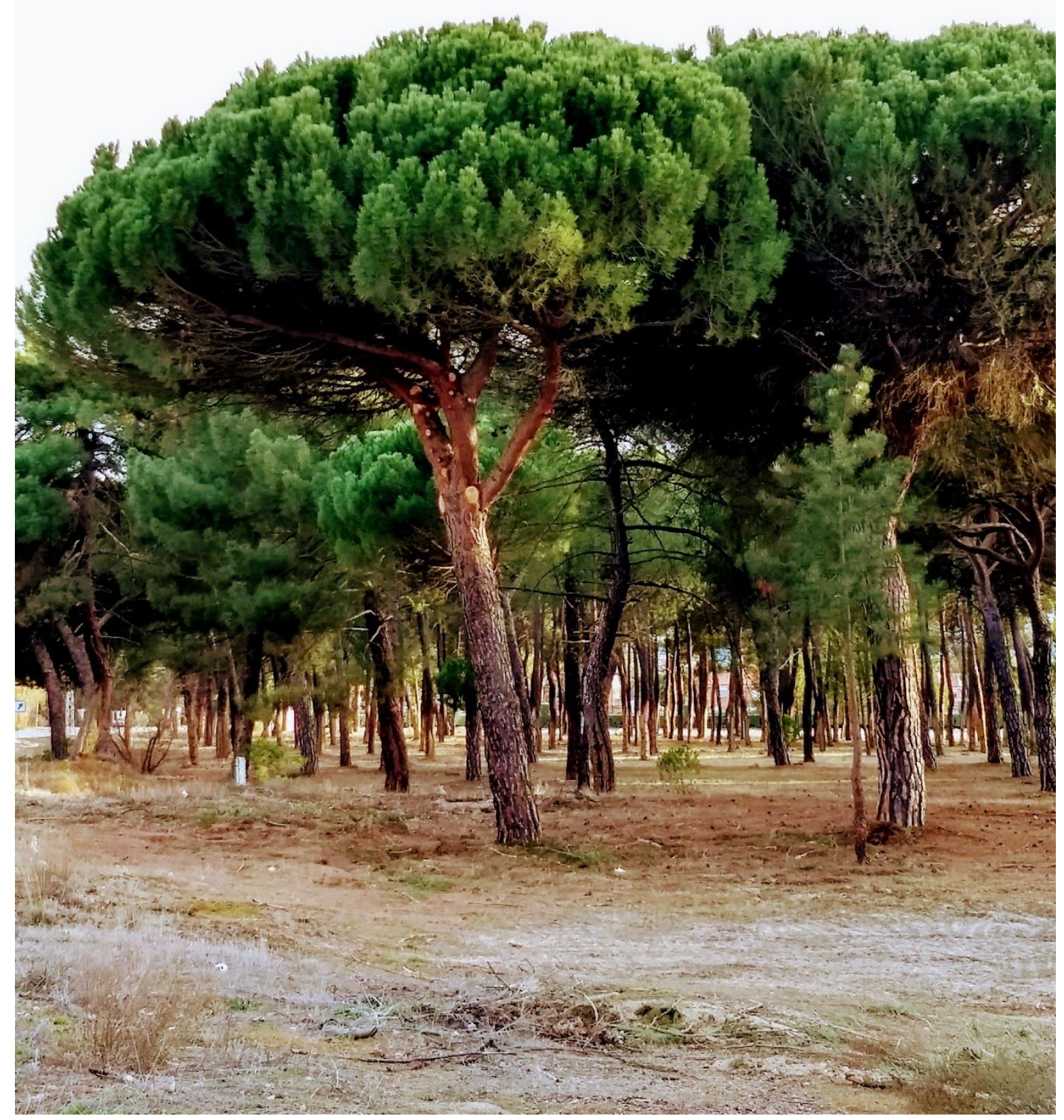

Figura 93. Pinar de Pinus pinea recién olivado. Imagen propia. 
Estudio de casos y aplicación práctica. Paisajes forestales con valor patrimonial.

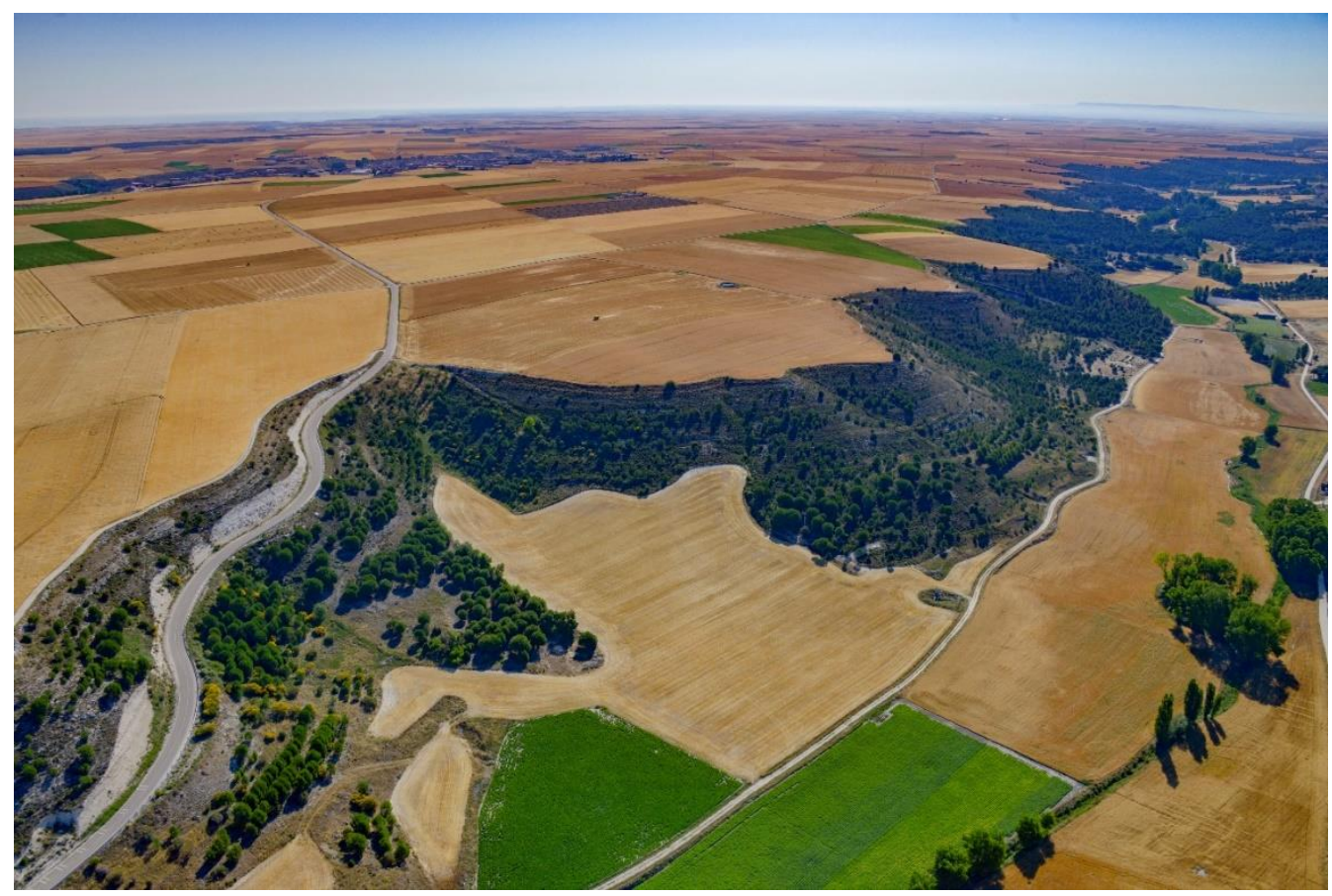

Figura 94. Las cuestas de los páramos ocupadas por el avance del pinar, en ocasiones repoblado y matorrales esclerófilos. Eugenio Baraja Rodríguez.

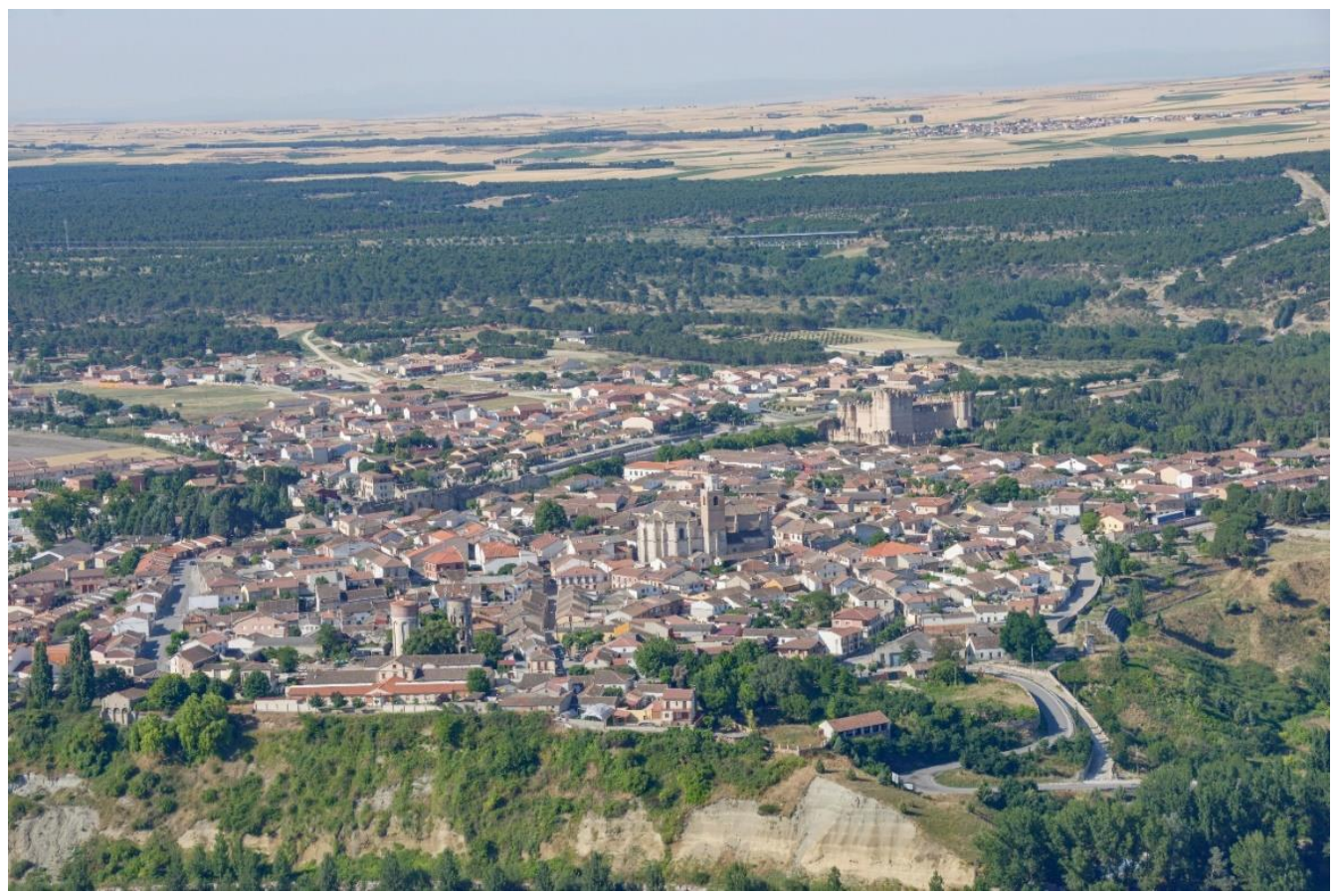

Figura 95. El municipio de Coca como ejemplo de núcleo de población compacto de La Tierra de Pinares. Eugenio Baraja Rodríguez. 
Este paisaje donde los protagonistas van a ser los pinos supone una excepción en la península ibérica. Los bosques, como se ha podido demostrar en los capítulos precedentes (Capítulo 2), se restringen generalmente a los espacios de montaña. Los espacios de llanura, por norma general, han sido explotados tradicionalmente mediante sistemas forestales de acompañamiento agropecuario (Capítulo 10), donde los espacios forestales en general y los árboles en particular son modificados de forma muy significativa con el objetivo de servir como sustento de una economía agropecuaria. Este caso, es algo excepcional en nuestra forma cultural de intervenir la foresta. Observando esta comarca, se va a apreciar un dominio de lo forestal, donde van a ser los usos agropecuarios islas que aparecen en claros donde los suelos ácidos arenosos han permitido el aprovechamiento agrícola (Figura 78). Igualmente, se ha desarrollado una ganadería intensiva con la proliferación de granjas avícolas y porcinas (Figura 96).
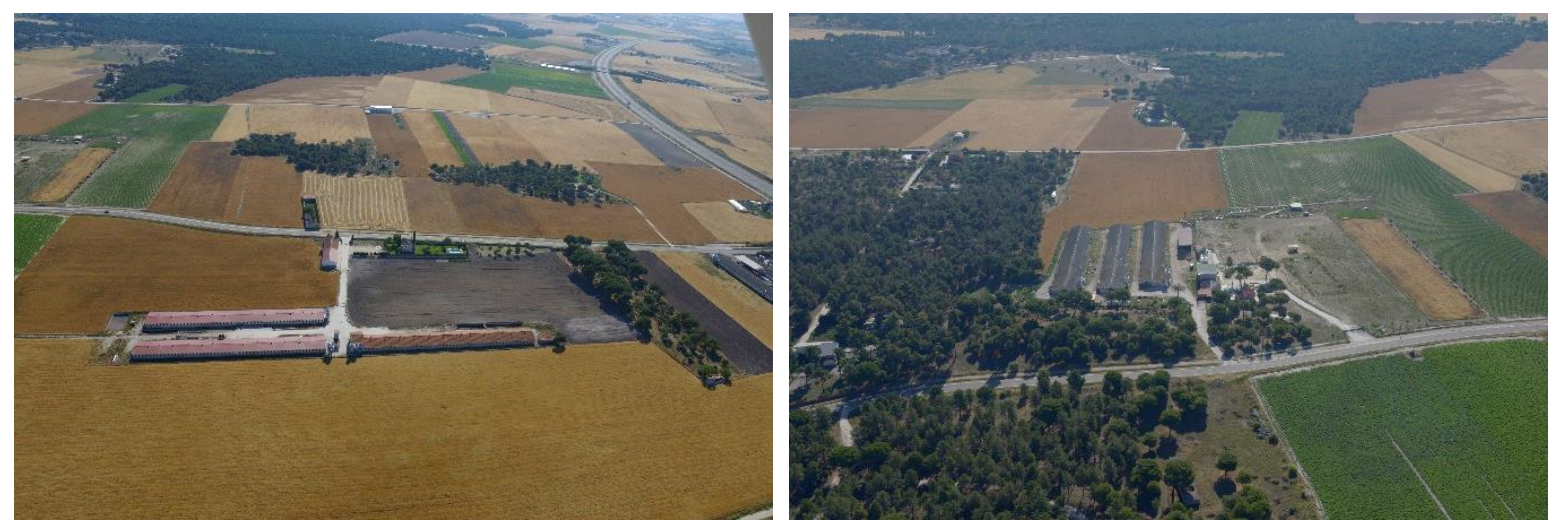

Figura 96. Granjas que salpican el paisaje en la Tierra de Pinares. Eugenio Baraja Rodríguez.

Este dominio del espacio forestal queda constatado mediante un proceso de trasposición horizontal de la información cartográfica, con el objetivo de hacer más sencillo comprender cómo se distribuyen las unidades de paisaje definidas, se han realizado distintos perfiles topográficos donde se ha incorporado la información vegetal a partir del Mapa Forestal de España $(1: 50.000)$ y la información sobre usos del suelo a partir de Corine 
Land Cover. Todo ello se ha contrastado mediante la observación directa en campos corrigiendo posibles errores de muestreo o generalización cartográfica (Figura 97 y Figura 98 y Figura 99).
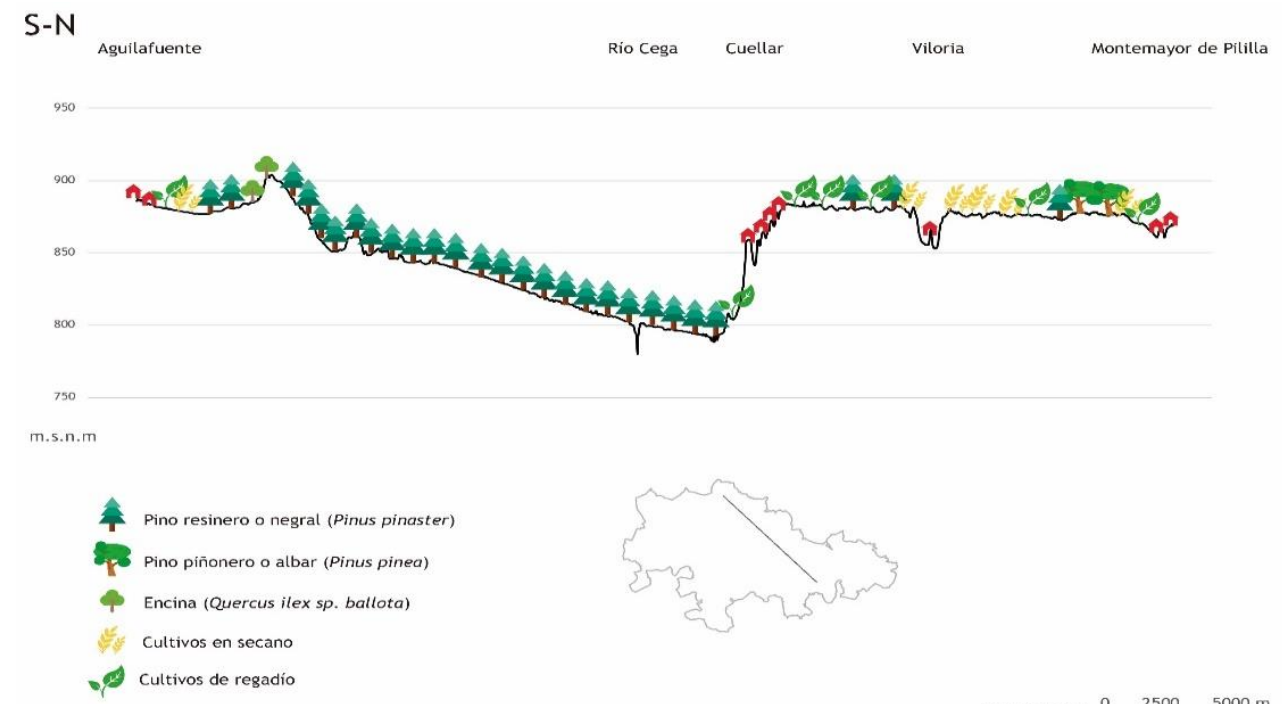

Figura 97. Perfil topográfico con información de usos Aguilafuente-Montemayor de Pililla. Elaboración propia.

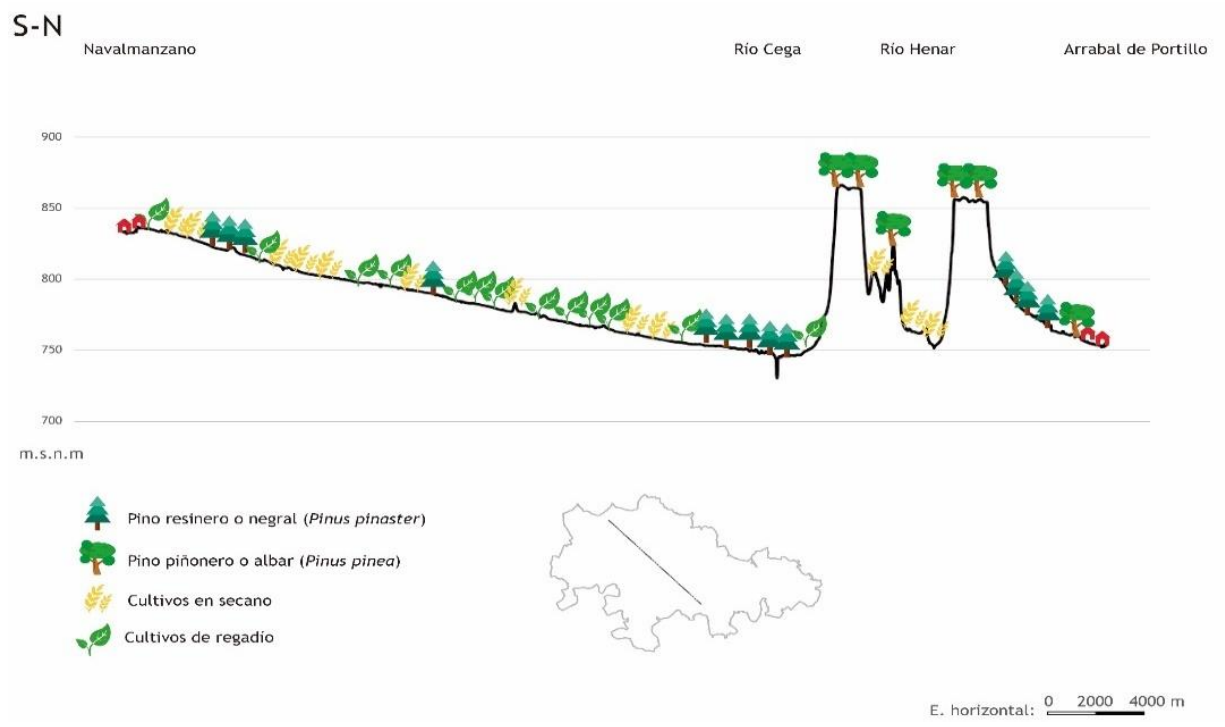

Figura 98. Perfil topográfico con información de usos Navalmanzano-Arrabal de Portillo. Elaboración propia. 
Estudio de casos y aplicación práctica. Paisajes forestales con valor patrimonial.

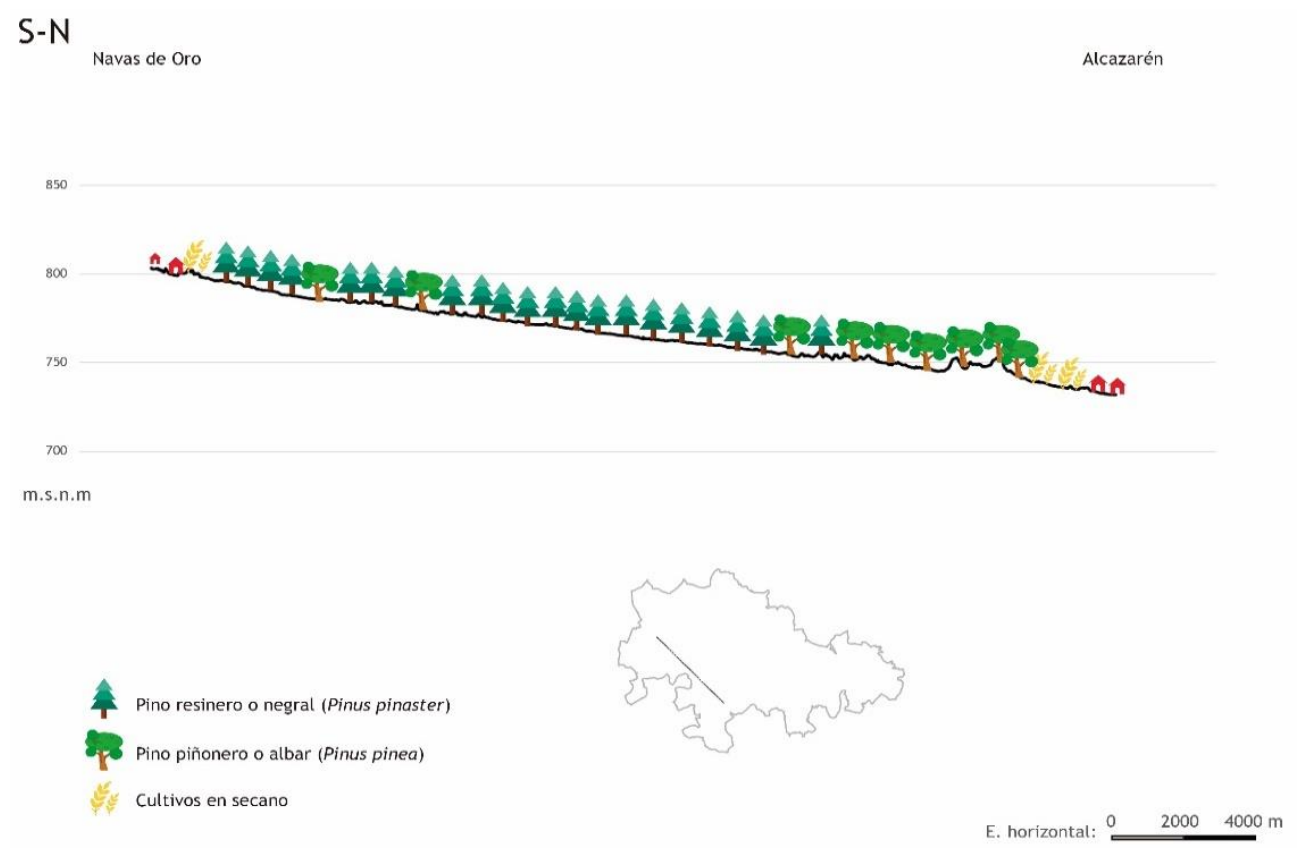

Figura 99. Perfil topográfico con información de usos Navas de Oro-Alcazarén. Elaboración propia. 


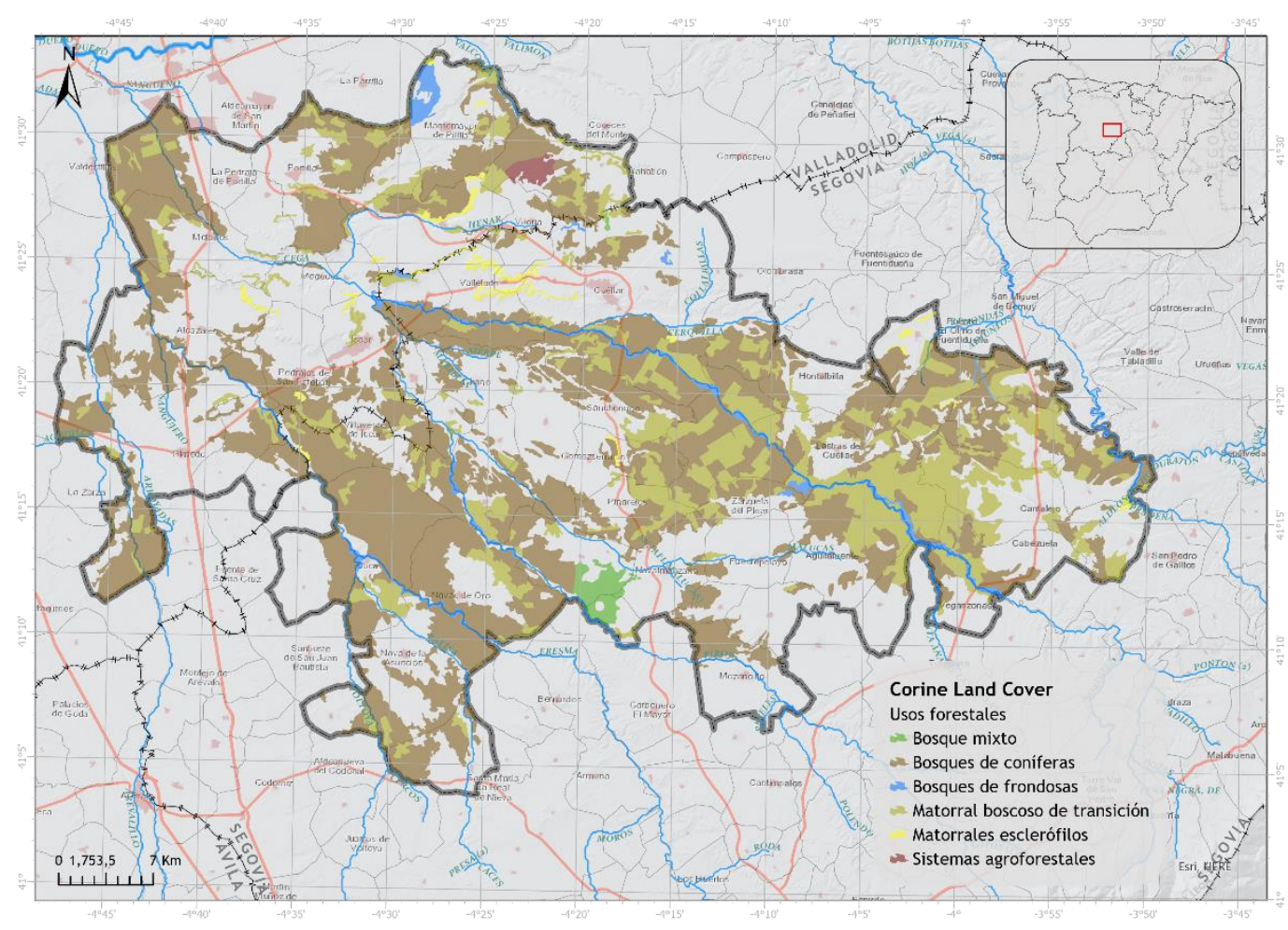

Figura 100. Mapa de usos del suelo destinados a los usos forestales. Elaboración propia a partir de Corine Land Cover. 


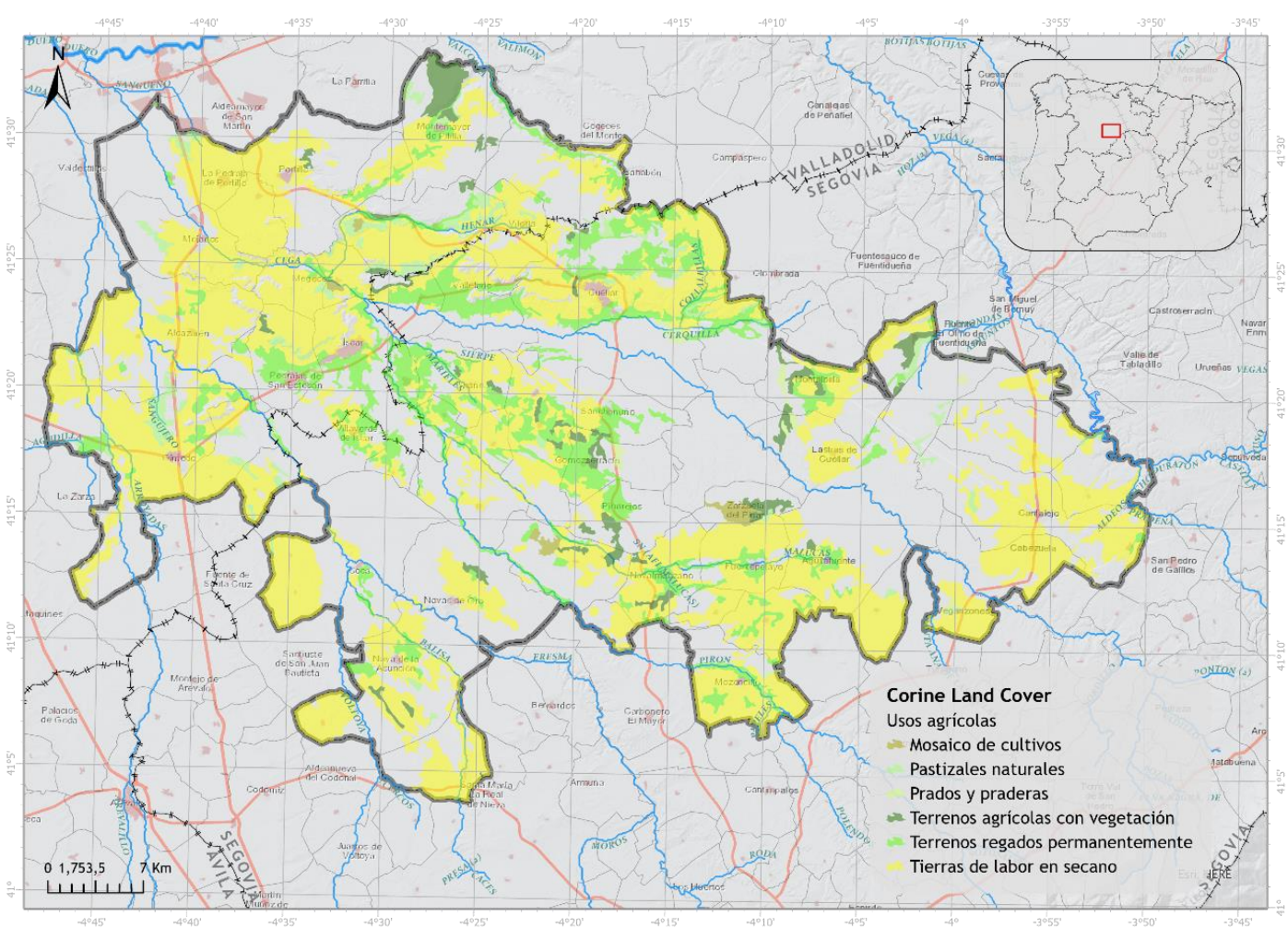

Figura 101. Mapa de Usos del suelo destinados a usos agrícolas. Elaboración propia a partir de Corine Land Cover.

\subsection{El proceso de patrimonialización a través de los indicadores.}

Este capítulo se ocupa de valorar los indicadores destinados a conocer el estado de patrimonialización del paisaje forestal de la Tierra de Pinares de Valladolid y Segovia. Con el objetivo de facilitar la comparación entre los diferentes casos de estudio se determina definir un término municipal que caracterice al conjunto. En este sentido se definen los criterios que se entienden esenciales para representar la realidad paisajística, social y económica. Se plantea, por tanto, escoger un municipio central que garantice la integridad paisajística, de igual manera se determina seleccionar un municipio posicionado en un rango medio atendiendo a la realidad demográfica y socioeconómica del conjunto. De esta manera se 
pretende obtener un testigo de la realidad geográfica del caso de estudio, la Tierra de Pinares de Valladolid y Segovia.

En primer lugar, se determinan los municipios centrales del área de estudio que van a garantizar la integridad paisajística. Mediante el tratamiento SIG se establecen 20 candidatos que aseguran sus límites completamente dentro del área delimitada como Tierra de Pinares (Figura 102), de esta manera se evitan interferencias de territorios aledaños con características diferentes. Por otro lado, se establece el criterio de centralidad demográfica, es decir será elegible aquel municipio que ocupe una posición intermedia en cuanto al número de habitantes (padrón 2017), garantizando la representatividad. De acuerdo con esto se escogen 7 candidatos que se sitúan entre la media y la mediana del conjunto de municipios centrales (Figura 103). Por último, para determinar el municipio que servirá como testigo se aplica el criterio de centralidad socioeconómica para lo que se ha determinado escoger un municipio que presente una posición intermedia en lo que se refiere al mercado laboral, atendiendo a la tasa de actividad global (afiliados a la seguridad social Julio 2017+parados julio 2017/Padrón 2017). Garantizando una representatividad socioeconómica que se aleje de extremos distorsionadores del conjunto (Tabla 32). El municipio que más se aproxima a esa posición central es Vallelado emplazándose en la mediana de la muestra, aunque algo por encima de la media, en cualquier caso, es un testigo fiable. 


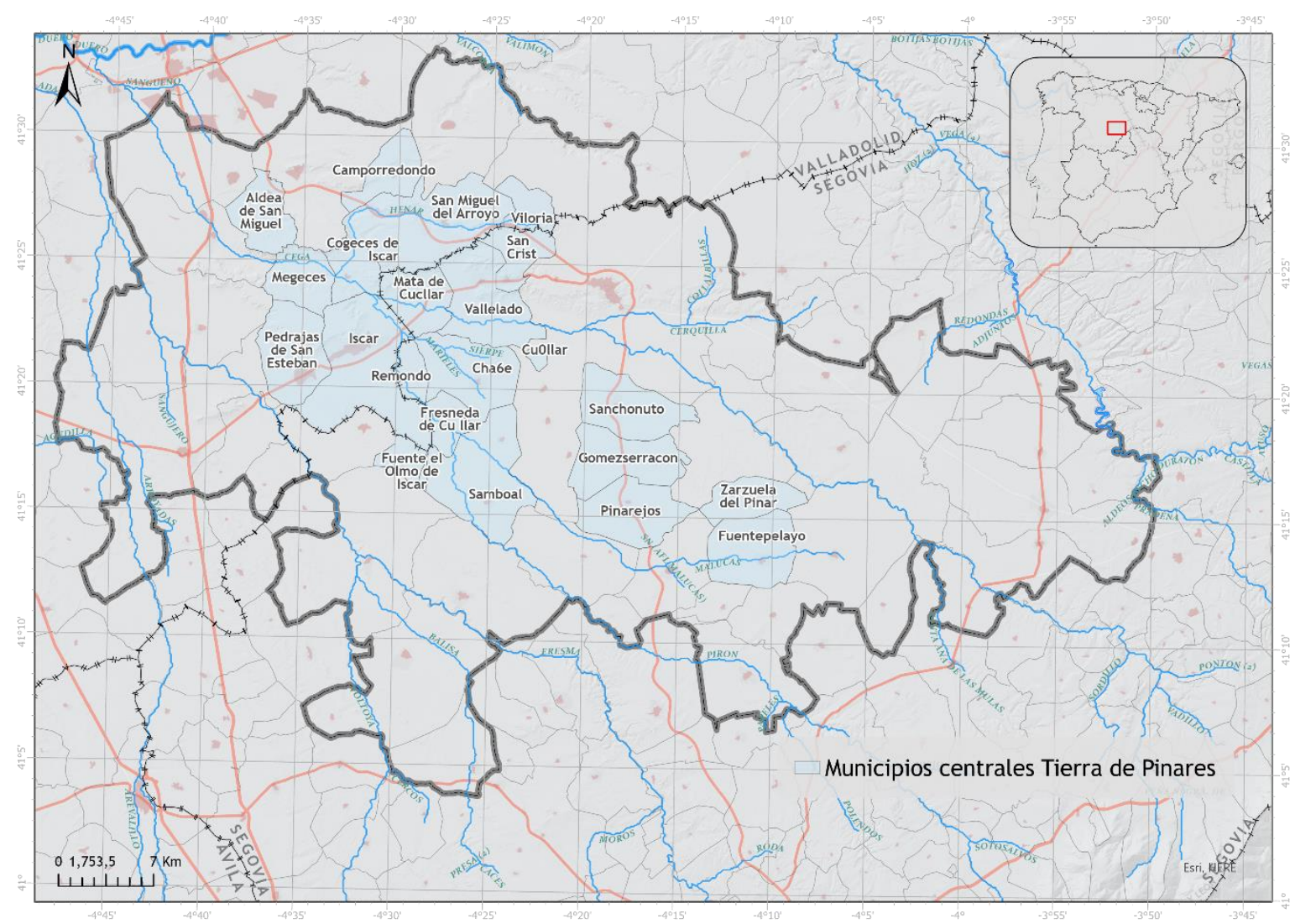

Figura 102. Mapa con los municipios que van a cumplir el criterio de centralidad establecido para servir como testigo de patrimonialización. Elaboración propia. 


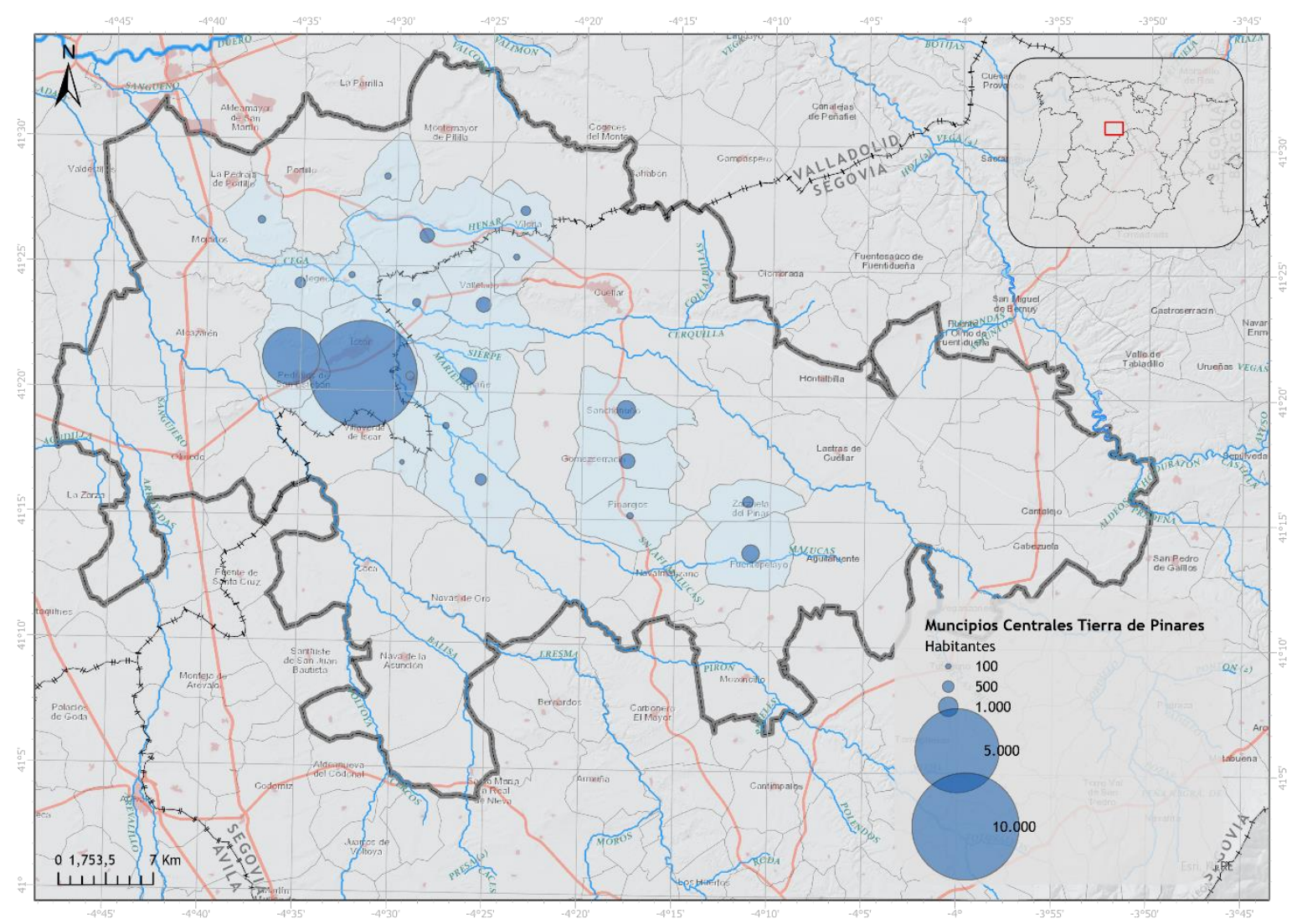

Distribución de los habitantes por municipio

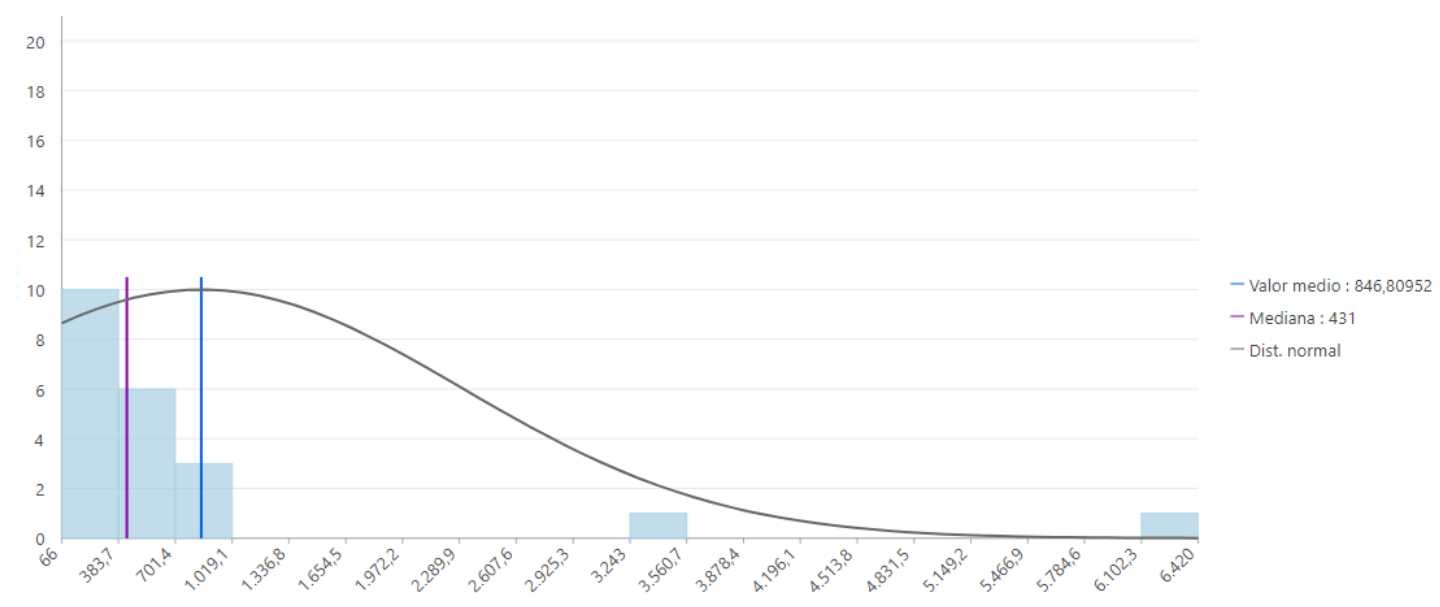

Habitantes

Figura 103. Mapa con la población de los municipios centrales de la Tierra de pinares. Elaboración propia. 


\begin{tabular}{l|lrrr} 
PROVINCIA & MUNICIPIO & POBLACIÓN & ACTIVOS & TASA ACTIVIDAD GLOBAL \\
\hline 40 SEGOVIA & 40065 CHAÑE & 813 & 463 & 0,5695 \\
47 VALLADOLID & 47087 MEGECES DE ISCAR & 431 & 202 & 0,4687 \\
47 VALLADOLID & 47145 SAN MIGUEL DEL ARROYO & 677 & 167 & 0,2467 \\
40 SEGOVIA & 40219 VALLELADO & 697 & 306 & 0,4390 \\
40 SEGOVIA & 40176 SAMBOAL & 469 & 121 & 0,2580 \\
40 SEGOVIA & 40095 GOMEZSERRACIN & 699 & 307 & 0,4392 \\
40 SEGOVIA & 40234 ZARZUELA DEL PINAR & 442 & 97 & 0,2195 \\
& & \multicolumn{2}{c}{ Media } & 0,3772 \\
& & \multicolumn{2}{c}{ Mediana } & 0,4390
\end{tabular}

Tabla 32. Tabla con la distribución laboral de los municipios que cumplen los criterios de población para ejercer como testigo en el proceso de patrimonialización de la Tierra de Pinares. Elaboración propia a partir de Datos Seguridad Social 2017.

Este municipio está situado en la provincia de Segovia, en su límite norte con la provincia de Valladolid, garantizando igualmente la existencia de los dos tipos de pinos que van a caracterizar el paisaje vegetal del área de estudio (Pinus pinaster Ait. y Pinus pinea L.) aunque con especial dominio del pino resinero (Pinus pinaster Ait.) Por otro lado, el municipio de Vallelado se sitúa a orillas del río Cega, uno de los principales ejes vertebradores de la Tierra de Pinares.

Una vez definido el municipio de Vallelado como testigo para el análisis de indicadores y de acuerdo con lo planteado en el apartado correspondiente (ver 6.3) se procede a la valoración.

\subsubsection{Indicador 1. Complejidad biológica}

\begin{tabular}{|l|c|}
\hline Criterio & Puntuación \\
\hline Evidencias bibliográficas de naturalidad & 3 \\
\hline Hábitat de Interés Comunitario & 4 \\
\hline Salud vegetal NDVI & 3 \\
\hline
\end{tabular}

Tabla 33. Resumen criterios valoración indicador Complejidad Biológica. 
Atendiendo la riqueza en flora vascular como indicador de diversidad ecológica algunos autores señalan que, pese a ser estos pinares de lógica industrial un refugio de biodiversidad en el contexto agrícola del centro de la cuenca del Duero, son algo más pobres que otros espacios como dehesas, bosques ribereños o límites de cuerpos de agua (Soliño et al., 2018). De igual manera, parece evidente que las prácticas recolectivas actuales son impactantes en la regeneración del sotobosque (González et al., 2009a; b; González, Martínez, et al., 2010), lo que empobrece en cierta medida la biodiversidad de este espacio forestal, lo que pudo comprobarse mediante la observación directa (Figura 104). Es indudable que la mecanización para la obtención de recursos y las prácticas actuales de aprovechamiento están mermando la capacidad de recuperación y mantenimiento de un ecosistema diverso. De acuerdo con esta información, el criterio propuesto que valora positivamente la naturalidad del espacio forestal no se cumple.

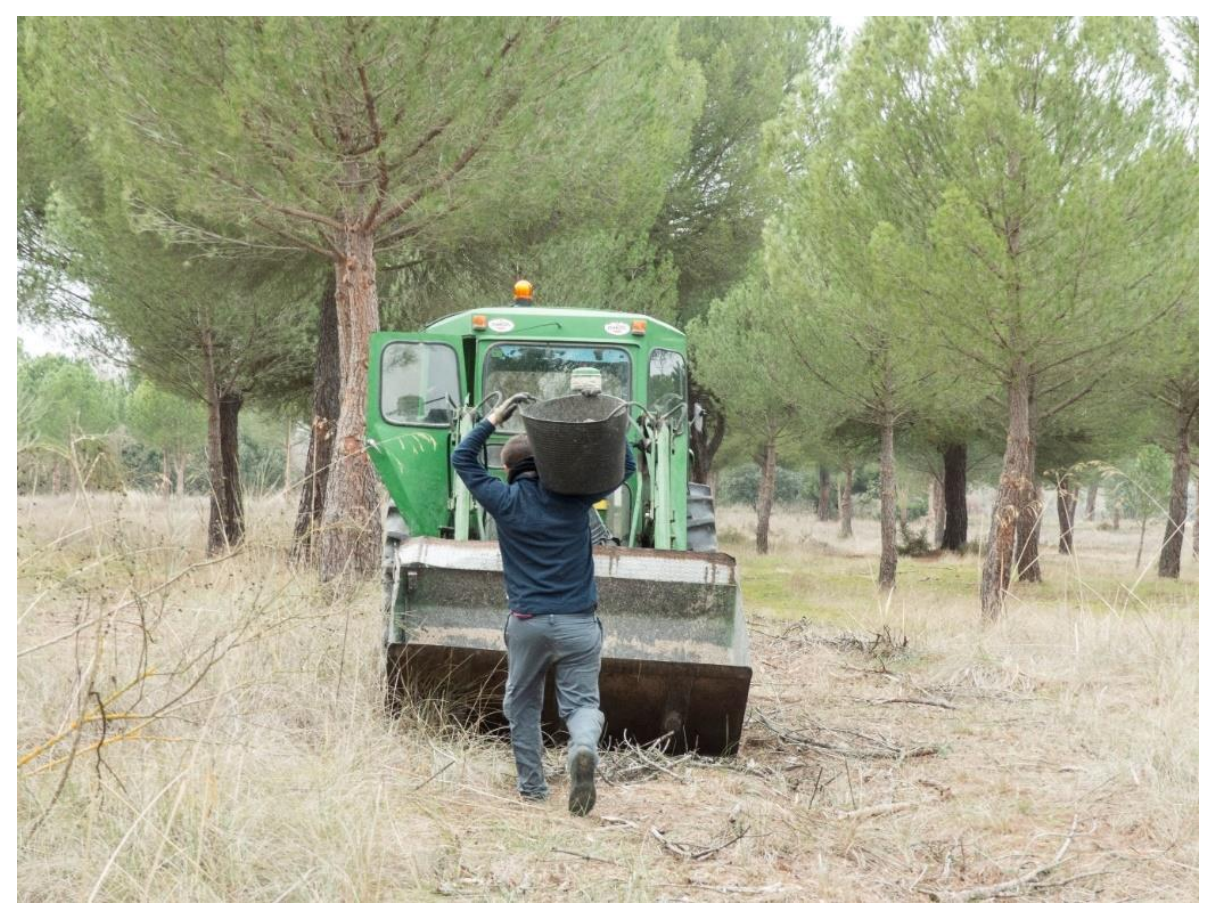

Figura 104. Ejemplo de actividad recolectiva en un pinar de Pinus pinea. Se puede apreciar la compactación de suelo y rotura de ramas. Imagen propia. 
En lo que se refiere a la Directiva Hábitat (Figura 105), el municipio alberga 4 comunidades vegetales catalogadas, de las cuales, las dos primeras están directamente relacionadas con el pinar, por un lado, los espliegares que se desarrollan en las cuestas de los páramos repobladas por pinos y por otro lado la formación de piornales con lavanda que componen el sotobosque del pinar de llanura. Igualmente, se encuentran catalogadas dos formaciones asociadas al bosque de ribera que se desarrolla a lo largo del Cega:

- Lino differentis-Salvietum lavandulifoliae (Espliegares)

- Lavandulo pedunculatae-Adenocarpetum aure (Piornales con lavanda)

- Salicetum salvifolio-lambertianae (Saucedas)

- Ranunculus penicillatus

De este modo, al encontrar dos formaciones catalogadas por la directiva hábitat asociadas directamente con el pinar, el criterio planteado se cumple. 


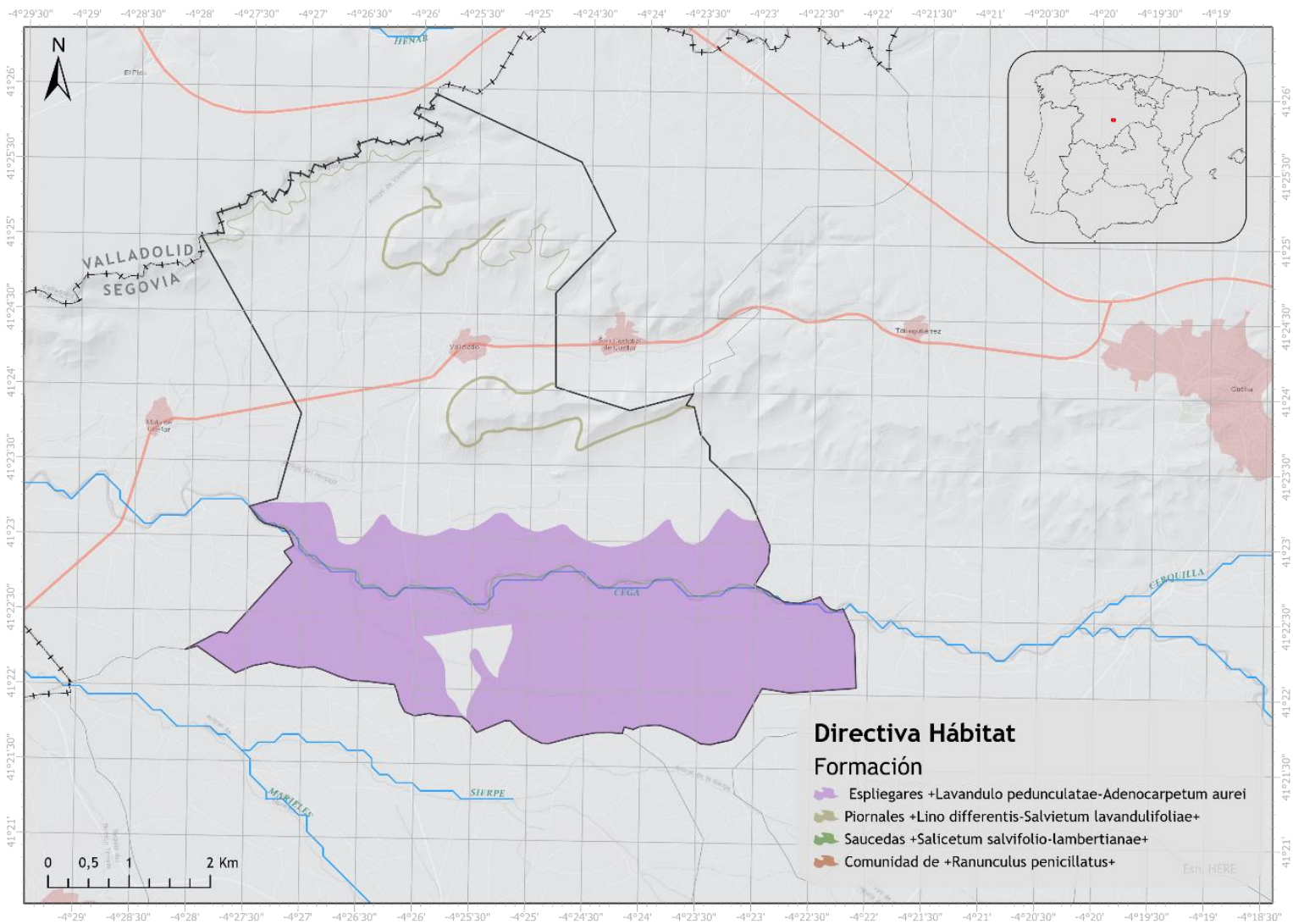

Figura 105. Mapa de las formaciones recogidas en la Directiva Hábitat en el municipio de Vallelado. Elaboración propia a partir de Directiva Hábitat Banco de Datos de la Naturaleza.

Por otro lado, y con la intención de ponderar el valor de este indicador con algunas evidencias cuantitativas, se ha procedido a elaborar el índice NDVI (Índice de Vegetación de Diferencia Normalizada) (ver 6.3.1) en las cuatro estaciones meteorológicas del año. De este modo se ha podido obtener la salud de la vegetación del municipio comparando las diferentes cubiertas con el pinar y arrojando un valor medio entre la elevada salud de la vegetación ripícola y la limitada vigorosidad de los secanos estivales. El pinar ha demostrado mantener cierta vigorosidad sostenida a lo largo del año (Tabla 34), presentándose como un cierto reservorio vegetal que, de no existir, estaría destinado a cultivos de secano monoespecíficos (Figura 106). En este caso el criterio planteado se cumple. 

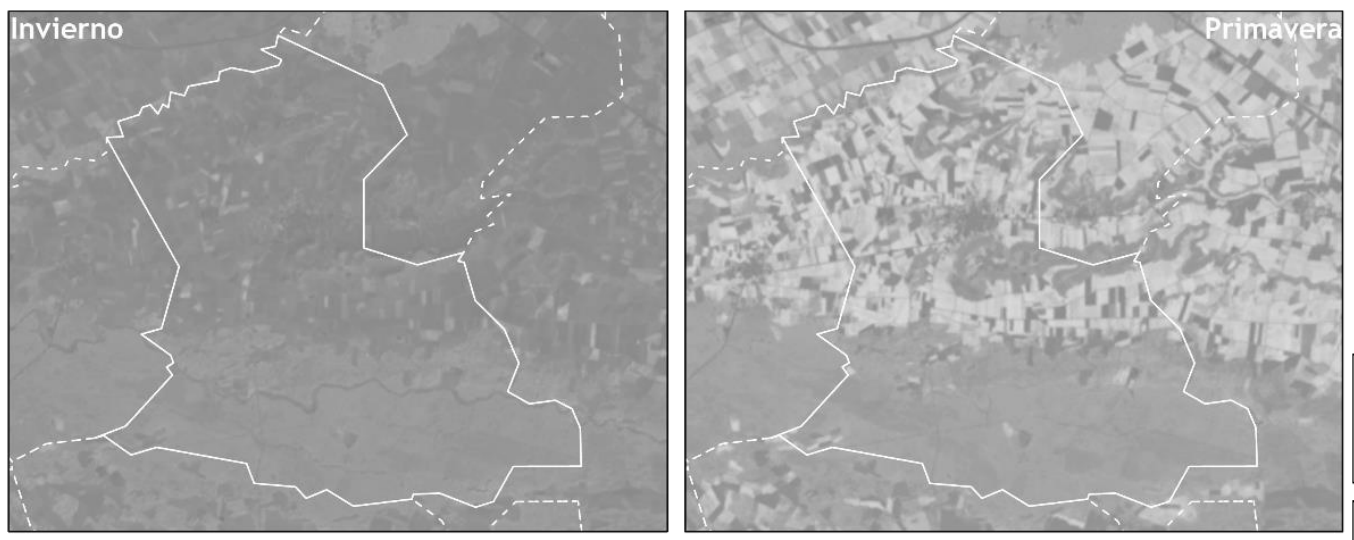

Municipio de
Vallelado
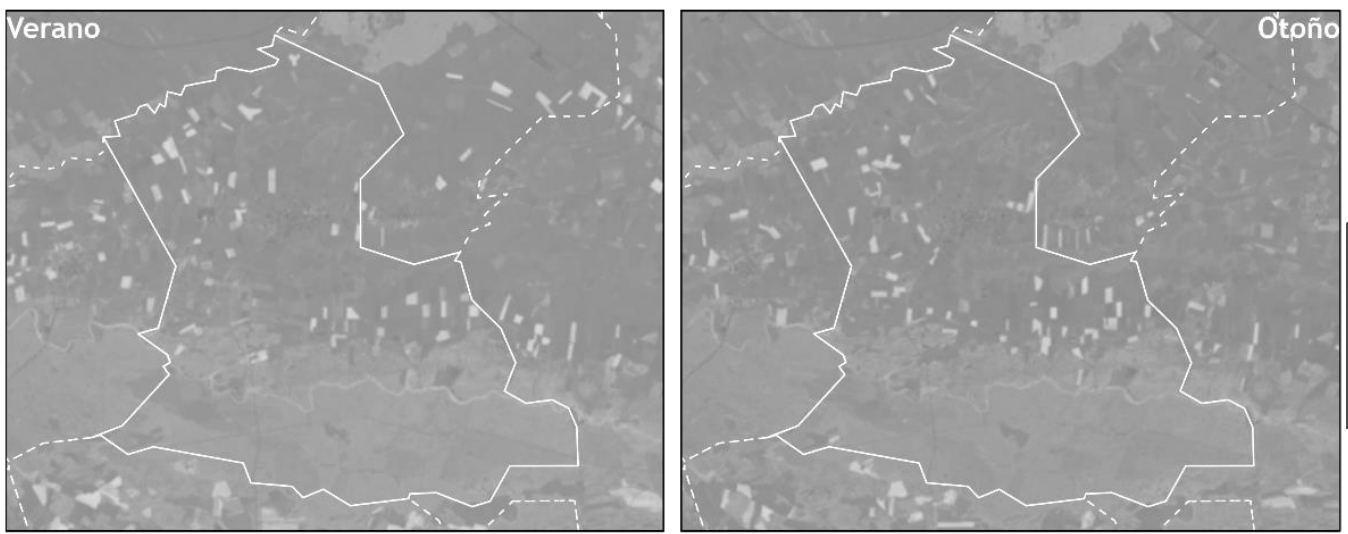

índice

NDVI

Figura 106. Representación del índice de vegetación de diferencia normalizada para los meses de febrero, mayo, agosto y octubre respectivamente. Imágenes Landsat 8 . Elaboración propia.

\begin{tabular}{|c|c|c|c|}
\hline & Pinar & Cultivos & Otra veg. (no existe) \\
\hline Invierno & 0,18 & 0,09 & \\
\hline Primavera & 0,27 & 0,46 & \\
\hline Verano & 0,24 & 0,14 & \\
\hline Otoño & 0,23 & 0,27 & \\
\hline
\end{tabular}

Tabla 34. Valor NDVI de distintas cubiertas a lo largo del periodo vegetativo. Elaboración propia. 


\begin{tabular}{|c|c|c|}
\hline Criterio & Puntuación & Cumplimiento \\
\hline $\begin{array}{c}\text { Evidencias bibliográficas de } \\
\text { naturalidad }\end{array}$ & 3 & $\begin{array}{c}\text { Las evidencias } \\
\text { demuestran una gran } \\
\text { intervención }\end{array}$ \\
\hline Hábitat de Interés Comunitario & 4 & $\begin{array}{c}\text { El hábitat protegido } \\
\text { está relacionado con el } \\
\text { pinar }\end{array}$ \\
\hline Salud vegetal NDVI & 3 & $\begin{array}{c}\text { Corresponde con un } \\
\text { reservorio vegetal }\end{array}$ \\
\hline
\end{tabular}

Tabla 35. Resumen criterios cumplidos valoración indicador Complejidad Biológica.

\subsubsection{Indicador 2. Figuras de protección, reconocimiento y salvaguarda presentes en el territorio}

\begin{tabular}{|l|c|}
\hline Criterio & Puntuación \\
\hline Figura otorgada por UNESCO & 4 \\
\hline Parque Nacional & 3 \\
\hline Parque Natural o inferior (CCAA) & 2 \\
\hline LIC o ZEPA & 1 \\
\hline Otras figuras & 0,5 \\
\hline
\end{tabular}

Tabla 36. Resumen criterios valoración indicador Figuras de protección.

El valor otorgado a este indicador se fundamenta en la recopilación de información sobre aquellas figuras administrativas que, enmarcadas dentro del municipio, están relacionadas con el paisaje forestal. En este caso la figura que se encuentra dentro del municipio no se ocupa directamente del pinar, aunque es evidente que los valores a los que aluden no serían relevantes de no ser por el contexto forestal, al estar la ribera, inmersa en un pinar fundamentalmente resinero.

Figura encontrada: 
- LIC Riberas del Río Cega (Figura 107)

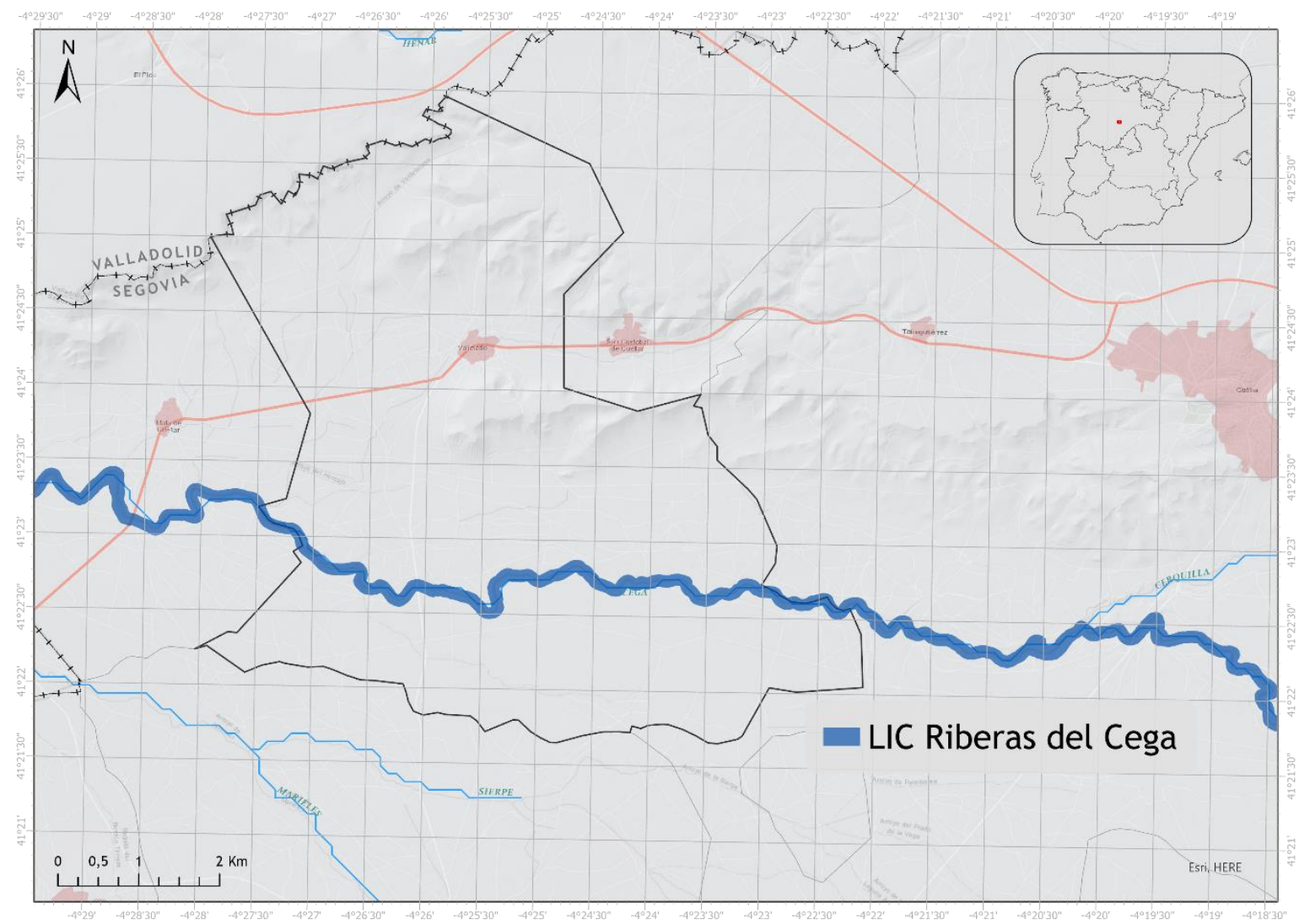

Figura 107. Mapa del Lugar de Interés Comunitario Riberas del Cega a su paso por el municipio de Vallelado. Elaboración propia a partir de Banco de Datos de la Naturaleza.

Por otro lado, la mayor parte del espacio forestal posee la declaración de Monte de Utilidad Pública, lo que va a avalar la preservación del uso forestal de este espacio. Esta figura, pese a no fundamentarse en valores propiamente naturales, preserva la propiedad forestal en manos públicas, siendo esto una garantía de persistencia del pinar (Figura 108). 


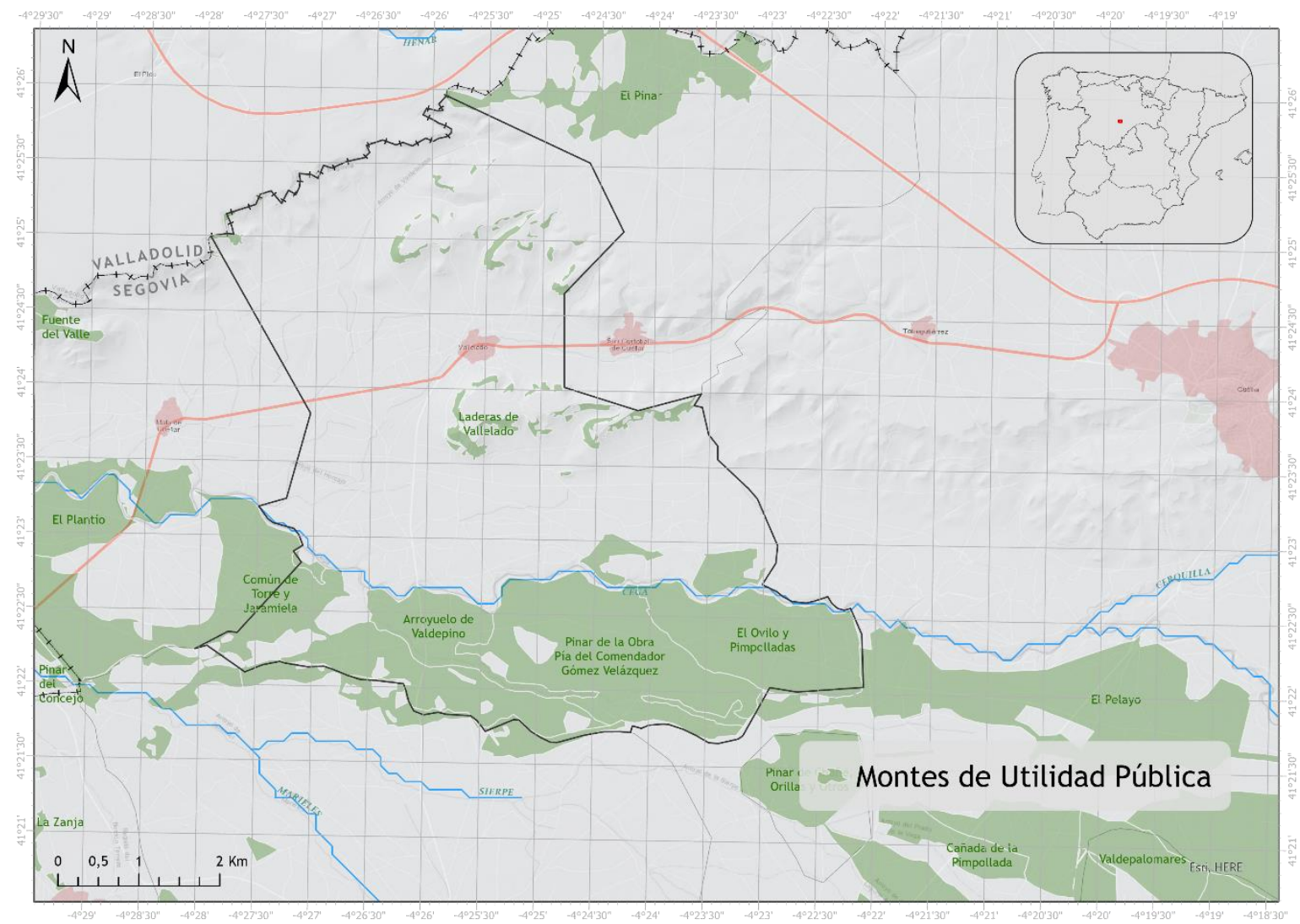

Figura 108. Mapa con los Montes de Utilidad Pública en el municipio de Vallelado. Elaboración propia a partir de Montes de Utilidad Pública Junta de Castilla y León.

De acuerdo con los criterios planteados obtiene 1 punto sobre 10 (Tabla 37).

\begin{tabular}{|c|c|c|}
\hline Criterio & Puntuación & Cumplimiento \\
\hline Figura otorgada por UNESCO & 4 & $\begin{array}{c}\text { No tiene } \\
\text { reconocimiento } \\
\text { UNESCO }\end{array}$ \\
\hline Parque Nacional & 3 & No es PN \\
\hline Parque Natural o inferior (CCAA) & 2 & No tiene otra \\
& & catalogación \\
\hline LIC o ZEPA & 0,5 & Posee un LIC \\
\hline Otras figuras & 0,5 & MUP \\
\hline
\end{tabular}


Tabla 37. Resumen criterios cumplidos valoración indicador Figuras de protección.

\subsubsection{Indicador 3. Existencia de vectores patrimoniales}

\begin{tabular}{|l|c|}
\hline Criterio & Puntuación \\
\hline Todos los vectores & 4 \\
\hline Al menos 50\% tratados patrimonialmente & 3 \\
\hline Identificados vectores de todos los tipos & 3 \\
\hline
\end{tabular}

Tabla 38. Resumen criterios valoración indicador Vectores Patrimoniales

En este caso, se alude a la existencia de vectores patrimoniales, entendidos como esos elementos que van a fijar el valor patrimonial al territorio. Para este indicador se conviene en analizar la existencia de los vectores que se han definido para el paisaje forestal del bosque productivo (ver 3.5.2) identificando los siguientes ejemplos.

Cuarteles: Los cuarteles están presentes el paisaje forestal actual pero su existencia y conservación responde más a su actual valor productivo que a algún tipo de tratamiento de conservación patrimonial (Figura 109)

Calles/cortafuegos: Al igual que el vector anterior la existencia de calles entre cuarteles y cortafuegos están relacionados directamente con el valor productivo y funcional del paisaje forestal (Figura 109).

Potes: están presentes y cuidados en tanto que son resultado del valor productivo del pinar. Hay que señalar que en el aspecto productivo se han sustituido los tradicionales de barro por nuevos potes de plástico (Figura 110).

Barricas metálicas: En este caso se han encontrado barricas. (Figura 111)

Pegueras: En el municipio de Vallelado no hay evidencia de ninguna peguera. 
Ejemplares monumentales: Existen algunos ejemplares significativamente más grandes que el resto, destinados en buena medida a servir de atalaya para las aves rapaces. Entre todos estos destaca la famosa "Pina" de Vallelado. (Figura 112).

Aperos: Existen evidencias de aperos, en ocasiones algunos de ellos continúan activos (Figura 113).

Resineras/chimeneas: En el municipio de Vallelado no se han encontrado construcciones de este tipo.

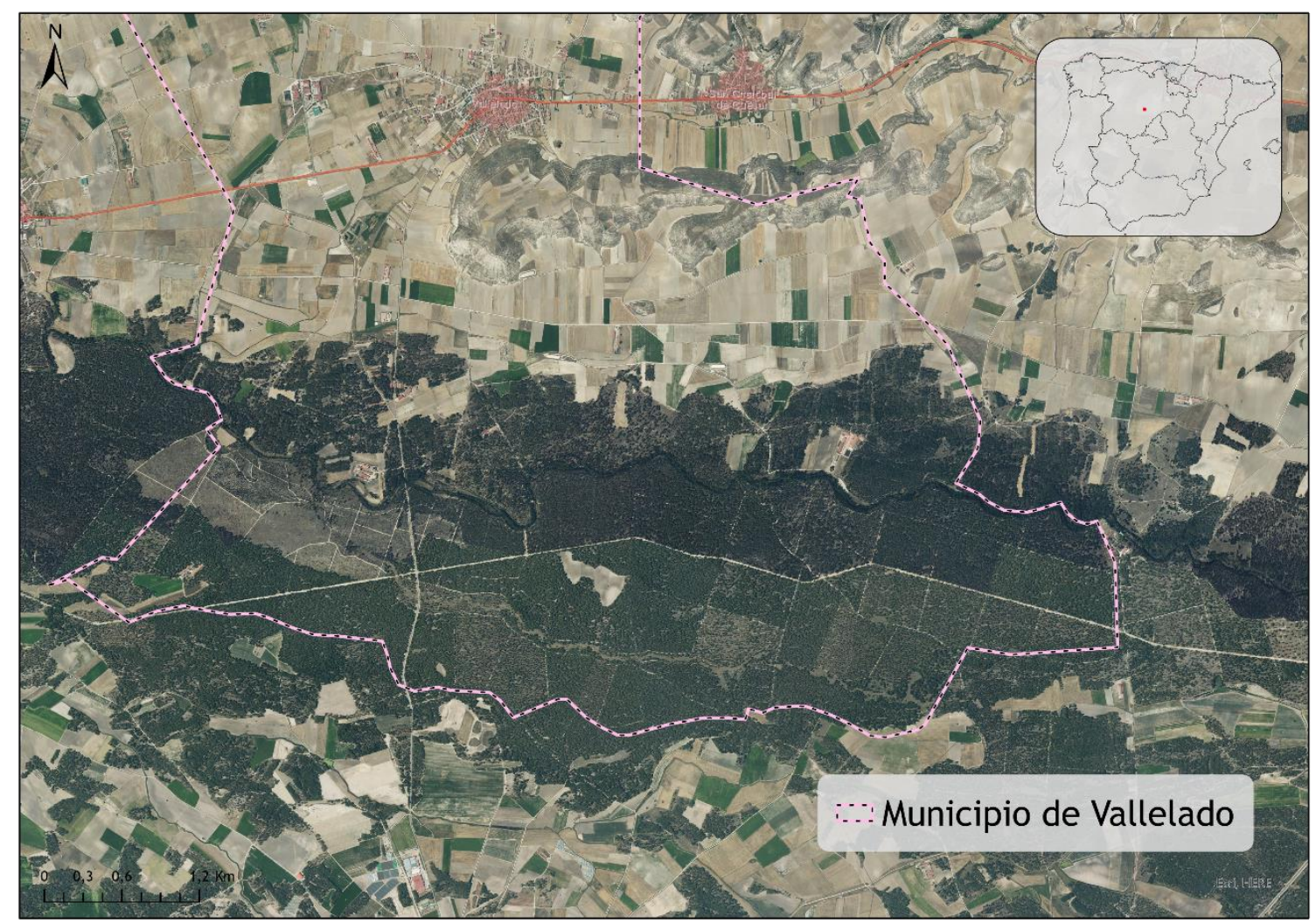

Figura 109. Imagen del Plan Nacional de Ortofotografía Aérea (PNOA) donde se identifican perfectamente los cuarteles de gestión forestal y los cortafuegos del pinar en Vallelado. Elaboración propia. 

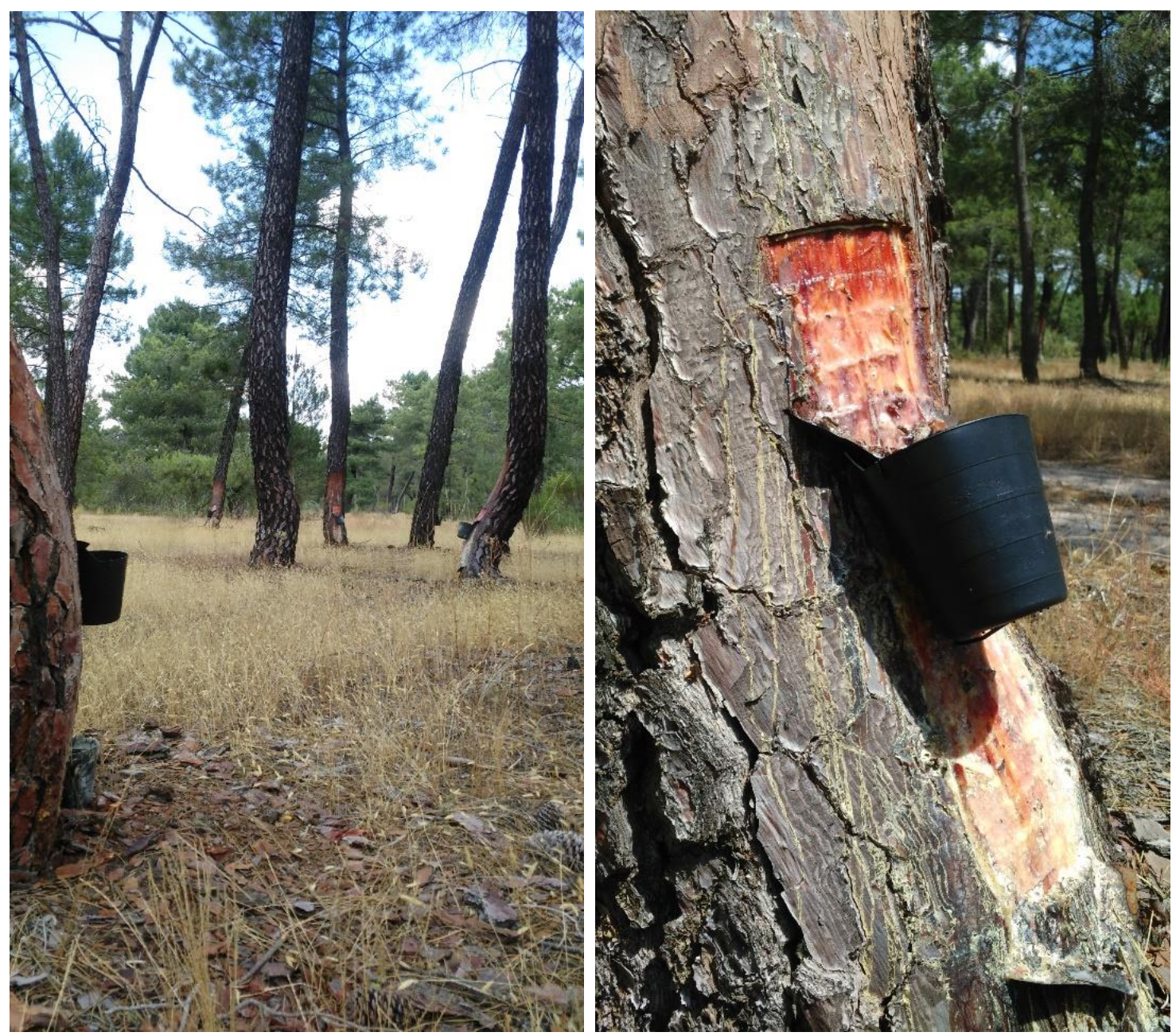

Figura 110. Potes de plástico destinados a la recogida de la miera. Imagen propia. 


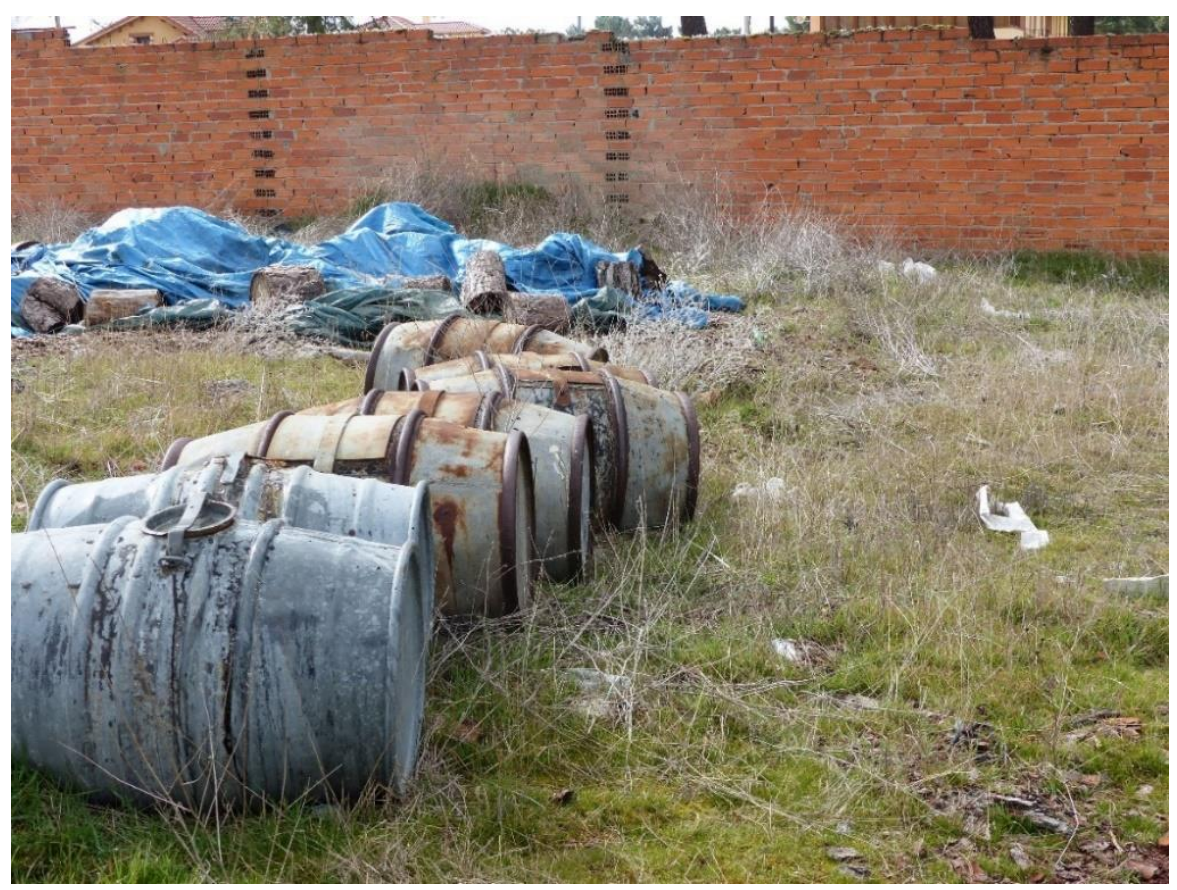

Figura 111. Barricas resineras para almacenar la miera. Imagen propia.

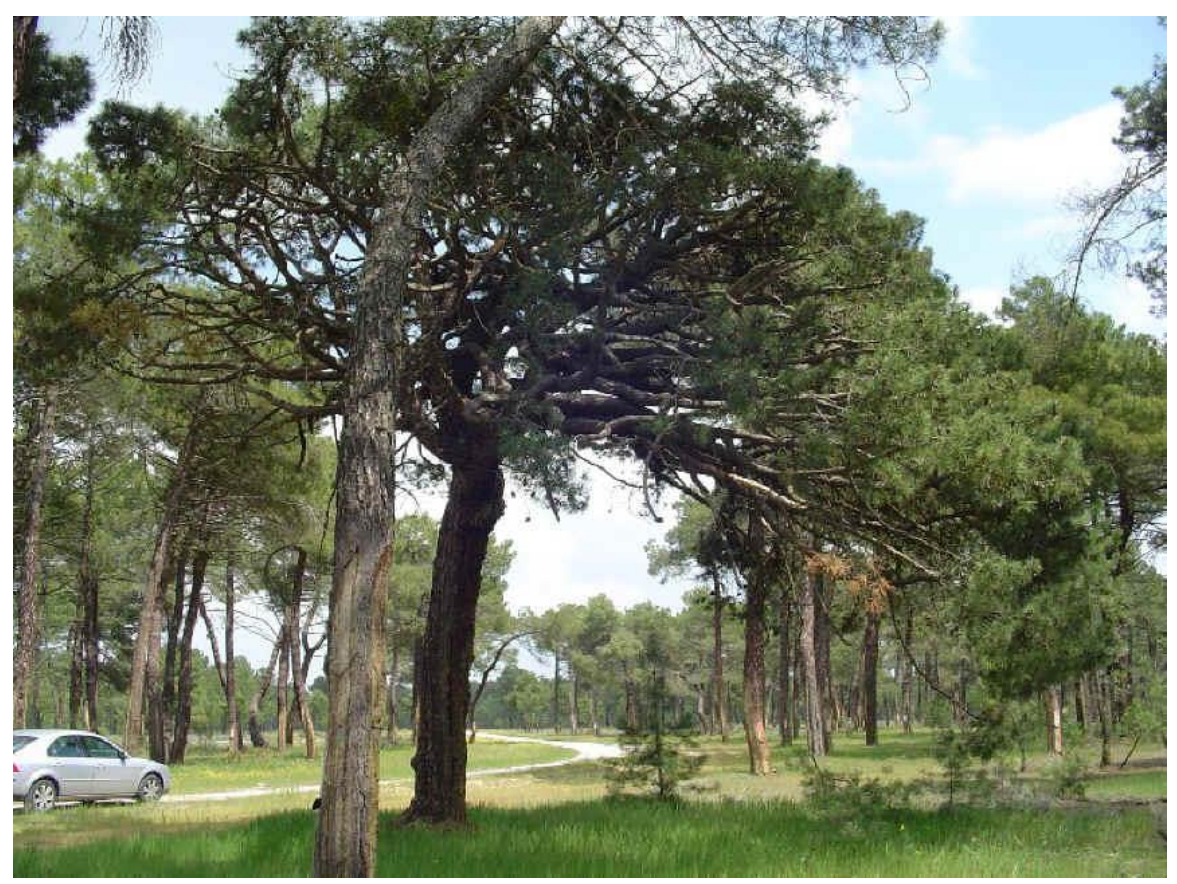

Figura 112. Imagen de "La Pina" de Vallelado, este ejemplar de Pinus pinaster Ait está catalogado por la Junta de Castilla y León con el código AS-SG-23 como Espécimen Vegetal de Singular Relevancia. Recuperado de http://www.vallelado.net/2006/07lapina/lapina.html 


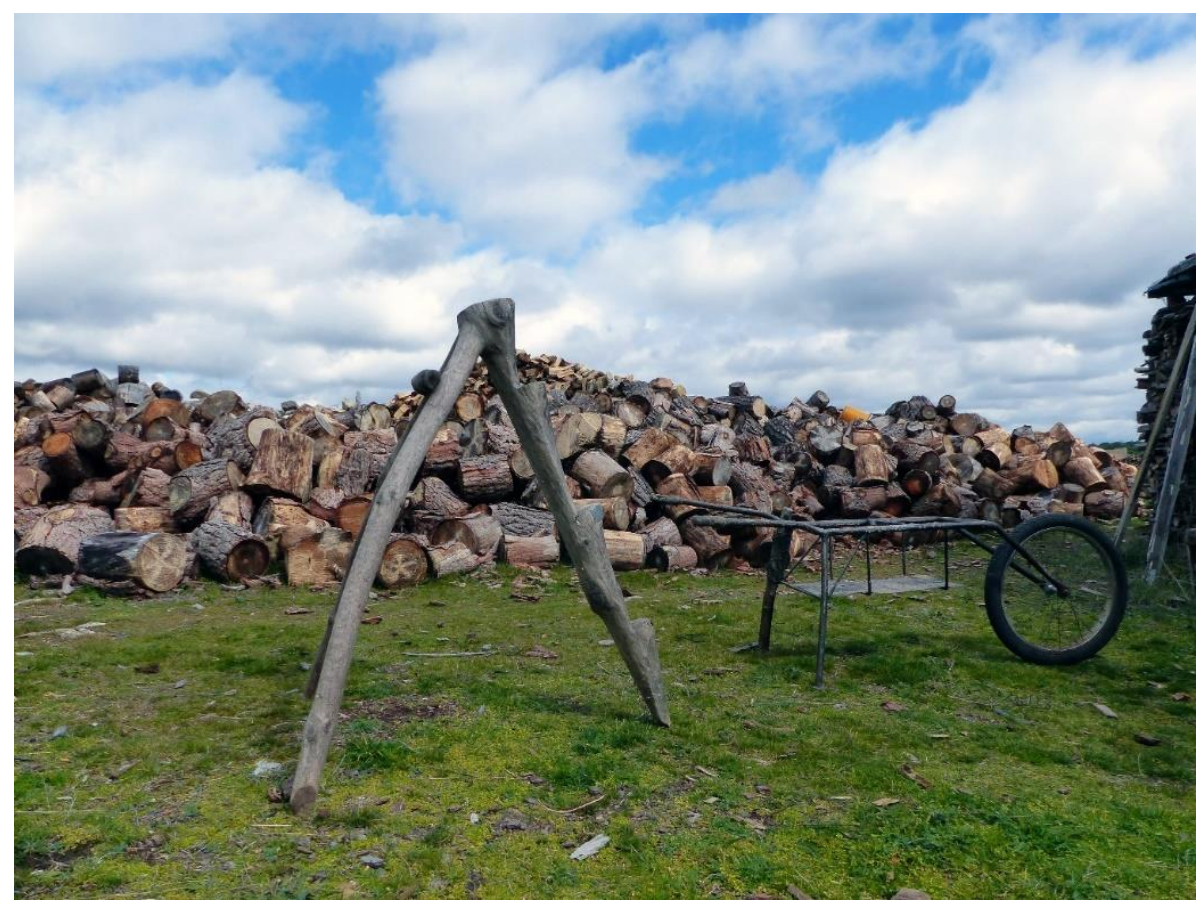

Figura 113. De izquierda a derecha, escalera de tres patas para la resinación, carro para transportar las barricas. Imagen propia.

De acuerdo con estas evidencias recogidas, no han sido identificados todos los vectores planteados para este paisaje, por lo que cumple el primer criterio (Tabla 39).

En cuanto al segundo criterio, los elementos encontrados no están activados patrimonialmente, algunos siguen siendo funcionales mientras que otros están abandonados. Este criterio no se cumple.

Por último, existen vectores correspondientes a los tres tipos, por lo que este criterio sí que se cumple. 


\begin{tabular}{|c|c|c|}
\hline Criterio & Puntuación & Cumplimiento \\
\hline Todos los vectores & 4 & $\begin{array}{c}\text { Algunos vectores } \\
\text { no parecen en } \\
\text { Vallelado }\end{array}$ \\
\hline Al tratados & 3 & $\begin{array}{c}\text { La activación } \\
\text { patrimonial es muy } \\
\text { escasa, la mayoría } \\
\text { no están tratados }\end{array}$ \\
\hline Inonialmente & & Existen vectores de \\
\end{tabular}

Tabla 39. Resumen criterios cumplidos valoración indicador Vectores Patrimoniales

\subsubsection{Indicador 4. Identificación y sentimiento de pertenencia}

\begin{tabular}{|l|c|}
\hline Criterio & Puntuación \\
\hline Toponimia & 2 \\
\hline Heráldica & 2 \\
\hline Iconografía administración & 2 \\
\hline Iconografía de particulares & 2 \\
\hline Referencias de asociaciones & 2 \\
\hline
\end{tabular}

Tabla 40. Resumen criterios valoración indicador Identificación de la población.

De acuerdo con lo planteado en el epígrafe que se propone la escala de valoración (ver 6.3.4), se examina la apropiación cultural, por parte de la sociedad, del paisaje forestal. Esta apropiación se produce a través el sentimiento de pertenencia, al entenderse que es un informador fiable capaz de establecer una tendencia. Para poder establecer un valor numérico se propusieron unos testigos que van a relacionar el paisaje forestal con la simbología utilizada por actores públicos o privados, dando una referencia válida para este indicador. 
Para el caso del que se ocupa del paisaje forestal de la Tierra de Pinares de Valladolid y Segovia y acudiendo al municipio escogido como testigo, se encuentran abundantes referencias toponímicas recogidas en el nomenclátor básico editado por el Instituto Geográfico Nacional. Así, algunos de los topónimos más relevantes son:

- Pinar de la Obra Pía

- Pinar del Cañal

- Pinar del Olivo

- Pinar del del Royo

- Pinar de Torre

- Arroyuelo de Valdepino

- Pinar de la Gila

- Prado de las Piñas

- El Pino del Coto Hontanar

Esto permite asegurar que cumple el primer criterio relacionado con la toponimia.

En cuanto a las referencias heráldicas al paisaje forestal en cuestión para el municipio de Vallelado, no se han encontrado. El escudo presenta otro elemento significativo del municipio como es el ajo, al ser sus arenales un gran productor de este producto (Figura 114).

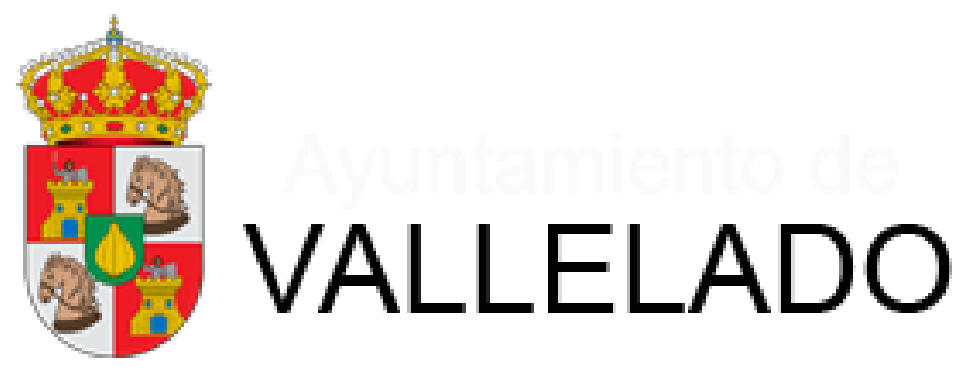

Figura 114. Escudo del municipio de Vallelado según Orden de 31 de enero de 1990 por la Consejería de Presidencia de la Junta de Castilla y León. Recuperado de http://www.vallelado.es 
En lo que respecta a la iconografía utilizada por la administración pública para identificar este municipio, no se han encontrado evidencias de la utilización del paisaje forestal del pinar, ni de elementos asociados.

De igual modo, los particulares no acuden a la iconografía relacionada con el pinar para identificar sus empresas. La gran mayoría de empresas sitas en Vallelado están dedicadas a la explotación agropecuaria y suelen escoger iconografía relacionada con sus actividades.

Las asociaciones encontradas suelen identificarse con la producción de ajos o el ajo como elemento identificativo del municipio por lo que no puede constatarse el uso del paisaje forestal ni sus elementos como destinados a la identificación local (Figura 115). 


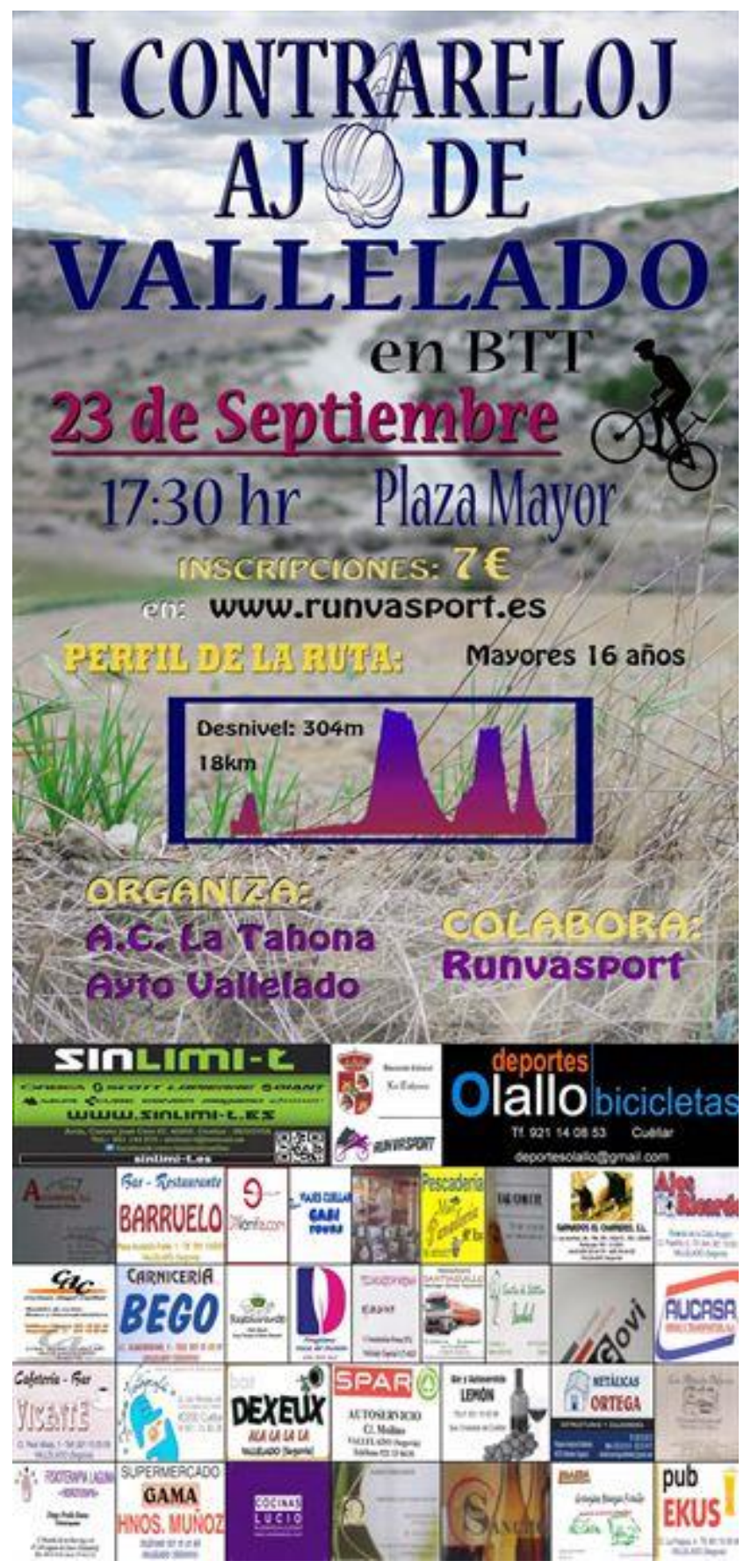

Figura 115. Cartel de promoción de una carrera para bicicleta de montaña que acude al ajo como referencia identitaria. Recuperado de http://inscripciones.runvasport.es/es/evento/i-contrareloj-ajo-de-vallelado-btt 


\begin{tabular}{|c|c|c|}
\hline Criterio & Puntuación & Cumplimiento \\
\hline Toponimia & 2 & $\begin{array}{c}\text { Aparecen multitud } \\
\text { de referencias }\end{array}$ \\
\hline Heráldica & 2 & $\begin{array}{c}\text { No se utiliza el } \\
\text { pinar }\end{array}$ \\
\hline Iconografía administración & 2 & $\begin{array}{c}\text { No se utiliza el } \\
\text { pinar }\end{array}$ \\
\hline Iconografía de particulares & 2 & $\begin{array}{c}\text { No se utiliza el } \\
\text { pinar }\end{array}$ \\
\hline Referencias de asociaciones & 2 & $\begin{array}{c}\text { No se utiliza el } \\
\text { pinar }\end{array}$ \\
\hline
\end{tabular}
población.

\subsubsection{Indicador 5. Museística}

\begin{tabular}{|l|c|}
\hline Criterio & Puntuación \\
\hline Centros de interpretación / museos oficiales & 4 \\
\hline Museos de particulares & 2 \\
\hline Jornadas de exaltación & 2 \\
\hline Mobiliario de exhibición o exaltación & 2 \\
\hline
\end{tabular}

Tabla 42. Resumen criterios valoración indicador Museística.

Este indicador que se fundamenta en la existencia de espacios destinados a conservar y preservar los valores derivados de prácticas tradicionales relacionadas con el paisaje forestal. Es indudable que la presencia en el territorio de estos espacios se convierte en un testigo fiable que permite conocer el momento patrimonial en que se encuentra el elemento. Por esta razón se fija la existencia y regularidad territorial de estos espacios como referencia válida para calificar este indicador. 
De acuerdo con los criterios planteados, el municipio de Vallelado no posee ningún museo público destinado a la puesta en valor del paisaje forestal del pinar.

Igualmente, no se han encontrado evidencias de que exista ningún museo o espacio destinado a la exposición de elementos asociados a la cultura material de la explotación tradicional del pinar.

El municipio de Vallelado no presenta jornadas destinadas a ensalzar los valores de las prácticas tradicionales del pinar ni sus productos. Las jornadas asociadas al ajo suelen copar este tipo de actividades.

No se han encontrado en el municipio evidencias de mobiliario que cuente con referencias relacionadas con el pinar, sus útiles o algún aspecto relacionado con el paisaje forestal o su aprovechamiento.

\begin{tabular}{|c|c|c|}
\hline Criterio & Puntuación & Cumplimiento \\
\hline $\begin{array}{c}\text { Centros de interpretación/museos } \\
\text { Museos de particulares }\end{array}$ & 4 & No existen \\
\hline Jornadas de exaltación & 2 & $\begin{array}{c}\text { No se han } \\
\text { encontrado }\end{array}$ \\
\hline Mobiliario de exhibición o exaltación & 2 & $\begin{array}{c}\text { No se han } \\
\text { encontrado }\end{array}$ \\
\hline
\end{tabular}

Tabla 43. Resumen criterios cumplidos valoración indicador Museística. 


\subsubsection{Indicador 6. Incorporación turística}

\begin{tabular}{|c|c|}
\hline Criterio & Puntuación \\
\hline Reivindicación turística supramunicipal & 4 \\
\hline Reivindicación turística municipal & 2 \\
\hline Reivindicación turística de particulares & 2 \\
\hline $\begin{array}{l}\text { Reivindicación turística igual que otros elementos } \\
\text { patrimoniales }\end{array}$ & 2 \\
\hline
\end{tabular}

Tabla 44. Resumen criterios valoración indicador Incorporación Turística

Hoy en día no se puede separar el patrimonio de su utilización como reclamo turístico, por ello se ha propuesto la frecuencia que se hace del patrimonio forestal como objeto turístico a modo de testigo fiable que califique el momento patrimonial de este.

En lo que concierne al reclamo turístico basado en el paisaje forestal del pinar "corporativo", no existen evidencias relevantes. Vallelado no posee iniciativas de reclamo turístico asociado al paisaje forestal propio del pinar. No se han encontrado ejemplos ni a nivel supramunicipal (Diputación, Junta de Castilla y León, etc.), ni a nivel municipal.

En cuanto a la iniciativa privada, Vallelado no posee ningún establecimiento hotelero y la restauración no está enfocada al turismo.

En lo que se refiere a la comparación de los reclamos turísticos del paisaje forestal con el resto de los reclamos turísticos hay que señalar la gran escasez de referencias de este tipo en el municipio de Vallelado, pero las pocas que existen van enfocadas a promocionar otros elementos culturales, especialmente la producción de ajos y algunos eventos de exaltación del folklore popular (Figura 116). Por esto, no se cumple el criterio planteado inicialmente. 


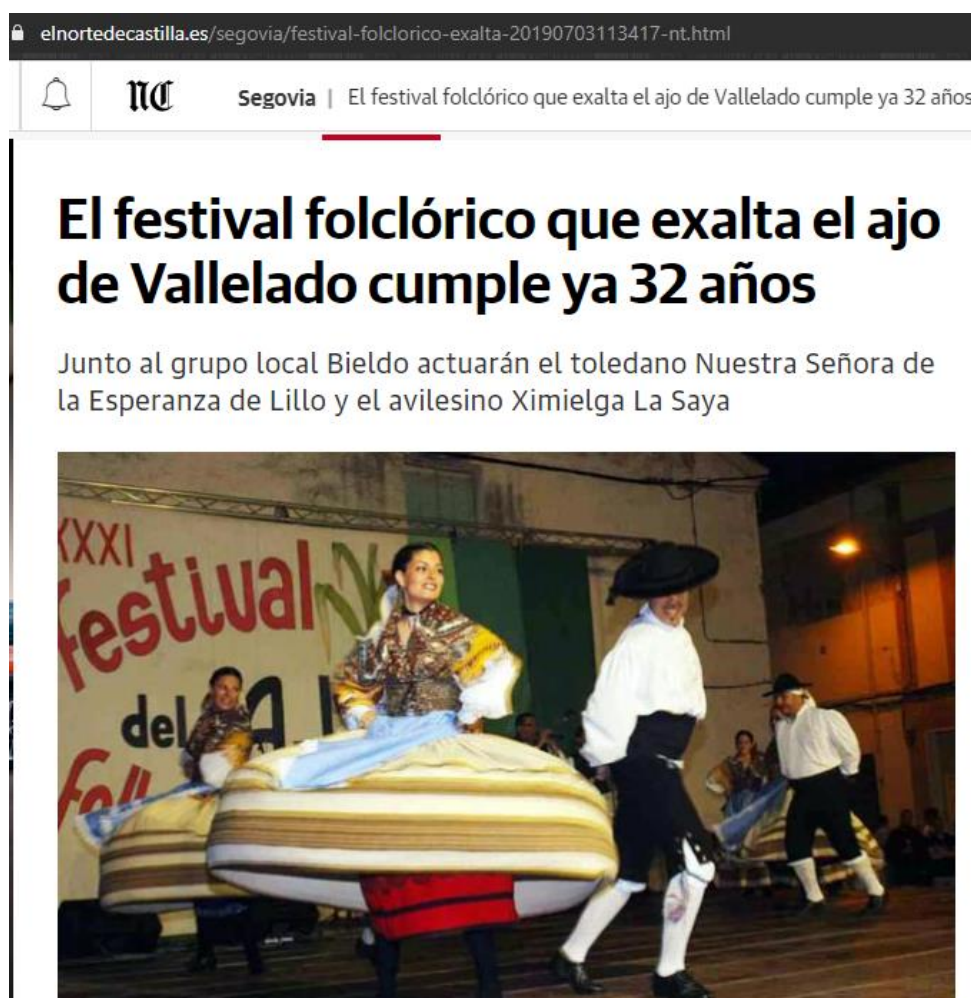

Figura 116. Noticia sobre el festival de folklore del ajo celebrado en Vallelado. Recuperado de: https://www.elnortedecastilla.es/segovia/festival-folclorico-exalta$\underline{20190703113417-\mathrm{nt} . \mathrm{html}}$

\begin{tabular}{|c|c|c|}
\hline Criterio & Puntuación & Cumplimiento \\
\hline $\begin{array}{c}\text { Reivindicación turística } \\
\text { supramunicipal }\end{array}$ & 4 & No se han encontrado \\
\hline $\begin{array}{c}\text { Reivindicación turística } \\
\text { municipal }\end{array}$ & 2 & No se han encontrado \\
\hline $\begin{array}{c}\text { Reivindicación turística de } \\
\text { particulares }\end{array}$ & 2 & No se han encontrado \\
\hline $\begin{array}{c}\text { Reivindicación turística igual } \\
\text { quetros elementos patrimoniales }\end{array}$ & 2 & Existen reclamos más \\
\end{tabular}

Tabla 45. Resumen criterios cumplidos valoración indicador Incorporación Turística 


\subsubsection{Indicador 7. Empleo relacionado}

\begin{tabular}{|l|c|}
\hline Criterio & Puntuación \\
\hline Al menos 0,5\% ocupados en Silvicultura & 3 \\
\hline Al menos 5\% de ocupados en sectores relacionados & 3 \\
\hline Trabajadores silvicultura se incrementan & 2 \\
\hline Trabajadores relacionados se incrementan & 2 \\
\hline
\end{tabular}

Tabla 46. Resumen criterios valoración indicador Empleo relacionado.

Este indicador pretende hacer visible la relación existente entre el momento patrimonial y la funcionalidad del elemento. El empleo resulta determinante para vigorizar la relación de cercanía de la sociedad más inmediata con su elemento patrimonial, observándose como un activo para mantener el dinamismo económico. De este modo el empleo relacionado directamente con el elemento patrimonial que se trata es un testigo de esa vinculación patrimonio-sociedad que, a la postre, es imprescindible en un proceso de patrimonialización exitoso.

De acuerdo con esto y atendiendo a la información que aportan los datos de empleo de la seguridad social. Vallelado no presenta ningún trabajador ocupado en el epígrafe 02 (Silvicultura y explotación forestal) para 2015, en lo referente a la población ocupada en sectores vinculados (epígrafes 16,17 y $31 \mathrm{CNAE}$ ) se encuentra algo por encima del $7 \%$ con un incremento sostenido de más de un 2\% entre 2007 y 2015 apoyándose en un importante incremento en la industria de la madera y el corcho (Figura 117), por lo que cumple los dos criterios planteados para valorar este indicador en lo que se refiere al empleo relacionado. En cambio, el empleo directo en labores de silvicultura no se cumple al no registrar ningún empleado en estas tareas. 
Evolución trabajadores Vallelado 2007-2015

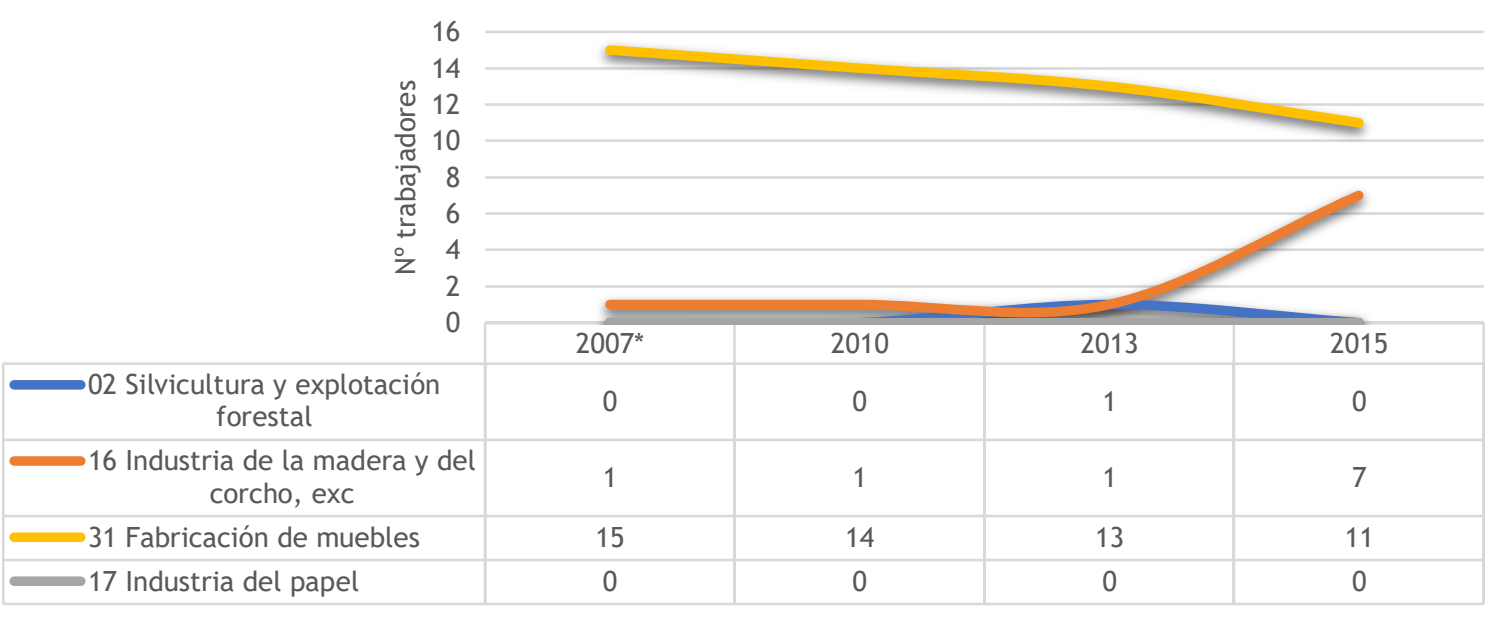

Figura 117. Distribución temporal de los trabajadores relacionados con actividades forestales o relacionadas en el municipio de Vallelado. Elaboración propia a partir de CNAE dos dígitos desagregado municipal. *transformación códigos CNAE93/CANE09.

\begin{tabular}{|c|c|c|}
\hline Criterio & Puntuación & Cumplimiento \\
\hline $\begin{array}{cccc}\text { Al menos } & 0,5 \% & \text { ocupados } & \text { en } \\
\text { Silvicultura } & & & \end{array}$ & 3 & $\begin{array}{l}\text { No hay ocupados en } \\
\text { este epígrafe }\end{array}$ \\
\hline $\begin{array}{l}\text { Al menos } 5 \% \text { de ocupados en sectores } \\
\text { relacionados }\end{array}$ & 3 & $\begin{array}{c}\text { Ocupa a más de un } \\
7 \%\end{array}$ \\
\hline $\begin{array}{lll}\text { Trabajadores } & \text { silvicultura } & \text { se } \\
\text { incrementan } & & \end{array}$ & 2 & $\begin{array}{l}\text { No hay ocupados en } \\
\text { este epígrafe }\end{array}$ \\
\hline $\begin{array}{lll}\text { Trabajadores } & \text { relacionados } & \text { se } \\
\text { incrementan } & & \end{array}$ & 2 & $\begin{array}{c}\text { Se han } \\
\text { incrementado } \\
\text { paulatinamente }\end{array}$ \\
\hline
\end{tabular}

Tabla 47. Resumen criterios valoración indicador Empleo relacionado 
Estudio de casos y aplicación práctica. Paisajes forestales con valor patrimonial.

\subsubsection{Valoración final}

\begin{tabular}{|l|l|}
\hline Indicador & Valoración \\
\hline I1. Complejidad biológica & 7 \\
\hline I2. Figuras de protección & 1 \\
\hline 13. Existencia de vectores & 3 \\
\hline 14. Identificación y sentimiento de pertenencia & 2 \\
\hline 15. Centros de interpretación/museos & 0 \\
\hline 16. Incorporación turística & 0 \\
\hline 17. Empleo relacionado & 5 \\
\hline & Valoración final \\
\hline
\end{tabular}

Tabla 48. Valor obtenido por cada uno de los indicadores propuestos para el paisaje referente al municipio de Vallelado.

\section{Bosque corporativo: Tierra de Pinares}

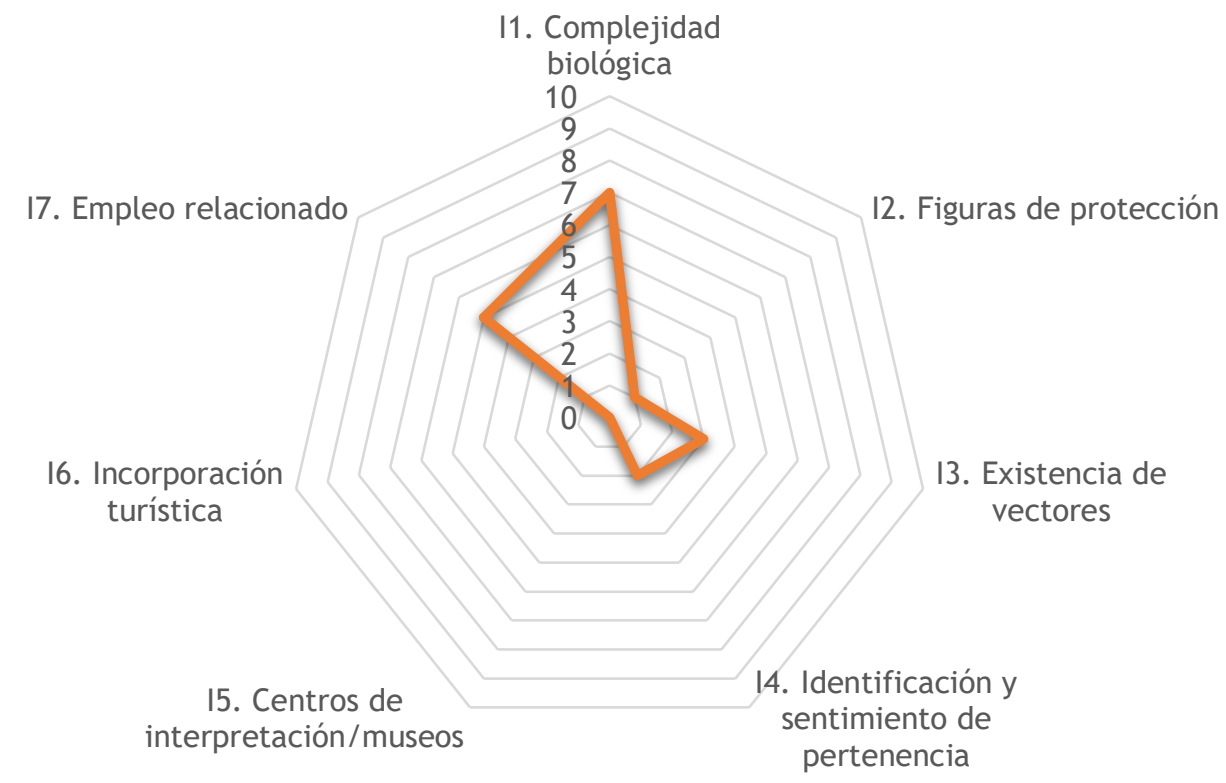

Figura 118. Representación de la situación patrimonial del pinar en Vallelado según los indicadores analizados. Elaboración propia 


\section{Capítulo 9. Silvicultura intensiva. Los Eucaliptales de Guriezo.}




\subsection{Distribución y localización del área de estudio}

El ámbito de estudio se sitúa en el norte peninsular, concretamente en el extremo oriental de la provincia de Cantabria, muy cerca del límite con la provincia de Vizcaya. Los límites elegidos para restringir el estudio responden a las fronteras del municipio de Guriezo en tanto que este municipio presenta una serie de peculiaridades que serán descubiertas en adelante y que van a ser determinantes para merecer un análisis singular.

El área de estudio se asienta sobre los materiales cretácicos del extremo norte de la Cordillera Cantábrica, presentando un relieve de importantes desniveles relativos. Esto se debe a la deformación durante los esfuerzos de la orogenia alpina, presentando una sucesión de anticlinales con dirección NO-SE atravesados por la falla de Laredo siguiendo esa misma dirección (Olivé y Ramírez, 1982).El plegamiento que se nos presenta es de débil buzamiento arrojando unos desniveles absolutos poco relevantes mientras que los materiales expansivos del "Keuper" subyacentes determinan unos importantes desniveles relativos alterando la disposición de los bloques fracturados. Pese a no aparecer aflorante en el área de estudio, el "Keuper", aparece en las proximidades como la Ría de Limpias, Laredo y Ampuero arrastrando incluso materiales jurásicos en su ascenso hacia la superficie. Esta fractura y desnivelación de los materiales suprayacentes cretácicos y su recolocación genera una sinuosidad y determina las pendientes del valle, lo que a la postre será determinante en el aprovechamiento de las vertientes.

Por otro lado, el elemento que va a determinar la configuración del relieve de la zona escogida es el río Agüera que circula con dirección S-N desde su nacimiento en los montes de Ordunte, virando ligeramente con dirección SE-NO al apoyarse en el flanco norte del anticlinal de ColindresAlto Guriezo, para volver a su dirección original en busca de la desembocadura. La capacidad erosiva y probablemente la antecedencia del río Agüera generan un vaciamiento en forma de "Cluse" al atravesar 
perpendicularmente el anticlinal de Liendo (Ramírez y Portero, 1978). El llamado Real Valle de Guriezo presenta unas altitudes que oscilan entre los 773 m.s.n.m. en el pico donde se sitúa la ermita de Las Nieves y los 0 m.s.n.m. en los que se sitúa la depresión que forma la ría de Oriñón, donde desemboca el Agüera (Figura 119).

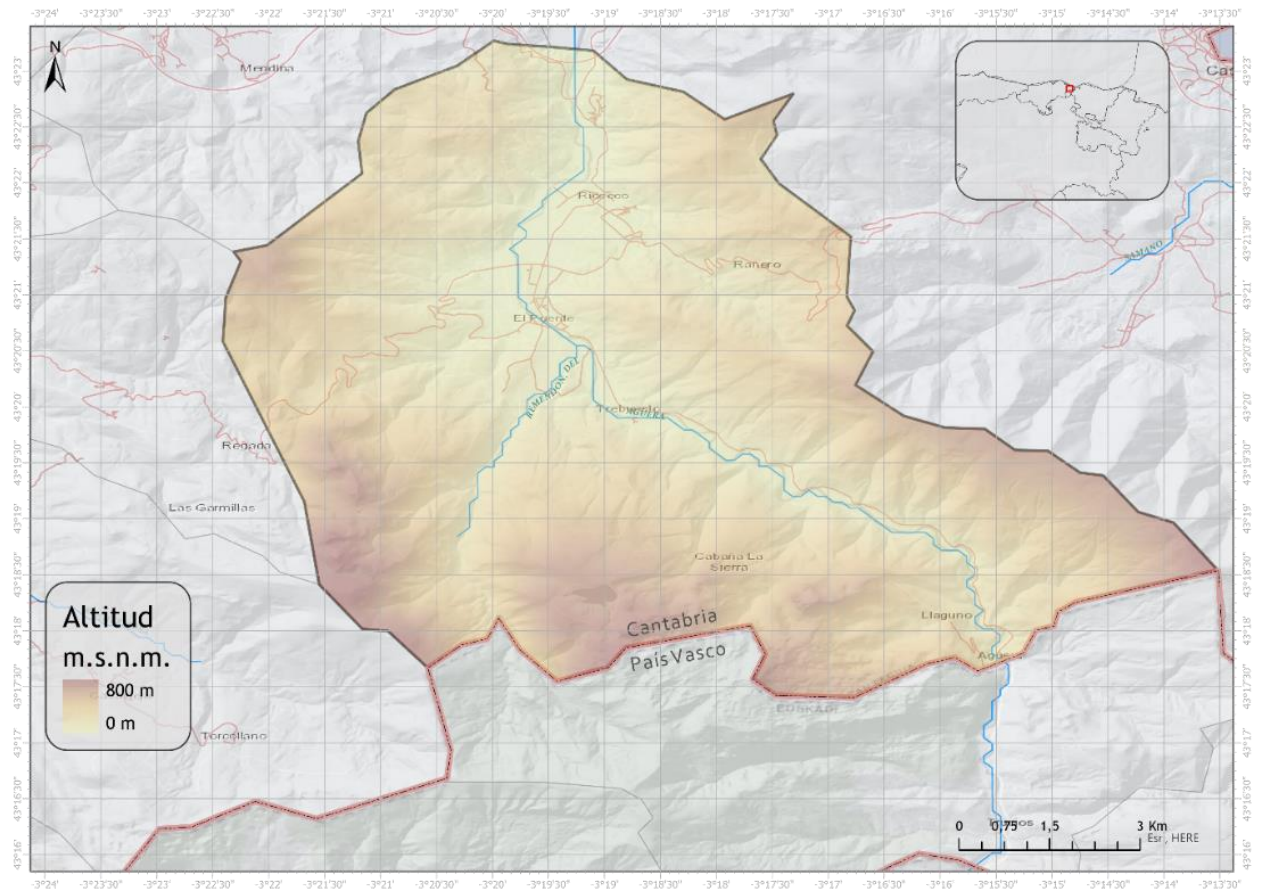

Figura 119. Mapa de altitud del municipio de Guriezo. Elaboración propia Modelo Digital del Terreno Instituto Geográfico Nacional.

Por todo esto, la existencia de este valle que vierte al Cantábrico hacia el norte, estructurado a partir del río Agüera y determinado por la desnivelación constante de bloques debido al "Keuper" subyacente, forma un sistema que gira en torno a las poblaciones que se asientan en el fondo del valle, con la peculiaridad de un poblamiento disperso y la inexistencia de un núcleo especialmente destacado. 
Estudio de casos y aplicación práctica. Paisajes forestales con valor patrimonial.

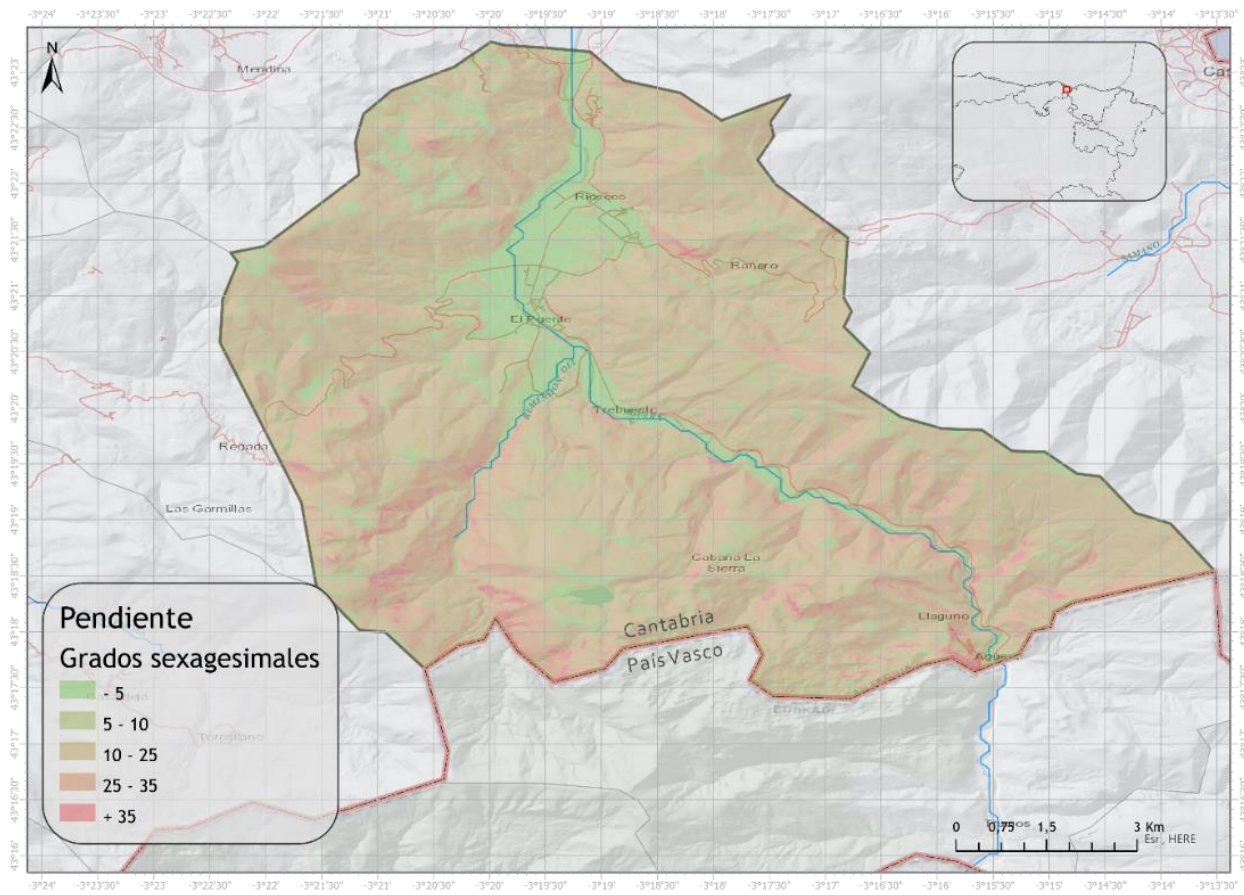

Figura 120. Mapa de pendientes del municipio de Guriezo. Elaboración propia Modelo Digital del Terreno Instituto Geográfico Nacional.

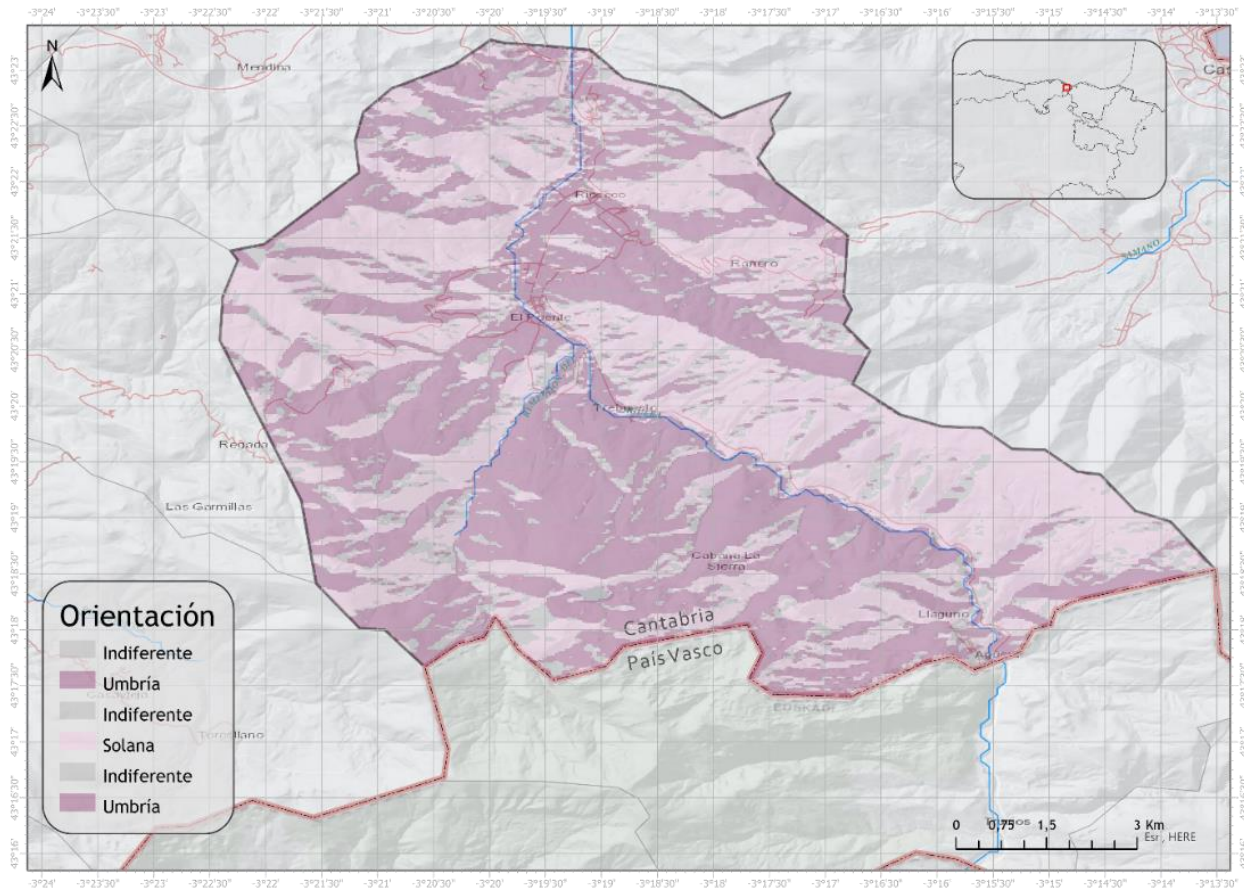

Figura 121. Mapa de orientaciones en el municipio de Guriezo. Elaboración propia Modelo Digital del Terreno Instituto Geográfico Nacional. 


\subsection{Caracterización del área de estudio}

Actualmente la distribución de usos del término municipal de Guriezo presenta una clara dicotomía, por un lado, el fondo del valle donde aparecen las actividades terciarias, industriales y los usos residenciales en torno a las vías de comunicación que circulan por la parte baja y prácticamente el resto del término municipal se encuentra ocupado por espacio forestal, generalmente plantaciones de eucaliptos (Figura 122). Pese a esta predominancia forestal productiva y aunque cada vez es menos frecuente, aparece un mosaico de prados de siega ocupando la llanada de relleno cuaternario del fondo del valle. Igualmente, los espacios destinados a pastos de diente se intercalan, en cierta medida, en el continuo forestal que forman las plantaciones (Figura 123).

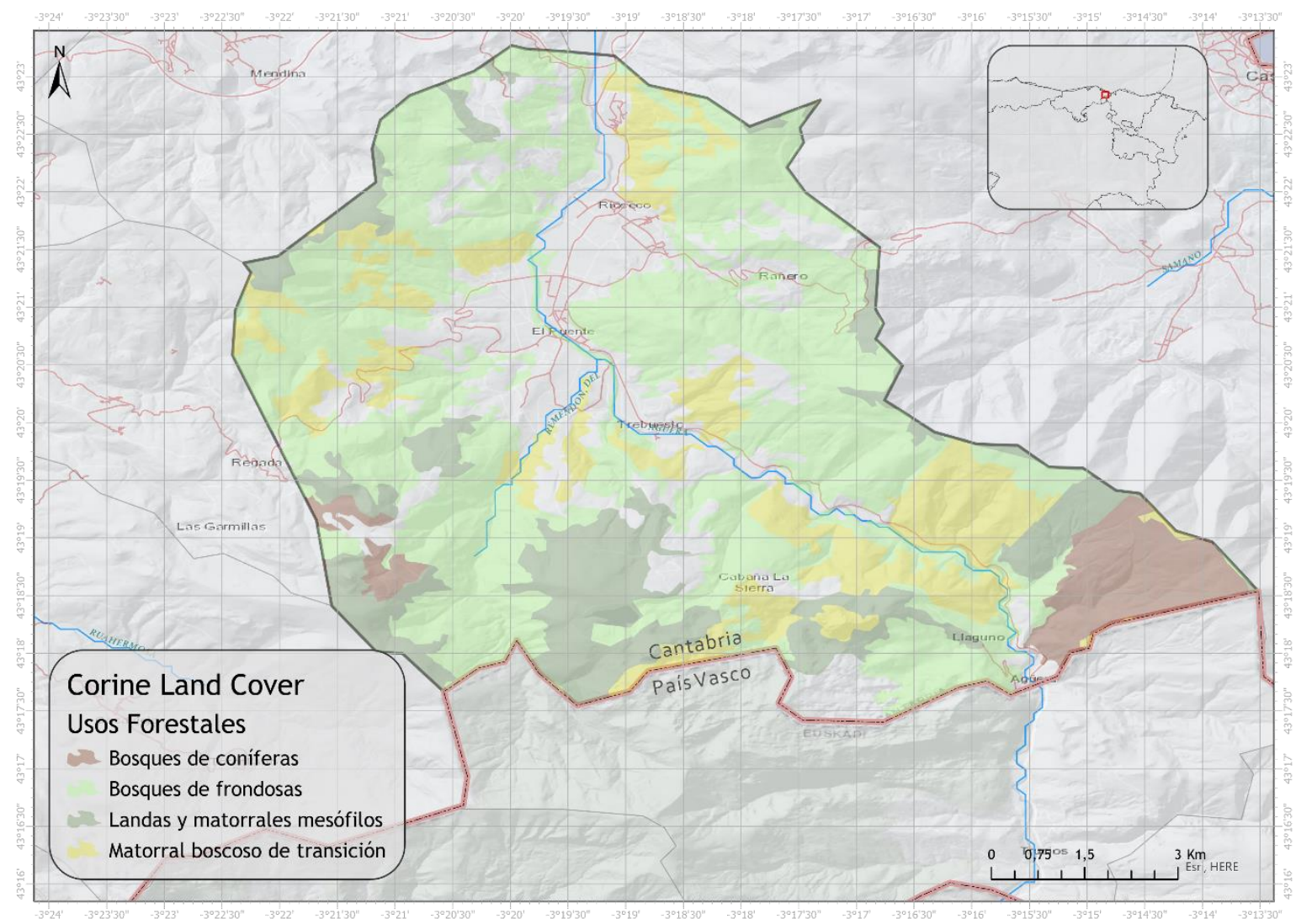

Figura 122. Mapa de usos del suelo de carácter forestal en Guriezo. Elaboración propia a partir de Corine Land Cover. 


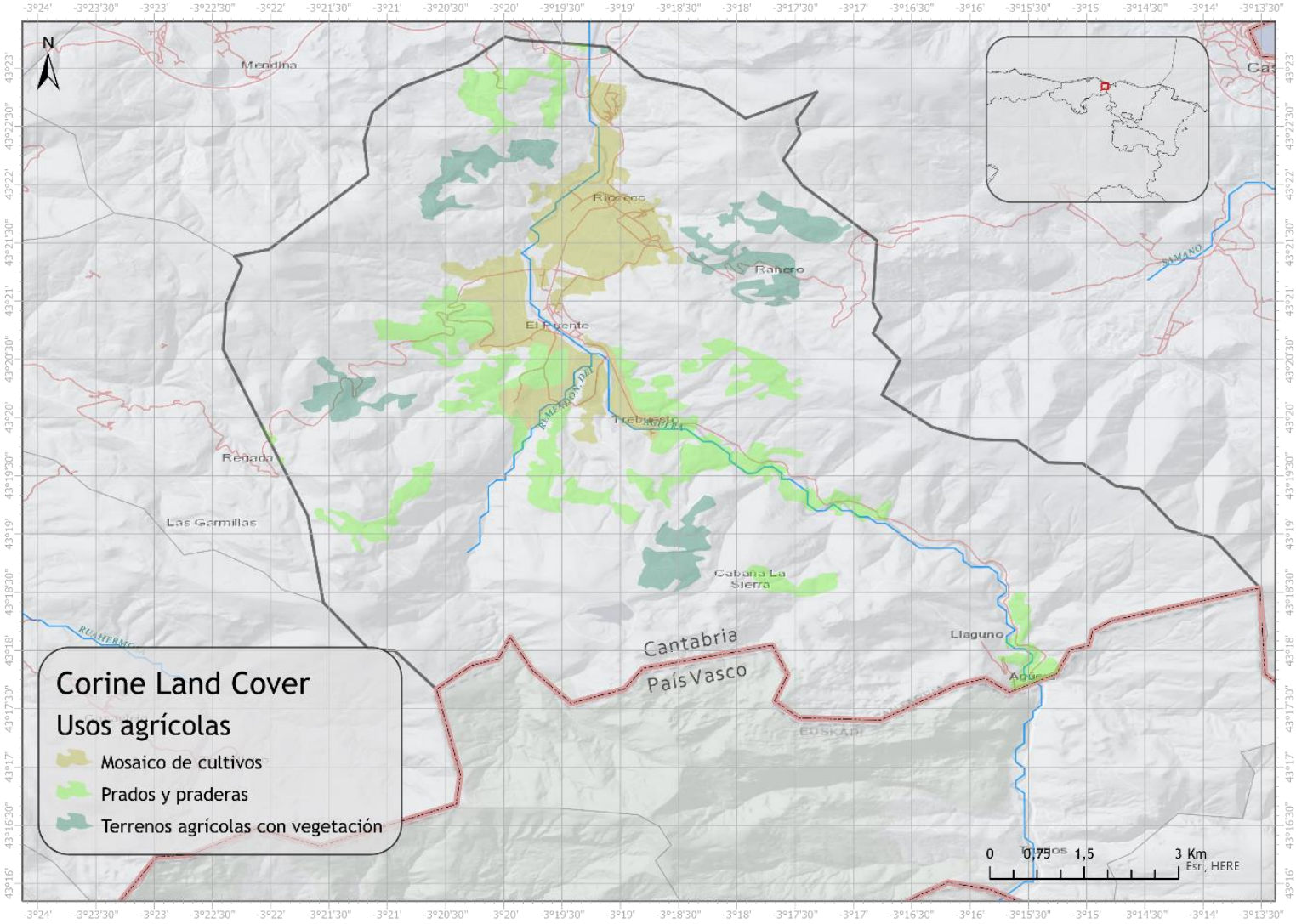

Figura 123. Mapa de usos del suelo de carácter agrícola en Guriezo. Elaboración propia a partir de Corine Land Cover.

El Real Valle de Guriezo supone un valle cerrado que presenta un cierto aislamiento. El acceso tradicional se llevaba a cabo a través de tres vías fundamentales. Por un lado, desde el sur, a través de la "cluse" de Agüera desde Bizkaia. Por otro lado, aprovechando la falla que desnivela los materiales cretácicos en el extremo occidental, a través del paso de Prado Tejo. O bien, a través de los accesos costeros de Castro Urdiales o Laredo. Esta dificultad de acceso tradicionalmente ha favorecido la preservación de ciertos aspectos paisajísticos y dinámicas territoriales que en su entorno inmediato se han perdido por completo, en buena medida asociado a la incorporación de algunos espacios a los usos turísticos y residenciales derivados de la influencia de la ciudad de Bilbao. El valle de Guriezo, en cambio, parece mantenerse ajeno, en cierta medida, a estos procesos. 


\subsection{El origen del espacio forestal}

Cuando se habla de un bosque de eucalipto en España, inevitablemente hay que destacar que se trata de un bosque adaptado al potencial ecológico, pero absolutamente artificial en tanto que se está formado por especies forestales exóticas. Como se ha señalado anteriormente, la llegada a España del eucalipto, y más concretamente a Cantabria hay que fijarla en el año 1863 gracias a Marcelino San de Sautuola (Herrera, 2000). El interés por esta especie se planteó, desde el principio, como una oportunidad productiva en la realidad forestal española (ver 2.1.3.4). Esta clara vocación productiva del eucalipto se demostró en sus primeros pasos en nuestro país, como manifiesta el propio informe de Sautuola "Apuntes sobre la aclimatación del E. globulus en la provincia de Santander" o la plantación experimental llevada a cabo en el reformatorio de menores de Viérnoles donde se demostró la frugalidad y la capacidad para brotar de cepa del eucalipto, lo que rápidamente supuso un oasis en la limitada producción de madera en España.

Pese a esta frugalidad esperanzadora para las necesidades celulósicas, el eucalipto comenzará su andadura en nuestro país como sustituto de especies más caras y de difícil producción, como el roble, en la tarea de entibación minera (Guerra, 2013).

Pero las dos claves que van a convertir al eucalipto en el gran protagonista del bosque de la España cantábrica en general y del valle de Guriezo en particular, van a ser las políticas públicas favorecedoras de su plantación. En el año 1940 comienza un proceso que va a ser determinante para el futuro de esta especie (García, 1975; Morales, 1982; Aedo et al., 1990; Rico, 1997; Ezquerra y Gil, 2004; Guerra, 2013), concretamente el 26 de abril de 1940 se aprueba el decreto que va a convertir a la SNIACE (empresa situada en Torrelavega y dedicada a la producción de celulosa) en una industria de interés nacional lo que suponía que esta podría consorciar directamente con los propietarios de los terrenos la plantación de eucalipto (España, 1940). Por otro lado, la Ley de 10 de marzo de 1941 
sobre el Patrimonio Forestal del Estado en su artículo 10 va a incentivar la nueva fiebre repobladora:

“El Patrimonio Forestal del Estado podrá conceder auxilios o subvenciones a los propietarios de terrenos o corporaciones públicas y particulares que realicen por su cuenta plantaciones, especialmente de las llamadas de turno corto y también a aquellas personas que emprendan la repoblación de un monte de su exclusiva propiedad"

(España, 1941)

Todo esto, apoyado finalmente por la Ley de 26 de mayo de 1944, que garantizaba los beneficios de Monte Público para los terrenos derivados que se acojan a repoblaciones mediante consorcio con la administración pública (Pérez y Picos, 2001) va a ser determinante para entender el paisaje forestal del Valle (Figura 124).

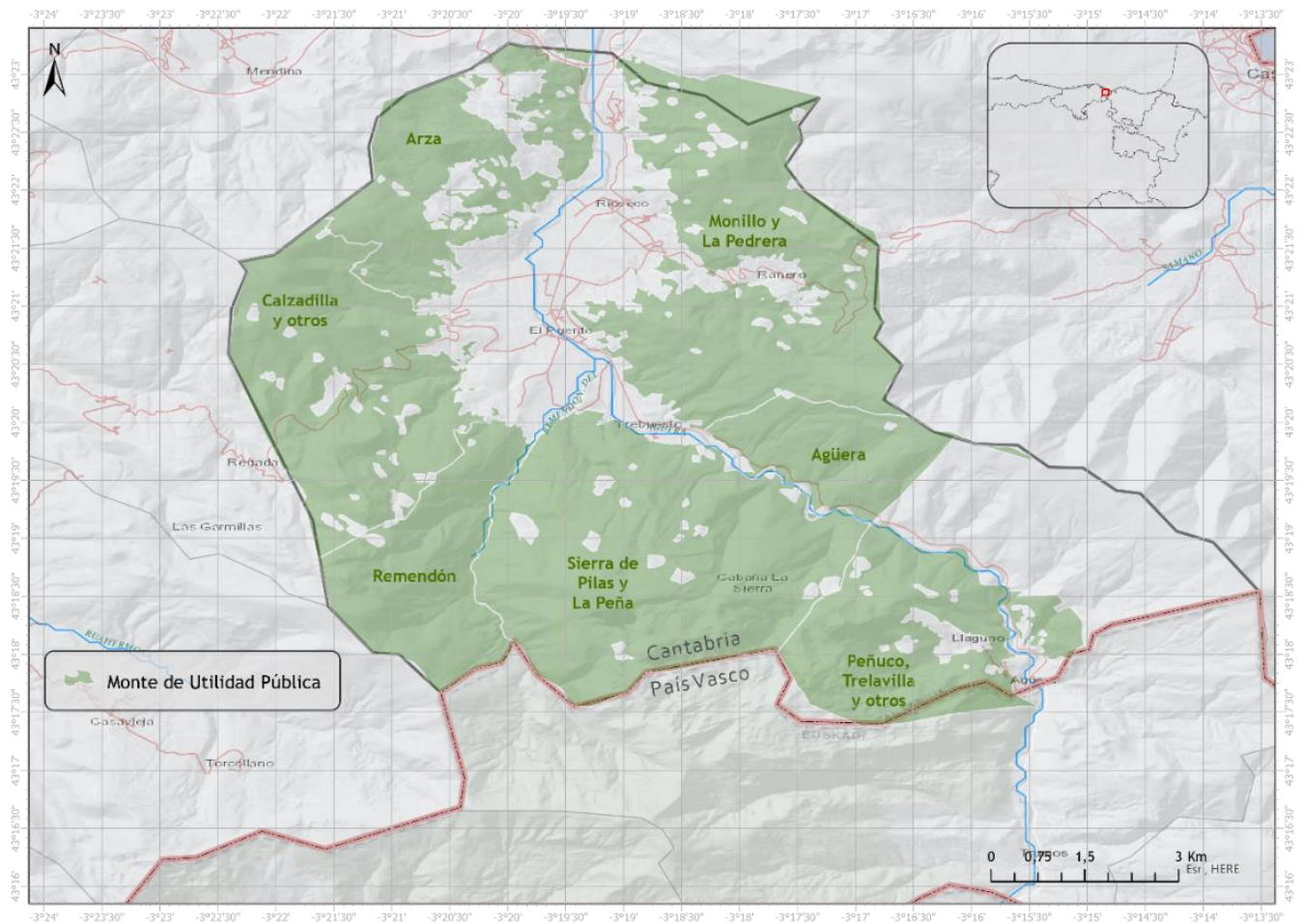

Figura 124. Mapa de los Montes de Utilidad Pública en el municipio de Guriezo. Elaboración propia a partir de Montes de Utilidad Pública Gobierno de Cantabria. 
Estudio de casos y aplicación práctica. Paisajes forestales con valor patrimonial.

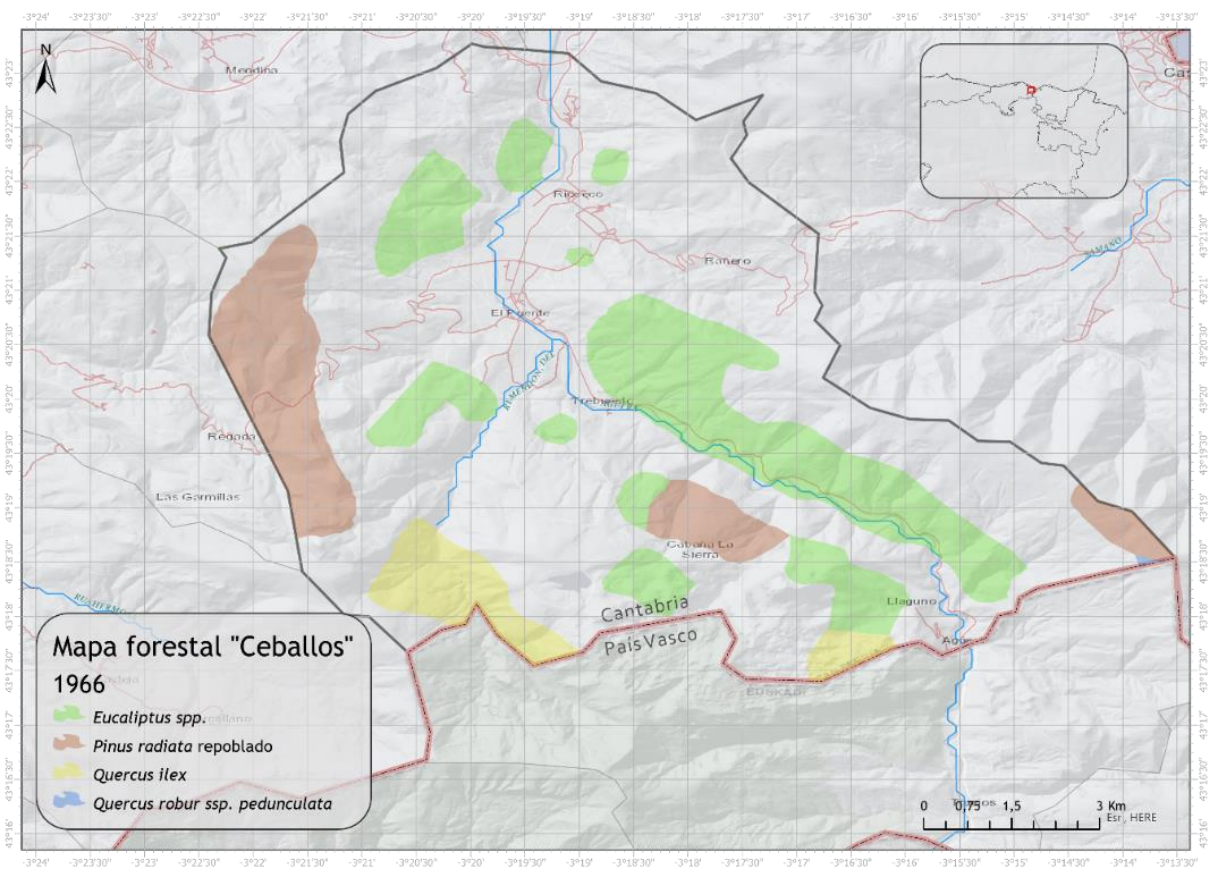

Figura 125. Mapa forestal de España (1966) conocido como “mapa Ceballos" para el municipio de Guriezo. Elaboración propia.

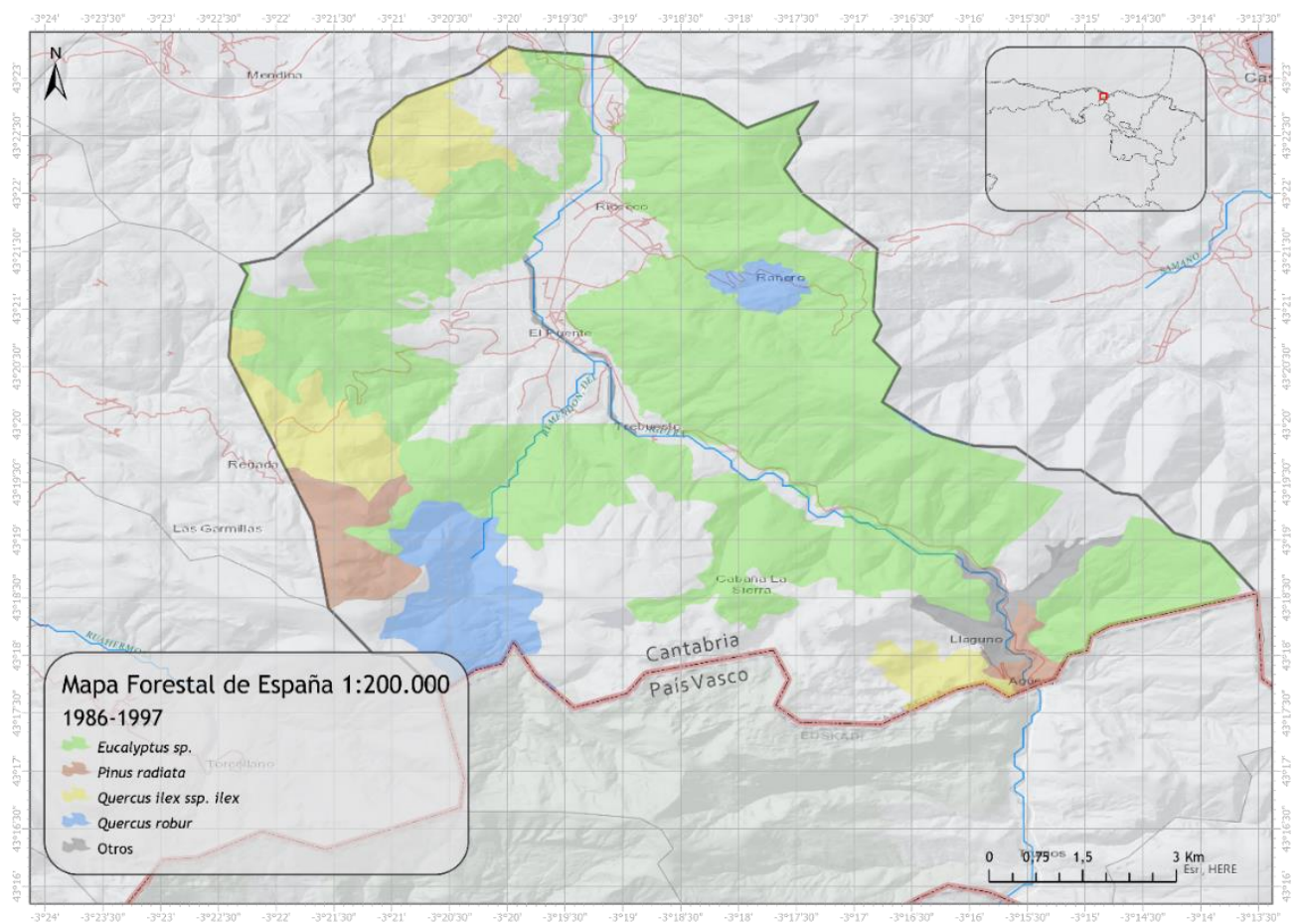

Figura 126. Mapa Forestal de España 1:200.000 para el municipio de Guriezo. Elaboración propia. 


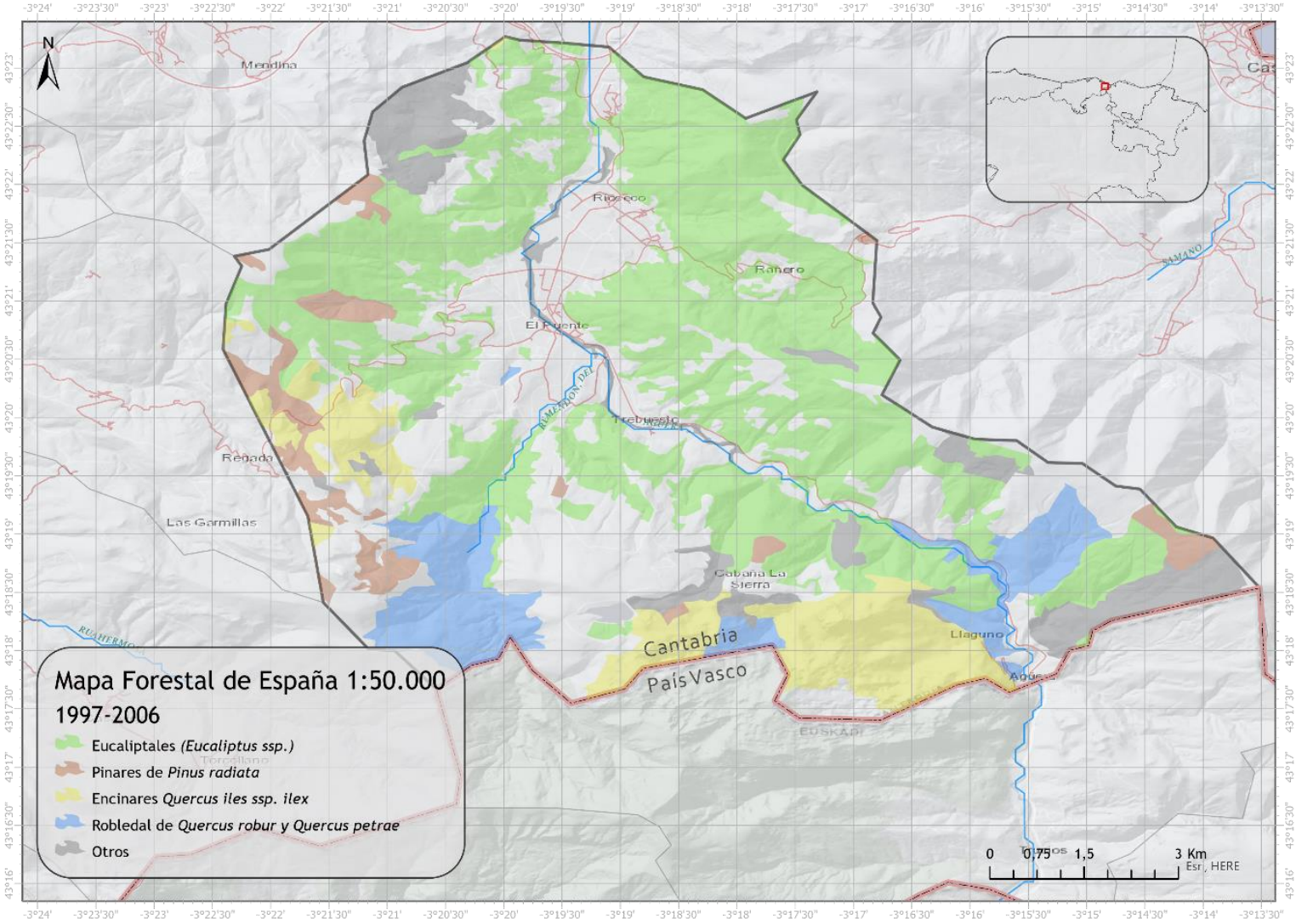

Figura 127. Mapa Forestal de España 1:50.000 para el municipio de Guriezo. Elaboración propia.

\subsection{El uso del eucaliptal}

Como se ha explicado, los bosques de eucalipto y el paisaje que van a condicionar en el norte de España van a venir definidos por las plantaciones autárquicas que se ponen en marcha en los años 40 para abastecer las necesidades de la empresa SNIACE. La propia empresa calcula una producción media histórica de $20 \mathrm{~m}^{3} \mathrm{C} . \mathrm{c} . / \mathrm{h} /$ año bajo condiciones de monte bajo sin intervención genética (Tejedor, 2007), de acuerdo con estos datos y asumiendo que el municipio de Guriezo va a albergar unas 3.000 hectáreas de eucaliptal (MAPAMA, 1997), se puede inferir una producción de madera de $60.000 \mathrm{~m}^{3}$ anuales. Esta producción de madera de eucalipto arrojaría un montante económico de $1.387 .000 €$, atendiendo a los precios licitados 
durante el año 2016 en España (Ministerio de Agricultura y Pesca, Alimentación y Medio Ambiente, 2017).

Esta producción maderera destinada fundamentalmente a la producción de celulosa es el uso principal de este espacio forestal. En esta ocasión no cabe definir otros usos que pudieran ser complementarios ya que estas plantaciones tienen este fin último. Se trata de una silvicultura intensiva que promueve las parcelas de turno con cortes a matarrasa. Es cierto que este espacio forestal no se encuentra cercado, no impide el acceso (salvo en algunas ocasiones), pero su objetivo es producir fustes de eucalipto que abastezcan la demanda industrial de celulosa y este objetivo hace muy difícil una convivencia de usos. Se puede apreciar la limpieza y la ordenación de este bosque que da buena idea de su personalidad productora (Figura 128).

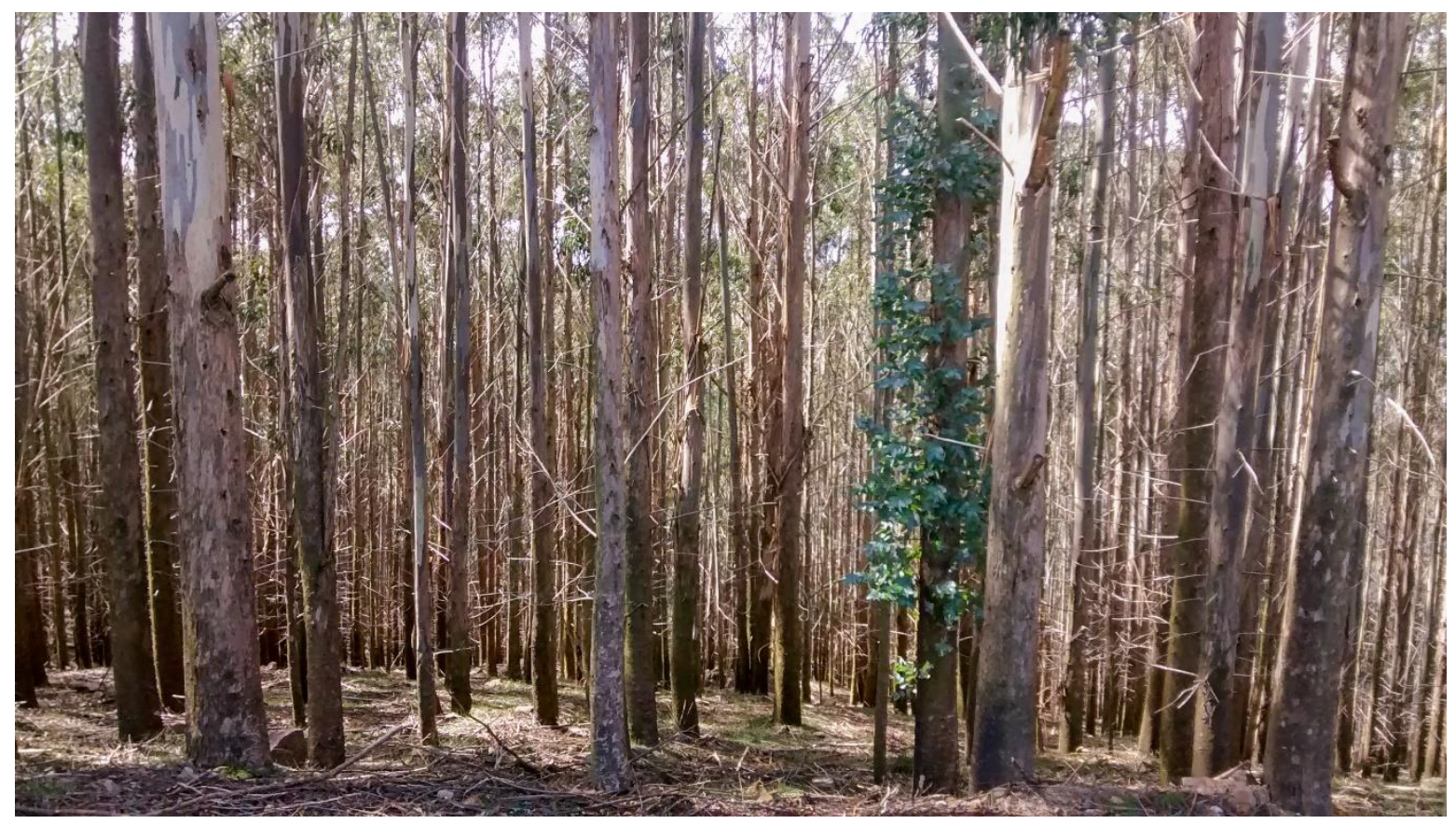

Figura 128. Bosque de eucaliptos adultos en Guriezo. Imagen propia. 


\subsection{El paisaje de un espacio productivo industrial}

El municipio de Guriezo alberga un paisaje forestal verdaderamente característico que va a estar dominado, de forma muy significativa, por la silvicultura. En este caso, el condicionante que introduce el uso del monte como espacio destinado a la producción industrial de madera va a ser el eje a partir del que se articulan el resto de los elementos. Este paisaje forestal que va a reflejar la vocación productiva industrial del bosque va a ser un paisaje de cierta monotonía cromática derivada de la monoespecificidad forestal, se trata de un paisaje de lógica industrial que no solo desdibuja el paisaje agrario atlántico, sino que lo hace desaparecer (Guerra, 2013).

Esta monotonía, que no es propia del paisaje atlántico tradicional, es el resultado de un paisaje resiliente, entendiendo este adjetivo como la necesidad de adaptación que estos espacios de ganadería extensiva y prados de siega hacia una economía de base industrial apoyada en la producción de madera. Es, por tanto, el paisaje de Guriezo, el resultado de una pérdida de valor de los usos tradicionales hacia un paisaje de rentabilidad. El eucaliptal y sus dimensiones van a ser el resultado dialéctico entre la tradición y la rentabilidad económica.

A través de un proceso de análisis con el apoyo del trabajo de campo se ha determinado una clasificación de unidades de paisaje y los elementos que actúan como catalizadores de patrimonialización del paisaje del municipio de Guriezo:

- Cultivos:

- Prados y praderas de fondo de valle (espacios destinados a la producción de pasto de diente y siega) (Figura 129).

- Forestal:

- El eucaliptal de producción industrial (Dominado por el Eucaliptus globulus y sus características destinadas a la producción silvícola) (Figura 130). 
- El robledal autóctono (caracterizado por el Quercus robur y el Quercus petrae) (Figura 131).

- El encinar autóctono (la singularidad que introduce un espacio arbolado con encina atlántica Quercus ilex ssp. ilex)

- Urbano (distribución tradicional a partir de la articulación del valle como unidad poblacional, los núcleos se van distribuyendo por el fondo del valle de forma más o menos homogénea sin generar núcleos de población de dimensiones relevantes) (Figura 132).

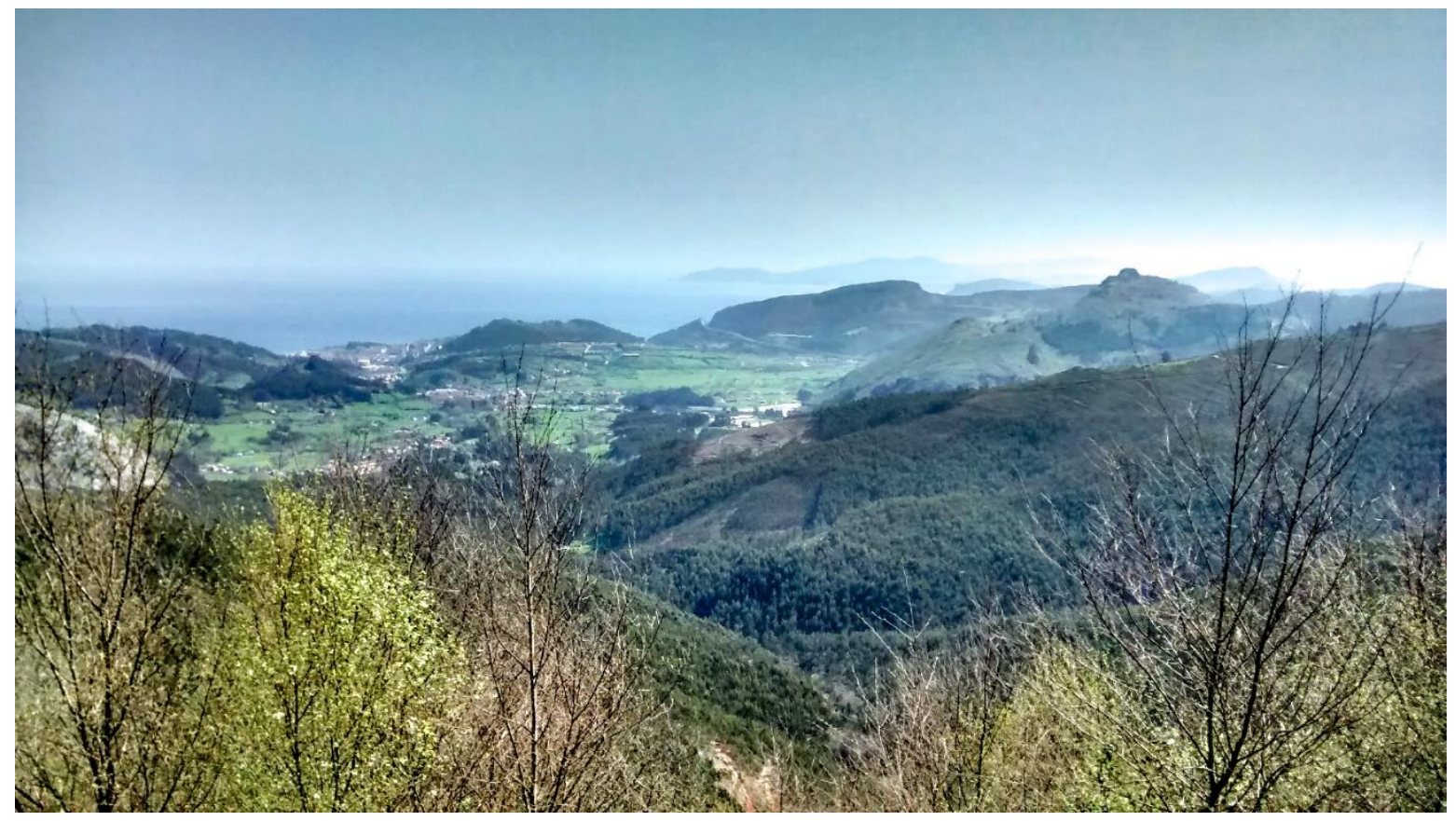

Figura 129. Contraste las laderas ocupadas por parcelas de turno de eucalipto y los prados de fondo de valle. Imagen propia. 
Estudio de casos y aplicación práctica. Paisajes forestales con valor patrimonial.

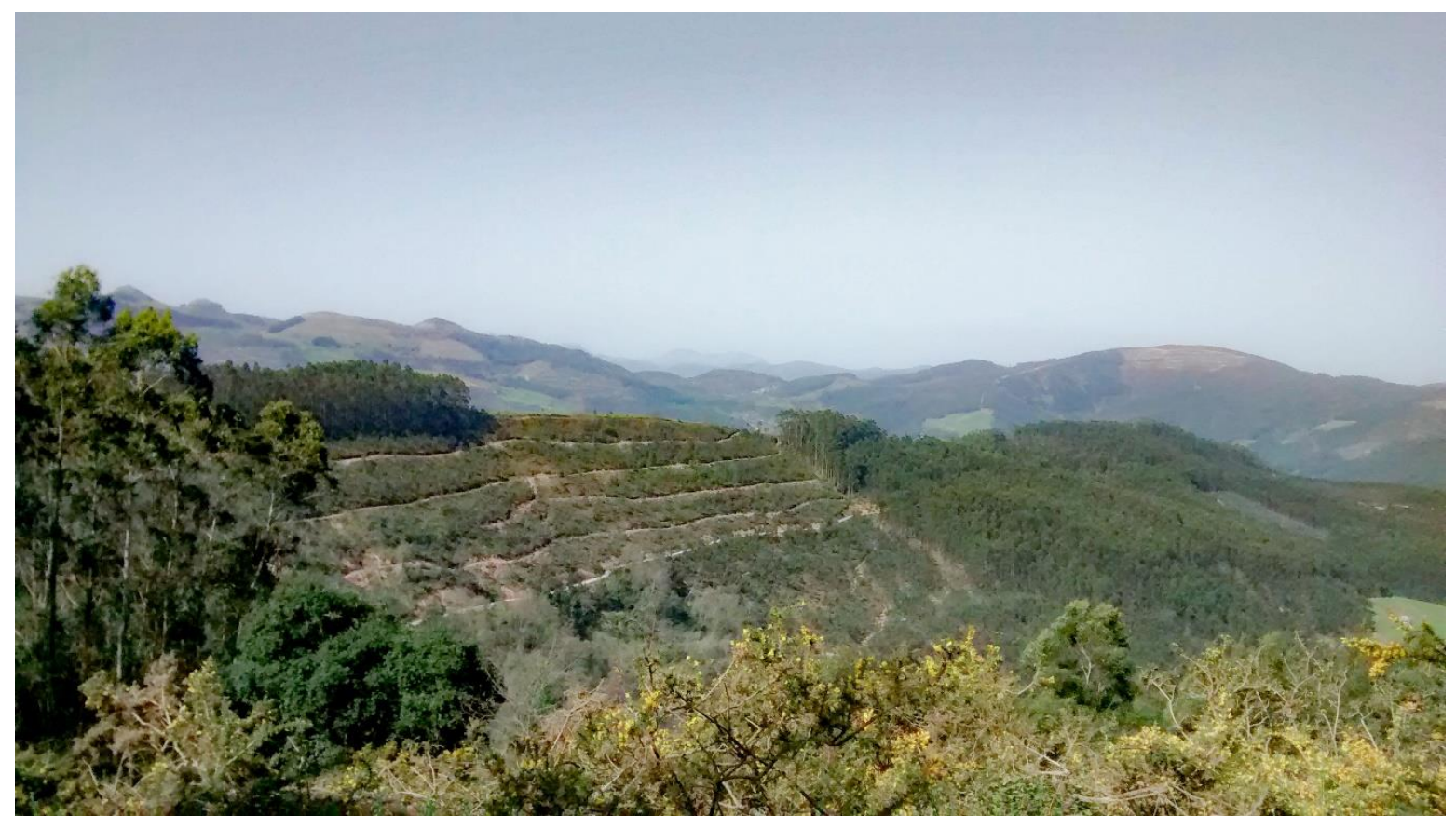

Figura 130. El eucaliptal de Guriezo, parcelas en diferentes turnos. Imagen propia.

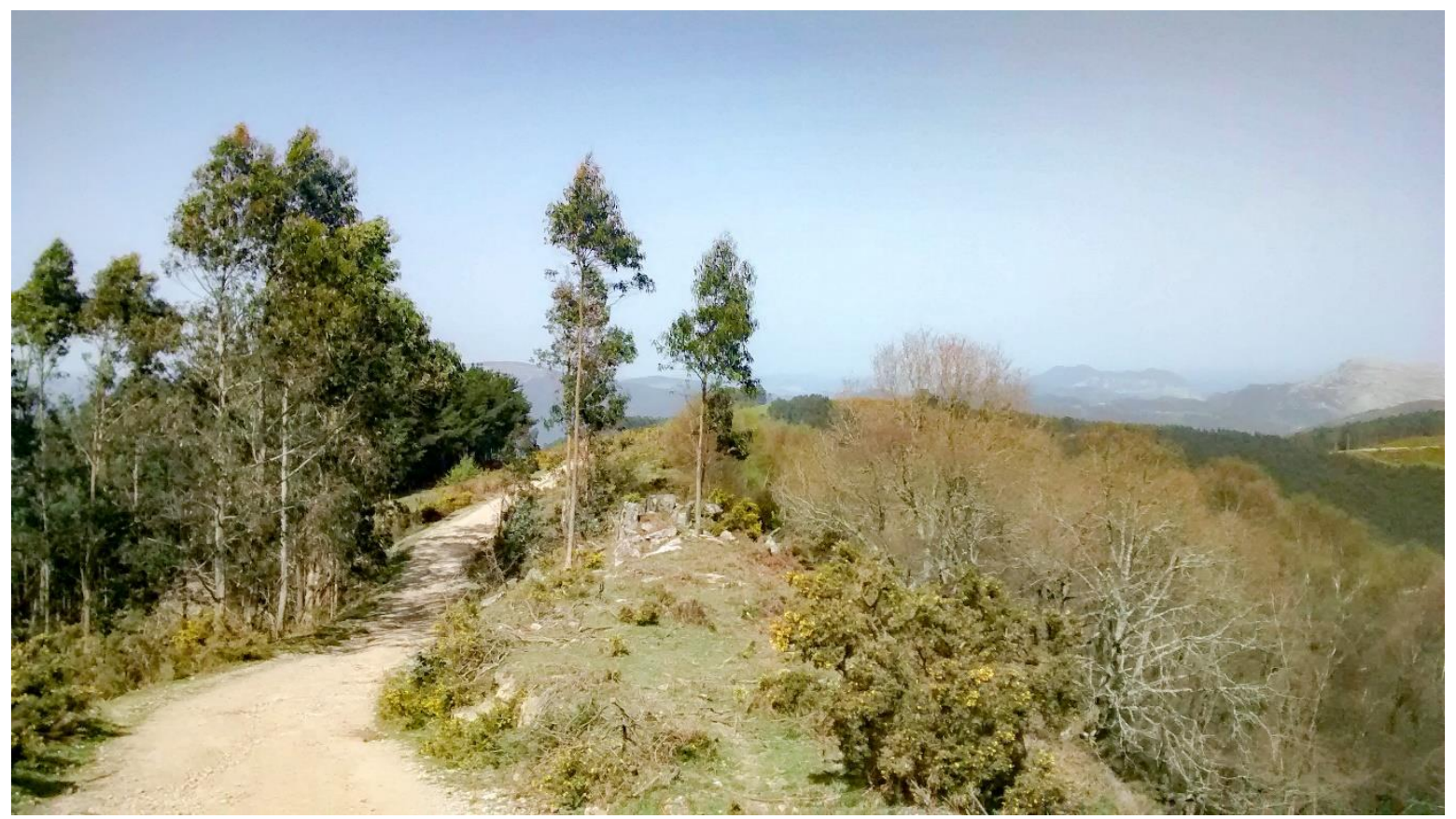

Figura 131. A la izquierda Eucaliptos adultos, a la derecha el robledal autóctono en Guriezo. Imagen propia. 


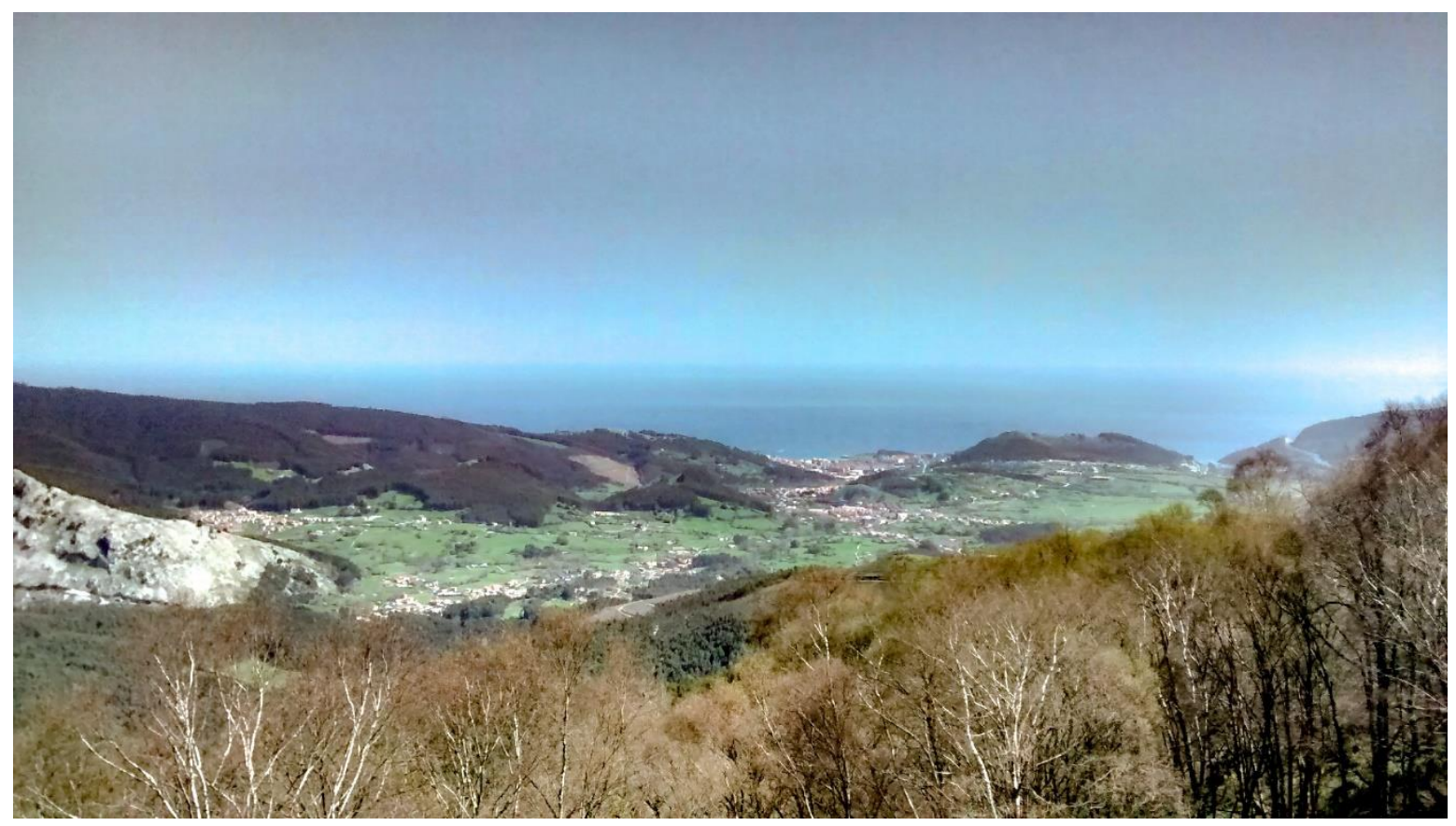

Figura 132. El valle de Guriezo con la distribución de los distintos núcleos de población. Imagen propia.

A partir de la información aportada por el Mapa Forestal de España 1:50.000 (Figura 127), y la información que facilita Corine Land Cover (Figura 122 y Figura 123), se ha procedido a realizar una trasposición vertical esquemática de la realidad paisajística en el municipio de Guriezo con el objetivo de hacer más sencillo interpretarlo. Estos esquemas se han rectificado en campo para evitar posibles errores de muestreo (Figura 133 y Figura 134). 
Estudio de casos y aplicación práctica. Paisajes forestales con valor patrimonial.

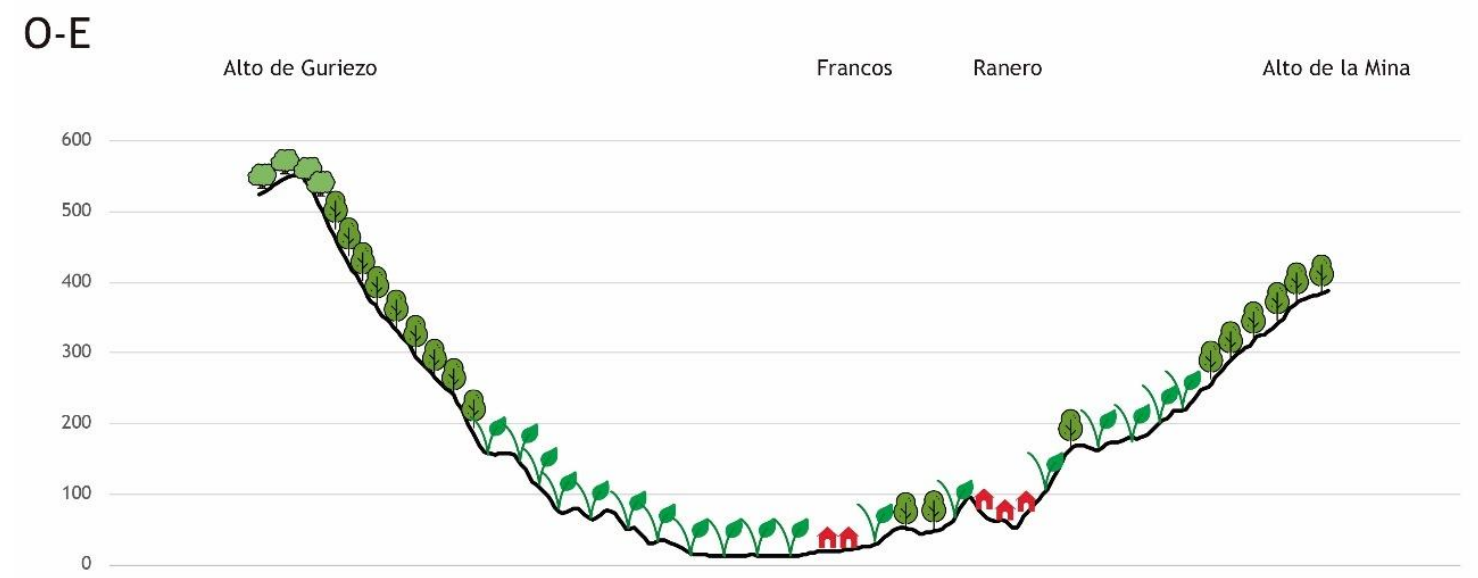

m.s.n.m

Eucalipto (Eucaliptus globulus)

Landas y matorrales mesófilos

Prados de siega

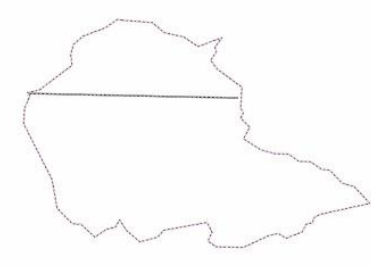

E. horizontal: $\stackrel{0}{\square} \quad 50 \quad 1000$ m

Figura 133. Perfil topográfico con información de usos Alto de Guriezo-Alto de La Mina. Elaboración propia a partir de trabajo de campo. 


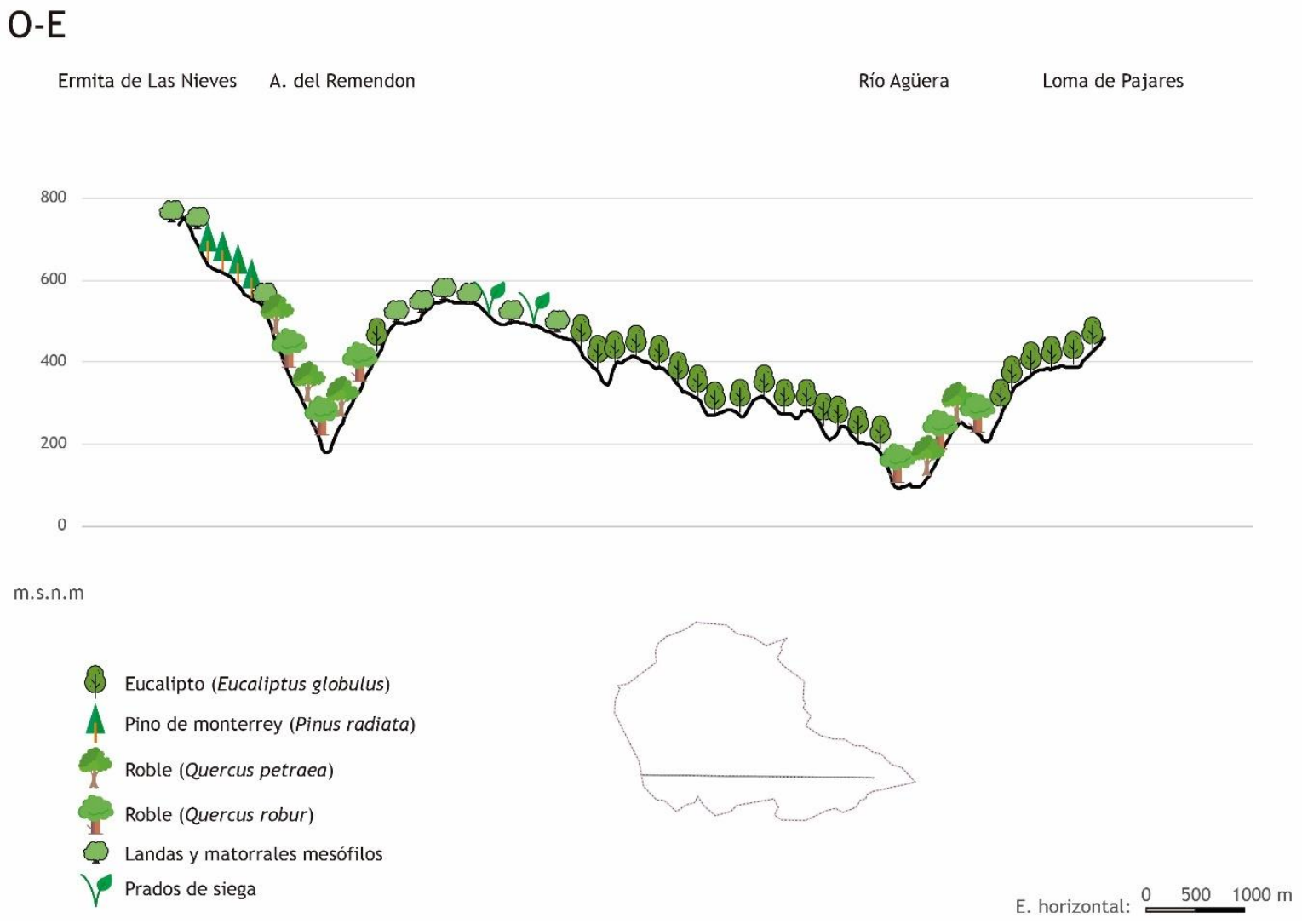

Figura 134. Perfil topográfico con información de usos Ermita de Las Nieves-Loma de Pajares. Elaboración propia a partir de trabajo de campo. 


\subsection{El proceso de patrimonialización a través de los indicadores.}

Este epígrafe está destinado a la valoración de los indicadores de patrimonialización que se fijaron en el apartado (6.3). En esta ocasión el caso de estudio se restringe a los límites del municipio de Guriezo por lo que será esta delimitación administrativa la que servirá de referencia.

\subsubsection{Indicador 1. Complejidad biológica}

\begin{tabular}{|l|c|}
\hline Criterio & Puntuación \\
\hline Evidencias bibliográficas de naturalidad & 3 \\
\hline Hábitat de Interés Comunitario & 4 \\
\hline Salud vegetal NDVI & 3 \\
\hline
\end{tabular}

Tabla 49. Resumen criterios valoración indicador Complejidad Biológica.

El valor de este indicador se fija a través de una investigación destinada a recoger evidencias bibliográficas que traten aspectos relacionados con la biodiversidad o riqueza biológica del paisaje forestal del eucaliptal de Guriezo o eucaliptales de similares características. Por otro lado, se realiza un trabajo de campo destinado a la observación directa tratando de encontrar apoyos que refuercen las evidencias bibliográficas.

De acuerdo con diversas investigaciones (Chen, 2001; Zhao et al., 2007) parece constatado a nivel internacional una relación directa entre la reducción de la biodiversidad y las plantaciones de eucalipto. El hecho de responder a plantaciones monoespecíficas, las cortas a matarrasa o la acidificación edáfica resultante de la descomposición de sus hojas, son algunos de los principales motivos de esta evidencia. En el contexto español se demuestra una relación directa entre la escasez de especies vegetales y el anidamiento de aves en los eucaliptales (Bas et al., 2018). Corroborado en el caso que ocupa a esta investigación, donde se han encontrado evidencias que así lo reflejan. Por un lado (Pérez, 2005) demuestra cómo 
estos eucaliptales son pobres en diversidad y existencia de aves, planteando la debilidad de las ramas y el cimbreo de los troncos como principales motivos que evitan el anidamiento. Mientras que (Molinero y Pozo, 2004) demuestran una bajada en el aporte de materia orgánica en los cursos de agua que discurren por plantaciones de este tipo, lo que será definitivo para encontrar una menor densidad de macroinvertebrados (González et al., 2003), esto va a ser determinante para inferir mayor o menor riqueza biológica.

En lo que respecta a la observación directa, es necesario destacar, la influencia de la mecanización derivada de la explotación industrial de este espacio forestal. Esta mecanización, resulta muy impactante en la estructura del bosque, generando una importante compactación del suelo, así como la destrucción de buena parte del sotobosque y la apertura de grandes caminos de acceso. Todo esto es definitivo para asegurar que se produce una sensación de artificialidad muy alejada del ideal de bosque natural (Figura 135).

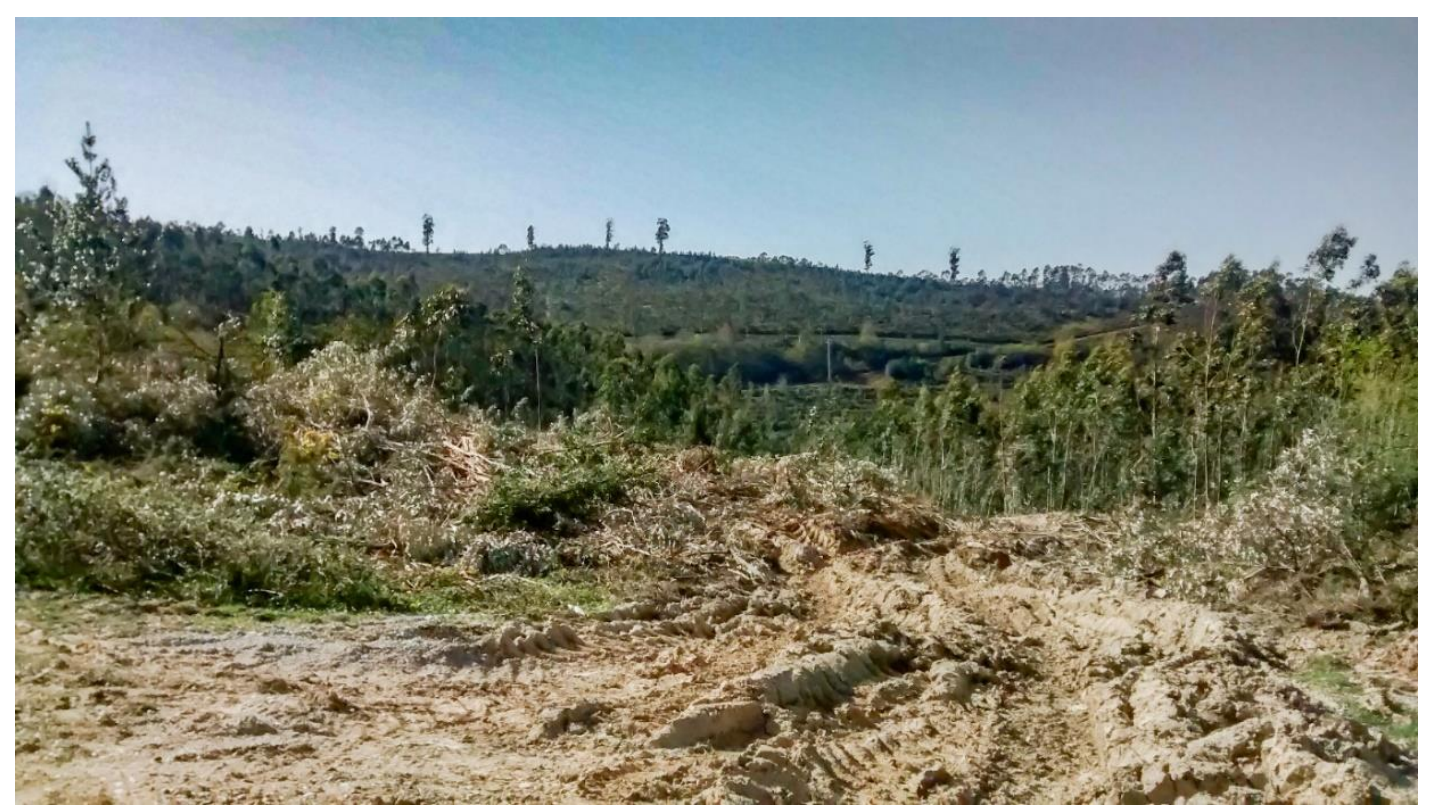

Figura 135. Huellas de la maquinaria pesada utilizada para los trabajos forestales en el eucaliptal de Guriezo. Imagen propia. 
Se entiende que nos encontramos ante un ecosistema reciente, muy intervenido y con escasas posibilidades de evolucionar hacia otro más complejo dado su carácter productivo. El paisaje que deriva de esta realidad forestal es, por tanto, un antagonista de lo que hemos descrito como un espacio donde las leyes de la naturaleza hacen su trabajo alejadas de la supervisión humana. Con estas evidencias no cabe más que dar por incumplido el primer criterio planteado.

En lo que se refiere a la Directiva Hábitat y sus hábitats de interés comunitario, en el municipio de Guriezo se han identificado 4 hábitats catalogados (Figura 136) pero todos ellos corresponden a formaciones vegetales de especies autóctonas que nada tienen que ver con las plantaciones de eucaliptos dominantes en el municipio:

- Lauro nobilis-Quercetum ilicis (Encinar cantábrico)

- Helictotricho cantabrici-Genistetum occidentalis (Aulagares cantábricos)

- Daboecio-Ulicetum cantabrici (gallii) (brezales cantábricos)

- Hyperico androsaemi-Alnetum glutinosae (Alisedas cantábricas)

Sobre estos cuatro hábitats delimitados por la Directiva, destaca la formación de encinar cantábrico que supone un ejemplo de bosque autóctono y se sitúa como un elemento de resistencia frente al avance del eucaliptal.

De acuerdo con estas premisas hay que señalar que, el criterio de relación entre el paisaje forestal y formaciones vegetales reconocidas como Hábitats de Interés Comunitario no se cumple ya que, el espacio ocupado por las plantaciones de eucalipto, quedan excluidas de este reconocimiento. 


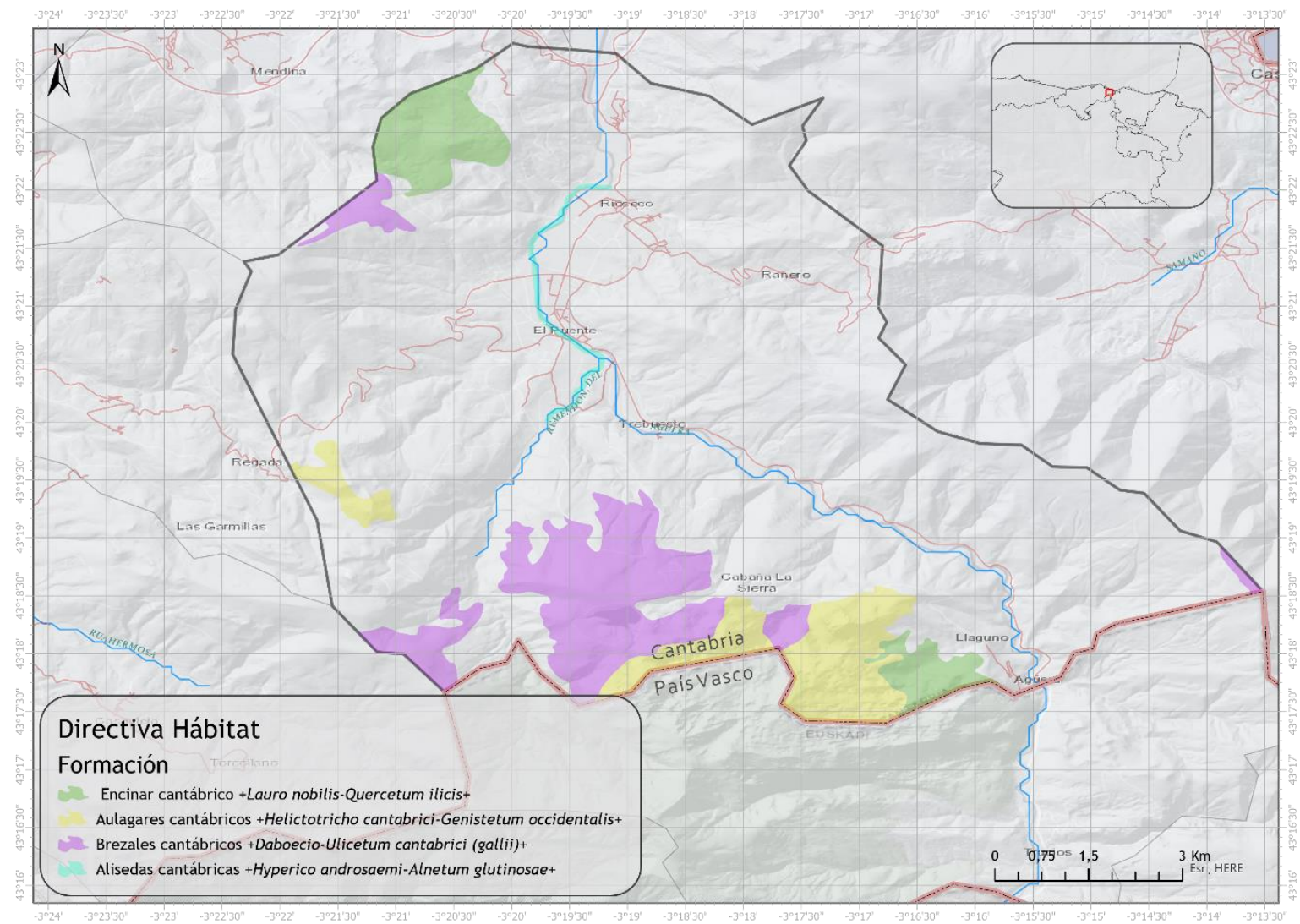

Figura 136. Mapa de las figuras recogidas por la Directiva Hábitat en el municipio de Guriezo. Elaboración propia a partir de Directiva Hábitat Banco de Datos de la Naturaleza.

En lo que concierne al análisis del índice NDVI (ver 6.3.1) para valorar la vigorosidad de la vegetación en las cuatro estaciones y poder comparar el bosque de eucaliptos con el resto de las formaciones que están presentes en el municipio, hay que señalar que el eucaliptal no destaca como la cubierta más relevante (Tabla 50), siendo las más destacadas las alisedas de ribera (Figura 137). Estas formaciones no tienen ninguna relación directa con el bosque de eucaliptos, pudiéndose plantear incluso que existe un antagonismo claro entre un bosque diverso y adaptado al medio y una plantación monoespecífica consumidora de recursos. Por todo esto el criterio planteado no se cumple. 

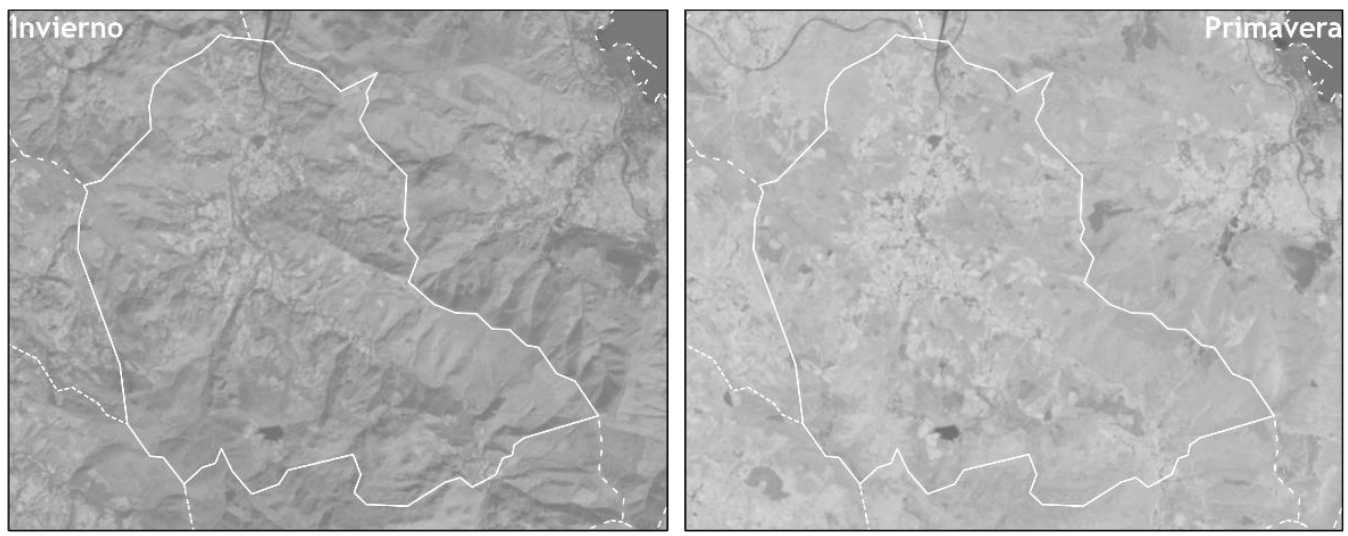

Municipio de

Guriezo

índice

NDVI
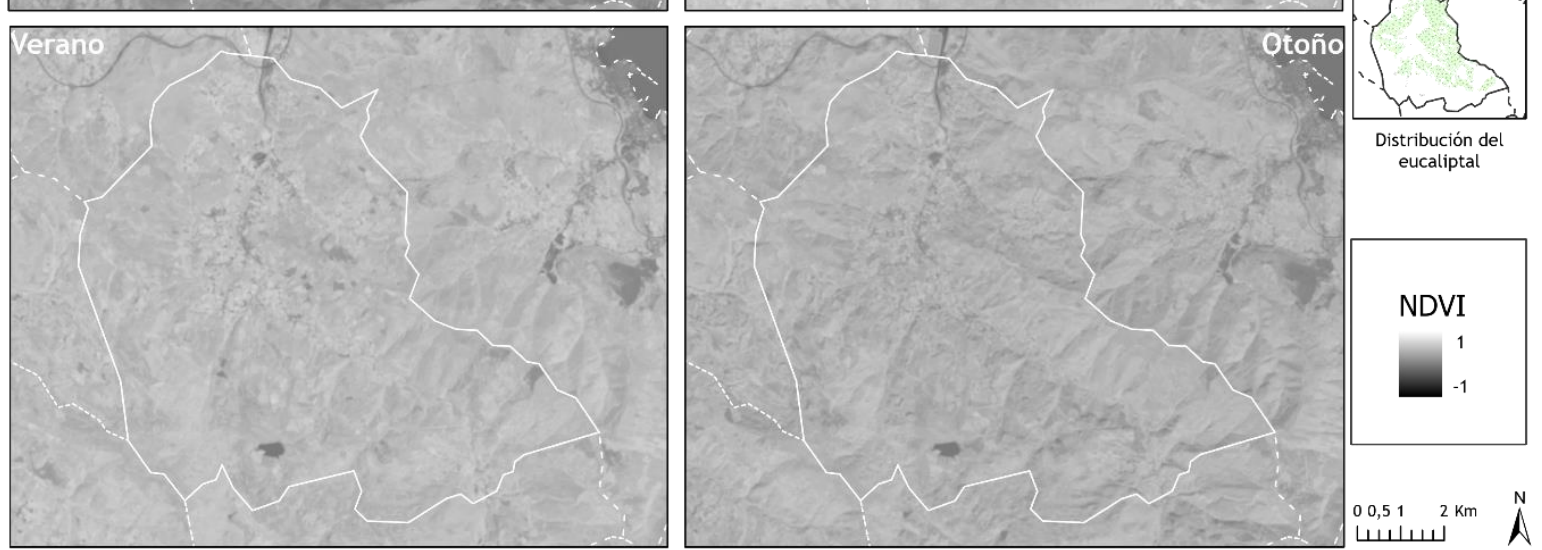

Figura 137. Representación del índice de vegetación de diferencia normalizada para los meses de febrero, mayo, agosto y octubre respectivamente. Imágenes Landsat 8 . Elaboración propia.

\begin{tabular}{|c|c|c|c|}
\hline & Eucaliptal & Cultivos & Otra veg. (Robledal) \\
\hline Invierno & 0.1 & 0.46 & 0.17 \\
\hline Primavera & 0.22 & 0.44 & 0.45 \\
\hline Verano & 0.35 & 0.5 & 0.46 \\
\hline Otoño & 0.26 & 0.37 & 0.37 \\
\hline
\end{tabular}

Tabla 50. Valor NDVI de distintas cubiertas a lo largo del periodo vegetativo. Elaboración propia. 


\begin{tabular}{|c|c|c|}
\hline Criterio & Puntuación & Cumplimiento \\
\hline $\begin{array}{c}\text { Evidencias bibliográficas de } \\
\text { naturalidad }\end{array}$ & 3 & $\begin{array}{c}\text { Evidencias contrarias a } \\
\text { la naturalidad }\end{array}$ \\
\hline Hábitat de Interés Comunitario & 4 & $\begin{array}{c}\text { Los hábitats } \\
\text { fuera del eucaliptal }\end{array}$ \\
\hline Salud vegetal NDVI & 3 & $\begin{array}{c}\text { Existen formaciones } \\
\text { más vigorosas }\end{array}$ \\
\hline
\end{tabular}

Tabla 51. Resumen criterios cumplidos valoración indicador Complejidad Biológica.

\subsubsection{Indicador 2. Figuras de protección, reconocimiento y} salvaguarda presentes en el territorio.

\begin{tabular}{|l|c|}
\hline Criterio & Puntuación \\
\hline Figura otorgada por UNESCO & 4 \\
\hline Parque Nacional & 3 \\
\hline Parque Natural o inferior (CCAA) & 2 \\
\hline LIC o ZEPA & 0,5 \\
\hline Otras figuras & 0,5 \\
\hline
\end{tabular}

Tabla 52. Resumen criterios valoración indicador Figuras de protección

El segundo indicador pone de manifiesto la relación entre las figuras administrativas que reconocen valores singulares en el territorio y el paisaje forestal en cuestión. Así, se realiza una recopilación de las figuras presentes en el territorio que están relacionadas de algún modo con la realidad forestal que se analiza. En este caso, las figuras de protección, reconocimiento o salvaguarda son muy escasas. Tan solo existe el LIC Río Agüera que contempla una franja de unos 70-80 metros en torno al cauce de dicho río, de su afluente Arroyo del Remendón y su desembocadura en 
forma de estuario, la cual se encuentra en su mayoría fuera del término municipal de Guriezo.

Como se ha puesto de manifiesto en el punto anterior, existe una estrecha relación entre este río de montaña y sus vertientes lo que implica un conflicto al estar constatado que las plantaciones de eucaliptos van a interferir mermando la riqueza biológica de esta ribera (González et al., 2003; Molinero y Pozo, 2004). Por este motivo resultaría presuntuoso relacionar los eucaliptales presentes en las vertientes con la declaración del LIC, más aún si se entiende que el objetivo de esta declaración es preservar y garantizar una conservación de los valores biológicos del bosque de ribera y su ecosistema, antagonista con las plantaciones monoespecíficas y sus resultados ambientales.

En cuanto al reconocimiento cultural solo se podría enmarcar el bosque de eucaliptos bajo las figuras de Montes de Utilidad Pública pertenecientes a entidades locales siendo esta una garantía de mantenimiento del uso forestal, pero que no contempla especiales medidas para el mantenimiento de valores naturales. (Figura 138). 


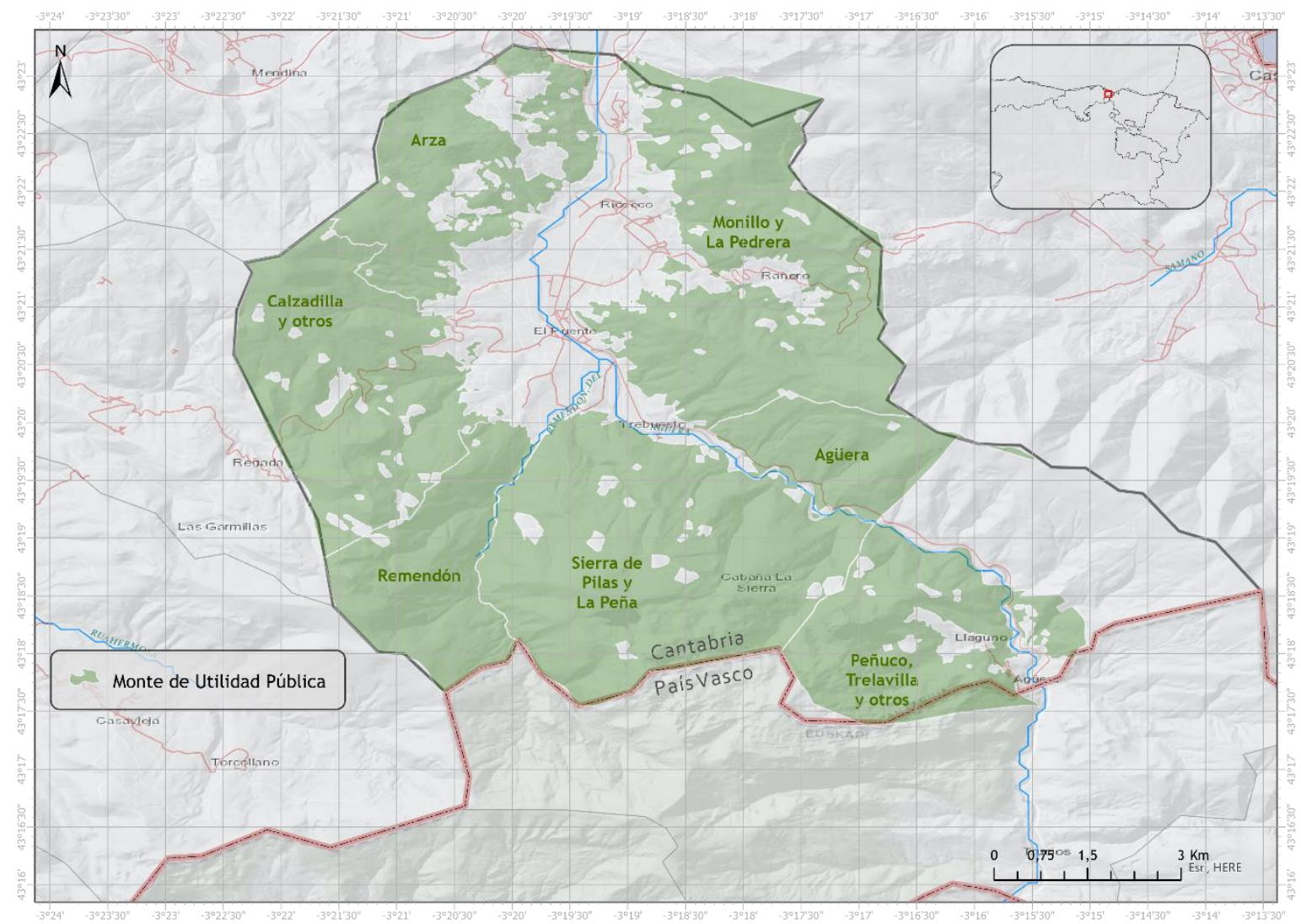

Figura 138. Mapa de los Montes de Utilidad Pública en el municipio de Guriezo. Elaboración propia a partir de Montes de Utilidad Pública Gobierno de Cantabria. 
De acuerdo con lo expuesto la valoración para este indicador será de 0,5 puntos al cumplir únicamente el criterio final, la declaración de Montes de Utilidad Pública que garantizan el uso forestal.

\begin{tabular}{|c|c|c|}
\hline Criterio & Puntuación & Cumplimiento \\
\hline Figura otorgada por UNESCO & 4 & $\begin{array}{c}\text { No tiene } \\
\text { reconocimiento } \\
\text { UNESCO }\end{array}$ \\
\hline Parque Nacional & 3 & No es PN \\
\hline Parque Natural o inferior (CCAA) & 2 & $\begin{array}{l}\text { No tiene figura de } \\
\text { protección regional }\end{array}$ \\
\hline LIC O ZEPA & 0,5 & $\begin{array}{c}\text { El LIC no tiene } \\
\text { vinculación con el } \\
\text { espacio forestal }\end{array}$ \\
\hline Otras figuras & 0,5 & $\overline{\text { MUP }}$ \\
\hline
\end{tabular}

Tabla 53. Resumen criterios cumplidos valoración indicador Figuras de protección

\subsubsection{Indicador 3. Existencia de vectores patrimoniales}

\begin{tabular}{|l|c|}
\hline Criterio & Puntuación \\
\hline Todos los vectores & 4 \\
\hline Al menos 50\% tratados patrimonialmente & 3 \\
\hline Identificados vectores de todos los tipos & 3 \\
\hline
\end{tabular}

Tabla 54. Resumen criterios valoración indicador Vectores Patrimoniales.

El tercer indicador basa su valoración en la presencia y tratamiento de los vectores patrimoniales asociados al paisaje forestal, concretamente en este caso al paisaje de la silvicultura intensiva del eucaliptal. Se entiende que los vectores patrimoniales van a fijar el valor patrimonial al ser condensadores de valores, así se van a identificar los vectores asociados 
a este paisaje, fijados en el epígrafe 3.5.3, se valorará su estado, su tratamiento y su conservación.

Pasan a ser descritos los vectores identificados para el paisaje forestal de la silvicultura intensiva:

Parcelas de turno: Se ha constatado la existencia de estas parcelas que determinan la realidad paisajística de mosaico, donde unas presentan ejemplares adultos mientras que otras aparecen copadas por brotes de cepa mostrando un aspecto de tallar (Figura 139). Este contexto paisajístico tan relevante no presenta ningún tipo de tratamiento patrimonial, siendo en general visto como algo negativo (Alonso, 2012).

Maquinaria industrial: Se han encontrado evidencias de maquinaria industrial repartida por el bosque de eucalipto, fundamentalmente cercanas a las pistas forestales. Nos se ha apreciado ningún tratamiento patrimonial, en buena medida estaría fundamentado por tratarse de elementos contemporáneos con una indudable vigencia de uso (Figura 135).

Iconografía: En este caso no se valora este vector al entenderse que existe un epígrafe destinado en exclusiva (10.7.4), lo que podría llevar a una doble valoración.

Fábricas: Al igual que en el caso de la maquinaria industrial, las fábricas identificadas con la producción silvícola y su transformación mantienen una vigencia de uso y una actualidad en su arquitectura que no recibe ninguna atención patrimonial. La empresa de explotación forestal presente en el municipio, Puente Garay Forestal S.L data de 1996 y está enfocada a la explotación forestal del eucaliptal (información facilitada por la empresa).

Beneficios económicos directos: La mayor parte del término municipal de Guriezo está declarada Monte de Utilidad Pública perteneciente a diferentes entidades locales. En cuanto al municipio, consorcia parcelas de aprovechamiento silvícola con vecinos del municipio que posteriormente son subastadas para la enajenación de la madera. De esta forma, existe un 
beneficio económico directo de los vecinos. Como ejemplo de estos beneficios el Boletín Oficial de Cantabria calculó en 2018 un aprovechamiento forestal cercano a los $800.000 €$ repartido entre 89 consorciantes, arrojando un beneficio medio cercano a los $9.000 €$ (Ayuntamiento de Guriezo, 2018). Existe otra entidad local, el concejo abierto de Agüera que consorcia igualmente los aprovechamientos con los vecinos revirtiendo directamente el beneficio en estos últimos (Concejo Abierto Agüera, 2019).

Puestos de trabajo: Este vector no se valora al existir un epígrafe destinado directamente a ello (0), podría suponer una doble valoración.

Incremento en los presupuestos de las administraciones: Como se ha señalado en el apartado que hace referencia a los beneficios económicos directos, el municipio de Guriezo recibe un importante beneficio económico derivado de los aprovechamientos forestales, pero no solo va destinado a los particulares sino que ingresa anualmente en sus presupuestos alrededor de $500.000 €$ destinados a cubrir las necesidades del municipio [460.000€ - 2017, 500.000€ - 2018, 500.000€ - 2019 (Ministerio de Hacienda, 2019)]. 


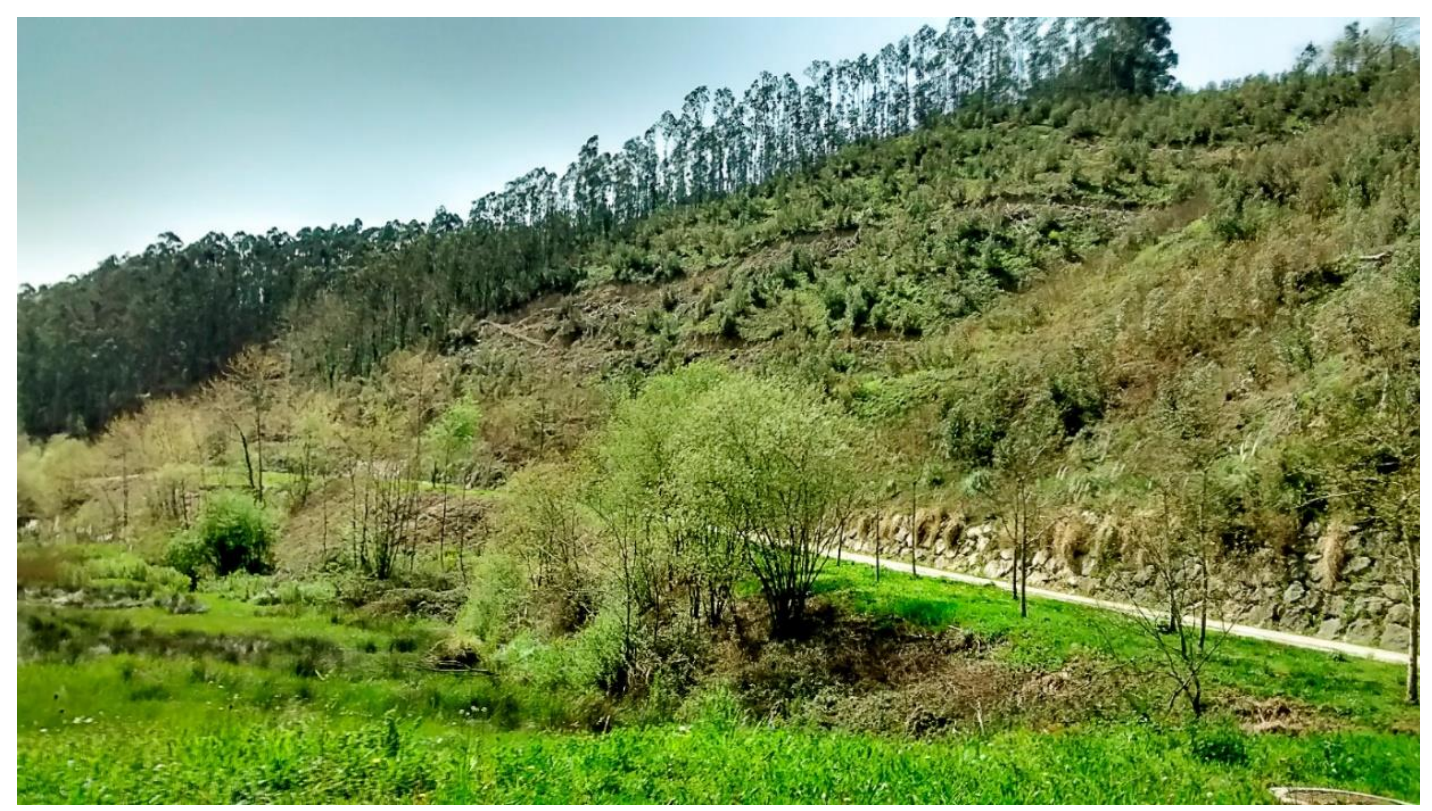

Figura 139. Parcelas de turno en el eucaliptal de Guriezo, donde se alternan ejemplares de diferentes edades. Imagen propia.

Con las evidencias recogidas hay que señalar que se han identificado todos los vectores planteados pero que ninguno de ellos aparece tratado patrimonialmente, en buena medida se debe a su vigencia de uso. De acuerdo con esto. la valoración de este indicador será de 7 puntos al cumplirse dos de los tres criterios propuestos (Tabla 55).

\begin{tabular}{|c|c|c|}
\hline Criterio & Puntuación & Cumplimiento \\
\hline Todos los vectores & 4 & $\begin{array}{c}\text { Todos se han } \\
\text { identificado }\end{array}$ \\
\hline $\begin{array}{c}\text { Al menos tratados } \\
\text { patrimonialmente }\end{array}$ & $30 \%$ No están tratados \\
\hline Identificados vectores de todos los \\
tipos
\end{tabular}

Tabla 55. Resumen criterios cumplidos valoración indicador Vectores Patrimoniales 


\subsubsection{Indicador 4. Identificación y sentimiento de pertenencia}

\begin{tabular}{|l|c|}
\hline Criterio & Puntuación \\
\hline Toponimia & 2 \\
\hline Heráldica & 2 \\
\hline Iconografía administración & 2 \\
\hline Iconografía de particulares & 2 \\
\hline Referencias de asociaciones & 2 \\
\hline
\end{tabular}

Tabla 56. Resumen criterios valoración indicador Identificación de la población.

Este indicador se valora a través de las evidencias reconocidas como apropiación cultural del paisaje forestal. Para identificar esta apropiación se han convenido una serie de referencias como son la toponimia, así como la iconografía y simbología utilizada por las administraciones y los particulares. De este modo se entiende que la utilización más o menos frecuente de símbolos relacionados, en este caso con los eucaliptos, determina esa vinculación de apropiación cultural, valorándose de acuerdo con la escala planteada (ver 6.3.4).

En lo que se refiere a la toponimia, se aprecia una tendencia a los topónimos centrados en los usos tradicionales previos a las plantaciones de eucalipto. En buena medida se han encontrado referencias que recuerdan antiguos bosques de especies autóctonas como “La Tejera”, “El Carrascal”; espacios destinados al aprovechamiento ganadero como "Gamonal”, "Prado Marqués" o "Prado Justo". Estos lugares con topónimos vinculados a prácticas tradicionales hoy aparecen, casi por completo, tapizados por plantaciones de eucaliptos. Por el contrario, no se ha encontrado ninguna referencia toponímica que haga referencia al eucalipto o sus actividades.

Las referencias heráldicas del municipio de Guriezo no presentan ninguna relación con su paisaje forestal, la simbología que refleja es una cruz de la orden de Calatrava sobre fondo azul (Figura 140). Por tanto, no 
va a utilizar ninguna reseña forestal, ni asociada a especies autóctonas ni asociadas al eucaliptal.

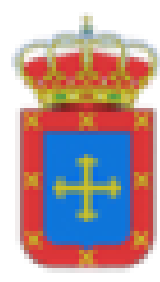

Figura 140. Escudo oficial del municipio de Guriezo. Recuperado de: https://aytoguriezo.es/

En cuanto a la utilización iconográfica por parte de la administración, el eucalipto está ausente por completo. En ningún caso se encuentran referencias que puedan asociar la realidad forestal del municipio con organismos municipales.

En lo que concierne a las actividades particulares no se han encontrado referencias al eucalipto, incluso en actividades relacionadas directamente con lo forestal se utilizan otras referencias que parecen alejarse del paisaje forestal del municipio. Así se han encontrado evidencias en la empresa forestal presente en el municipio que recurre a iconografía más cercana al pino que al eucalipto (Figura 141).

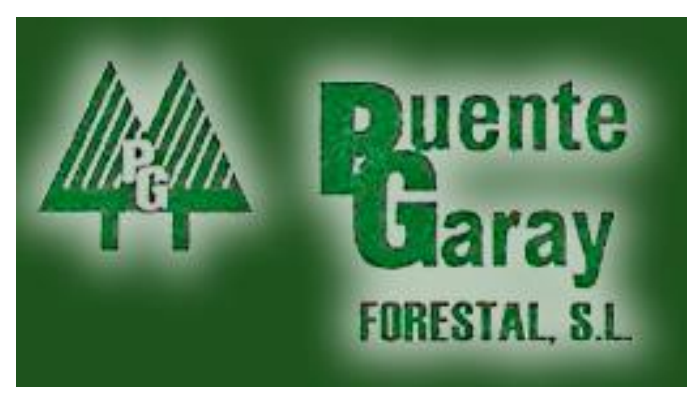

Figura 141. Logotipo de la empresa Puente Garay Forestal S.L. Recuperado de: http://www.puentegarayforestal.com/es/

Respecto a las asociaciones presentes en el municipio, no se han encontrado referencias al eucaliptal en ningún caso, como ejemplo se 
puede destacar una importante actividad deportiva que se celebra anualmente y que discurre, en buena medida, por los bosques de eucalipto la cual representa dos pináceas huyendo del eucalipto como icono identificativo. Igualmente se han encontrado otras actividades que van a utilizar la famosa imagen de la Ermita de Nuestra Señora de las Nieves (Figura 142). la Reforzando esta idea de huida de las referencias al eucalipto encontramos a una asociación cultural formada por diferentes vecinos destinada a "defender el Patrimonio Cultural y Natural de Guriezo". Entre las actividades y actuaciones en defensa del patrimonio de Guriezo, recogidas en un archivo descargable en su web no aparece ninguna referencia al eucaliptal, destacando la preocupación por actuaciones centradas en el patrimonio arquitectónico del municipio.
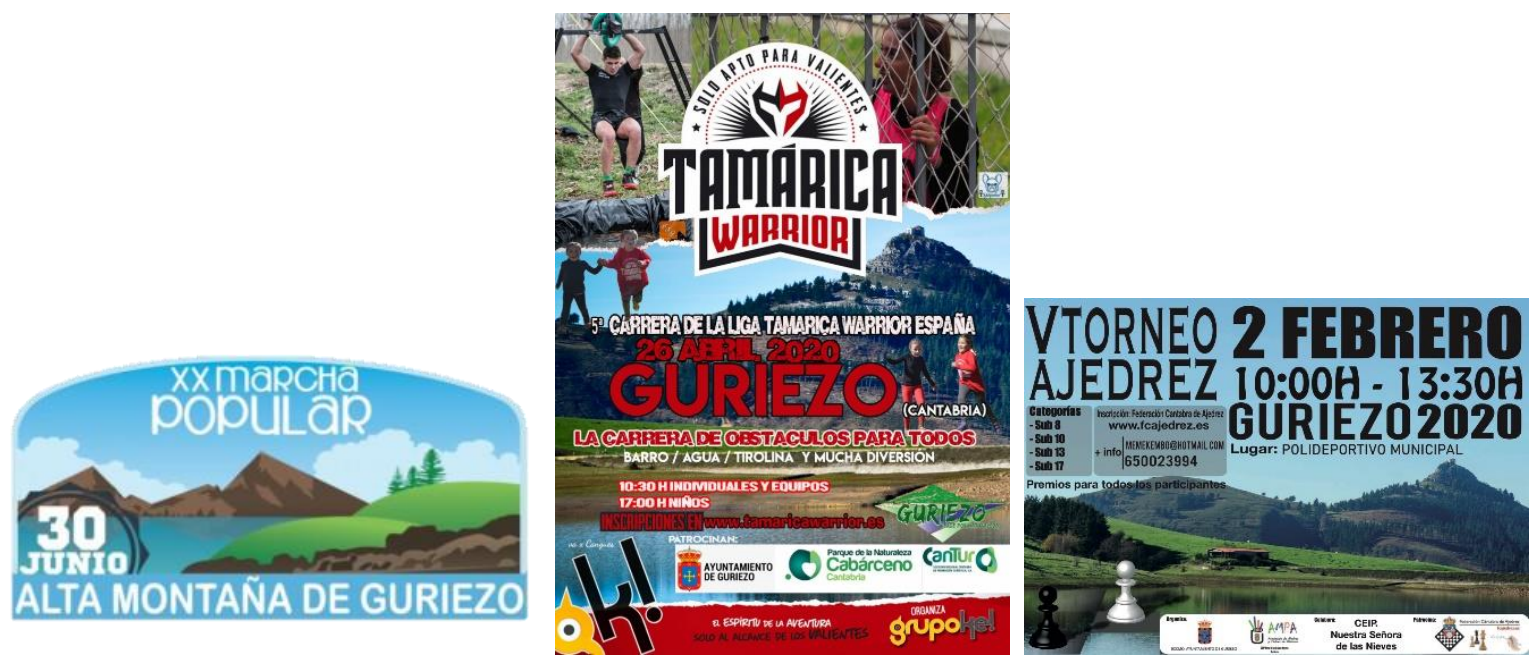

Figura 142. Imágenes de diferentes eventos deportivos. De izquierda a derecha: Carrera de alta montaña, recuperado de: https: / / turismodecantabria.com/proximamente/eventos/8726-marcha-de-alta-montanaguriezo/buscador-

ZmVjaGFTZXQ9MSZtZXM9NiZhbnlvPTIwMTkmZGIhPSZpZENhdGVnb3JpYT00Jg==. Carrera de obstáculos, recuperado de: https://www.avaibooksports.com/inscripcion/tamaricawarrior-guriezo-cantabria/. Torneo de ajedrez, recuperado de: https://www.fcajedrez.es/torneo/2020/v-torneo-de-ajedrez-escolar-de-guriezo/.

De acuerdo con estas evidencias el paisaje forestal del municipio de Guriezo, sostenido de forma mayoritaria en el eucaliptal, no cumple ninguno de los criterios establecidos para este indicador. 


\begin{tabular}{|c|c|c|}
\hline Criterio & Puntuación & Cumplimiento \\
\hline Toponimia & 2 & No existen \\
topónimos \\
\hline Heráldica & 2 & No hay referencias \\
forestales
\end{tabular}

\subsubsection{Indicador 5. Museística}

\begin{tabular}{|l|c|}
\hline Criterio & Puntuación \\
\hline Centros de interpretación / museos oficiales & 4 \\
\hline Museos de particulares & 2 \\
\hline Jornadas de exaltación & 2 \\
\hline Mobiliario de exhibición o exaltación & 2 \\
\hline
\end{tabular}

Tabla 58. Resumen criterios valoración museística

La valoración de este indicador se sustenta en la existencia, o no, de espacios públicos o privados destinados a exaltar y preservar los valores asignados al paisaje forestal en cuestión. Se trata de recopilar evidencias de estos espacios en relación con el paisaje del eucaliptal. Los centros de interpretación o museos son un testigo determinante para identificar el momento patrimonial de cualquier elemento, por lo que se ha escogido su existencia y abundancia como indicador para determinar el momento patrimonial de este paisaje. 
En este caso no se han encontrado evidencias de la existencia de museos o centros de interpretación que giren en torno al eucalipto, ni en el municipio de Guriezo, ni en otro lugar de la Península. Parece que el paisaje del eucalipto y sus usos están, por el momento, muy alejados de ser tratados como un valor positivo, más allá de la rentabilidad económica. No hay evidencias de la existencia de este tipo de espacios ni públicos ni privados, así como tampoco se han encontrado evidencias de la existencia de jornadas relacionadas con el eucalipto, ni existe mobiliario urbano destinado a representar esta especie vegetal. Concretamente en Guriezo existe un museo en la antigua Ferrería de la Yseca destinado a exhibir los instrumentos y las instalaciones destinadas a la herrería. En cuanto a las jornadas de exaltación se realiza en Guriezo una feria anual destinada a la exposición de ganado ovino y caprino (Figura 143).

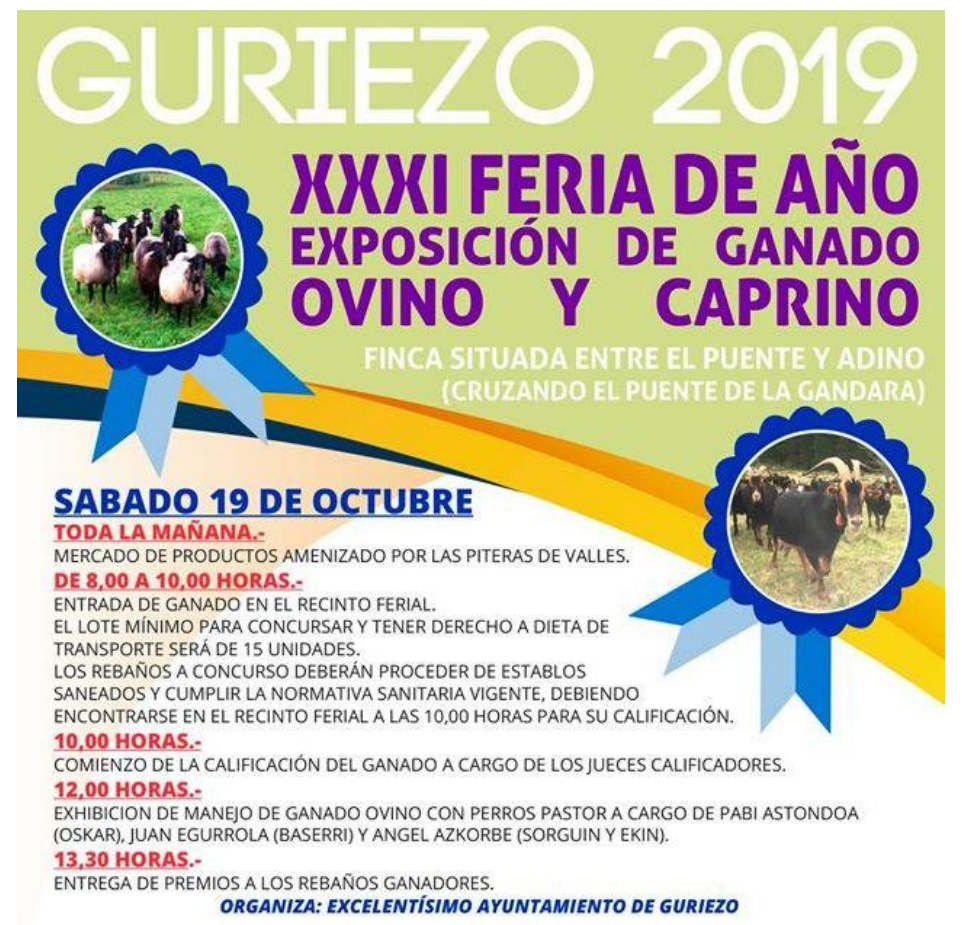

Figura 143. Cartel de la feria de ganado del año 2019 en Guriezo. Recuperado de: https://www.turismodecantabria.com/proximamente/eventos/9274-feria-de-ano-deguriezo. 


\begin{tabular}{|c|c|c|}
\hline Criterio & Puntuación & Cumplimiento \\
\hline $\begin{array}{c}\text { Centros de interpretación/museos } \\
\text { oficiales }\end{array}$ & 4 & No existen \\
\hline Museos de particulares & 2 & $\begin{array}{c}\text { No se han } \\
\text { encontrado }\end{array}$ \\
\hline Jornadas de exaltación & 2 & No se han \\
& & encontrado \\
\hline Mobiliario de exhibición o exaltación & 2 & encontrado ningún \\
\end{tabular}

Tabla 59. Resumen criterios cumplidos valoración museística

\subsubsection{Indicador 6. Incorporación turística}

\begin{tabular}{|c|c|}
\hline Criterio & Puntuación \\
\hline Reivindicación turística supramunicipal & 4 \\
\hline Reivindicación turística municipal & 2 \\
\hline Reivindicación turística de particulares & 2 \\
\hline Reivindicación turística igual que otros elementos & 2 \\
\hline
\end{tabular}

Tabla 60. Resumen criterios valoración indicador Incorporación Turística

Como ya se ha comentado, la incorporación turística de lo patrimonial en el contexto actual es indudable. Tanto las administraciones como los particulares acuden a lo patrimonial como reclamo para hacer más atractivo su territorio. Por esto, se considera este acto de fusión de lo patrimonial y lo turístico como fundamental para comprender en que punto del proceso de patrimonialización se encuentra cada paisaje. Según lo propuesto en el apartado correspondiente donde se determinan los anclajes para la valoración (6.3.6), la mayor o menor recurrencia al recurso forestal se va a usar como testigo fiable para valorar este indicador. 
Para este paisaje no se han encontrado referencias que pongan de manifiesto la utilización del eucalipto, el eucaliptal, sus usos y prácticas o cualquier aspecto relacionado con este bosque con el reclamo turístico. En ningún caso se acude a nada de ello, ni como protagonista ni como complemento para la oferta turística.

En este territorio existen dos reclamos turísticos principales, por un lado, la tradición de las ferrerías asociadas al río Agüera, destacando la ferrería de la Yseca (s.XIII) y la ermita de las nieves situada en una peña caliza que destaca sobre su entorno y que es la imagen icónica utilizada por el municipio para su promoción turística y estos dos elementos van a ser la base de la publicidad turística por parte de las administraciones, tanto las supramunicipales (Figura 144) como la propia administración local (Figura 145). En ningún caso se acude al paisaje forestal para complementar la oferta turística. Igualmente, los reclamos turísticos por parte de particulares no parecen enfocarse al paisaje del eucalipto. De acuerdo con los criterios planteados hay que señalar que ninguno de ellos se cumple, por lo que la valoración será de 0 puntos (Tabla 61). 
- turismodecantabria.com/descubrela/municipios/59-guriezo

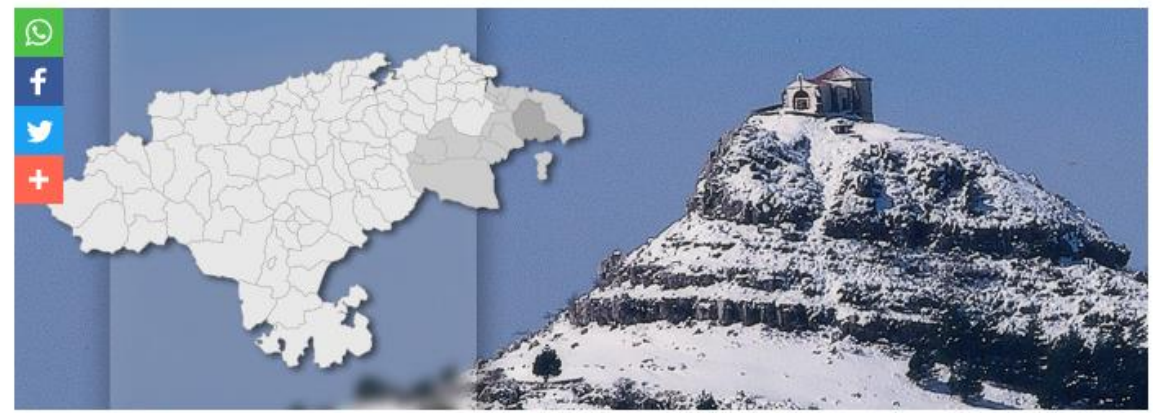

El municipio de Guriezo se extiende en torno al río Agüera, que lo cruza de sur a norte dando lugar al valle del mismo nombre.

La iglesia parroquial de San Vicente, en el pueblo de Rioseco, es su monumento más preciado. Se trata de un edificio de los siglos XVI y XVII con un grandioso pórtico configurado por un gran arco. El extraordinario retablo que conserva en su interior fue construido en 1658 por el maestro Martín de Arada.

En Guriezo podemos encontrar además un bello conjunto de casas populares montañesas de interés etnológico (La Corra), una cueva de la Edad de Bronce (Llaguno), las ermitas de San Antonio y San Mamés (en Llaguno y Lugarejos, respectivamente) y las casonas de La Magdalena y los Corro (El Puente). En esta última localidad llama la atención el puente viejo, de tres arcos de medio punto rebajado y que data del siglo XVI.

Su gastronomía es rica y variada. Sobresale un plato de curioso nombre, la "olla podrida", junto a los quesos y la jalea.

Los amantes de la pesca pueden encontrar un fabuloso escenario para la práctica de este deporte en el río Agüera.

\section{Ferrería de la Yseca}

La forja del hierro y otros metales ha gozado tradicionalmente de gran desarrollo en Guriezo. Fruto de la proliferación

Figura 144. Espacio reservado para la promoción turística de Guriezo en el portal de turismo de Cantabria. Recuperado de:

\section{https://www.turismodecantabria.com/descubrela/municipios/59-guriezo}

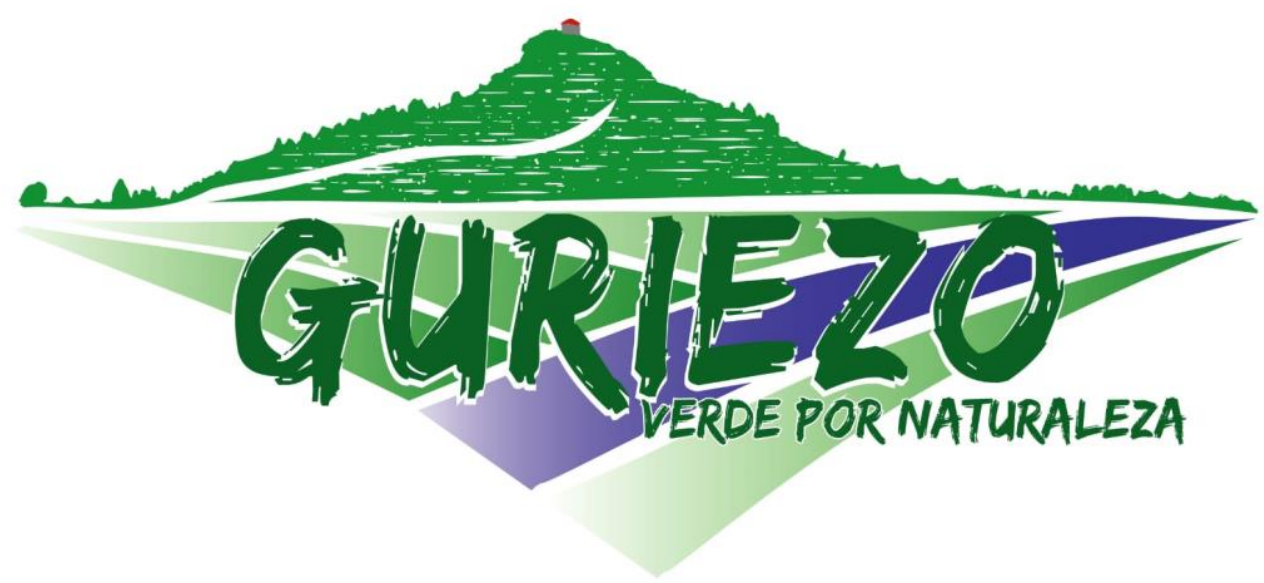

Figura 145. Logotipo de promoción turística del Ayuntamiento de Guriezo. Recuperado de: https://aytoguriezo.es/portfolio/fitur-2020/. 
Estudio de casos y aplicación práctica. Paisajes forestales con valor patrimonial.

\begin{tabular}{|c|c|c|}
\hline Criterio & Puntuación & Cumplimiento \\
Rupramunicipal turística & 4 & No se ha encontrado \\
\hline $\begin{array}{c}\text { Reivindicación turística } \\
\text { municipal }\end{array}$ & 2 & $\begin{array}{c}\text { La publicidad se entra } \\
\text { en otros elementos }\end{array}$ \\
\hline $\begin{array}{c}\text { Reivindicación turística de } \\
\text { particulares }\end{array}$ & 2 & No se ha encontrado \\
\hline $\begin{array}{c}\text { Reivindicación turística igual } \\
\text { otros elementos patrimoniales }\end{array}$ & 2 & Hay elementos mucho \\
\end{tabular}

Tabla 61. Resumen criterios cumplidos valoración indicador Incorporación Turística 


\subsubsection{Indicador 7. Empleo relacionado}

\begin{tabular}{|l|c|}
\hline Criterio & Puntuación \\
\hline Al menos 0,5\% ocupados en Silvicultura & 3 \\
\hline Al menos 5\% de ocupados en sectores relacionados & 3 \\
\hline Trabajadores silvicultura se incrementan & 2 \\
\hline Trabajadores relacionados se incrementan & 2 \\
\hline
\end{tabular}

Tabla 62. Resumen criterios valoración indicador Empleo relacionado

El indicador que hace referencia al empleo se fundamenta en la estrecha relación que existe entre el patrimonio y el valor de uso en la sociedad contemporánea. Aquellos elementos que son susceptibles de generar actividad económica son vistos como mucho más amigables que los elementos patrimoniales que suponen inversiones poco recuperables. Siguiendo esta premisa, fundamental para entender buena parte de los procesos de patrimonialización, se plantea este indicador.

La valoración se realiza de acuerdo con la escala planteada en el apartado correspondiente (6.3.7), mediante el análisis de los datos facilitados por la Seguridad Social.

De acuerdo con la información facilitada por la Seguridad Social no parece que el empleo que se pueda asociar a la explotación de las plantaciones forestales sea especialmente relevante en el municipio (Figura 146), aunque cumple sobradamente el primer criterio ya que en torno al $1 \%$ de la población está ocupada en tareas de silvicultura (Seguridad Social 2015). Se puede observar que, incluso en los peores momentos de la crisis económica reciente, la industria metálica supone el gran nicho de empleo para el municipio. Este dominio de la industria metálica hay que atribuirlo a la localización en el municipio del Grupo Vitrinor, Sociedad Anónima Laboral dedicada a la fabricación de diferentes productos metálicos, especialmente menaje para el hogar. Su forma jurídica, donde los trabajadores poseen buena parte de la propiedad hace 
que sea una empresa muy arraigada y genera una fuerte identidad territorial, basada en la industria metálica, tan antigua en el Municipio.

En cuanto a las actividades vinculadas, los epígrafes 16, 17 y 31 de la CNAE (Industria de la madera, Industria del papel y fabricación de muebles respectivamente), ocupan a un $0,26 \%$ de los empleados para 2015, por lo que no cumple el criterio propuesto.

En cuanto a la evolución de los trabajadores empleados en la silvicultura, no se cumple el criterio establecido ya que se ha producido una paulatina reducción de trabajadores desde 2010 hasta la actualidad pasando de 12 trabajadores a 9 en 2015.

Por último, los trabajadores empleados en actividades relacionadas presentan igualmente una tendencia a la baja, si bien es cierto que en ningún momento se ha tratado de un nicho de empleo destacado, (ocupando a un máximo de 4 trabajadores para datos de 2010) no parece que exista un nicho en la industria de la madera y el papel, siendo la madera extraída de sus montes llevada a industrias fuera del municipio. 
Estudio de casos y aplicación práctica. Paisajes forestales con valor patrimonial.

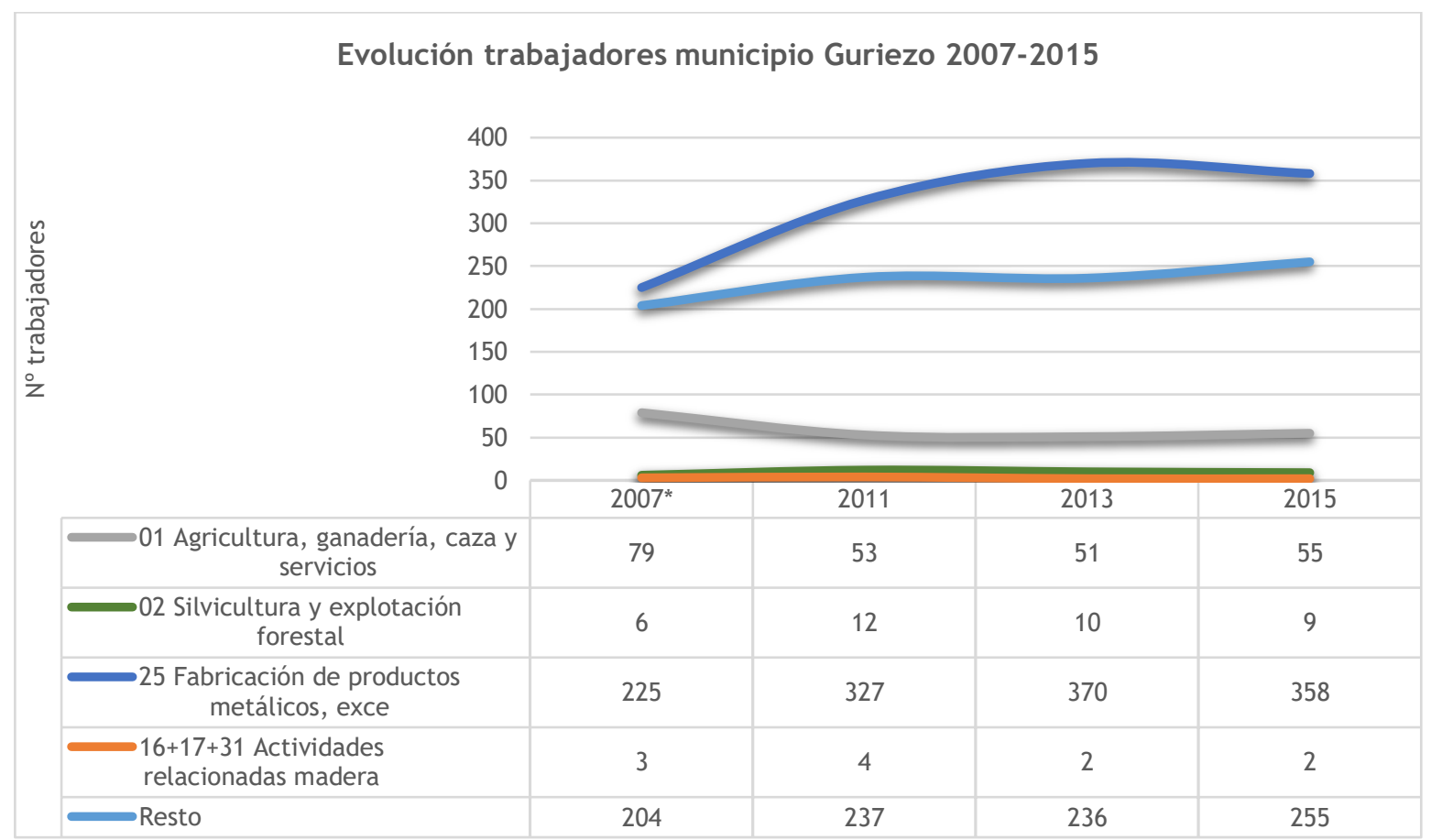

Figura 146.Distribución temporal de los trabajadores en el municipio de Guriezo. Elaboración propia a partir de Datos Seguridad Social. CNAE dos dígitos desagregado municipal. *transformación códigos CNAE93/CANE09

\begin{tabular}{|c|c|c|}
\hline Criterio & Puntuación & Cumplimiento \\
\hline $\begin{array}{c}\text { Al menos 0,5\% ocupados en } \\
\text { Silvicultura }\end{array}$ & 3 & $\begin{array}{c}\text { El 1\% está ocupado } \\
\text { en silvicultura }\end{array}$ \\
\hline $\begin{array}{c}\text { Al menos 5\% de ocupados en sectores } \\
\text { relacionados }\end{array}$ & 3 & $\begin{array}{c}0,26 \% \text { están } \\
\text { ocupado en } \\
\text { sectores } \\
\text { relacionados }\end{array}$ \\
\hline $\begin{array}{c}\text { Trabajadores silvicultura se } \\
\text { incrementan se }\end{array}$ & 2 & Descienden \\
\hline $\begin{array}{c}\text { Trabajadores relacionados sescienden } \\
\text { incrementan }\end{array}$ & & \\
\hline
\end{tabular}

Tabla 63. Resumen criterios cumplidos valoración indicador Empleo relacionado 
Estudio de casos y aplicación práctica. Paisajes forestales con valor patrimonial.

\subsubsection{Valoración final}

\begin{tabular}{|l|l|}
\hline Indicador & Valoración \\
\hline I1. Complejidad biológica & 0 \\
\hline 12. Figuras de protección & 0,5 \\
\hline 13. Existencia de vectores & 7 \\
\hline 14. Identificación y sentimiento de pertenencia & 0 \\
\hline 15. Centros de interpretación/museos & 0 \\
\hline 16. Incorporación turística & 0 \\
\hline 17. Empleo relacionado & 3 \\
\hline & Valoración final \\
\hline
\end{tabular}

Tabla 64. Valor obtenido por cada uno de los indicadores propuestos para el paisaje referente al municipio de Vallelado.

\section{Silvicultura intensiva: Eucaliptales de Guriezo}

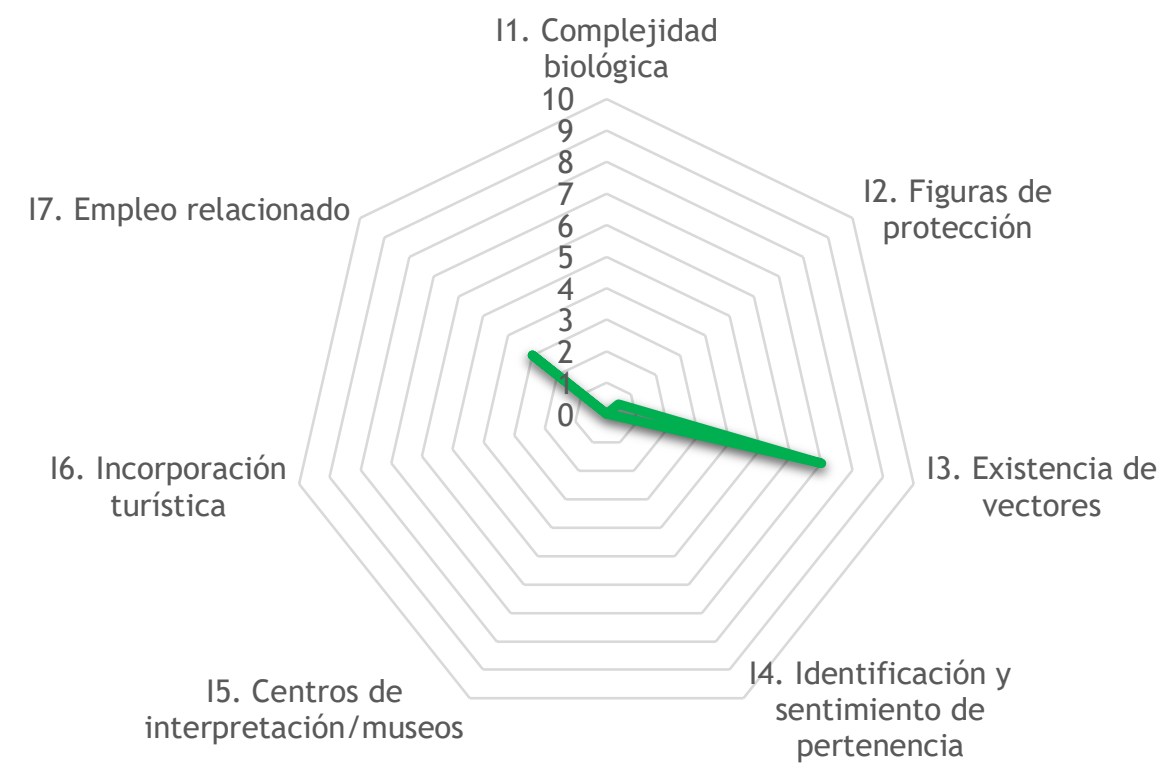

Figura 147. Representación de la situación patrimonial del pinar en Vallelado según los indicadores analizados. Elaboración propia 


\section{Capítulo 10. Arbolado de acompañamiento agropecuario. Los Trasmochos del Jiloca.}


Los chopos cabeceros, como se llaman en la vertiente aragonesa de la Cordillera Ibérica, son ejemplares de chopo o álamo negro (Populus nigra) que son cultivados tradicionalmente para la producción de determinados elementos que han acompañado a las sociedades locales durante siglos y que, en muchas ocasiones han perdido su vigencia de uso. Los trasmochos no son más que otro tipo de silvicultura, en este caso, el aprovechamiento no es la tala completa de los individuos, sino el desmoche o corta de la parte superior para que este desarrolle un amplio ramaje.

Este espacio forestal tiene su fundamento en el acompañamiento de las actividades agrícolas y ganaderas tradicionales. Los chopos se plantaban en prados destinados a pastos, en lindes de tierras de labor, en acequias destinas al riego; es decir, se trata de un aprovechamiento íntimamente ligado con un sistema agro-pastoril tradicional el cual, destinaba determinados espacios poco productivos o marginales para el cultivo de estos ejemplares.

\subsection{Distribución y localización del área de estudio}

El ámbito de estudio se sitúa en el límite de las provincias de Teruel y Zaragoza, este límite divide en dos la cuenca fluvial del río Jiloca, escogida para delimitar el espacio objeto de análisis (Figura 148). El río Jiloca discurre con dirección $\mathrm{S}-\mathrm{N}$ en su parte alta, la cual, diferentes autores han defendido su origen antrópico mediante la construcción de canales que drenan humedales endorreicos (Rubio, 2002; Simón et al., 2010) a la altura de Calamocha el río toma dirección SE-NO hasta desembocar en el Jalón. 


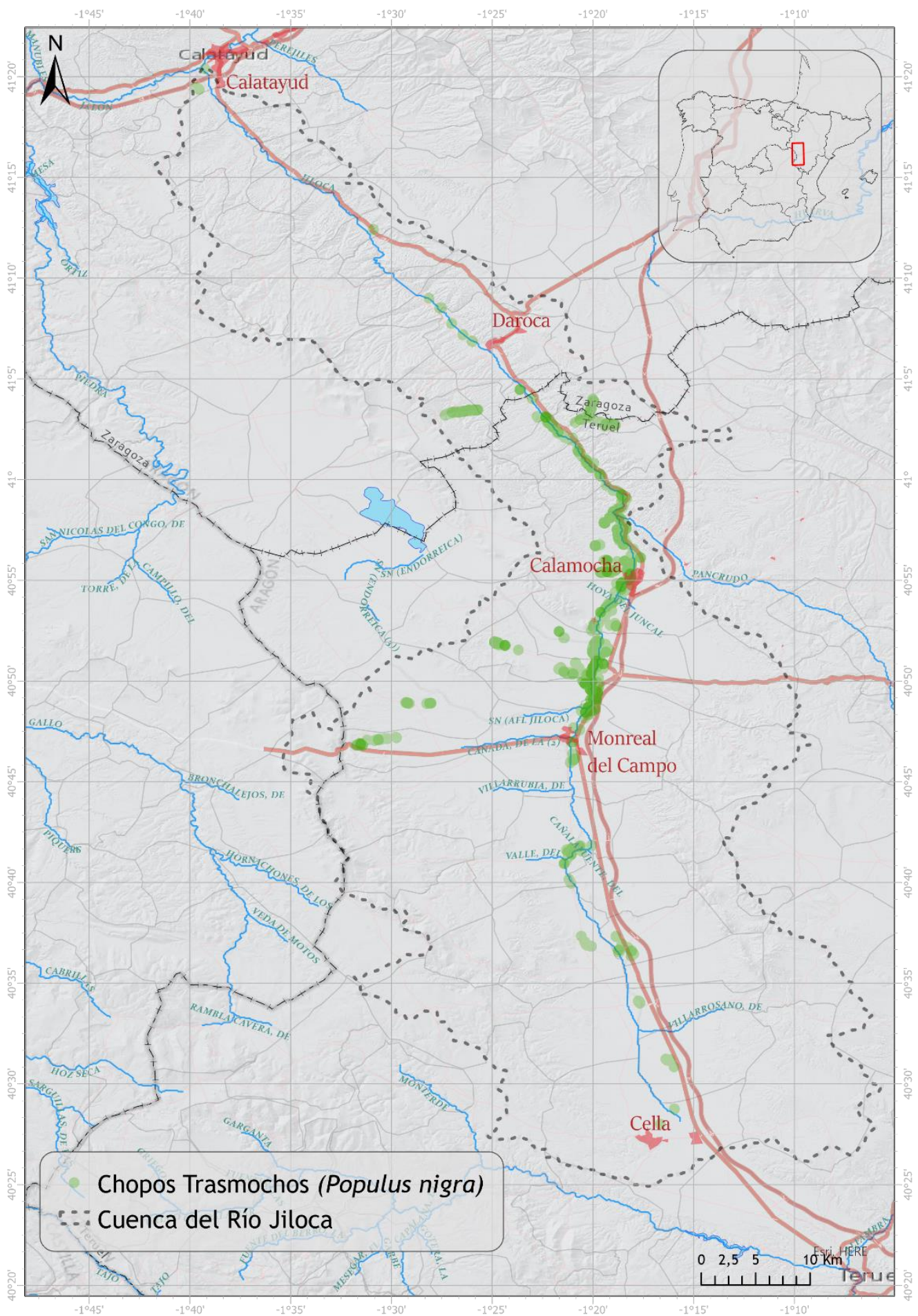

Figura 148. Mapa de localización de la cuenca del Río Jiloca con los chopos objetos d estudio. Elaboración propia a partir de (Bellido y López, 2008). 
La cuenca queda enmarcada dentro de las depresiones de la Cordillera Ibérica con una altitud que oscila entre los 900 y los 1000 m.s.n.m (Figura 149) y rodeada por cadenas montañosas poco enérgicas (Figura 150) que destacan hasta alcanzar los 1500-1900 m.s.n.m. otorgándole a la cuenca cierto grado de aislamiento.

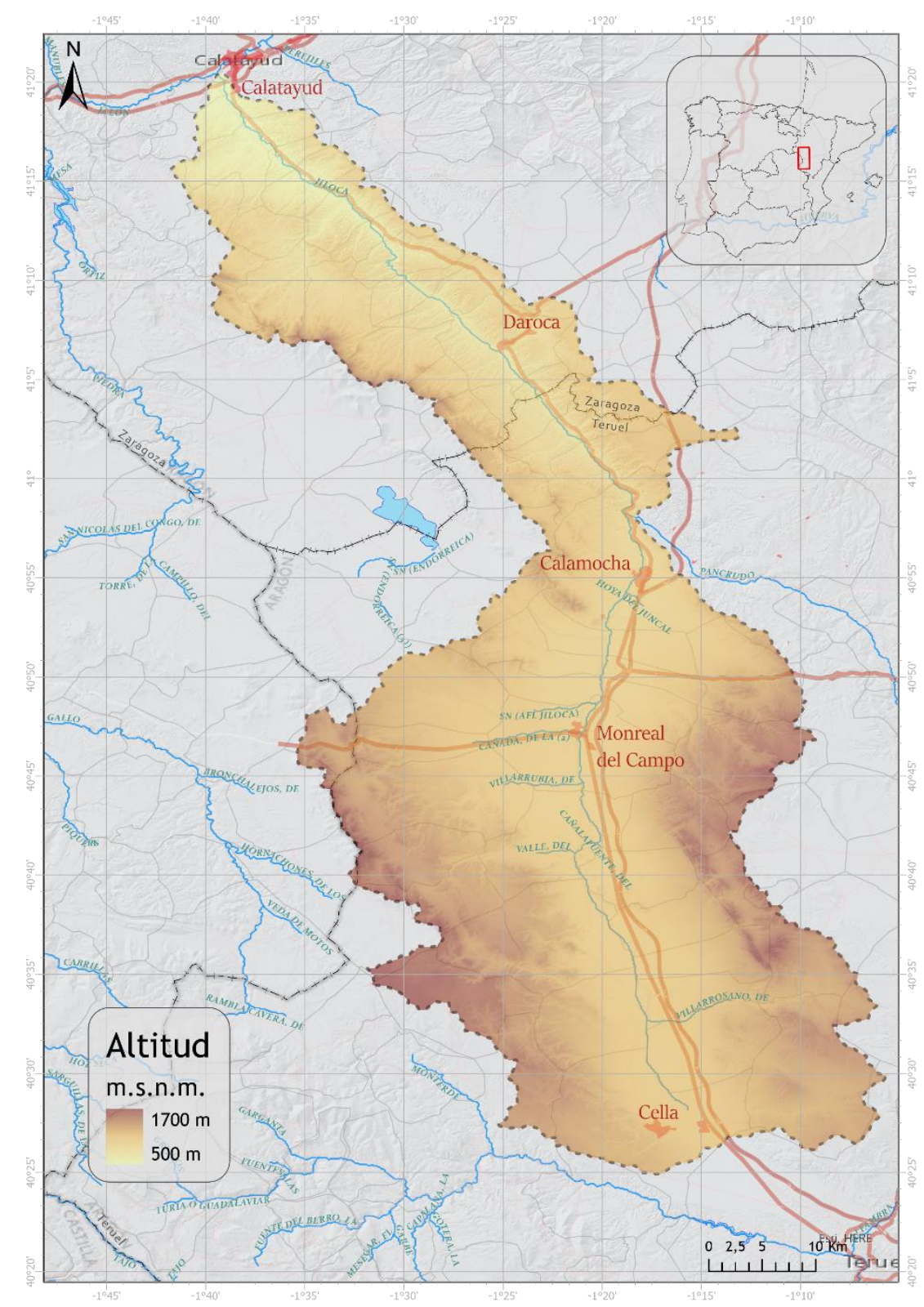

Figura 149. Mapa altimétrico de la cuenca del río Jiloca. Elaboración propia Modelo Digital del Terreno Instituto Geográfico Nacional. 


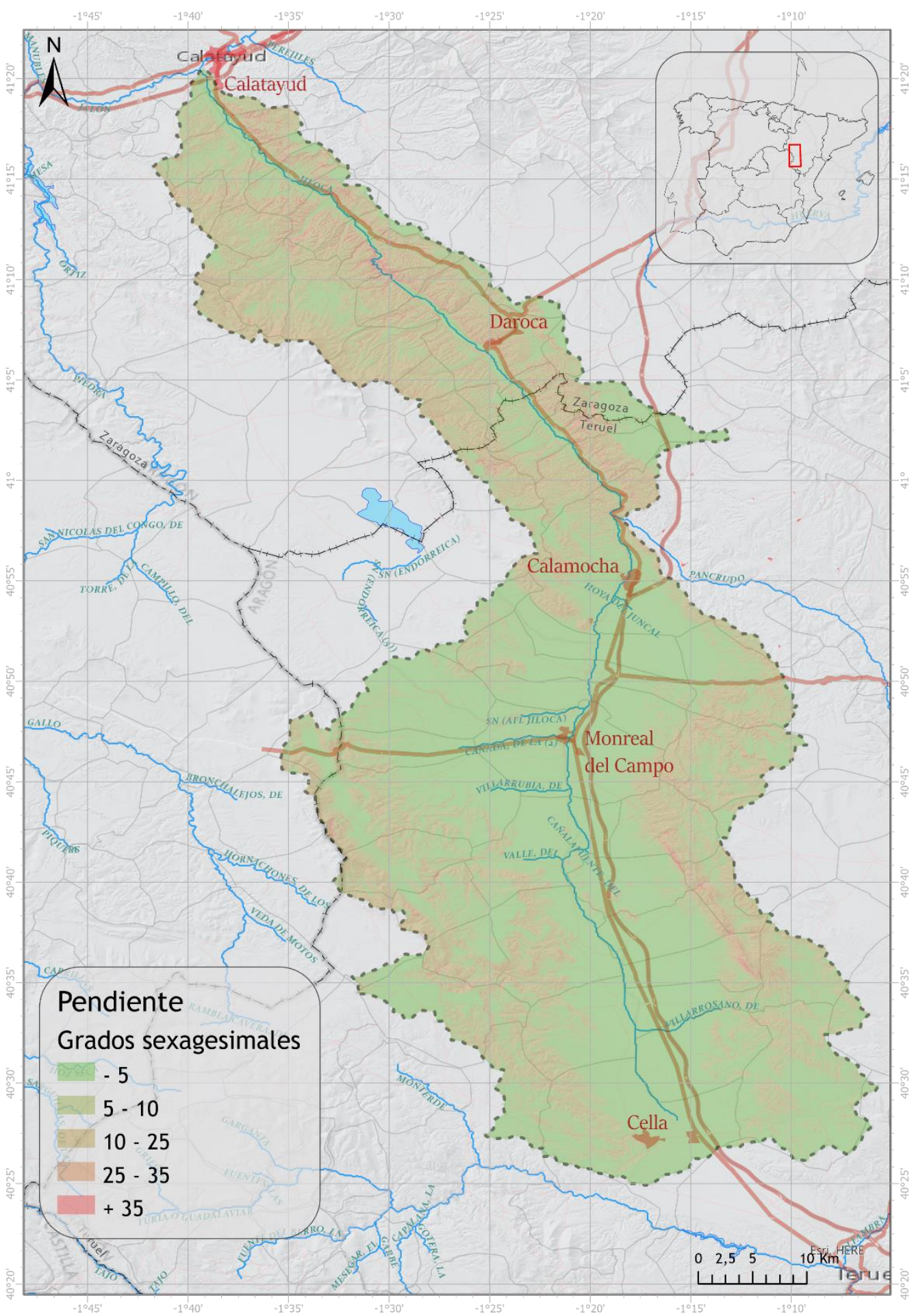

Figura 150. Mapa de pendientes de la cuenca del Jiloca. Elaboración propia Modelo Digital del Terreno Instituto Geográfico Nacional. 
Estudio de casos y aplicación práctica. Paisajes forestales con valor patrimonial.

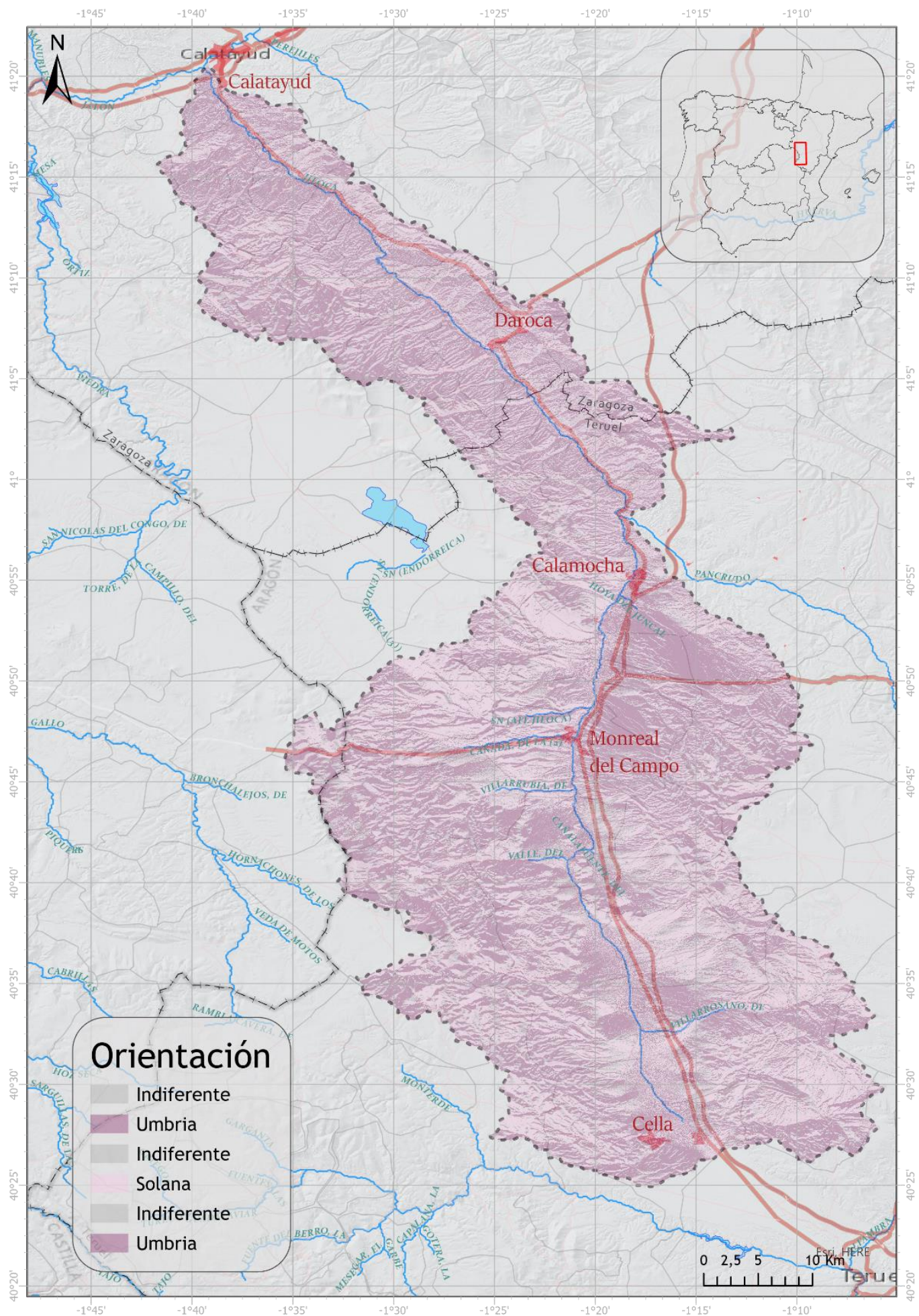

Figura 151. Mapa de orientaciones de la cuenca del río Jiloca. Elaboración propia Modelo Digital del Terreno Instituto Geográfico Nacional. 


\subsection{Caracterización del área de estudio}

Los límites escogidos para definir esta zona de estudio responden a una depresión tectónica reciente generada por un proceso de extensión y limitada por fallas neógeno-cuaternarias (Simón et al., 2010) la mitad sur de esta depresión quedaría reservada para un ambiente endorreico de escasos desniveles mientras la mitad norte se estrecha cuando el propio río se encaja en la falla de Calamocha generando una importante erosión remontante (Hernández et al., 1983) (Figura 152).

Esta dicotomía: valle amplio y de pequeños desniveles al sur y un valle más cerrado, encajado y de fondo más estrecho en el norte, se va a reflejar en una importante diferencia paisajística. La zona endorreica de la cabecera del Jiloca presenta un valle agrícola que reserva la parte más cercana a los canales de agua para el cultivo de regadío, mientras que los glacis miocenos detríticos que tapizan las laderas y rellenan la fosa, sustentan cultivos cerealísticos de secano (Figura 153). Una vez que el curso de agua se encaja en la falla de Calamocha, el relleno sedimentario terciario y cuaternario se restringe a la margen izquierda del río mientras que la margen derecha presenta los afloramientos de pizarras y areniscas paleozoicas cuyos suelos se han aprovechado como pastos y monte; así, el regadío se restringe al relleno aluvial del fondo del valle donde dominan los cultivos de frutales que se extienden por las laderas alternándose con viñedos o pequeños campos de secano en función del relleno detrítico en forma de glacis que tapiza de forma discontinua las laderas. 
Estudio de casos y aplicación práctica. Paisajes forestales con valor patrimonial.

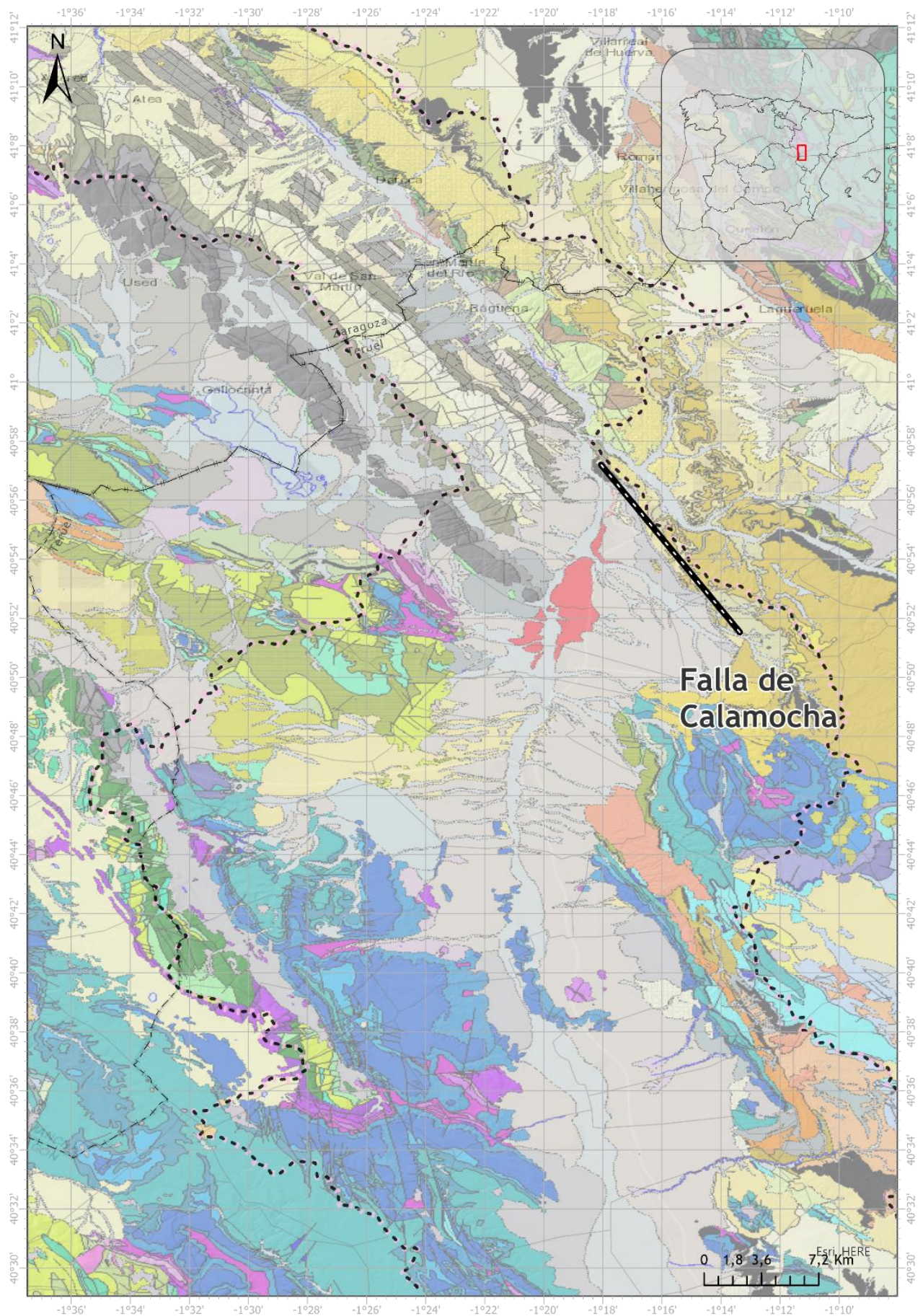

Figura 152. La falla de Calamocha. Elaboración propia a partir de Geode50 (IGME). 


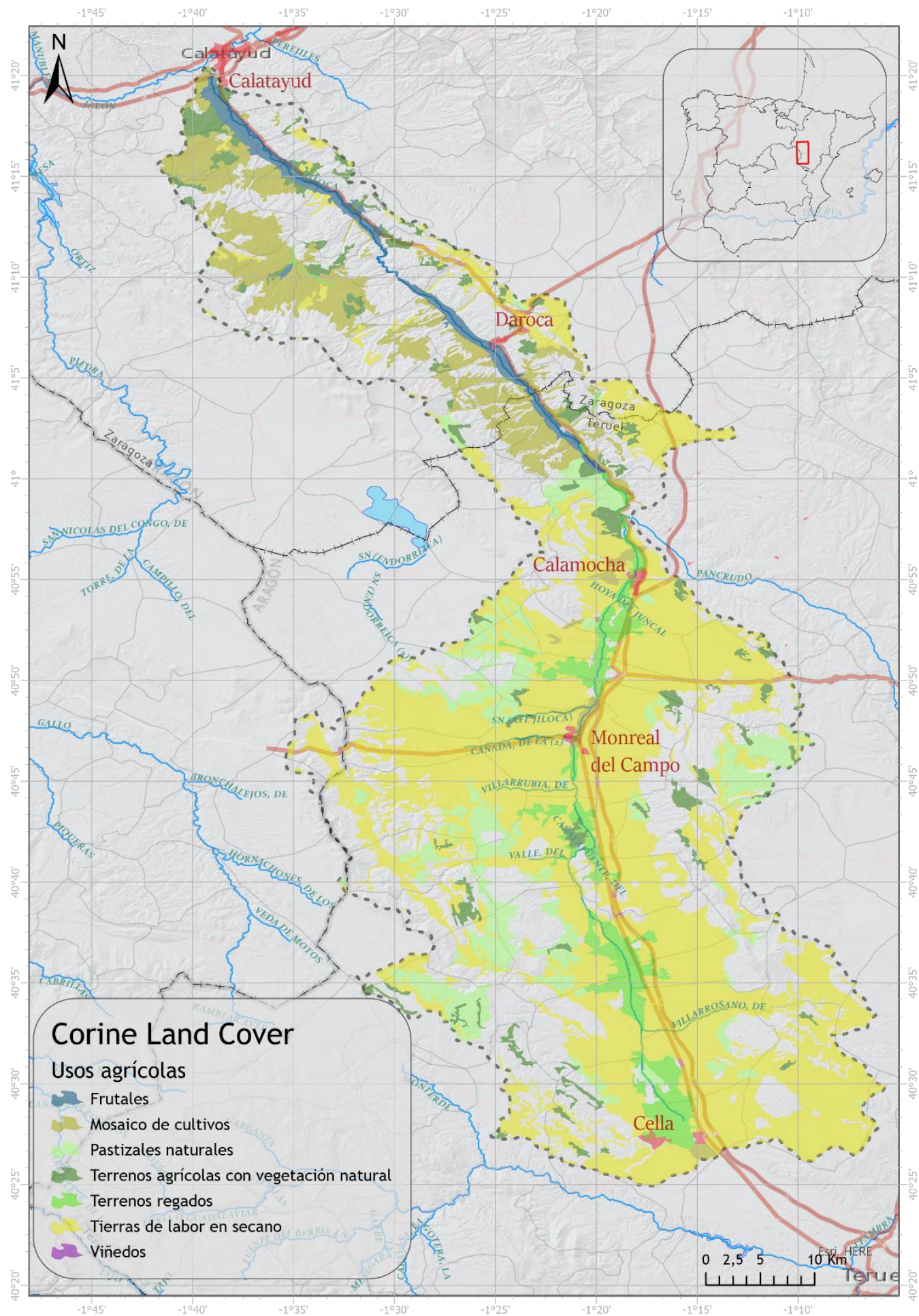

Figura 153. Mapa usos del suelo de carácter agrícola en la cuenca del Jiloca a partir de Corine Land Cover. Elaboración propia. 


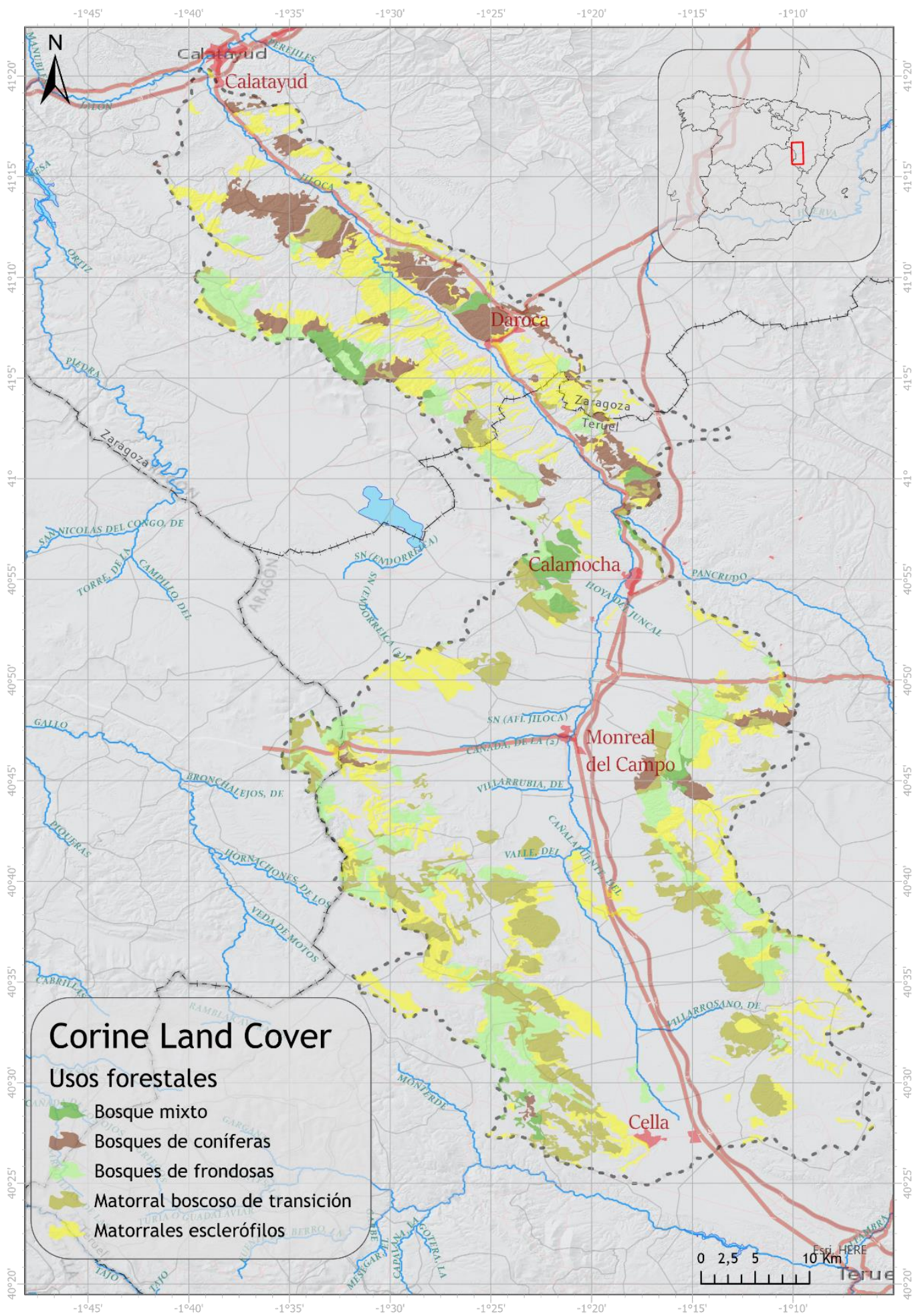

Figura 154. Mapa de usos del suelo de carácter forestal en la cuenca del Jiloca a partir de Corine Land Cover. Elaboración propia. 
Esta diferencia paisajística es fruto de la existencia de un área endorreica en la parte más meridional de la depresión. Se trata de una cuenca que cerraban las calizas jurásicas que afloran en la localidad de Singra y que fue drenada durante diferentes periodos para el aprovechamiento agrícola (De Jaime y Herrero, 2007; Rubio, 2007).

El caudal del Jiloca o río Cella (Rubio, 2002) discurre en su parte alta subálveo durante buena parte de su recorrido apareciendo y desapareciendo en función de las condiciones de humedad (Figura 155). Es a partir de Monreal del Campo cuando realmente se puede hablar de río Jiloca propiamente dicho, tanto si aludimos a su caudal permanente como si aludimos a su nacimiento real que debe fijarse en la surgencia que representan los llamados “Ojos" de dicha localidad. Es en este momento cuando los ejemplares de chopo (Populus nigra), que son protagonistas del estudio, se incrementan en número y se hacen especialmente relevantes en el paisaje agrícola tradicional en las orillas del canal principal, así como en las acequias destinadas al regadío (Figura 148).

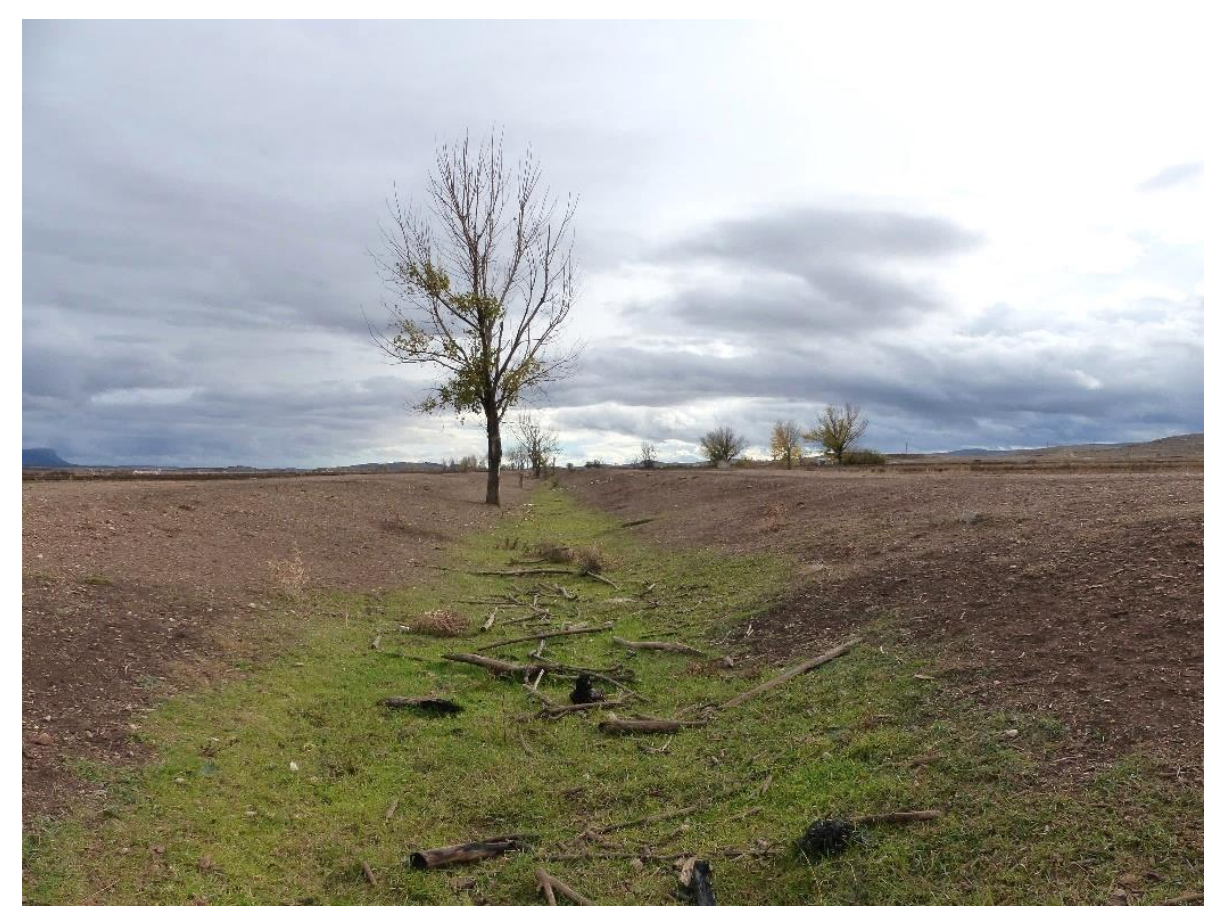

Figura 155. Cauce del río Jiloca junto a Villafranca del Campo. Se aprecia como el río circula subálveo. Imagen propia. 


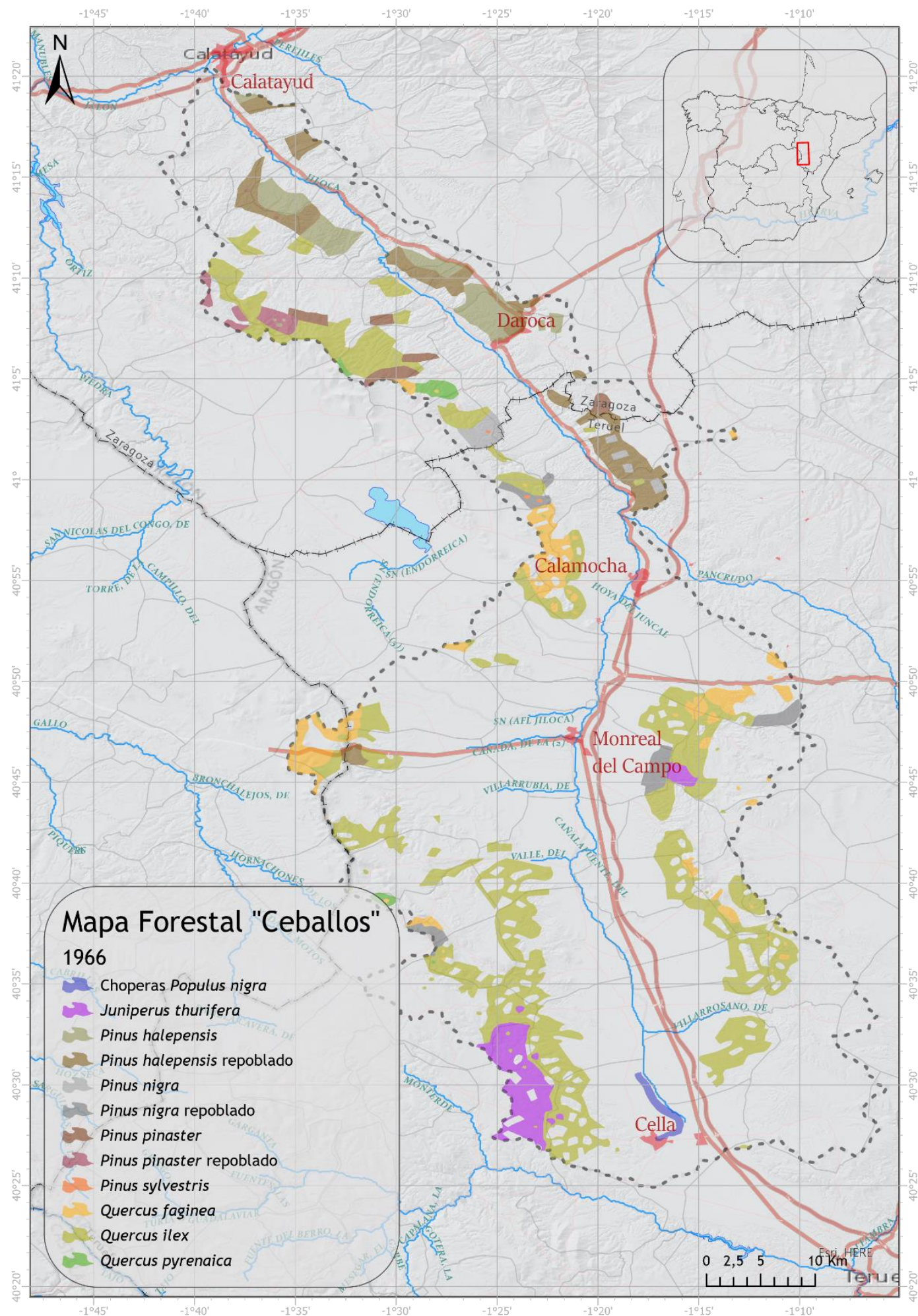

Figura 156. Mapa forestal de España (1966) conocido como “mapa Ceballos" para la cuenca del río Jiloca. Elaboración propia. 


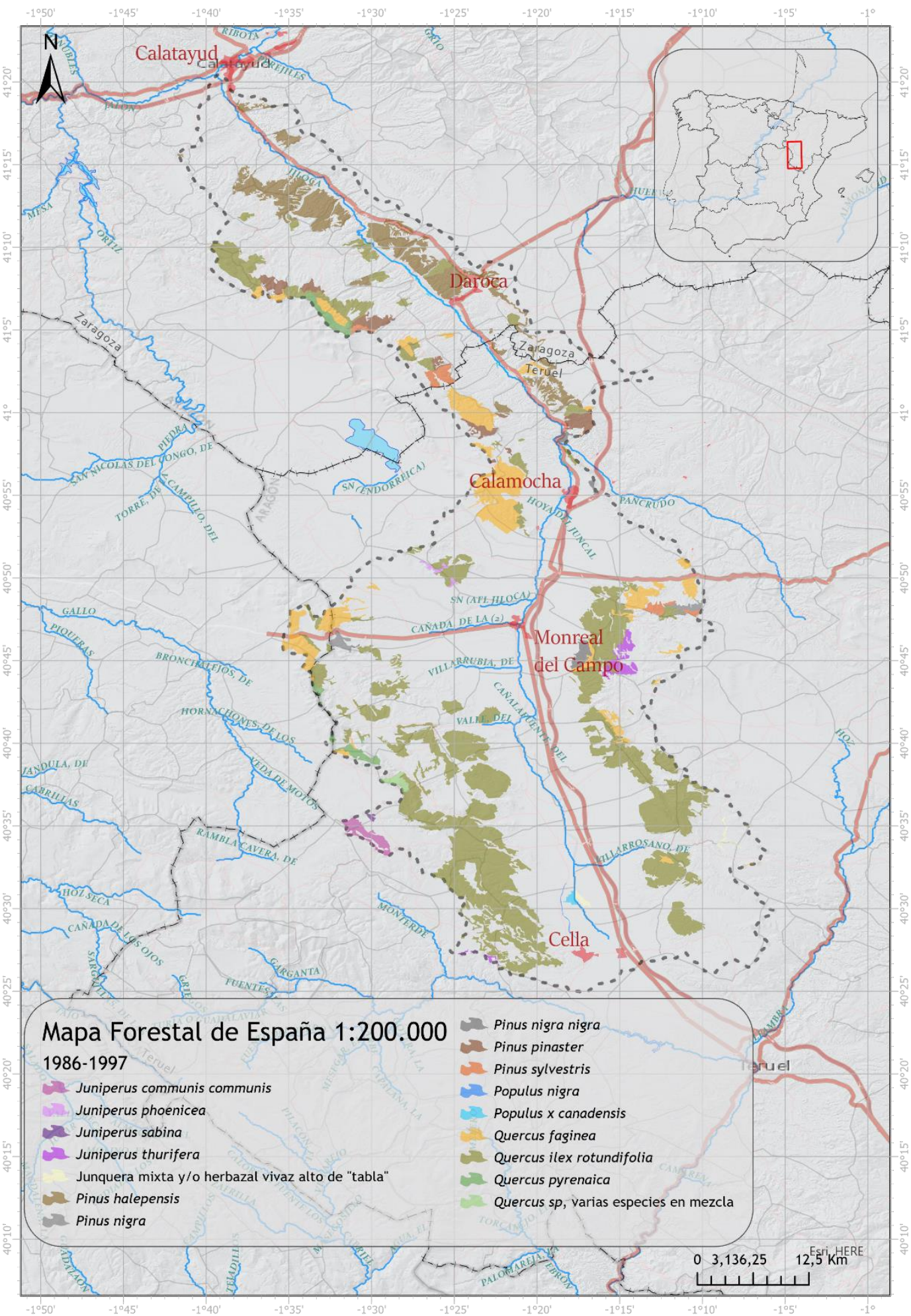

Figura 157. Mapa Forestal de España 1:200.000 para la cuenca del río Jiloca. Elaboración propia. 
Estudio de casos y aplicación práctica. Paisajes forestales con valor patrimonial.

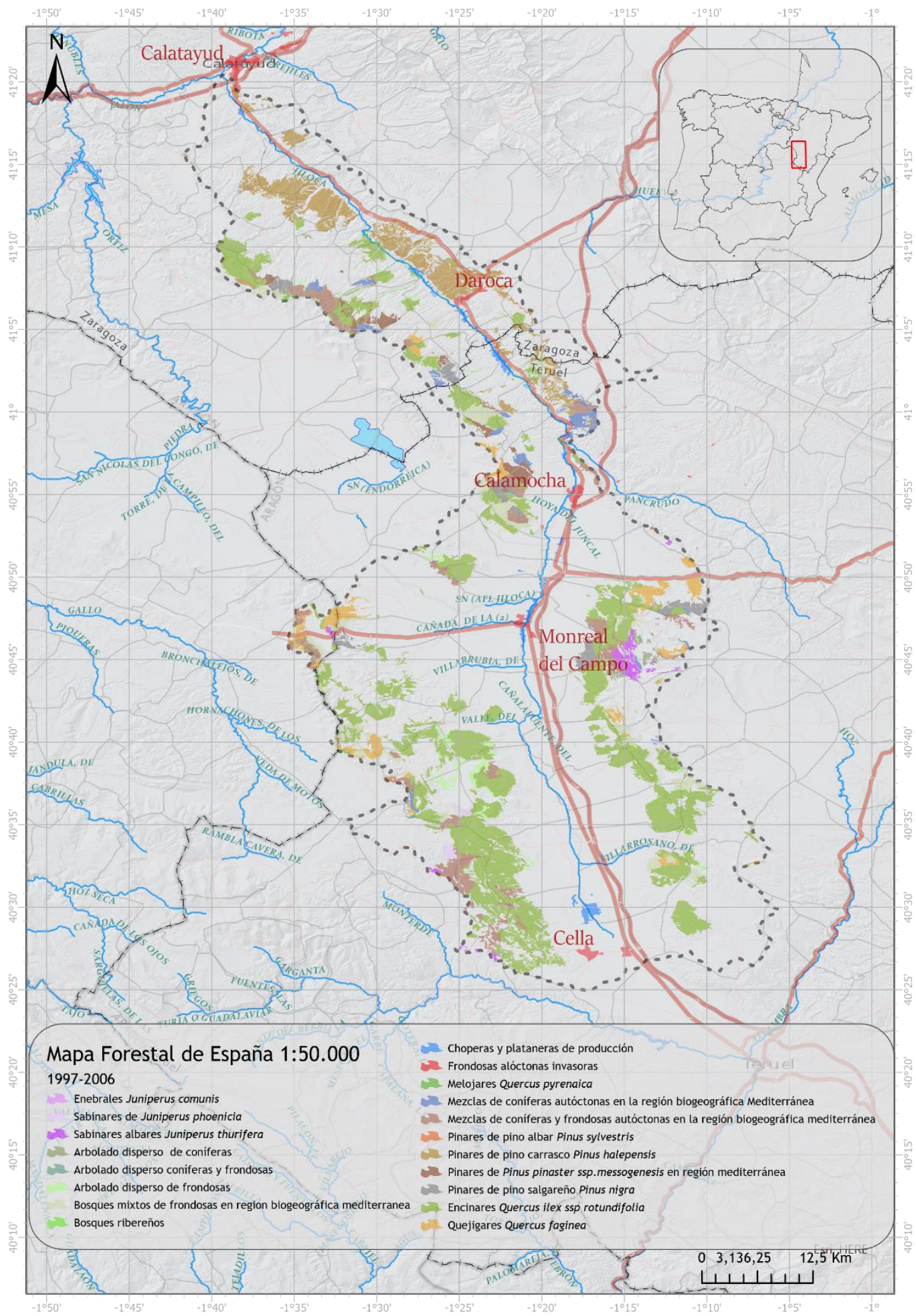

Figura 158. Mapa Forestal de España 1:50.000 para la cuenca del río Jiloca. Elaboración propia. 


\subsection{El origen del espacio forestal}

La presión agropastoril que ha sufrido durante siglos la vertiente aragonesa de la cordillera Ibérica ha generado un espacio deforestado destinado a los pastos de la cabaña de ganado ovino de la Corona de Aragón (O'flanagan et al., 2011) y posteriormente reconvertido al cultivo agrícola de secano, frutales y viñedos en las laderas menos apropiadas y regadío en el fondo del valle. Esta vocación pastoril en un principio y agrícola después tenía como consecuencia la inexistencia de un estrato arbóreo que aportase los recursos necesarios como vigas para construcción o leña para combustible, principalmente. Ante la necesidad de obtener estos recursos de algún modo se optó por el desarrollo de los chopos o álamos negros (Populus nigra) mediante la técnica del trasmocheo lo que evitaba que el ganado acabase con los brotes por su inaccesibilidad.

Los chopos trasmochos de la vertiente aragonesa de la Cordillera Ibérica están asociados de forma indisoluble con el paisaje agrario tradicional. La existencia de los chopos responde de forma directa a plantación en lugares marginales para la obtención de diferentes productos. Es evidente que la existencia de esta especie en la cuenca, fuera del bosque de ribera mixto que pudiera desarrollarse, no responde a un criterio natural ya esta cuenca no posee un potencial ecológico apropiado para el Populus nigra que necesita ambientes húmedos (Rebolledo, 2007) por encima de $400 \mathrm{~mm}$ anuales que no se alcanzan en la mayor parte de la cuenca debido, en gran medida a su posición interior y al estar rodeada de sierras, recibe precipitaciones escasas (Valle, 1993) o se alcanzan de forma muy justa (Figura 159). Por esta razón parece acertado asegurar que buena parte del aprovechamiento tradicional de esta especie se basa en la humedad que aporta el nivel subálveo derivado del carácter endorreico de la cuenca. 


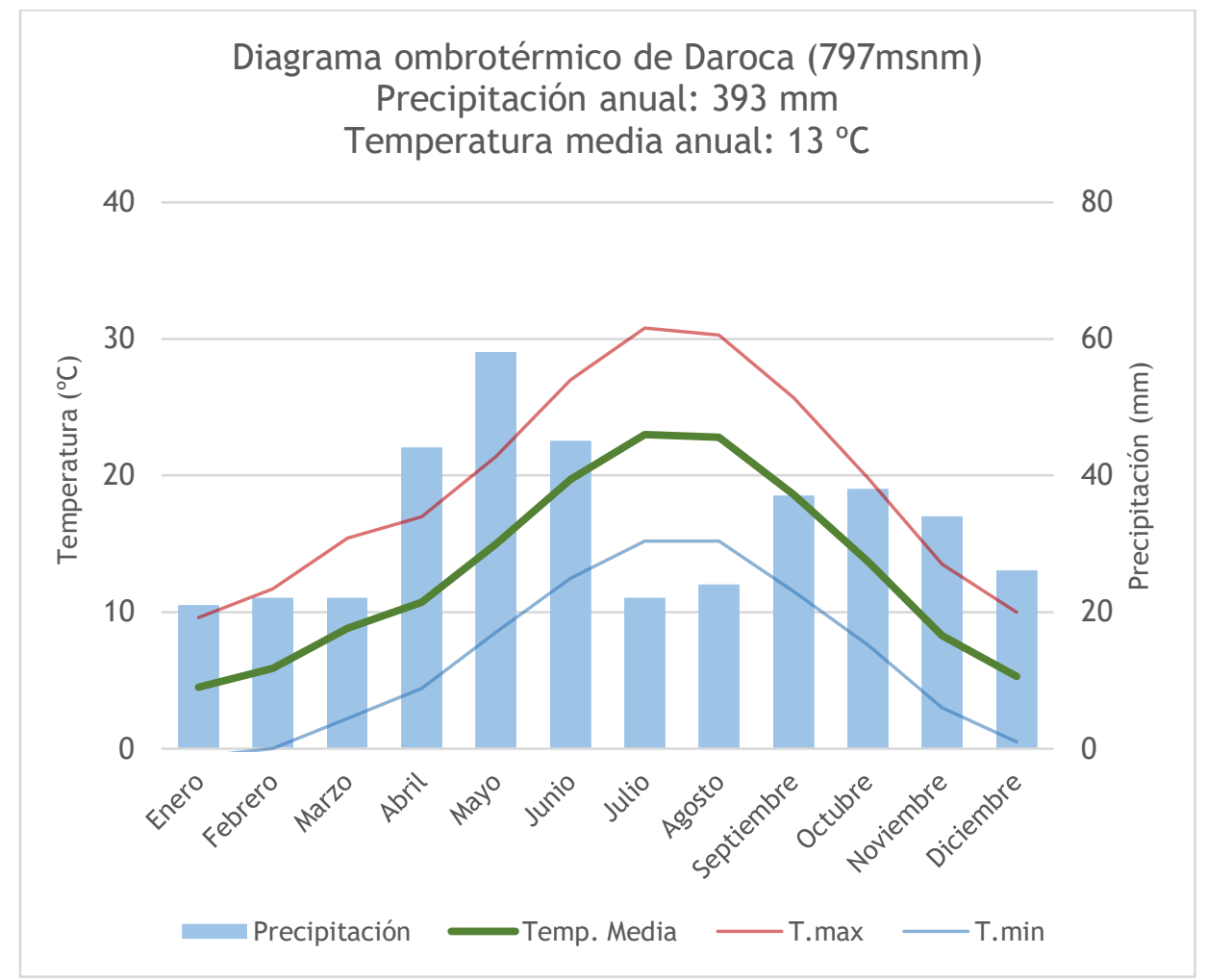

Figura 159. Diagrama ombrotérmico de Daroca. Elaboración propia a partir de datos AEMET

Una vez que el Jiloca pasa a tener un caudal permanente, los chopos aparecen distribuidos siguiendo el propio cauce del río, acequias de riego tradicionales o ramblas perpendiculares al cauce principal; estos cursos aportan los requerimientos hídricos necesarios para el chopo.

La plantación de los chopos en ocasiones se realizaba de forma privada y en otras ocasiones se plantaban en prados boyales de propiedad comunal cuyo origen se establece en la declaración de la Ley de Aguas de finales del siglo XIX que incorporó buena parte de suelos privados y ejemplares adultos a manos públicas en virtud de:

“Art. 36. Las riberas, aun cuando sean de dominio privado en virtud de antigua ley o de costumbre, están sujetas en toda su extensión, y las márgenes en una zona de tres metros, a la servidumbre de la navegación, la flotación, la pesca y el salvamento" (De Palau, 1879) 
Este hecho resulta imprescindible para poder asegurar que estamos ante un aprovechamiento comunal que tendría más de un siglo de antigüedad siendo esta propiedad comunal fundamental para la conservación de estos chopos y su paisaje tradicional al introducir cierto sentimiento de "corporatividad" en la sociedad local; lo que permite, en último término, que se produzca el proceso de incorporación patrimonial. Derivado de este carácter público se encuentra ahora la regulación de aprovechar los recursos del chopo, siendo necesario realizar una solicitud a la entidad gestora del Dominio Público Hidráulico, en este caso la Confederación Hidrográfica del Ebro, que suele concederse sin problemas (De Jaime y Herrero, 2007).

\subsection{El uso tradicional}

La existencia de esta realidad forestal se fundamenta en el aprovechamiento de diferentes productos que ofrece el chopo, aprovechamiento que está directamente relacionado con el manejo mediante la poda para la modificación de sus características físicas.

En buena parte de la cordillera ibérica en su vertiente aragonesa y más concretamente en la cuenca del Jiloca el aprovechamiento principal del chopo trasmocho era la obtención de vigas para construcción (Figura 160), hecho que podemos comprobar en diferentes construcciones tradicionales. Esta producción de vigas fue tan importante en el origen de estas plantaciones que las propias ramas que se dejan como guías para el desarrollo de la planta toman el nombre de "vigas" en el vocabulario vernáculo. Pero el aprovechamiento tradicional del chopo trasmocho no solo se restringe a la obtención de vigas de construcción, sino que, como aseguran los habitantes de este valle, se trata del "cerdo" de los árboles refiriéndose a su completo aprovechamiento que incluye el aprovechamiento de recursos después de muerto. 


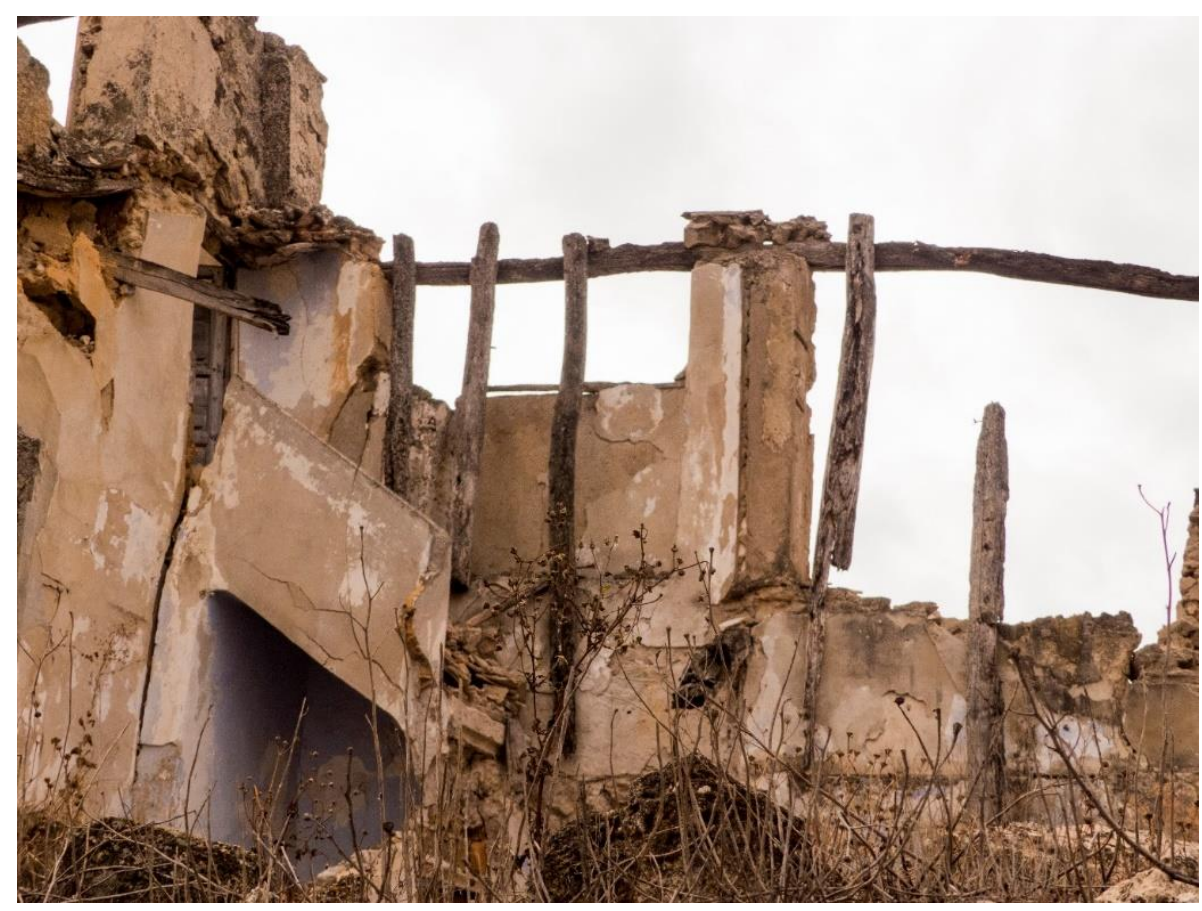

Figura 160. Vigas de chopo en una construcción en ruinas en Calamocha. Imagen propia.

Los chopos trasmochos se han aprovechado como alimento para el ganado en forma de ramón mediante la poda de las ramas finas de abundantes hojas verdes para el consumo del ganado estabulado o como añadido a los pastos de consumo del ganado ovino que discurre por las vías pecuarias (Figura 161). Este recurso, generado por los trasmochos presentes en los prados boyales, distribuyéndose en forma de dehesa, sería un complemento a la sombra de humedad que aportaría el ramaje de los chopos para el mantenimiento de los pastos (Allende et al., 2013). 


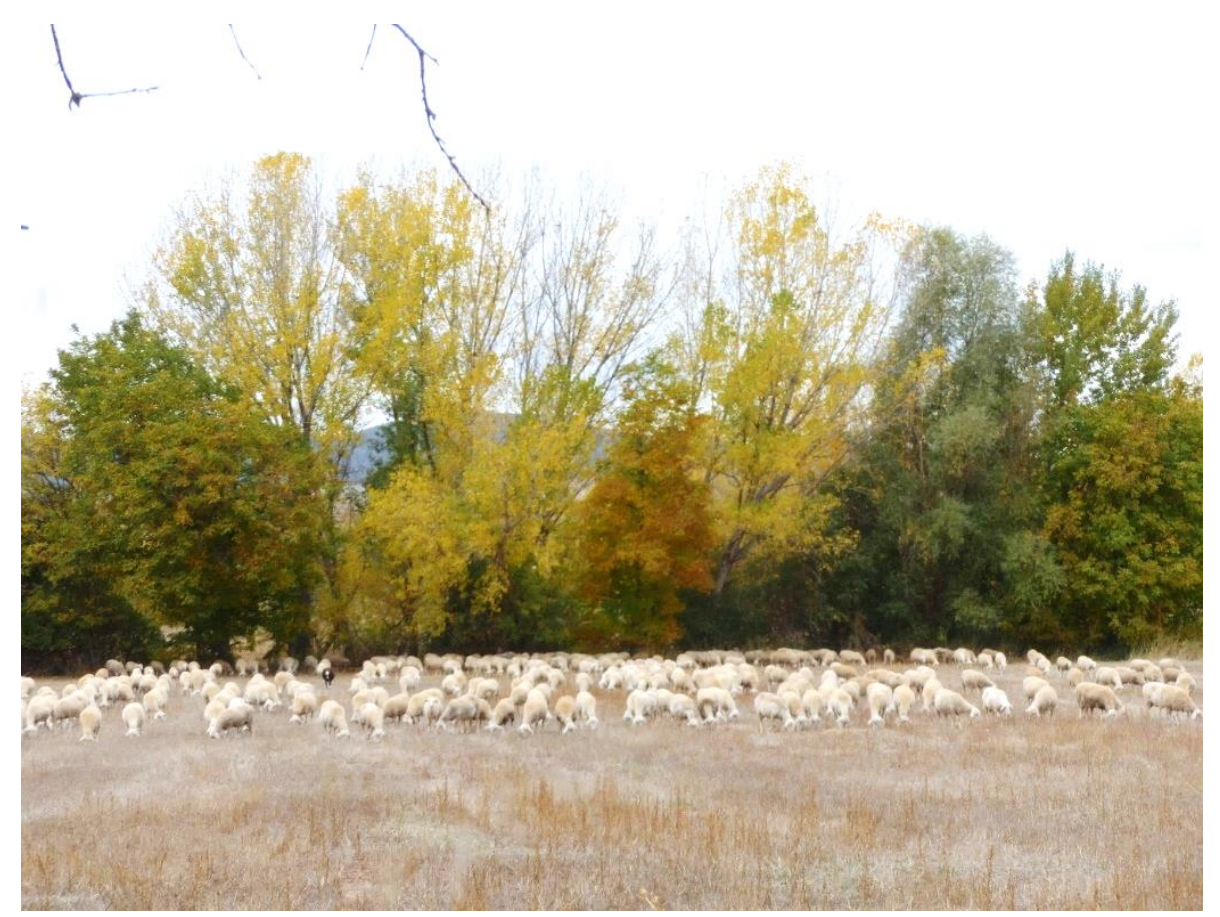

Figura 161. Ganado ovino pastando a los pies de los chopos cabeceros en Luco de Jiloca. Imagen propia.

Otro de los recursos que aporta el chopo cabecero es la biomasa destinada a la producción energética en forma de leña para calentar las casas mediante su combustión. Pese a que el chopo no es reconocido por su gran poder calorífico, la existencia de podas destinadas a la producción de leña y astillas es hoy en día el principal aprovechamiento de estos chopos. La madera que genera el chopo no solo ha sido destinada al aprovechamiento energético, sino que, la utilización de esta para la producción se embalajes ha sido destacable especialmente a mediados del siglo XX, esta madera se ha utilizado para el transporte y embalaje principalmente de frutas y verduras, pero la introducción de chopos híbridos para el desenrolle (Enríquez, 2012) mucho más productivos, redujo este aprovechamiento hoy prácticamente inexistente.

Un aprovechamiento especialmente peculiar sería el destinado al lavado tradicional de la ropa (De Jaime y Herrero, 2007), antes de la llegada de productos químicos a la comarca. La disolución de ceniza 
residual de la combustión de madera de chopo, rica en potasio, calcio y magnesio favorecía el blanqueamiento de la ropa.

Pero el aprovechamiento tradicional del chopo en la cuenca del Jiloca no se restringe al uso de sus productos, sino que buena parte de la existencia de los chopos cabeceros que hoy encontramos está relacionada con la necesidad de fijar el suelo ante la erosión, esta necesidad se aprecia perfectamente en la estrecha relación que existe entre los bordes de los canales construidos para drenar la cuenca, así como acequias de riego y la existencia de chopos en sus márgenes (Figura 162). Parece acertado asegurar que estas nuevas construcciones requerían de la fijación de las márgenes para evitar la continua destrucción o modificación de los trazados para lo que se utilizó esta especie autóctona de chopo que poblaba los alrededores de la laguna previamente a su desecación (De Jaime y Herrero, 2007).

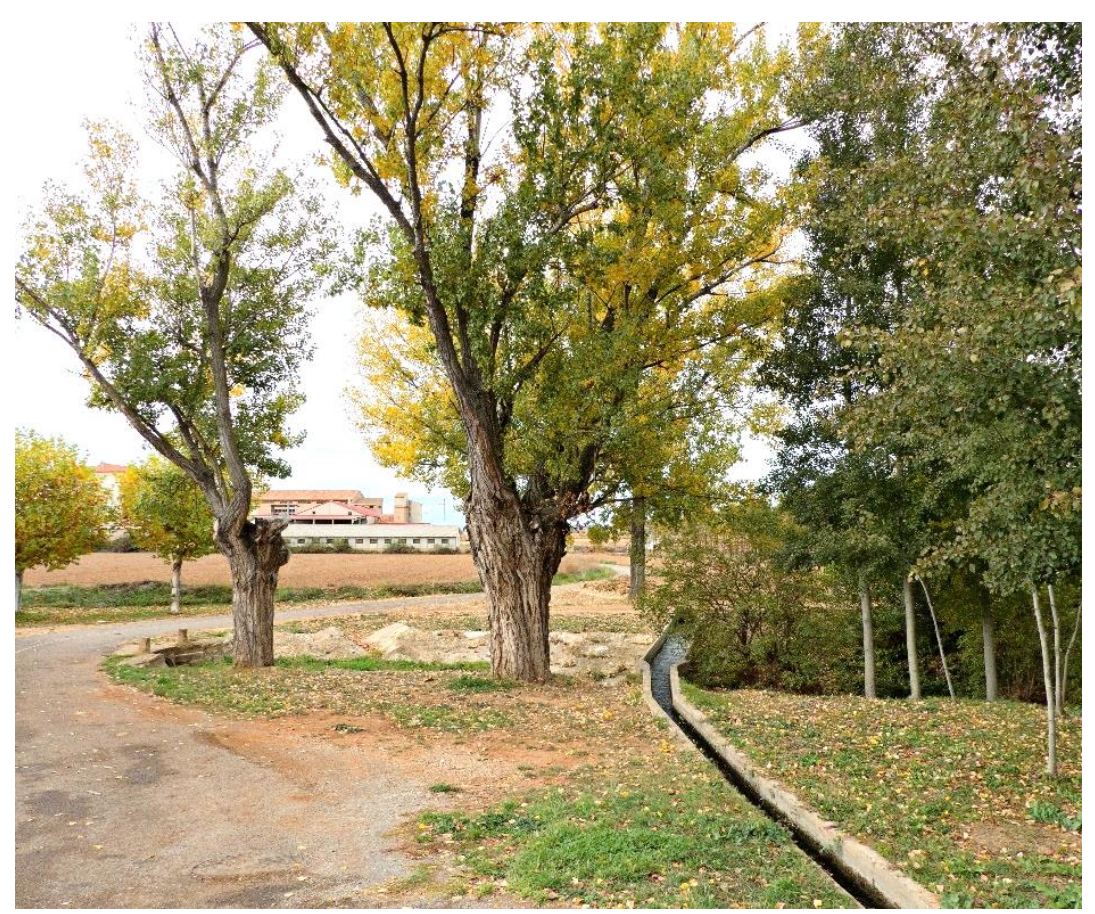

Figura 162. Chopos cabeceros en Monreal del Campo custodiando las acequias para garantizar su trazado. Imagen propia. 


\subsection{El abandono}

Como la mayoría de los usos agrícolas o silvopastoriles tradicionales, los chopos trasmochos han sufrido un abandono relacionado con diferentes factores que han sustituido los productos que estos árboles ofrecían. En primer lugar, su principal producto, las vigas para construcción quedaron sustituidas por nuevos materiales a principios del siglo $X X$ y definitivamente a partir de la década de los 60 . Las vigas de madera sufrieron un progresivo abandono con la aparición de las vigas de acero y la llegada de los encofrados de hormigón que solucionaban de forma adecuada las necesidades constructivas y aportaban nuevas soluciones hasta entonces imposibles de desarrollar (Figura 163). Por otro lado, se produjo un progresivo abandono de la leña de chopo que era la principal fuente energética en las casas y fue sustituida por combustibles fósiles mucho más limpios y eficientes. Estos dos hechos, junto con el progresivo abandono de las actividades agropecuarias en el medio rural, especialmente la actividad ganadera extensiva, condenan a los chopos a la pérdida de valor productivo. Pero los chopos trasmochos no solo se han visto afectados por el abandono y la sustitución de sus productos tradicionales, la entubación de buena parte de las acequias y canales de riego son claves para entender la muerte de muchos de estos ejemplares, que anteriormente obtenían sus necesidades hídricas de las acequias que custodiaban y que hoy no encuentran la humedad necesaria. 


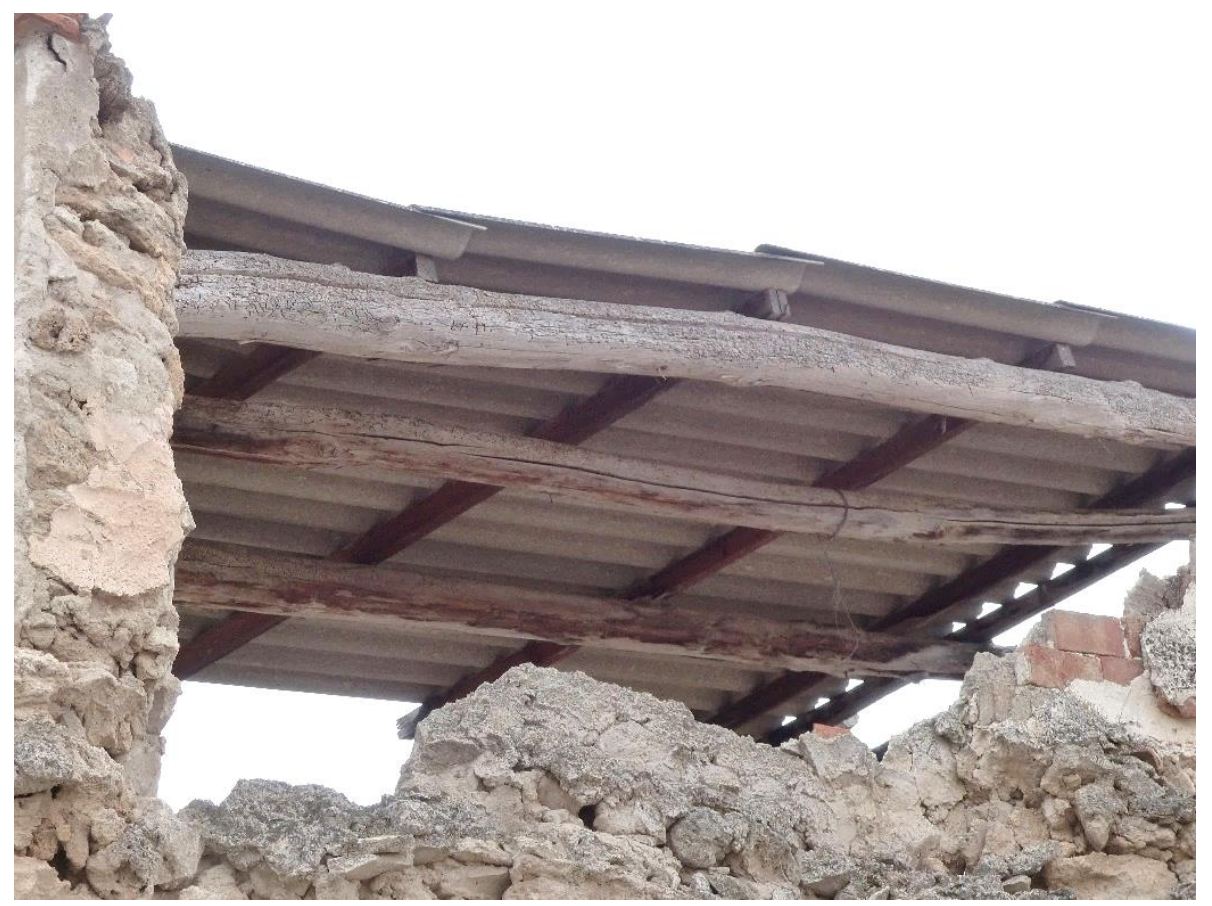

Figura 163. Las vigas de chopo conviven con nuevos materiales constructivos como las tejas de fibrocemento. Imagen propia.

Esta pérdida de valor de uso abre una nueva expectativa que ha llevado diferentes escenarios. Algunas choperas destinadas tradicionalmente a la obtención de los productos que ofrecía el trasmocho sufren una naturalización de su entorno, la falta de escamondas, así como el abandono de la supresión del sotobosque para eliminar competencia, deriva en el desarrollo de un espacio renaturalizado que comienza a presentar diferentes especies vegetales (Figura 164). En otras ocasiones el abandono de los chopos ha conllevado su muerte siendo sustituidos por matorrales propios de espacios degradados como rosales silvestres (Rosa canina), zarzas (Rubus ulmifolius), etc (Figura 164). 


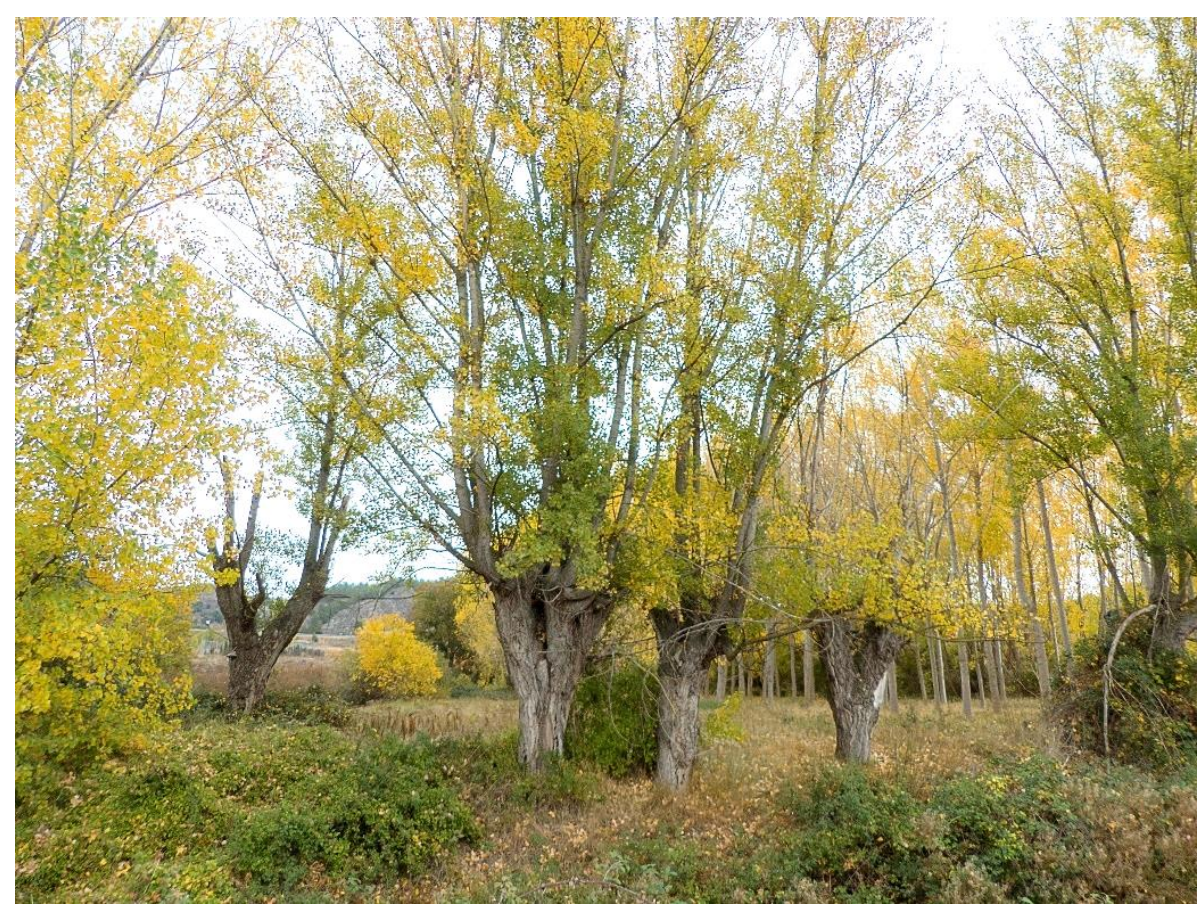

Figura 164. Los chopos trasmochos comienzan a convivir con un sotobosque en avance debido al abandono de usos. Imagen propia.

\subsection{El paisaje de un espacio agrario tradicional}

Cuando se analiza el paisaje de la cuenca del río Jiloca, se pone de manifiesto su clara vocación agrícola y silvopastoril basada en elementos puramente tradicionales resultado de una gestión tradicional de los recursos durante siglos. Esta cuenca, presenta una importante presión agropecuaria, pese a no destacar extraordinariamente por su densidad demográfica. En este sentido, el paisaje dominante va a ser, sin ningún género de dudas, un paisaje propiamente agropecuario, donde los elementos antrópicos, los artefactos, las delimitaciones o los topónimos destacan de forma muy significativa sobre los elementos puramente naturales o del medio físico.

Se propone la siguiente clasificación de unidades de paisaje y una síntesis de los elementos que imprimen carácter al paisaje de la cuenca del río Jiloca: 
- Cultivos

- Secano (cultivos cerealísticos de llanura, se localizan en los glacis terciarios que tapizan las laderas descendiendo suavemente hacia el centro de la fosa) (Figura 165)

- Regadío (Cultivos tradicionales en el fondo del valle, aprovechan el relleno cuaternario y la circulación subálvea del Jiloca) (Figura 166)

- Mosaico (Frutales y viñedos) alternos con matorral mediterráneo (Generalmente almendros o cerezos abancalados que se ajustan a la escasa energía de las laderas paleozoicas). (Figura 167)

- Forestal

- Coníferas de repoblación (aparecen y desaparecen algunas repoblaciones de Pinus sp y Abies sp en algunas laderas enérgicas) (Figura 168)

- Bosque autóctono (muy escaso debido a la importante presión ganadera que ha sufrido esta cuenca, en algunos lugares se encuentra en expansión la carrasca (Quercus ilex ssp. ballota) (Figura 168)

- Urbano (Donde se diferencian dos tipologías muy contrastadas: los centros urbanos tradicionales y las expansiones de mitad del siglo XX) (Figura 169) 


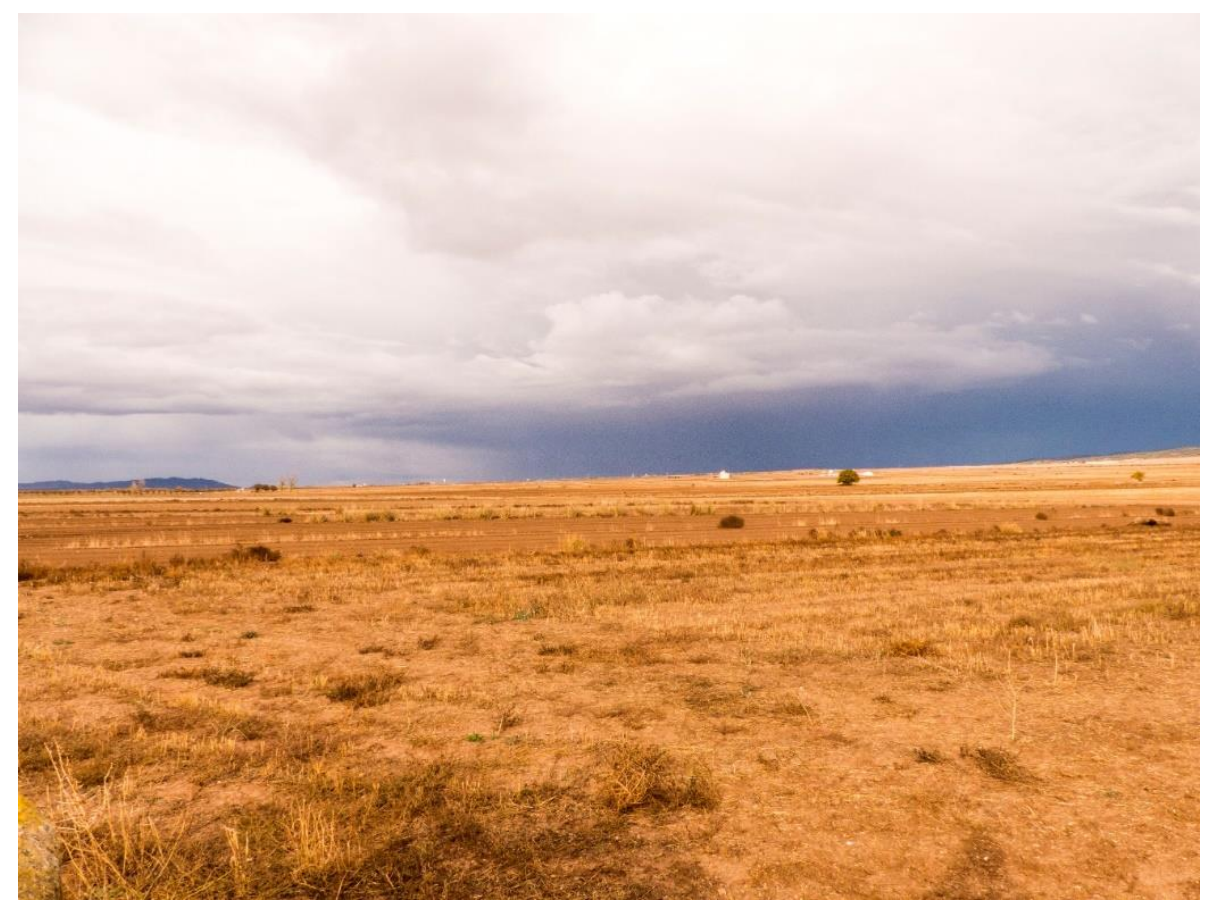

Figura 165. El paisaje agrario de secano en la cuenca del Jiloca, en la llanura entre Monreal del Campo y Singra. Imagen propia.

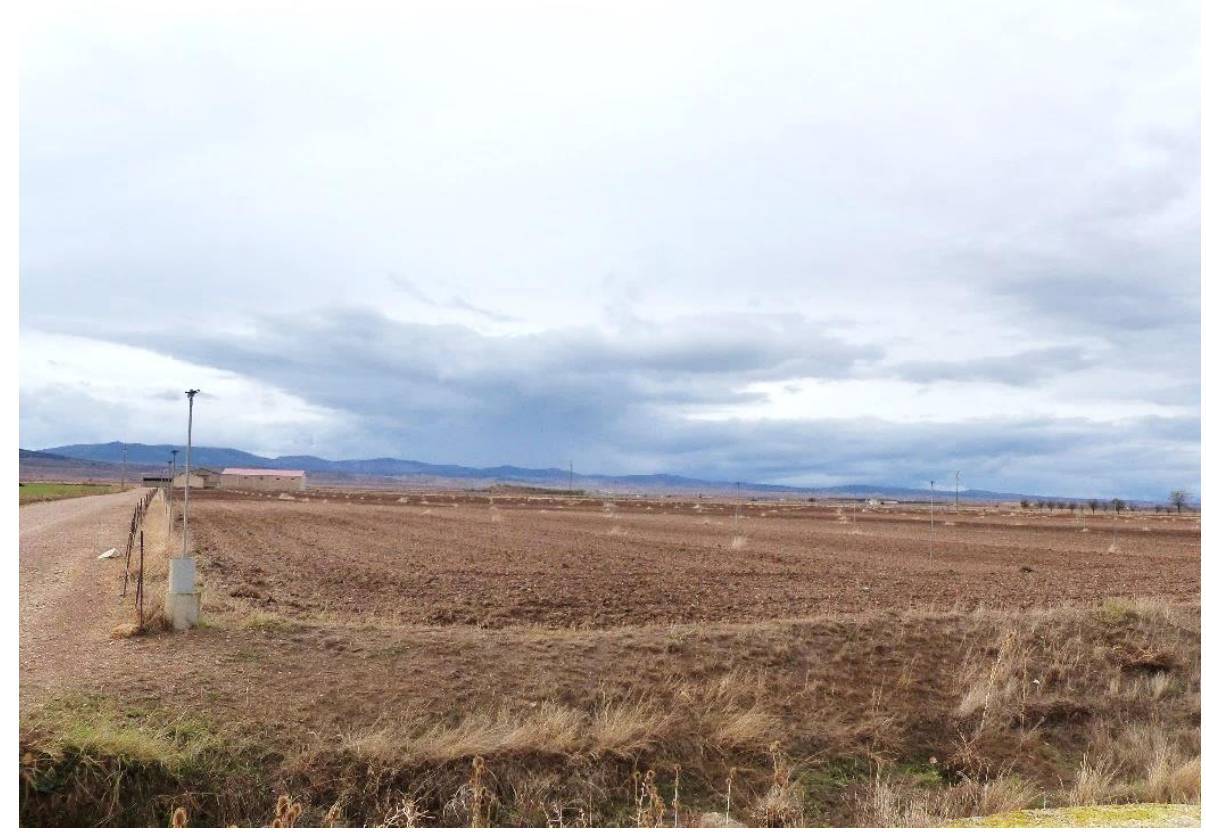

Figura 166. Espacios destinados a los cultivos de regadío junto a Monreal del Campo, los sistemas de aspersión presumen una plantación de maíz. Imagen propia. 
Estudio de casos y aplicación práctica. Paisajes forestales con valor patrimonial.

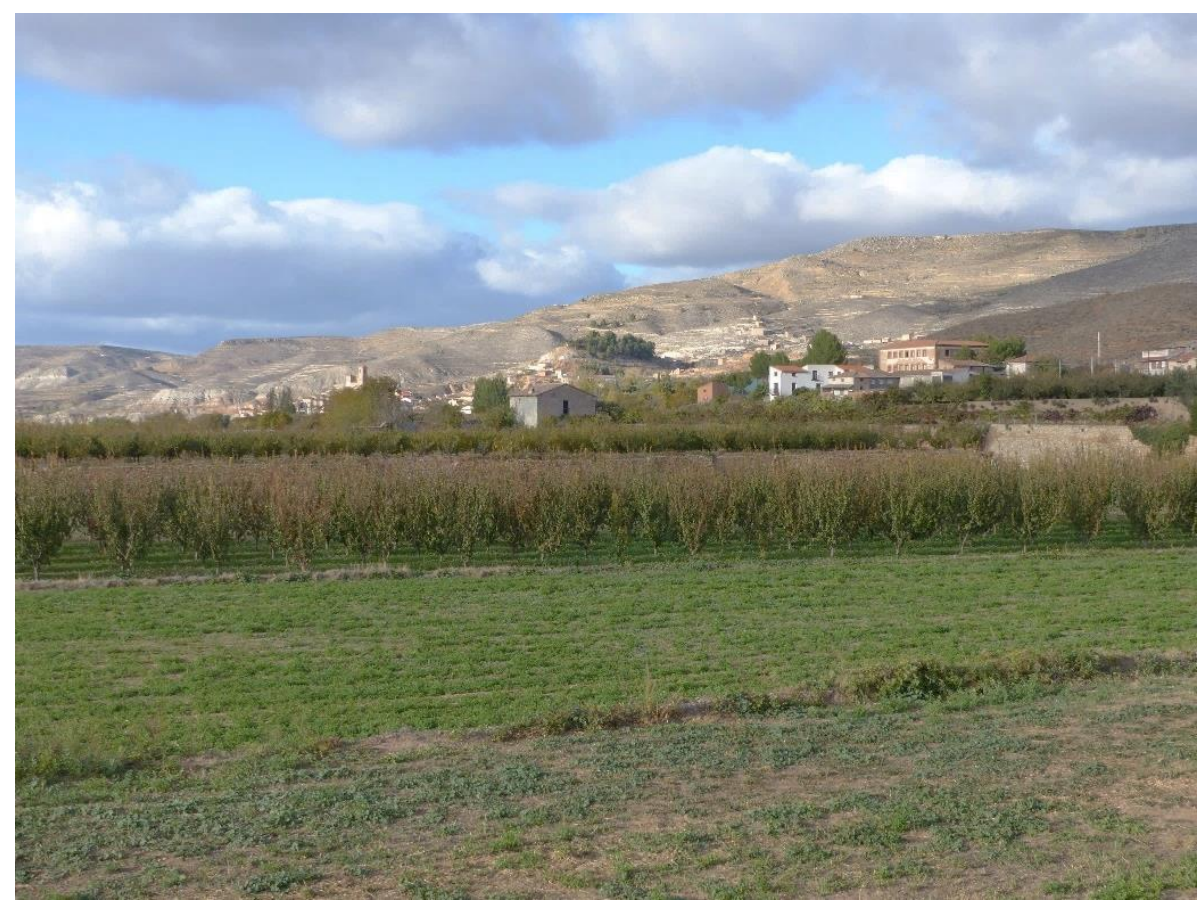

Figura 167. Cultivos de frutales en Villafeliche. Imagen propia.

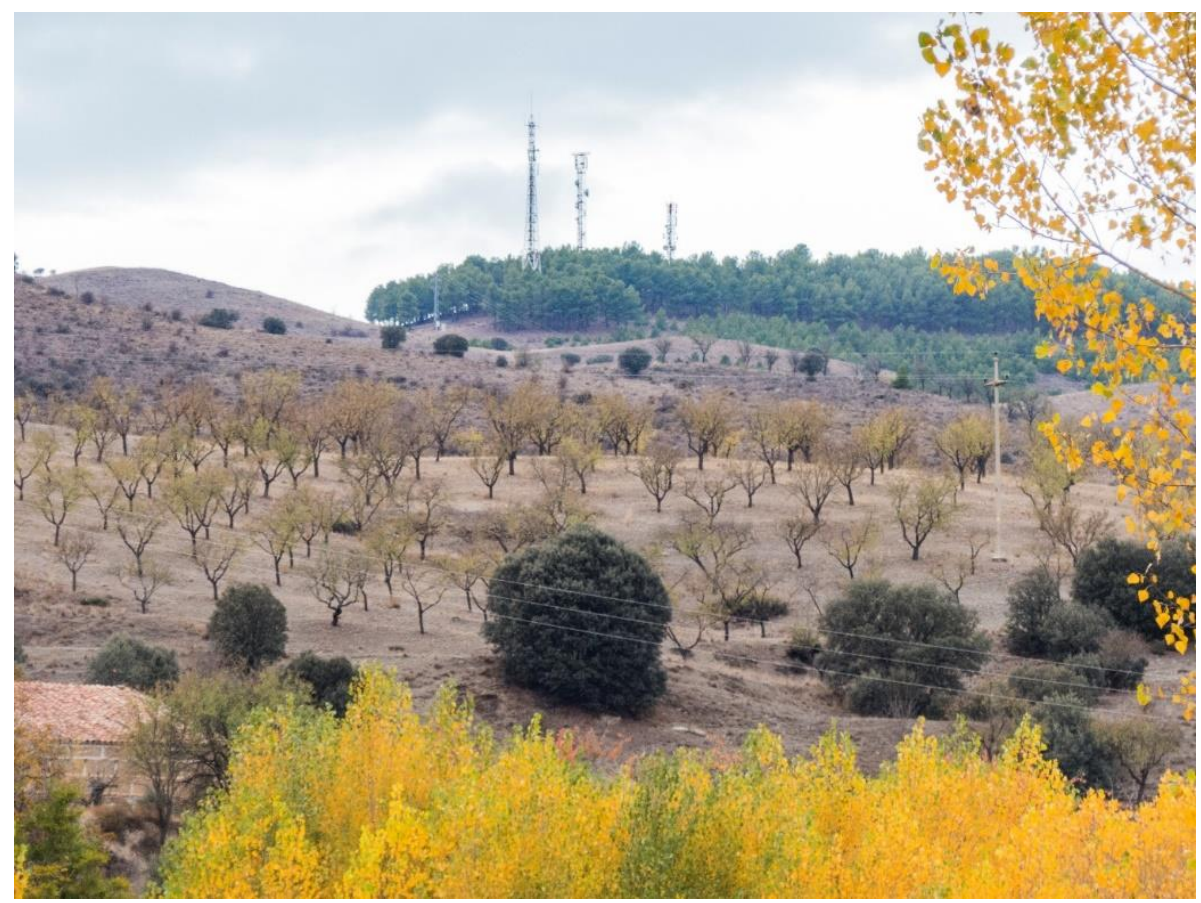

Figura 168. Carrasca (Quercus ilex ssp. ballota) en avance, cultivos de frutales y coníferas de repoblación en la culminación de las laderas junto a Burbáguena. Imagen propia. 


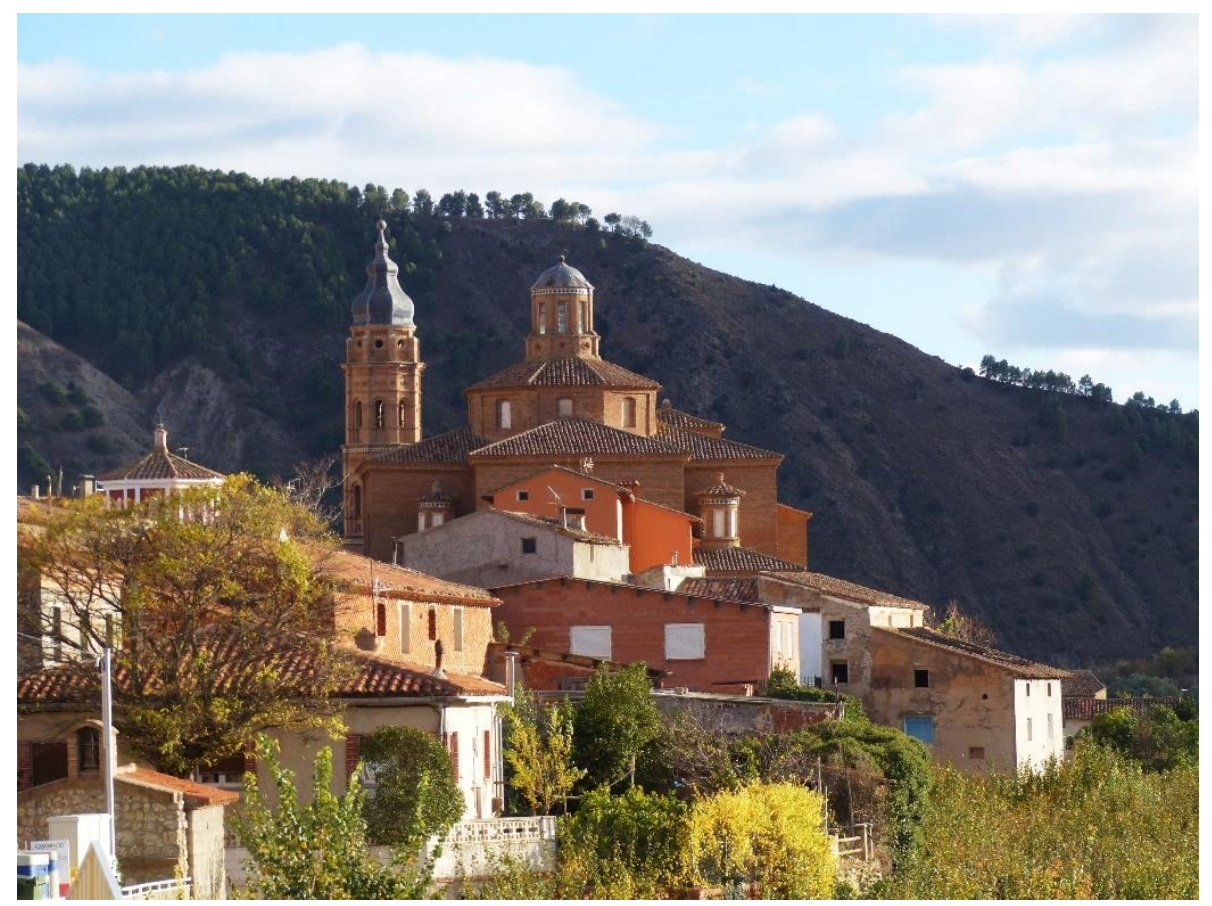

Figura 169. Villafeliche como ejemplo de núcleo tradicional compacto. Imagen propia.

Dentro de este paisaje agrícola tradicional o mejor definido "agrosilvopastoril", los elementos que centran el estudio son los chopos trasmochos que en la zona toman el nombre de "chopos cabeceros". Estos chopos salpican la cuenca que sirve como límite para el estudio, generando un paisaje extraordinariamente singular, el cual se reproduce en otras regiones, pero con otras especies vegetales. En esta ocasión, la particularidad que van a introducir los chopos cabeceros a este paisaje rural, que podría replicarse en cierta manera en el resto de la península ibérica, es su aparición vinculada a otros elementos agrosilvopastoriles:

- Formación de setos que sirven de lindes

- Acompañamiento de acequias tradicionales de riego

- Dehesas en prados boyales

- Seguimiento de vías pecuarias 
Parece indudable relacionar que se trata de un paisaje rural tradicional de elevada presión agropecuaria y donde la existencia del chopo negro va a ser la singularidad que va a introducir carácter en este paisaje. Esta singularidad, es el resultado de una intervención antrópica secular que ha pasado de generación en generación arrojando un paisaje patrimonial que carece de figuras institucionales de reconocimiento.

El chopo o álamo negro (Populus nigra), en este caso trasmocho, es la singularidad del paisaje de la cuenca del Jiloca. Este árbol intervenido, se caracteriza por recibir una poda concurrente en turnos de 12-15 años, esta poda consiste en eliminar su rama principal a una edad aproximada de cinco años, edad escogida para que la planta crezca lo suficiente para evitar el ramoneo de los animales domésticos; de este modo el ejemplar cesa su crecimiento vertical y se desarrolla a partir de las diferentes guías que se dejan en su ramaje. No existe una técnica única para el desmoche, pero se observa una tendencia que consiste en dejar cinco o seis guías en los pies suficientemente regados, mientras que los pies que se encuentran en ambientes menos propicios para su desarrollo como cursos esporádicos o ramblas suelen presentar dos guías popularmente conocidas como "horca" y “pendón”.

Estas podas destinadas al aprovechamiento tradicional de los recursos en un espacio que, fruto de la presión agroganadera, eliminó de forma significativa el bosque mediterráneo autóctono, generan un paisaje de horizontes amplios donde emergen ejemplares trasmochos caracterizados por su deformación. Así, los chopos ceden su característico porte esbelto y vertical para convertirse en árboles de troncos excepcionalmente gruesos con deformaciones y engrosamientos en su copa que le dan un aspecto de gran cabeza, de donde toman su nombre tradicional de "chopos cabeceros" (Figura 170 y Figura 171). 


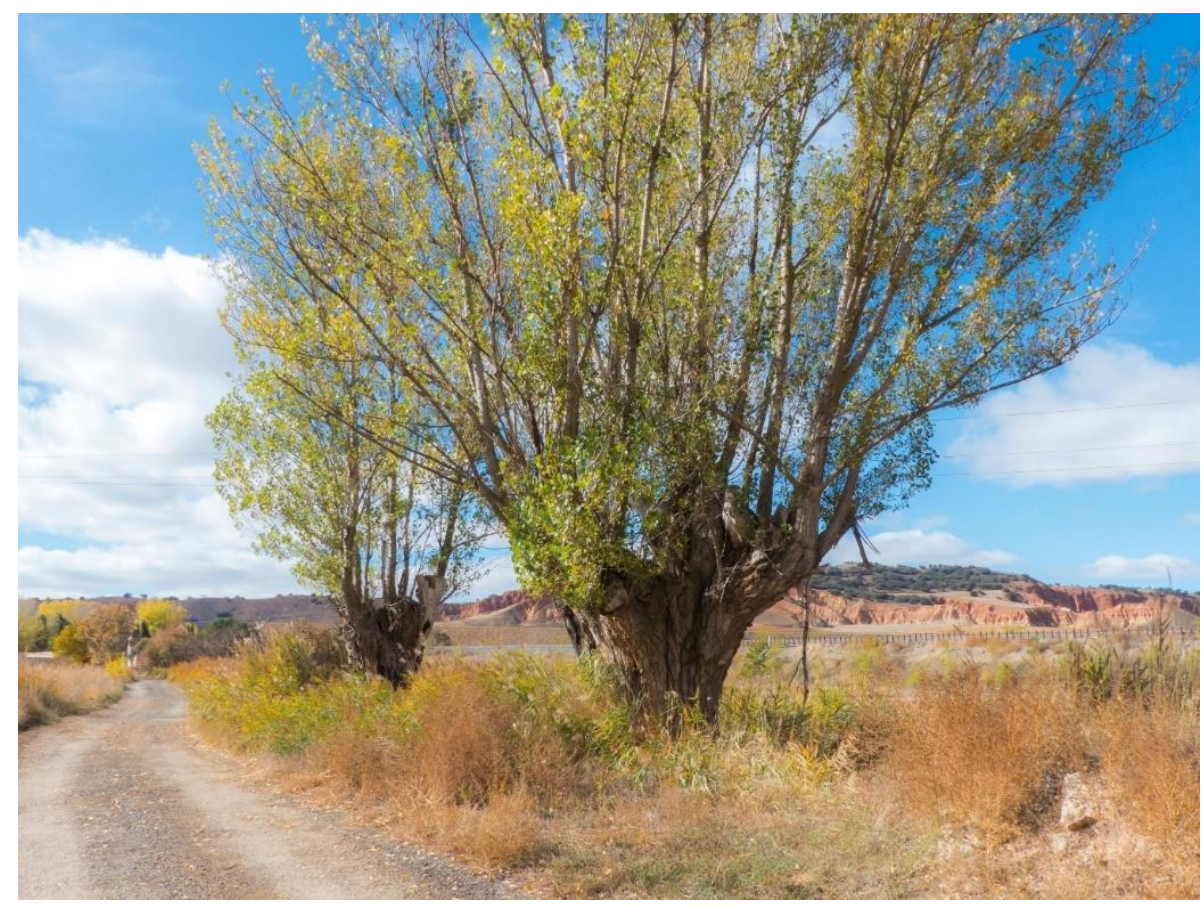

Figura 170. Chopos cabeceros de importantes dimensiones en la Cuenca del Jiloca. Imagen propia.

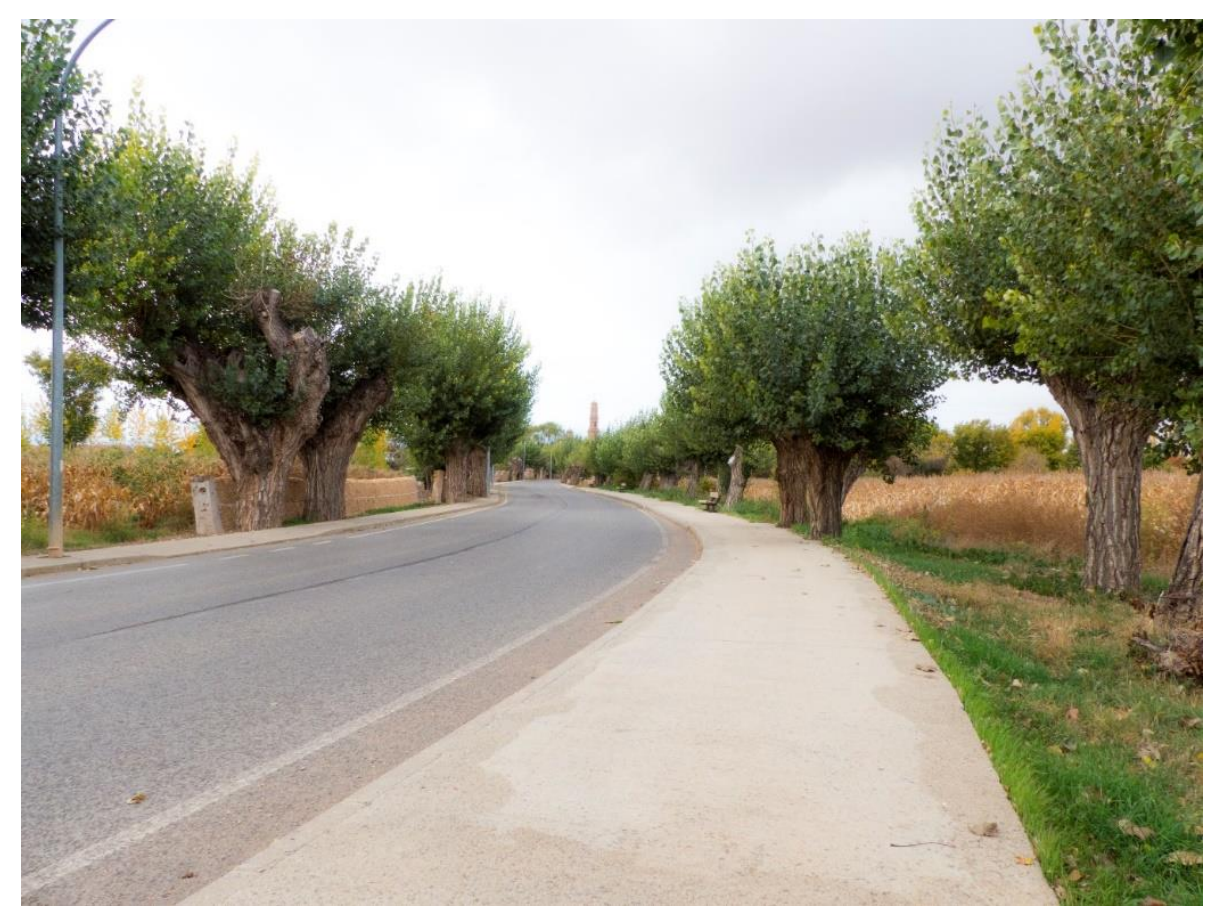

Figura 171. Chopos cabeceros podados con un año de rebrote en la entrada de Torrijo del Campo. Imagen propia. 
Con el objetivo de facilitar la interpretación de la realidad paisajística de la cuenca del río Jiloca se ha realizado una trasposición vertical de la información. Gracias al Mapa Forestal de España 1:50.000 (Figura 158), a la información facilitada por Corine Land Cover (Figura 153 y Figura 154) y a la observación directa mediante el trabajo de campo que permite rectificar y afinar errores se han obtenido los siguientes perfiles topográficos a los cuales se les ha superpuesto la información paisajística (Figura 172, Figura 173 y Figura 174).

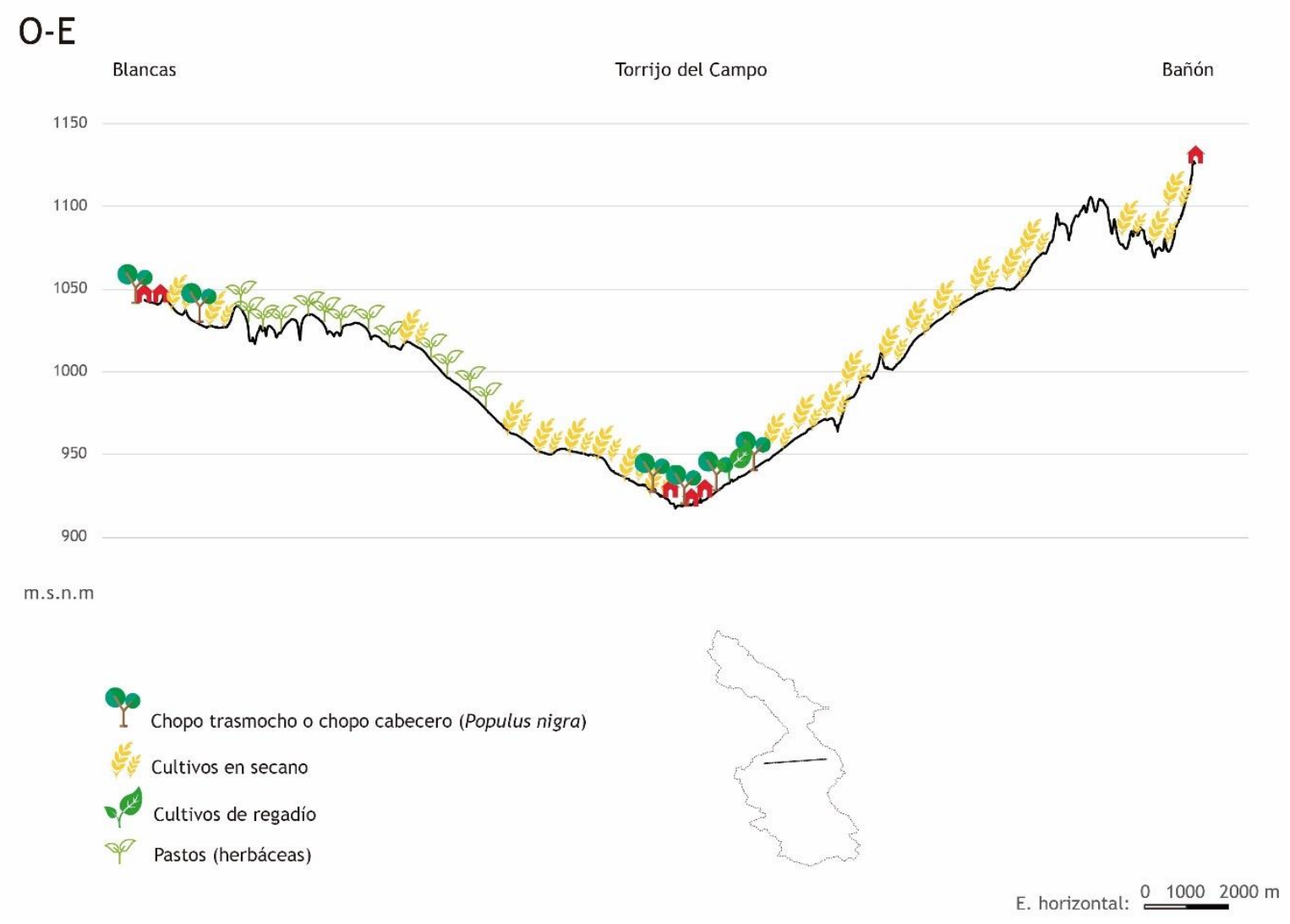

Figura 172. Perfil topográfico con información de usos Blancas a Bañón. Elaboración propia a partir de trabajo de campo. 
Estudio de casos y aplicación práctica. Paisajes forestales con valor patrimonial.

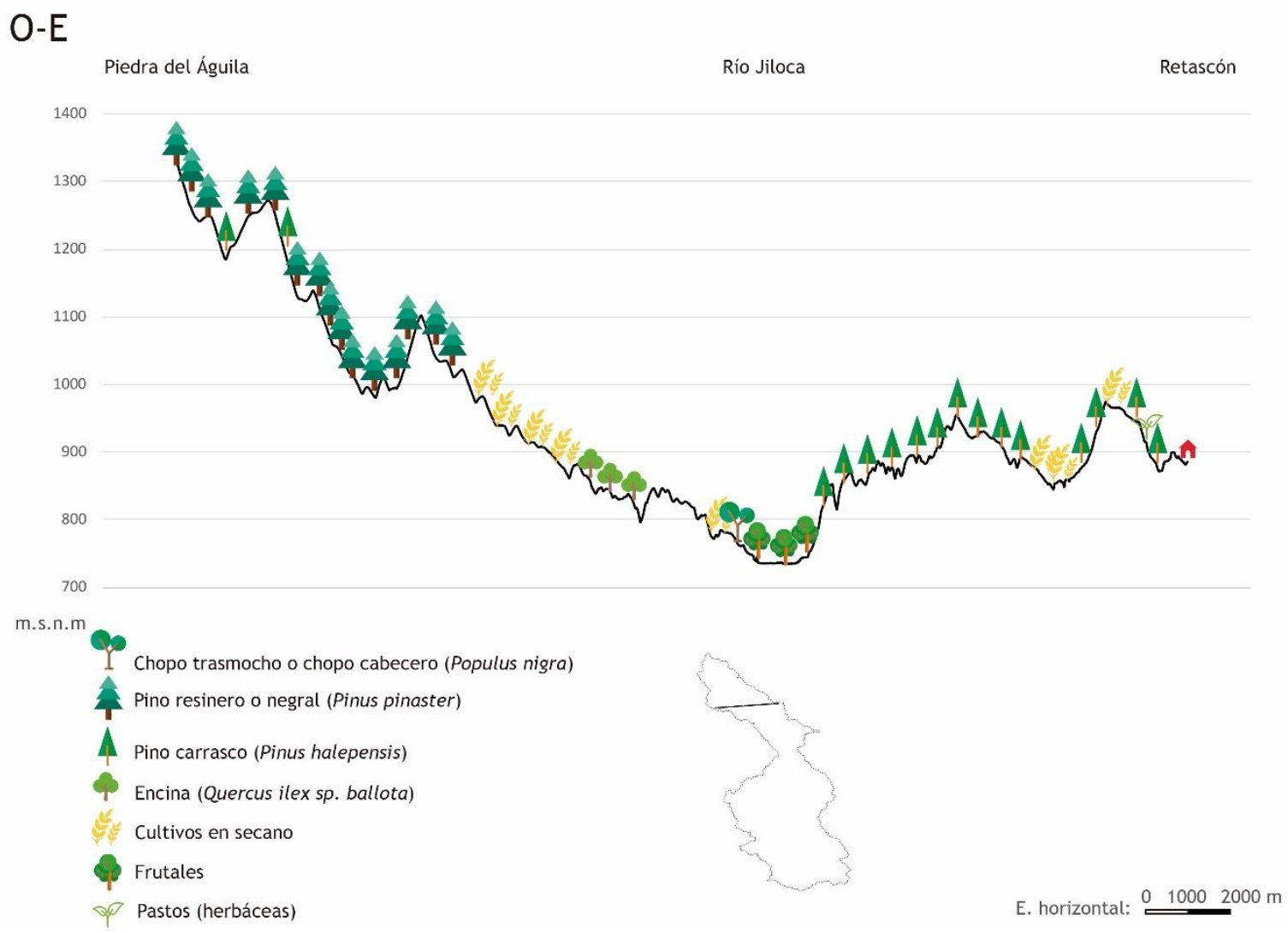

Figura 173. Perfil topográfico con información de usos Piedra del Águila a Retascón. Elaboración propia a partir de trabajo de campo. 


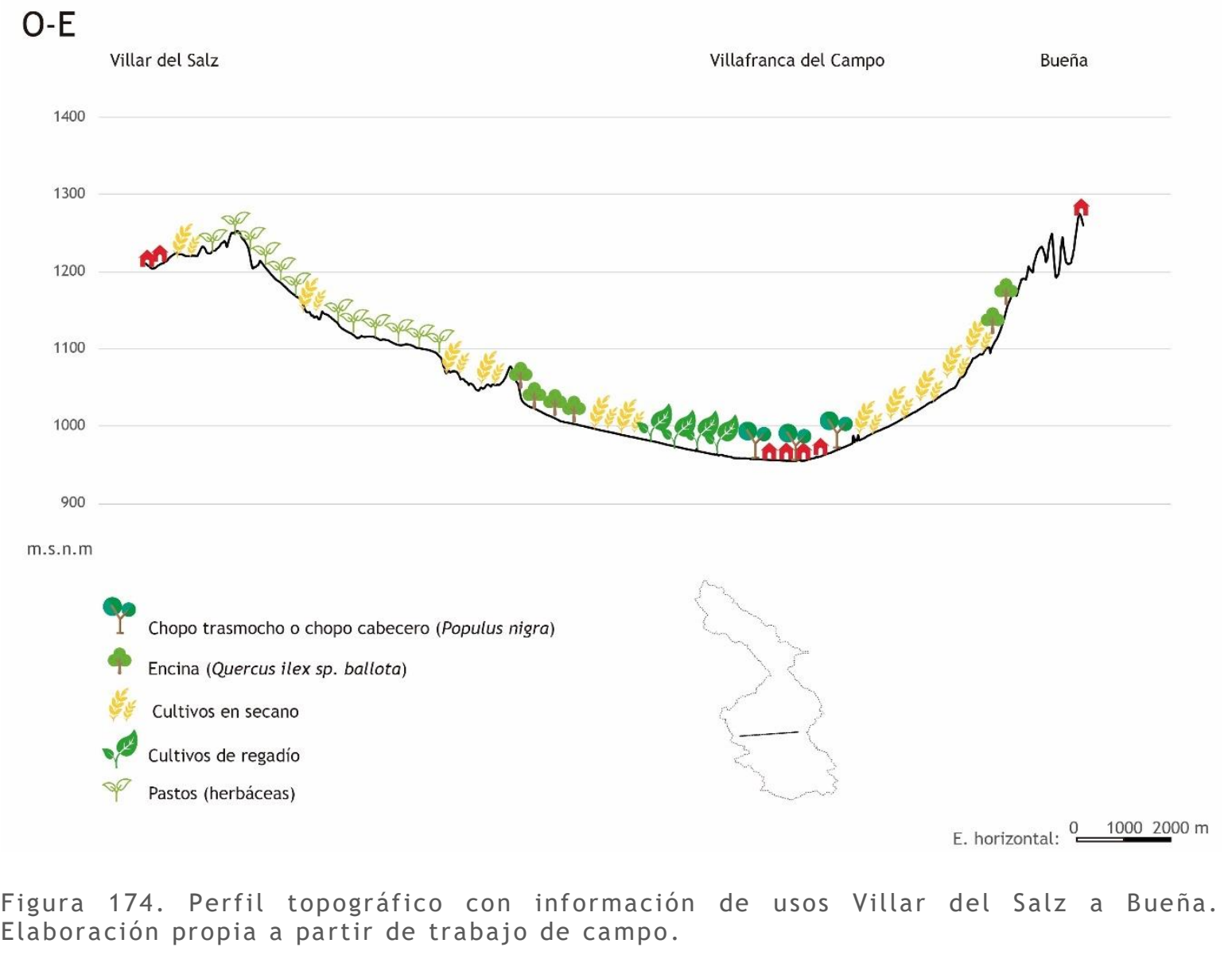

\subsection{El valor patrimonial}

En el caso del paisaje que ocupa a este capítulo, los chopos trasmochos como ejemplo de un espacio forestal de acompañamiento agropecuario que han perdido por completo su valor de uso suponen un recurso patrimonial de primer orden. Este recurso ha sido identificado, fundamentalmente, por una sociedad civil organizada que se ha cristalizado mediante un movimiento que reclama un reconocimiento para estos árboles. La reivindicación, llevada a cabo fundamentalmente por el Centro de Estudios del Xiloca, ha conseguido dos hitos para la declaración patrimonial de estos monumentos vivos que suponen los chopos trasmochos. En primer lugar, el gobierno de Aragón procedió a declarar Bien de Interés Cultural Inmaterial 
la Cultura del Chopo Cabecero en el sur de Aragón (Gobierno de Aragón, 2016), en segundo lugar, pese a no incluir a la cuenca del río Jiloca, en 2018 se procedió a delimitar como Parque Cultural la cuenca alta del río Alfambra (Gobierno de Aragón, 2018), al tratarse de un territorio con una presión demográfica muy pequeña, el paisaje de los chopos cabeceros toma una dimensión muy relevante. Estos hitos que van a determinar el reconocimiento de estos árboles y su aprovechamiento cultural demuestran el valor patrimonial que va a tener este paisaje.

Por otro lado, ha quedado constatado que, en un espacio de dominante agropecuaria, que presenta unas características de asepticidad ecosistémica, los chopos surgen como auténticos refugios biológicos (Schwendtner et al., 2005). De esta manera, el chopo cabecero no solo va a ser un recurso patrimonial de carácter cultural, sino que es, a su vez, un recurso patrimonial de carácter eminentemente biológico.

\subsection{El proceso de patrimonialización a través de los indicadores.}

Al igual que en el resto de los casos de estudio, se plantea la necesidad de valorar el proceso de patrimonialización mediante testigos que hagan más sencilla la comparación entre los diferentes paisajes. Con este cometido se planten estos indicadores que valorarán cada uno de los aspectos definidos en el epígrafe 6.3 para el paisaje forestal de los chopos trasmochos del valle del río Jiloca.

Al plantear este objetivo de comparación de los procesos de patrimonialización se hace necesario adoptar la escala municipal como referencia. De esta manera se determina escoger un municipio de este caso de estudio que sirva como representante del conjunto. Para el caso del paisaje forestal de los chopos trasmochos, sitos en la cuenca fluvial del río Jiloca, se determina escoger un municipio que cumpla una serie de criterios garantes de su representatividad. Se establece que se trate de un municipio central de la cuenca, garantizando la integridad paisajística, mediante 
tratamiento SIG se han obtenido 20 candidatos que aseguran mantener todo su término municipal en el interior de la cuenca (Figura 175). Por otro lado, se establece que debe tratarse de un municipio que se sitúe en una posición central en cuanto a criterios demográficos y socioeconómicos, avalando su elección como testigo fiable. De acuerdo con estas premisas se ha examinado el Padrón relativo al año 2017 para seleccionar aquellos municipios que se sitúen en una posición central evitando las distorsiones por exceso o defecto demográfico. En este caso los municipios que se van a encontrar entre la media y la mediana poblacional se reducen a 4 (Figura 176). En lo que se refiere a su situación socioeconómica se establece el criterio de centralidad en cuanto a la situación laboral. Para ello se acude a la tasa de actividad global que va a poner de manifiesto la población activa sobre el total de población del municipio (afiliados a la seguridad social julio 2017+ parados registrados julio 2017/padrón 2017), garantizando una representatividad que evite distorsiones por exceso o defecto (Tabla 65). Por último, se hace imprescindible que albergue un número significativo de ejemplares de chopo cabecero que hagan pertinente su estudio, fijándose en al menos el 5\% (125 ejemplares) sobre el total presentes en la cuenca (2502 ejemplares). De esta forma se obtiene el municipio de Burbáguena, en la provincia de Teruel, que servirá como testigo fiable de la realidad patrimonial de la cuenca del río Jiloca. En este caso, el municipio se encuentra aproximadamente en el centro de la cuenca, muy cerca de la frontera con la provincia de Zaragoza y alberga unos 145 ejemplares de chopo cabecero lo que garantiza la representatividad de este municipio sobre el total de los municipios del área de estudio. 


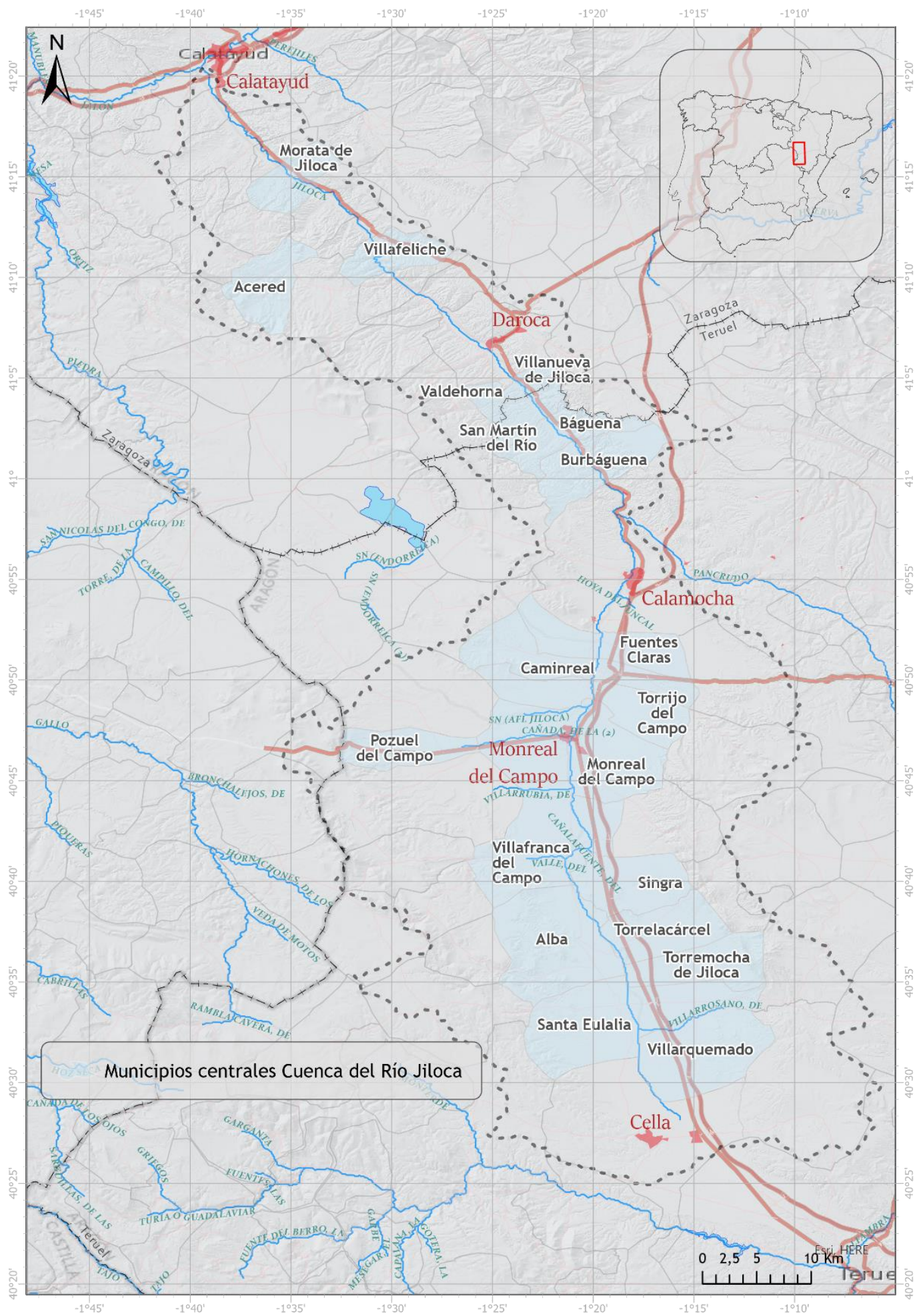

Figura 175. Mapa con los municipios centrales de la cuenca del río Jiloca. Elaboración propia. 

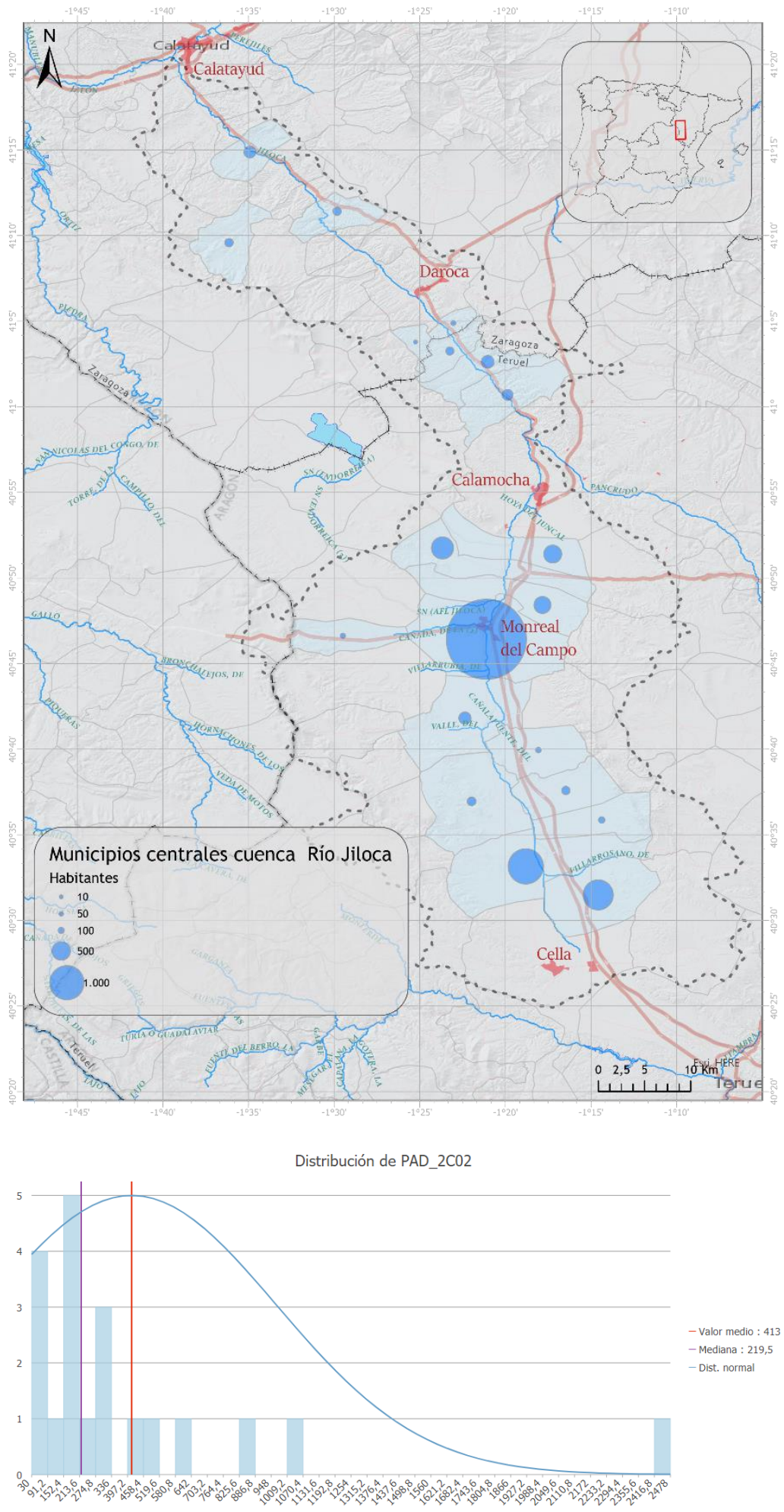

Figura 176. Distribución de la población de los municipios centrales de la cuenca. Elaboración propia. 
Estudio de casos y aplicación práctica. Paisajes forestales con valor patrimonial.

\begin{tabular}{|c|c|c|c|}
\hline MUNICIPIO & ACTIVOS & POBLACIÓN & TASA DE ACTIVIDAD GLOBAL \\
\hline 44033 BAGUENA & 49 & 318 & 0,1541 \\
\hline 44047 BURBAGUENA & 72 & 254 & 0,2835 \\
\hline 44251 VILLAFRANCA DEL CAMPO & 106 & 289 & 0,3668 \\
\hline 50176 MORATA DE JILOCA & 102 & 282 & 0,3617 \\
\hline \multicolumn{3}{|r|}{ vecula } & 0,2915 \\
\hline & & Mediana & 0,3226 \\
\hline
\end{tabular}

Tabla 65. Tabla con la distribución laboral de los municipios que cumplen los criterios de población para ejercer como testigo en el proceso de patrimonialización de la cuenca del río Jiloca. Elaboración propia a partir de Datos Seguridad Social 2017.

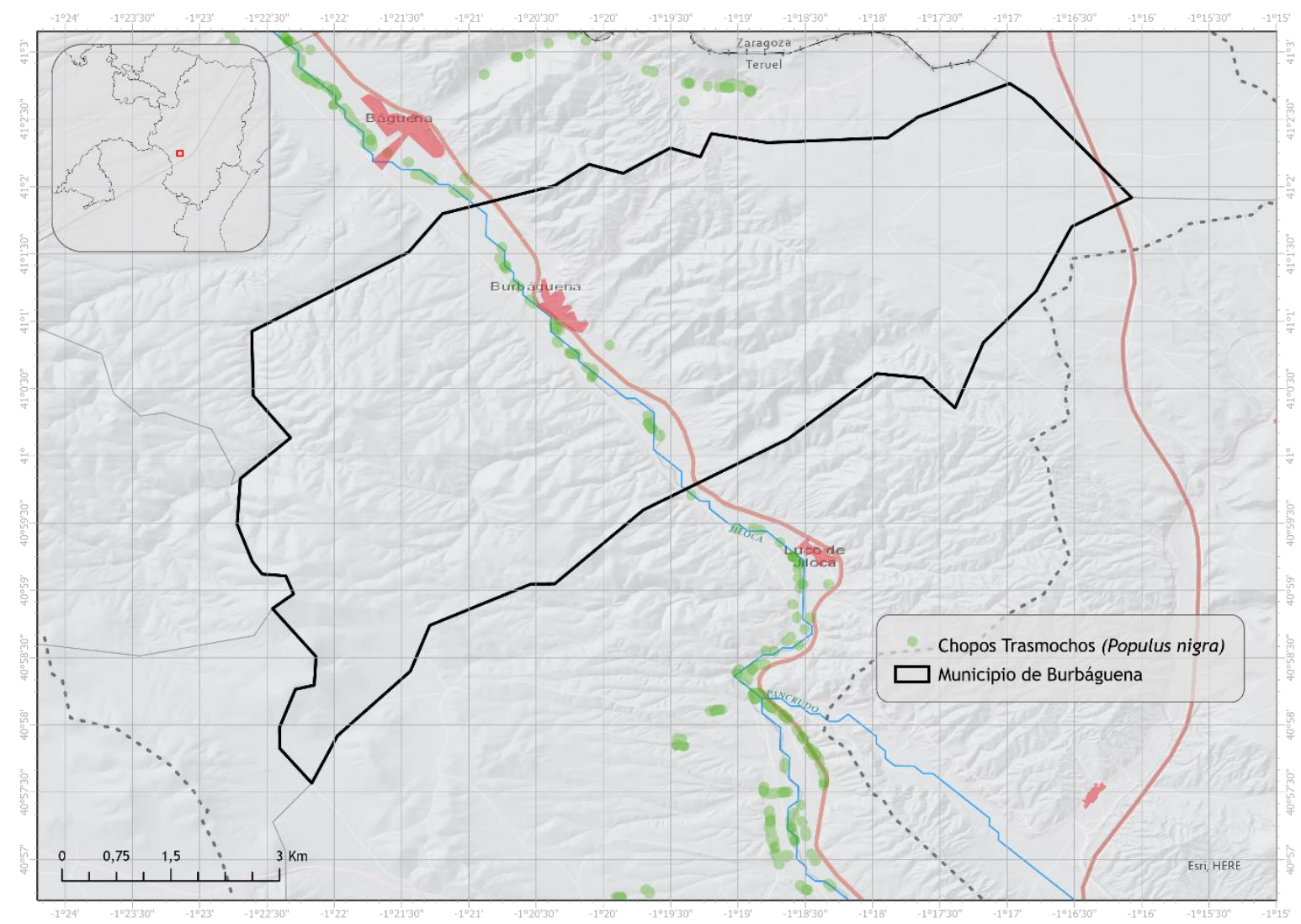

Figura 177. Localización del municipio de Burbáguena con los chopos cabeceros que alberga. Elaboración propia a partir de (Bellido y López, 2008) 
10.8.1. Indicador 1. Complejidad biológica

\begin{tabular}{|l|c|}
\hline Criterio & Puntuación \\
\hline Evidencias bibliográficas de naturalidad & 3 \\
\hline Hábitat de Interés Comunitario & 4 \\
\hline Salud vegetal NDVI & 3 \\
\hline
\end{tabular}

Tabla 66. Resumen criterios valoración indicador Complejidad Biológica

El indicador que se trata en este epígrafe hace alusión a las características biológicas de los elementos que forman el paisaje forestal. Se trata de obtener, mediante la recopilación de información científica y la observación directa, una valoración que haga más sencillo estimar el aporte ambiental del paisaje en cuestión.

El paisaje forestal que se trata en este capítulo, como se ha descrito, responde a una sucesión de pies de chopo negro (Populus nigra L.) intervenidos, que aparece, principalmente, asociados a un curso de agua. Esta estrecha relación entre los chopos cabeceros y los cursos de agua hace imprescindible señalar el valor de estos árboles como protagonistas en la morfología fluvial de este territorio. Está constatado que la vegetación riparia determina las características de los cauces (Bennett y Simon, 2004), adecuando el régimen y las características del caudal (Darby, 1999; Gran y Paola, 2001) o evitando el lavado de suelos, fundamentales para el desarrollo agrícola (Schlosser y Karr, 1981). Por todas estas razones resultaría más acertada la obtención de recursos forestales del chopo mediante este método tradicional que mediante las plantaciones de híbridos actuales, las cuales alteran los cursos de agua (García et al., 2018). En el mismo orden de cosas, los chopos negros (Populus nigra L.) no solo son importantes para el mantenimiento de las riberas y sus entornos, sino que van a suponer un pionero en la recolonización de riberas lejanas, gracias a la capacidad viajera de sus semillas (Splunder et al., 1995; 
Mahoney y Rood, 1998; Rood et al., 2005; Smulders et al., 2008) lo que supone un reservorio genético de gran importancia.

Los árboles trasmochos en general y los chopos cabeceros en particular se presentan como árboles viejos repletos de cavidades y grietas derivadas de las continuas intervenciones. Por otro lado, presentan necrosidades propias de ejemplares mucho más viejos. Estas características recrean hábitats muy valiosos e imprescindibles para el desarrollo de algunas especies de invertebrados propias de los bosques viejos naturales (Schwendtner et al., 2005; Schwendtner y Cárcamo, 2009; Schwendtner, 2010). Este es el caso de los insectos saproxílicos que se alimentan de maderas muertas y podredumbres, necesitando huecos y grietas para refugiarse (Fundación HAZI Fundazioa, 2013; Castro y Fernández, 2018) algunos de estos invertebrados son de interés comunitario (Verdú et al., $2011)$.

Otro de los aspectos que se deben destacar en lo que se refiere a sus evidencias de naturalidad es la utilización por algún tipo de quiróptero (murciélago forestal) de las cavidades que existen en estos longevos trasmochos y que son resultado de las continuas intervenciones y podas (Goiti et al., 2007). Los quirópteros son fundamentales para controlar las poblaciones de invertebrados evitando posibles plagas (Guixé y Camprodon, 2018). En una zona tan deforestada y con gran escasez de bosques maduros el refugio que suponen los chopos trasmochos para estos mamíferos es fundamental (Alcalde et al., 2008).

Por último y con el apoyo de la observación directa mediante el trabajo de campo, donde se puede apreciar como estos árboles trasmochos suponen un auténtico "refugio" de biodiversidad en un contexto de “limpieza” agropecuaria (Figura 178), es imprescindible destacar su valor como garante o refugio ecosistémico. 


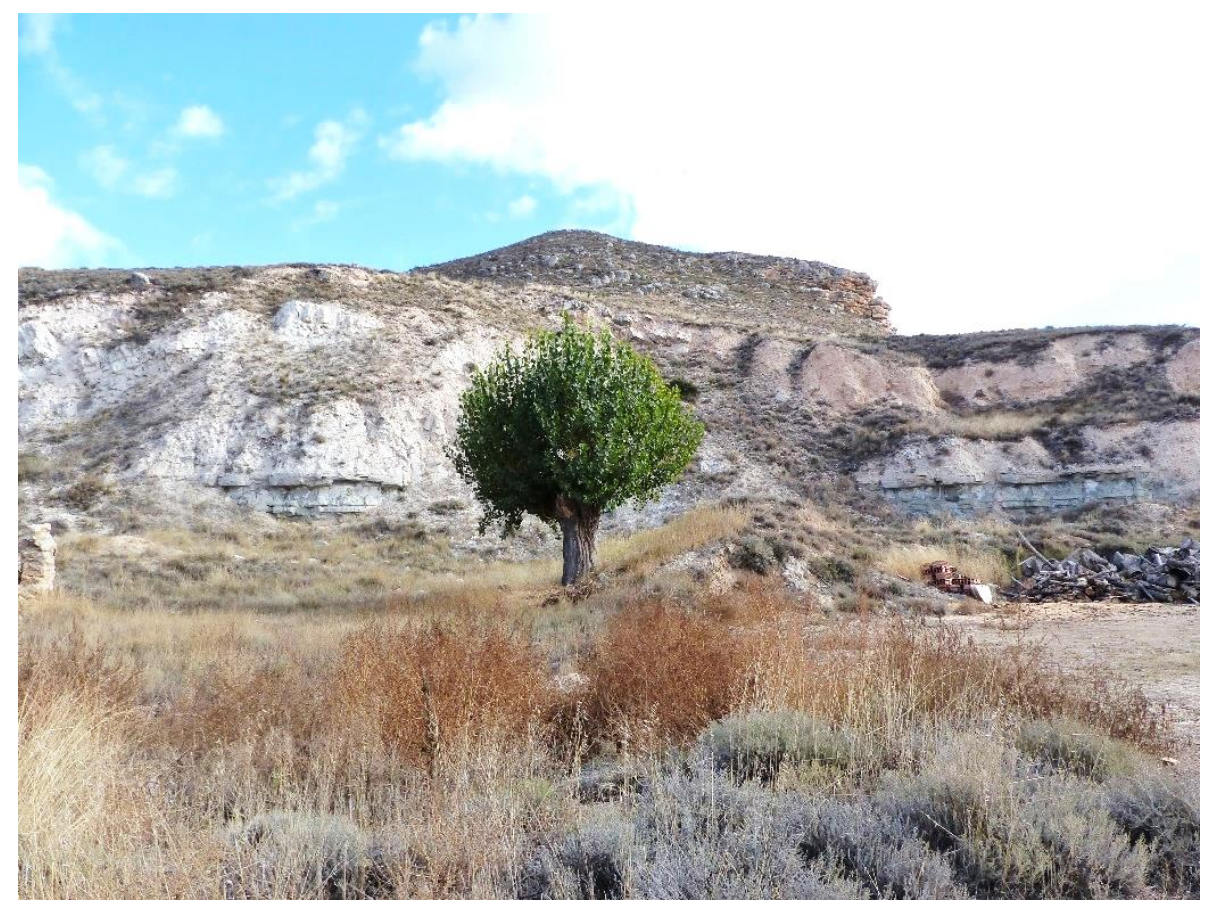

Figura 178. Chopo aislado. Supone un auténtico reservorio biológico. Imagen propia.

De acuerdo con las premisas establecidas y las evidencias encontradas se va a determinar que los chopos cabeceros van a cumplir este primer requisito de naturalidad al mostrarse como un oasis biológico en un espacio de dominante agraria industrial. Por esta razón se conviene dar este requisito como cumplido.

En cuanto al criterio establecido para la valoración que otorga un valor de 4 puntos a la existencia de comunidades vegetales incluidas en la Directiva Hábitat y que están relacionadas directamente con el paisaje vegetal patrimonial objeto de estudio, hay que señalar que el municipio de Burbáguena alberga tres formaciones amparadas bajo esta figura de protección.

- Zonas subestépicas de gramíneas y anuales del TheroBrachypodietea

- Bosques de galería de Salix alba L. 1753

- Bosque de galería de Populus alba L. 1753 
Por un lado, se trata de una formación herbácea de pastos xerófilos que pueden contener algunos endemismos ibéricos pero que no puede relacionarse en ningún caso con los chopos trasmochos. Por otro lado, existen pequeñas masas catalogada bajo la protección de la Directiva Hábitat y que hacen referencia al bosque de galería formado por sauces y chopos, en esta ocasión se podría inferir que la catalogación está asociada directamente a la especie objeto de estudio (Populus nigra L.), pero se ha confirmado que no existen ejemplares de esta especie en este lugar, por lo que no se puede dar este requisito por cumplido.

Por último, para valorar este indicador incorporando criterios propiamente cuantitativos, se ha realizado un tratamiento de teledetección a partir de fotografías obtenidas por el satélite Landsat 8 en diferentes periodos, procurando obtener imágenes libres de distorsiones nubosas y representativas de las cuatro estaciones para elaborar el índice NDVI (Índice de Vegetación de Diferencia Normalizada) que permita interpretar la salud de los ejemplares protagonistas del estudio y compararlos con su entorno inmediato (ver 6.3.1). Mediante este análisis y su interpretación se detecta que los chopos cabeceros, que están asociados directamente con la corriente permanente que supone el río Jiloca van a representar un auténtico reservorio vegetal que permanece vigoroso cuando las condiciones estivales son más adversas, erigiéndose prácticamente como la excepción vegetal en determinados momentos (Figura 179). Es necesario, en cualquier caso, manifestar que durante el invierno se detecta la ausencia de vigor vegetal que aportan los chopos en tanto que se encontrarían en su periodo de quiescencia a la espera de condiciones más favorables. Pese a esta excepción invernal los chopos van a ser auténticas excepciones de vigorosidad vegetal en un entorno prácticamente exento de vegetación natural a lo largo del año (Tabla 67). Por esta razón los chopos cabeceros sitos en Burbáguena cumplen el criterio planteado. 

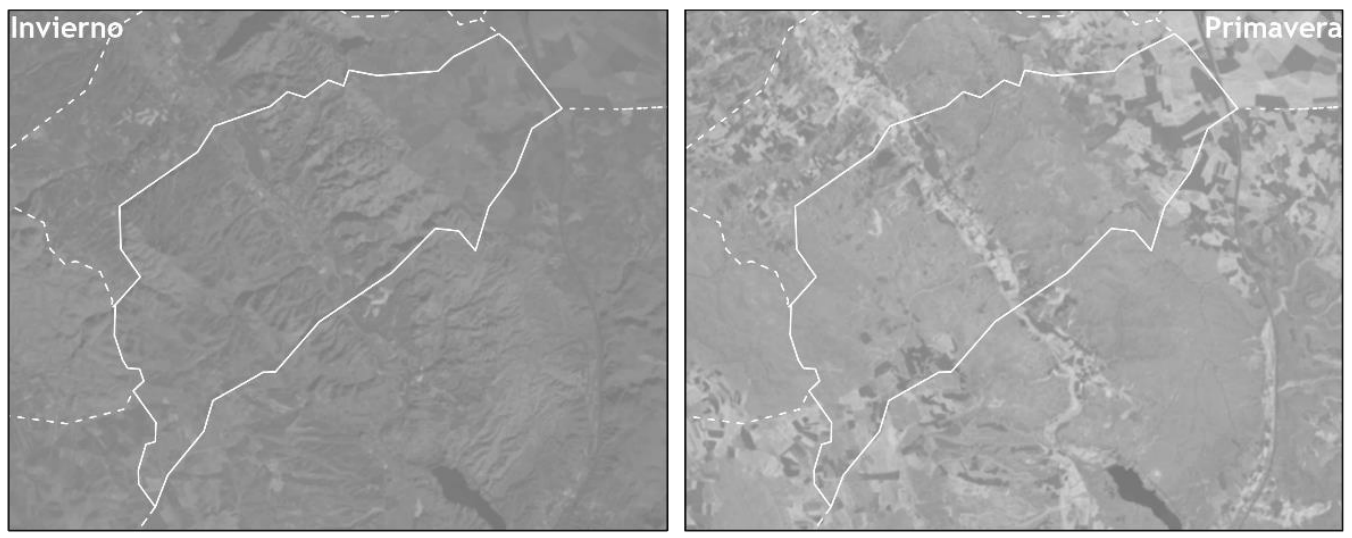

Municipio de
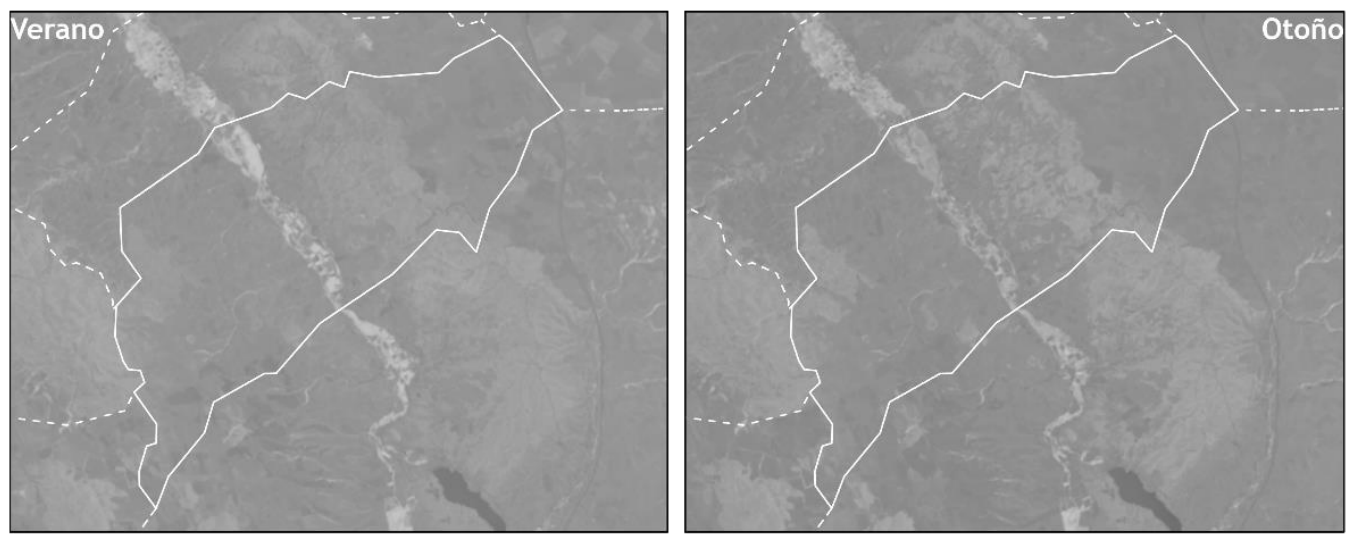

Burbáguena

índice

NDVI

Figura 179. Representación del índice de vegetación de diferencia normalizada para los meses de enero, mayo, agosto y octubre respectivamente. Imágenes Landsat 8 . Elaboración propia.

\begin{tabular}{|c|c|c|c|}
\hline & Chopos & Cultivos & Otra veg. (Encinar) \\
\hline Invierno & 0.15 & 0.18 & 0.13 \\
\hline Primavera & 0.32 & 0.48 & 0.26 \\
\hline Verano & 0.29 & 0.12 & 0.21 \\
\hline Otoño & 0.29 & 0.10 & 0.18 \\
\hline
\end{tabular}

Tabla 67. Valor NDVI de distintas cubiertas a lo largo del periodo vegetativo. Elaboración propia. 


\begin{tabular}{|c|c|c|}
\hline Criterio & Puntuación & Cumplimiento \\
\hline $\begin{array}{c}\text { Evidencias de } \\
\text { naturalidad }\end{array}$ & 3 & $\begin{array}{c}\text { La bibliografía } \\
\text { consultada } \\
\text { confirma el } \\
\text { reservorio natural }\end{array}$ \\
\hline Hábitat de Interés Comunitario & 4 & $\begin{array}{c}\text { Los hábitats } \\
\text { catalogados no } \\
\text { tienen relación }\end{array}$ \\
\hline Salud vegetal NDVI & 3 & $\begin{array}{c}\text { Se confirman los } \\
\text { chopos cabeceros } \\
\text { como un reservorio } \\
\text { vegetal }\end{array}$ \\
\hline
\end{tabular}

Tabla 68. Resumen criterios cumplidos valoración indicador Complejidad Biológica

10.8.2. Indicador 2. Figuras de protección, reconocimiento y salvaguarda presentes en el territorio.

\begin{tabular}{|l|c|}
\hline Criterio & Puntuación \\
\hline Figura otorgada por UNESCO & 4 \\
\hline Parque Nacional & 3 \\
\hline Parque Natural o inferior (CCAA) & 2 \\
\hline LIC o ZEPA & 0,5 \\
\hline Otras figuras & 0,5 \\
\hline
\end{tabular}

Tabla 69. Resumen criterios valoración indicador Figuras de protección

El valor del indicador propuesto se establece mediante la recopilación de las figuras administrativas que aparecen presentes en el término municipal de Burbáguena. Las figuras de reconocimiento, protección o salvaguarda presentan una peculiaridad y es que es más relevante el ensalzamiento de los valores culturales que los naturales pese a encontrarnos ante un elemento vegetal, vivo por tanto. Lo más destacable 
en cuanto al paisaje forestal de los chopos trasmochos es el reconocimiento, por parte del Gobierno de Aragón, como Bien de Interés Cultural Inmaterial la cultura del chopo cabecero en el sur de Aragón (Gobierno de Aragón, 2016). De igual manera, en un territorio colindante, siendo el río que vertebra la cuenca el Alfambra (Afluente del Turia), se ha declarado el Parque Cultural del Chopo Cebecero del Alto Alfambra (Gobierno de Aragón, 2018). En este territorio eminentemente rural, la cultura del chopo, sus usos tradicionales y su paisaje han perdurado posiblemente gracias a su aislamiento.

En cuanto a las figuras de protección y salvaguarda presentes en el término municipal hay que señalar que no existen como tal únicamente aparece un LIC aledaño asociado a los montes de la cuenca de Gallocanta, pero ni guarda relación con el paisaje vegetal en cuestión ni se encuentra dentro de los límites del municipio.

Atendiendo a todo esto solo se cumple el criterio de la existencia de una figura de reconocimiento asociada a su valor cultural inmaterial.

\begin{tabular}{|c|c|c|}
\hline Criterio & Puntuación & Cumplimiento \\
\hline Figura otorgada por UNESCO & 4 & $\begin{array}{l}\text { No existe } \\
\text { reconocimiento } \\
\text { UNESCO }\end{array}$ \\
\hline Parque Nacional & 3 & $\begin{array}{c}\text { No existe la figura } \\
\text { de PN }\end{array}$ \\
\hline Parque Natural o inferior (CCAA) & 2 & $\begin{array}{c}\text { No existe ninguna } \\
\text { figura de } \\
\text { competencia } \\
\text { autonómica }\end{array}$ \\
\hline LIC O ZEPA & 0,5 & $\begin{array}{c}\text { No existe ningún } \\
\text { LIC o ZEPA }\end{array}$ \\
\hline Otras figuras & 0,5 & $\begin{array}{l}\text { Reconocimiento } \\
\text { Bien de Interés } \\
\text { Cultural Inmaterial }\end{array}$ \\
\hline
\end{tabular}

Tabla 70. Resumen criterios cumplidos valoración indicador Figuras de protección 
10.8.3. Indicador 3. Existencia de vectores patrimoniales

\begin{tabular}{|l|c|}
\hline Criterio & Puntuación \\
\hline Todos los vectores & 4 \\
\hline Al menos 50\% tratados patrimonialmente & 3 \\
\hline Identificados vectores de todos los tipos & 3 \\
\hline
\end{tabular}

Tabla 71. Resumen criterios valoración indicador Vectores Patrimoniales.

El indicador que se trata a continuación pretende indagar en el estado de patrimonialización del paisaje forestal con aquellos elementos que fijan el valor patrimonial en el territorio, los vectores. De esta manera, se buscan evidencias de los vectores propuestos en el Capítulo 3, su existencia o no y su tratamiento. Se entiende que una mayor preocupación por la conservación de estos vectores determina un mayor grado en el proceso de patrimonialización.

En el caso que atiende este epígrafe, serán los vectores propuestos para el paisaje forestal del bosque de acompañamiento agropecuario (ver Tabla 6), pasándose a analizar:

Ejemplares modificados para su aprovechamiento: En el caso del paisaje forestal de los chopos cabeceros este vector es el más relevante, al entenderse que son los árboles los grandes protagonistas que fijan el patrimonio al territorio, se han identificado multitud de ejemplares en el municipio, pero poco cuidados (Figura 177 y Figura 180).

Canales y acequias: Se han encontrado canalizaciones y acequias tradicionales, las cuales, en ocasiones siguen siendo funcionales como abrevadero y abastecimiento de riego (Imagen “Figura 181").

Círculos de carboneras: En este caso no se ha encontrado ninguna evidencia de la existencia de este vector, se entiende que el aprovechamiento de los chopos cabeceros como combustible se hace a 
través de la madera, no se realiza el proceso de carbonización a través de parvas.

Chozos: No se han encontrado evidencias de la existencia de estos elementos. Al acudirse al registro del Catálogo de Patrimonio Arquitectónico Aragonés (SIPCA-Gobierno de Aragón, 2019) no existen referencias a estas edificaciones en la cuenca del Jiloca, restringiéndose a la mitad norte del territorio aragonés. De igual modo el trabajo de campo tampoco ha evidenciado la existencia de elementos de este tipo. Parece ser que la clara vocación agrícola de grandes explotaciones y el paso a una ganadería ovina intensiva industrial, ha homogeneizado en buena medida el paisaje, eliminando posibles construcciones de carácter pastoril. (Figura $165)$.

Abrevaderos: Se han encontrado algunos elementos de este tipo en toda la cuenca y concretamente uno en el municipio de Burbáguena (Figura 182), presentando un buen tratamiento patrimonial. Estos elementos están recogidos como bienes inmuebles en el Catálogo de Patrimonio Arquitectónico Aragonés (SIPCA-Gobierno de Aragón, 2019). La mayor parte responden a fuentes con adaptaciones para abrevar el ganado. Por otro lado, la existencia de multitud de acequias y surgencias ha generado una red complementaria de abrevaderos (Figura 181).

Corrales: Al igual que los chozos o construcciones de refugio pastoril, el Catálogo de Patrimonio Aragonés (SIPCA-Gobierno de Aragón, 2019), pone de evidencia la inexistencia de corrales para el ganado ovino en la cuenca del Jiloca. La homogenización del paisaje ha eliminado la existencia de estos elementos, mientras que en la mitad norte de Aragón sí que aparecen este tipo de construcciones en la cuenca del Jiloca en general, y en Burbáguena en particular no se han encontrado.

Rediles: Estos elementos del paisaje pastoril tampoco se han encontrado, no existe ningún catálogo ni se ha encontrado ningún ejemplo durante las jornadas de trabajo de campo. La homogenización del paisaje puede haber sido el causante de esta desaparición. 


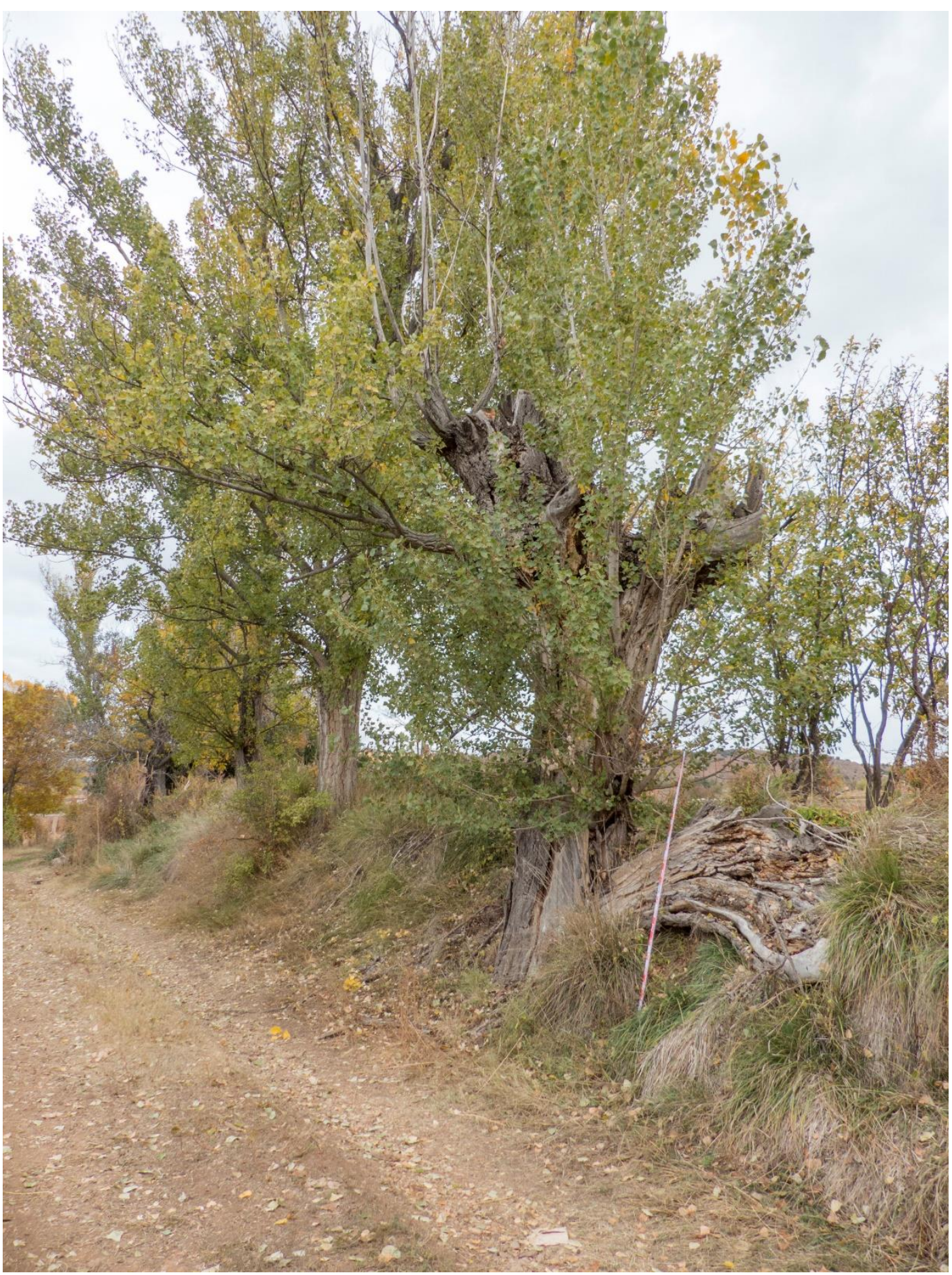

Figura 180. Chopos cabeceros en Burbáguena, se aprecia un abandono que deriva en podredumbres y roturas de ramas y tronco. Imagen propia. 


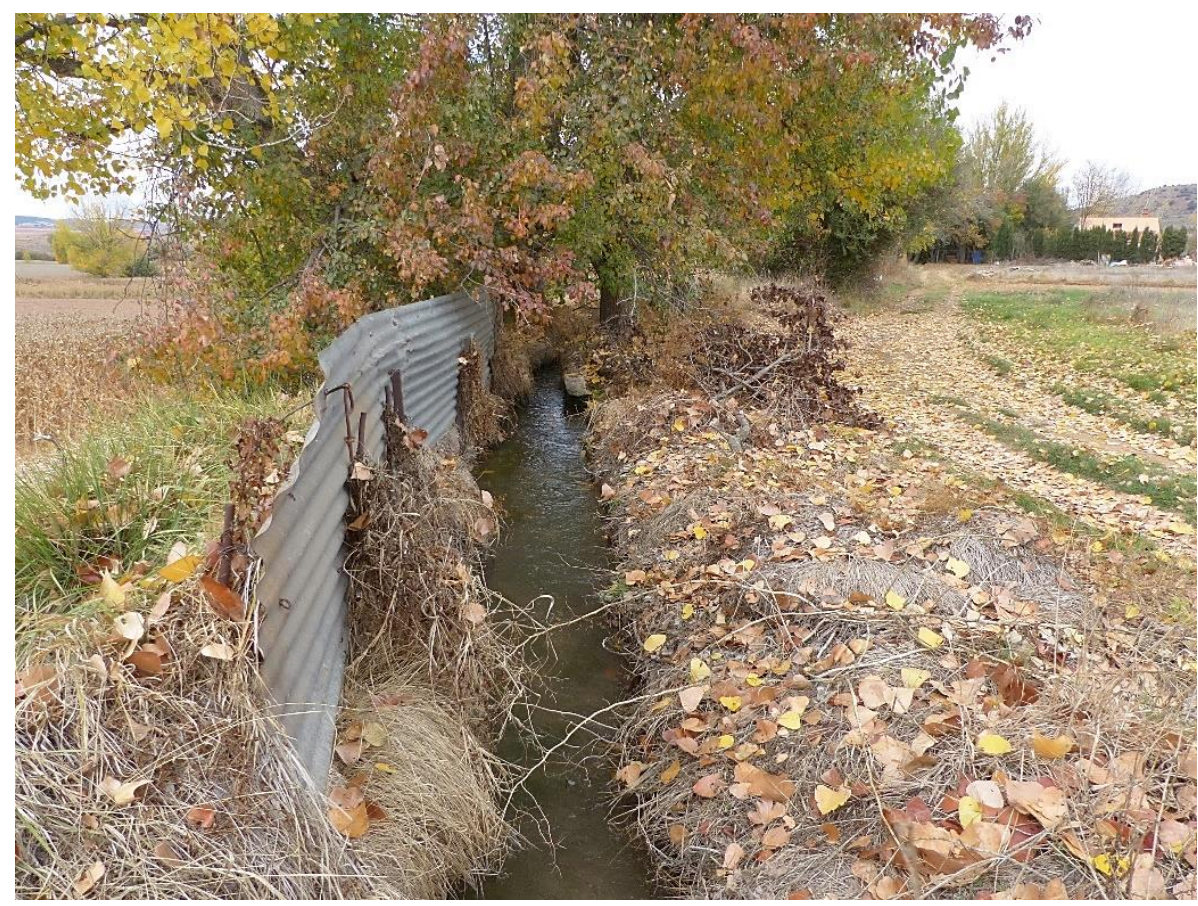

Figura 181. Acequias funcionales en Burbáguena. Imagen propia.

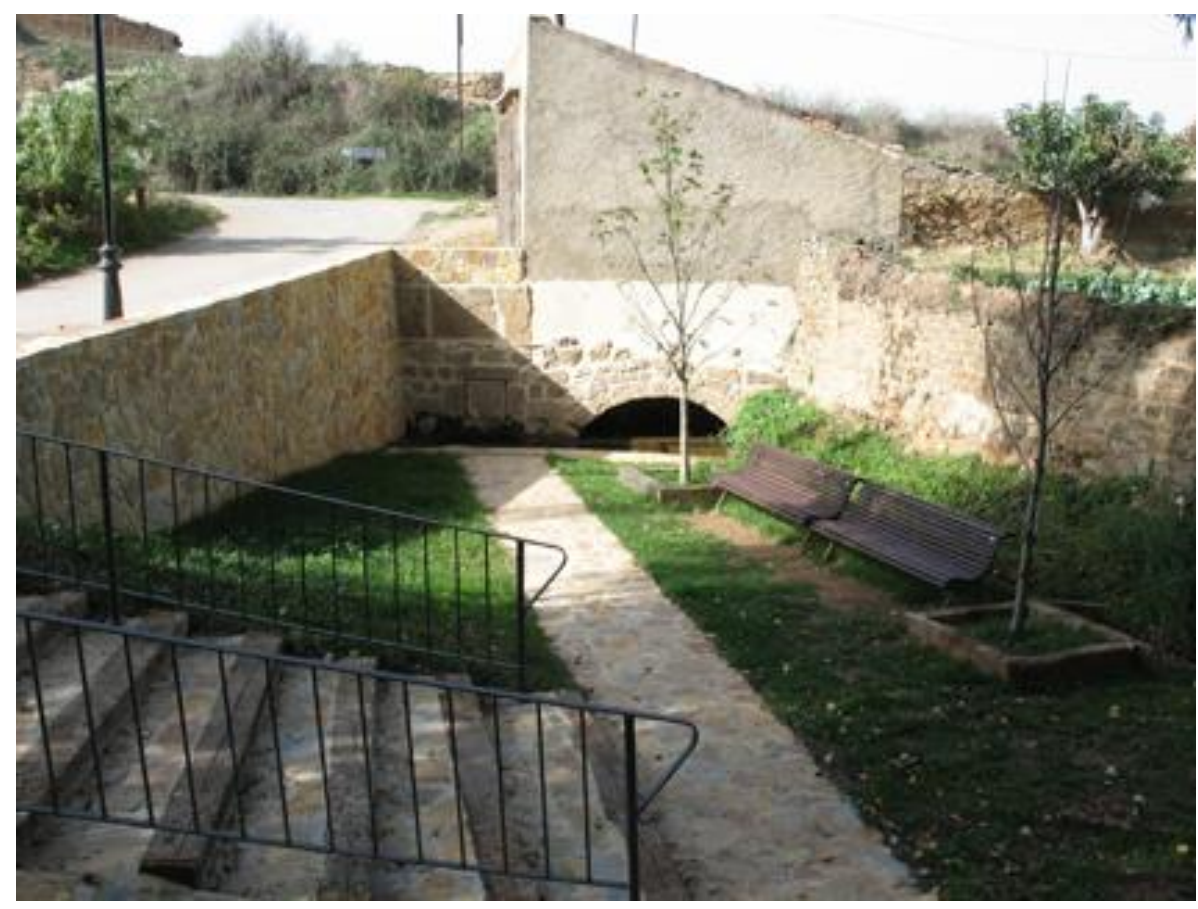

Figura 182. Fuente Vieja en Burbáguena. Imagen recuperada de http://xiloca.org/xilocapedia/index.php?title=Fuente_(Burb\%C3\%A1guena) 
De acuerdo con las evidencias recogidas y la escala de valoración planteada se infiere que este indicador no cumple los dos primeros criterios. No se han identificado la mayor parte de los vectores inscritos a la cultura inmaterial de la tradición agropecuaria, muy probablemente derivado de un proceso de homogenización paisajística asociada a la agricultura industrial cerealista. De igual manera los vectores que se han encontrado no están activados o tratados patrimonialmente, tan solo la fuente que servía como abrevadero lo está. Por último, los chopos cabeceros identificados en este municipio no tienen tratamiento patrimonial, se encuentran en un entorno donde existe un claro proceso de naturalización que se hace evidente ante un avance de matorral formando un denso sotobosque impropio de ejemplares que conservan su valor de uso tradicional. En el caso que ocupa a este epígrafe sí se han encontrado vectores asociados a todos los tipos por lo que se cumple este criterio.

\begin{tabular}{|c|c|c|}
\hline Criterio & Puntuación & Cumplimiento \\
\hline Todos los vectores & 4 & $\begin{array}{c}\text { No se han } \\
\text { encontrado todos } \\
\text { los vectores }\end{array}$ \\
\hline 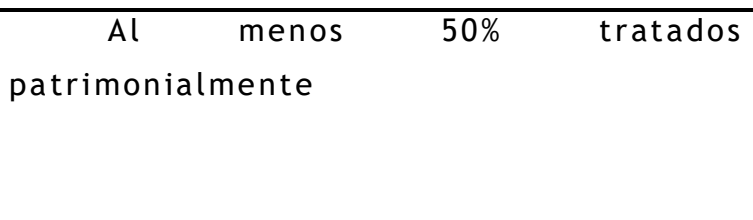 & 3 & $\begin{array}{c}\text { En su mayor parte } \\
\text { los vectores no } \\
\text { están tratados } \\
\text { patrimonialmente }\end{array}$ \\
\hline $\begin{array}{l}\text { Identificados vectores de todos los } \\
\text { tipos }\end{array}$ & 3 & $\begin{array}{c}\text { Sí se han } \\
\text { encontrado } \\
\text { vectores de todos } \\
\text { los tipos }\end{array}$ \\
\hline
\end{tabular}

Tabla 72. Resumen criterios cumplidos valoración indicador Vectores Patrimoniales 
Indicador 4. Identificación y sentimiento de pertenencia

\begin{tabular}{|l|c|}
\hline Criterio & Puntuación \\
\hline Toponimia & 2 \\
\hline Heráldica & 2 \\
\hline Iconografía administración & 2 \\
\hline Iconografía de particulares & 2 \\
\hline Referencias de asociaciones & 2 \\
\hline
\end{tabular}

Tabla 73. Resumen criterios valoración indicador Identificación de la población.

Según lo propuesto para la evaluación de este indicador en el apartado (6.3.4) se asignará un valor numérico en función de las evidencias encontradas en relación con la apropiación cultural del paisaje forestal, siendo este sustento de la identidad territorial. Para constatar este sentimiento de pertenencia de la población local y definir objetivamente la valoración, se han buscado evidencias en la iconografía y simbología que utilizan tanto las administraciones como los particulares.

En primer lugar, el análisis toponímico a partir del nomenclátor básico editado por el Instituto Geográfico Nacional no arroja ninguna referencia directa al paisaje relacionado con los chopos cabeceros ni a sus aprovechamientos directos. En su gran mayoría los topónimos de Burbáguena están relacionados con la tradición pastoril, destacando "La Dehesa" "Las Cañadillas" o multitud de "parideras".

No se han encontrado evidencias que acudan a los chopos cabeceros como referente iconográfico heráldico. En este caso el escudo municipal, compuesto por una "B" dorada y las cuatro barras aragonesas, se limita a representar un escudo medieval presente en el ayuntamiento con fecha 1621 y que ha sido replicado en varias ocasiones (Alcañíz y Loraque, 2006) (Figura 183). 

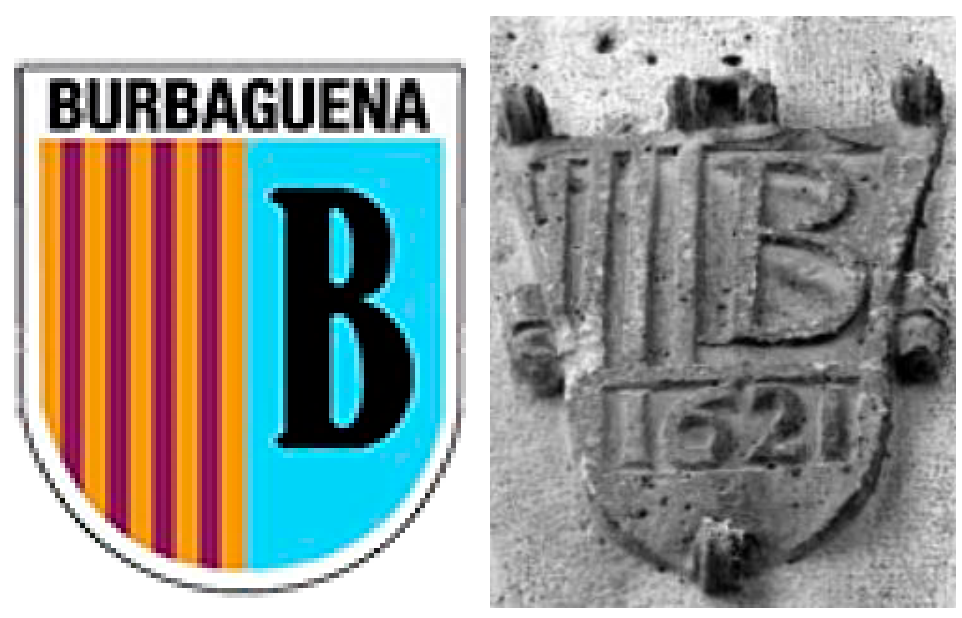

Figura 183. De izquierda a derecha, escudo actual de Burbáguena, recuperado de http://www.burbaguena.es/. Escudo medieval de Burbáguena recuperado de (Alcañíz y Loraque, 2006).

En lo que se refiere a la iconografía utilizada por la administración municipal, siempre referente de la identidad territorial a la hora de tomar nombres o simbología relacionada con el patrimonio, no se ha encontrado referencia alguna a estos elementos del paisaje vegetal. Por otro lado, los particulares no van a recurrir en ningún caso a los chopos cabeceros como referencias iconográficas para identificar sus actividades. Las referencias al arte mudéjar suelen ser más recurrentes (Figura 184).

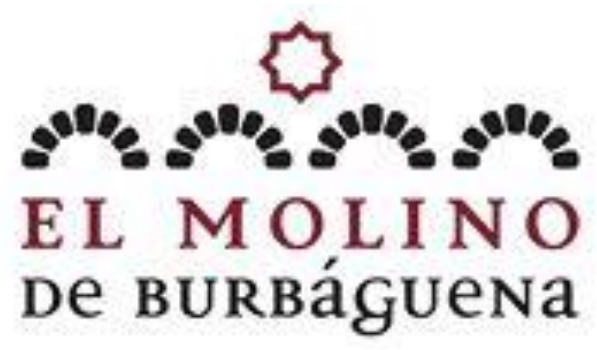

Figura 184. Infografía utilizada por el Hotel El Molino de Burbáguena. Recuperado de http://elmolinodeburbaguena.com/.

Respecto del asociacionismo, Burbáguena, pese a su escasa población posee multitud de colectivos preocupados por la vida cultural del municipio como así lo atestiguan sus múltiples asociaciones articuladas a través de 
diferentes figuras entre las que destacan las cofradías religiosas, las comunidades de regantes articuladas a través de las acequias o asociaciones sectoriales como la de jubilados y pensionistas. De modo especial hay que destacar la Asociación Cultural Burbaca destinada a la recuperación de tradiciones y costumbres locales. En cualquier caso, no se han encontrado referencias iconográficas a los chopos cabeceros por parte de estas asociaciones (Figura 185).

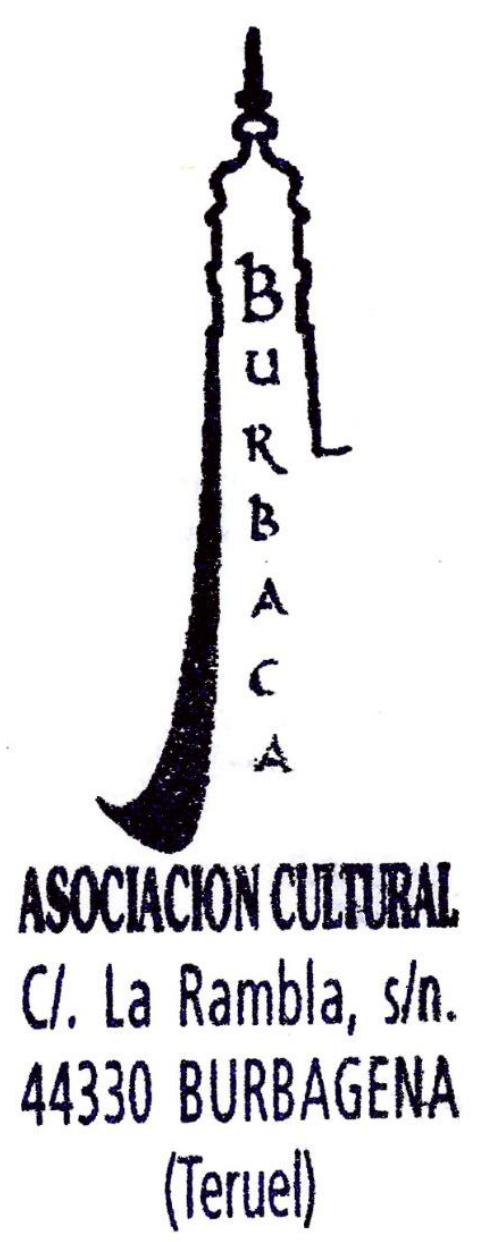

Figura 185. Logotipo de la Asociación Cultural Burbaca. Recuperado de https: / / burbaca.wordpress.com/quienes-somos/

De acuerdo con este análisis se deben dar por incumplidos todos los criterios destinados a valorar este indicador (Tabla 74). 


\begin{tabular}{|c|c|c|}
\hline Criterio & Puntuación & Cumplimiento \\
\hline Toponimia & 2 & No está relacionada \\
\hline Heráldica & 2 & $\begin{array}{l}\text { No se recurre al } \\
\text { chopo cabecero }\end{array}$ \\
\hline Iconografía administración & 2 & $\begin{array}{c}\text { No se utiliza el } \\
\text { chopo como } \\
\text { referencia }\end{array}$ \\
\hline Iconografía de particulares & 2 & $\begin{array}{l}\text { No recurren a los } \\
\text { chopos como icono }\end{array}$ \\
\hline Referencias de asociaciones & 2 & $\begin{array}{c}\text { Se inspiran en } \\
\text { motivos religiosos } \\
\text { o artísticos }\end{array}$ \\
\hline
\end{tabular}

\subsubsection{Indicador 5. Museística}

\begin{tabular}{|l|c|}
\hline Criterio & Puntuación \\
\hline Centros de interpretación / museos oficiales & 4 \\
\hline Museos de particulares & 2 \\
\hline Jornadas de exaltación & 2 \\
\hline Mobiliario de exhibición o exaltación & 2 \\
\hline
\end{tabular}

Tabla 75. Resumen criterios valoración indicador museística

La existencia de centros de interpretación o museos siempre está relacionada con la conservación y exaltación de los valores patrimoniales. Es por esto, que la existencia de estos espacios sirve como un testigo fiable para situar el proceso de patrimonialización. De acuerdo con ello, su existencia o no, será determinante para valorar este indicador de acuerdo con los criterios planteados. 
En lo que respecta al paisaje de los chopos trasmochos en la cuenca del Jiloca, no son muy abundantes las referencias encontradas sobre existencia de museos o centros de interpretación. Tan solo se ha encontrado una evidencia sobre la futura existencia de un centro de interpretación sobre el chopo cabecero y su cultura tradicional, en este caso no se encuentra dentro del límite establecido para el análisis, sino que es el municipio de Torre Los Negros en la cuenca del río Pancrudo, afluente del Jiloca, a unos $20 \mathrm{~km}$ del municipio de Burbáguena (Figura 186). En lo que respecta al propio municipio no existen centros oficiales destinados a la exaltación del chopo. De igual manera, no se han encontrado referencias a la existencia de museos o colecciones de particulares.

C 4 diariodeteruel.es/movil/noticia.asp?notid=1008985\&secid $=3$

\section{Diario de Teruel}

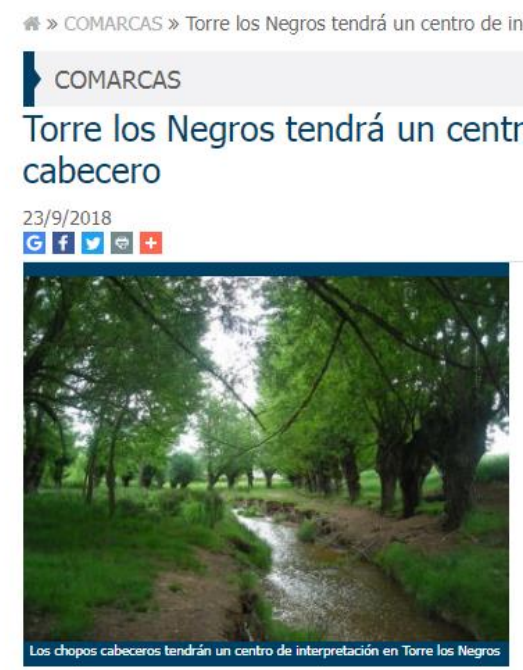

El municipio de Torre los Negros va a contar con un centro de
interpretación del chopo cabecero. La obra del centro estará
finalizada en este año. El Ayuntamiento dispone de 100.000
euros provenientes del Fondo de Inversiones de Teruel para la
construcción del centro del chopo cabecero.

El alcalde de Torre los Negros, Manuel Gambaro Royo, manifestó que para la construcción del centro de interpretación del chopo cabecero el Ayuntamiento dispone de una subvención de 100.000 euros provenientes del Fondo de Inversiones de Teruel por lo que tiene que estar finalizada su construcción antes de que acabe el presente año. En este punto, Manuel Gambaro, reseñó el poco plazo de tiempo que se otorga desde la aprobación a la ejecución del proyecto, 31 de diciembre de 2018 por lo que reclamó más celeridad en la aprobación o otorgar plazos más largos para la ejecución.

Figura 186. Noticia relacionada con el centro de interpretación que se instalará en el municipio de Los Lo Negros. Recuperado de: https://www.diariodeteruel.es/movil/noticia.asp?notid=1008985\&secid=3

En lo que respecta a jornadas de exaltación destinadas a los usos y prácticas tradicionales, el municipio de Burbáguena no va a presentar 
ningún evento en este sentido. Se han encontrado referencias a algunas prácticas tradicionales más relacionadas con la matanza y la exaltación de productos típicos del cerdo. Así la "matacía del cerdo" o la elaboración de “panecicos” son algunos ejemplos (Alcañíz y Loraque, 2006) (Figura 187).
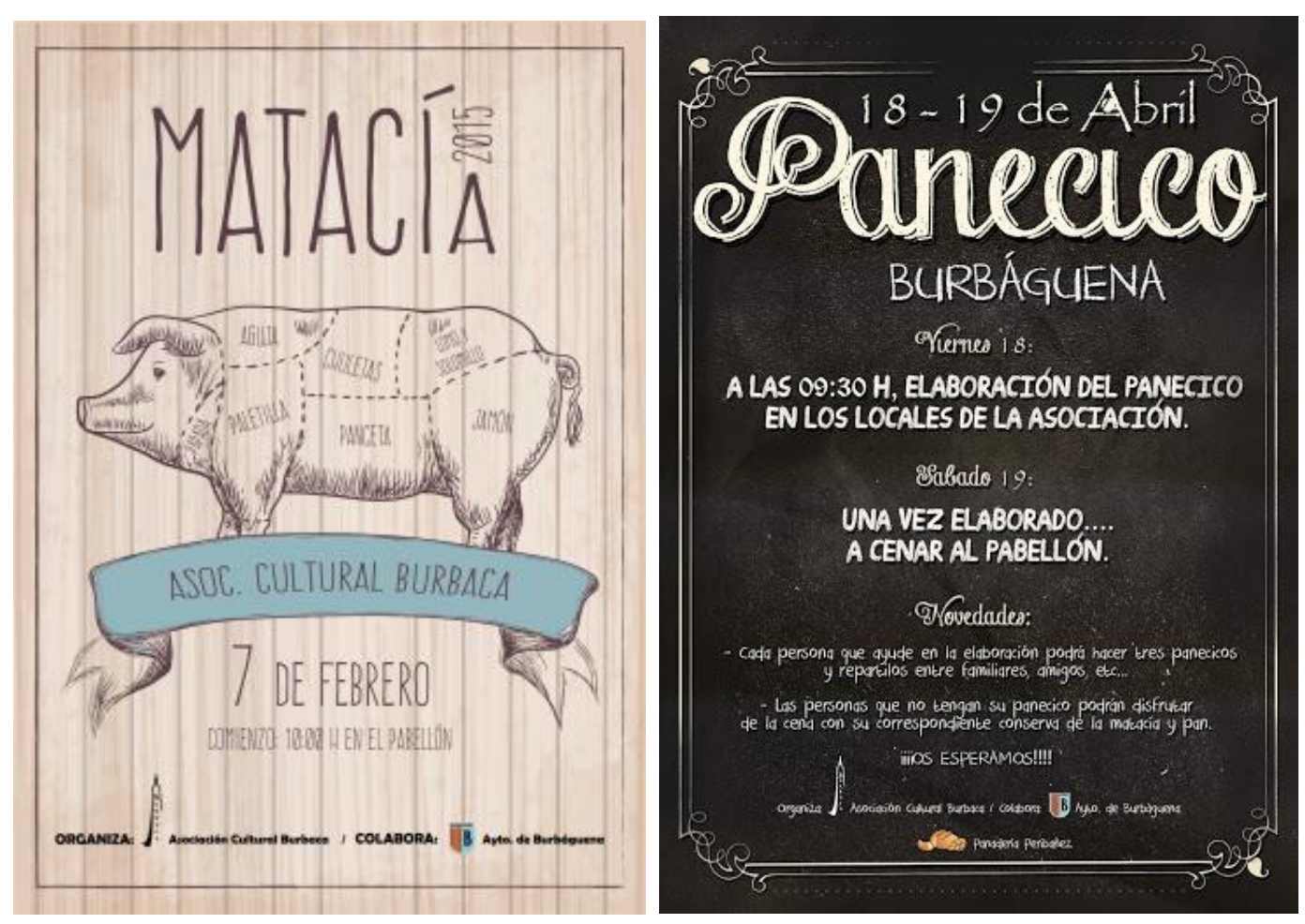

Figura 187. Cartel que anuncia la jornada de exaltación de la matanza del cerdo y cartel que anuncia las jornadas gastronómicas del "panecico". Recuperado de https: //burbaca.wordpress.com/

Por último, en lo que se refiere a la existencia de mobiliario urbano que tenga como referencia el chopo cabecero, sus prácticas tradicionales o sus productos no se han encontrado referencias. En este sentido es destacable la existencia de un escultor local, José Azul, que realiza escultura metálica y que ha diseñado diferentes obras destinadas a la escultura pública destacando la escultura que va a servir como premio para la Fiesta del Chopo Cabecero que organiza el Centro de Estudios del Jiloca y que premia anualmente a una persona relevante para el mantenimiento 
de la cultura del chopo trasmocho, reconociendo al "Amigo del Chopo Cabecero" (Figura 188).

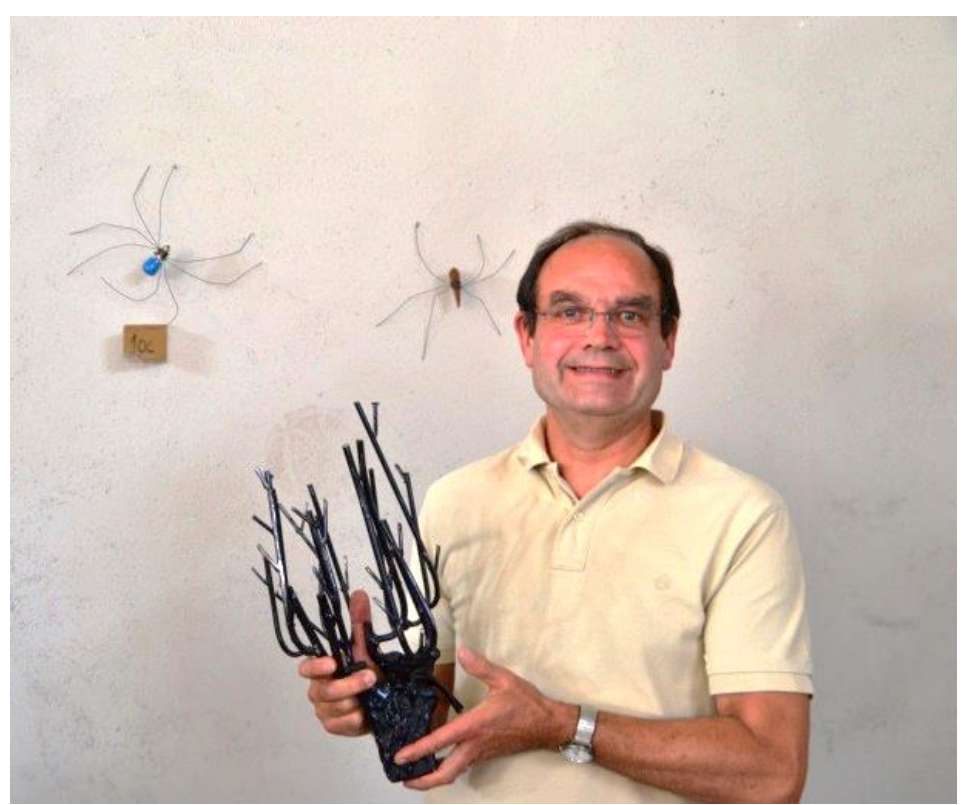

Figura 188. Dominique Mansion tras recoger el premio “Amigo del Chopo Cabecero". Recuperado de: http://www.xiloca.org/espacio/archivos/6890

De acuerdo con las premisas planteadas y las evidencias recogidas el indicador que va a tratar la museización del chopo cabecero se va a resolver con el cumplimiento del último de los criterios, el resto de los criterios propuestos no se cumplen (Tabla 76). 


\begin{tabular}{|c|c|c|}
\hline Criterio & Puntuación & Cumplimiento \\
\hline $\begin{array}{c}\text { Centros de interpretación/museos } \\
\text { oficiales }\end{array}$ & 4 & $\begin{array}{c}\text { No existen museos } \\
\text { ni centros de } \\
\text { interpretación }\end{array}$ \\
\hline Museos de particulares & 2 & $\begin{array}{c}\text { No se han } \\
\text { encontrado museos } \\
\text { particulares }\end{array}$ \\
\hline Jornadas de exaltación & 2 & $\begin{array}{c}\text { No existen jornadas } \\
\text { destinadas al chopo }\end{array}$ \\
\hline Mobiliario de exhibición o exaltación & 2 & $\begin{array}{c}\text { Premio “Amigo del } \\
\text { Chopo Cabecero" }\end{array}$ \\
\hline
\end{tabular}

Tabla 76. Resumen criterios cumplidos valoración indicador museística

10.8.5. Indicador 6. Incorporación turística

\begin{tabular}{|l|c|}
\hline Criterio & Puntuación \\
\hline Reivindicación turística supramunicipal & 4 \\
\hline Reivindicación turística municipal & 2 \\
\hline Reivindicación turística de particulares & 2 \\
\hline Reivindicación turística igual que otros elementos & 2 \\
\hline
\end{tabular}

Tabla 77. Resumen criterios valoración indicador Incorporación Turística

El patrimonio, actualmente, es utilizado de forma sistemática como reclamo turístico por lo que supone un testigo fiable para posicionar el momento patrimonial de un bien. Se parte de la premisa de que la incorporación a los reclamos o publicidad turística es directamente proporcional a la madurez del proceso, por lo que, mediante la recopilación de evidencias, se valorará lo relevante de la incorporación turística del paisaje forestal, en este caso del paisaje de los chopos cabeceros. En el 
apartado correspondiente (6.3.6) se ha planteado la escala de valoración que ayude a transformar los valores cualitativos en cuantitativos.

Este capítulo se ocupa del paisaje forestal protagonizado por los chopos trasmochos, conocidos en el sur de Aragón como chopos cabeceros. Por lo que las evidencias vienen determinadas por el uso, o no, de este paisaje como reivindicación turística. En cuanto al uso del paisaje del chopo cabecero como reclamo por parte de administraciones supramunicipales, entre las que se deben incluir el gobierno de Aragón, la Diputación Provincial de Teruel o la Comarca del Jiloca, hay que destacar que existe una preocupación por publicitar el turismo asociado a este paisaje vegetal, así el gobierno de Aragón presenta este paisaje como un patrimonio cultural visitable (Figura 189). De igual modo, aparece incorporado en la publicidad turística de la Comarca del Jiloca, así como en la web corporativa que publicita el Camino del Cid. Por otro lado, la diputación de Teruel en su página web turística no hace referencia al chopo cabecero, su declaración de Bien de Interés Cultural Inmaterial o a la existencia de un Parque Cultural inspirado en este paisaje forestal.

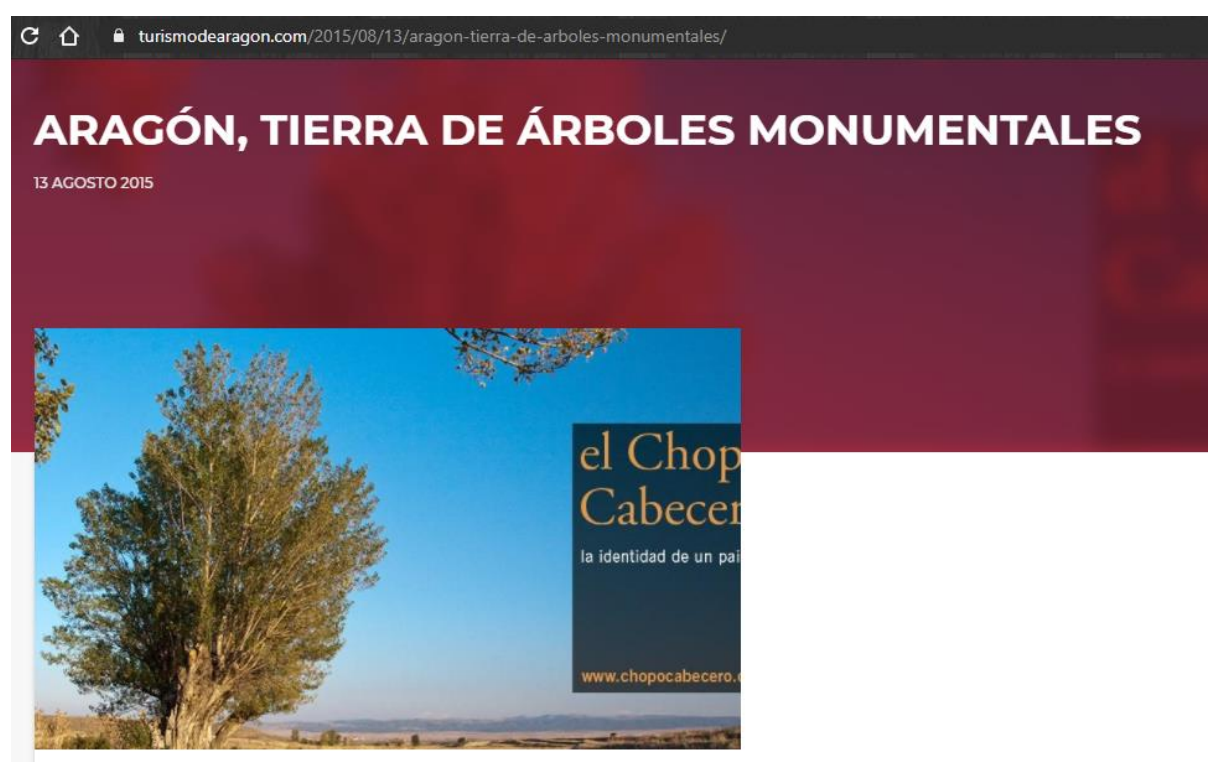

Figura 189. Publicidad turística en el portal Turismo de Aragón. Recuperado de https: / / www.turismodearagon.com/2015/08/13/aragon-tierra-de-arbolesmonumentales/ 
En lo que respecta al uso del chopo cabecero como reclamo turístico desde la administración municipal no se realiza una publicidad turística que ponga de manifiesto la existencia de estos ejemplares patrimoniales ni su cultura tradicional (Figura 190).

En cuanto a las iniciativas privadas que publiciten o se sirvan del paisaje forestal asociado a los chopos cabeceros se ha identificado una publicación en forma de revista de viajes que va a dedicar un ejemplar al paisaje del chopo cabecero y su potencial turístico (Figura 191).

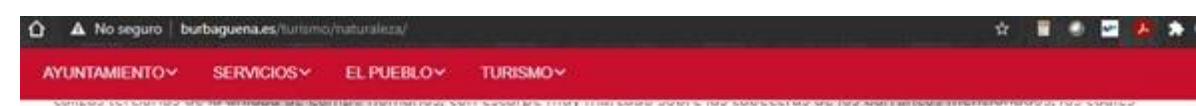

aparecen ocupados por masas forestales de pino carrasco, con un sotobosque pobre, tarto en variedad como en el grado de cobertura.

Uno de los lugares más importantes es la Laguna de Gallocanta, que se localiza entre las comarcas de Campo de Daroca y Jiloca. La reserva natural fue declarada como tal el 30 de noviembre de 2006.

Abarca una superficie de 1924 ha y otras 4553 ha de zona periférica de protección. Tiene longitud máxima de $7 \mathrm{~km}$ y una anchura máxima de $2 \mathrm{~km}$, siendo la mayos laguna natural de la peninsula bérica y junto con la laguna de Fuente de Piedra (provincia de Mallaga) es la mayor laguna salada de Europa. Tiene una profundidad media de 70 cm y la máxima es de $2 \mathrm{~m}$.

Es un buen ejemplo de cuenca endorreica de montaña, es decir, que no tiene salida al mar. Su aguas proceden principalmente de torrentes subterrdheos, por lo que su salinidad es muy alta: diez veces superior a la del agua de mar, lo que hace que en periodos secos se lleguen a formar a en sus playas costras de sal.

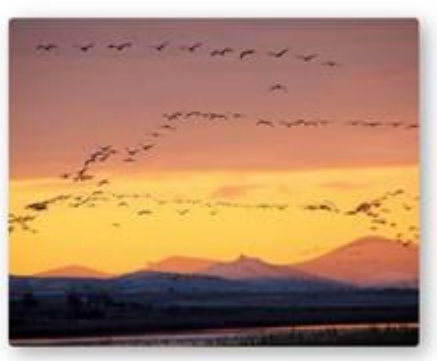

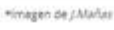

Figura 190. Captura del portal de turismo del Ayuntamiento de Burbáguena. Su publicidad turística se centra, de forma muy relevante, en la laguna de Gallocanta (fuera del término municipal). Recuperado de: http://www.burbaguena.es/turismo/naturaleza/ 


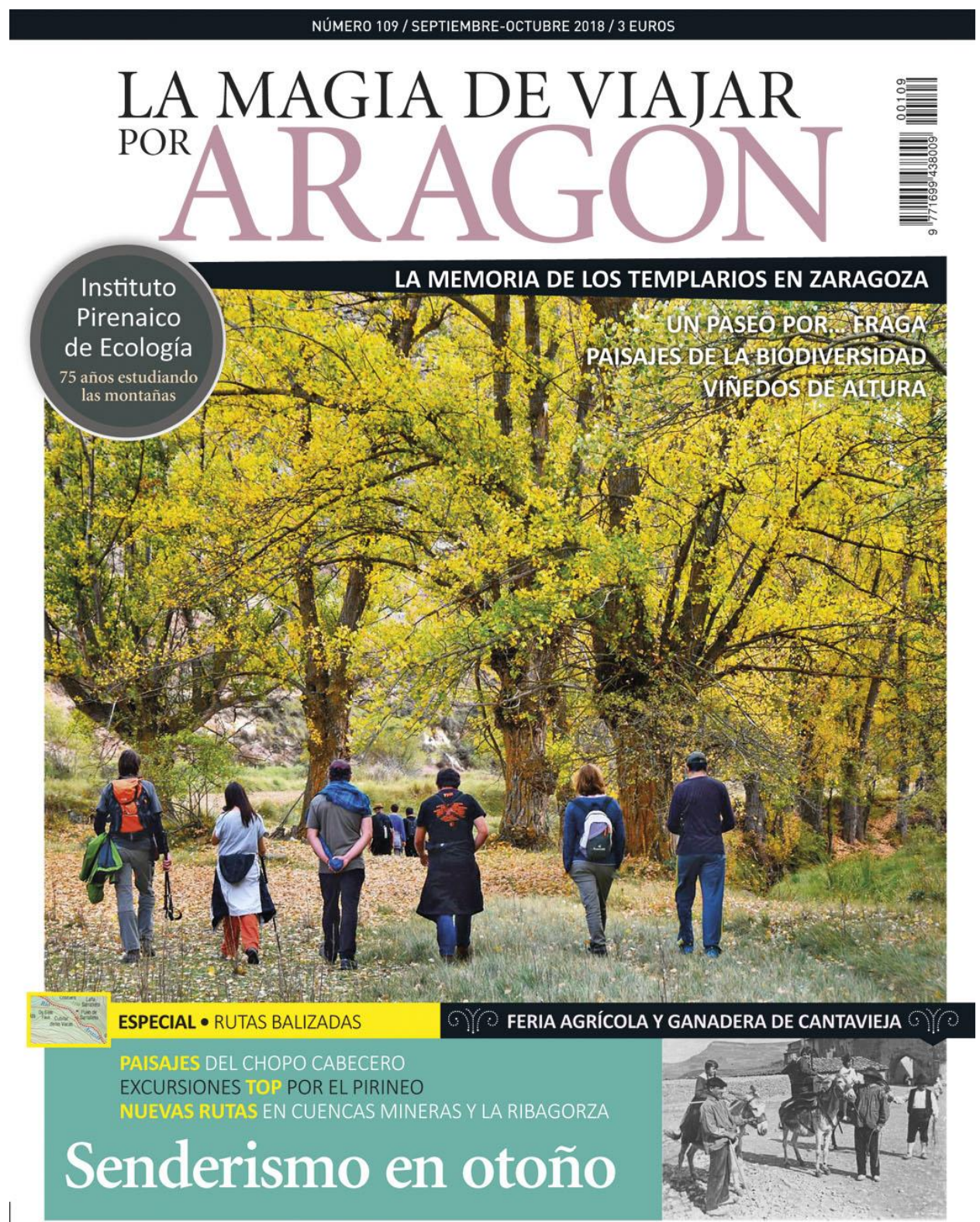

Figura 191. Portada del número 109 de la revista "La Magia de Viajar por Aragón". Recuperado de: https://www.lamagiadeviajar.com/index.php

Parece un hecho que existen reclamos turísticos asociados al paisaje de los chopos cabeceros, aunque son incipientes. Es la administración pública la que se erige como pionera en la utilización de este paisaje para completar la oferta turística, y es ahí donde se va a fundamentar la 
valoración de este indicador. El paisaje del chopo cabecero se presenta como un complemento que surge en los últimos años. En buena medida esta incorporación parece asociada a la necesidad de ofrecer "naturaleza" en una oferta turística excesivamente copada por aspectos arquitectónicos y etnológicos que van a ser los dominantes.

De acuerdo con estas premisas, el paisaje forestal y su activación turística en el municipio de Burbáguena solamente cumplirá el criterio destinado a valorar la activación turística por parte de las administraciones supramunicipales y por parte de la iniciativa privada.

\begin{tabular}{|c|c|c|}
\hline Criterio & Puntuación & Cumplimiento \\
\hline $\begin{array}{ll}\text { Reivindicación } & \text { turística } \\
\text { supramunicipal } & \end{array}$ & 4 & $\begin{array}{l}\text { Existe una amplia } \\
\text { reivindicación } \\
\text { supramunicipal }\end{array}$ \\
\hline $\begin{array}{ll}\text { Reivindicación } & \text { turística } \\
\text { municipal } & \end{array}$ & 2 & $\begin{array}{c}\text { No existe } \\
\text { reivindicación por } \\
\text { parte del ayuntamiento }\end{array}$ \\
\hline $\begin{array}{lll}\text { Reivindicación } & \text { turística } & \text { de } \\
\text { particulares } & \end{array}$ & 2 & $\begin{array}{c}\text { Existe una revista } \\
\text { privada que dedica un } \\
\text { ejemplar a este paisaje } \\
\text { forestal }\end{array}$ \\
\hline $\begin{array}{l}\text { Reivindicación turística igual } \\
\text { que otros elementos patrimoniales }\end{array}$ & 2 & $\begin{array}{c}\text { Elementos } \\
\text { arquitectónicos o } \\
\text { etnográficos destacan }\end{array}$ \\
\hline
\end{tabular}

Tabla 78. Resumen criterios cumplidos valoración indicador Incorporación Turística 


\subsubsection{Indicador 7. Empleo relacionado}

\begin{tabular}{|l|c|}
\hline Criterio & Puntuación \\
\hline Al menos 0,5\% ocupados en Silvicultura & 3 \\
\hline Al menos 5\% de ocupados en sectores relacionados & 3 \\
\hline Trabajadores silvicultura se incrementan & 2 \\
\hline Trabajadores relacionados se incrementan & 2 \\
\hline
\end{tabular}

Tabla 79. Resumen criterios valoración indicador Empleo relacionado

Este indicador pone de manifiesto la estrecha relación que existe entre el paisaje forestal y el empleo, siendo este último fundamental para vincular a la población local con su patrimonio. Esta relación activa la preocupación social por el elemento al reconocerlo como un nicho laboral. Por todo esto, se fija el empleo como un testigo fiable para situar el momento patrimonial del paisaje de los chopos trasmochos.

Atendiendo a los datos referentes al empleo recogidos por la Seguridad Social no se han encontrado puestos en actividades que estén relacionadas con los chopos cabeceros. El pequeño municipio de Burbáguena que sirve como testigo para este análisis apenas presenta actividades más allá del sector primario que ocupa a 10 trabajadores y el gran nicho de empleo que supone la residencia de ancianos que va a ocupar a 40 trabajadores para 2015. El resto de las actividades van a ocupar a 25 trabajadores que se reparten por diferentes actividades principalmente de servicios como comercio u hostelería. Tan solo se ha encontrado un trabajador relacionado con la industria de la madera y el corcho para el año 2011 y que no se verá reflejado en años posteriores (Figura 192). De acuerdo con estos datos no se puede establecer ninguna relación entre los chopos cabeceros y actividades relacionadas con su explotación o mantenimiento. 


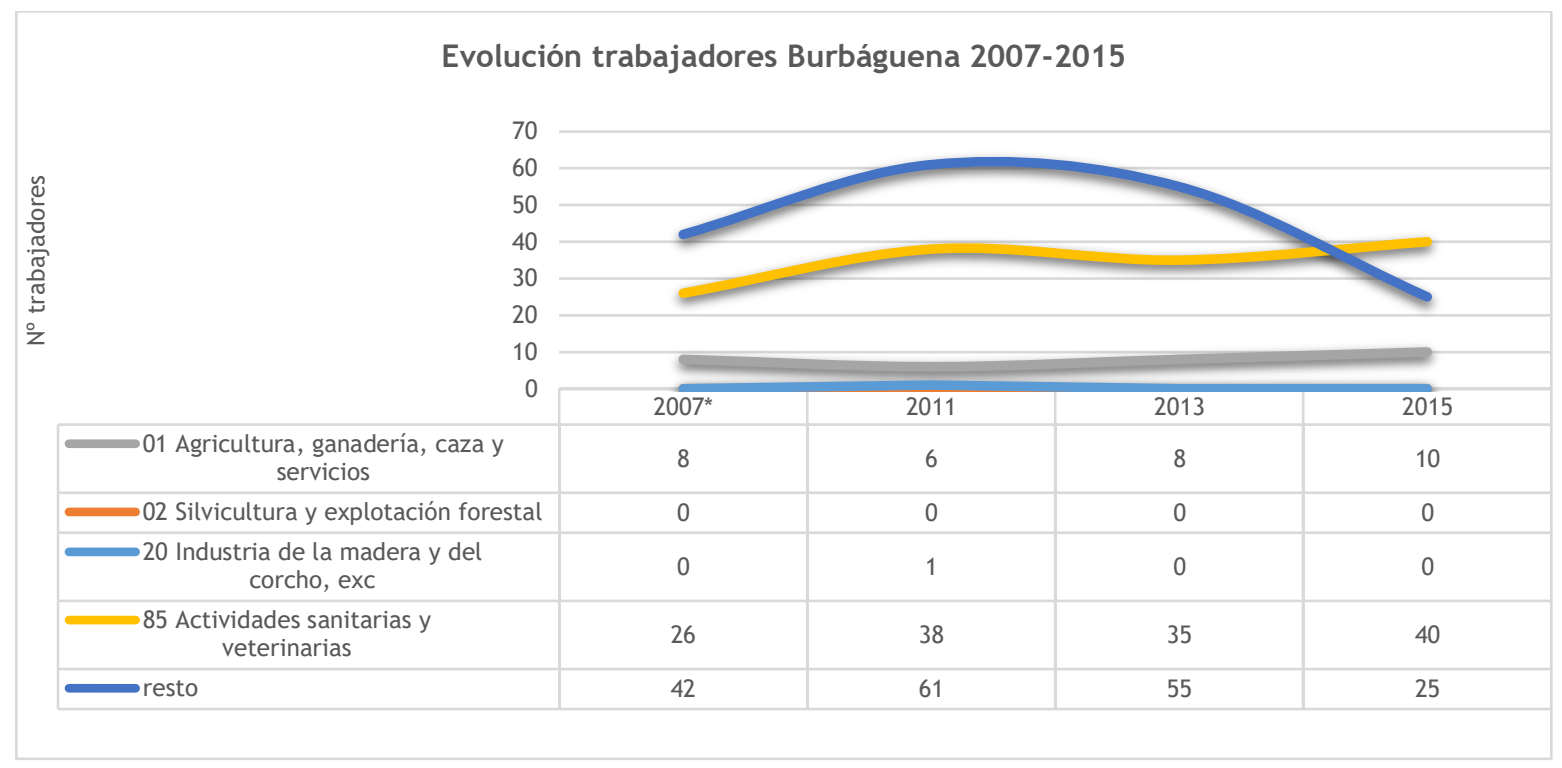

Figura 192. Distribución temporal de los trabajadores en el municipio de Burbáguena. Elaboración propia a partir de Datos Seguridad Social. CNAE dos dígitos desagregado municipal. *transformación códigos CNAE93/CANE09

A la luz de toda esta información, la relación que existe entre el valor de uso de los chopos cabeceros es inexistente por lo que no se cumple ninguno de los indicadores planteados.

\begin{tabular}{|c|c|c|}
\hline Criterio & Puntuación & Cumplimiento \\
\hline Al menos 0,5\% ocupados en & 3 & No hay ocupados \\
Silvicultura & 3 & No se encuentran \\
ol menos 5\% de ocupados en sectores & & No se produce \\
relacionados se & 2 & ningún incremento \\
\hline $\begin{array}{l}\text { Trabajadores silvicultura se } \\
\text { Trabajadores relacionados }\end{array}$ & 2 & No se produce \\
\hline
\end{tabular}

Tabla 80. Resumen criterios cumplidos valoración indicador Empleo relacionado 
Estudio de casos y aplicación práctica. Paisajes forestales con valor patrimonial.

\subsubsection{Valoración final}

\begin{tabular}{|l|l|}
\hline Indicador & Valoración \\
\hline I1. Complejidad biológica & 6 \\
\hline I2. Figuras de protección & 0,5 \\
\hline 13. Existencia de vectores & 3 \\
\hline 14. Identificación y sentimiento de pertenencia & 0 \\
\hline 15. Centros de interpretación/museos & 2 \\
\hline 16. Incorporación turística & 6 \\
\hline 17. Empleo relacionado & 0 \\
\hline & Valoración final \\
\hline
\end{tabular}

Tabla 81. Valor obtenido por cada uno de los indicadores propuestos para el paisaje referente al municipio de Burbáguena.

\section{Bosque de acompañamiento agropecuario: Trasmochos del Valle del Jiloca}

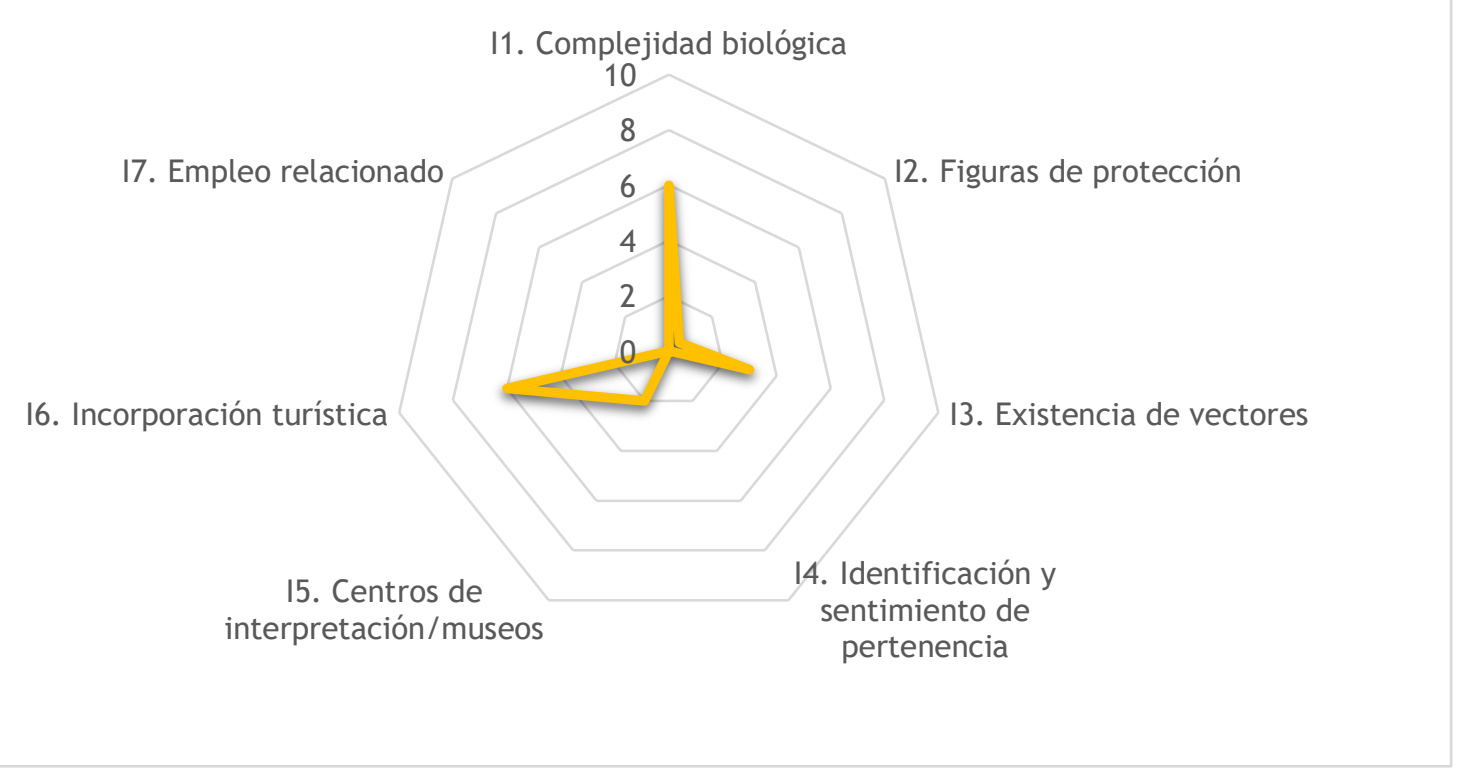

Figura 193. Representación de la situación patrimonial de los chopos trasmochos en Burbáguena según los indicadores analizados. Elaboración propia 


\section{Capítulo 11. Los árboles monumentales. Los Tejos catalogados en Castilla y León.}


Este capítulo se va a ocupar no tanto de articular un relato en torno al paisaje donde el protagonista será una formación vegetal, sino que se ocupa de indagar en torno a ejemplares concretos y únicos, ejemplares que podrían escribirse con mayúscula, se trata de árboles que son reconocidos de forma individual así que será un ejemplar en cuestión, y no otro, el protagonista de este análisis. En este caso se trata de ejemplares de especial consideración, atendiendo a sus condiciones estéticas, de excepcionalidad o singularidad. Serán estos valores los que conviertan a estos árboles en susceptibles de ser considerados un paisaje patrimonial.

\subsection{Distribución y localización del área de estudio}

El ámbito de estudio escogido para este capítulo que se ocupa de ejemplares monumentales va a ser el ámbito autonómico de Castilla y León, al haber sido este el escogido para una declaración administrativa de protección, reconocimiento o salvaguarda para determinados ejemplares arbóreos repartidos por la Comunidad. Castilla y León, a través de la Consejería de Medio Ambiente y mediante el "Catálogo de Especímenes Vegetales de Singular Relevancia de Castilla y León" ha generado un listado de ejemplares arbóreos que serán reconocidos por su valor patrimonial, su significado cultural, histórico o científico de singular trascendencia (Junta de Castilla y León, 2003). Concretamente se ha escogido una especie dentro de este amplio catálogo con el objetivo de centrar el análisis, concretamente han sido los tejos (Taxus baccata L.) al considerarlos una especie con un poso cultural excepcional dentro del conjunto de especies que contempla el catálogo. Esta declaración es la base que sirve para delimitar el ámbito de estudio de este capítulo (Figura 194). 


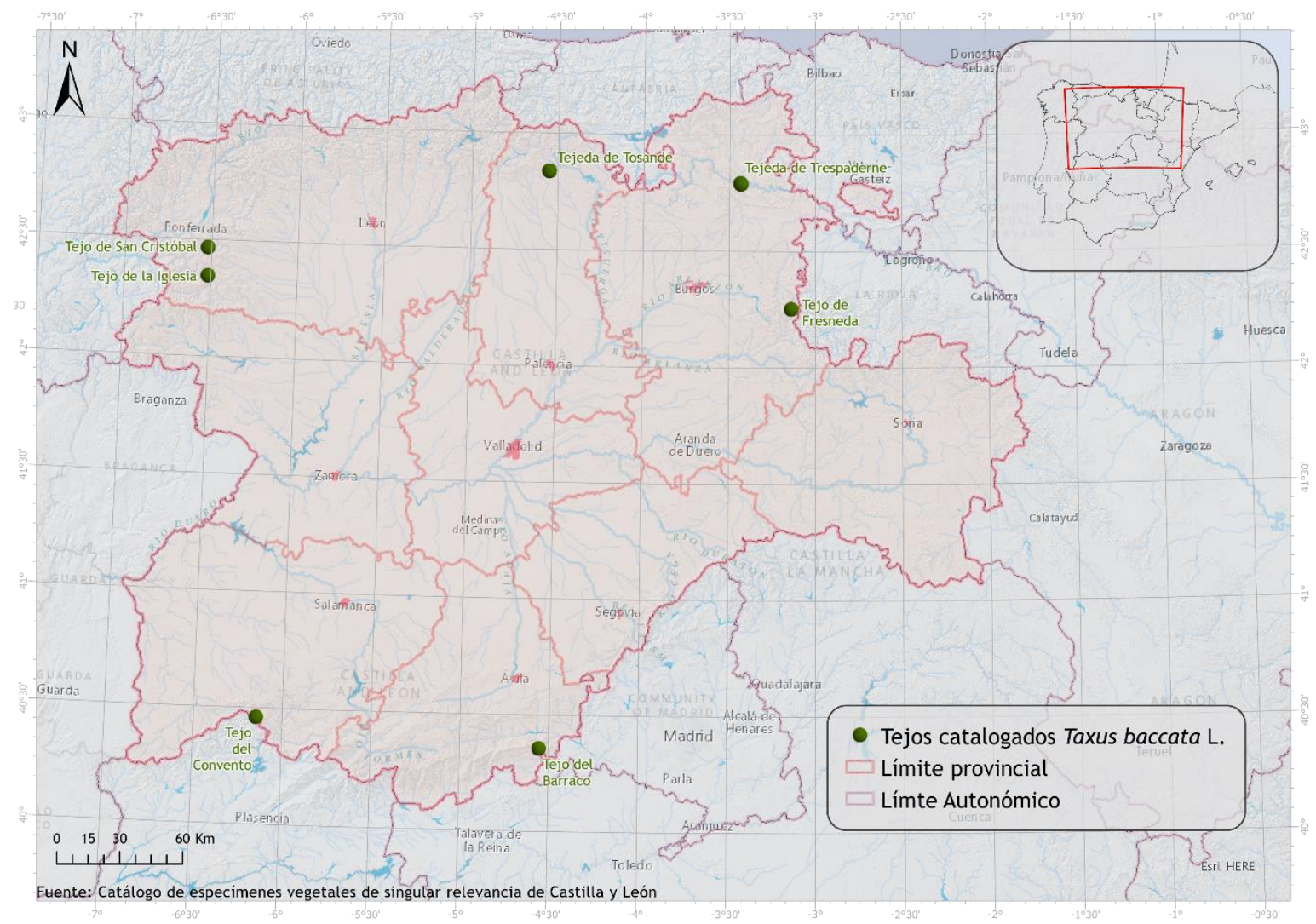

Figura 194. Mapa con los tejos catalogados por la Junta de Castilla y León como especímenes vegetales de singular relevancia. Elaboración propia a partir de Catálogo de Especímenes Vegetales de Singular Relevancia de Castilla y León.

Los tejos catalogados por la Junta se van a distribuir por la orla montañosa que delimita la Autonomía. Concretamente existen dos ejemplares catalogados en la comarca del Bierzo, concretamente en los Montes de León en las localidades de San Cristóbal de Valdueza y Noceda de Cabrera; tres ejemplares en la tejeda de Tosande en Dehesa de Montejo, en la montaña palentina; tres ejemplares en el municipio de Trespaderne (Burgos), los conocidos como Tejos de la Horadada en la Sierra de Tesla; un tejo en Fresneda de la Sierra Tirón (Burgos) en la Sierra de la Demanda; un ejemplar en la Reserva Natural del Valle de Iruelas en el municipio de El Barraco en Ávila y un ejemplar en el paraje de Las Batuecas, perteneciente al municipio de La Alberca en Salamanca. 


\subsection{Caracterización del área de estudio}

Todos los tejos catalogados por la Consejería de Medio Ambiente de la Junta de Castilla y León comparten la singularidad de encontrarse en espacios de especial dificultad para acceder, si bien es cierto que unos se encuentran en lugares más dificultosos, en general su existencia va a derivar de esta situación de aislamiento. Los once ejemplares contemplados como monumentales pueden agruparse en tres tipologías.

Por un lado, aquellos que aparecen anexos a una construcción de carácter religioso y que, pese a no ser de fácil acceso, se encuentran en un espacio claramente antropizado. Este va a ser el caso de los tejos bercianos, que aparecen anexos a sendas ermitas (Figura 195 y Figura 196). Tambien podría considerarse en esta categoría el Tejo del Convento que se encuentra anexo al Monasterio Desierto de San Juan de Batuecas Carmelitas Descalzos, pese a no estar en un núcleo de población tiene una clara vinculación con esta edificación monástica (Figura 197).

Por otro lado, se encuentran los tejos catalogados inmersos en un bosque donde existen multitud de estos ejemplares, este es el caso de los Tejos de la Horadada (Figura 198) y de los Tejos de Tosande (Figura 199) que no tienen vinculación con elementos construidos, sino que forman parte de una formación vegetal más o menos natural.

Por último, los tejos que se encuentran totalmente aislados y no guardan relación con otros ejemplares de su especie. En esta categoría estarían los ejemplares de El Barraco (Figura 200), que se encuentra en el paraje de Los Cantos Gordos, junto al puerto de Casillas que va a comunicar el Valle de Iruelas con el Valle del Tietar y el tejo de Fresneda de La Sierra Tirón que se encuentra en el barranco de Zarzabala en pleno corazón de la Sierra de la Demanda (Figura 201). Ambos ejemplares presentan unas cualidades de aislamiento verdaderamente significativas. 


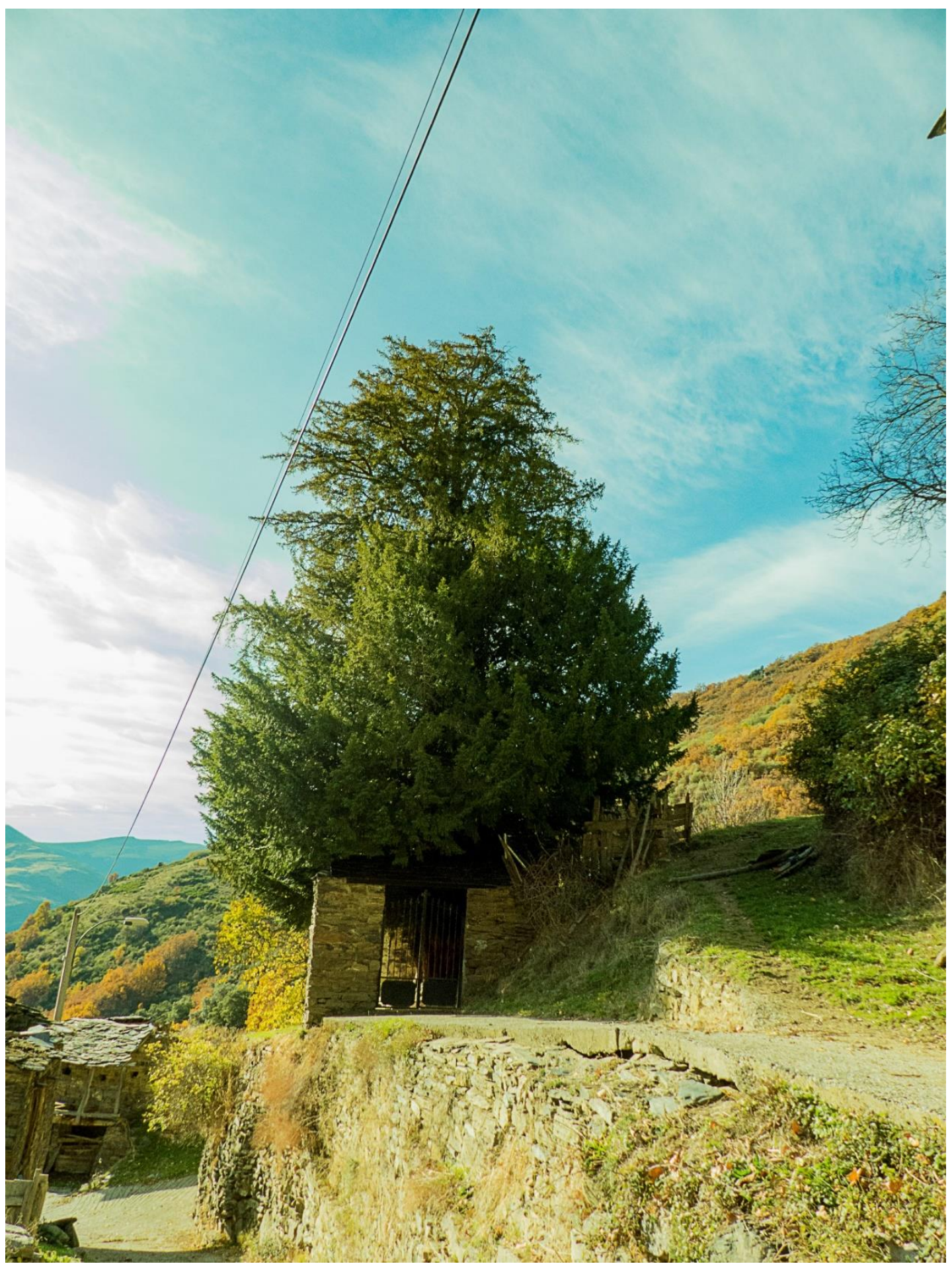

Figura 195. Tejo de la Iglesia en Noceda de Cabrera (AS-LE-03). Imagen propia. 
Estudio de casos y aplicación práctica. Paisajes forestales con valor patrimonial.

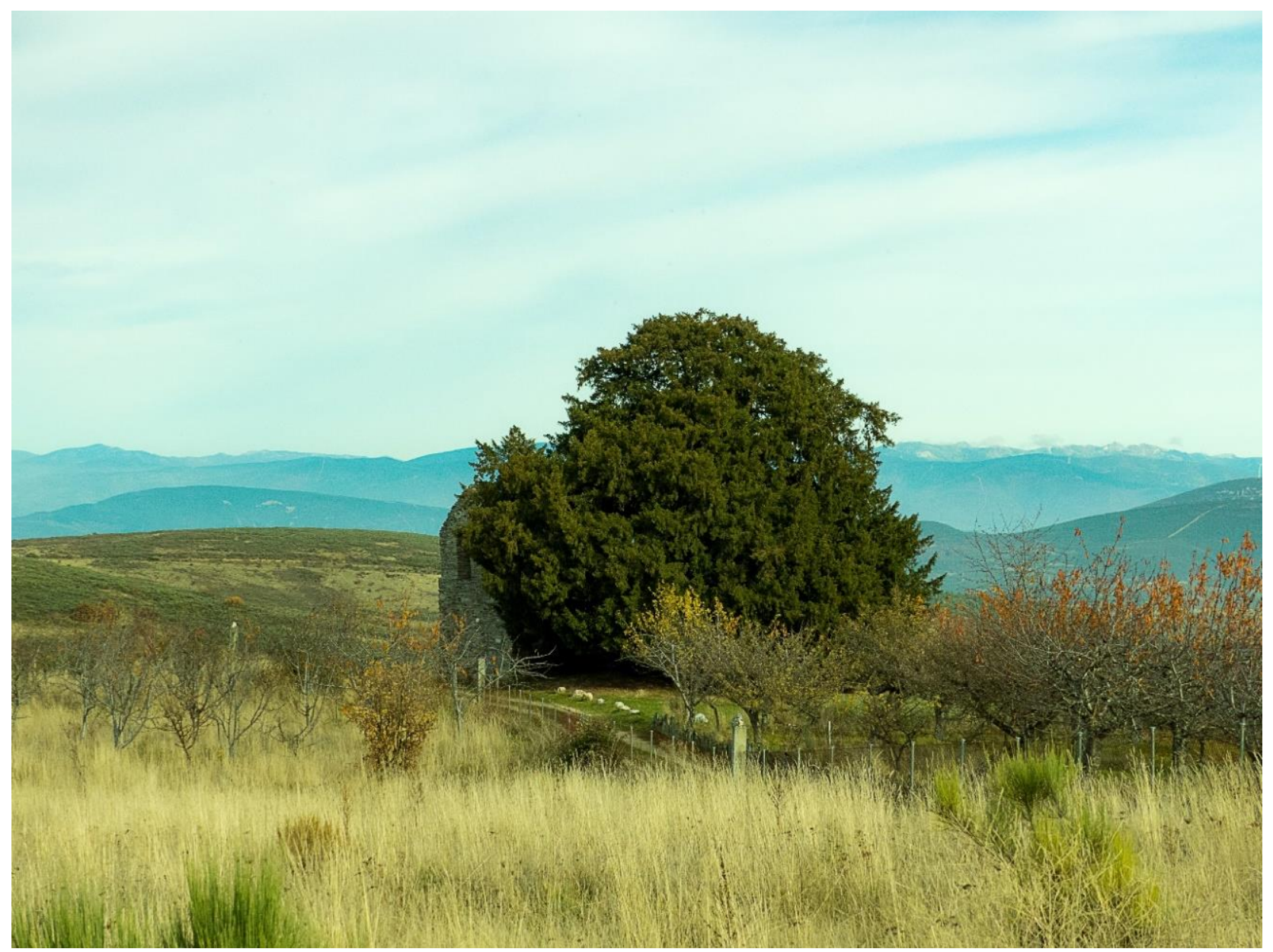

Figura 196. Tejo de San Cristóbal en San Cristóbal de Valdueza (AS-LE-04). Imagen propia. 


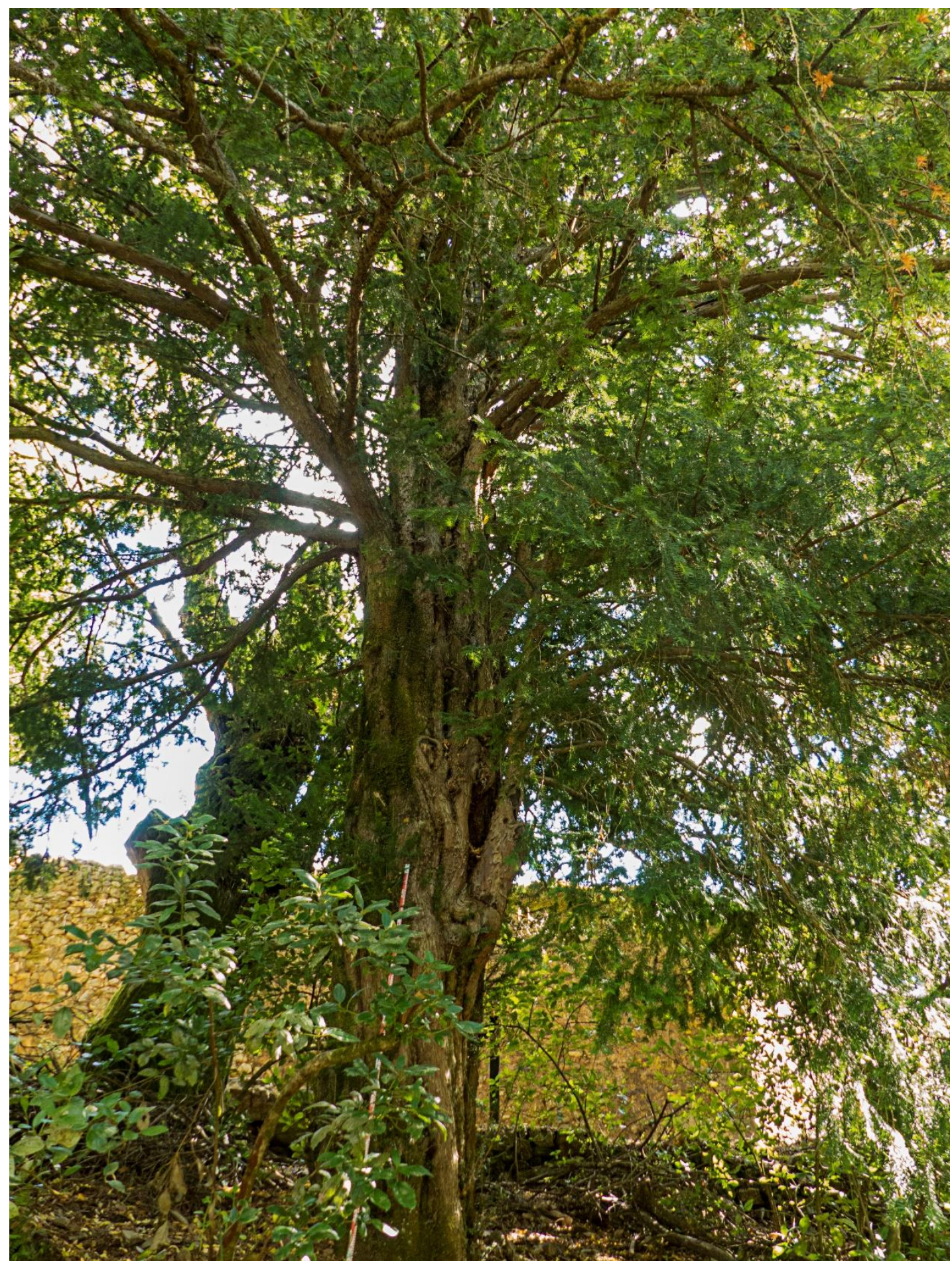

Figura 197. Tejo del Convento en Las Batuecas (AS-SA-05). Imagen propia. 


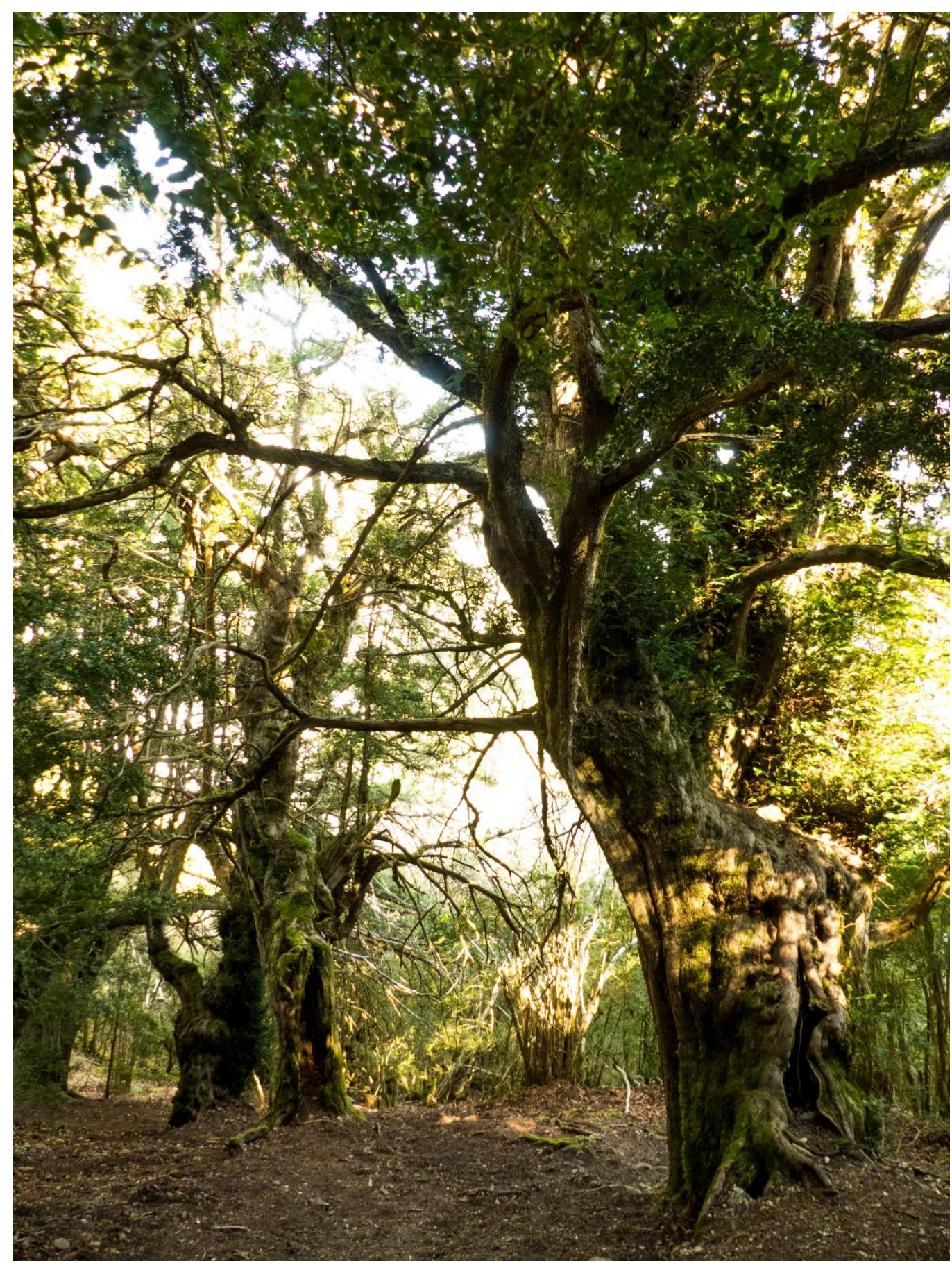

Figura 198. Tejos de la Horadada en el municipio de Trespaderne. Imagen propia. 


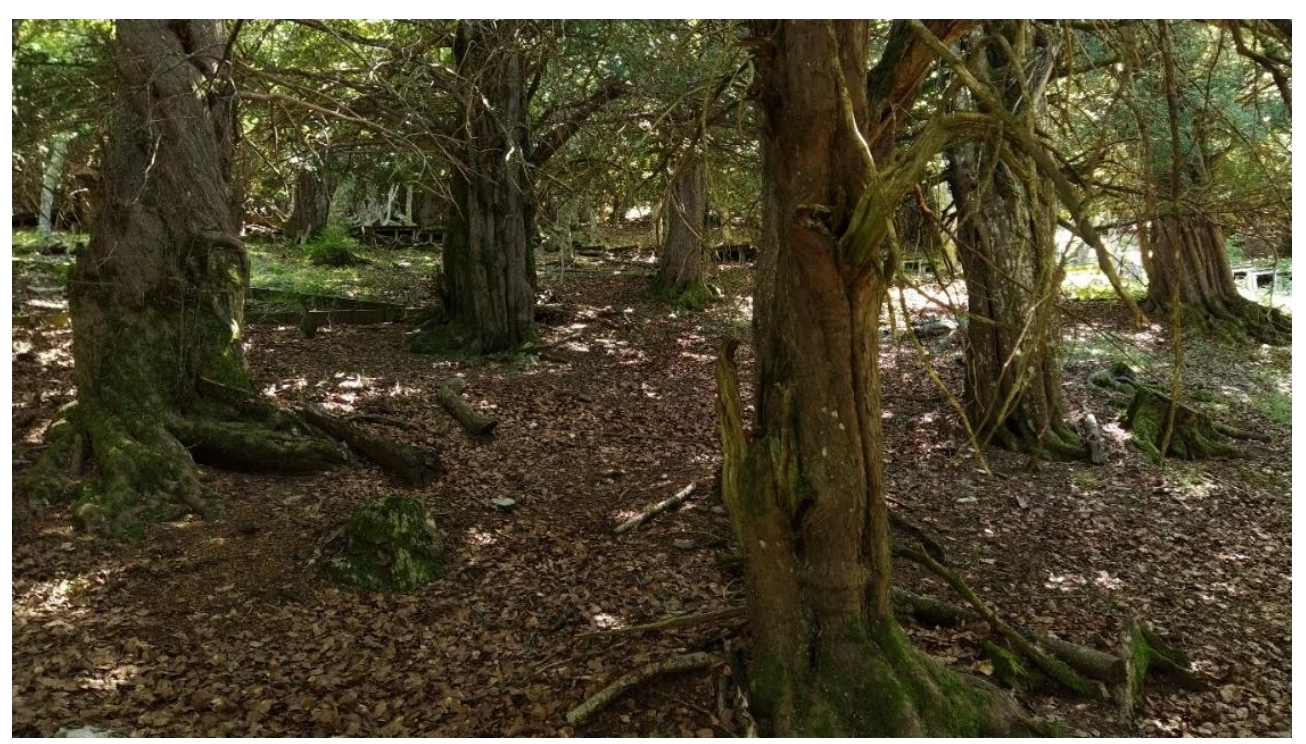

Figura 199. La Tejeda de Tosande en Dehesa de Montejo. Alfonso Pisabarro Pérez.

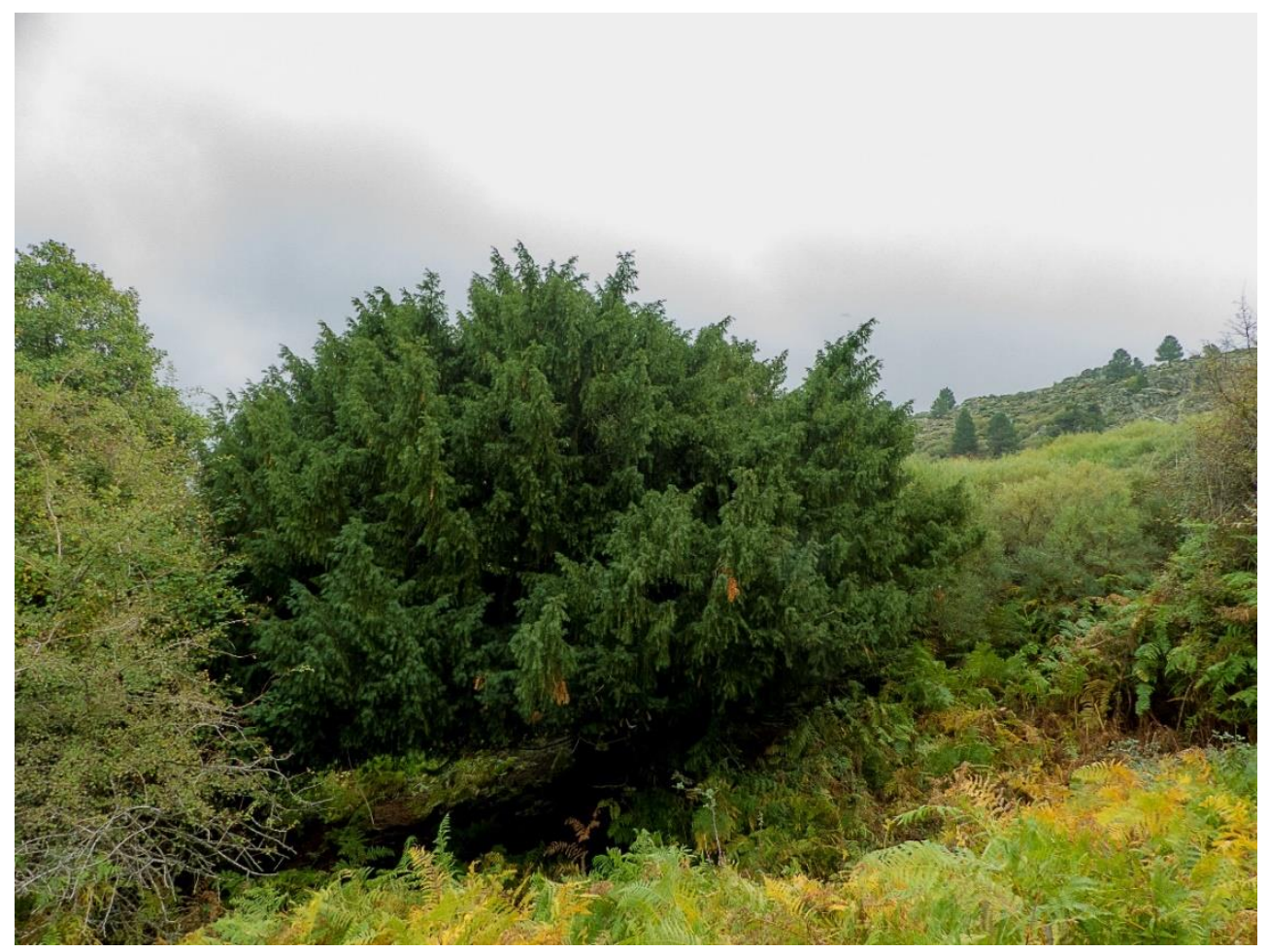

Figura 200. Tejo del Barraco (AS-AV-12). Imagen propia. 


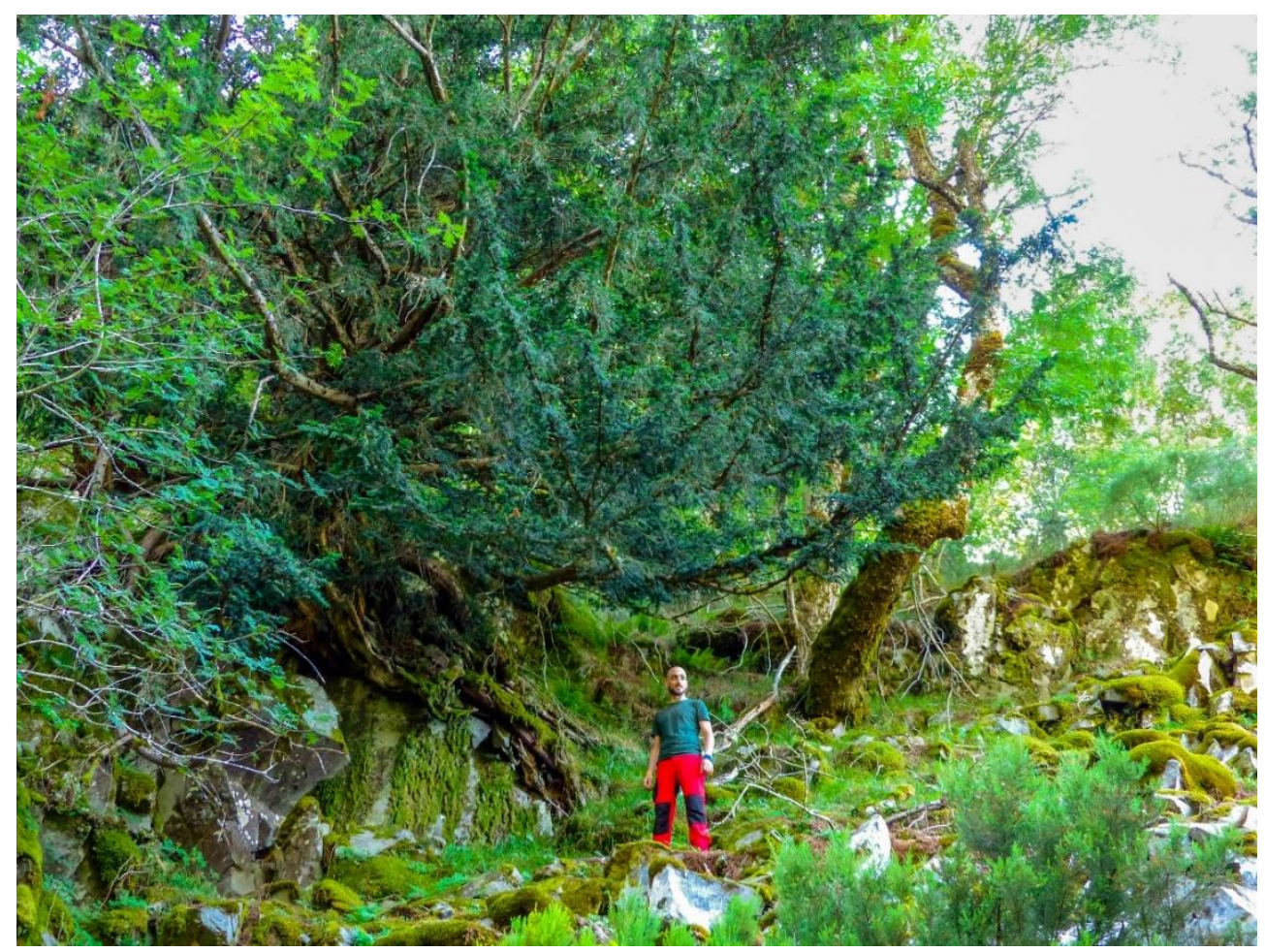

Figura 201. El Tejo de Fresneda en Fresneda de La Sierra Tirón (AS-BU-25). Imagen propia.

\subsection{El origen de los tejos}

El tejo, como especie vegetal de porte arbóreo supone una auténtica excepcionalidad en la realidad forestal peninsular. Como se ha explicado en el epígrafe correspondiente (2.1.1.4), se trata de un vestigio de la vegetación pretérita de al menos 200 millones de años. Estos árboles serían los últimos ejemplares de un proceso de retroceso derivado de la competencia de especies mucho mejor preparadas a las condiciones actuales, como las hayas e incentivado por la deforestación antrópica de la península y el favorecimiento de algunas especies más aprovechables. En líneas generales, los tejos se van a encontrar actualmente de manera aislada, como reflejo de la acción humana amparada en su valor místico y cultural o formando pequeños rodales, alejándose de la formación de 
bosques que pudieron poblar la península durante periodos pretéritos como el Holoceno medio (Pérez et al., 2013).

Para entender el porqué de los tejos en general y de los tejos catalogados por la Consejería de Medio Ambiente de la Junta de Castilla y León en particular, es necesario entender su valor cultural y patrimonial pues va a ser la clave de su existencia.

\subsection{El tejo, el valor patrimonial como garante de su existencia.}

Los tejos, en la Península Ibérica, se encuentran en una situación de regresión producida por la unión entre procesos naturales de competencia vegetal, donde especies arbóreas como las hayas compiten por el nicho ecológico y están mucho mejor preparadas para este cometido, pero tambien por procesos antrópicos en los cuales, el aprovechamiento maderero y el incentivo a otras especies vegetales más productivas han provocado un arrinconamiento de los tejos. Estos árboles tan singulares van a deber su distribución actual, fundamentalmente en las decisiones humanas.

Los tejos se erigen como un ejemplo de ideal vegetal, forma bosque umbrosos, con formas sinuosas, caóticas, parecería el resultado de un capricho natural, muy alejado de cualquier intervención o supervisión humana. En este sentido, su existencia genera una sensación de naturalidad muy cercana al gusto actual de preferencia clorofílica. Los tejos han sido y son un referente iconográfico cuando se quiere aludir a la vegetación natural (Figura 202). Los tejos no solo presentan esas características de improvisación natural que le otorgan admiración, sino que son un referente cultural, por ejemplo, el famoso bosque de Sherwood, donde Robin Hood se refugiaba, podría ser una tejeda o al menos contener estos árboles:

"And set my bright sword at my head

Mine arrows at my feet 
Estudio de casos y aplicación práctica. Paisajes forestales con valor patrimonial.

And lay my yew-bow by my side..."

"Y pon mi brillante espada en mi cabeza

Mis flechas a mis pies

Y tiende mi arco de tejo a mi lado..."

Traducción propia de (Matthews, 2016)
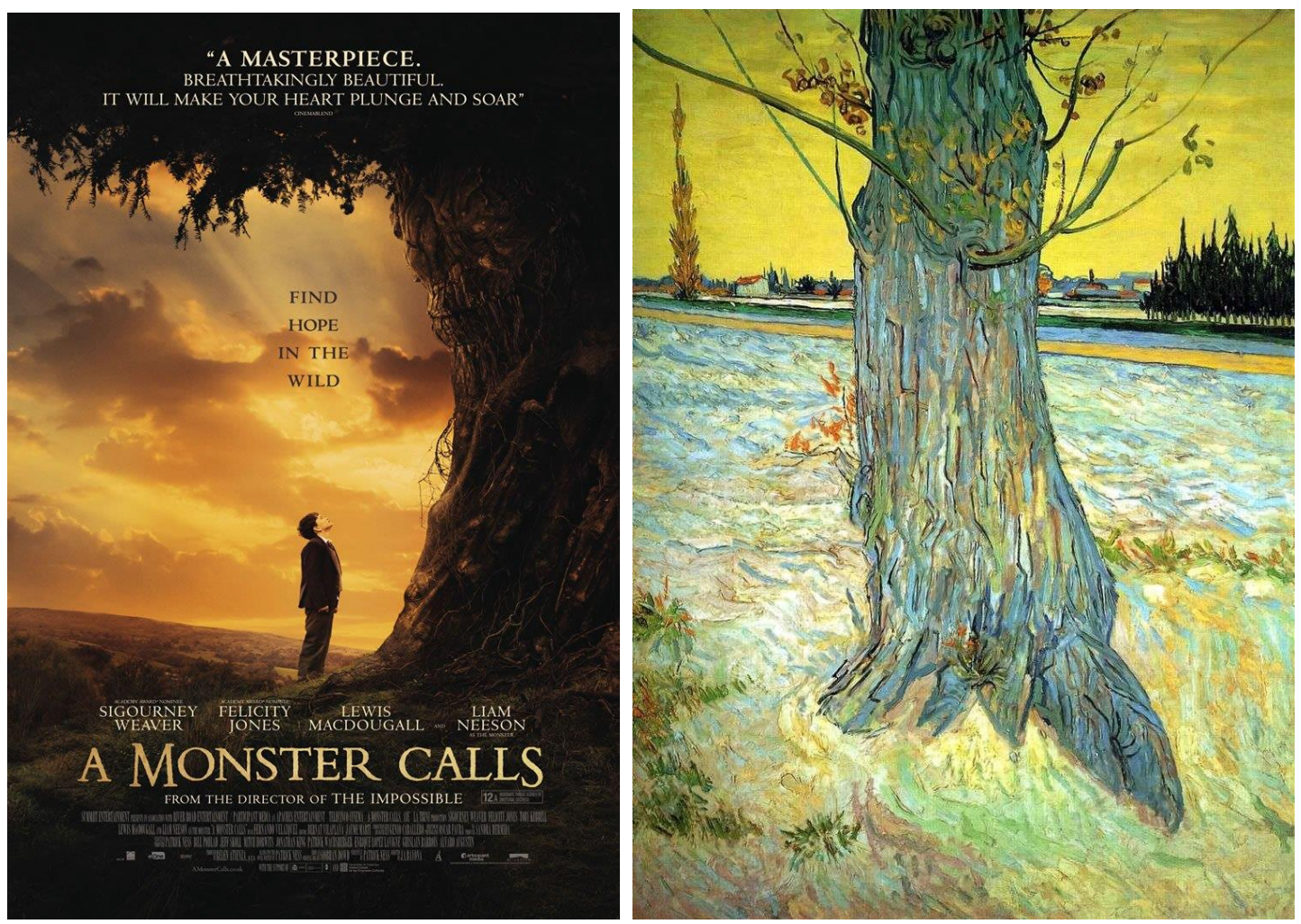

Figura 202. De izquierda a derecha: Cartel original de la película "Un Monstruo Viene a Verme", Juan Antonio Bayona. Pintura “El Tronco de Un Viejo Tejo”, Van Gogh 1888. Recuperado de: https://www.ecartelera.com/peliculas/un-monstruo-viene-averme/cartel/19048/ y https://painting-planet.com/el-tronco-del-viejo-tejo-vincentvan-gogh/ respectivamente.

Pero hay que ahondar en esta relación cultural para entender de forma adecuada la situación actual de los tejos en nuestra sociedad. La cultura 
del tejo hinca sus raíces mucho más profundo que en la siempre apariencia de naturalidad o como ejemplo icónico de bosque ideal. Los tejos han sido condensadores de valores por multitud de culturas y han ido pasando de una a otra sin solución de continuidad, se puede decir que el tejo está en el tuétano de la civilización (Rogers, 1905). Por todo el planeta aparecen referencias místicas que relacionan la vida, la muerte y el tejo (Hageneder, 2015), considerándose una manifestación de la existencia de Dios (Klein, 1987). Dentro de esta relación cultural que existe entre el tejo y las sociedades humanas es imprescindible hacer una especial mención a la cultura celta. Esta cultura que se dispersó por buena parte de Europa durante la Edad del Hierro tenía en común una estrecha relación con la naturaleza y atribuía los fenómenos naturales al control de los dioses, pero en lo que concierne al tejo en particular existen multitud de referencias que ponen de manifiesto el carácter espiritual y patrimonial de esta especie vegetal como ajuares mortuorios o figuras antropomorfas de madera de tejo (Delahunty, 2002). La relación cultural celta con el tejo se va a traducir en la posterior vinculación religiosa del cristianismo, de esta manera, el tejo va a continuar siendo un referente místico en las posteriores civilizaciones de tradición cristiana como atestigua la constante vinculación entre las edificaciones religiosas y los tejos. Esta vinculación parece que se explica a partir de un proceso de adaptación de lugares de veneración paganos (Neeson, 1991) en lo que supone un viaje de las iglesias hacia el árbol y que se consolida con la plantación de estos ejemplares en las posteriores construcciones (Lucas, 2017).

De acuerdo con esto, se podrían explicar, sin ningún género de dudas, tres de los once ejemplares que aparecen aledaños a edificios religiosos. El resto de los casos no pueden atribuirse a esta vinculación religiosa lo que permite asegurar que son resultado del asilamiento como vestigio de una extensión superior, más aún si se atiende a las características ecológicas de su emplazamiento, las cuales se adaptan a los requerimientos de esta especie (Abella, 2009). 
De cualquier manera, ya sea su existencia y pervivencia como resultado de cuestiones culturales, religiosas o biológicas, los tejos son actualmente árboles misteriosos que albergan una admiración especial y que han sido reconocidos por diferentes administraciones como ejemplares singulares o monumentales (Junta de Castilla y León, 2003; Presidencia y consellerías de la generalitat Valenciana, 2006; Olabe et al., 2010).

\subsection{El proceso de patrimonialización a través de los indicadores.}

El objetivo de este epígrafe es la valoración, mediante una serie de indicadores planteados en el apartado (6.3). Como ya se ha planteado, la escala de comparación debe restringirse a los límites municipales. El caso de estudio del que se ocupa este capítulo, pese a responder a distintos municipios, posee una escala autonómica ya que se encuentran dispersos por toda la Comunidad de Castilla y León. Debido a esto se hace necesario definir un municipio que sirva como testigo en la comparación de los procesos que se lleva a cabo. Los tejos monumentales, como se ha visto, se encuentran situados en la orla montañosa que circunda la Autonomía lo que va a introducir una peculiaridad basada en su extraordinaria lejanía determinando características demográficas, sociales, económicas, climáticas o paisajísticas completamente diferentes. Ante estas diferencias encontradas en los municipios que albergan alguno de los tejos catalogados por la Junta de Castilla y León se ha optado por analizar todos los municipios por separado (ver Anexo) con el objetivo de escoger aquel que presente unos resultados medios en el análisis de los indicadores, de esta manera se pretende excluir aquellos que pudieran presentar singularidades que falseen el proceso de patrimonialización del conjunto. De esta manera, se garantiza que, el municipio escogido será un testigo fiable para la comparación con el resto de los casos de estudio.

De acuerdo con lo planteado el municipio que ha resultado como representante del conjunto y que será el testigo del proceso de 
patrimonialización es La Alberca (Figura 203). El tejo presente en este municipio de Salamanca supone un caso intermedio entre la acumulación de figuras de protección de espacios como la Cordillera Cantábrica y la ausencia total de los ejemplos presentes en El Bierzo, igualmente el tejo de La Alberca aparece junto a construcciones que actúan como vectores, pero fuera del núcleo urbano lo que va a suponer un punto medio entre la situación de los tejos propiamente forestales y aquellos que son claramente un ejemplar ornamental. Se puede asegurar, por tanto, que se va a tratar de un testigo que arroje resultados intermedios que no falseen el resultado del conjunto de tejos monumentales.

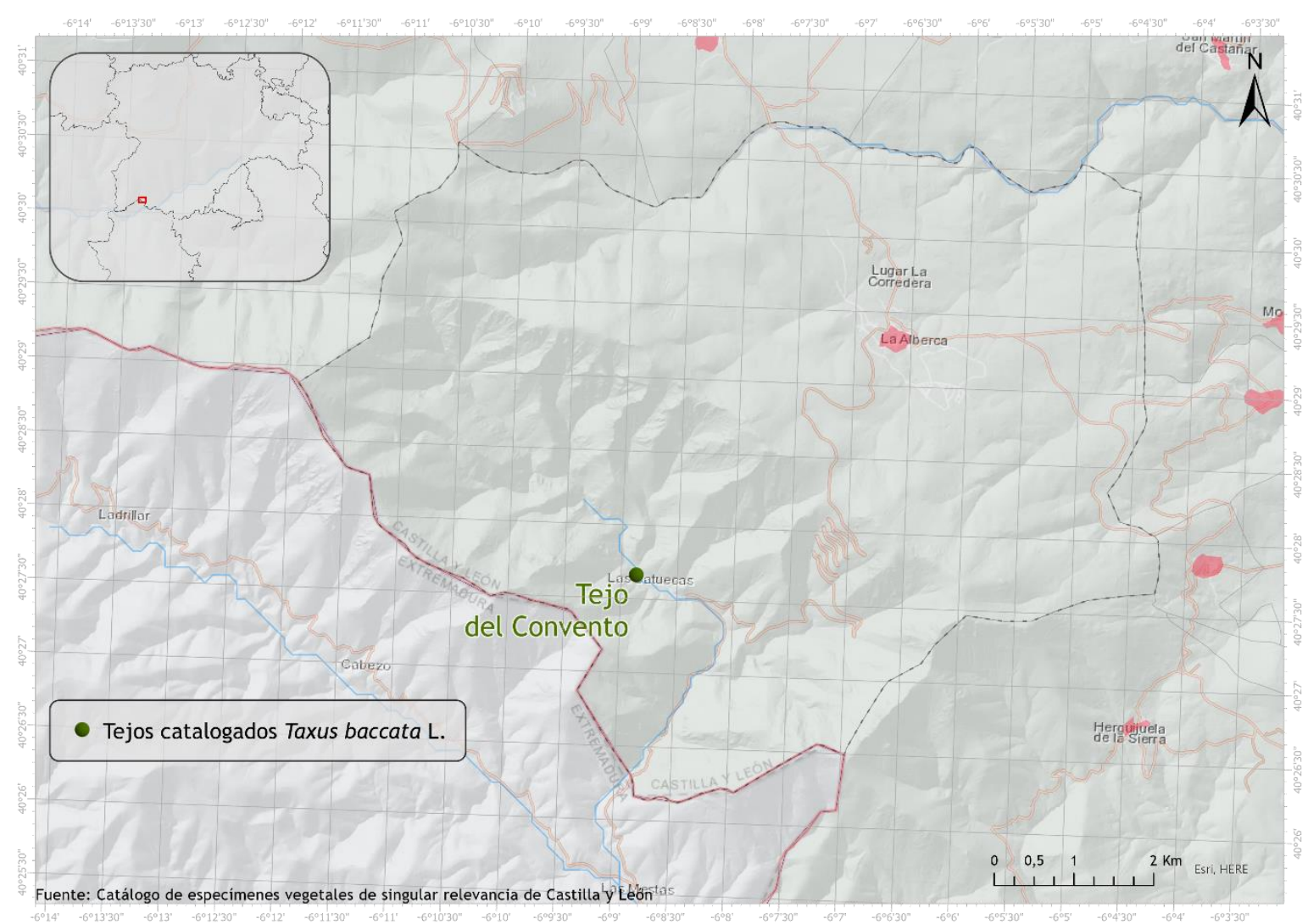

Figura 203. Mapa con el Tejo del Convento, en el municipio de la Alberca, catalogado por la Junta de Castilla y León como Especímene Vegetal de Singular Relevancia”. Elaboración propia. 


\subsubsection{Indicador 1. Complejidad biológica}

\begin{tabular}{|l|c|}
\hline Criterio & Puntuación \\
\hline Evidencias bibliográficas de naturalidad & 3 \\
\hline Hábitat de Interés Comunitario & 4 \\
\hline Salud vegetal NDVI (observación directa) & 3 \\
\hline
\end{tabular}

Tabla 82. Resumen criterios valoración indicador Complejidad Biológica.

El primer indicador valora, mediante la recopilación bibliográfica y la observación directa, la complejidad o riqueza biológica del paisaje forestal en cuestión, en este caso el paisaje asociado a los tejos recogidos en el Catálogo de Especímenes Vegetales de Singular Relevancia de Castilla y León. Estos tejos suponen un “monumento" vivo que es considerado por sus “medidas excepcionales, por su edad, conformación, historia, particularidad científica, por su interés ecológico, paisajístico o cultural" (Junta de Castilla y León, 2003). En este caso serán los valores ecológicos los relevantes para valorar este indicador.

Los tejos mediterráneos están reconocidos como hábitats prioritarios para la conservación de la biodiversidad en la Unión Europea (Comisión Europea, 1992) y se han visto recluidos a refugios muy inaccesibles como resultado de la regresión previa a la Edad del Hielo (Bennett et al., 1991) y a la influencia humana (0'Connell y Molloy, 2001), principalmente por las prácticas de pastoreo (Farris y Filigheddu, 2008). Esta singularidad, por si sola, ya los hace una especie de especial importancia biológica. Pero es en sus características genómicas donde se encuentra su mayor riqueza ya que se trata de una especie muy poco evolucionada por lo que es un refugio genético de primer orden para estudiar la evolución biológica durante el cretácico (Hsu et al., 2014).

Pero no solo el tejo como elemento aislado, sino que sus bosquetes o rodales presentan características muy cercanas a la concepción perfecta de bosque natural, sombrío, nemoroso, copado por líquenes y musgos, en 
definitiva, resultado aparente de las leyes naturales. Se puede afirmar que un bosquete de tejos es la representación perfecta de ese ideal anteriormente definido como "clorofilia" (Figura 204).

Los tejos escogidos para el estudio, en la mayoría de las ocasiones, suponen un elemento aislado y descontextualizado de su ecosistema. Aunque por otro lado poseen una estrecha relación con el ideal de bosque natural y poseen una importante función de reservorio genético, por lo que se da por cumplido el primer criterio de valoración.

En lo que se refiere a la relación del tejo monumental de La Alberca y las formaciones catalogadas como Hábitat de Interés Comunitario, hay que señalar que se encuentra ubicado dentro de la delimitación que comprende la formación de aliseda mediterránea (Scrophulario scorodoniae-Alnetum glutinosae) pero esto se debe a su ubicación cercana al cauce del río Batuecas que presenta esta vegetación ripícola (Figura 205), pero que no presenta una relación directa con esta formación. De acuerdo con esto el criterio no se cumple. 


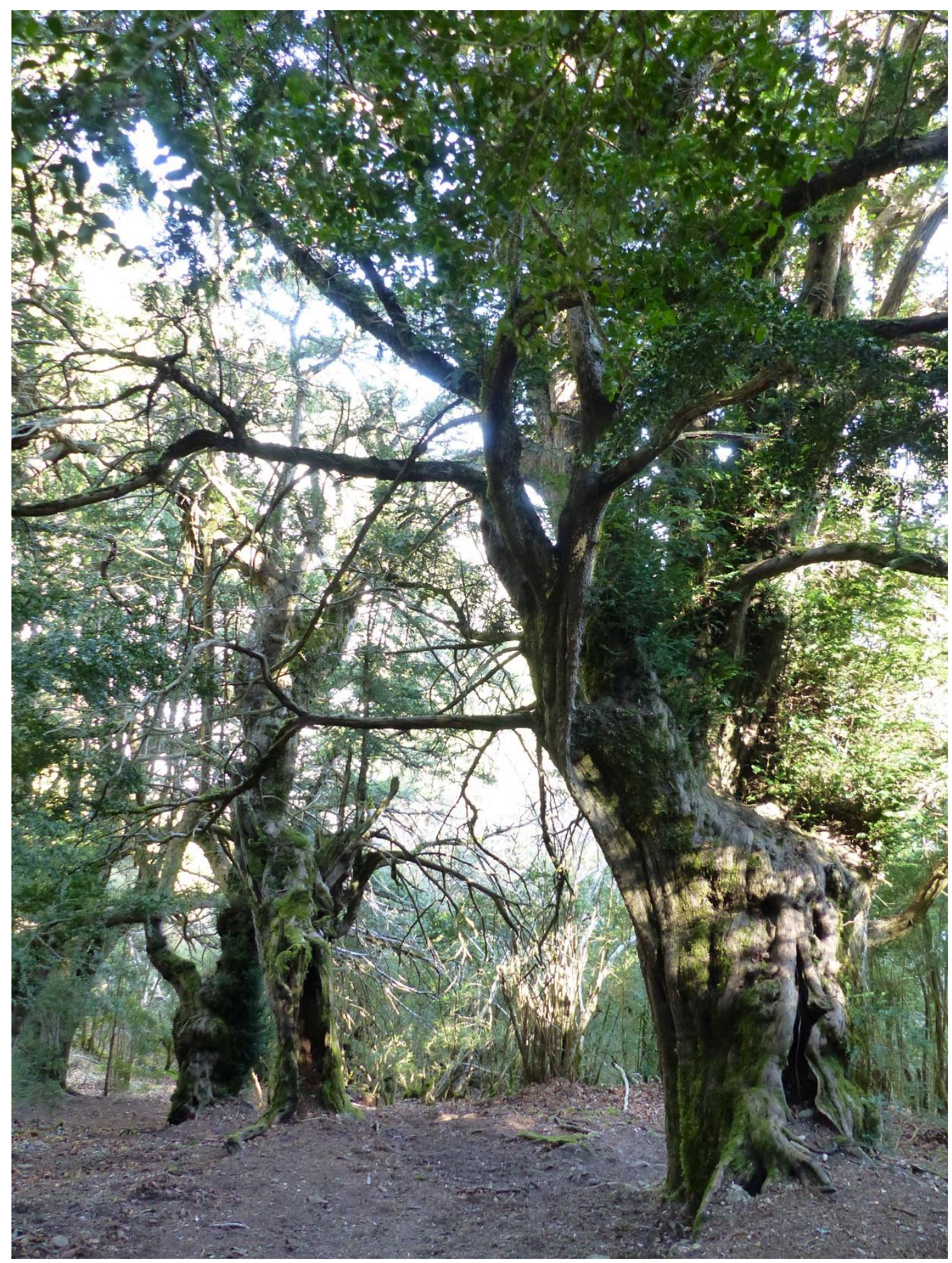

Figura 204. Tejeda de Trespaderne (Burgos), un ejemplo de bosque al gusto actual. Imagen propia. 


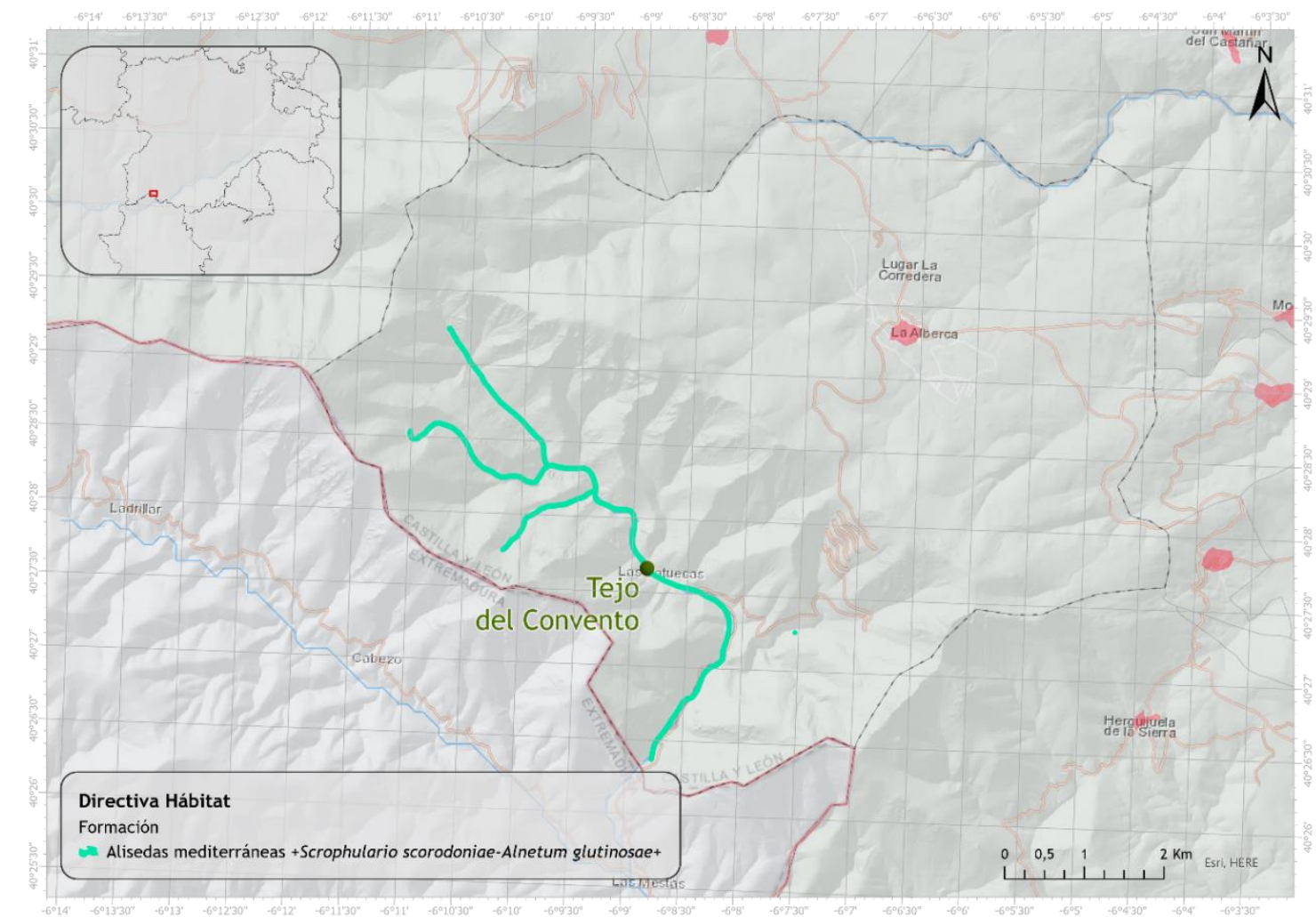

Figura 205. Mapa de la formación recogida por la Directiva Hábitat. Elaboración propia a partir de Directiva Hábitat Banco de Datos de la Naturaleza.

A la hora de analizar la salud vegetal del ejemplar con respecto a su entorno mediante el método NDVI, al tratarse de un único ejemplar la teledetección no es concluyente, más aún en tanto que el pie de tejo en cuestión se encuentra rodeado por la formación de alisos anteriormente citada que extiende su follaje por encima de este, por lo que queda a la sombra de la vista satelital. Por esta razón, se ha realizado una observación directa sobre el ejemplar y su entorno para poder valorar este criterio (Figura 206). Este análisis visual concluye que la salud vegetal del tejo no es para nada óptima, situándose al borde de un concurrido camino sufre continuas agresiones, de igual modo, su situación bajo el follaje de los alisos, mucho más vigorosos, limitan su desarrollo. Por estas razones, no se cumple el criterio. 


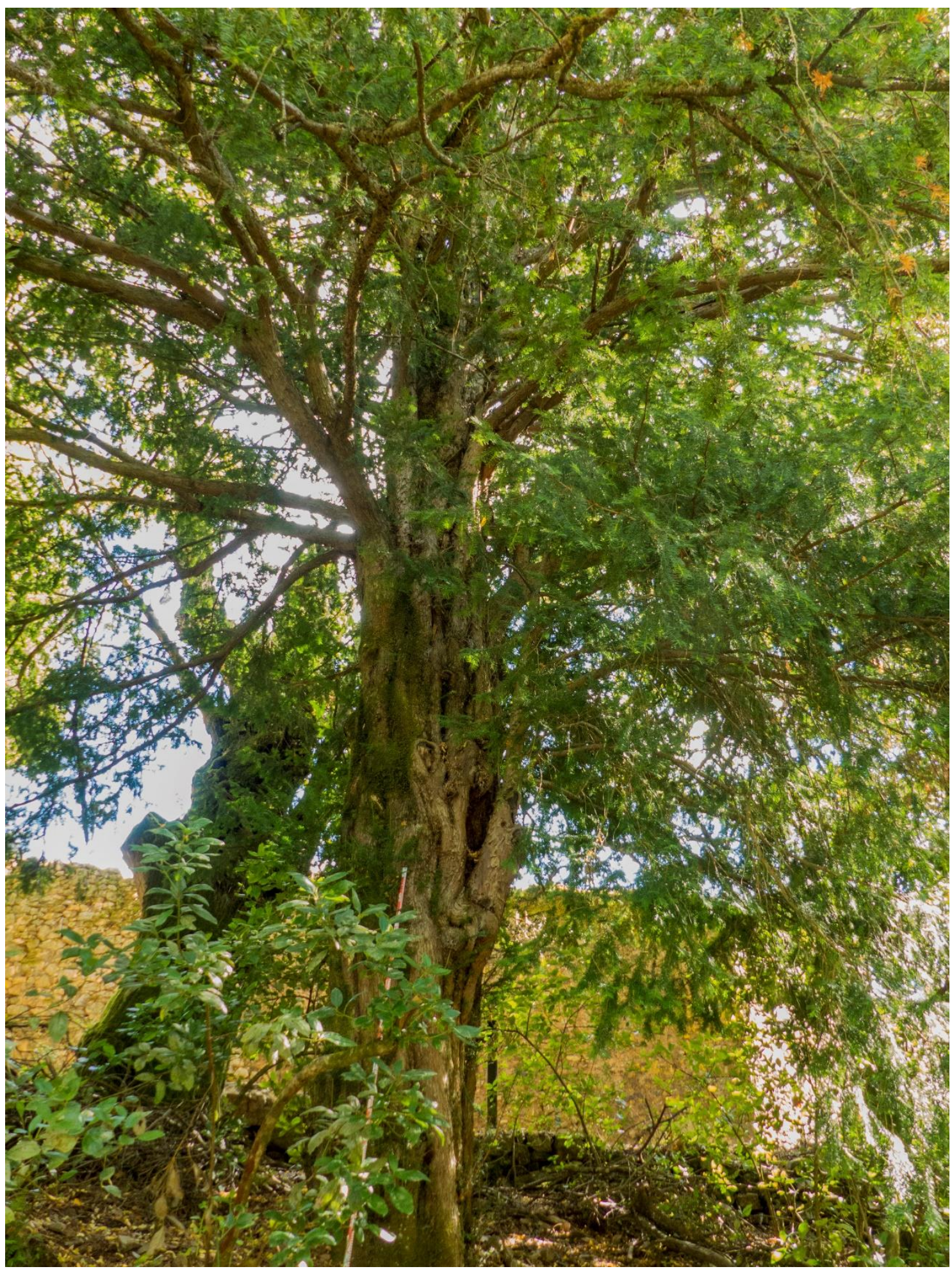

Figura 206. El tejo de La Alberca. Se encuentra bajo un dosel de fresnos. Imagen propia 


\begin{tabular}{|c|c|c|}
\hline Criterio & Puntuación & Cumplimiento \\
\hline $\begin{array}{c}\text { Evidencias bibliográficas de } \\
\text { naturalidad }\end{array}$ & 3 & $\begin{array}{c}\text { Reservorio genético } \\
\text { muy relevante }\end{array}$ \\
\hline Hábitat de Interés Comunitario & 4 & No tiene relación \\
directa
\end{tabular}

Tabla 83. Resumen criterios cumplidos valoración indicador Complejidad Biológica.

11.5.2. Indicador 2. Figuras de protección, reconocimiento y salvaguarda presentes en el territorio

\begin{tabular}{|l|c|}
\hline Criterio & Puntuación \\
\hline Figura otorgada por UNESCO & 4 \\
\hline Parque Nacional & 3 \\
\hline Parque Natural o inferior (CCAA) & 2 \\
\hline LIC o ZEPA & 0,5 \\
\hline Otras figuras & 0,5 \\
\hline
\end{tabular}

Tabla 84. Resumen criterios valoración indicador Figuras de protección

El valor de este segundo indicador se fija a través de la recopilación de figuras administrativas de protección, salvaguarda o reconocimiento que afecten a alguno de los tejos escogidos. En principio, las figuras seleccionadas deben ser las relacionadas con lo forestal, como se propuso en el epígrafe correspondiente de valoración (6.3.2) pero se entiende que al tratarse de ejemplares concretos podría caber la posibilidad de otro tipo de figuras que no fuesen estrictamente "naturales" para sustanciar la valoración.

En el caso que ocupa a este capítulo, los ejemplares ya poseen su propia figura de protección como Especímenes Vegetales de Singular 
Relevancia de Castilla y León, por lo que parten de una posición de fuerza que va a determinar su valoración. De esta forma, las figuras que se han identificado para el tejo perteneciente al municipio de La Alberca son:

La Alberca (Salamanca):

- PN Las Batuecas-Sierra de Francia (Figura 207)

- Reserva de la Biosfera Sierras de Béjar y Francia (Figura 208)

- LIC Las Batuecas-Sierra de Francia (Figura 209).

- ZEPA Las Batuecas-Sierra de Francia (Figura 210).

- BIC Sitio Histórico Valle de las Batuecas (Figura 211).

De acuerdo con esta información se puede observar como el tejo se encuentra situado en una auténtica pirámide protectora que va desde su propia catalogación como ejemplar monumental hasta el reconocimiento como Reserva de la Biosfera UNESCO. Por todas estas razones, es indudable que nos encontramos ante algunos de los paisajes forestales más reconocidos y protegidos de los que hemos tratado.

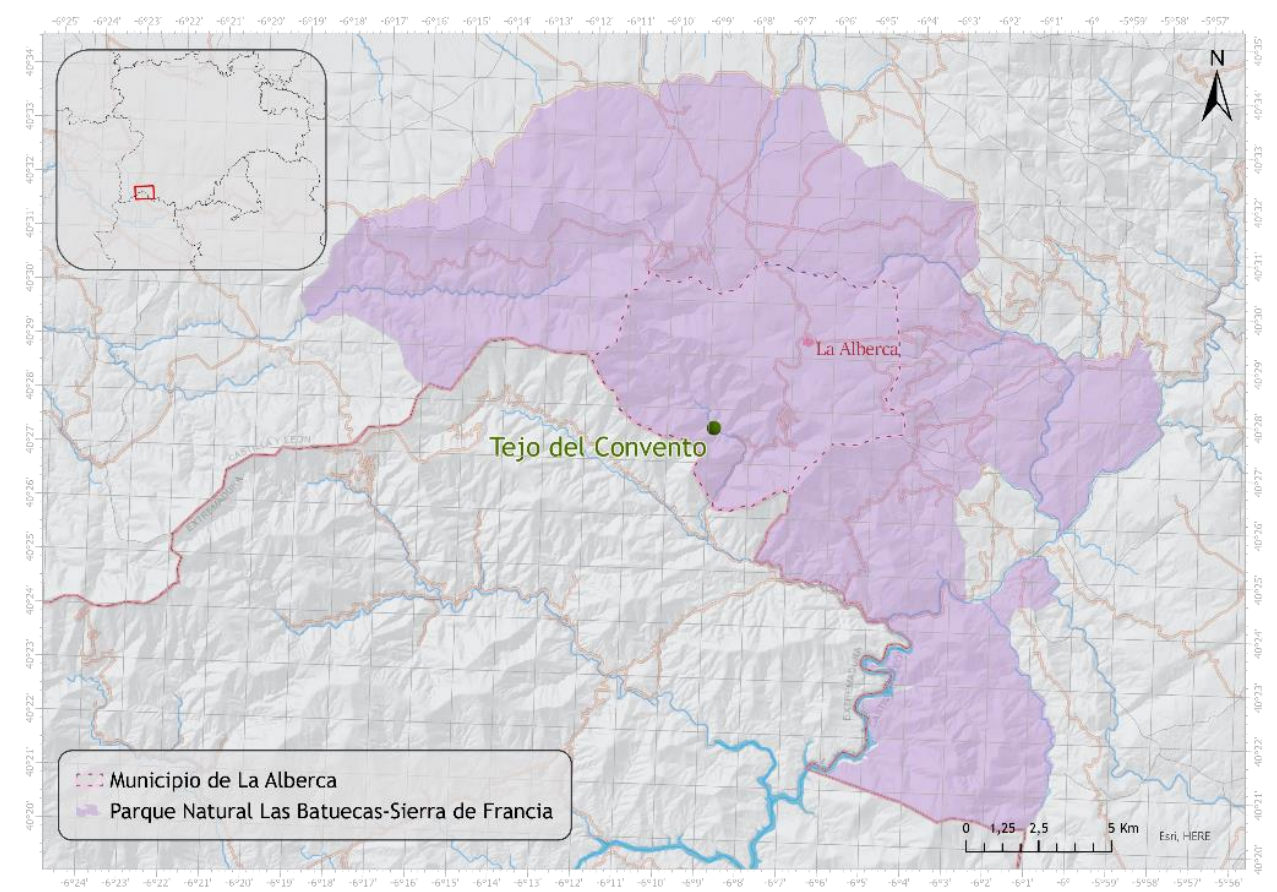

Figura 207. Parque Natural Las Batuecas-Sierra de Francia. Elaboración propia. 
Estudio de casos y aplicación práctica. Paisajes forestales con valor patrimonial.

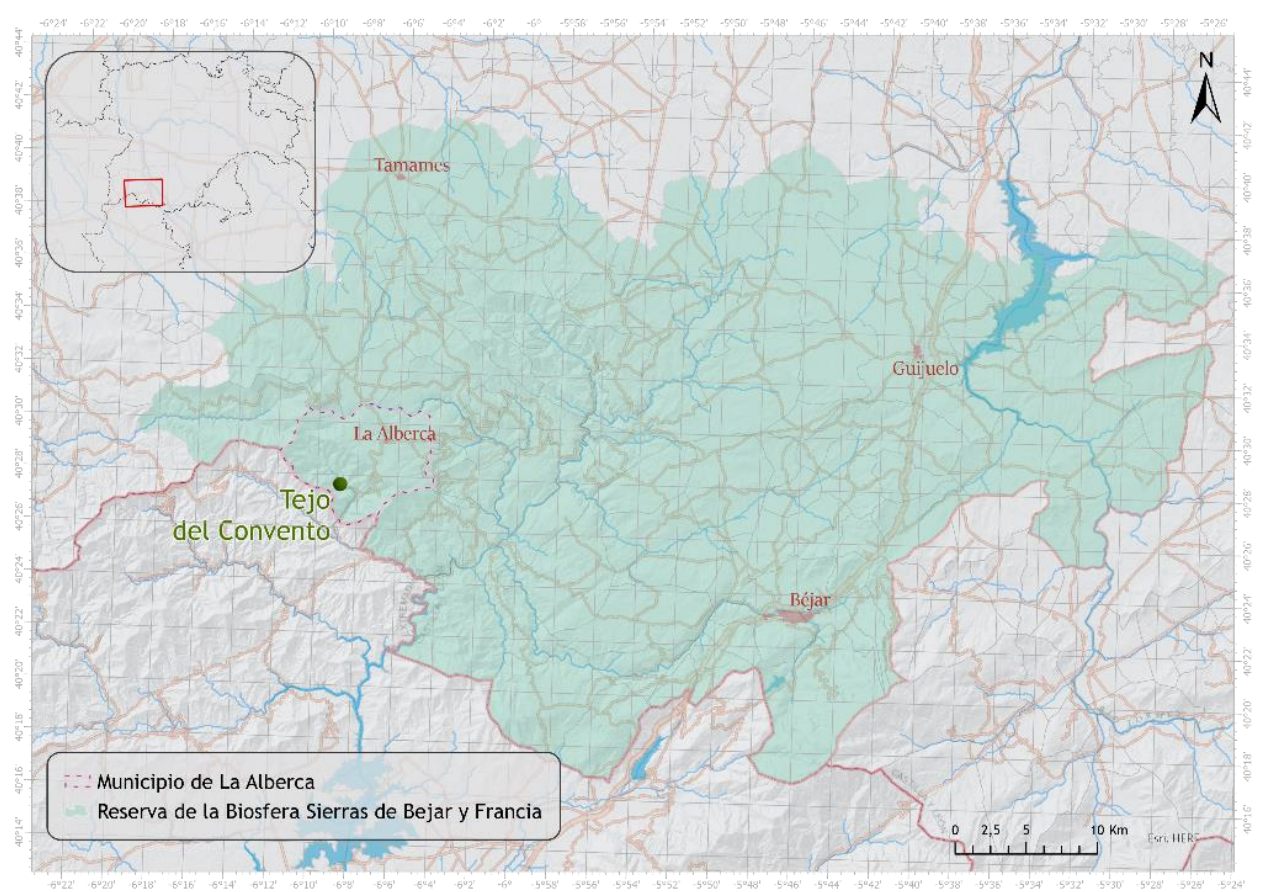

Figura 208. Reserva de la Biosfera Sierras de Béjar y Francia. Elaboración propia.

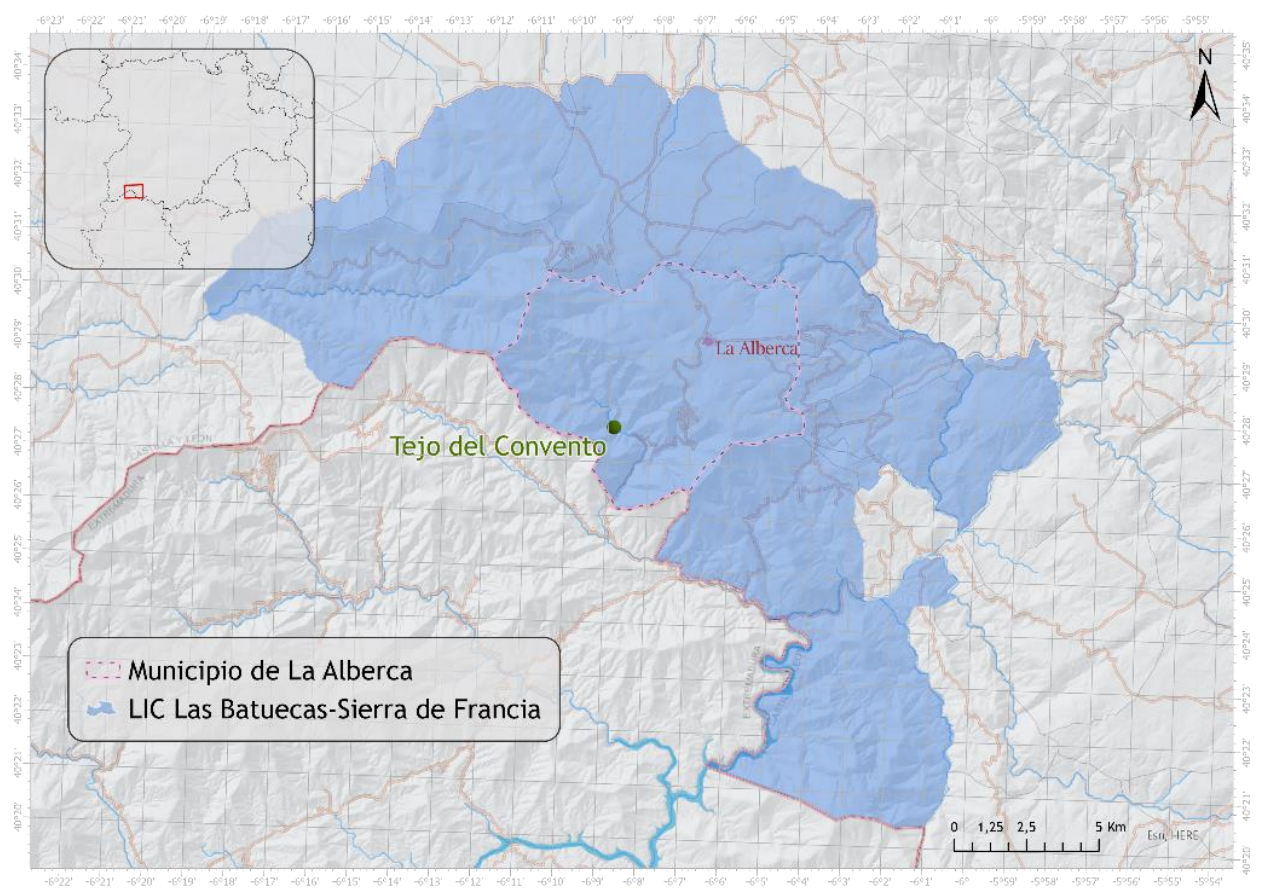

Figura 209. Lugar de Interés Comunitario Sierra de Francia. Elaboración propia. 
Estudio de casos y aplicación práctica. Paisajes forestales con valor patrimonial.

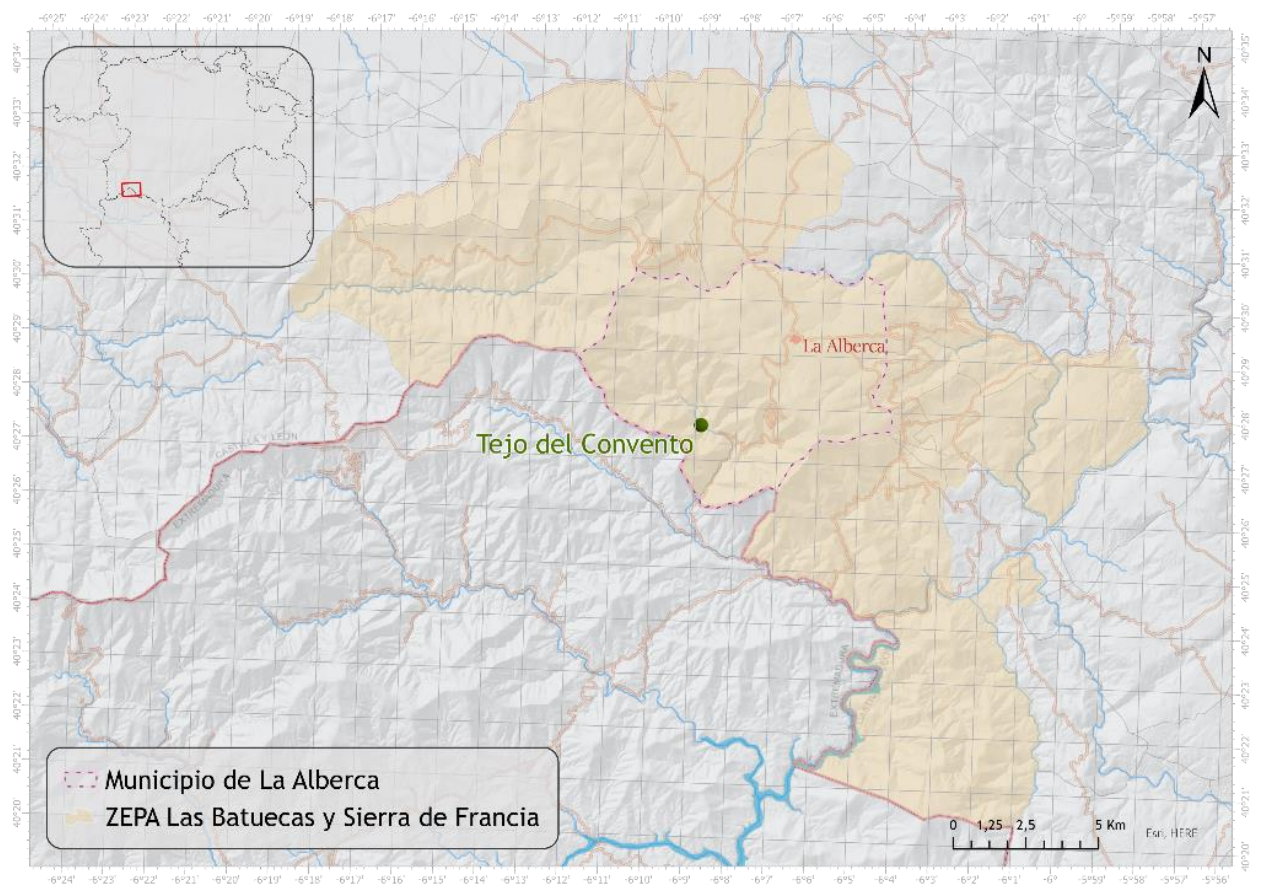

Figura 210. Zona de Especial Protección para las Aves Las Batuecas y Sierra de Francia. Elaboración propia.

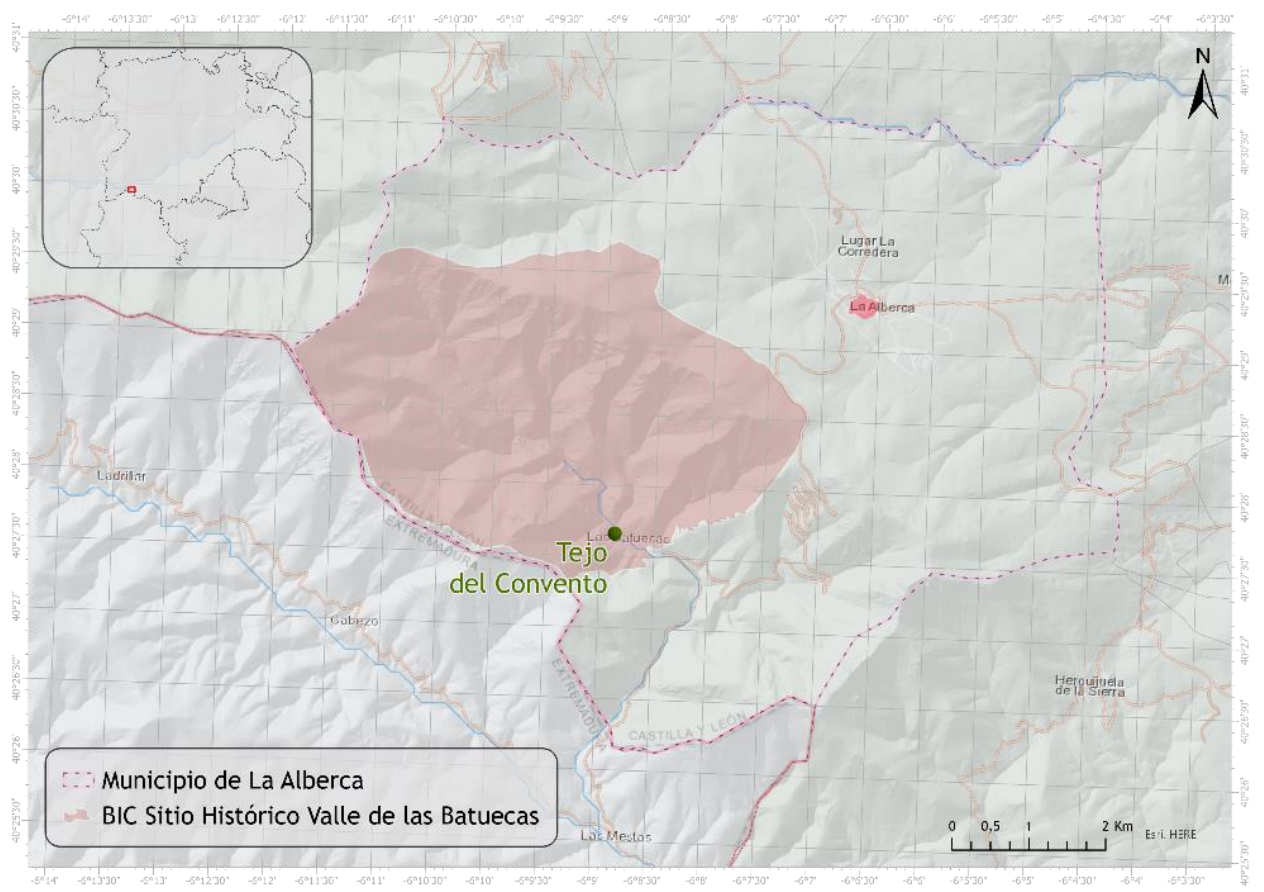

Figura 211. Bien de Interés Cultural. Sitio Histórico Valle de las Batuecas. Elaboración propia. 


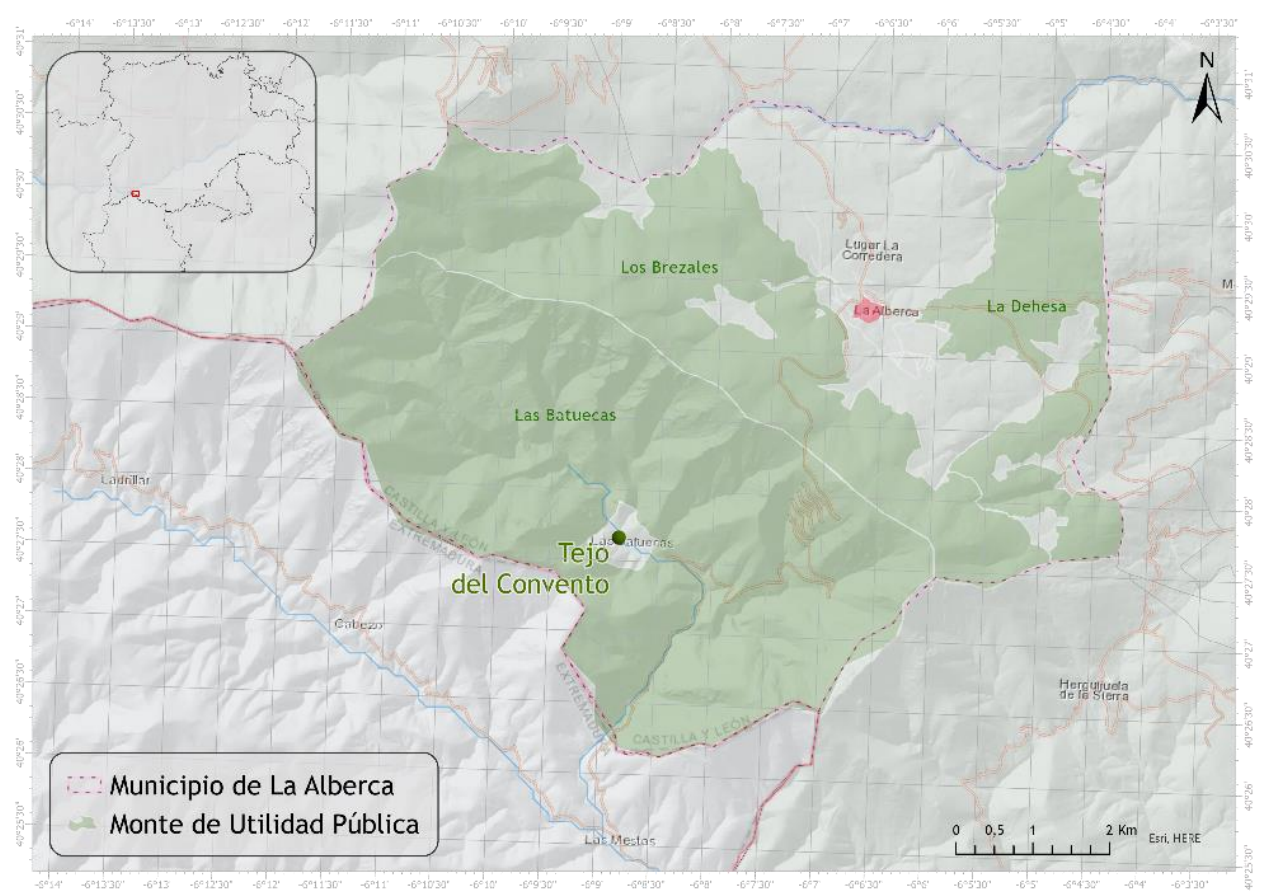

Figura 212. Montes de Utilidad Pública en el municipio de La Alberca. Elaboración propia a partir de Montes de Utilidad Pública Junta de Castilla y León.

\begin{tabular}{|l|c|c|}
\hline Criterio & Puntuación & Cumplimiento \\
\hline Figura otorgada por UNESCO & 4 & $\begin{array}{c}\text { Reserva de la } \\
\text { Biosfera }\end{array}$ \\
\hline Parque Nacional & 3 & $\begin{array}{c}\text { No tiene esta } \\
\text { catalogación }\end{array}$ \\
\hline Parque Natural o inferior (CCAA) & 2 & Parque Natural \\
\hline LIC o ZEPA & 0,5 & LIC y ZEPA \\
\hline Otras figuras & 0,5 & BIC \\
\hline
\end{tabular}

Tabla 85: Resumen criterios cumplidos valoración indicador Figuras de protección 


\subsubsection{Indicador 3. Existencia de vectores patrimoniales}

\begin{tabular}{|l|c|}
\hline Criterio & Puntuación \\
\hline Todos los vectores & 4 \\
\hline Al menos 50\% tratados patrimonialmente & 3 \\
\hline Identificados vectores de todos los tipos & 3 \\
\hline
\end{tabular}

Tabla 86. Resumen criterios valoración indicador Vectores Patrimoniales

Como se ha señalado, los vectores son esos elementos que establecen el valor patrimonial en el territorio. Su tratamiento se considera determinante para situar el momento patrimonial en que se encuentra el paisaje. En este caso se analizan los vectores que se han considerado para el paisaje forestal de los árboles monumentales en el epígrafe 3.5.5.

El paisaje forestal que responde a los ejemplares catalogados presenta la peculiaridad de que los propios ejemplares declarados monumentales son un vector en sí mismo y su tratamiento va a ser determinante para fijar el valor de este indicador. Según los vectores definidos (Tabla 6) pasa a analizarse para el ejemplar escogido:

Ejemplares singulares: El tejo perteneciente al municipio de La Alberca muestra una pequeña intervención en forma de cartel identificativo pero su conservación es bastante precaria. El árbol se encuentra rodeado de maleza, residuos y presenta daños, su localización junto al camino de acceso a una ruta senderista lo hace vulnerable (Figura 213).

Construcciones monumentales: El tejo está asociado al monasterio de San José de las Batuecas, la leyenda de su plantación se atribuye a los monjes que se asentaron en este paraje. El convento está intervenido patrimonialmente, después de haber sido rehabitado ahora presenta estancias de recogimiento y está incluido en la declaración del BIC Valle de las Batuecas (Figura 214).

Cementerios: No se encuentra asociado a un cementerio. 
Ermitas: No se encuentra asociado a una ermita.

Como conclusión para este indicador hay que señalar que no se han identificado todos los vectores planteados, por lo que el valor va a carecer de los criterios que plantean la necesidad de poder reconocer todos los vectores. En cambio, dos de los cuatro están tratados patrimonialmente. 


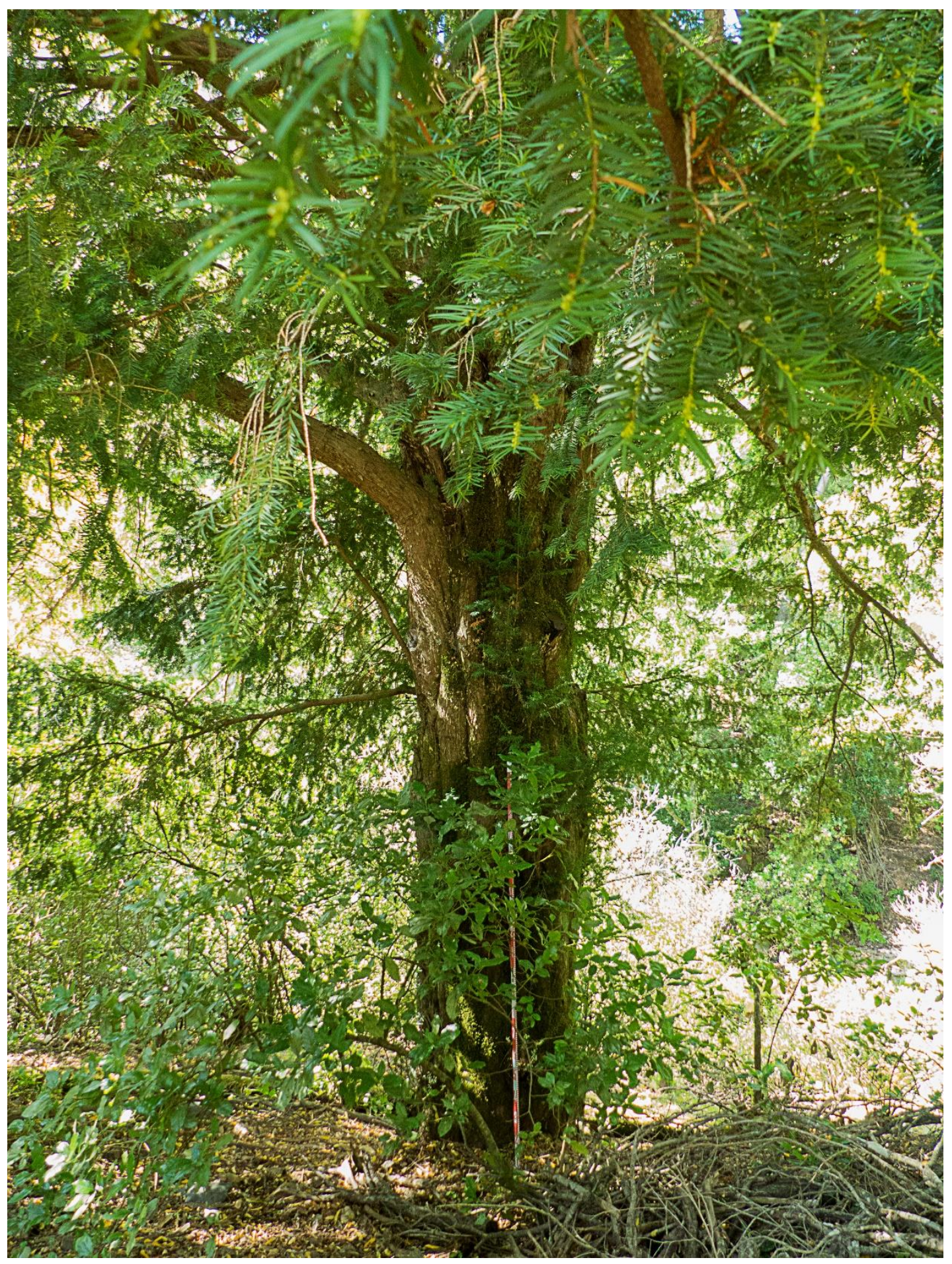

Figura 213. El Tejo del Convento. Imagen propia. 


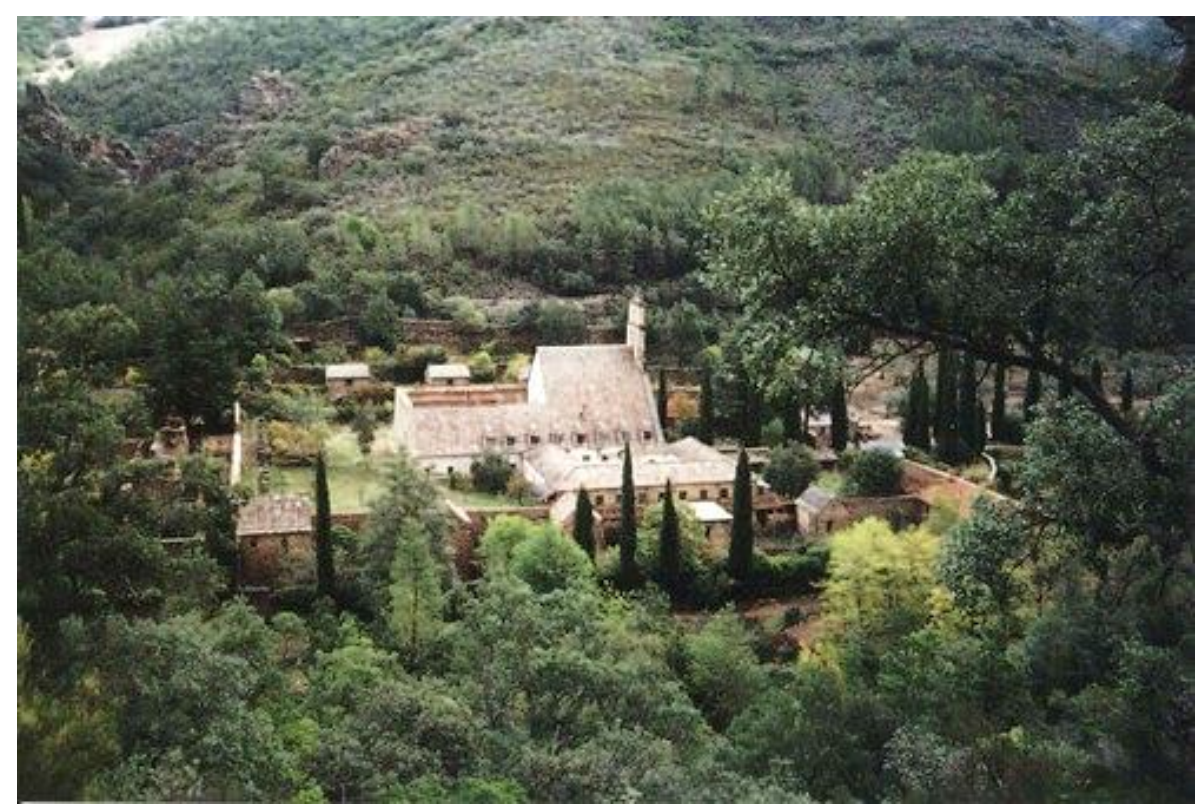

Figura 214. Monasterio de San José de Las Batuecas. Recuperado de: https://monasteriodelasbatuecas.wordpress.com/el_monasterio/

\begin{tabular}{|c|c|c|}
\hline Criterio & Puntuación & Cumplimiento \\
\hline $\begin{array}{c}\text { Todos los vectores } \\
\text { Al menos 50\% tratados } \\
\text { patrimonialmente }\end{array}$ & 3 & No se han identificado \\
\hline $\begin{array}{l}\text { Identificados vectores de todos } \\
\text { los tipos }\end{array}$ & 3 & $\begin{array}{c}\text { Dos de los cuatro } \\
\text { vectores están tratados }\end{array}$ \\
\hline
\end{tabular}

Tabla 87. Resumen criterios cumplidos valoración indicador Vectores Patrimoniales 
Estudio de casos y aplicación práctica. Paisajes forestales con valor patrimonial.

11.5.4. Indicador 4. Identificación y sentimiento de pertenencia

\begin{tabular}{|l|c|}
\hline Criterio & Puntuación \\
\hline Toponimia & 2 \\
\hline Heráldica & 2 \\
\hline Iconografía administración & 2 \\
\hline Iconografía de particulares & 2 \\
\hline Referencias de asociaciones & 2 \\
\hline
\end{tabular}

Tabla 88. Resumen criterios valoración indicador Identificación de la población.

Para valorar este indicador se recopilan evidencias que se han planteado como testigos de la apropiación cultural que da poso a la identidad territorial. Los testigos propuestos son una serie de referencias que relacionan el paisaje que se trata con la iconografía o simbología utilizada por administraciones y particulares (ver 6.3.4). Concretamente se ha establecido la utilización de simbología relacionada con la heráldica municipal, la utilización de referencias al paisaje forestal en nombres de edificios, simbología o eventos públicos y el uso de referencias al paisaje forestal en empresas o propaganda de particulares, así como las referencias toponímicas.

El tejo catalogado en el municipio de La Alberca se localiza en el paraje de las batuecas, junto al convento de San José. Esta circunstancia le hace estar muy alejado de cualquier núcleo de población, especialmente del núcleo principal del municipio al que pertenece. Por otro lado, la identidad de los albercanos se halla muy centrada en su arquitectura fundamentalmente vernácula, la cual se ha conservado y restaurado generando un núcleo de población homogéneo muy reconocido. De igual modo la identidad local se relaciona constantemente con aspectos del medio físico como el valle de Las Batuecas tan reconocido como lugar de aislamiento y reflexión (Instituto) o la Sierra de Francia (Colegio Público). En cuanto al uso de topónimos no se ha encontrado ninguna referencia al 
tejo en todo el ámbito municipal en general y tampoco en las inmediaciones del propio árbol, por lo que este criterio no se va a cumplir.

Las referencias heráldicas del municipio de La Alberca hacen alusión a motivos forestales, concretamente un castaño (Figura 215), lo que hace constatar que en ningún caso se va a recurrir al tejo como identificación.

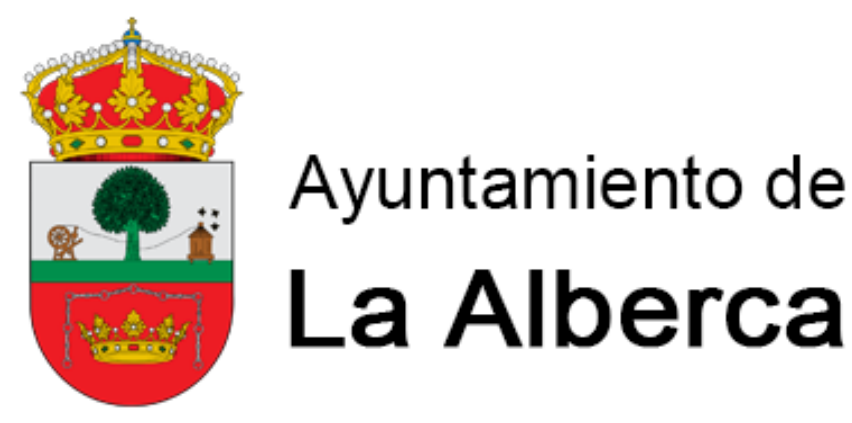

Figura 215. Escudo oficial del Municipio de La Alberca. Recuperado de: http://www.laalberca.com/images/logos/Escudo-Ayto.png

No se han encontrado evidencias de la utilización del tejo como referencia o iconografía ni por la administración, ni por particulares (Figura 216 y Figura 217) y las asociaciones presentes en el municipio no aluden al tejo en ningún caso (Figura 218). Durante el trabajo de campo se trató de conocer la relación de la población local con el tejo catalogado y no se encontró ningún habitante del municipio que conociera su existencia. 
Estudio de casos y aplicación práctica. Paisajes forestales con valor patrimonial.

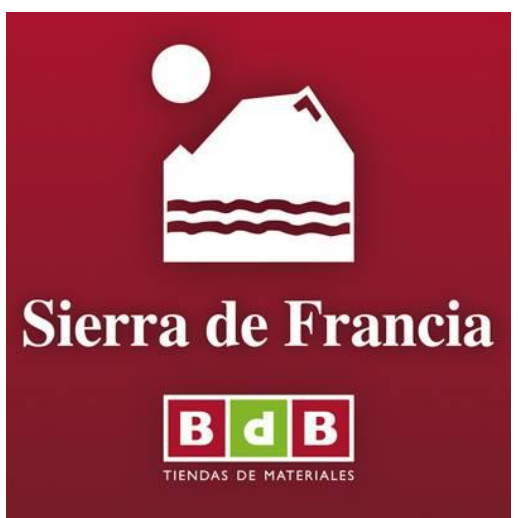

Figura 216. Ejemplo de referencia paisajística en una empresa de comercialización de materiales de construcción. Recuperado de: https://scontent-cdt11.xx.fbcdn.net/v/t1.0-

9/12541019_218046751872015_3150684018406080703_n.jpg?_nc_cat $=110 \& \mathrm{ccb}=2 \& \_n c \_s i d$

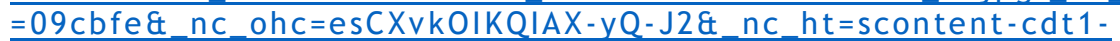

1.xx\&oh=06a5dd5aa4e1cb489a8e5b185a738af4\&oe=6030030D

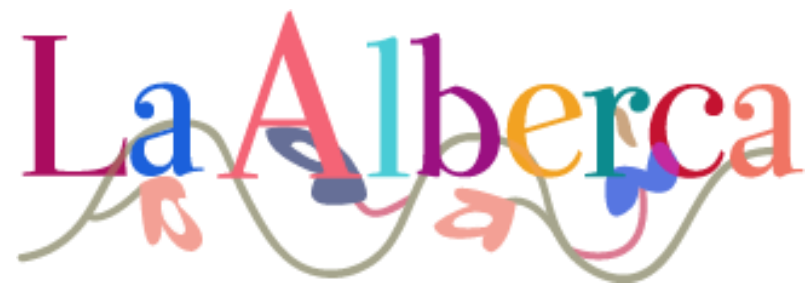

Figura 217. Imagen corporativa del Ayuntamiento de La Alberca. Recuperado de http://www.laalberca.com/.

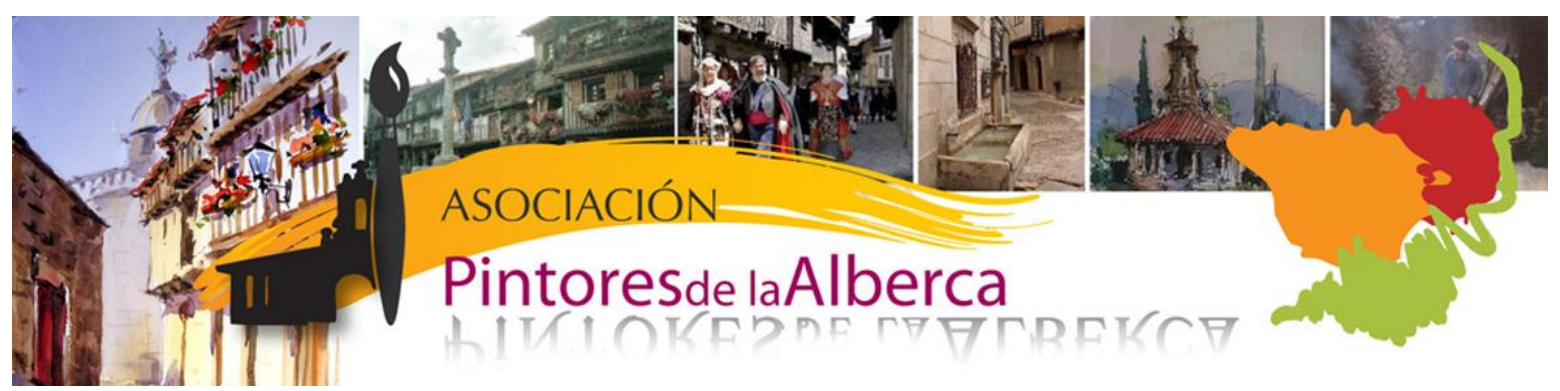

Figura 218. Asociación de pintores de La Alberca, en su iconografía se alude a elementos arquitectónicos tan relevantes en La Alberca. Recuperado de: http://asociacionpintoresdelaalberca.com/index.php 
Con todo esto, se puede decir que la identidad de los albercanos no va a estar en ningún caso relacionada con el tejo monumental que contiene su término municipal. No cumple ninguno de los criterios planteados para valorar este indicador (Tabla 89). 


\begin{tabular}{|c|c|c|}
\hline Criterio & Puntuación & Cumplimiento \\
\hline Toponimia & 2 & No hay topónimos \\
\hline Heráldica & 2 & No se alude al tejo \\
\hline Iconografía administración & 2 & $\begin{array}{c}\text { No se han } \\
\text { encontrado } \\
\text { referencias }\end{array}$ \\
\hline Iconografía de particulares & 2 & $\begin{array}{c}\text { No se han } \\
\text { encontrado } \\
\text { referencias }\end{array}$ \\
\hline Referencias de asociaciones & 2 & $\begin{array}{c}\text { No se han } \\
\text { encontrado } \\
\text { referencias }\end{array}$ \\
\hline $\begin{array}{l}\text { Tabla 89. Resumen criterios cumplidos valoración indicador } \\
\text { población. }\end{array}$ & & \begin{tabular}{l} 
Identificación de la \\
\hline
\end{tabular} \\
\hline
\end{tabular}

\subsubsection{Indicador 5. Museística}

\begin{tabular}{|l|c|}
\hline Criterio & Puntuación \\
\hline Centros de interpretación / museos oficiales & 4 \\
\hline Museos de particulares & 2 \\
\hline Jornadas de exaltación & 2 \\
\hline Mobiliario de exhibición o exaltación & 2 \\
\hline
\end{tabular}

Tabla 90. Resumen criterios valoración indicador museística.

El quinto indicador pretende relacionar los centros de interpretación, museos o espacios similares con un valor numérico que haga más sencilla la interpretación. Estos espacios ensalzan los valores de los elementos patrimoniales y permiten conservarlos a lo largo del tiempo por lo que se considera que son un testigo fiable para valorar el momento patrimonial. 
Los tejos sobre los que gira el capítulo son en sí mismo un elemento susceptible de ser tratado como una pieza de museo, con la peculiaridad de que son bienes inmuebles que presentan localizaciones más o menos inaccesibles. Pese a ello, en algunos casos han sido tratados “museísticamente" favoreciendo su identificación, catalogación o explicaciones mediante diferentes soportes, por lo que esto se valorará en este indicador.

No existe un espacio destinado a su interpretación por parte de ninguna administración, pese a ello, el tejo posee un pequeño cartel informativo a su pie (Figura 220) lo que permite dar por cumplido este criterio. En cuanto a alguna referencia museística por parte de particulares no se ha encontrado ningún ejemplo que permita cumplir este criterio, el municipio de La Alberca cuenta con un museo particular destinado a exaltar y conservar la forma de vivir tradicional (Figura 219). Igualmente, no se han identificado jornadas o eventos que permitan asegurar que existen jornadas destinadas a exaltar este ejemplar monumental. En el mismo sentido, no se ha encontrado ningún elemento de mobiliario urbano que permita cumplir este criterio.

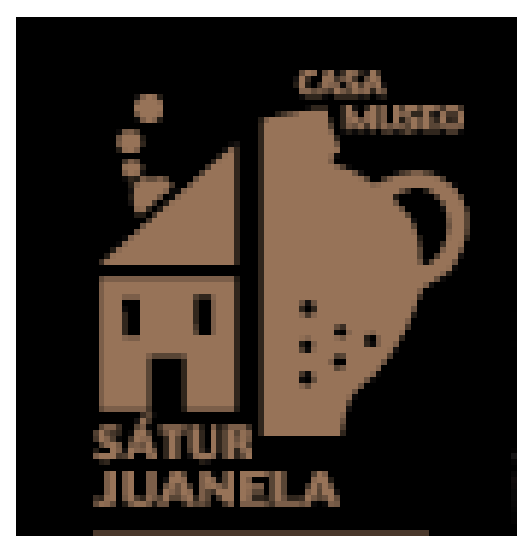

Figura 219. Logotipo del museo privado Casa Museo SaturJuanela. Recuperado de: http://www.casamuseosaturjuanela.com/ 


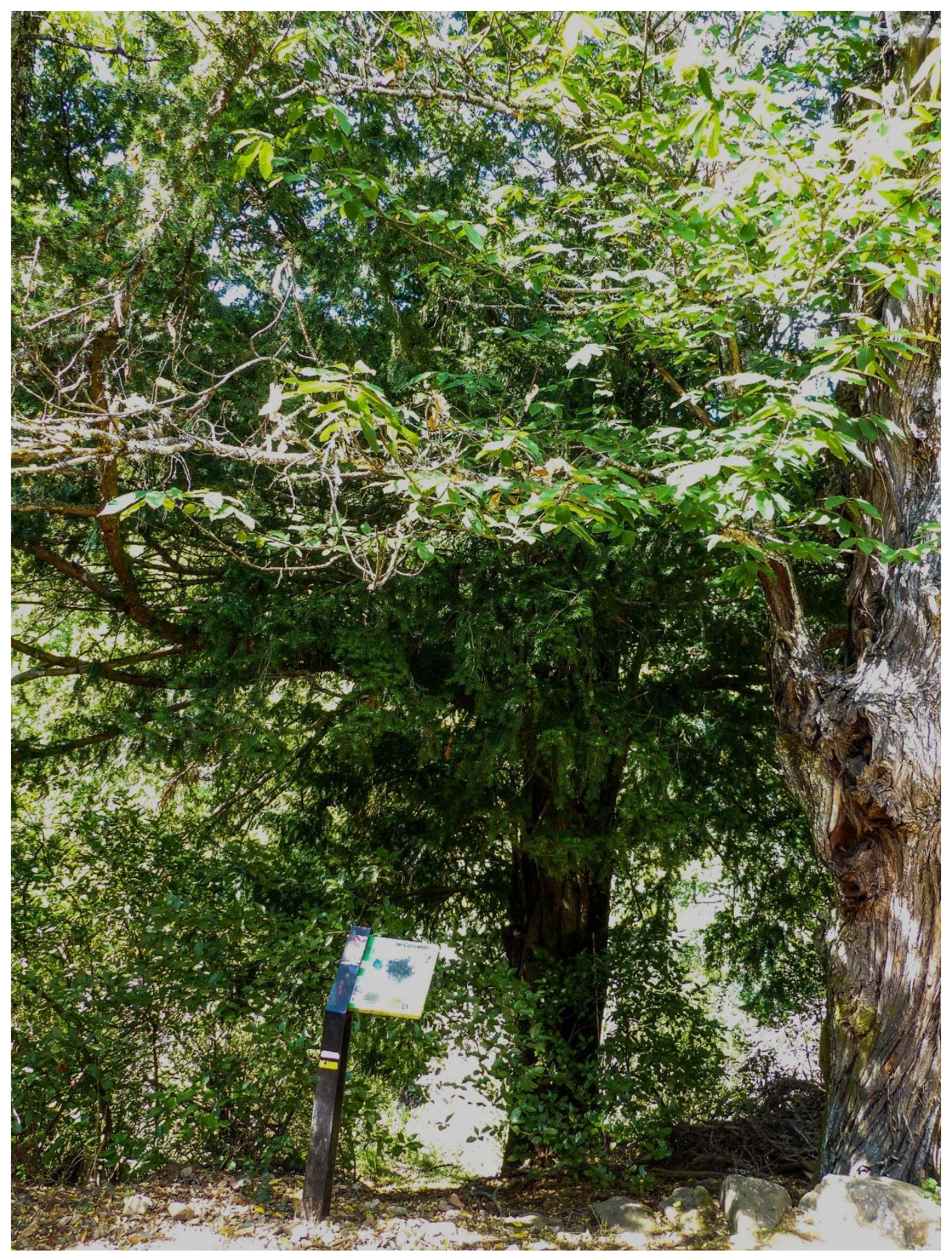

Figura 220. Tejo del Convento en La Alberca con el cartel informativo asociado. Imagen propia. 


\begin{tabular}{|c|c|c|}
\hline Criterio & Puntuación & Cumplimiento \\
\hline $\begin{array}{l}\text { Centros de interpretación/museos } \\
\text { oficiales }\end{array}$ & 4 & $\begin{array}{l}\text { Cartel informativo } \\
\text { junto al tejo }\end{array}$ \\
\hline Museos de particulares & 2 & $\begin{array}{l}\text { No se han } \\
\text { encontrado }\end{array}$ \\
\hline Jornadas de exaltación & 2 & $\begin{array}{l}\text { No se han } \\
\text { encontrado }\end{array}$ \\
\hline Mobiliario de exhibición o exaltación & 2 & $\begin{array}{c}\text { No se ha } \\
\text { encontrado }\end{array}$ \\
\hline
\end{tabular}

Tabla 91. Resumen criterios cumplidos valoración indicador museística

\subsubsection{Indicador 6. Incorporación turística}

\begin{tabular}{|c|c|}
\hline Criterio & Puntuación \\
\hline Reivindicación turística supramunicipal & 4 \\
\hline Reivindicación turística municipal & 2 \\
\hline Reivindicación turística de particulares & 2 \\
\hline Reivindicación turística igual que otros elementos & 2 \\
\hline
\end{tabular}

Tabla 92. Resumen criterios valoración indicador Incorporación Turística.

Hoy en día el uso turístico de los bienes considerados patrimoniales es fundamental para entender el momento en que se encuentra el proceso, es evidente que un elemento fuertemente patrimonializado se utiliza como reclamo turístico, bien en sí mismo o bien como complemento de una red turística. De acuerdo con esto y con la base para la valoración que se plantea en el apartado correspondiente (6.3.6) se analizan el tejo de La Alberca.

En este caso no se ha encontrado ninguna referencia que utilice al tejo catalogado como reivindicación turística por parte del municipio, ni como 
protagonista ni como complemento de la oferta. Igualmente, no se ha encontrado ningún ejemplo de reclamo turístico supramunicipal que fije la atención en el tejo monumental (Figura 221 y Figura 222).

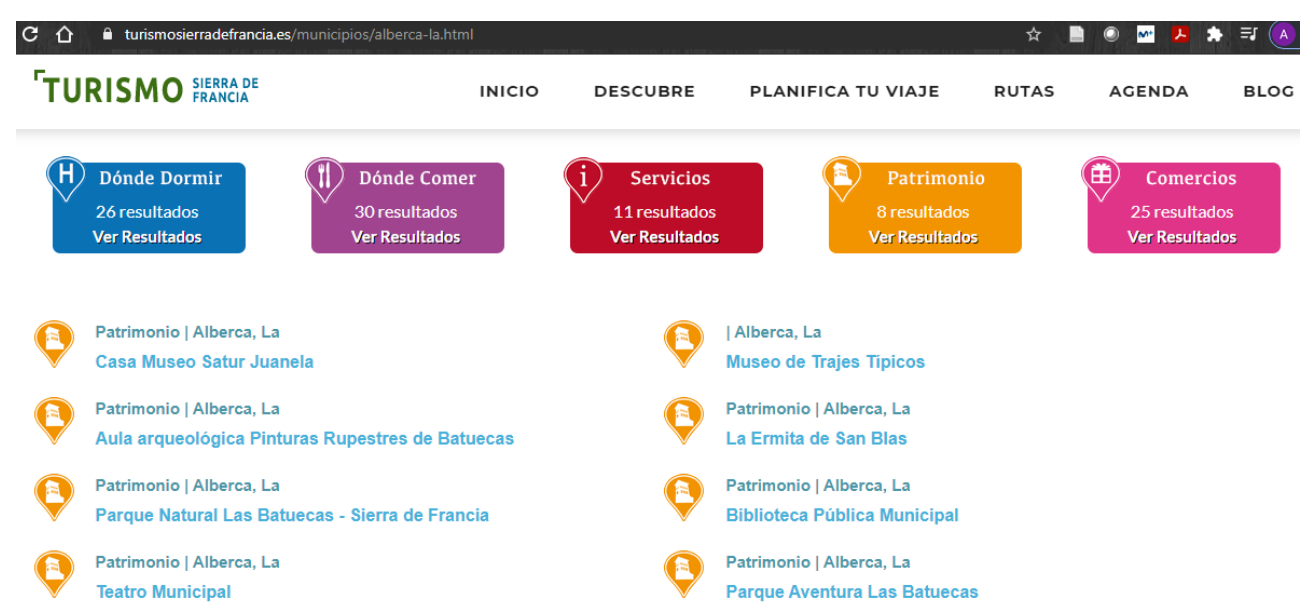

Figura 221. Captura del portal de turismo de la mancomunidad de municipios Sierra de Francia. Se hace un recopilatorio patrimonial en el que no aparece el tejo monumental. Recuperado de https://www.turismosierradefrancia.es/municipios/alberca-la.html

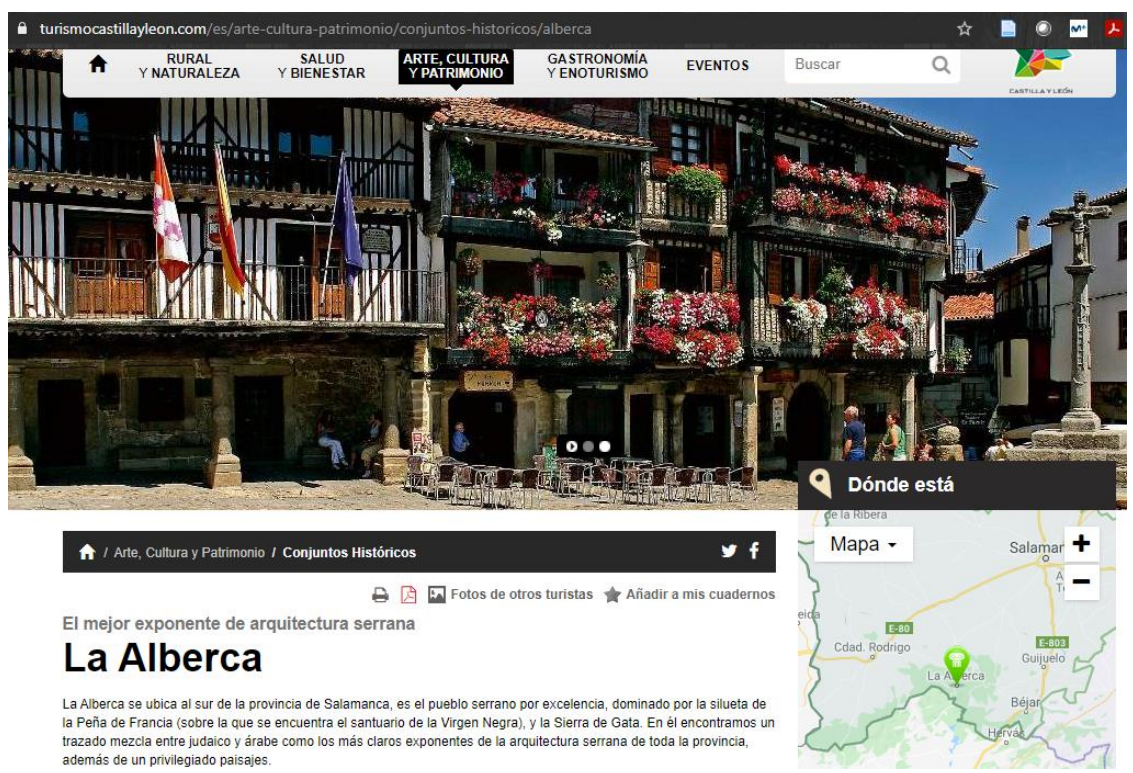

Figura 222. Captura del portal de turismo de Castilla y León. El enfoque turístico en el municipio de La Alberca se centra en la arquitectura tradicional. Recuperado de https://www.turismocastillayleon.com/es/arte-cultura-patrimonio/conjuntos-

historicos/alberca 
En cuanto a las actividades de particulares, La Alberca posee multitud de alojamientos turísticos y de hostelería dado su gran éxito turístico, pero ninguno de ellos presenta alusiones al tejo monumental como reclamo para complementar su oferta ni se ha detectado que se ofrezca la visita al tejo como una de las actividades a realizar.

Evidentemente, dado el carácter eminentemente turístico del municipio de La Alberca y con las premisas anteriores es indudable señalar que la publicidad turística está centrada en aspectos arquitectónicos, gastronómicos o espirituales muy alejados de recoger los valores del tejo monumental en cuestión.

En definitiva, de acuerdo con las evidencias recogidas y bajo las pautas fijadas en el apartado de valoración correspondiente (6.3.6), se determina que no se cumple ninguno de los criterios planteados para valorar este indicador.

\begin{tabular}{|c|c|c|}
\hline Criterio & Puntuación & Cumplimiento \\
\hline $\begin{array}{c}\text { Reivindicación turística } \\
\text { supramunicipal }\end{array}$ & 4 & No se utiliza el \\
tejo
\end{tabular}

Tabla 93. Resumen criterios cumplidos valoración indicador Incorporación Turística 


\subsubsection{Indicador 7. Empleo relacionado}

\begin{tabular}{|l|c|}
\hline Criterio & Puntuación \\
\hline Al menos 0,5\% ocupados en Silvicultura & 3 \\
\hline Al menos 5\% de ocupados en sectores relacionados & 3 \\
\hline Trabajadores silvicultura se incrementan & 2 \\
\hline Trabajadores relacionados se incrementan & 2 \\
\hline
\end{tabular}

Tabla 94. Resumen criterios valoración indicador Empleo relacionado

Como se ha señalado, se entiende que el empleo relacionado con el elemento patrimonial es un elemento que estrecha la vinculación social, lo que a la postre acaba siendo determinante en el proceso de patrimonialización. En el caso que ocupa a este capítulo los puestos de trabajo vinculados al epígrafe 02 de la CNAE (Silvicultura y explotación forestal) no tienen ninguna relación con los tejos monumentales ya que se trata de pies concretos que no van a estar destinados a su aprovechamiento maderero o recolectivo. Valorar el empleo que está ocupado en este epígrafe puede llevar a tener una falsa perspectiva, ya que puede haber empleados ocupados en estas tareas, los cuales no tienen absolutamente ninguna relación con el tejo catalogado. Por este motivo se conviene dar por incumplidos los criterios de valoración al entender que, en este caso, el elemento forestal no va puede arrojar datos de empleo directa o indirectamente relacionados. Podría caber la posibilidad de que, partiendo de la base de que se trata de un elemento que ha perdido su valor de uso y ha pasado a ser un vector patrimonial en sí mismo, el empleo que pudiera arrojar pudiera estar relacionado con su aprovechamiento turístico, pero como se ha visto anteriormente, no se han encontrado evidencias de que este tejo esté aprovechado turísticamente. 
Estudio de casos y aplicación práctica. Paisajes forestales con valor patrimonial.

\begin{tabular}{|c|c|c|}
\hline Criterio & Puntuación & Cumplimiento \\
\hline $\begin{array}{cccc}\text { Al menos } & 0,5 \% & \text { ocupados en } \\
\text { Silvicultura } & & & \end{array}$ & 3 & No existe relación \\
\hline $\begin{array}{l}\text { Al menos 5\% de ocupados en sectores } \\
\text { relacionados }\end{array}$ & 3 & No existe relación \\
\hline $\begin{array}{ll}\text { Trabajadores } & \text { silvicultura } \\
\text { incrementan } & \end{array}$ & 2 & No existe relación \\
\hline $\begin{array}{ll}\text { Trabajadores } & \text { relacionados } \\
\text { incrementan } & \end{array}$ & 2 & No existe relación \\
\hline
\end{tabular}

Tabla 95. Resumen criterios cumplidos valoración indicador Empleo relacionado. 
Estudio de casos y aplicación práctica. Paisajes forestales con valor patrimonial.

\subsubsection{Valoración final}

\begin{tabular}{|l|l|}
\hline Indicador & Valoración \\
\hline I1. Complejidad biológica & 3 \\
\hline I2. Figuras de protección & 7 \\
\hline 13. Existencia de vectores & 6 \\
\hline 14. Identificación y sentimiento de pertenencia & 0 \\
\hline 15. Centros de interpretación/museos & 4 \\
\hline 16. Incorporación turística & 0 \\
\hline 17. Empleo relacionado & 0 \\
\hline & Valoración final \\
\hline
\end{tabular}

Tabla 96. Valor obtenido por cada uno de los indicadores propuestos para el paisaje referente al municipio de Vallelado.

\section{Los árboles monumentales: Los Tejos en Castilla y León}

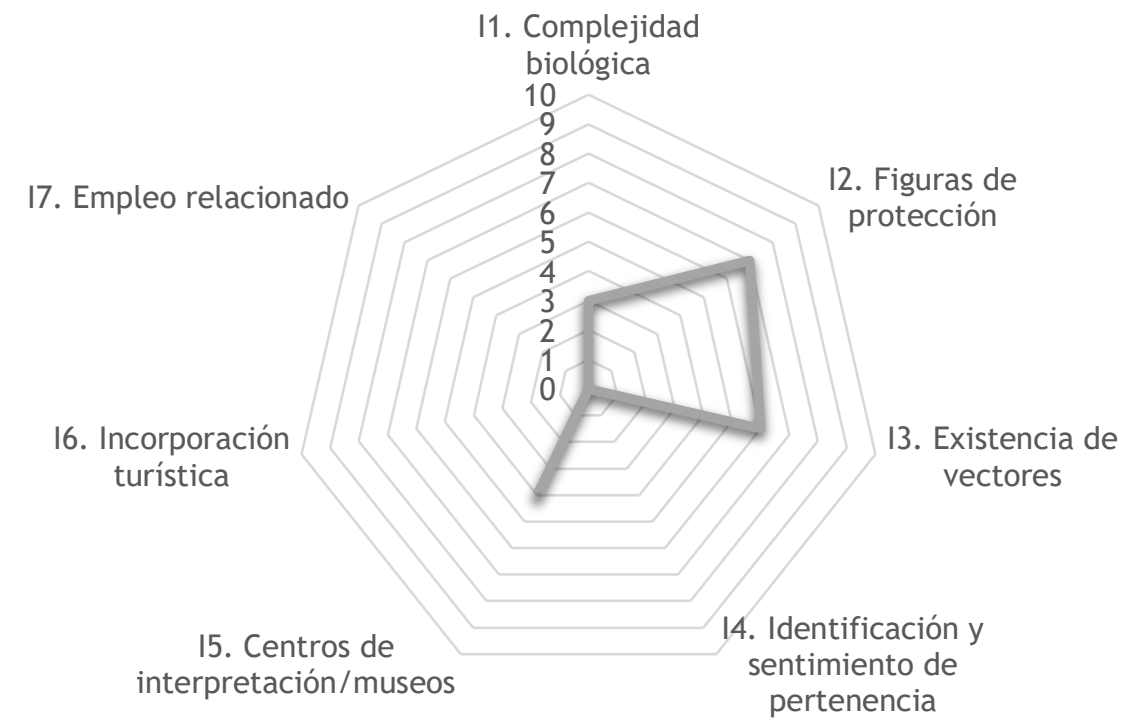

Figura 223. Representación de la situación patrimonial del pinar en Vallelado según los indicadores analizados. Elaboración propia 


\section{Capítulo 12. Discusión sobre el proceso de patrimonialización a través de los indicadores.}


El proceso de patrimonialización se definió en el epígrafe correspondiente (6.1) relativo al capítulo 6 que trataba de sentar las bases sobre las que giraría el concepto de paisaje patrimonial. Este proceso asumió la idea de patrimonialización como el procedimiento de reconocimiento de un valor y la voluntad de conservarlo y transmitirlo (Dérioz, 2010), entendiendo que ese valor no es estático, sino que evoluciona con la sociedad y se encuentra en cambio constante, por lo que se va a entender más como un relato que como un valor en sí mismo. De esta manera cualquier análisis de un proceso de patrimonialización podrá ser replicado en el tiempo con distinto resultado.

Este resultado va a variar en función de la sociedad, su gusto, sus valores, su percepción, sus preocupaciones, etc. Y será más o menos voluble en función de los agentes que promuevan el proceso de patrimonialización, mientras que los procesos derivados de la toma de conciencia de la sociedad local y erigidos hacia la administración van a depender esencialmente de criterios sentimentales o identitarios, los procesos planteados por la academia o la institución tendrán un poso más racional y menos emocional aunque siempre necesitarán de la asunción por parte de la sociedad local para culminar su proceso patrimonializador.

En el estudio de casos se realizó un análisis a través de indicadores que permitiese la comparación del momento patrimonial en que se van a encontrar los paisajes propuestos en este trabajo: Los hayedos atlánticos del municipio de Posada de Valdeón (León), los pinares mediterráneos de las Tierras de Pinares de Segovia y Valladolid representados por el municipio de Vallelado (Segovia), los eucaliptales atlánticos paradigmáticos del municipio de Guriezo (Cantabria), el paisaje de los chopos trasmochos de la cuenca del río Jiloca encarnado por el municipio de Burbáguena (Teruel) y los tejos monumentales registrados en el Catálogo de Especímenes Vegetales de Singular Relevancia de la Junta de Castilla y León representados por el tejo de La Alberca (Salamanca). Este estudio mediante indicadores arroja una valoración cuantitativa capaz de reflejar el momento patrimonial y capaz de permitir la comparación tanto a nivel 
global como de cada uno de los indicadores propuestos. Estos indicadores se han valorado sobre un máximo de diez puntos, siendo el valor máximo correspondiente a la suma de los siete indicadores de setenta puntos (ver $6.3)$.

Desde el punto de vista global, los indicadores van a reflejar acusadas diferencias entre los distintos paisajes arrojando valores comprendidos entre 38 puntos para los hayedos leoneses de Posada de Valdeón y 10,5 puntos correspondientes al paisaje de los eucaliptales cántabros de Guriezo. Esta abultada diferencia aventura importantes contrastes en cuanto a la patrimonialización del paisaje vegetal de cada uno de los casos de estudio. Por otro lado, desde el punto de vista particular de los distintos indicadores se da la diferencia extrema, existiendo paisajes que obtienen el valor máximo y otros el valor mínimo para el mismo indicador, lo que los hace considerablemente diferentes. Con estas premisas se pasan a discutir cada uno de los indicadores haciendo especial énfasis en la valoración global que dará una visión de conjunto capaz de admitir la comparación.

\subsection{Complejidad biológica}

Este primer indicador se ha valorado a través de diferentes criterios, siempre con el objetivo de garantizar la objetividad en su evaluación. Los resultados que se han obtenido permiten comparar un aspecto fundamental en un patrimonio vivo como es el paisaje forestal, la complejidad biológica y su calidad natural van a determinar en buena medida el valor patrimonial del paisaje analizado. De esta manera va a destacar significativamente la valoración obtenida por el paisaje relativo al hayedo atlántico de Posada de Valdeón obteniendo la puntuación máxima, este hayedo se erige como un auténtico reservorio biológico dominado por un bosque húmedo de gran calidad, con unos suelos desarrollados, un sotobosque diverso y que va a servir como sustento para un ecosistema vigoroso que alberga multitud de formaciones recogidas en la Directiva Hábitat. De igual manera el hayedo supone un bosque de umbría capaz de mantener la vitalidad a lo largo del año, sin verse apenas influenciado por condiciones climatológicas adversas. 
En el lado opuesto, el eucaliptal del municipio de Guriezo obtiene la menor valoración posible al no haber cumplido ninguno de los criterios propuestos para valorar este indicador. El eucaliptal presenta unas características ecosistémicas muy pobres asociadas a su monoespecificidad. Su longevidad se ve directamente afectada por las talas a "matarrasa" que no solo empobrecen el sotobosque, sino que provocan lavados de suelos y desecación. La múltiple maquinaria de gran tonelaje empleada para su aprovechamiento interfiere de forma muy negativa tambien en la calidad ecosistémica del eucaliptal y las características propias del eucalipto sitúan a estas formaciones en clara desventaja con respecto a otras formaciones autóctonas en lo que a vigorosidad vegetal se refiere.

En lo referente al pinar y su paisaje vegetal obtiene una puntuación elevada al tratarse de una formación que, pese a ser prácticamente monoespecífica en lo que respecta al porte arbóreo, presenta un ecosistema rico, variado y susceptible de ser protegido, como sucede con ciertas formaciones puramente pinariegas mediante la Directiva Hábitat. Los puntos débiles del pinar respecto a este indicador van a ser las intervenciones a las que se ve sometido para su aprovechamiento. Tanto la obtención de piñas como el aprovechamiento resinero requieren de maquinaria, fundamentalmente vehículos a motor, que deterioran de forma sustancial la capacidad regenerativa del sotobosque, así como la salud edafológica debido a la compactación de suelos. En el apartado positivo, el pinar es un referente de vigorosidad vegetal a lo largo de todo el año, capaz de mantener unas condiciones bastante estables que garantizan su situación de reservorio forestal en una pobre cuenca central del Duero, así el pinar surge como contrapunto a los aprovechamientos agroganaderos intensivos cada vez más monoespecíficos y asépticos.

En cuanto a los chopos trasmochos de la cuenca del Jiloca y concretamente a los situados en el municipio de Burbáguena, van a destacar como un auténtico nicho biológico capaz de albergar especies animales de gran valor y esto se produce en un entorno prácticamente libre de otro tipo de vegetación arbórea, si acaso se observa una expansión del sotobosque 
pero se trata de especies pioneras que aprovechan el abandono de ciertos usos tradicionales, en cualquier caso no van a suponer ecosistemas de interés vegetal. Igualmente, los chopos cabeceros analizados componen una vegetación ripícola que garantiza una elevada vigorosidad estival cuando las condiciones climáticas son más adversas en la cuenca del Jiloca. Por estas razones, los chopos de Burbáguena presentan una valoración considerable pero contenida, fundamentalmente asociada a la inexistencia de formaciones complejas que hayan sido catalogadas mediante la Directiva Hábitat.

Por último, el tejo de La Alberca, como representante de los tejos catalogados por la Junta de Castilla y León, ostenta una valoración que se sustenta en su singularidad como reservorio genético en sí mismo. El propio valor del tejo determina su valoración, por otro lado, no se han encontrado evidencias que sitúen a los tejos como especímenes de excepcional vigorosidad en su entorno, compartiendo hábitat con especies mucho más vigorosas. Igualmente, no presentan formaciones vegetales que dependan directamente de ellos, sino que, como demuestra el ejemplo del tejo de La Alberca, suponen ejemplares totalmente aislados incluso podría decirse que inconexos en su hábitat. 


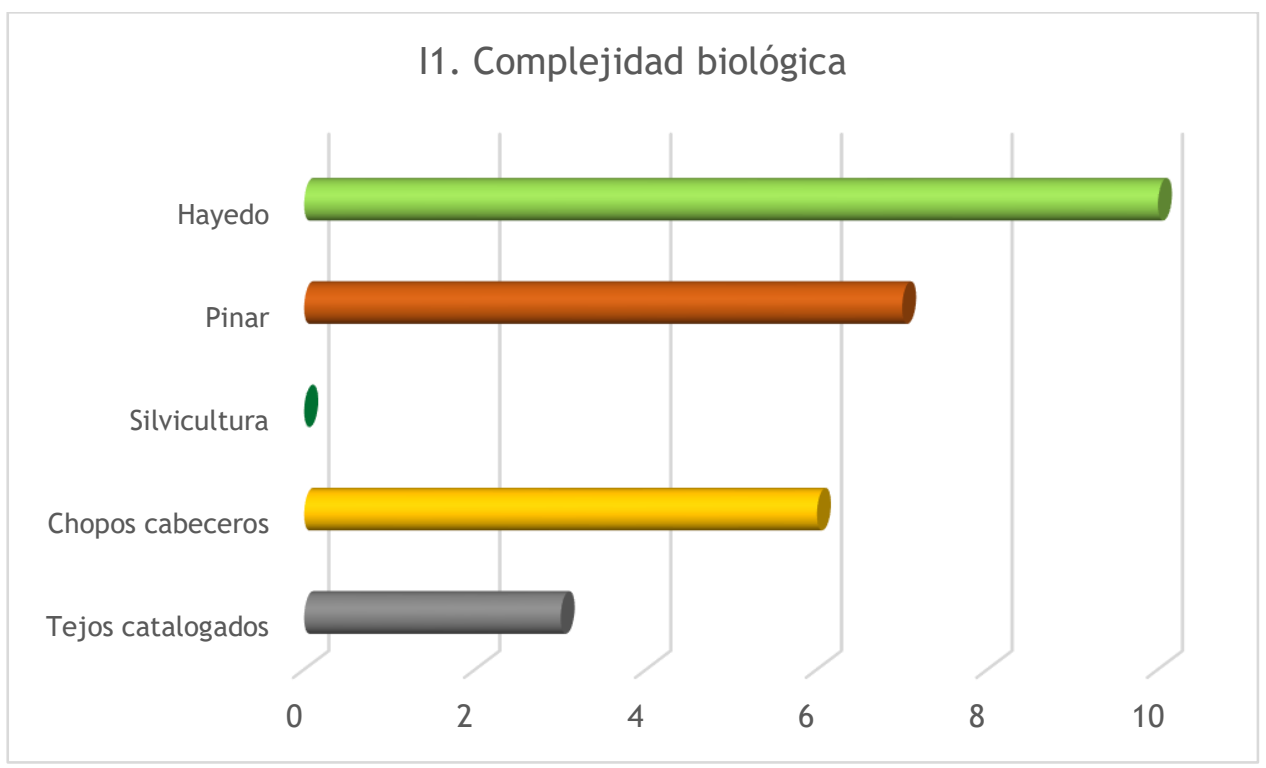

Figura 224. Gráfico resumen indicador complejidad biológica para los distintos casos de estudio. Elaboración propia

\subsection{Figuras de protección}

Este indicador pretende poner en relación las figuras de protección y salvaguarda presentes en el territorio con el paisaje vegetal analizado. Actualmente el patrimonio no puede entenderse sin el reconocimiento de la administración y es a través de estas figuras que pretenden preservar determinados valores, cómo los organismos oficiales ponen el foco sobre los elementos patrimoniales. El indicador se ha valorado mediante la recopilación de figuras por lo que garantiza su objetividad y presenta este indicador como fiable para la comparación.

Como no podía ser de otra manera, el municipio de Posada de Valdeón y por tanto el paisaje vegetal relativo al hayedo presenta una superposición de figuras de reconocimiento y salvaguarda verdaderamente notable. Es imprescindible situar este municipio dentro del Parque Nacional de Los Picos de Europa, algo que va a ser determinante y que condiciona una cascada de figuras que van de lo general a lo particular, reconociendo los valores naturales, pero también culturales presentes en el territorio. Este 
mosaico de figuras determina la valoración máxima que obtiene este indicador.

Por otro lado, otro de los paisajes que presenta un elevado valor en este indicador es el tejo de La Alberca, su localización en la Sierra de Las Batuecas determina tambien la superposición de figuras de salvaguarda que van a otorgar la elevada puntuación que este indicador obtiene.

En el otro extremo, los municipios de Guriezo y Burbáguena, testigos del paisaje del eucaliptal y los chopos cabeceros respectivamente. Estos municipios apenas obtienen una valoración testimonial asociada a la existencia de alguna figura de salvaguarda, pero de importancia limitada. En Guriezo, la valoración viene determinada por la existencia de Monte de Utilidad Pública en buena parte de su territorio, lo que va a garantizar su carácter forestal. En Burbáguena la declaración del Gobierno de Aragón de Bien de Interés Cultural Inmaterial de la cultura del chopo cabecero es la causante de la valoración, pero no presenta más figuras.

En cuanto al paisaje del pinar representado por el municipio de Vallelado, apenas existen figuras de protección, aunque es destacable la existencia de LIC (Lugar de Interés Comunitario) de las riberas del Cega, elemento que articula en buena medida la Tierra de Pinares. Igualmente, la figura de Monte de Utilidad Pública va a preservar la personalidad forestal del territorio.

Observando este indicador se puede apreciar que la situación periférica va a determinar la existencia de figuras y su superposición. Los espacios de montaña son garantes de protección ambiental, mientras que los espacios más dinámicos y que favorecen las actividades más intensivas van a carecer de este tipo de figuras o al menos van a ser testimoniales o muy acotadas a elementos puntuales, evitando abarcar grandes espacios. 


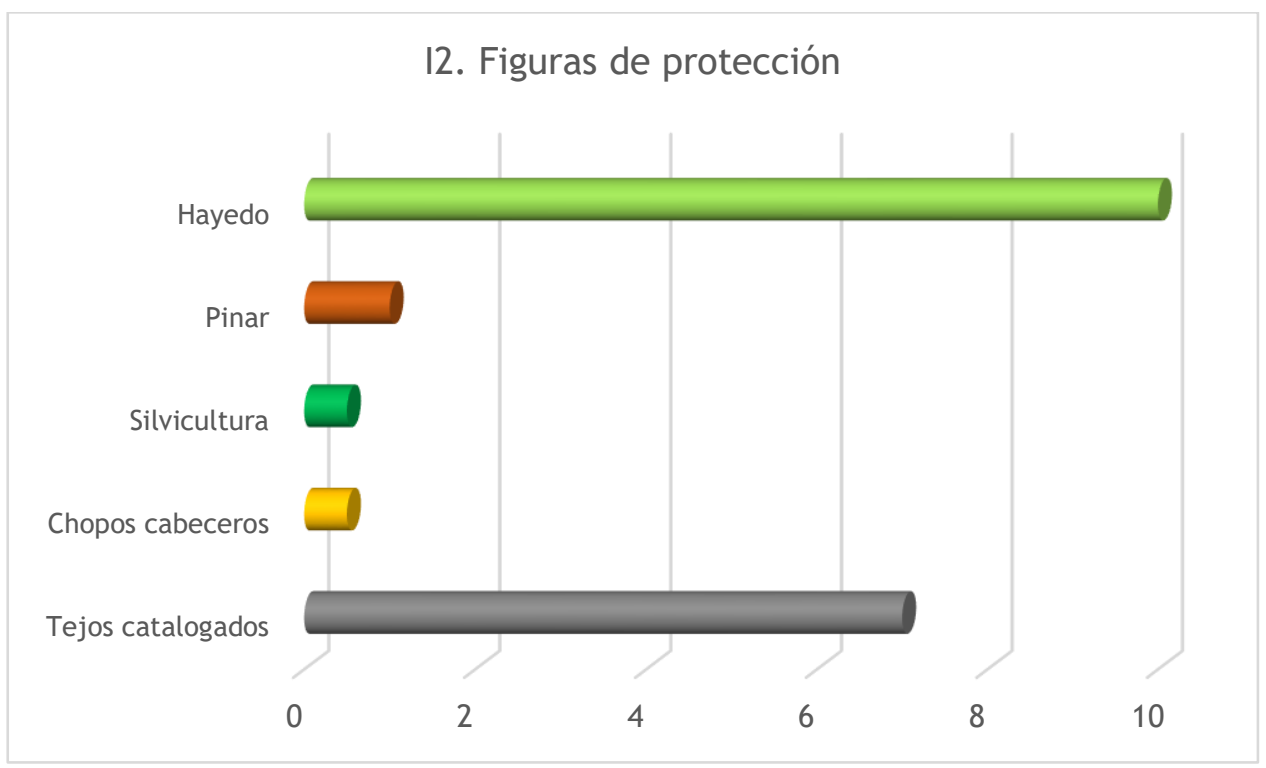

Figura 225. Gráfico resumen indicador figuras de protección para los distintos casos de estudio. Elaboración propia.

\subsection{Existencia de vectores}

Este indicador, se fundamenta en la existencia y tratamiento de los vectores identificados para cada tipo de paisaje forestal en el capítulo 4. Se ha expuesto como uno de los pilares patrimoniales es el reflejo de su cultura mediante determinados elementos que condensan esos valores y como, en buena medida, siguen presentes en el territorio. Estos elementos muestran un trato desigual en función de que se hayan asimilado como patrimonio o no, igualmente varía en función de su vigencia funcional o no. Aparecen grandes diferencias entre los distintos paisajes, incluso los motivos por los que estos vectores existen y son tratados son diversos.

Lo que se hace constatable mediante este análisis es que los vectores asociados al paisaje forestal, por norma general, no están tratados patrimonialmente. Los elementos que se han identificado no presentan cuidados, cartelería o identificación que ponga en valor la razón cultural de dichos elementos. Tan solo el caso del tejo de La Alberca ha obtenido la puntuación asociada a este testigo de tratamiento patrimonial. La razón 
de este tratamiento es que el tejo está catalogado en sí mismo como elemento monumental y por otro lado el paisaje asociado a los árboles monumentales se encuentra estrechamente vinculado con elementos arquitectónicos religiosos los cuales suelen presentar tratamientos patrimoniales habitualmente.

Otra de las peculiaridades que se han detectado es que, el ejemplo del paisaje de la silvicultura intensiva que supone el eucaliptal de Guriezo, presenta todos los vectores asociados a este paisaje. El motivo de que todos los vectores estén presentes es su vigencia funcional, por otro lado, esto impide un tratamiento patrimonial.

El resto de los casos presentan algunos o todos los vectores, pero comparten la inexistencia de tratamiento patrimonial.

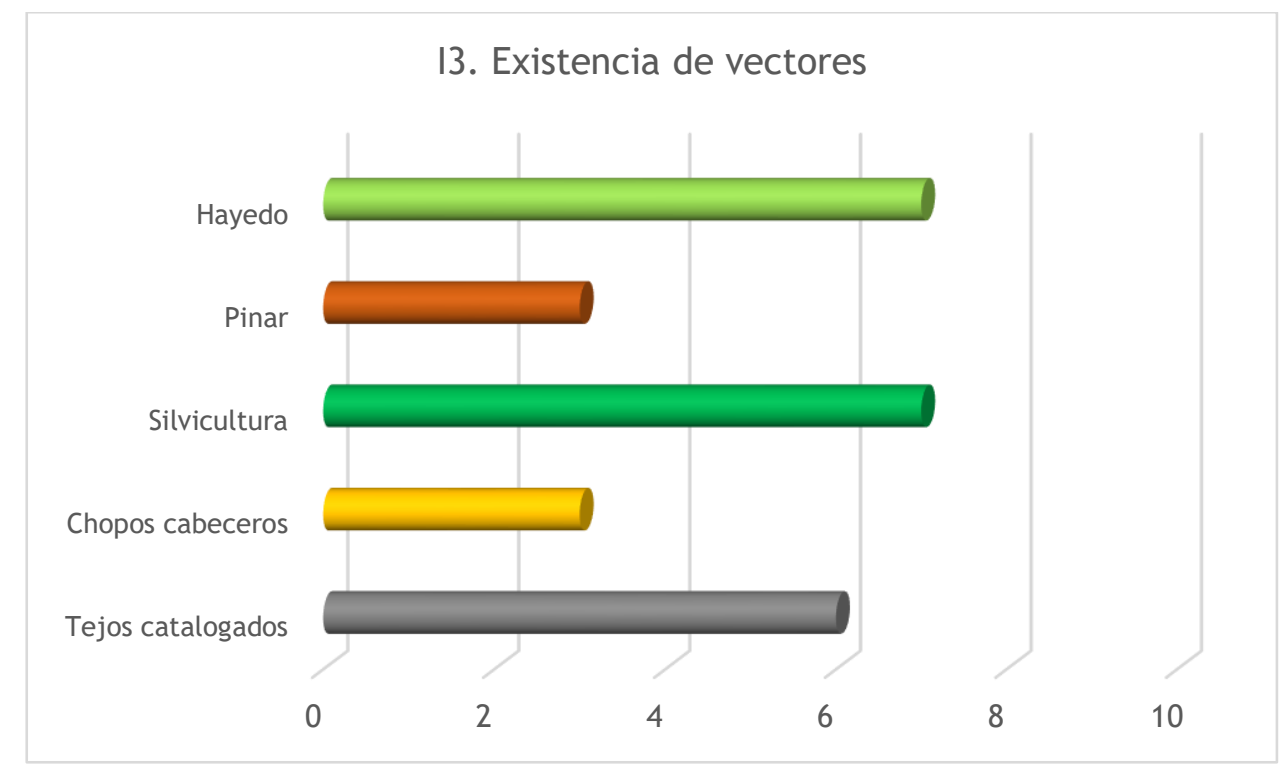

Figura 226. Gráfico resumen indicador vectores para los distintos casos de estudio. Elaboración propia.

\subsection{Identificación y sentimiento de pertenencia}

En cuanto a la identificación con los valores relativos al paisaje forestal en cuestión por parte de la población local se convino en 
determinarlo a través de la existencia de referencias toponímicas e iconográficas. Se entendió que la sociedad que toma conciencia de su patrimonio lo va a reflejar en su día a día utilizándolo como identificador distintivo de carácter territorial.

En este sentido, los municipios escogidos como testigos de los distintos tipos de paisaje no han aportado referencias iconográficas que permitan relacionar su patrimonio paisajístico forestal con su identificación. Tan solo el caso de los pinares de Vallelado han arrojado una valoración positiva en el testigo destinado a valorar la toponimia. Esta estrecha relación entre la nomenclatura espacial y la sociedad va a hincar sus raíces en la estrecha relación que la sociedad pinariega tiene con su realidad forestal como se ha visto a lo largo de este trabajo.

Cómo conclusión sobre el análisis de la identificación local es necesario señalar que todos los municipios que han servido como testigo poseen elementos patrimoniales distintivos, es decir, la sociedad si va a poner de relevancia su identidad territorial mediante el uso patrimonial pero no han acudido al paisaje forestal para exaltar esta identidad.

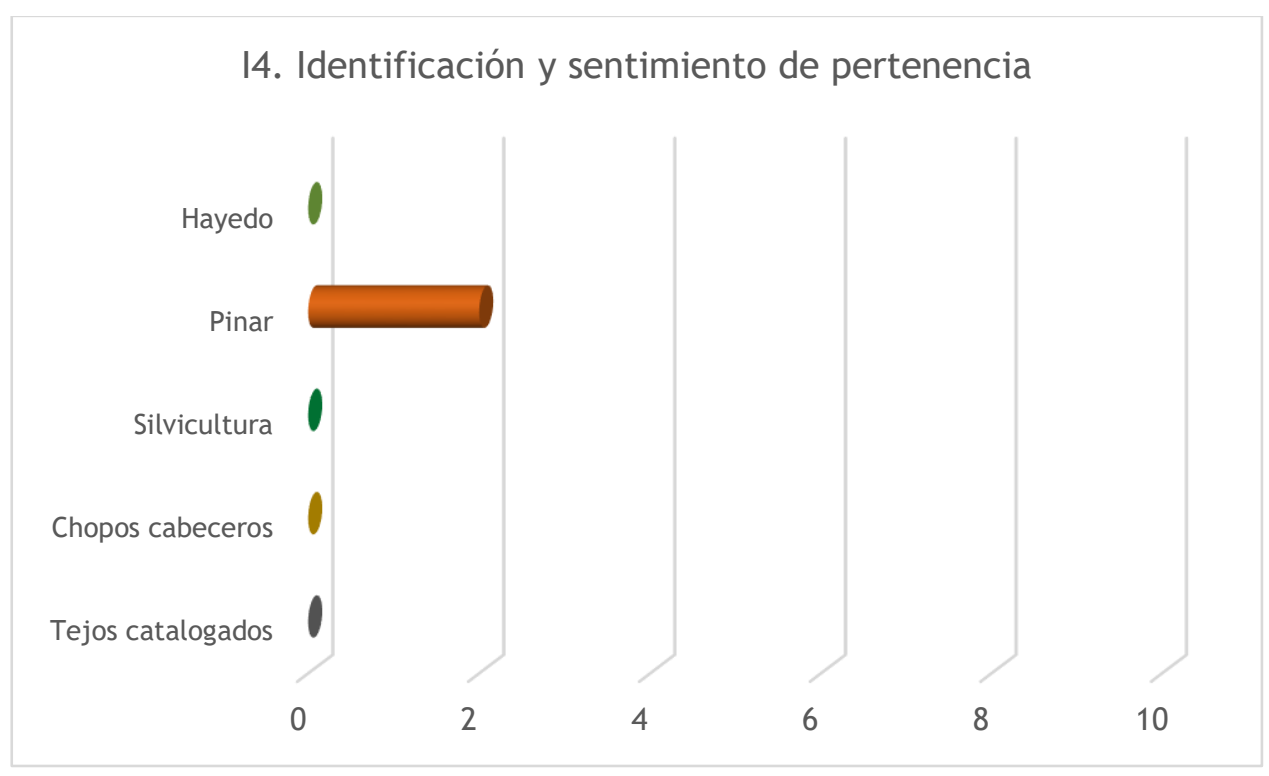

Figura 227. Gráfico resumen indicador identificación y sentimiento de pertenencia para los distintos casos de estudio. Elaboración propia. 


\subsection{Centros de interpretación/museos}

Una de las principales herramientas que garantizan la conservación de los valores asociados a cualquier elemento patrimonial es la existencia de museos que garanticen una catalogación y exaltación de estos valores. En el caso que ocupa al paisaje forestal se convino en crear este indicador con la intención de poder comparar unos casos con otros.

Mediante el análisis de este indicador se han detectado dos grupos claramente diferenciados y que en buena medida van a venir determinados por la vigencia de uso de sus recursos forestales. Por un lado, El paisaje del hayedo de Posada de Valdeón va a garantizar a través de su futuro centro de visitantes exhibir los valores propios del hayedo, de igual manera el tejo de La Alberca garantiza esta exhibición mediante la instalación de un cartel junto al ejemplar. Los chopos cabeceros de la cuenca del río Jiloca representados por el municipio de Burbáguena presentan la singularidad de la creación de una estatuilla inspirada en un ejemplar de chopo cabecero y que sirve como premio para el galardón que lleva su nombre, garantizando de este modo, mediante un elemento escultórico la conservación de valores culturales asociados al chopo trasmocho.

Por el contrario, los paisajes del pinar en Vallelado y el eucaliptal en Guriezo no poseen ningún tratamiento museístico que garantice esta conservación de valores. En buena medida esto se puede explicar en tanto que las actividades de explotación, resinera y silvícola respectivamente siguen vigentes, haciendo menos visible el valor patrimonial de estos paisajes forestales. 


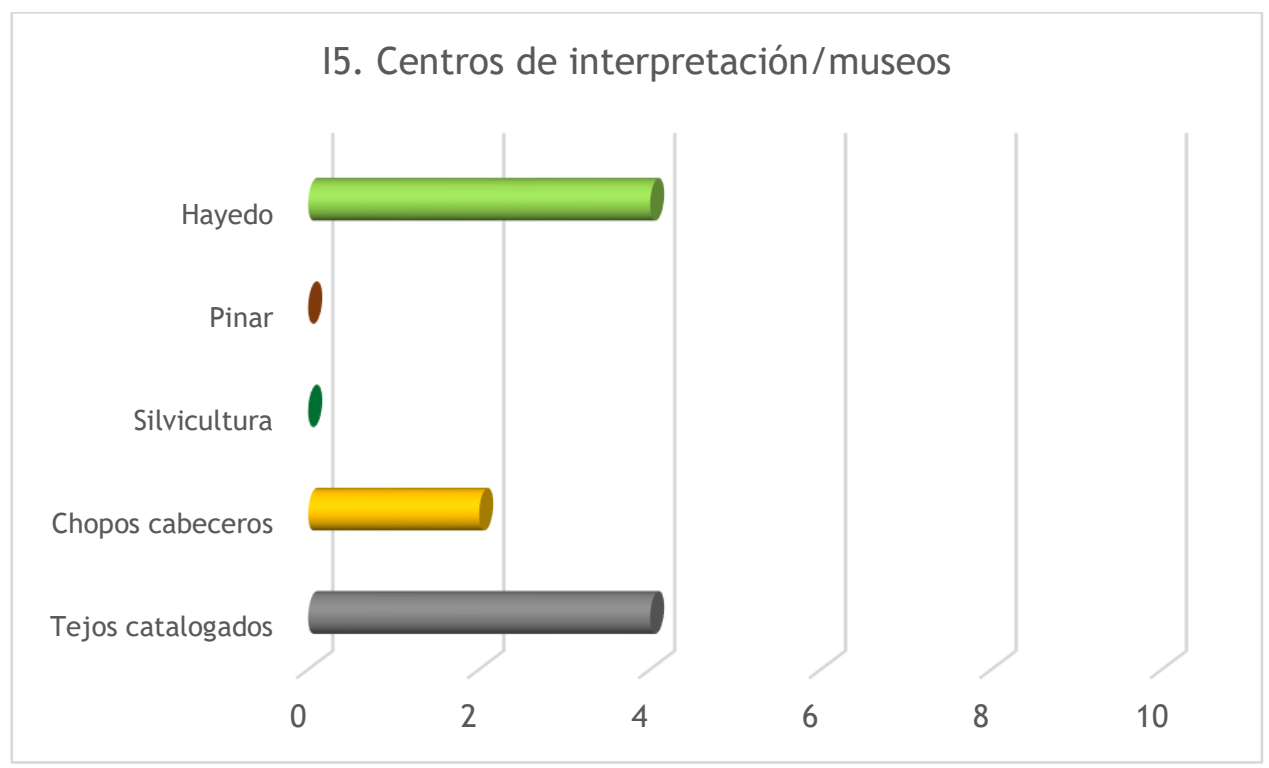

Figura 228. Gráfico resumen indicador museos para los distintos casos de estudio. Elaboración propia.

\subsection{Incorporación turística}

El turismo, actualmente, está estrechamente vinculado con los recursos patrimoniales de un territorio, así las administraciones y los particulares acuden de forma reiterada a estos elementos cargados de valores como recursos turísticos. Esta utilización se debe, en buena medida, a la necesidad de singularizar un producto turístico, haciéndolo atractivo a través de la excepcionalidad. Es por estas razones que se plantea la existencia de ofertas turísticas basadas en el paisaje forestal como testigo para evaluar la situación patrimonial. Se traza la premisa de que aquellos territorios que acudan de forma recurrente al paisaje forestal para fomentar su actividad turística se van a encontrar en una situación más avanzada en el proceso de patrimonialización. De esta manera se ha tratado de recopilar evidencias de promoción turística de los territorios en cuestión que fijen sus raíces es el paisaje forestal.

Se han encontrado dos situaciones completamente opuestas, por un lado, territorios en los que la promoción turística a través del paisaje 
forestal existe y, por otro lado, territorios en los que es absolutamente inexistente. En cualquier caso, la promoción turística no es elevada. Mientras que el hayedo de Posada de Valdeón y los chopos cabeceros de Burbáguena sí son promocionados como recurso turístico por parte de la administración municipal y supramunicipal y de forma privada en el caso de los chopos, el resto de los casos de estudio no se van a promocionar por ninguna administración, poniendo el foco en otros elementos patrimoniales. Por otro lado, hay que destacar que no se han encontrado referencias de particulares que utilicen el recurso forestal como reclamo turístico en ninguno de los casos de estudio.

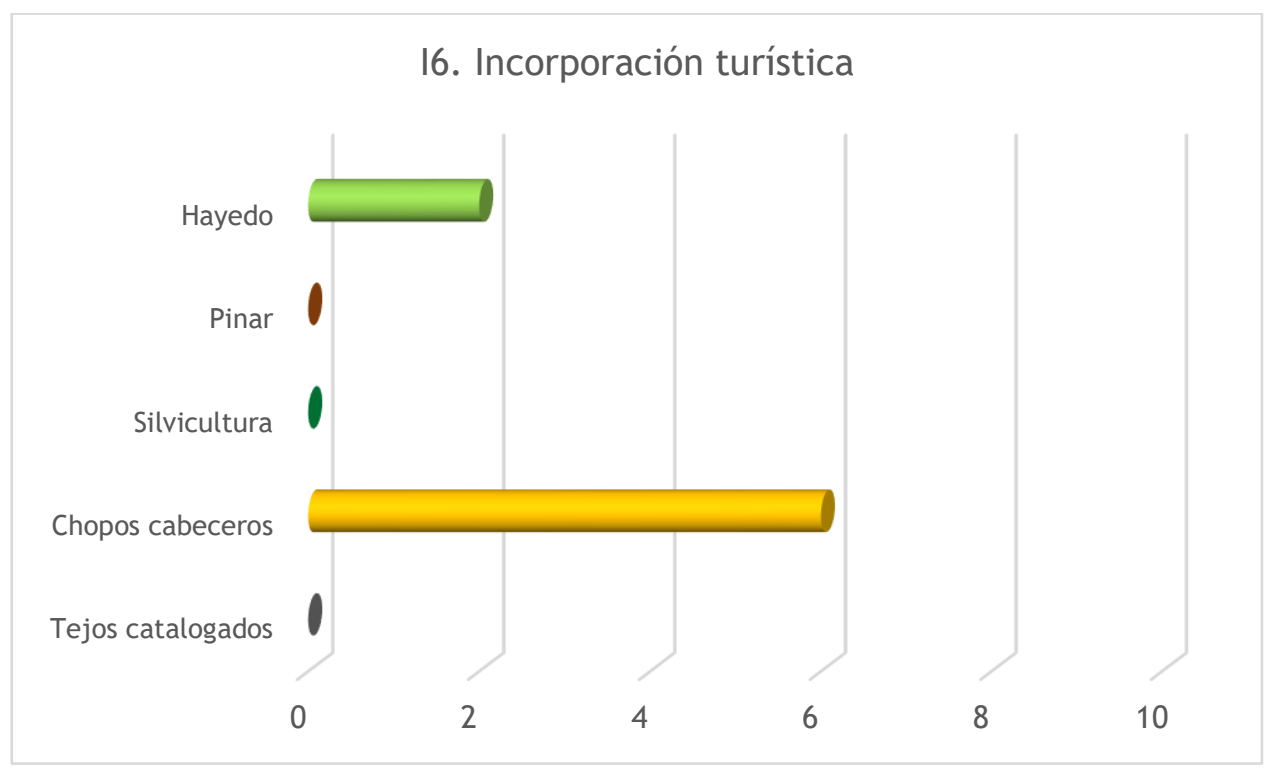

Figura 229. Gráfico resumen indicador incorporación turística para los distintos casos de estudio. Elaboración propia.

\subsection{Empelo relacionado}

El empleo capaz de generar se ha determinado fundamental para entender la relación patrimonial entre elementos y sociedad. Aquellos recursos que promueven la creación de empleo a través de su aprovechamiento son visto por la sociedad local como positivos, por lo que 
se utiliza esta relación como indicador para comprender y comparar el momento patrimonial de cada uno de los casos de estudio.

De esta manera se han definido los sectores vinculados a cada uno de los paisajes y se ha analizado su capacidad como nicho laboral.

Se ha identificado dos casos contrapuestos, por un lado, aquellos municipios que sí presentan una relación entre el paisaje forestal y mercado laboral y por otro lado aquellos municipios que no presentan ningún vínculo. En el primer caso van a destacar Posada de Valdeón, donde cerca del $1 \%$ de la población está ocupada en actividades de silvicultura, habiéndose incrementado esta proporción en los últimos años. Por otro lado, el municipio de Guriezo va a presentar un 1\% de población ocupada en actividades silvícolas, observándose un pequeño descenso de la importancia de la silvicultura como nicho de empleo. Pero especialmente destaca Vallelado, dónde cerca del 7\% de la población está ocupada en actividades relacionadas con la madera, observándose un importante incremento en los últimos años.

Por otro lado, los municipios de Burbáguena y La Alberca, representantes del paisaje de los chopos trasmochos y los tejos monumentales respectivamente, no presentan ninguna relación laboral entre sus recursos forestales y el mercado laboral. 


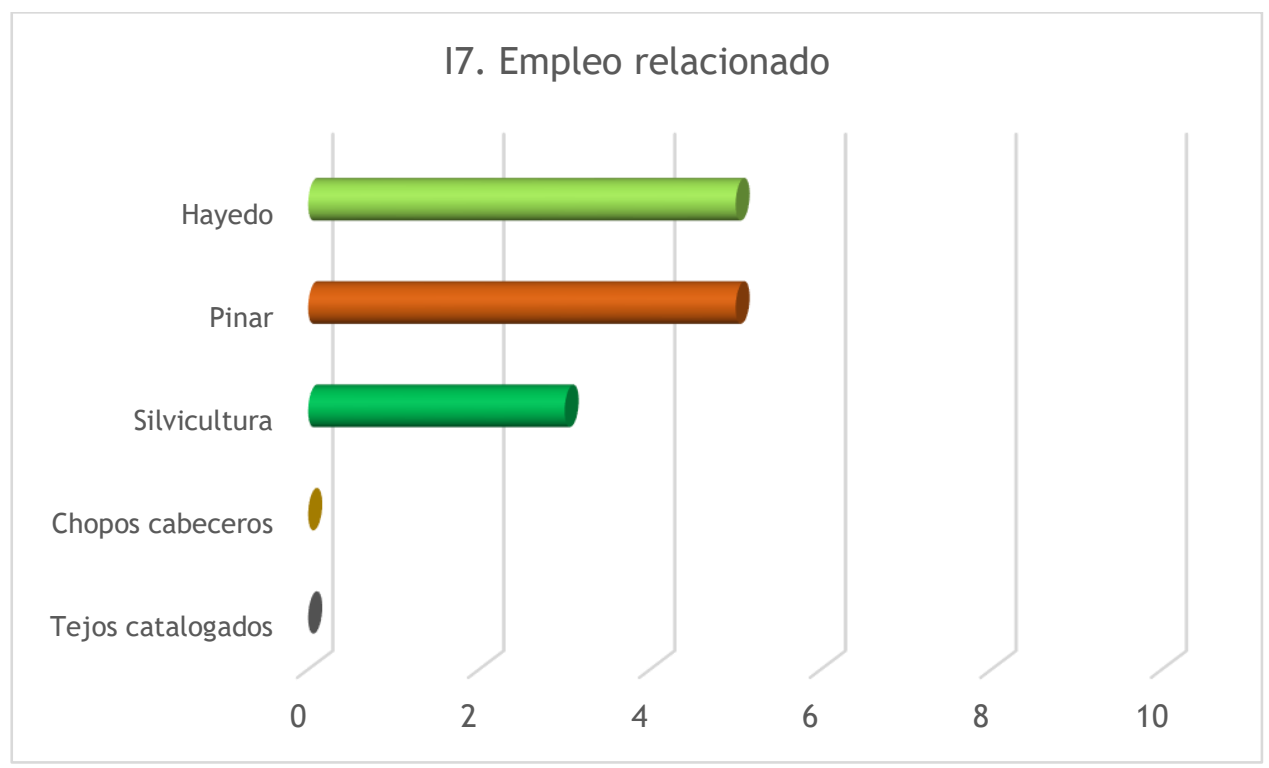

Figura 230. Gráfico resumen indicador empleo relacionado para los distintos casos de estudio. Elaboración propia.

\subsection{Resumen de indicadores}

Atendiendo al análisis de los indicadores planteados cabe realizar una comparación entre los cinco casos de estudio planteados como ejemplos de los distintos tipos de paisaje forestal. El hayedo de Posada de Valdeón ha respondido con una elevada puntuación en su situación patrimonial que viene derivada fundamentalmente de su personalidad de bosque refugio. Este tipo de bosque guarda las esencias de naturalidad y por consiguiente salvaguarda de estos valores como va a venir a reflejar su elevada puntuación en los indicadores de complejidad biológica y figuras de protección. En buena medida estas esencias vienen definidas por su realidad periférica, tanto desde el punto de vista económico como espacial. El bosque de Posada de Valdeón es relativamente inaccesible en su conjunto como así lo van a atestiguar los bosques catalogados por UNESCO como hayedos primigenios. Esta situación periférica ha garantizado una intervención muy baja, siempre a través de usos y prácticas tradicionales que han permitido transmitir este paisaje forestal de generación en 
generación prácticamente inalterado. Todo esto ha resultado determinante para la valoración que obtiene el paisaje forestal de Posada de Valdeón que se apoya, como se ha dicho, en su calidad biológica para alcanzar la puntuación más alta, 38 sobre 70 puntos.

En lo que se refiere al paisaje del pinar de Vallelado, se ha puesto de manifiesto que existe una vocación patrimonial pero que se encuentra en construcción, su situación de centralidad económica, en el centro de la cuenca del Duero, en una de las comarcas más dinámicas de la Comunidad Autónoma de Castilla y León y los aprovechamientos de plena vigencia (piñón y resinas) impiden observar el pinar como un recurso de vocación natural y es visto más como un recurso puramente económico. Esto se pone de manifiesto en los aprovechamientos con maquinaria que se realizan en el pinar, en su estrecha vinculación con el mercado laboral y en la escasa relación con el turismo o la museística demostrando que aún no es percibido como un recurso puramente patrimonial.

El paisaje de la silvicultura intensiva, representado por los eucaliptales del municipio de Guriezo demuestran cómo se encuentran en la situación más baja de patrimonialización. Al igual que en el paisaje del pinar, la silvicultura del eucalipto está plenamente vigente, su valor de uso se mantiene inalterado lo que impide la puesta en marcha de mecanismos que preserven sus valores. Se observa como la mayor puntuación de este paisaje la obtiene en la existencia de vectores que, como se ha dicho, se fundamenta en su plena vigencia funcional. Igualmente, la relación con el mercado laboral es estrecha garantizando su vinculación social. Por otro lado, su vigencia de uso impide el desarrollo de un ecosistema que garantice su valor biológico y, por ende, impide la declaración de figuras de protección y salvaguarda que imposibilitarían su explotación.

El paisaje de acompañamiento agropecuario que representan los chopos cabeceros del Jiloca y concretamente los de Burbáguena demuestra que se trata de un paisaje en pleno descubrimiento patrimonial. La pérdida 
de su vigencia de uso hace aproximadamente medio siglo ha hecho que se conviertan en referentes naturales que están siendo reconocidos y protegidos aludiendo a esos valores biológicos, pero sin olvidar su vocación cultural de suministradores de materias primas. Al perder su vigencia de uso, estos elementos forestales están siendo reincorporados patrimonialmente y se pueden apreciar iniciativas turísticas y museísticas que así lo ponen de manifiesto, aunque aún son incipientes.

Por último, los tejos monumentales de Castilla y León catalogados a través de la figura de Especímenes Vegetales de Singular Relevancia y representados en este trabajo por el tejo de La Alberca, han puesto de manifiesto que se encuentran en una situación intermedia en su proceso patrimonializador. Pese a tener un reconocimiento natural y cultural excepcional, la población no los percibe como elementos de referencia identitaria y no se están utilizando como recurso turístico. Uno de los principales motivos que se pueden apuntar como causante de este olvido patrimonial por parte de instituciones y particulares es la ingente cantidad de recursos patrimoniales que presentan los municipios donde se suelen localizar estos ejemplares monumentales. Su localización periférica a lo largo y ancho de la orla montañosa que rodea la Comunidad de Castilla y León en general y su localización en el asilado enclave de Las Batuecas en particular, hacen que se haya garantizado la transferencia patrimonial de edificaciones y prácticas culturales, generando una inmensa cantidad de recursos entre los que los tejos pierden importancia. 


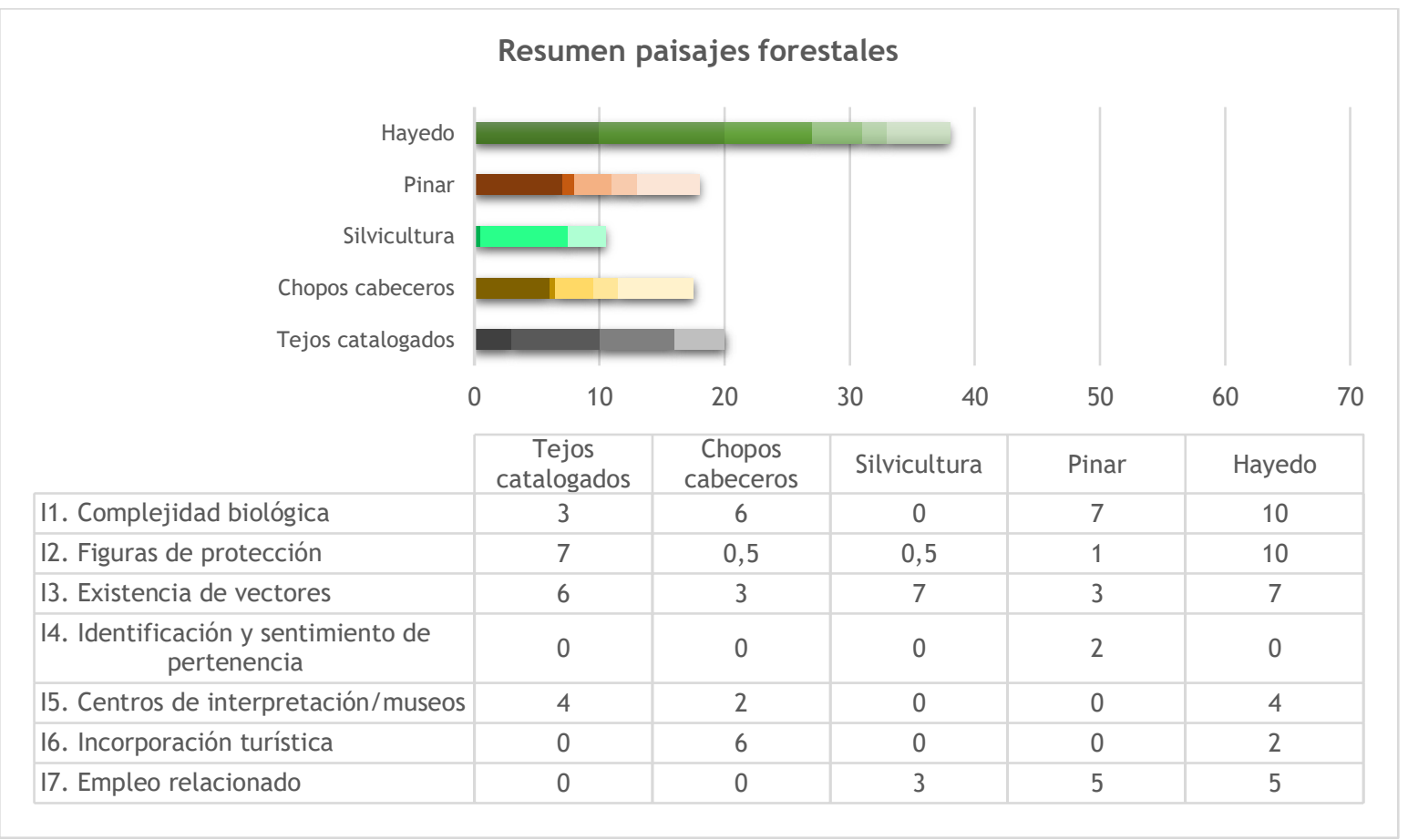

Figura 231. Gráfico resumen de los indicadores de patrimonialización en los distintos casos de estudio. Elaboración propia.

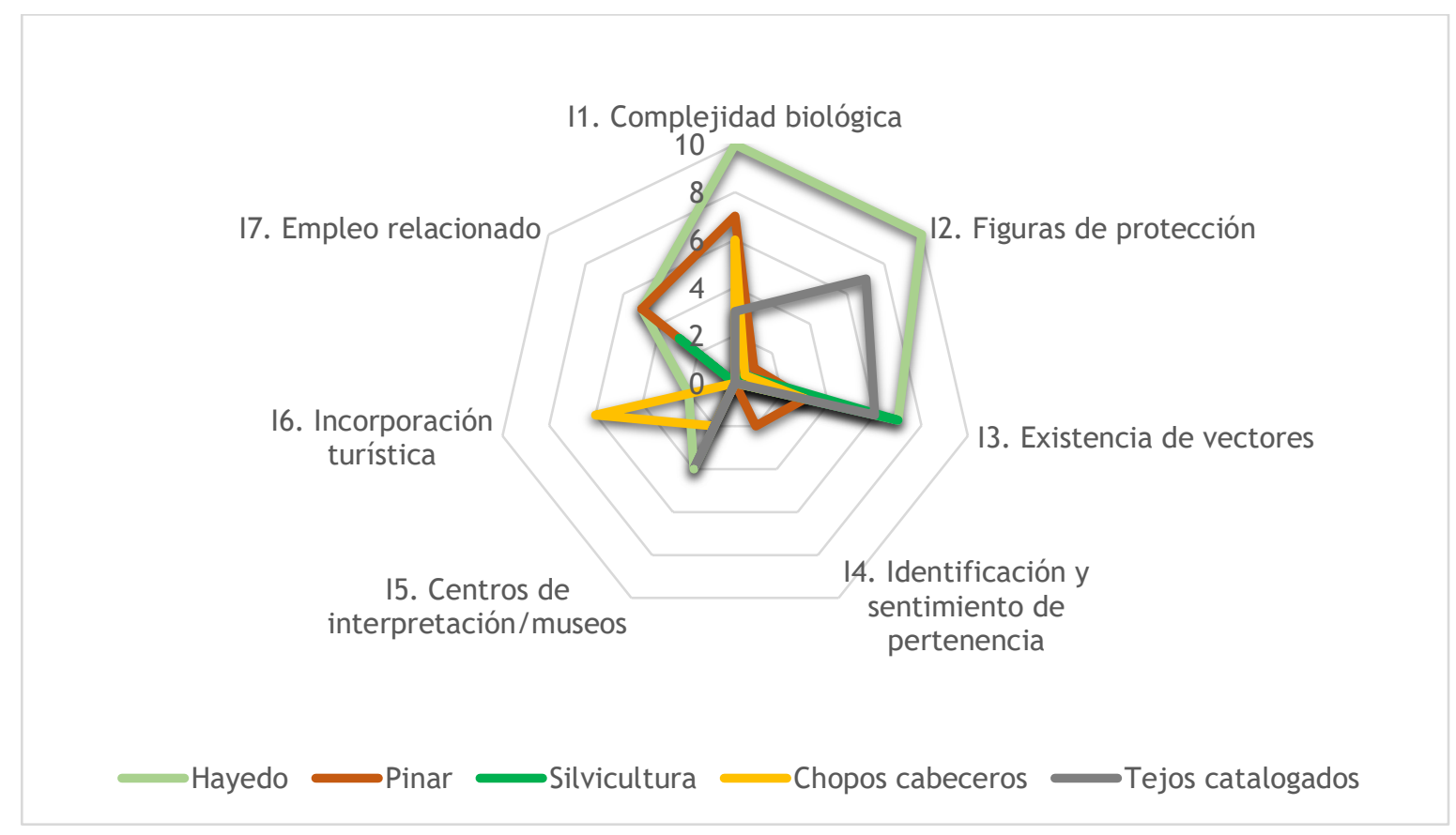

Figura 232. Resumen de los indicadores de patrimonialización comparados para los diferentes casos de estudio. Elaboración propia. 


\section{Conclusiones}


- La realidad forestal de la España peninsular ha seguido un camino marcado por diferentes hitos, todos ellos determinantes para comprender la situación actual. Lo forestal, dominado por los condicionantes ecológicos en un primer momento, va a dar paso progresivamente a una realidad donde las decisiones humanas van a ser determinantes. Algunos de los principales hitos que han condicionado de forma muy sustancial lo forestal en la España peninsular a lo largo de la historia han sido: la creación del Concejo de La Mesta, la Desamortización y el fenómeno de abandono rural a partir de 1950. Estos van a ser los tres pilares básicos que, junto con otros fenómenos, determinan la realidad forestal actual.

- Como se ha podido ver, las decisiones humanas son definitorias y definitivas en cuanto a la realidad forestal actual por lo que es necesario atacar lo forestal desde la perspectiva paisajística, en tanto que el paisaje va a ser el resultado de las intervenciones antrópicas sobre el medio físico en general y sobre lo forestal en particular.

- El enfoque paisajístico ha pasado, desde su origen como representación y cuyo valor fundamental era lo simbólico a ser un espacio vivido, un reflejo de las actuaciones humanas que debe servir para orientar la protección, la gestión y la ordenación.

- El paisaje en general y el paisaje forestal de la España peninsular, en particular, es una herencia resultado de dos fuerzas motrices, por un lado, los condicionantes ecológicos y por otro lado las prácticas culturales desarrolladas por la población a lo largo del tiempo. Este proceso dialéctico entre los procesos naturales y la intervención humana ha generado una realidad que puede ser clasificada en función de su carácter. Este carácter, que se erige como la marca dejada por la intervención humana, va a ser el legado que le otorga al paisaje su valor patrimonial.

- Al entender el paisaje forestal como una discusión entre naturaleza y cultura, se plantea una clasificación que pone de manifiesto la 
preeminencia de las prácticas humanas como modelador del paisaje. Sin olvidar los condicionantes naturales, las disposiciones humanas asociadas al aprovechamiento de los recursos son la clave sobre la que analizar el paisaje forestal.

- Este cambio de foco para analizar el paisaje, donde el peso va a recaer sobre la cultura de la población, va a necesitar de un enfoque paisajístico holístico, que garantice contemplar todos los motivos por los cuales la realidad sensorial es así y no de otro modo.

- El paisaje forestal, desde esta perspectiva, va a surgir como un aglutinador cultural, será un documento que refleje las actividades humanas a lo largo del tiempo convirtiéndolo en un patrimonio en sí mismo. Es decir, el paisaje forestal no va a ofrecer solamente una colección de elementos patrimoniales que actúen como islas dentro de un contexto ecológico, sino que va a ser en sí mismo un todo, contenido y continente patrimonial.

- La patrimonialización, entendida como ese proceso por el cual se adquieren los valores que permiten vincular la conciencia social con elementos naturales o culturales que serán los garantes de nuestra memoria colectiva, es un proceso multifactorial. En buena medida, este proceso que genera sentimiento de comunidad y sensación de pertenencia sigue dos vertientes claramente diferenciadas. Por un lado, la administración reconoce e identifica ciertos valores asociados a un elemento y lo activa como condensador moral mediante una declaración administrativa $y$, por otro lado, la sociedad local toma conciencia de un elemento como acumulador de valores y es elevado para su reconocimiento mediante procesos de participación colectiva.

- En lo que concierne a los distintos tipos de paisaje forestal y que han sido representados por cinco ejemplos concretos, se han detectado los puntos sobre los que se apoya cada tipo de paisaje para su reconocimiento patrimonial, en cualquiera de las dos vertientes, pero dando especial importancia a la vertiente social al 
ser la preferida por los organismos internacionales de salvaguarda patrimonial.

- En cualquier caso, el análisis mediante indicadores permite comparar el momento patrimonial en que se encuentran cada uno de los casos de estudio y detectar cuáles son aquellos aspectos sobre los que va a girar el reconocimiento patrimonial del paisaje forestal. Así, se puede afirmar que, el valor natural o biológico y el reconocimiento de este mediante figuras de salvaguarda ambiental, van a ser los puntos fuertes en la patrimonialización del paisaje forestal. Por otro lado, se ha detectado un importante déficit en aquellos aspectos que ponen de manifiesto la carga cultural que está detrás del paisaje actual. Se detecta por tanto una tendencia hacia la patrimonialización de lo biológico, de lo ecológico, dejando a un lado las prácticas culturales desarrolladas por una sociedad y que han sido, en último término, garantes de la existencia de la realidad forestal que hoy observamos. Esta tendencia hacia la explicación biológica de la realidad paisajística forestal puede generar importantes pérdidas patrimoniales.

- De acuerdo con esta tendencia detectada, que asienta la patrimonialización en los valores naturales, se pone de manifiesto la necesidad de establecer figuras de protección ambiental y salvaguarda biológica que sirvan como paraguas preservador de los valores culturales, mucho más susceptibles a las pérdidas patrimoniales. Igualmente, se detecta la necesidad de establecer procedimientos que sitúen las prácticas culturales de gestión forestal en la explicación de estos espacios, preservando el valor material e inmaterial modelador de estos paisajes forestales.

- Por último, el método planteado para la comparación va a admitir realizar este mismo proceso en otro paisaje forestal, permitiendo identificar el momento en que se encuentra, así como detectar las fortalezas y debilidades de patrimonialización, planteado si fuese necesario, correcciones que eviten una banalización patrimonial. 


\section{Agradecimientos}

A mis padres por todo el apoyo, soporte y comprensión, sin su ayuda no hubiese sido posible estar hoy aquí.

A mis abuelos por sus cuidados, su inteligencia y el recuerdo constante de quienes somos y de dónde venimos.

A Erica por su insistencia y su ejemplo. Ha dedicado su tiempo para acompañarme en algunas jornadas de trabajo de campo. Sin ella no hubiese llegado aquí.

A mis primos Pablo y Carlos, y mi “primo" Pablo que me han acompañado a lo largo de toda mi vida, son parte de lo que hoy soy.

A mis amigos, la familia que se elige. Todos ellos, en sus distintos contextos, han aportado algo a este trabajo.

A mis amigos surgidos durante la licenciatura, los llamados "geócratas" siempre están ahí, sus conversaciones siempre enriquecen cualquier situación.

A mis tutores y directores Fernando Molinero, Juan Carlos Guerra y Alipio García de Celis por sus consejos, su esfuerzo y su cercanía.

A Alfonso Pisabarro con el que he compartido aventuras y desventuras durante tantos años. En muchas ocasiones fue el único contacto personal durante días.

Al Departamento de Geografía y todos los miembros que lo componen y lo compusieron.

A Eugenio Baraja por sus fotografías y su cercanía.

A Chabier de Jaime por su cercanía, disponibilidad e inspiración.

A Cecilia, Manuel, Danilo y Yina, mi familia chilena. 
Al Centro de Estudios del Desarrollo Regional y Políticas Públicas, en especial a Marisela sin su ayuda y apoyo no estaría aquí.

A las comunidades mapuche que me acogieron, inspiraron y modificaron mi percepción del "mapu", especialmente a Marcela, Sergio e Isabel que me acogieron sin pedir nada a cambio.

A todos los que me he olvidado y que han formado parte de esto y de $\mathrm{mi}$ vida durante estos años.

A los defensores de los servicios públicos, especialmente la educación y la sanidad que equiparan y garantizan oportunidades.

¡A las geógrafas, a los geógrafos, a la geografía! 


\section{Bibliografía}

Abella, I. 2009. La cultura del tejo: esplendor y decadencia de un patrimonio vital. La Editorial de Urueña.

Aedo, C., Diego, C., García, J.C., Moreno, G. 1990. El bosque en Cantabria. Universidad de Cantabria [etc.], Santander.

Agúndez, D., Martín, S., De Miguel, J., Galera, R.M., Jiménez, M.P., M.DíazFernández, P. 1995. Las regiones de procedencia de Fagus sylvatica L. en España. ICONA, Madrid.

Alcalde, C., Morla, C., García, I., Sánchez, L.J., Gómez, F., Rubiales, J.M., Maldonado, J., Mijarra, J.M. 2004. Nuevos datos de carbones y maderas fósiles de Pinus pinaster Aiton en el Holoceno de la Península Ibérica. Investigación agraria. Sistemas y recursos forestales 13: 152-163.

Alcalde, J.T., Trujillo, D., Artázcoz, A., Agirre-Mendi, P.T. 2008. Distribución y estado de conservación de los quirópteros en Aragón. Graellsia 64: 3-16.

Alcañíz, A., Loraque, M. 2006. Burbáguena. Revista del Centro de Estudios del Xiloca 34: 219-243.

Alcaraz, D., Baldi, G., Durante, P., Garbulsky, M.F. 2008. Análisis de la dinámica temporal del NDVI en áreas protegidas: tres casos de estudio a distintas escalas espaciales, temporales y de gestión. Revista Ecosistemas 17:.

Allen, J.R.M., Huntley, B., Watts, W.A. 1996. The vegetation and climate of northwest Iberia over the last 14,000 years. Journal of Quaternary Science 11: 125-147.

Allende, F., Gómez, G., López, N., Sobrino, J. 2013. Podas y trasmochos en las ordenanzas forestales del Sistema Central español y su impronta en el paisaje forestal actual. Cuadernos de la Sociedad Española de Ciencias Forestales 38: .

Allué, E., Angelucci, D.E., Caceres, Fiocchi, C., Fontanals, M., García, M., Huguet, R. et al. 2000. El registro paleoecológico y arqueológico de La Cativera (El Catllar, Tarragona): datos preliminares sobre el límite Pleistoceno-Holoceno en el sur de Cataluña. En $3^{\circ}$ Congresso de Arqueología Peninsular: UTAD, Vila Real, Portugal, setembro de 
1999, Vol. 9, 2000 (Contributos das ciencias e das tecnologias para a arqueologia da Península Ibérica), ISBN 972-98807-3-5, págs. 8198, pp. 81-98. ADECAP.

Allué, E., Vernet, J.-L., Cebrià, A. 2009. Holocene vegetational landscapes of NE Iberia: charcoal analysis from Cova de Barcelona, Spain. The Holocene 19: 765-773.

la Guineu,

Alonso, J.M. 2012. La mala prensa del eucalipto.

Anón. XVII-XVIII. Vista Cartográfica de un tramo del río Voltoya entre Moraleja de Coca y Nava de la Asunción (Segovia).

Anón. 1766. Carta topográfica de un terreno litigioso entre Quintanas Rubias de Arriba y Quintanas Rubias de Abajo (Soria).

Anón. 1825. Carta topográfica de un sector de pinares delimitado por líneas de mojones, situado entre Nava de la Asunción y el río Voltoya (Segovia).

Arnesen, T. 2011. Landscape as a sign. Semiotics and methodological issues in landscape studies. En Landscapes, identities and development, pp. 363-376. Ashgate, Farnham, UK.

Arranz, C., Mañanes, T., Martín, P.P., Tardón, G. 1995. Villa y tierra de íscar. $2^{a}$ ed. Comunidad de Villa y Tierra de Íscar, Íscar (Valladolid).

Ayuntamiento de Guriezo. 2018. BOC 103 - Anuncio de enajenación.

Badal, E. 2009. Estudio Antracológico de la Secuencia Holocena de la Cova de les Cendres. En pp. 125-220.

Bas, S., Guitián, J., Sobral, M.S. 2018. Biodiversidad en plantaciones de eucalipto y en bosques de carballo del sur de Galicia: plantas y aves. Nova Acta Científica Compostelana 25.

Bauer, E., Laso, M.P. 1964. La propiedad forestal en España. Revista de Estudios Agrosociales7-53.

Bauer, E. 1991. Los montes de España en la historia. Ministerio de Agricultura, Pesca y Alimentación, Madrid.

Bellido, T., López, J.R. 2008. Estudio ecológico, etnobiológico y paisajístico de los chopos cabeceros en el valle del jiloca.

Bennett, K.D., Tzedakis, P.C., Willis, K.J. 1991. Quaternary Refugia of North European Trees. Journal of Biogeography 18: 103-115. 
Bennett, S.J., Simon, A. 2004. Riparian Vegetation and Fluvial Geomorphology. American Geophysical Union.

Bertrand, C., Bertrand, G., Rodríguez Martínez, F. 2007. Geografía del medio ambiente: el sistema GTP, geosistema, territorio y paisaje. Universidad de Granada, Granada.

Besse, J.-M. 2010. La sombra de las cosas: sobre paisaje y geografía. Biblioteca Nueva, Madrid.

Blanco, E., Casado, M.Á., Costa, M., Escribano, R., García, M., Génova, M., Gómez, Á. et al. 2005. Los bosques ibéricos: una interpretación geobotánica. Planeta, Barcelona.

Blázquez, J.M. 1971. Economía de Hispania al final de la República Romana ya comienzos del Imperio según Estrabón y Plinio. Estudios de Historia Esconómica I 78: 57-143.

Böck, K., Muhar, S., Muhar, A., Polt, R. 2015. The Ecosystem Services Concept: Gaps between Science and Practice in River Landscape Management. GAIA - Ecological Perspectives for Science and Society 24: $32-40$.

Bolòs, M. de. 1983. La tendencia del paisaje integrado en geografía. Vasconia: Cuadernos de historia - geografía75-92.

Borrell, F. 1901. Paisaje de El Escorial.

Bowles, W. 1789. Introducción a la historia natural y á la geografía física de España. en la Imprenta Real, En Madrid.

Boyer-Klein, A. 1980. Nouveaux résultats palynologiques de sites solutréens et magdaléniens cantabriques. Bulletin de la Société préhistorique française 77: 103-107.

Boyer-Klein, A. 1985. Nouveaux résultats Palynologiques dans les Cantabres au Tardiglaciare. En Actes des jornées du 25-26-27 janvier. 1984, pp. 397-399. Sophia Antipolis, París.

Burjachs, F. 1994. Palynology of the upper Pleistocene and Holocene of the North-East Iberian Peninsula: Pla de l'Estany (Catalonia). Historical Biology 9: 17-33.

Busquets, J., Cortina, A. 2009. Gestión del paisaje. Manual de protección, gestión y ordenación del paisaje. Ariel, Barcelona.

Cacho, C., Fumanal, M.P., López, P., López, J.A., Ripoll, M.P., Valle, R.M., Uzquiano, P. et al. 1995. El Tossal de la Roca (Vall d' Alcalá, Alicante). Reconstrucción paleoambiental y cultural de la transición 
del tardiglaciar al Holoceno inicial. Recerques del Museu d'Alcoi 0: $11-101$.

Calonge, G. 1987. El complejo ecológico y la organización de la explotación forestal en la tierra de pinares segoviana. Diputación Provincial de Segovia, Segovia.

Calvo, L. 2003. Catálogo de montes: origen y evolución histórica (18591901). Organismo Autónomo Parques Nacionales, Madrid.

Cáncer, L. 1994. Lectura crítica de las teorías más representativas de la ciencia del paisaje. Geographicalia 31: 17-30.

Cáncer, L. 1995. Una lectura geográfica de las bases legales para la protección de los paisajes: el marco general de España y el particular de Aragón. Boletín de la Asociación de Geógrafos Españoles 20: 101 . 114.

Cano, N. 2007. Más allá de la vista: Paisajes con otros sentidos. Revista de desarrollo rural y cooperativismo agrario133-146.

Capel, H. 2013. El patrimonio natural y territorial. De la protección a la gestión y regeneración del paisaje cultural. ZARCH: Journal of interdisciplinary studies in Architecture and Urbanism 10-41.

Capel, H. 2014. El patrimonio: la construcción del pasado y del futuro. 1 a. ed. Ediciones del Serbal, Barcelona.

Carrión, A. 2015. Plan Nacional de Paisaje Cultural.

Carrión, J.S., Munuera, M., Navarro, C., Sáez, F. 2000. Paleoclimas e historia de la vegetación cuaternaria en españa a través del análisis polínico. Viejas falacias y nuevos paradigmas. Complutum 11: 115. 142.

Carrión, J.S., Andrade, A., Bennett, K.D., Navarro, C., Munuera, M. 2001. Crossing forest thresholds: inertia and collapse in a Holocene sequence from south-central Spain: The Holocene 11: 635-653.

Carrión, J.S., Munuera, M., Dupré, M., Andrade, A. 2001. Abrupt vegetation changes in the Segura Mountains of southern Spain throughout the Holocene. Journal of Ecology 89: 783-797.

Carrión, J.S., Yll, E.I., Walker, M.J., Legaz, A.J., Chaín, C., López, A. 2003. Glacial refugia of temperate, Mediterranean and Ibero-North African flora in south-eastern Spain: new evidence from cave pollen at two Neanderthal man sites. Global Ecology and Biogeography 12: 119-129. 
Carrión, J.S., Scott, L., Arribas, A., Fuentes, N., Gil-Romera, G., Montoya, E. 2006. Pleistocene landscapes in central Iberia inferred from pollen analysis of hyena coprolites. Journal of Quaternary Science 22: 191202.

Carrión, Y. 2005. La vegetación mediterránea y atlántica de la Península Ibérica: nuevas secuencias antracológicas. Diputación de Valencia, Valencia.

Carrión, Y., Kaal, J., López, J.A., López, L., Martínez, A. 2010. Holocene vegetation changes in NW Iberia revealed by anthracological and palynological records from a colluvial soil.

Casalderrey, M.C. 2017. ¿Cuánto 'vale' el bosque nativo? Quid 16.146-159.

Castro, A., Fernández, J. 2018. Coleópteros saproxílicos de interés comunitario en espacios Red Natura 2000 en Gipuzkoa (norte de España). Munibe Ciencias naturales.

Castro, D.R. 2013. Monitoreo de bosques utilizando NDVI Rededge de Rapideye. Revista Geoespacial58-71.

Cavanilles, A. 1858. Lequeitio en 1857. Imprenta de J. Martín Alegría, Madrid.

Chen, Q.-B. 2001. A review of researches on biodiversity in Eucalyptus plantations. Chinese Journal of Tropical Crops 22: 82-90.

Comisión Europea. 1992. Council Directive 92/43/EEC of 21 May 1992 on the conservation of natural habitats and of wild fauna and flora.

Concejo Abierto Agüera. 2019. BOC 66 - Anuncio de enajenación.

Consejo De Europa. 2000. Convenio europeo del paisaje. Florencia, Italia.

Consejo de Ministros. 2002. Plan Forestal Español.

Coromines, J., Pascual, J.A. 1991. Diccionario crítico etimológico castellano e hispánico. Elliot's Books.

Cortijo, M.L. 2007. Los árboles silvestres en la lberia de Estrabón. Zephyrus: Revista de prehistoria y arqueología209-219.

Corvol, A. 2010. Arbres remarqués - Arbres remarquables. Journée d'Etudes «Environnement, Forêt et Société, XVIe-XXe siècle». Groupe d'histoire des forêts françaises. Paris. 
Costa, M., Aguilella, A. 1997. Influencias antrópicas en la vegetación mediterránea occidental. Monografías del Jardín Botánico de Córdoba27-37.

Costanza, R., d’Arge, R., Groot, R. de, Farber, S., Grasso, M., Hannon, B., Limburg, K. et al. 1997. The value of the world's ecosystem services and natural capital. Nature 387: 253-260.

Daily, G., Postel, S., Bawa, K., Kaufman, L. 1997. Nature's Services: Societal Dependence On Natural Ecosystems. Island Press, Whashington, DC.

Daly, H.E. 1999. Ecological economics and the ecology of economics essays in criticism. Edward Elgar, Cheltenham, UK [etc.

Darby, S.E. 1999. Effect of Riparian Vegetation on Flow Resistance and Flood Potential. Journal of Hydraulic Engineering 125: 443-454.

De Jaime, C., Herrero, F. 2007. El chopo cabecero en el sur de Aragón: La identidad de un paisaje. Centro de Estudios del Jiloca.

De la Cruz, J. 1855. Estudios sobre el ramo de montes arbolados de España insertos en el clamor público de 1845: seguidos de una recopilación legislativa-forestal desde el fuero juzgo hasta 31 de diciembre de 1854, y de otros documentos curiosos ë importantes. Imprenta de José Trujillo.

De Palau, M. 1879. Ley de aguas de 13 de junio de 1879. $2^{\text {a }}$ ed. aum. Antonio de Sanmartín; Texidó y Parera, Madrid; Barcelona.

Delahunty, J.L. 2002. Religion, war, and changing landscapes: An Historical and Ecological Account of the Yew Tree (Taxus baccata L.) in Ireland. University of Florida, Florida.

Dérioz, P. 2010. Les ambiguïtés de la patrimonialisation des «paysages naturels». Sud-Ouest européen. Revue géographique des Pyrénées et du Sud-Ouest19-36.

Desprat, S., Sánchez Goñi, M.F., McManus, J.F., Duprat, J., Cortijo, E. 2009. Millennial-scale climatic variability between 340000 and 270 000 years ago in SW Europe: evidence from a NW Iberian margin pollen sequence. Clim. Past 5: 53-72.

Diago, M. 2012. Los aprovechamientos de las tierras de titularidad pública en las Comunidades de Villa y Tierra de la Extremadura castellanoleonesa entre los ss. XIII y XVII. 85-113. 
Díaz, S., Pascual, U., Stenseke, M., Martín-López, B., Watson, R.T., Molnár, Z., Hill, R. et al. 2018. Assessing nature's contributions to people. Science 359: 270-272.

Díez, S., Muñoz, M., Picardo, A., Cupido, R. 2011. La bionergía en Castilla y León, un sector estratégico para la Comunidad Autónoma. Foresta16-21.

Ehrlich, P.R., Ehrlich, A.H. 1982. Extinction: the causes and consequences of the disappearance of species. Random House.

Enríquez, A. 2012. Especies invasoras. El chopo híbrido (Populus $x$ canadensis Moench.), una especie ignorada.

España. 1940. DECRETO de 26 de abril de 1940, por el que se declara de interés nacional la industria de fibras téxtiles artificiales de la S.N.I.A.C.E.

España. 1941. Ley de 10 de marzo de 1941 sobre el Patrimonio Forestal del estado.

Estrabón, Meana, M.J., Piñero, F. 1998. Geografía. Libros III-IV. Gredos, Madrid.

Eversley, D. 1974. Conservation for the minority? Built Environment 3: 1415.

Ezquerra, F., Gil, L. 2004. La transformación histórica del paisaje forestal en Cantabria.

Ezquerra, F.J., Jiménez, F., Pinto, D., Osorio, M.A., Alfaro, R.M. 2009. Actuaciones forestales en el corredor entre las dos poblaciones subcantábricas de oso pardo (León, Palencia): resumen de 15 años de trabajo y nuevos retos. En $5^{\circ}$ Congreso Forestal Español. Montes y Sociedad: Saber qué hacer., Junta de Castilla y León, Ávila.

FAO. Servicios ecosistémicos y biodiversidad | Organización de las Naciones Unidas para la Alimentación y la Agricultura. Disponible en: http://www.fao.org/ecosystem-services-biodiversity/es/ [Accedido 11 de julio de 2018].

Farris, E., Filigheddu, R. 2008. Effects of browsing in relation to vegetation cover on common yew (Taxus baccata L.) recruitment in Mediterranean environments. Plant Ecology 199: 309-318.

Fernández, E. 1990. Pasado, presente y futuro de los bosques de la Península Ibérica. Acta Botánica Malacitana 15: . 
Fernández, F. 2014. El nacimiento del concepto de paisaje y su contraste en dos ámbitos culturales: el viejo y el nuevo mundo. En Perspectivas sobre el paisaje. Editado por Susana Barrera Lobatón y Julieth Monroy Hernández. Bogotá: Universidad Nacional de Colombial Jardín Botánico José Celestino Mutis,

Fernández, M.Á., Belmonte, F., Romero, A., Robledano, F. 2016. La forestación de tierras agrarias en la Región de Murcia a través de los Programas de Desarrollo Rural en España: Una medida con impacto medioambiental positivo en el medio rural. En Aportación Española al 33 Congreso Internacional de Geografía., Beijing.

Fernández, V., Silva, R. 2015. Criterios para la identificación y selección de paisajes españoles susceptibles de ser incluidos en la lista del Patrimonio Mundial de UNESCO. Boletín de la Asociación de Geógrafos Españoles 68: 253-278.

Figueiral, I. 1995. Charcoal analysis and the history of Pinus pinaster (cluster pine) in Portugal. Review of Palaeobotany and Palynology 89: $441-454$.

Figueiral, I., Terral, J.-F. 2002. Late Quaternary refugia of Mediterranean taxa in the Portuguese Estremadura: charcoal based palaeovegetation and climatic reconstruction. Quaternary Science Reviews 21: 549-558.

Fisher, B., Turner, R.K., Morling, P. 2009. Defining and classifying ecosystem services for decision making. Ecological Economics 68: $643-653$.

Franco, F., García, M., Maldonado, J., Morla, C., Sainz, H. 2001. The Holocene history of Pinus forests in the Spanish Northern Meseta. Holocene 11: 343-358.

Franco, F., García, M., Maldonado, J., Morla, C., Sainz, H. 2005. Ancient pine forest on inland dunes in the Spanish northern meseta. Quaternary Research 63: 1-14.

Frolova, M. 2009. La evolución reciente de las políticas de paisaje en España y el convenio europeo del paisaje - Recent developments in the political landscape of Spain and the European Landscape Convention. Proyección 6: 27.

Fuentenebro, F. 1986. Ordenanzas del Concejo de Cantalejo, año 1550. Anuario de historia del derecho español729-752.

Fundación HAZI Fundazioa. 2013. Apuntes Sobre Trasmochos. Guía de buenas prácticas para el trasmocheo. 
Gaceta de Madrid. 1896. R.D. 20 Septiembre 1896.

Gallego, D., Blanco, J.l., Roca, E.Á., Sebastián, J. 1994. Más allá de la propiedad perfecta. El proceso de privatización de los montes públicos españoles (1859-1926). Noticiario de Historia Agaria99-152.

García, A., Goldsmith, F.B. 1988. Cantabrican mountain beechwoods: A survey and the case for their conservation. Biological Conservation 45: $121-134$.

García, A. 1992. Conserving the species-rich meadows of Europe. Agriculture, Ecosystems \& Environment 40: 219-232.

García, D., Martínez, V., Fazelpoor, K., González, M. 2018. Riparian vegetation encroacment in mediterranean rivers. 8.

García, E.J., Llaneza, L., Palacios, V., López, J.V. 2014. Segumiento de las poblaciones de lobos en el parque nacional Picos de Europa, 2013.

García, I., Gómez, F., Rubiales, J.M., Granja, H.M., Soares, G., Morla, C. 2007. The Late Quaternary coastal forests of western Iberia: A study of their macroremains. Palaeogeography, Palaeoclimatology, Palaeoecology 254: 448-461.

García, I., Rubiales, J.M., Moreno, E., Iglesias, R., Gómez, F. 2011. New macrofossil evidence of Pinus nigra Arnold on the Northern Iberian Meseta during the Holocene. Review of Palaeobotany and Palynology 163: $281-288$.

García, J. 1975. Organización del espacio y economía rural en la España Atlántica. $1 \mathrm{a}$ ed. Siglo Veintiuno, Madrid [etc.].

García, J. 1996. Medio ambiente y crisis rural. Universidad de Valladolid [etc.], Valladolid.

García, J. 2001. Geografía Física o Ciencias Naturales. Investigaciones Geográficas33-49.

García, J. 2002. La explotación de los montes y la humanización del paisaje vegetal (cuestiones de método previas).

García, J. 2004. La explotación tradicional en «La Tierra de Pinares» segoviana. Investigaciones geográficas5-24.

García, M., Franco, F., Maldonado, J., Morla, C., Sainz, H. 1997. New data concerning the evolution of the vegetation in Lillo pinewood (Leon, Spain). Journal of Biogeography 24: 929-934. 
García, M., Franco, F., Morla, C., Maldonado, J. 2011. The biogeographical role of Pinus forest on the Northern Spanish Meseta: a new Holocene sequence. Quaternary Science Reviews 30: 757-768.

Garrabou, R., Naredo, J.M. 2008. El paisaje en perspectiva histórica: formación y transformación del paisaje en el mundo mediterráneo. Universidad de Zaragoza.

Getzner, M. 2010. Ecosystem services, financing, and the regional economy: A case study from Tatra National Park, Poland. Biodiversity 11: 5561.

Gil, G., Antón, M.G., Calleja, J.A. 2008. The late Holocene palaeoecological sequence of Serranía de las Villuercas (southern Meseta, western Spain). Vegetation History and Archaeobotany 17: 653-666.

Gil, L., Torre, M., Picardo, Á., Gordo, F.J. eds. . 2007. Atlas forestal de Castilla y León. 1a. ed. Junta de Castilla y León, Valladolid.

Gil, L. 2011. El bosque que nos ha llegado: extinción local de los bosques en España. En La evolución del paisaje vegetal y el uso del fuego en la Cordillera Cantábrica, Fundación Patrimonio Natural de Castilla y León, León.

Gobierno de Aragón. 2016. DECRETO 175/2016, de 30 de noviembre, del Gobierno de Aragón, por el que se declara la cultura del Chopo cabecero en el sur de Aragón como Bien de Interés Cultural Inmaterial.

Gobierno de Aragón. 2018. DECRETO 69/2018, de 24 de abril, del Gobierno de Aragón, por el que se declara el Parque Cultural del Chopo Cabecero del Alto Alfambra.

Goiti, U., Aihartza, J., Garin, I., Napal, M., Salsamendi, E. 2007. Revisión de la situación de los quirópteros en el parque natural de Gorbeia. Plan de gestión de refugios.

Gómez, J. 1992. Ciencia y política de los montes españoles (1848-1936). ICONA, Madrid.

Gómez, J., Mata, R. 1992. Actuaciones forestales públicas desde 1940: objetivos, criterios y resultados. En Medio siglo de cambios agrarios en España, 1993, ISBN 84-7784-061-X, págs. 151-190, Instituto Alicantino de Cultura Juan Gil-Albert.

Gómez, J. 2001. Las políticas repobladoras del siglo XX. Anñalisis de discursos. En Congresos-CARGA FINAL. 
Gómez, J. 2002. Paisajes forestales e ingeniería de montes. Paisaje y ordenación del territorio.-Sevilla: Consejería de Obras Públicas y transportes, Fundación Duques de Soria237-254.

Gómez, J. 2006. La mirada de la geografía. Paisajes en transformación: el caso de los paisajes forestales. En El paisaje y la gestión del territorio: criterios paisajísticos en la ordenación del territorio y el urbanismo, pp. 89-102. Diputació Provincial de Barcelona.

Gómez, J., Mata, R. 2006. Paisajes forestales españoles y sostenibilidad: tópicos y realidades. Areas: Revista internacional de ciencias sociales 25: $13-30$.

Gómez, J. 2012. Del patrimoni paisatge als paisatges patrimoni. Documents d'Anàlisi Geogràfica 59: 5-20.

Gómez, J., Madrazo, G., Sáez, E. 2014. Dinámica histórica de paisajes forestales y sostenibilidad.

Gómez, L., Ramil, P., Muñoz, C., Rodríguez, M. 2001. Análisis polínico y cronológico de los depósitos pleistocenos de Moucide (Cangas de Foz, Lugo) y río Boó (Muras, Lugo). En Palinología: diversidad y aplicaciones : trabajos del XII Simposio de Palinología (APLE) León, 1998, 2001, ISBN 84-7719-948-5, págs. 153-160, pp. 153-160. Servicio de Publicaciones, León.

Gómez, L., Ramil, P., Muñoz, C. 2007. The Würm in NW Iberia, a pollen record from Area Longa (Galicia). Quaternary Research 67: 438-452.

Gómez, M., Roig, S., Reque Kilchenmann, J.A. 2008. Caracterización selvícola de los hayedos cantábricos: influencia de las condiciones de estación y los usos antrópicos. Investigación Agraria: Sistemas y Recursos Forestales 17: 155-167.

González, J., Martínez, C., Bravo, F. 2009a. Evaluating different harvest intensities over understory plant diversity and pine seedlings, in a Pinus pinaster Ait. natural stand of Spain. Plant Ecology 201: 211220.

González, J., Martínez, C., Bravo, F. 2009b. Vegetación herbácea en una masa característica de Pinus pinaster en la región de procedencia "Meseta Castellana": efecto de la intensidad de corta sobre la diversidad y composición florística.

González, J., Martínez, C., Marrs, R.H., Bravo, F. 2010. Influence of harvesting intensity on the floristic composition of natural Mediterranean maritime pine forest. Acta Oecologica 36: 349-356. 
González, J.M., Basaguren, A., Pozo, J. 2003. Macroinvertebrate communities along a third-order Iberian stream. Annales De Limnologie-international Journal of Limnology - ANN LIMNOL-INT J LIMNOL 39: 287-296.

González, P. 1998. Estudio palinológico de la cueva de En Pardo (Planes, Alicante) Primeros resultados. Cuaternario y Geomorfología 12: 4561.

González, P., Leroy, S.A.G., Carrión, J.S., Fernández, S., García, M., GilGarcía, M.J., Uzquiano, P. et al. 2010. Steppes, savannahs, forests and phytodiversity reservoirs during the Pleistocene in the Iberian Peninsula. Review of Palaeobotany and Palynology 162: 427-457.

Gordi, J. 2009. Paisajes forestales. En Gestión del paisaje, 2009, ISBN 978 84-344-2890-4, págs. 135-148, pp. 135-148. Ariel.

Gran, K., Paola, C. 2001. Riparian vegetation controls on braided stream dynamics. Water Resources Research 37: 3275-3283.

de Groot, R.S., Alkemade, R., Braat, L., Hein, L., Willemen, L. 2010. Challenges in integrating the concept of ecosystem services and values in landscape planning, management and decision making. Ecological Complexity 7: 260-272.

Guerra, J.C. 2001. La acción humana, el paisaje vegetal y el estudio biogeográfico. Boletín de la Asociación de Geógrafos Españoles 47-60.

Guerra, J.C., Baraja, E., Cascos, C. 2010. Aproximacion a la componente forestal de los paisajes agrarios de Castilla y León. En Actas del XV Coloquio de Geografía Rural: Territorio, paisaje y patrimonio rural: Cáceres, 28 a 30 de abril de 2010, pp. 16. Servicio de Publicaciones.

Guerra, J.C. 2012. Neoproductivismo, herencias, nuevos paradigmas y clorofila: los paisajes del bosque en Castilla y León. Polígonos. Revista de Geografía 21: 223-258.

Guerra, J.C. 2013. Entre la silvicultura intensiva y el arquetipo de naturaleza: los paisajes forestales de la España atlántica. En Atlas de los paisajes agrarios de España, pp. 99-117. Ministerio de Agricultura, Alimentación y Medio Ambiente, Madrid.

Guixé, D., Camprodon, J. eds. . 2018. Manual de conservación y seguimiento de los quirópteros forestales. Ministerio para la Transición Ecológica, Madrid.

von Haaren, C., Albert, C., Barkmann, J., Groot, R., Spangenberg, J., Schröter-Schlaack, C., Hansjürgens, B. 2014. From explanation to application: introducing a practice-oriented ecosystem services 
evaluation (PRESET) model adapted to the context of landscape planning and management. Landscape Ecol 29: 1335-1346.

Hageneder, F. 2015. Ancient trees and their social recognition: Taxus baccata L. Yew and ancient kingship rituals-European traditions and their Anatolian roots. En Procedings of the 1 st international yew workshop, pp. 39-49. Duzce University-Turkey.

Haines-Young, R., Potschin, M. 2010. The links between biodiversity, ecosystem services and human well-being. En Ecosystem Ecology, pp. 110-139. Cambridge University Press, Cambridge.

Haines-Young, R., Potschin, M. 2012. Paper prepared following consultation on CICES Version 4.

Harvey, D. 2007. Espacios del capital: hacia una geografía crítica. Akal, Madrid.

Hein, L. 2011. Economic Benefits Generated by Protected Areas: the Case of the Hoge Veluwe Forest, the Netherlands. Ecology and Society 16: $\operatorname{art13.}$

Heink, U., Kowarik, I. 2010. What are indicators? On the definition of indicators in ecology and environmental planning. Ecological Indicators 10: 584-593.

Heredia, N., Rodríguez Fernández, L.R., Suarez, A., Álvarez Marrón, J. 1990. Memoria y mapa MAGNA de Burón $N^{\circ} 80$.

Hernández, A., Olivé, A., Portero, J.M., Gutierrez, M., Aguilar, M.J., Leal, M.C. 1983. Memoria MAGNA N491 Calamocha.

Herrera, A. 2000. El eucalipto en Cantabria. Anales del Instituto de Estudios Agropecuarios173-188.

Higueras, A. 2003. Teoría y método de la geografía: introducción al análisis geográfico regional. 1a. ed. Prensas Universitarias de Zaragoza, Zaragoza.

Hopfner, H. 1954. La evolución de los bosques de Castilla la Vieja en tiempos históricos: contribución a la investigación del primitivo paisaje de la España central. Estudios geográficos 15: 415-430.

Hsu, C.-Y., Wu, C.-S., Chaw, S.-M. 2014. Ancient Nuclear Plastid DNA in the Yew Family (Taxaceae). Genome Biology and Evolution 6: 2111-2121.

Hueso, K. 2017. Salt in our veins. The patrimonialization processes of artisanal salt and saltscapes in Europe and their contribution to local development. Ph.D. Thesis. Universitat de Barcelona. 
Huntley, B., Birks, H. 1983. An atlas of past and present pollen maps for Europe, 0-13,000 years ago. Cambridge University Press, Cambridge.

Ibarra, J. 1777. Tomo quarto de autos-acordados que contiene los libros sexto, septimo, octavo y nono por el orden de títulos de las leyes de recopilación. Real Compañía de Impresores, i Libreros del Reino, Madrid.

ICONA. 1993. Catálogo de los montes y demás terrenos forestales exceptuados de la desamortización por razones de utilidad pública. Instituto Nacional para la Conservación de la Naturaleza, Madrid.

de la Iglesia, J.S. 2006. Valdeón: un fragor de vida en los Picos de Europa.

IPBES. 2017. Update on the classification of nature's contributions to people by the Intergovernmental Science-Policy Platform on Biodiversity and Ecosystem Services.

Jackson, J.B. 1986. Discovering the Vernacular Landscape. Edición: Revised. Yale Univ Pr.

Jalut, G., Esteban Amat, A., Bonnet, L., Gauquelin, T., Fontugne, M. 2000. Holocene climatic changes in the Western Mediterranean, from south east France to south-east Spain. Palaeogeography, Palaeoclimatology, Palaeoecology 160: 255-290.

Jiménez, J.I. 2002. El monte: una atalaya de la historia. Historia agraria: Revista de agricultura e historia rural141-190.

Julivert, M., Navarro, D. 1984. Memoria y mapa MAGNA de Beleño No 55.

Junta de Castilla y León. 2003. Decreto 63/2003.

Kim, H.W., Kim, J.-H., Li, W., Yang, P., Cao, Y. 2017. Exploring the impact of green space health on runoff reduction using NDVI. Urban Forestry \& Urban Greening 28: 81-87.

Klein, R.M. 1987. The Green World: An Introduction to Plants and People. Harper \& Row.

La Notte, A., D’Amato, D., Mäkinen, H., Paracchini, M.L., Liquete, C., Egoh, B., Geneletti, D., Crossman, N.D. 2017. Ecosystem services classification: A systems ecology perspective of the cascade framework. Ecological Indicators 74: 392-402.

Lasanta, T., Nadal, M.E., Gómez, A., Serrano, M.P. 2014. Los estudios sobre cambios de gestión y ocupación del suelo en la montaña española cuarenta años después. En Geoecología, cambio ambiental y paisaje: homenaje al profesor José María García Ruiz, 2014, ISBN 978-84-617. 
3212-8, págs. 347-372, pp. 347-372. Instituto Pirenaico de Ecología, Universidad de La Rioja.

Le Goff, J. 2008. Lo maravilloso y lo cotidiano en el Occidente medieval. $3^{\text {a }}$ ed. Gedisa, Barcelona.

Lefebvre, H. 2013. La producción del espacio. Capitán Swing.

Llana, J., Villar, R., Martínez, A. 1996. Secuencia paleoambiental y cultural de la cueva de A Valiña (Castroverde, Lugo): una ocupación Chatelperroniense en Galicia. En Dinámica y Evolución de Medios Cuaternarios, pp. 97-112. Santiago de Compostela.

López, J.A., López, L., Alba, F., Pérez, S., Abel, D., Carrión, J.S. 2010. Late Holocene ecological history of <Emphasis Type="Italic">Pinus pinaster</Emphasis> forests in the Sierra de Gredos of central Spain. Plant Ecology 206: 195.

López, L., López, J.A., Zapata, M.B.R., García, M.J.G. 2008. Reconstructing the history of beech (Fagus sylvatica L.) in the north-western Iberian Range (Spain): From Late-Glacial refugia to the Holocene anthropicinduced forests. Review of Palaeobotany and Palynology 152: 58-65.

López, L. 2009. Paleoambiente y antropización en Asturias durante el Holoceno.

López, L., Martínez, A., López, J. 2010. Early agriculture and palaeoenvironmental history in the North of the Iberian Peninsula: a multi-proxy analysis of the Monte Areo mire (Asturias, Spain). Journal of Archaeological Science 37: 1978-1988.

López, P. 1978. Resultados polínicos en el holoceno en la península ibérica. Trabajos de Prehistoria9-44.

Lozano, P., Meaza, G., Aguirre, J. 2002. Paleobiogeografía cultural de la reserva de la biosfera de Urdaibai (Vizcaya). Boletín de la Asociación de Geógrafos Españoles, ISSN 0212-9426, No. 34, 2002, pags. 193-212.

Lucas, A.T. 2017. The sacred trees of Ireland. Society of Irish Foresters.

Luginbühl, Y. 2002. La política de paisaje en Francia y sus desarrollos. En Paisaje y ordenación del territorio, pp. 213-221. Consejería de Obras Públicas y Transportes, Sevilla.

Luís, E. de, Tárrega, R., Valbuena, M.L., Calvo, L. 2001. Fuego y paisaje en áreas de dominio del Roble Rebollo. Ecosistemas 10: 2-10.

Luque, J.J. 2014. Revisión del Plan de Recuperación del Oso Pardo (Ursus arctos) en la Comunidad Autónoma de Castilla y León. 74. 
Madrazo, G. 2010. La evolución del paisaje forestal en la vertiente segoviana de la sierra de Guadarrama. Junta de Castilla y León, Valladolid.

Mahoney, J.M., Rood, S.B. 1998. Streamflow requirements for cottonwood seedling recruitment-An integrative model. Wetlands 18: 634-645.

Manero, F. 1983. La Tierra de Pinares de Valladolid: El significado de la intervención humana en la organización de un paisaje vegetal. 179 . 186.

MAPAMA. 1997. Mapa Forestal de España a escala 1:50.000 (MFE50) Inventario y Cartografia - Política forestal - Desarrollo Rural magrama.es.

Martínez, A.J. 2014. La elaboración de la Ordenanza de Montes de Marina, de 31 de enero de 1748 , base de la política oceánica de la monarquía española durante el siglo XVIII. Anuario de Estudios Americanos 71: 571-602.

Martínez, E. 1993. Apuntes histíricos sobre el fuego y el uso de la tierra en España. En pp. 5.

Martínez, E. 1999. Los montes en la cultura islámica: El bosque de AlAndalus desde el siglo VIII al VIII. En Los montes y su historia: una perspectiva política, económica y social: I Jornadas Forestales: historia, socioeconomía y política forestal, 1999, ISBN 84-95089-22$X$, págs. 63-88, pp. 63-88. Universidad de Huelva.

Martínez, E. 2010. Saber ver el paisaje. Estudios geográficos 71: 395-414.

Martino, E. 1980. La montaña de Valdeburón: (biografía de una región (eonesa). Univ Pontifica Comillas.

Mata, R. 2008a. El paisaje, patrimonio y recurso para el desarrollo territorial sostenible. Conocimiento y acción pública. Arbor 184: 155172 .

Mata, R. 2008b. El paisaje, percepción y carácter del territorio: Conocimiento y acción pública. En Paisaje vivido, paisaje estudiado. Miradas complementarias desde el cine, la literatura y la ciencia., pp. 43-72. Junta de Andalucía, Consejería de Medio Ambiente. Universidad de Córdoba, Servicio de Publicaciones., Córdoba.

Mata, R., Meer, Á., Puente, L. 2012. Sustainable development and the making of territory and everyday landscapes as heritage-an experience in the Cantabrian mountains. En Territorial Heritage and Development, pp. 141-158. Taylor and Francis, London. 
Mata, R. 2014. El Convenio Europeo del Paisaje del Consejo de Europa. Notas sobre su aplicación en España. Patrimonio cultural y derecho175-206.

Matthews, J. 2016. Robin Hood. Amberley Publishing Limited.

MEA. 2003. Ecosystems and human well-being: a framework for assessment. Island, Washington, DC.

Merino, A. 2018. El paisaje de las llanuras pinariegas del sur del Duero. Un espacio forestal de fuerte carácter antrópico. En Paisajes patrimoniales de España. III tomos, pp. 848-859. Ministerio de Agricultura, Pesca y Alimentación, Ministerio para la Transición Ecológica- UAM ediciones, Madrid.

Michel, M. 2003. El pino radiata (Pinus Radiata D.Don) en la historia forestal de la Comunidad Autónoma del País Vasco : análisis de un proceso de forestalismo intensivo. phd. E.T.S.I. Montes (UPM).

Mighall, T.M., Martínez, A., Biester, H., Turner, S.E. 2006. Proxy climate and vegetation changes during the last five millennia in NW Iberia: Pollen and non-pollen palynomorph data from two ombrotrophic peat bogs in the North Western Iberian Peninsula. Review of Palaeobotany and Palynology 141: 203-223.

Ministerio de Agricultura y Pesca, Alimentación y Medio Ambiente. 2017. Informe de precios de la madera a partir de las licitaciones publicadas en España en 2016.

Ministerio de Fomento. 1916. Ley de 7 de diciembre de 1916, de Parques Nacionales de España.

Ministerio de Hacienda. 2019. Publicación de información de los presupuestos por Entidades Locales: Ministerio de Hacienda. Disponible en: http://www.hacienda.gob.es/es ES/Areas\%20Tematicas/Administracion\%20Electronica/OVEELL/Pagin as/PublicacionPresupuestosEELL.aspx [Accedido 24 de mayo de 2019].

Miras, Y., Ejarque, A., Riera, S., Palet, J.M., Orengo, H., Euba, I. 2007. Dynamique holocène de la végétation et occupation des Pyrénées andorranes depuis le Néolithique ancien, d'après l'analyse pollinique de la tourbière de Bosc dels Estanyons $(2180 \mathrm{~m}$, Vall del Madriu, Andorre). Comptes Rendus Palevol 6: 291-300.

Molinero, F., García, A., Cascos, C., Baraja, E., Guerra, J.C. 2008. La percepción local de los incendios forestales y sus motivaciones en Castilla y León. Ería213-229. 
Molinero, F., Tort, J. eds. . 2018. Paisajes patrimoniales de España. III Tomos. Ministerio de Agricultura, Pesca y Alimentación, Ministerio para la Transición Ecológica- UAM ediciones, Madrid.

Molinero, J., Pozo, J. 2004. Impact of a Eucalyptus (Eucalyptus globulus Labill.) Plantation on the Nutrient Content and Dynamics of Coarse Particulate Organic Matter (CPOM) in a Small Stream. Hydrobiologia 528: $143-165$.

Montero, G., Cañellas, I. 2000. Selvicultura de Pinus pinea L. Estado actual de los conocimientos en España. En Simposio del Pino piñonero, pp. 21-38. Junta de Castilla y León, Valladolid.

Montero, G., Serrada, R. 2013. La situación de los bosques y el sector forestal en España-ISFE 2013. Sociedad Española de Ciencias Forestales, Lourizan (Pontevedra).

Morales, A., Martínez, S. 2003. Informe sobre los restos de mamíferos recuperados en los niveles neolíticos de la Cueva de La Vaquera. En Estremera S (ed.), Primero agricultores y ganaderos en la Meseta norte: El Neolítico en la Cueva de La Vaquera (Torreiglesias, Segovia)., Arqueología en Castilla y León, pp. 257-313. Junta de Castilla y León, Consejería de Educación y Cultura, Zamora.

Morales, G. 1982. Explotación de los recursos forestales en Asturias. Ería: Revista cuatrimestral de geografía35-54.

Morla, C., Alcalde, C., Hernández, L., García, M., García-López, J., García, C., Guerrero, S. et al. 2009. Investigaciones paleobotánicas en la cuenca central del Duero.

Müller, U.C. 2000. A Late-Pleistocene pollen sequence from the Jammertal, south-western Germany with particular reference to location and altitude as factors determining Eemian forest composition. Vegetation History and Archaeobotany 9: 125-131.

Muñoz, C., Ramil, P., Rodríguez, M. 1997. Upland vegetation in the northwest Iberian peninsula after the last glaciation: Forest history and deforestation dynamics. Vegetation History and Archaeobotany 6: 215-233.

Muñoz, C., Ramil, P., Rodríguez, M.A. 2001. Vegetation in the mountains of northwest lberia during the last glacial-interglacial transition. Vegetation History and Archaeobotany 10: 7-21.

Muñoz, C., Ramil, P., Gómez, L., Díaz, R.A. 2005. Palynological data on major Holocene climatic events in NW Iberia. Boreas 34: 381-400. 
Muñoz, C., Ramil, P., Gómez, L. 2007. Late Würm and early Holocene in the mountains of northwest Iberia: biostratigraphy, chronology and tree colonization. Vegetation History and Archaeobotany 16: 223240 .

Muñoz, C., Ramil, P., Gómez, L., Ferreiro, J., Díaz, R. 2008. Climatic and human effects on the post-glacial dynamics of Fagus sylvatica L. in NW Iberia. Plant Ecology 203: 317-340.

Nahlik, A.M., Kentula, M.E., Fennessy, M.S., Landers, D.H. 2012. Where is the consensus? A proposed foundation for moving ecosystem service concepts into practice. Ecological Economics 77: 27-35.

Naranjo, J. 2010. Los espacios cordobeses con valoración patrimonial: paisajes y lugares que se han convertido en un referente colectivo. Andalucía en la historia 30: 46-49.

Neeson, E. 1991. A History of Irish Forestry. Lilliput Press.

Nogué, J. 2009. Entre paisajes. Ambit Serveis Editorials, S.A., Madrid.

O'Connell, M., Molloy, K. 2001. Farming and Woodland Dynamics in Ireland during the Neolithic. Biology and Environment: Proceedings of the Royal Irish Academy 101B: 99-128.

O’flanagan, P., Lasanta Martínez, T., Errea Abad, M.P. 2011. Restoration of sheep transhumance in the Ebro valley, Aragon, Spain. Geographical Review 101: 556-575.

Olabe, F., Val, Y., Schwendtner, O. 2010. Monumentos Naturales de Navarra. Gobierno de Navarra.

Oliet, J., Pardo, F., Lösing, H. 2014. Fagus sylvatica L. Producción y manejo de semillas y plantas forestales.

Olivé, A., Ramírez, J. 1982. Memoria y mapa MAGNA de Castro Urdiales ${ }^{\circ}$ 36.

Olivera, A. 2011. Patrimonio inmaterial, recurso turístico y espíritu de los territorios. Cuadernos de Turismo 0: 663-677.

Oria, J.A., Díez, J. 2003. Los bosques de Castilla y León. Ámbito, Valladolid.

Ortega, J. 1998. El patrimonio territorial: El territorio como recurso cultural y económico. Ciudades: Revista del Instituto Universitario de Urbanística de la Universidad de Valladolid33-48. 
Ortega, J. 2000. Los horizontes de la geografía: teoría de la geografía. Ariel.

van Oudenhoven, A.P.E., Petz, K., Alkemade, R., Hein, L., de Groot, R.S. 2012. Framework for systematic indicator selection to assess effects of land management on ecosystem services. Ecological Indicators 21: 110-122.

Pascual, A. 1868. Sobre el vocablo: forestal. Revista Forestal.

Pèlachs, A. 2004. Deu mil anys de geohistòria ambiental al pirineu central català. Aplicació de tècniques paleogeogràfiques per a l'estudi del territori i el paisatge a la Coma de Burg i a la Vallferrera. Ph.D. Thesis. Universitat Autònoma de Barcelona.

Pèlachs, A., Soriano, J.M., Nadal, J., Esteban i Amat, A. 2007. Holocene environmental history and human impact in the Pyrenees. Contributions to science 421-429.

Peña, L., Peña, L.Z., Gazólaz, J.G., Morales, M.G., Sesma, J.S., Straus, L.G. 2005. The spread of agriculture in northern Iberia: new archaeobotanical data from El Mirón cave (Cantabria) and the openair site of Los Cascajos (Navarra). Vegetation History and Archaeobotany 14: 268-278.

Peñalba, M.C. 1989. Dynamique de végétation tardiglaciaire et holocène du Centre-Nord de l'Espagne d'après l'analyse pollinique. AixMarseille 3.

Peñalba, M.C. 1994. The History of the Holocene Vegetation in Northern Spain from Pollen Analysis. Journal of Ecology 82: 815-832.

Pérez, I., Picos, J. 2001. Los consorcios para la repoblación forestal: historia y perspectivas.

Pérez, J.M. 2005. Gestión forestal y conservación de las aves rapaces diurnas forestales en un municipio vizcaíno: Muskiz. Estudios del Museo de Ciencias Naturales de Álava141-154.

Pérez, M., Matías, R. 2008. Plinio y la minería aurífera romana: nueva traducción e interpretación de PLIN. Nat. 33.66-78/Pliny and the Roman Gold Mining: a new Translation and Interpretation of PLIN. Nat. 33.66-78. Cuadernos de Filología Clásica. Estudios Latinos 28: $43-58$.

Pérez, S., López, J.A., Ruiz, M., Zapata, L., Abel, D. 2013. Holocene history of Taxus baccata in the Basque Mountains (Northern Iberian Peninsula). LAZAROA 34: 29-41. 
Perrings, C., Folke, C., Mäler, K.-G. 1992. The Ecology and Economics of Biodiversity Loss: The Research Agenda. Ambio 21: 201-211.

Pettorelli, N., Vik, J.O., Mysterud, A., Gaillard, J.-M., Tucker, C.J., Stenseth, N.Chr. 2005. Using the satellite-derived NDVI to assess ecological responses to environmental change. Trends in Ecology \& Evolution 20: 503-510.

Pita, P.A. 1963. Repoblaciones forestaes en general. En II Asamblea Técnica Forestal, pp. 325-357. Ministerio de Agricultura, Madrid.

Postigo, J.M., Burjachs, F., Gómez, F., Morla, C. 2007. A palaeoecological interpretation of the lower-middle Pleistocene Cal Guardiola site (Terrassa, Barcelona, NE Spain) from the comparative study of wood and pollen samples. Review of Palaeobotany and Palynology 146: 247 264.

Potenciano, A. 2004. Estudio de las inundaciones históricas del río Amarguillo (Toledo). Universidad Complutense de Madrid.

Potschin, M.B., Haines-Young, R.H. 2011. Ecosystem services: Exploring a geographical perspective. Progress in Physical Geography 35: 575594.

Prats, L. 1998. El concepto de patrimonio cultural. Política y sociedad6376.

Prats, L. 2006. La mercantilización del patrimonio: entre la economía turística y las representaciones identitarias. revista ph 58. Especial: $72-80$.

Presidencia y consellerías de la generalitat Valenciana. 2006. Ley 4/2006, de 19 de mayo, de la Generalitat, de Patrimonio Arbóreo Monumental de la Comunitat Valenciana (2006/6142).

Quiroga, D. 1962. Valles de León. El Valle de Valdeón. Tierras de León: Revista de la Diputación Provincial 2: 143-147.

R.A. Española, A.D.A. Española. 2014. Diccionario de la lengua española, 23.

Ramil, P., Gómez, L., Muñoz, C., Rodríguez, M. 1996. Valoración de las secuencias polínicas del Norte de la Península Ibérica para el último ciclo glaciar-interglaciar. Férvedes: Revista de investigación33-116.

Ramil, P., Rodríguez, M.A., Muñoz, C., Gómez, L. 2000. Some considerations about the postglacial history and recent distribution of <Emphasis Type="Italic">Fagus sylvatica</Emphasis> in the NW Iberian Peninsula. Folia Geobotanica 35: 241-271. 
Ramírez, J., Portero, J.M. 1978. Memoria y mapa MAGNA de Valmaseda $\mathrm{N}^{\circ} 60$.

Real Sociedad Económica de los Amigos del País de la Provincia de Segovia. 1785. Actas y memorias de la Real Sociedad Económica de los Amigos del País de la Provincia de Segovia. La Sociedad, Segovia.

Rebolledo, A. 2007. Caracterización Geográfica Y Fenotípica Del Álamo (pupulus Nigra), En La Región De Magallanes, Para Estimular Su Uso Como Cortinas Forestales. Universidad de Magallanes.

Rico, E. 1995. Política forestal e repoboacións en Galicia: 1941-1971. Universidade de Santiago de Compostela, Santiago de Compostela.

Rico, E. 1997. La Creación de celulosas de Pontevedra y su influencia en el sector forestal de la provincia. Programa de Historia Económica Fundación Empresa Pública, Madrid.

Riutort, M., Alvarez, M. 2017. Biodiversidad de planarias terrestres en dos Parques Nacionales: indicios de una historia de macro y microrefugios Pleistocénicos. Ministerio de Medio Ambiente. Organismo autónomo de Parques Nacionales.

Rodríguez, L., Curetti, G., Garegnani, G., Grilli, G., Pastorella, F., Paletto, A. 2016. La valoración de los servicios ecosistémicos en los ecosistemas forestales: un caso de estudio en Los Alpes Italianos. Bosque (Valdivia) 37: 41-52.

Rodríguez, L.R., Heredia, N. 1988. La estratigrafía del Carbonífero y la estructura de la unidad de Pisuerga-Carrión. NO de España.

Rodríguez, L.R., Díaz de Neira, J.A., Cabra Gil, P., López Olmedo, F., Solé Pont, J., Hernáiz Huerta, P.P., Díaz Arranz, R. 2007. Memoria y mapa MAGNA de Cantalejo $N^{\circ} 430$.

Rodríguez, L.R., Martín-Serrano, A., Nozal, F. 2007. Memoria y mapa MAGNA de Medina del Campo $N^{\circ} 427$.

Rodríguez, M., Maya, A. 2008. Los puertos y la trashumancia en los valles leoneses de Sajambre y Valdeón: tradición y perspectivas de futuro. Universidad de León, Secretariado de Publicaciones, León.

Rodríguez, M.O. 2000. El paisaje vegetal de la Depresión de Vera durante la prehistoria reciente. Una aproximación desde la antracología. Trabajos de Prehistoria 57: 145-156.

Roger, A., Maderuelo, J. 2007. Breve tratado del paisaje. Biblioteca Nueva, Madrid. 
Rogers, J.E. 1905. The Tree Book: A Popular Guide to a Knowledge of the Trees of North America and to Their Uses and Cultivation. Douleday, Page.

Rojo, A., Montero, G., Pérez, A. 2001. Cuarenta años de ordenación del monte" Cabeza de hierro"(Rascafría, Madrid): Desarrollo de la ordenación y resultados conseguidos. Cuadernos de la Sociedad Española de Ciencias Forestales23-34.

Rood, S., M. Samuelson, G., H. Braatne, J., R. Gourley, C., M. Mahoney, J. 2005. Managing River Flows to Restore Floodplain Forests. Frontiers in Ecology and The Environment - FRONT ECOL ENVIRON 3: 193-201.

Ros, M.T. 1988. l'aplicacio de l'analisi antrocologi-ca a l'arqueologia catalana. Cota Zero 4: 51-60.

Ross, F. 2014. Paisajes sensoriales: Sensación y emoción en el hacer del lugar. Bifurcaciones: revista de estudios culturales urbanos 1.

Ross, M. 2004. Planning and the Heritage: Policy and procedures. Taylor \& Francis.

Rubiales, J., Hernández, L., Morla, C., Sanz, F., Alfaro, E. 2005. Nuevas aportaciones al conocimiento de los paisajes vegetales en el holoceno de la cuenca del Duero.

Rubiales, J.M., García, I., Génova, M., Gómez, F., Morla, C. 2007. The Holocene history of highland pine forests in a submediterranean mountain: the case of Gredos mountain range (Iberian Central range, Spain). Quaternary Science Reviews 26: 1759-1770.

Rubiales, J.M., García, I., García, S., Gómez, F. 2008. The Late Holocene extinction of Pinus sylvestris in the western Cantabrian Range (Spain). Journal of Biogeography 35: 1840-1850.

Rubiales, J.M., García, I., García, S., Morla, C. 2009. Anthracological evidence suggests naturalness of Pinus pinaster in inland southwestern Iberia. Plant Ecology 200: 155-160.

Rubiales, J.M., Hernández, L., Romero, F., Sanz, C. 2011. The use of forest resources in central Iberia during the Late Iron Age. Insights from the wood charcoal analysis of Pintia, a Vaccaean oppidum. Journal of Archaeological Science 38: 1-10.

Rubio, J.C. 2002. Las lagunas perdidas del Alto Jiloca: el mayor humedal de Aragón : descripción y propuesta.

Rubio, J.C. 2007. Pasado, presente y futuro de la laguna del Cañizar. Xiloca: revista del Centro de Estudios del Jiloca189-202. 
Ruiz, J. 2006. Flora Mayor. Organismo Autónomo Parques Nacionales \& Dirección General para la Biodiversidad.

Ruiz, M.B., Pérez, A., Dorado, M., Valdeolmillos, A., De Bustamante, I., Gil, M.J. 2000. Caracterización de las etapas áridas del Pleistoceno Superior en la Región Central Peninsular. Geotemas 1: 273-278.

Ruiz, M.B., Gil, M.J., Dorado, M., Valdeolmillos, A., Vegas, J., PérezGonzález, A. 2002. Clima y vegetación durante el pleistoceno superior y el holoceno en la Sierra de Neila (Sistema Ibérico noroccidental). Cuaternario y Geomorfología 16: 9-20.

Sabaté, J. 2004. Paisajes culturales. El patrimonio como recurso básico para un nuevo modelo de desarrollo. Urban8.

Sachs, J. 2011. Economía para un planeta abarrotado. Penguin Random House Grupo Editorial España.

Sanz, C. 2000. El paisaje como recurso. En Estudios sobre el paisaje, 2000, ISBN 84-7477-801-8, págs. 281-292, pp. 281-292. Fundación Duques de Soria, Servicio de Publicaciones.

Sanz, M., Sobrino, E., Dana, E.D. 2004. Atlas de las plantas alóctonas invasoras en España. Dirección General para la Biodiversidad. Madrid.

Sauer, C.0. 1925. The Morphology of Landscape. University of California Press.

Scazzosi, L. 2006. «Valorar» los paisajes. En El paisaje y la gestión del territorio: criterios paisajísticos en la ordenación del territorio y el urbanismo, 2006, ISBN 84-9803-144-3, págs. 267-302, pp. 267-302. Diputació Provincial de Barcelona.

Schlosser, I.J., Karr, J.R. 1981. Water quality in agricultural watersheds: impact of riparian vegetation during base flow. JAWRA Journal of the American Water Resources Association 17: 233-240.

Schröter, M., Zanden, E.H. van der, Oudenhoven, A.P.E. van, Remme, R.P., Serna-Chavez, H.M., Groot, R.S. de, Opdam, P. 2014. Ecosystem Services as a Contested Concept: a Synthesis of Critique and Counter Arguments. Conservation Letters 7: 514-523.

Schröter, M., Stumpf, K.H., Loos, J., van Oudenhoven, A.P.E., BöhnkeHenrichs, A., Abson, D.J. 2017. Refocusing ecosystem services towards sustainability. Ecosystem Services 25: 35-43.

Schwendtner, O., Cárcamo, S. 2009. Bosques viejos y árboles viejos: importancia para la fauna. En pp. 8-23. 
Schwendtner, O., Recalde, I., Alcalde, J., Gómez, J., Cárcamo, S. 2005. Importancia de los árboles senescentes y la madera muerta en la gestión de los bosques naturales. Actas IV Congreso Forestal Español.

Schwendtner, 0. 2010. Hayas y robles trasmochos en la Navarra atlántica: antiguas técnicas y problemas actuales. Navarra Forestal12-16.

Secall, J. 1896. El «pinus insignis», Dougl., de la Escuela de Montes. Revista de Montes XX: 73-76.

Silva, R., Fernández, V. 2015. Claves para el reconocimiento de la dehesa como «paisaje cultural» de Unesco. Anales de Geografía de la Universidad Complutense 35: 121-142.

Silva, R. 2016. Landscape, heritage and territory. Some notes from the Spanish geographic perspective. En Spanish Contribution to 33 re IGC Beijing 2016. Spanish Committee International Geographical Union, pp. 54-62. Asociación de Geógrafos Españoles, Instituto Geográfico Nacional, Gobierno de España.

Silva, R., Fernández, V. 2017. El nuevo paradigma del patrimonio y su consideración con los paisajes: Conceptos, métodos y prospectivas. Documents d'Anàlisi Geogràfica 63: 129.

Silva, R., Jover, J. 2017. Los paisajes patrimoniales de la Sierra de Huelva. Ensayo metodológico. Estudios Geográficos 77: 647-670.

Simón, J.L., Rubio, J.C., Soriano, M.A. 2010. Sobre el origen y edad de la depresión del Jiloca (Teruel, Cordillera Ibérica centro-oriental). Geogaceta.

SIPCA-Gobierno de Aragón. 2019. Catálogo de Patrimonio Arquitectónico Aragonés. Disponible en: http://www.sipca.es/censo/busqueda_simple.html [Accedido 27 de mayo de 2019].

Small, N., Munday, M., Durance, I. 2017. The challenge of valuing ecosystem services that have no material benefits. Global Environmental Change 44: 57-67.

Smulders, M.J.M., Cottrell, J.E., Lefevre, F., Vosman, B., Tabbener, H.E., Grassi, F., Fossati, T. et al. 2008. Structure of the genetic diversity in black poplar (Populus nigra L.) populations across European river systems: Consequences for conservation and restoration. Forest Ecology and Management 12 .

Soliño, M., Yu, T., Alía, R., Auñón, F., Bravo-Oviedo, A., Chambel, M.R., de Miguel, J. et al. 2018. Resin-tapped pine forests in Spain: 
Ecological diversity and economic valuation. Science of The Total Environment 625: 1146-1155.

Spangenberg, J.H., von Haaren, C., Settele, J. 2014. The ecosystem service cascade: Further developing the metaphor. Integrating societal processes to accommodate social processes and planning, and the case of bioenergy. Ecological Economics 104: 22-32.

Splunder, I.V., Coops, H., Voesenek, L. a. C.J., Blom, C.W.P.M. 1995. Establishment of alluvial forest species in floodplains: the role of dispersal timing, germination characteristics and water level fluctuations. Acta Botanica Neerlandica 44: 269-278.

Stobbelaar, D.J., Pedroli, B. 2011. Perspectives on Landscape Identity: A Conceptual Challenge. Landscape research v. 36: 321-339.

Tejedor, C. 2007. Selección de una variedad clonal de Eucalyptus globulus ssp. globulus tolerante a la enfermedad foliar Mycosphaerella sp. en el norte de España. Boletín del CIDEU57-66.

Terán, M. de, Solé, L., Vilá, J. eds. . 1988. Geografia regional de España. $6^{a}$ ed. Ariel, Esplugues de Llobregat (Barcelona).

Tzedakis, P.C., Lawson, I.T., Frogley, M.R., Hewitt, G.M., Preece, R.C. 2002. Buffered Tree Population Changes in a Quaternary Refugium: Evolutionary Implications. Science 297: 2044-2047.

UNESCO World Heritage Committe. 2008. Operational Guidelines for the Implementation of the World Heritage Convention. Paris.

UNESCO. 2017. Decisions adopted during the 41st session of the World Heritage Committee. Krakow.

Uriarte, R. 2000. Explotación forestal e industria resinera en España: 1900 1936. Estudios Geográficos 61: 655-682.

Uriarte, R. 2010. Repoblaciones, paisaje forestal y desarrollo industrial en el País Vasco atlántico (1940-1975). Historia agraria: Revista de agricultura e historia rural109-142.

Uzquiano, P. 1992a. L'Homme et le bois au Paléolithique en région Cantabrique, Espagne. Exemples d'Altamira et d'El Buxu. Bulletin de la Société Botanique de France 139: 361-372.

Uzquiano, P. 1992b. Recherches anthracologiques dans le sécteur PyréneoCantabrique (Pays Basque, Cantabria et Asturias): Environnements et rélations homme-milieu au Pléistocène supérieur et début de l'Holocène. Universidad de Montpellier II, Montpellier. 
Uzquiano, P. 1992c. The Late Glacial/Postglacial Transition in the Cantabrian Cordillera (Asturias and Cantabria, Spain) Based on Charcoal Analysis. PALAIOS 7: 540.

Uzquiano, P. 2002. Vegetation and firewood management at Cueva de la Vaquera (Segovia, Spain) between 6 and 3,7 kyrs BP: anthracological contribution to the landscape archaeology of the Spanish Central Mountains. British Archaeological Reports Proccedings of IInd International Meeting of Anthracology Paris 2000 S1063: 109-112.

Uzquiano, P., Arbizu, M.A., Arsuaga, J.L., Adán, G.E., Aranburu, A., Iriarte, E. 2008. Datos paleoflorísticos en la Cuenca media del Nalón entre 40-32 Ka. BP: antracoanálisis de la Cueva del Conde (Santo Adriano, Asturias). Cuaternario y Geomorfología ,2008,22(3-4),121133.

Valette, P., Carozza, J.-M. eds. . 2019. Géohistoire de l'environnement et des paysages. CNRS Editions.

Valle, J. del. 1993. El régimen pluviométrico de la Cuenca del Jiloca. Geographicalia145-154.

Verdú, J.R., Numa, C., Galante, E. eds. . 2011. Atlas y libro rojo de los invertebrados amenazados de España (especies vulnerables). Organismo Eutónomo Parques Nacionales, Madrid.

Voces, R., Diaz-Balteiro, L., E, L.-P. 2010. Spatial valuation of recreation activities in forest systems: Application to province of Segovia (Spain). Forest Systems 19: 36-50.

Wascher, D.M. 2005. European landscape character areas: typologies, cartography and indicators for the assessment of sustainable landscapes. Final Project report as deliverable from the EU's Accompanying Measure project European Landscape Character Assessment Initiative (ELCAI), funded under the 5th Framework Programme on Energy, Environment and Sustainable Development (4.2.2). Ladscape Europe, Wagenningen.

Watts, W.A. 1986. Stages of Climatic Change from Full Glacial to Holocene in Northwest Spain, Southern France and Italy: A Comparison of the Atlantic Coast and the Mediterranean Basin. En Current Issues in Climate Research, pp. 101-112. Springer, Dordrecht.

Westman, W.E. 1977. How Much are Nature's Services Worth. Science (New York, N.Y.) 197: 960-4.

Willis, K.J., Niklas, K.J. 2004. The role of Quaternary environmental change in plant macroevolution: the exception or the rule? Philosophical 
Transactions of the Royal Society B: Biological Sciences 359: 159172.

Zavala, M.A., Montoya, D., Benito, M., Purves, D.W. 2011. Principales determinantes de la distribución de las especies forestales ibéricas a diferentes escalas: efectos potenciales del cambio climático. En La evolución del paisaje vegetal y el uso del fuego en la Cordillera Cantábrica, León.

Zhao, Y.H., Yang, Y.M., Yang, S.Y., Wang, J. 2007. A review of the biodiversity in Eucalyptus plantation. J Yunnan Agric Univ 22: 741 746.

Zoido, F. 2004. El paisaje, patrimonio público y recurso para la mejora de la democracia. revista ph 0: .

Zoido, F. 2006. Landscape and spatial planning. En Landscape and sustainable development: challenges of the Europe Landscape Convention, Council of Europe Publishing. 
Índice de figuras y tablas

Índice de figuras y
tablas 
Figura 1. Secuencia polínica del Lago de Ajo en la Cordillera Cantábrica, León. Fuente. (Watts, 1986) recuperado de (Carrión García et al., 2000). Se puede apreciar el progresivo descenso del género Pinus en

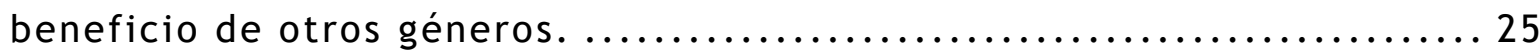

Figura 2. Distribución de los bosques de hayas en la Cordillera Cantábrica. Elaboración propia a partir de Mapa Forestal de España $1: 50.000$ .28

Figura 3. Distribución de los bosques de hayas pirenaicas y prepirenaicas. Elaboración propia a partir de Mapa Forestal de España $1: 50.000$. 28

Figura 4. Los hayedos en la Cordillera Central. Elaboración propia a partir de Mapa Forestal de España 1:50.000.

Figura 5. Distribución de los bosques de robles en el noroeste español. Elaboración propia a partir de Mapa Forestal de España 1:50.000. 31

Figura 6. Distribución de los bosques de robles en los Pirineos. Elaboración propia a partir de Mapa Forestal de España 1:50.000...... 31

Figura 7. Distribución de los pinares eurosiberianos en la España peninsular. Elaboración propia a partir de Mapa Forestal de España $1: 50.000$.

Figura 8. Distribución de las formaciones menores del bosque atlántico en el noroeste peninsular. Elaboración propia a partir de Mapa Forestal de España 1:50.000.... 34

Figura 9. Distribución de las formaciones menores del bosque atlántico en el noreste peninsular. Elaboración propia a partir de Mapa Forestal de España $1: 50.000$

Figura 10. Distribución de las formaciones menores del bosque atlántico en el noreste peninsular. Elaboración propia a partir de Mapa Forestal de España 1:50.000.

Figura 11. Distribución de las formaciones menores del bosque atlántico en el sur peninsular. Elaboración propia a partir de Mapa Forestal

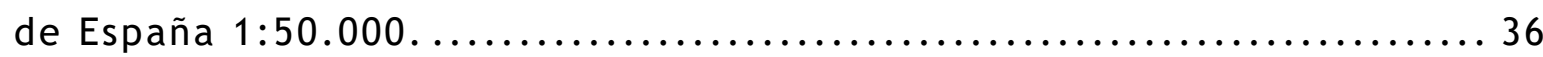


Figura 12. Distribución de los encinares y alcornocales en la España peninsular. Elaboración propia a partir de Mapa Forestal de España $1: 50.000$

Figura 13. Distribución de los sabinares y enebrales en la España peninsular. Elaboración propia a partir de Mapa Forestal de España $1: 50.000$.

Figura 14. Distribución de los pinares mediterráneos en la España Peninsular. Elaboración propia a partir de Mapa Forestal de España $1: 50.000$

Figura 15. Distribución de los bosques marcescentes en la España peninsular. Elaboración propia a partir de Mapa Forestal de España $1: 50.000$. 51

Figura 16. Distribución de los abetales de Abies alba en la España peninsular. Elaboración propia a partir de Mapa Forestal de España $1: 50.000$.

Figura 17. Distribución de los pinsapares en la España peninsular. Elaboración propia a partir de Mapa Forestal de España 1:50.000. 55

Figura 18. Distribución de los bosques de producción de especies exóticas en la España peninsular. Elaboración propia a partir de Mapa Forestal de España 1:50.000. 56

Figura 19. Evolución de la superficie forestal española (millones de hectáreas). Elaboración propia a partir de (Montero y Serrada, 2013) ...59

Figura 20. Secuencia polínica de Quintanar de la Sierra, Burgos. Fuente: (Peñalba, 1994) recuperado de (Carrión et al., 2000). Se aprecia la aparición de los cereales y la matorralización sincrónicamente con la reducción de los Quercus Robur, Betula sp. Y Corylus sp. y la expansión del Fagus sylvatica

Tabla 1. Los árboles silvestres en la Iberia de Estrabón. Fuente: recuperado de (Cortijo, 2007) 65

Figura 21. Carta topográfica de un sector de pinares delimitado por líneas de mojones, situado entre Nava de la Asunción y el río Voltoya (Segovia). Archivo de la Real Chancillería de Valladolid (Anón, 1825) ..667 
Figura 22. Carta topográfica de un terreno litigioso entre Quintanas Rubias de Arriba y Quintanas Rubias de Abajo (Soria) (Anón, 1766). Se puede apreciar la reclusión hacia las cumbres de los espacios arbolados......669

Figura 23. Paisaje de El Escorial (Borrell, 1901). Se puede observar la Sierra de Guadarrama al fondo, completamente deforestada.......... 75

Tabla 2. Superficies repobladas en España por el Patrimonio Forestal del Estado en 1940-1960, por especies. Fuente: (Pita, 1963) recuperado de (Uriarte, 2010) 81

Tabla 3. Resumen de los acontecimientos más relevantes en la historia forestal española. Elaboración propia.

Figura 24. Resumen de la orientación en los estudios de paisaje. Elaboración propia. .91

Tabla 4. Resumen de los tipos de paisaje según el PNPC. Elaboración propia.

Tabla 5. Elaboración propia a partir de (Guerra et al., 2010; Guerra, 2012). Características principales de las categorías de paisaje forestal.

Tabla 6. Resumen de los vectores de patrimonialización de los diferentes tipos de paisaje forestal. Elaboración propia..............113

Figura 25. Distribución de los tipos de bosque según esta clasificación en la España peninsular. Elaboración propia a partir de Mapa Forestal de

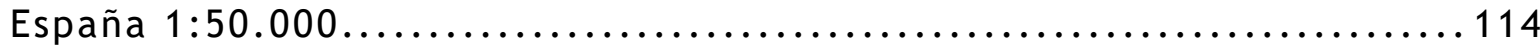

Tabla 7. Clasificación de los SSEE según "Ecosystems and human wellbeing: a framework for assessment" (MEA, 2003). Elaboración propia ..117

Figura 26. Elaboración propia a partir de la cascada de los SSEE de

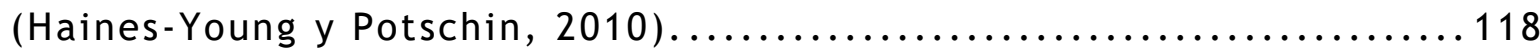

Figura 27. Elaboración propia a partir de la cascada de los SSEE de (Spangenberg et al., 2014).

Figura 28. Cambio en la valoración de los SSEE desde el planteamiento de los Ecosistemas del Milenio hacia el actual paradigma de contribuciones naturales a la sociedad. Elaboración propia a partir de (Díaz et al., 2018). 
Tabla 8. Contribuciones Naturales a la Sociedad según el informe IPBES (IPBES, 2017). Traducción y elaboración propias.

Figura 29. secuencia de patrimonialización en sus dos vertientes. Elaboración propia .135

Figura 30. Características del paisaje patrimonial. Elaboración propia a partir de (Gómez, 2012).

137

Figura 31. Proceso de evolución y formación del paisaje geográfico (asimilación en busca de beneficio económico que va a destruir las permanencias). Elaboración propia a partir de (Harvey, 2007).......... 141

Tabla 9. Resumen criterio valoración indicador Complejidad Biológica. ........................................................... 144

Tabla 10. Resumen criterio valoración indicador Figuras de protección.

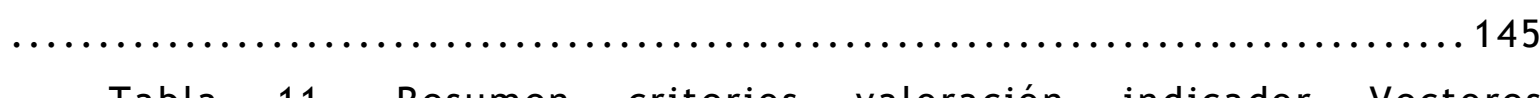

Tabla 11. Resumen criterios valoración indicador Vectores Patrimoniales. ................................................. 146

Tabla 12. Resumen criterios valoración indicador Identificación de la población. ................................................... 147

Tabla 13. Resumen criterios valoración indicador Museística...... 148

Tabla 14. Resumen criterios valoración indicador Incorporación Turística. ....................................................... 149

Tabla 15. Resumen criterios valoración indicador Empleo relacionado.

Figura 32. Mapa de localización del área de estudio, municipio Posada de Valdeón. Elaboración propia a partir de Mapa Forestal de España $1: 50.000$.

Figura 33. Mapa de altitud en el municipio de Posada de Valdeón. Elaboración propia a partir de Modelo Digital del Terreno Instituto Geográfico Nacional.

Figura 34. Mapa de pendientes en el municipio de Posada de Valdeón. Elaboración propia Modelo Digital del Terreno Instituto Geográfico Nacional. 
Figura 35. Mapa de orientaciones en el municipio de Posada de Valdeón. Elaboración propia Modelo Digital del Terreno Instituto Geográfico

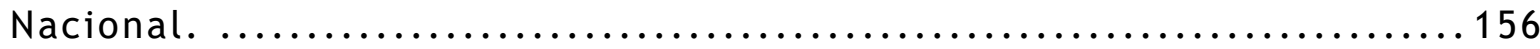

Figura 36. Mapa edáfico del municipio de Posada de Valdeón. Elaboración propia a partir de IRNASA $1: 400.000 \ldots \ldots \ldots \ldots \ldots \ldots \ldots \ldots . \ldots 158$

Figura 37. Usos del suelo en el municipio de Posada de Valdeón. A partir de Corine Land Cover, elaboración propia.................... 159

Figura 38. Montes de Utilidad Pública en el municipio de Posada de Valdeón. Elaboración propia a partir de MUP CyL .......................162

Figura 39. Prados de diente, siega y huertos en el fondo del Valle junto a Posada de Valdeón. Imagen propia. 168

Figura 40. Bancales abandonados (marcados con línea discontinua) con matorral en avance. Imagen propia. 168

Figura 41. Hayedo en las laderas de umbría, Caldevilla de Valdeón, Soto de Valdeón, Posada de Valdeón y el Macizo Central de los Picos de Europa al fondo. Imagen propia.

Figura 42. Praderas y robledales en el Monte Corona. Imagen propia. 169

Figura 43. Mapa Forestal de España 1966, conocido como “mapa Ceballos", en Posada de Valdeón. Elaboración propia.

Figura 44. Mapa Forestal de España (1986-1997) en Posada de Valdeón. Elaboración propia.

Figura 45. Mapa Forestal de España (1997-2006) en Posada de Valdeón. Elaboración propia.

Figura 46. Perfil vegetal del municipio de Posada de Valdeón, sector oriental. Elaboración propia a partir de trabajo de campo. ...........175

Figura 47. Perfil vegetal del municipio de Posada de Valdeón, sector occidental. Elaboración propia a partir de trabajo de campo. .176

Tabla 16. Resumen criterios valoración indicador Complejidad Biológica. 
Figura 48. Mapa formaciones recogidas en la Directiva Hábitat en Posada de Valdeón. Elaboración propia a partir de Directiva Hábitat Banco de Datos de la Naturaleza. ..................................... 179

Tabla 17. Valor NDVI de distintas cubiertas a lo largo del periodo vegetativo. Elaboración propia. 180

Figura 49. Representación del índice de vegetación de diferencia normalizada para los meses de enero, mayo, agosto y octubre respectivamente. Imágenes Landsat 8 . Elaboración propia. ............180

Tabla 18. Resumen criterios cumplidos valoración indicador Complejidad Biológica. .181

Figura 50. Parque Nacional Picos de Europa. Elaboración propia...183

Figura 51. Reserva de la Biosfera Picos de Europa. Elaboración propia.

Figura 52. Lugar de Interés Comunitario Picos de Europa. Elaboración propia.

Figura 53. Zona de Especial Protección para las Aves Picos de Europa. Elaboración propia.

Figura 54. Localización de los hayedos catalogados como Patrimonio de la Humanidad por UNESCO. Elaboración propia. .185

Figura 55. Mapa de los Montes de Utilidad Pública en Posada de Valdeón. Elaboración Propia a partir de Montes de Utilidad Pública Junta de Castilla y León. .186

Tabla 20. Resumen criterios cumplidos valoración indicador Figuras de protección.

Tabla 21. Resumen criterios valoración indicador Vectores Patrimoniales 187

Figura 56. Haya (Fagus sylvatica) sujeta a distintos aprovechamientos en repetidas ocasiones, hayedo de Posada de Valdeón. Imagen propia..189

Figura 57. Espacio circular, diáfano, destinado a la elaboración de carbón en el hayedo de Posada de Valdeón. Imagen propia. 189

Figura 58. Haya intervenida con el objetivo de eliminar individuos dominados. Imagen propia. 190 
Tabla 22. Resumen criterios cumplidos valoración indicador Vectores Patrimoniales

Tabla 23. Resumen criterios valoración indicador Identificación de la población

Figura 59. Escudo del municipio de Posada de Valdeón. Recuperado de www.valdeon.org.

Figura 60. Imagen corporativa del Ayuntamiento de Posada de Valdeón. Recuperado de www.valdeon.org 194

Figura 61. Imágenes de distintos negocios en Posada de Valdeón. De izquierda a derecha: Toba aventura (www.tobaraventura.com), Queserías Picos de Europa S.L. (www.quesospicosdeeuropa.com), Taxis Valdeonissimo (www.valdeonissimo.com).

Figura 62. Logotipo utilizado por el Grupo para el Estudio y Defensa de la Montaña Oriental Leonesa sito en Santa Marina de Valdeón. Recuperado de www.gedemol.org

Tabla 24. Resumen criterios cumplidos valoración indicador Identificación de la población .................................... 196

Tabla 25. Resumen criterios valoración indicador Museística......196

Figura 63. Una de las noticias relacionadas con la instalación destinada a la recepción de visitantes en Posada de Valdeón. Recuperado de https://www.leonoticias.com/comarcas/posada-valdeon-albergara20200806132829-nt.html. ...

Figura 64. Carteles de dos de los eventos tradicionales más relevantes en Posada de Valdeón. Recuperados de https://valdeon.org/actualidad/fiestas-y-celebraciones/ .............198

Figura 65. El "Chorco de los Lobos", construcción tradicional para el control poblacional de lobos ibéricos en Posada de Valdeón. Imagen propia.

Figura 66. Ermita Corona en Posada de Valdeón. Imagen propia....200

Figura 67. Hórreo tradicional en el núcleo de Posada de Valdeón. Imagen propia............................................... 200 
Tabla 26. Resumen criterios cumplidos valoración indicador Museística. ................................................... 201

Tabla 27. Resumen criterios valoración indicador Incorporación

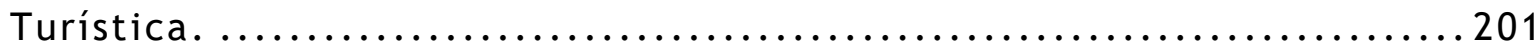

Figura 68. La ruta del Cares como principal reclamo en el portal de turismo de la Junta de Castilla y León. Recuperado de https://www.turismocastillayleon.com/turismocyl/es/ruralnaturaleza/espacios-naturales/parque-nacional-picos-europa. ........202

Figura 69. Mapa turístico interactivo del Municipio de Posada de Valdeón, en el se puede apreciar la importancia que tienen los hayedos Patrimonio de la Humanidad. Recuperado de: https://valledevaldeon.es/descubre-valdeon/mapa-interactivo/.......203

Figura 70. Infografía Hotel Cumbres de Valdeón, uno de los alojamientos más importantes del municipio. Recuperado de: https://hotelcumbresvaldeon.com ................................ 204

Figura 71. Infografías de algunas de las casas rurales más relevantes del Municipio de Posada de Valdeón. Recuperado de: https: / / casaruralposadadevaldeon.com; https: / /www.eltombolarisa.com/; https://casaruralcares.com/; respectivamente. ....................204

Tabla 28.: Resumen criterios cumplidos valoración indicador Incorporación Turística .......................................... 205

Tabla 29. Resumen criterios valoración indicador Empleo relacionado.

Figura 72. CNAE09 dos dígitos desagregado municipal. *transformación códigos CNAE93/CANE09. * ${ }^{*}$ CNAE 93 código 55. Elaboración propia.....207 207

Tabla 30. Resumen criterios cumplidos valoración indicador Empleo relacionado

Tabla 31. Valor obtenido por cada uno de los indicadores propuestos para el paisaje referente al municipio de Posada de Valdeón. ..........208

Figura 73. Representación de la situación patrimonial del hayedo de Posada de Valdeón según los indicadores analizados. Elaboración propia 208 
Figura 74. Mapa de localización del área de estudio escogida para la Tierra de Pinares de Valladolid y Segovia. Elaboración propia a partir de

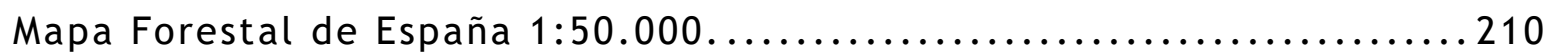

Figura 75. Mapa de altitud de la zona de estudio planteada, Tierra de Pinares de Valladolid y Segovia. Elaboración propia Modelo Digital del

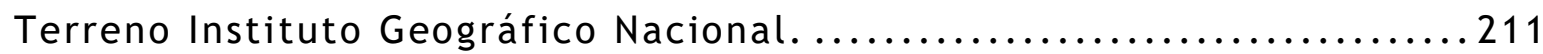

Figura 76. Mapa de pendientes de la Tierra de Pinares de Valladolid y Segovia. Elaboración propia Modelo Digital del Terreno Instituto Geográfico Nacional.

Figura 77. Mapa de orientaciones de la Tierra de Pinares de Valladolid y Segovia. Elaboración propia Modelo Digital del Terreno Instituto Geográfico Nacional.

Figura 78. Clasificación de los arenosoles. Elaboración propia a partir de mapa IRNASA 1:400.000.

Figura 79. Esquema geológico de los límites de la Tierra de Pinares de Valladolid y Segovia. Elaboración propia a partir de Geode 50 (IGME). . 216

Figura 80. Mapa con la delimitación de la comarca de “El Carracillo" según la Comunidad de Regantes del Carracillo. Elaboración propia. ...217

Figura 81. Vista cartográfica de un tramo del río Voltoya entre Moraleja de Coca y Nava de la Asunción (Segovia). Donde se puede apreciar las importantes dimensiones del pinar. Archivo de la Real Chancillería de

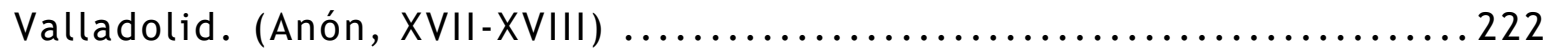

Figura 82. Mapa forestal de España (1966) conocido como “mapa Ceballos" para la Tierra de pinares de Valladolid y Segovia. Elaboración propia.

Figura 83. Mapa Forestal de España 1:200.000 para la Tierra de Pinares de Valladolid y Segovia. Elaboración propia. .223

Figura 84. Mapa Forestal de España 1:50.000 para la Tierra de Pinares de Valladolid y Segovia. Elaboración propia. .224

Figura 85. Mapa con los Montes de Utilidad Pública en la Tierra de Pinares de Valladolid y Segovia. Elaboración propia a partir de Montes de Utilidad Pública Junta de Castilla y León. 
Figura 86. Empresa Naturpellet en Gomezserracín. Imagen propia. 228

Figura 87. Camión para la recogida de piñas en el interior de un pinar de La Pedraja de Portillo. Imagen propia.

Figura 88. Troncos amontonados en las proximidades de Cantalejo. Imagen propia.

Figura 89. Mapa con la variación de trabajadores ocupados en tareas relacionadas directamente con la silvicultura en la Tierra de Pinares de Valladolid y Segovia entre 2007-2015. Elaboración propia a partir de Datos Seguridad Social CNAE. .230

Figura 90. Imagen aérea de los regadíos de “El Carracillo". Eugenio

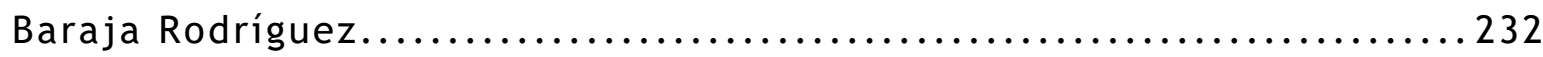

Figura 91. Cultivos de secano sobre los que se intercalan pequeños rodales de pinar. Eugenio Baraja Rodríguez...................... 232

Figura 92. Pinar resinado junto a Gomezserracín. Imagen propia. .233

Figura 93. Pinar de Pinus pinea recién olivado. Imagen propia....234

Figura 94. Las cuestas de los páramos ocupadas por el avance del pinar, en ocasiones repoblado y matorrales esclerófilos. Eugenio Baraja

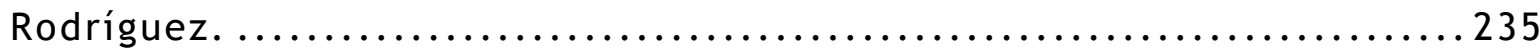

Figura 95. El municipio de Coca como ejemplo de núcleo de población compacto de La Tierra de Pinares. Eugenio Baraja Rodríguez. .........235

Figura 96. Granjas que salpican el paisaje en la Tierra de Pinares.

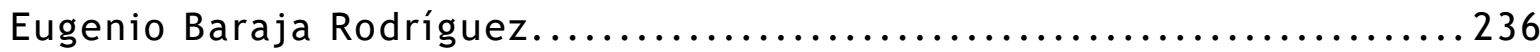

Figura 97. Perfil topográfico con información de usos AguilafuenteMontemayor de Pililla. Elaboración propia.........................237

Figura 98. Perfil topográfico con información de usos Navalmanzano-

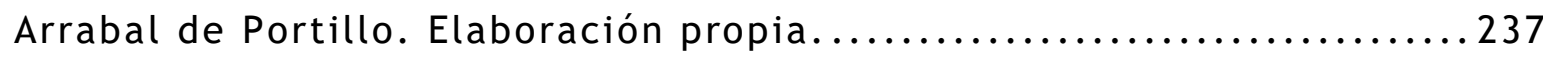

Figura 99. Perfil topográfico con información de usos Navas de OroAlcazarén. Elaboración propia. 238

Figura 100. Mapa de usos del suelo destinados a los usos forestales. Elaboración propia a partir de Corine Land Cover...................239

Figura 101. Mapa de Usos del suelo destinados a usos agrícolas. Elaboración propia a partir de Corine Land Cover......................240 
Figura 102. Mapa con los municipios que van a cumplir el criterio de centralidad establecido para servir como testigo de patrimonialización.

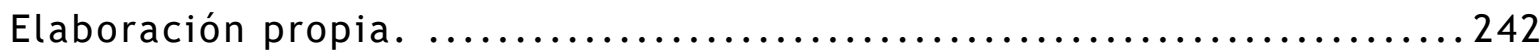

Figura 103. Mapa con la población de los municipios centrales de la Tierra de pinares. Elaboración propia. .243

Tabla 32. Tabla con la distribución laboral de los municipios que cumplen los criterios de población para ejercer como testigo en el proceso de patrimonialización de la Tierra de Pinares. Elaboración propia a partir

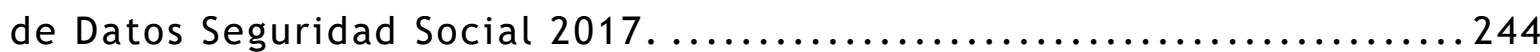

Tabla 33. Resumen criterios valoración indicador Complejidad Biológica. 244

Figura 104. Ejemplo de actividad recolectiva en un pinar de Pinus pinea. Se puede apreciar la compactación de suelo y rotura de ramas. Imagen propia.

Figura 105. Mapa de las formaciones recogidas en la Directiva Hábitat en el municipio de Vallelado. Elaboración propia a partir de Directiva Hábitat Banco de Datos de la Naturaleza.........................247

Figura 106. Representación del índice de vegetación de diferencia normalizada para los meses de febrero, mayo, agosto y octubre respectivamente. Imágenes Landsat 8. Elaboración propia. ...........248

Tabla 34. Valor NDVI de distintas cubiertas a lo largo del periodo vegetativo. Elaboración propia.

248

Tabla 35. Resumen criterios cumplidos valoración indicador

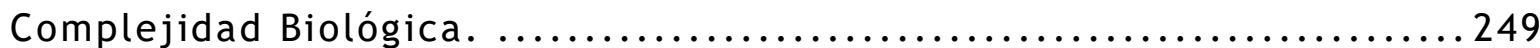

Figura 107. Mapa del Lugar de Interés Comunitario Riberas del Cega a su paso por el municipio de Vallelado. Elaboración propia a partir de Banco

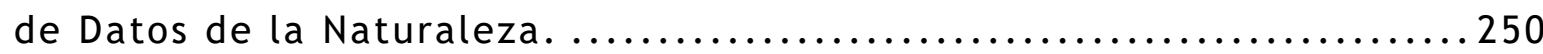

Figura 108. Mapa con los Montes de Utilidad Pública en el municipio de Vallelado. Elaboración propia a partir de Montes de Utilidad Pública Junta de Castilla y León.

Tabla 37. Resumen criterios cumplidos valoración indicador Figuras de protección. 
Tabla 38. Resumen criterios valoración indicador Vectores Patrimoniales .............................................. 252

Figura 109. Imagen del Plan Nacional de Ortofotografía Aérea (PNOA) donde se identifican perfectamente los cuarteles de gestión forestal y los cortafuegos del pinar en Vallelado. Elaboración propia................253

Figura 110. Potes de plástico destinados a la recogida de la miera. Imagen propia................................................ 254

Figura 111. Barricas resineras para almacenar la miera. Imagen propia.

Figura 112. Imagen de "La Pina" de Vallelado, este ejemplar de Pinus pinaster Ait está catalogado por la Junta de Castilla y León con el código AS-SG-23 como Espécimen Vegetal de Singular Relevancia. Recuperado de http: / / www.vallelado.net/2006/07-lapina/lapina.html...............255

Figura 113. De izquierda a derecha, escalera de tres patas para la resinación, carro para transportar las barricas. Imagen propia. ........256

Tabla 39. Resumen criterios cumplidos valoración indicador Vectores Patrimoniales

Tabla 40. Resumen criterios valoración indicador Identificación de la población. .257

Figura 114. Escudo del municipio de Vallelado según Orden de 31 de enero de 1990 por la Consejería de Presidencia de la Junta de Castilla y León. Recuperado de http://www.vallelado.es......................258

Figura 115. Cartel de promoción de una carrera para bicicleta de montaña que acude al ajo como referencia identitaria. Recuperado de http://inscripciones.runvasport.es/es/evento/i-contrareloj-ajo-devallelado-btt ....

Tabla 41. Resumen criterios cumplidos valoración indicador Identificación de la población. 261

Tabla 42. Resumen criterios valoración indicador Museística. .261

Tabla 43. Resumen criterios cumplidos valoración indicador Museística. 262 
Tabla 44. Resumen criterios valoración indicador Incorporación

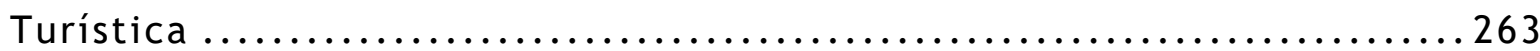

Figura 116. Noticia sobre el festival de folklore del ajo celebrado en Vallelado. Recuperado de: https: / / www.elnortedecastilla.es/segovia/festival-folclorico-exalta-

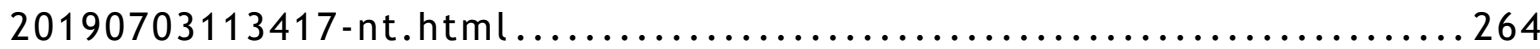

Tabla 45. Resumen criterios cumplidos valoración indicador

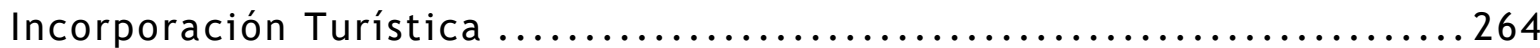

Tabla 46. Resumen criterios valoración indicador Empleo relacionado.

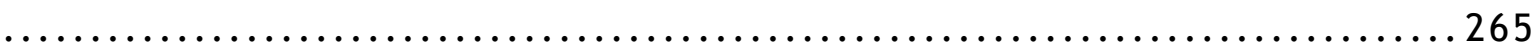

Figura 117. Distribución temporal de los trabajadores relacionados con actividades forestales o relacionadas en el municipio de Vallelado. Elaboración propia a partir de CNAE dos dígitos desagregado municipal. *transformación códigos CNAE93 / CANE09......................... 266

Tabla 47. Resumen criterios valoración indicador Empleo relacionado

Tabla 48. Valor obtenido por cada uno de los indicadores propuestos para el paisaje referente al municipio de Vallelado................267

Figura 118. Representación de la situación patrimonial del pinar en Vallelado según los indicadores analizados. Elaboración propia.........267

Figura 119. Mapa de altitud del municipio de Guriezo. Elaboración propia Modelo Digital del Terreno Instituto Geográfico Nacional. .....2 270

Figura 120. Mapa de pendientes del municipio de Guriezo. Elaboración propia Modelo Digital del Terreno Instituto Geográfico Nacional. ......271

Figura 121. Mapa de orientaciones en el municipio de Guriezo. Elaboración propia Modelo Digital del Terreno Instituto Geográfico

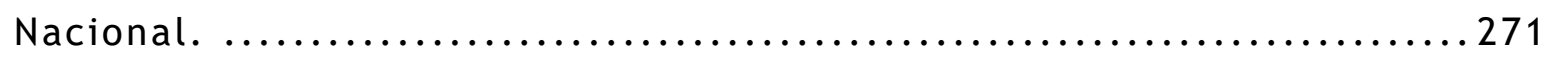

Figura 122. Mapa de usos del suelo de carácter forestal en Guriezo. Elaboración propia a partir de Corine Land Cover.................. 272

Figura 123. Mapa de usos del suelo de carácter agrícola en Guriezo. Elaboración propia a partir de Corine Land Cover....................273 
Figura 124. Mapa de los Montes de Utilidad Pública en el municipio de Guriezo. Elaboración propia a partir de Montes de Utilidad Pública Gobierno

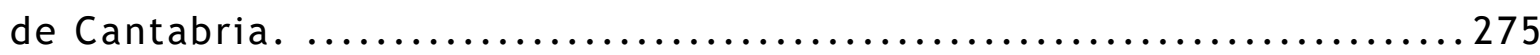

Figura 125. Mapa forestal de España (1966) conocido como “mapa Ceballos" para el municipio de Guriezo. Elaboración propia. .276

Figura 126. Mapa Forestal de España 1:200.000 para el municipio de

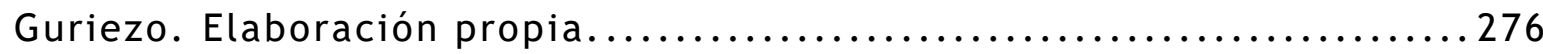

Figura 127. Mapa Forestal de España 1:50.000 para el municipio de

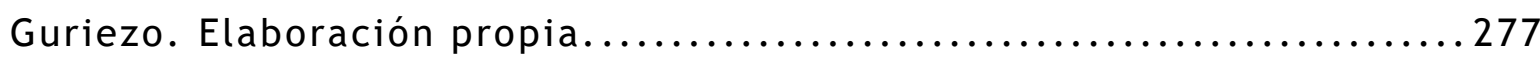

Figura 128. Bosque de eucaliptos adultos en Guriezo. Imagen propia.

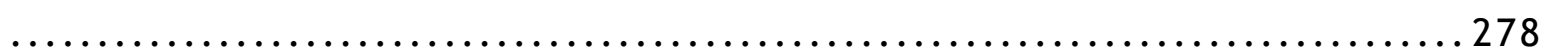

Figura 129. Contraste las laderas ocupadas por parcelas de turno de eucalipto y los prados de fondo de valle. Imagen propia. 280

Figura 130. El eucaliptal de Guriezo, parcelas en diferentes turnos. Imagen propia.

Figura 131. A la izquierda Eucaliptos adultos, a la derecha el robledal autóctono en Guriezo. Imagen propia. .281

Figura 132. El valle de Guriezo con la distribución de los distintos núcleos de población. Imagen propia.

Figura 133. Perfil topográfico con información de usos Alto de GuriezoAlto de La Mina. Elaboración propia a partir de trabajo de campo. ....283

Figura 134. Perfil topográfico con información de usos Ermita de Las Nieves-Loma de Pajares. Elaboración propia a partir de trabajo de campo. .284

Tabla 49. Resumen criterios valoración indicador Complejidad

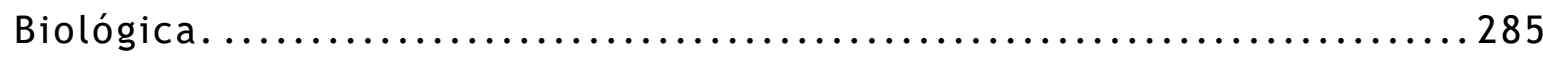

Figura 135. Huellas de la maquinaria pesada utilizada para los trabajos forestales en el eucaliptal de Guriezo. Imagen propia. .286

Figura 136. Mapa de las figuras recogidas por la Directiva Hábitat en el municipio de Guriezo. Elaboración propia a partir de Directiva Hábitat

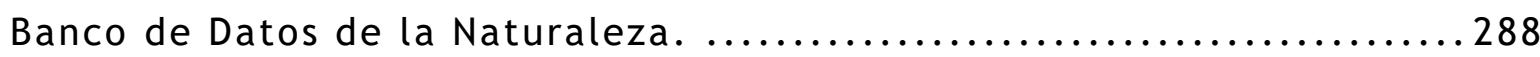


Figura 137. Representación del índice de vegetación de diferencia normalizada para los meses de febrero, mayo, agosto y octubre respectivamente. Imágenes Landsat 8. Elaboración propia. ...........289

Tabla 50. Valor NDVI de distintas cubiertas a lo largo del periodo vegetativo. Elaboración propia. .289

Tabla 51. Resumen criterios cumplidos valoración indicador Complejidad Biológica. .290

Tabla 52. Resumen criterios valoración indicador Figuras de protección .......... .290

Figura 138. Mapa de los Montes de Utilidad Pública en el municipio de Guriezo. Elaboración propia a partir de Montes de Utilidad Pública Gobierno de Cantabria.

Tabla 53. Resumen criterios cumplidos valoración indicador Figuras de protección

Tabla 54. Resumen criterios valoración indicador Vectores Patrimoniales.

Figura 139. Parcelas de turno en el eucaliptal de Guriezo, donde se alternan ejemplares de diferentes edades. Imagen propia............296

Tabla 55. Resumen criterios cumplidos valoración indicador Vectores

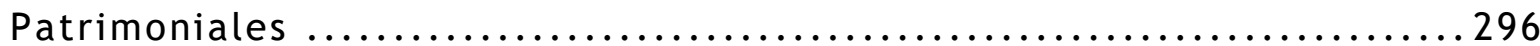

Tabla 56. Resumen criterios valoración indicador Identificación de la población.

297

Figura 140. Escudo oficial del municipio de Guriezo. Recuperado de: https: / / aytoguriezo.es/ 298

Figura 141. Logotipo de la empresa Puente Garay Forestal S.L. Recuperado de: http://www.puentegarayforestal.com/es/...........298

Figura 142. Imágenes de diferentes eventos deportivos. De izquierda a derecha: Carrera de alta montaña, recuperado de: https: / / turismodecantabria.com/proximamente/eventos / 8726 - marcha-dealta-montana-guriezo/buscadorZmVjaGFTZXQ9MSZtZXM9NiZhbnlvPTIwMTkmZGIhPSZpZENhdGVnb3JpYT00Jg $==$ Carrera de obstáculos, recuperado de: 
https: / /www.avaibooksports.com/inscripcion/tamarica-warrior-guriezocantabria/. Torneo de ajedrez, recuperado de: https: / /www.fcajedrez.es/torneo/2020/v-torneo-de-ajedrez-escolar-deguriezo/ 299

Tabla 57. Resumen criterios cumplidos valoración indicador

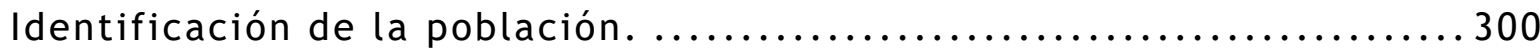

Tabla 58. Resumen criterios valoración museística................300

Figura 143. Cartel de la feria de ganado del año 2019 en Guriezo. Recuperado

de: https://www.turismodecantabria.com/proximamente/eventos/9274-feria-

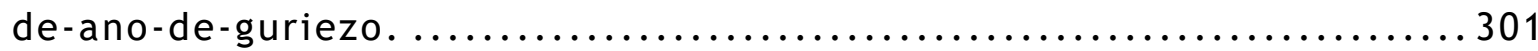

Tabla 59. Resumen criterios cumplidos valoración museística ..... 302

Tabla 60. Resumen criterios valoración indicador Incorporación Turística

Figura 144. Espacio reservado para la promoción turística de Guriezo en el portal de turismo de Cantabria. Recuperado de: https: / /www.turismodecantabria.com / descubrela/municipios / 59 -guriezo .304

Figura 145. Logotipo de promoción turística del Ayuntamiento de Guriezo. Recuperado de: https://aytoguriezo.es/portfolio/fitur-2020/.304

Tabla 61. Resumen criterios cumplidos valoración indicador

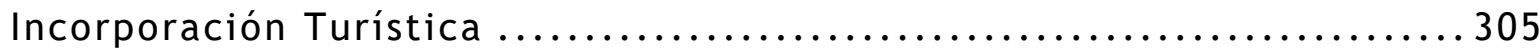

Tabla 62. Resumen criterios valoración indicador Empleo relacionado

Figura 146.Distribución temporal de los trabajadores en el municipio de Guriezo. Elaboración propia a partir de Datos Seguridad Social. CNAE dos dígitos desagregado municipal. *transformación códigos CNAE93/CANE09 308

Tabla 63. Resumen criterios cumplidos valoración indicador Empleo relacionado 308

Tabla 64. Valor obtenido por cada uno de los indicadores propuestos para el paisaje referente al municipio de Vallelado. 309 
Figura 147. Representación de la situación patrimonial del pinar en Vallelado según los indicadores analizados. Elaboración propia......... 309

Figura 148. Mapa de localización de la cuenca del Río Jiloca con los chopos objetos d estudio. Elaboración propia a partir de (Bellido y López, 2008).

Figura 149. Mapa altimétrico de la cuenca del río Jiloca. Elaboración propia Modelo Digital del Terreno Instituto Geográfico Nacional. .......313

Figura 150. Mapa de pendientes de la cuenca del Jiloca. Elaboración propia Modelo Digital del Terreno Instituto Geográfico Nacional. .......314

Figura 151. Mapa de orientaciones de la cuenca del río Jiloca. Elaboración propia Modelo Digital del Terreno Instituto Geográfico Nacional. 315

Figura 152. La falla de Calamocha. Elaboración propia a partir de Geode50 (IGME).

Figura 153. Mapa usos del suelo de carácter agrícola en la cuenca del Jiloca a partir de Corine Land Cover. Elaboración propia...............318

Figura 154. Mapa de usos del suelo de carácter forestal en la cuenca del Jiloca a partir de Corine Land Cover. Elaboración propia. 319

Figura 155. Cauce del río Jiloca junto a Villafranca del Campo. Se aprecia como el río circula subálveo. Imagen propia. .................. 320

Figura 156. Mapa forestal de España (1966) conocido como “mapa Ceballos" para la cuenca del río Jiloca. Elaboración propia. 321

Figura 157. Mapa Forestal de España 1:200.000 para la cuenca del río Jiloca. Elaboración propia........................................ 322

Figura 158. Mapa Forestal de España 1:50.000 para la cuenca del río Jiloca. Elaboración propia........................................ 323

Figura 159. Diagrama ombrotérmico de Daroca. Elaboración propia a

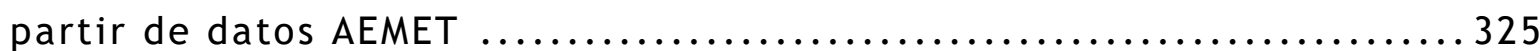

Figura 160. Vigas de chopo en una construcción en ruinas en Calamocha. Imagen propia.

Figura 161. Ganado ovino pastando a los pies de los chopos cabeceros en Luco de Jiloca. Imagen propia. .328 
Figura 162. Chopos cabeceros en Monreal del Campo custodiando las acequias para garantizar su trazado. Imagen propia...................329

Figura 163. Las vigas de chopo conviven con nuevos materiales constructivos como las tejas de fibrocemento. Imagen propia. .........331

Figura 164. Los chopos trasmochos comienzan a convivir con un sotobosque en avance debido al abandono de usos. Imagen propia.....332

Figura 165. El paisaje agrario de secano en la cuenca del Jiloca, en la llanura entre Monreal del Campo y Singra. Imagen propia. .............334

Figura 166. Espacios destinados a los cultivos de regadío junto a Monreal del Campo, los sistemas de aspersión presumen una plantación de

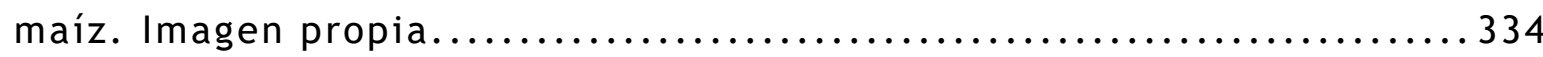

Figura 167. Cultivos de frutales en Villafeliche. Imagen propia....335

Figura 168. Carrasca (Quercus ilex ssp. ballota) en avance, cultivos de frutales y coníferas de repoblación en la culminación de las laderas junto a Burbáguena. Imagen propia.

Figura 169. Villafeliche como ejemplo de núcleo tradicional compacto. Imagen propia. .336

Figura 170. Chopos cabeceros de importantes dimensiones en la Cuenca

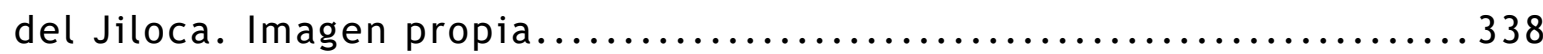

Figura 171. Chopos cabeceros podados con un año de rebrote en la entrada de Torrijo del Campo. Imagen propia. .338

Figura 172. Perfil topográfico con información de usos Blancas a Bañón. Elaboración propia a partir de trabajo de campo..............339

Figura 173. Perfil topográfico con información de usos Piedra del Águila a Retascón. Elaboración propia a partir de trabajo de campo... 340

Figura 174. Perfil topográfico con información de usos Villar del Salz a Bueña. Elaboración propia a partir de trabajo de campo............341

Figura 175. Mapa con los municipios centrales de la cuenca del río

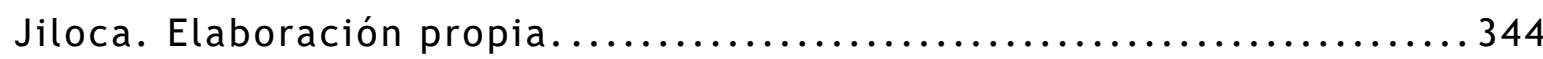

Figura 176. Distribución de la población de los municipios centrales de la cuenca. Elaboración propia. 
Tabla 65. Tabla con la distribución laboral de los municipios que cumplen los criterios de población para ejercer como testigo en el proceso de patrimonialización de la cuenca del río Jiloca. Elaboración propia a

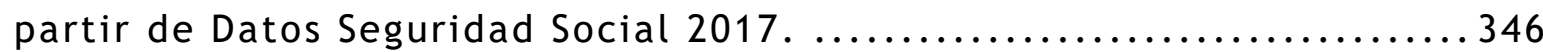

Figura 177. Localización del municipio de Burbáguena con los chopos cabeceros que alberga. Elaboración propia a partir de (Bellido y López, 2008) .346

Tabla 66. Resumen criterios valoración indicador Complejidad

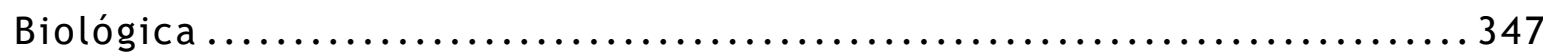

Figura 178. Chopo aislado. Supone un auténtico reservorio biológico.

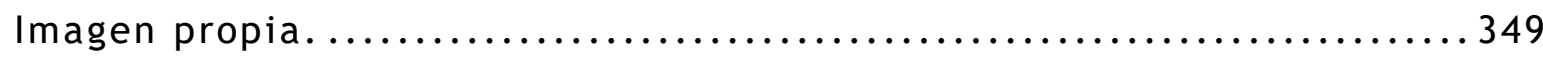

Figura 179. Representación del índice de vegetación de diferencia normalizada para los meses de enero, mayo, agosto y octubre respectivamente. Imágenes Landsat 8 . Elaboración propia.

Tabla 67. Valor NDVI de distintas cubiertas a lo largo del periodo vegetativo. Elaboración propia.

Tabla 68. Resumen criterios cumplidos valoración indicador Complejidad Biológica .352

Tabla 69. Resumen criterios valoración indicador Figuras de protección

Tabla 70. Resumen criterios cumplidos valoración indicador Figuras de protección .353

Tabla 71. Resumen criterios valoración indicador Vectores Patrimoniales. .354

Figura 180. Chopos cabeceros en Burbáguena, se aprecia un abandono que deriva en podredumbres y roturas de ramas y tronco. Imagen propia.

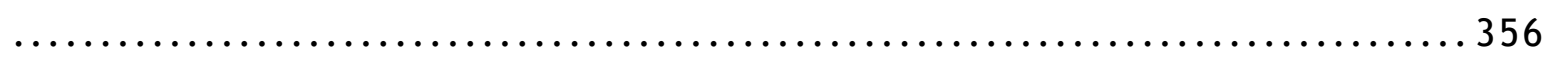

Figura 181. Acequias funcionales en Burbáguena. Imagen propia... 357

Figura 182. Fuente Vieja en Burbáguena. Imagen recuperada de http://xiloca.org/xilocapedia/index.php?title=Fuente_(Burb\%C3\%A1guena) 
Tabla 72. Resumen criterios cumplidos valoración indicador Vectores Patrimoniales 358

Tabla 73. Resumen criterios valoración indicador Identificación de la población. .359

Figura 183. De izquierda a derecha, escudo actual de Burbáguena, recuperado de http://www.burbaguena.es/. Escudo medieval de Burbáguena recuperado de (Alcañíz y Loraque, 2006)..................360

Figura 184. Infografía utilizada por el Hotel El Molino de Burbáguena. Recuperado de http://elmolinodeburbaguena.com/....................360

Figura 185. Logotipo de la Asociación Cultural Burbaca. Recuperado de https: / / burbaca.wordpress.com /quienes-somos/ ................... 361

Tabla 74. Resumen criterios cumplidos valoración indicador Identificación de la población.

Tabla 75. Resumen criterios valoración indicador museística...... 362

Figura 186. Noticia relacionada con el centro de interpretación que se instalará en el municipio de Torre Los Negros. Recuperado de: https: / / www.diariodeteruel.es/movil/noticia. asp?notid=1008985\&secid=3

Figura 187. Cartel que anuncia la jornada de exaltación de la matanza del cerdo y cartel que anuncia las jornadas gastronómicas del "panecico". Recuperado de https://burbaca.wordpress.com / ..................... 364

Figura 188. Dominique Mansion tras recoger el premio "Amigo del Chopo Cabecero". Recuperado de: http: / / www.xiloca.org/espacio/archivos / $6890 \ldots \ldots \ldots \ldots \ldots \ldots \ldots . \ldots . \ldots 365$

Tabla 76. Resumen criterios cumplidos valoración indicador museística

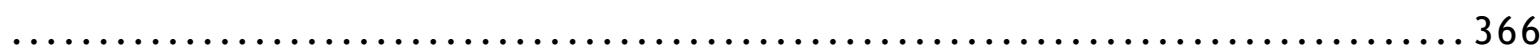

Tabla 77. Resumen criterios valoración indicador Incorporación Turística 366

Figura 189. Publicidad turística en el portal Turismo de Aragón. Recuperado de https://www.turismodearagon.com/2015/08/13/aragontierra-de-arboles-monumentales/ ................................ 367 
Figura 190. Captura del portal de turismo del Ayuntamiento de Burbáguena. Su publicidad turística se centra, de forma muy relevante, en la laguna de Gallocanta (fuera del término municipal). Recuperado de: http: / /www.burbaguena.es/turismo/naturaleza / ................. 368

Figura 191. Portada del número 109 de la revista "La Magia de Viajar por Aragón”. Recuperado de: https://www.lamagiadeviajar.com/index.php 369

Tabla 78. Resumen criterios cumplidos valoración indicador

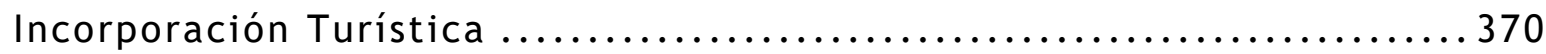

Tabla 79. Resumen criterios valoración indicador Empleo relacionado

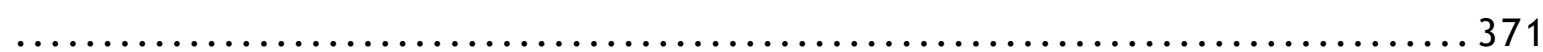

Figura 192. Distribución temporal de los trabajadores en el municipio de Burbáguena. Elaboración propia a partir de Datos Seguridad Social. CNAE dos dígitos desagregado municipal. *transformación códigos CNAE93/CANE09.

Tabla 80. Resumen criterios cumplidos valoración indicador Empleo relacionado

Tabla 81. Valor obtenido por cada uno de los indicadores propuestos para el paisaje referente al municipio de Burbáguena. .373

Figura 193. Representación de la situación patrimonial de los chopos trasmochos en Burbáguena según los indicadores analizados. Elaboración propia

Figura 194. Mapa con los tejos catalogados por la Junta de Castilla y León como especímenes vegetales de singular relevancia. Elaboración propia a partir de Catálogo de Especímenes Vegetales de Singular

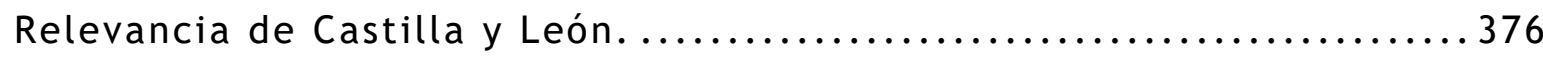

Figura 195. Tejo de la Iglesia en Noceda de Cabrera (AS-LE-03). Imagen propia.

Figura 196. Tejo de San Cristóbal en San Cristóbal de Valdueza (AS-LE04). Imagen propia.

Figura 197. Tejo del Convento en Las Batuecas (AS-SA-05). Imagen propia. 380 
Figura 198. Tejos de la Horadada en el municipio de Trespaderne.

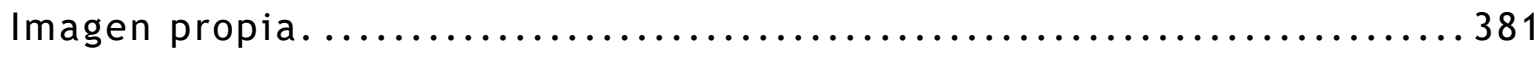

Figura 199. La Tejeda de Tosande en Dehesa de Montejo. Alfonso Pisabarro Pérez.

Figura 200. Tejo del Barraco (AS-AV-12). Imagen propia........... 382

Figura 201. El Tejo de Fresneda en Fresneda de La Sierra Tirón (ASBU-25). Imagen propia.

Figura 202. De izquierda a derecha: Cartel original de la película "Un Monstruo Viene a Verme", Juan Antonio Bayona. Pintura “El Tronco de Un Viejo Tejo", Van Gogh 1888. Recuperado de: https: / / www.ecartelera.com/peliculas/un-monstruo-viene-averme/cartel/19048/ y https://painting-planet.com/el-tronco-del-viejotejo-vincent-van-gogh/ respectivamente. 385

Figura 203. Mapa con el Tejo del Convento, en el municipio de la Alberca, catalogado por la Junta de Castilla y León como Especímene Vegetal de Singular Relevancia". Elaboración propia.................. 388

Tabla 82. Resumen criterios valoración indicador Complejidad

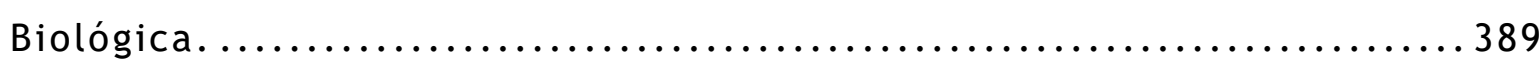

Figura 204. Tejeda de Trespaderne (Burgos), un ejemplo de bosque al

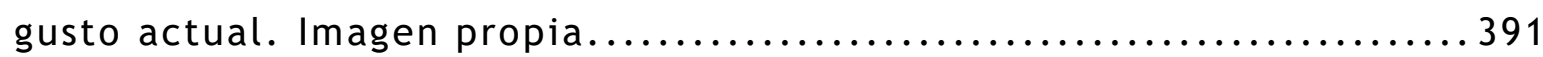

Figura 205. Mapa de la formación recogida por la Directiva Hábitat. Elaboración propia a partir de Directiva Hábitat Banco de Datos de la

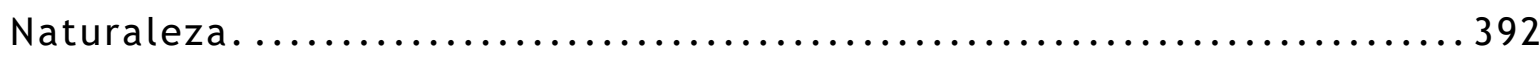

Figura 206. El tejo de La Alberca. Se encuentra bajo un dosel de

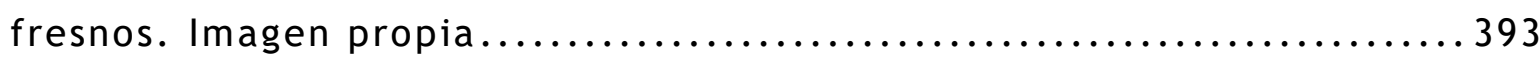

Tabla 83. Resumen criterios cumplidos valoración indicador

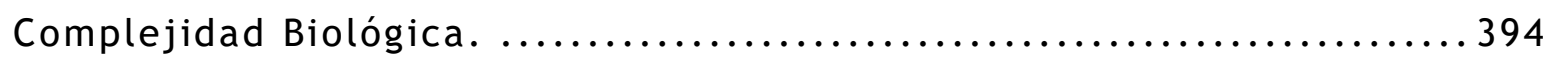

Tabla 84. Resumen criterios valoración indicador Figuras de protección

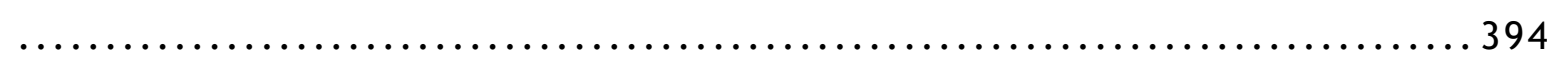

Figura 207. Parque Natural Las Batuecas-Sierra de Francia. Elaboración propia. 395 
Figura 208. Reserva de la Biosfera Sierras de Béjar y Francia.

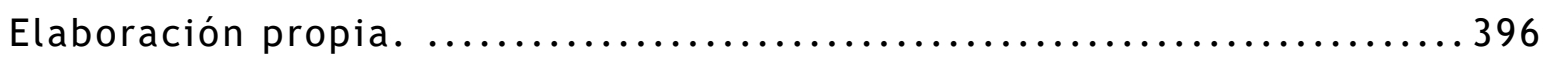

Figura 209. Lugar de Interés Comunitario Sierra de Francia.

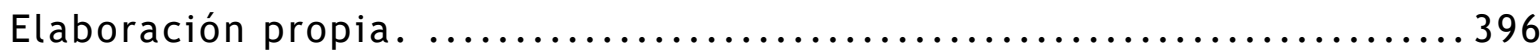

Figura 210. Zona de Especial Protección para las Aves Las Batuecas y Sierra de Francia. Elaboración propia.

Figura 211. Bien de Interés Cultural. Sitio Histórico Valle de las Batuecas. Elaboración propia.

Figura 212. Montes de Utilidad Pública en el municipio de La Alberca. Elaboración propia a partir de Montes de Utilidad Pública Junta de Castilla y León. 398

Tabla 85: Resumen criterios cumplidos valoración indicador Figuras de protección 398

Tabla 86. Resumen criterios valoración indicador Vectores Patrimoniales 399

Figura 213. El Tejo del Convento. Imagen propia...............401

Figura 214. Monasterio de San José de Las Batuecas. Recuperado de: https://monasteriodelasbatuecas.wordpress.com/el_monasterio/ ....402

Tabla 87. Resumen criterios cumplidos valoración indicador Vectores Patrimoniales 402

Tabla 88. Resumen criterios valoración indicador Identificación de la población. 403

Figura 215. Escudo oficial del Municipio de La Alberca. Recuperado de: http: / / www.laalberca.com/images/logos/Escudo-Ayto.png ...........4404

Figura 216. Ejemplo de referencia paisajística en una empresa de comercialización de materiales de construcción. Recuperado de: https: / / scontent-cdt1-1.xx.fbcdn.net/v/t1.0-

9/12541019_218046751872015_3150684018406080703_n.jpg?_nc_cat $=110 \& c$ $\mathrm{cb}=2 \&$ \&c_sid=09cbfe\&_nc_ohc=esCXvkOIKQIAX-yQ-J2\&_nc_ht=scontent cdt1 - 1.xx\&oh=06a5dd5aa4e1cb489a8e5b185a738af4\&oe=6030030D ....405

Figura 217. Imagen corporativa del Ayuntamiento de La Alberca. Recuperado de http://www.laalberca.com/....................405 
Figura 218. Asociación de pintores de La Alberca, en su iconografía se alude a elementos arquitectónicos tan relevantes en La Alberca. Recuperado de: http://asociacionpintoresdelaalberca.com/index.php . 405

Tabla 89. Resumen criterios cumplidos valoración indicador Identificación de la población. ...............................407

Tabla 90. Resumen criterios valoración indicador museística......407

Figura 219. Logotipo del museo privado Casa Museo SaturJuanela. Recuperado de: http://www.casamuseosaturjuanela.com/..........4408

Figura 220. Tejo del Convento en La Alberca con el cartel informativo asociado. Imagen propia. 409

Tabla 91. Resumen criterios cumplidos valoración indicador museística

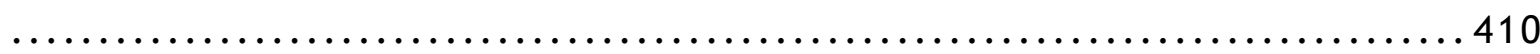

Tabla 92. Resumen criterios valoración indicador Incorporación Turística. 410

Figura 221. Captura del portal de turismo de la mancomunidad de municipios Sierra de Francia. Se hace un recopilatorio patrimonial en el que no aparece el tejo monumental. Recuperado de https://www.turismosierradefrancia.es/municipios/alberca-la.html ...411

Figura 222. Captura del portal de turismo de Castilla y León. El enfoque turístico en el municipio de La Alberca se centra en la arquitectura tradicional.

Recuperado

de https: / /www.turismocastillayleon.com/es/arte-culturapatrimonio/conjuntos-historicos/alberca

Tabla 93. Resumen criterios cumplidos valoración indicador

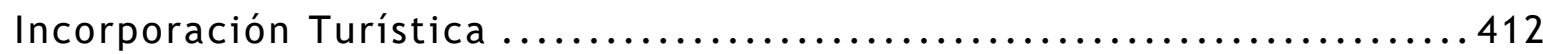

Tabla 94. Resumen criterios valoración indicador Empleo relacionado

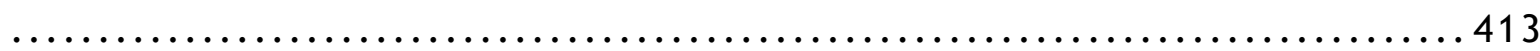

Tabla 95. Resumen criterios cumplidos valoración indicador Empleo relacionado.

Tabla 96. Valor obtenido por cada uno de los indicadores propuestos para el paisaje referente al municipio de Vallelado. 
Figura 223. Representación de la situación patrimonial del pinar en Vallelado según los indicadores analizados. Elaboración propia.........415

Figura 224. Gráfico resumen indicador complejidad biológica para los distintos casos de estudio. Elaboración propia .....................421

Figura 225. Gráfico resumen indicador figuras de protección para los distintos casos de estudio. Elaboración propia. .....................423

Figura 226. Gráfico resumen indicador vectores para los distintos casos de estudio. Elaboración propia. ................................ 424

Figura 227. Gráfico resumen indicador identificación y sentimiento de pertenencia para los distintos casos de estudio. Elaboración propia. ...425

Figura 228. Gráfico resumen indicador museos para los distintos casos de estudio. Elaboración propia.

Figura 229. Gráfico resumen indicador incorporación turística para los distintos casos de estudio. Elaboración propia. 428

Figura 230. Gráfico resumen indicador empleo relacionado para los distintos casos de estudio. Elaboración propia. 430

Figura 231. Gráfico resumen de los indicadores de patrimonialización en los distintos casos de estudio. Elaboración propia. 433

Figura 232. Resumen de los indicadores de patrimonialización comparados para los diferentes casos de estudio. Elaboración propia. .433 
Anexo 


\section{El proceso de patrimonialización a través de los indicadores en los tejos catalogados de Castilla y León (proceso de selección como testigo fiable del conjunto):}

\section{$>$ Figuras de protección y salvaguarda que amparan a los distintos tejos catalogados.}

Fresneda de la Sierra Tirón (Burgos):

- LIC Sierra de la Demanda

- ZEPA Sierra de la Demanda

Trespaderne (Burgos):

- PN Montes Obarenes-San Zadornil

- LIC Sierra de la Tesla-Valdivielso

- LIC Montes Obarenes

- ZEPA Sierra de la Tesla-Valdivielso

- ZEPA Montes Obarenes

Dehesa de Montejo (Palencia):

- PN Fuentes Carrionas y Fuente el Cobre. Montaña Palentina

- LIC Fuentes Carrionas y Fuente el Cobre. Montaña Palentina

- ZePa Fuentes Carrionas y Fuente el Cobre. Montaña Palentina

San Cristóbal de Valdueza (Ponferrada, León):

- Sin figuras

Noceda de Cabrera (Castrillo de Cabrera, León):

- Sin figuras

La Alberca (Salamanca):

- PN Las Batuecas-Sierra de Francia

- Reserva de la Biosfera Sierras de Bejar y Francia

- LIC Las Batuecas-Sierra de Francia

- ZEPA Las Batuecas-Sierra de Francia

- BIC El Valle de las Batuecas

El Barraco (Ávila):

- Reserva Natural Valle de Iruelas 
- LIC Valle de Iruelas

- ZEPA Valle de Iruelas

\section{Los vectores para cada uno de los tejos catalogados:}

Fresneda de la Sierra Tirón (Burgos)

Ejemplares singulares: El tejo incluido en el catálogo de la Junta de Castilla y León presenta un escaso tratamiento patrimonial, se encuentra muy alejado de cualquier núcleo de población lo que hace más difícil su activación. Tan solo presenta una ruta desarrollada por el ayuntamiento para poder visitarlo, pero no hay ninguna intervención que facilite el acceso, ni presenta intervenciones para su conservación.

Construcciones monumentales: En este caso el tejo se encuentra en el interior de un espacio forestal por lo que no está asociado a ninguna construcción.

Cementerios: Igualmente, al encontrarse asociado a un amplio espacio forestal no está asociado a un cementerio.

Ermitas: No se encuentran ermitas cercanas que puedan ser identificadas como vectores.

Trespaderne (Burgos)

Ejemplares singulares: Al igual que el tejo de Fresneda, el aislamiento de los tejos catalogados, sitos en una ladera de umbría bastante inaccesible condiciona su tratamiento patrimonial. En este caso los tejos han sido identificados mediante una chapa (ninguna administración se hace responsable de ellas) que contiene alguna información, pero el trabajo de campo ha evidenciado bastante abandono al demostrar que uno de los ejemplares ha muerto, cayendo sobre un importante tejo y no se ha realizado ninguna operación para solventarlo.

Construcciones monumentales: Los tejos catalogados están incluidos en un pequeño bosquete de tejos donde existen otros ejemplares no catalogados y este pequeño bosque rodeado de un amplio espacio rural que recoge diferentes usos del suelo como bosques más o menos naturales o repoblaciones forestales. Por lo que no pueden asociarse a ningún tipo de construcción.

Cementerios: De igual modo, su aislamiento condiciona la inexistencia de cementerios que puedan asociarse a estos tejos.

Ermitas: No se han encontrado ermitas cercanas que puedan asociarse a estos ejemplares.

Dehesa de Montejo (Palencia) 
Ejemplares singulares: En este caso los tejos se encuentran incluidos en el famoso bosque de Tosande, poseen un importante tratamiento patrimonial con intervenciones que facilitan su visita, así como intervenciones para su conservación

Construcciones monumentales: Al encontrarse en un espacio forestal aislado de los núcleos de población no se encuentran construcciones relacionadas con estos ejemplares.

Cementerios: De igual modo, no puede asociarse ningún cementerio a estos tejos al ser un espacio forestal.

Ermitas: No se han encontrado ermitas que puedan relacionarse con la existencia de estos tejos.

San Cristóbal de Valdueza (Ponferrada, León)

Ejemplares singulares: En este caso el tejo está muy intervenido, se aprecian tratamientos destinados a su conservación, así como actuaciones patrimoniales como la construcción de un mirador y un panel informativo

Construcciones monumentales: Al encontrarse asociado a una desaparecida ermita y un cementerio y haber sido definido estos como vectores en sí mismos, se valora en su vector correspondiente.

Cementerios: El tejo está directamente asociado al cementerio de la localidad.

Ermitas: Aledaño a la antigua ermita hoy vacía aparece el tejo de San Cristóbal. Hay que remarcar que la propia ermita ha desaparecido quedando solamente visible el campanario.

Noceda de Cabrera (Castrillo de Cabrera, León)

Ejemplares singulares: El ejemplar, pese a estar en el centro del núcleo de Noceda, no presenta ninguna intervención ni tratamiento patrimonial.

Construcciones monumentales: El árbol aparece aledaño al cementerio y ermita, por lo que se trata en su vector correspondiente.

Cementerios: El tejo aparece situado en la puerta del cementerio lo que le reafirma como espécimen de carácter místico.

Ermitas: De igual modo, el cementerio de Noceda está adosado a una pequeña ermita que continúa en pie pese a sus escasas intervenciones de conservación. Resulta evidente el abandono de toda la arquitectura tradicional del pueblo y la ermita no es una excepción

La Alberca

Ejemplares singulares: El tejo perteneciente al municipio de La Alberca muestra una pequeña intervención en forma de cartel identificativo pero su conservación es 
bastante precaria. El árbol se encuentra rodeado de maleza, residuos y presenta daños, su localización junto al camino de acceso a una ruta senderista lo hace vulnerable

Construcciones monumentales: El tejo está asociado al monasterio de San José de las Batuecas, la leyenda de su plantación se atribuye a los monjes que se asentaron en este paraje. El convento está intervenido patrimonialmente, después de haber sido rehabitado ahora presenta estancias de recogimiento y está incluido en la declaración del BIC Valle de las Batuecas

Cementerios: No se encuentra asociado a un cementerio.

Ermitas: No se encuentra asociado a una ermita.

El Barraco

Ejemplares singulares: El tejo sito en el Valle de Iruelas, perteneciente al municipio de El Barraco se encuentra muy inaccesible ya que solamente se puede visitar caminando y la población más cercana se encuentra a 20 kilómetros de distancia. Este aislamiento hace que no presente ninguna intervención patrimonial.

Construcciones monumentales: Se encuentra muy alejado de cualquier construcción que pudiera ser susceptible de asociarse a él.

Cementerios: No existe constancia de que esté asociado a un cementerio.

Ermitas: No está relacionado con una ermita.

Identificación y sentimiento de pertenencia para cada uno de los tejos catalogados:

Fresneda de la Sierra Tirón (Burgos):

En este caso no se puede acudir a la heráldica del municipio ya que carece de escudo oficial. Por otro lado, el paisaje forestal del municipio está dominado por una importante fresneda que acapara las escasas referencias. El tejo de Fesneda se encuentra muy alejado de la población y bastante inaccesible por lo que no parece ser un elemento de referencia. Por último, una población muy reducida y envejecida (101 habitantes INE 2018) impiden un dinamismo que pudiera utilizar referencias patrimoniales, apenas existen empresas, no se realizan eventos de relevancia y no existe una dotación de edificios públicos. Por todo esto no se encuentran referencias que puedan ser valoradas positivamente para este indicador.

Trespaderne (Burgos):

Los tejos que pertenecen al municipio de Trespaderne aparecen muy alejados del núcleo principal, será la localidad de Tartales de Cilla la más próxima. La identidad 
local aparece especialmente asociada a las merindades y su profundidad histórica, así puede apreciarse en el escudo oficial del municipio donde aparecen los símbolos fundamentales de esta tradicional comarca (el castillo y las aguas). El bosque que alberga los tres tejos catalogados se encuentra muy inaccesible, es necesario caminar algo más de dos horas para poder acceder a su ubicación, esto hace que no sean un elemento demasiado conocido entre los habitantes, incluso suelen hacer referencia a que nunca ha sido un lugar visitable, sino que se trata más bien de un lugar desestimado para su aprovechamiento debido a su difícil acceso. Por último, la localidad más próxima, Tartales de Cilla, tan solo cuenta con tres habitantes censados (INE 2018) lo que hace muy difícil encontrar relaciones de pertenencia grupales que sean relevantes, así como eventos que pudieran ser susceptibles de usar cualquier tipo de simbología. Como conclusión no se encuentran evidencias que puedan ser valoradas positivamente para este indicador.

\section{Dehesa de Montejo (Palencia):}

El caso de los tejos del Tosande, pertenecientes al municipio de Dehesa de Montejo están mucho más relacionados con la identidad local que los casos anteriores. En este caso el acceso a la Tejeda, donde se encuentran los ejemplares catalogados, es mucho más sencillo. Para acceder basta con caminar por una senda habilitada cuya entrada aparece bien señalizada en la carretera. En cuanto a las evidencias que sirven para definir la valoración de este indicador, el tejo es un claro protagonista en el escudo municipal, apareciendo claramente en la parte inferior. En cuanto a la utilización como simbología propia por parte de la administración o los particulares no se encuentran evidencias, en cierta medida basadas en la importante despoblación del municipio (136 habitantes INE 2018) lo que le convierte en un desierto de actividad.

\section{San Cristóbal de Valdueza (Ponferrada, León):}

Este caso es muy particular ya que el tejo catalogado se encuentra en la localidad de San Cristóbal de Valdueza, perteneciente al municipio de Ponferrada, por lo que su importancia identitaria queda supeditada al protagonismo de la ciudad de Ponferrada. El uso heráldico no es relevante ya que la localidad no tiene escudo oficial, en cuanto al uso como simbología por parte de la administración o los particulares es casi inexistente al ser una pequeña localidad muy despoblada (48 habitantes INE 2018) sin apenas actividad económica ni edificios que alberguen servicios públicos susceptibles de ser bautizados. Pese a ello, durante el trabajo de campo se recogieron evidencias de una relación de intimidad entre algunos habitantes y el tejo, relación que se corrobora con la jornada de exaltación que celebra la Junta Vecinal de San Cristóbal. Esta estrecha relación puede deberse, posiblemente a la cercanía y fácil acceso del ejemplar.

Noceda de Cabrera (Castrillo de cabrera, León): 
Al igual que en el caso anterior, el tejo se encuentra dentro de la localidad de Noceda de Cabrera, perteneciente al municipio de Castrillo de Cabrera, junto a la iglesia lo que le hace especialmente accesible y visible. En este caso, la localidad esta especialmente deshabitada (8 habitantes INE 2018) lo que hace muy difícil encontrar referencias derivadas de la actividad tanto pública como privada. Durante el trabajo de campo se han recogido evidencias, mediante entrevistas con la población local, que afirman sentirse identificados o representados por su tejo (probablemente lo más relevante de su pequeña localidad).

La Alberca (Salamanca):

El tejo catalogado en el municipio de La Alberca se localiza en el paraje de las batuecas, junto al convento de San José. Esta circunstancia le hace estar muy alejado de cualquier núcleo de población, especialmente del núcleo principal del municipio al que pertenece. Por otro lado, la identidad de los albercanos se halla muy centrada en sus características arquitectónicas, las cuales se han conservado y restaurado generando un núcleo de población homogéneo muy reconocido. De igual modo la identidad local se relaciona constantemente con aspectos del medio físico como el valle de Las Batuecas tan reconocido como lugar de aislamiento y reflexión (Instituto) o la Sierra de Francia (Colegio Público). No se han encontrado evidencias de la utilización del tejo como referencia o iconografía ni por la administración ni por particulares. Durante el trabajo de campo se trató de conocer la relación e la población local con el tejo catalogado y no se encontró nadie del municipio que conociera su existencia.

\section{El Barraco (Ávila):}

El tejo monumental que pertenece al municipio de El Barraco se encuentra bastante inaccesible por lo que, durante el trabajo de campo se intentaron buscar evidencias de su conocimiento por parte de la población local y nadie decía conocer dicho ejemplar. Por otro lado, El Barraco, que debe su nombre a la figura zoomórfica encontrada posiblemente de origen prerrománico se ha centrado en la exaltación de este símbolo como identificador local. La potencia de este elemento deja muy poco espacio para la convivencia con otro tipo de simbologías. En lo que respecta al paisaje forestal parece más relevante el paisaje de la dehesa, el encinar y la ganadería extensiva que alguna referencia al tejo situado en el paraje del Valle de Iruelas. Esto se debe a la existencia de la llamada Sociedad del Monte Encinar, entidad destinada a la gestión de determinadas parcelas del municipio de forma comunitaria. En este caso se encuentran referencias que pueden relacionar la identidad con este paisaje forestal. En contraposición, el tejo no aparece en ninguna referencia ni pública ni privada como identificador local. 


\section{Centros de interpretación y museos para cada uno de los tejos catalogados:}

Fresneda de la Sierra Tirón (Burgos):

No existe ningún espacio destinado a la interpretación, conservación o explicación del tejo monumental. El tejo posee cierto grado de tratamiento, existiendo una ruta señalizada por el ayuntamiento.

Trespaderne (Burgos):

No existe ningún centro destinado a este efecto. Tanto los tejos incluidos en el catálogo como los que no lo están aparecen identificados con una chapa identificativa que aporta alguna información, aunque no se ha encontrado ninguna administración responsable de estas chapas identificativas.

Dehesa de Montejo (Palencia):

Existe un centro de recepción de visitantes centrado en la interpretación de la tejeda, se ha puesto en marcha durante el verano de 2018. Por otro lado, la propia tejeda está muy habilitada para la observación, las rutas están muy bien señalizadas y existen diferentes paneles informativos para facilitar la interpretación.

San Cristóbal de Valdueza (Ponferrada, León):

No se han encontrado evidencias de un espacio reservado a la interpretación del tejo, pero se ha colocado un panel informativo en un pequeño mirador destinado a ello.

Noceda de Cabrera (Castrillo de Cabrera, León):

No existe ninguna evidencia de la existencia de museos, centros de interpretación ni otro tipo de tratamiento destinado a ensalzar los valores del tejo catalogado.

La Alberca (Salamanca):

No existe un espacio destinado a su interpretación. El tejo posee un pequeño cartel informativo a su pie.

El Barraco (Ávila):

No existe un espacio destinado a su interpretación, tampoco se han encontrado elementos destinados a ello en el propio tejo ni una ruta específica que facilite su visita.

\section{$>$ Incorporación turística para cada uno de los tejos catalogados:}




\section{Fresneda de la Sierra Tirón (Burgos):}

Se encuentra cierta utilización turística por parte del ayuntamiento que plantea una ruta para la visita al tejo, aunque da más protagonismo a otros elementos patrimoniales de carácter arquitectónico. No se encuentra activación turística por parte de otra administración.

\section{Trespaderne (Burgos):}

En este caso se encuentran referencias de activación turística por parte de una empresa privada que sirve como enlace entre turistas y particulares. El Ayuntamiento centra su oferta turística en elementos arquitectónicos y etnográficos. No se han encontrado referencias turísticas por parte de otras administraciones.

\section{Dehesa de Montejo (Palencia):}

En cuanto a la tejeda de Tosande está muy reclamada turísticamente. Se han encontrado evidencias de diferentes administraciones como la Junta de Castila y León, Incluso ayuntamientos cercanos utilizan la tejeda como reclamo turístico para complementar su oferta pese a no encontrarse en su límite territorial. En este caso la activación turística trasciende de la administración pública, así, empresas particulares utilizan este espacio forestal para complementar su oferta

San Cristóbal de Valdueza (Ponferrada, León):

El tejo catalogado aparece en reclamos turísticos por parte del ayuntamiento de Ponferrada y es incluido en diferentes rutas por la comarca del bierzo completando la oferta turística.

Noceda de Cabrera (Castrillo de Cabrera, León):

Al igual que el caso anterior, es el ayuntamiento quien incluye este ejemplar entre su oferta turística, aunque en este caso la recurrencia del tejo en las rutas o la oferta turística complementaria no es tan extensa como en el caso anterior.

La Alberca (Salamanca):

En este caso no se ha encontrado ninguna referencia que utilice al tejo catalogado como reivindicación turística, ni como protagonista ni como complemento de la oferta.

\section{El Barraco (Ávila):}

No se ha encontrado ninguna referencia turística al tejo catalogado en el Valle de Iruelas, perteneciente al término de El Barraco. 



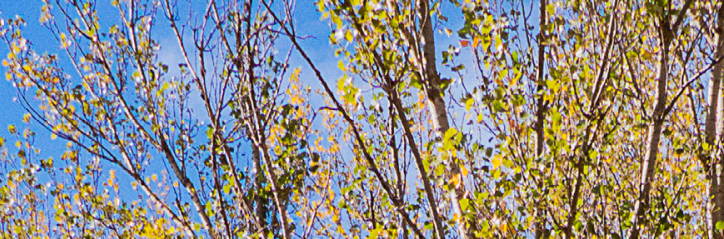
ton

\section{Universidad deValladolid}

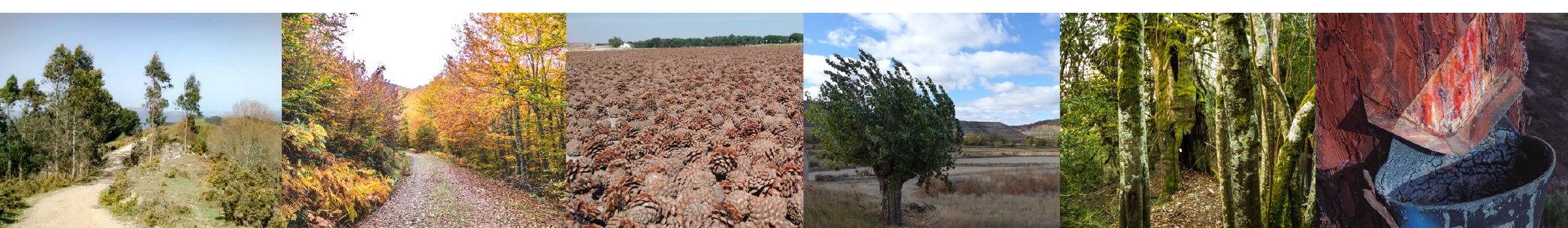

